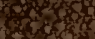

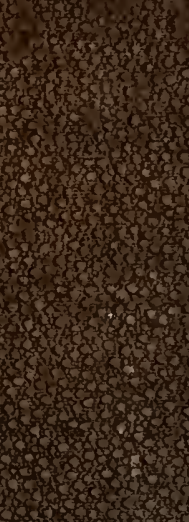

\section{(25)}

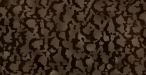

ming

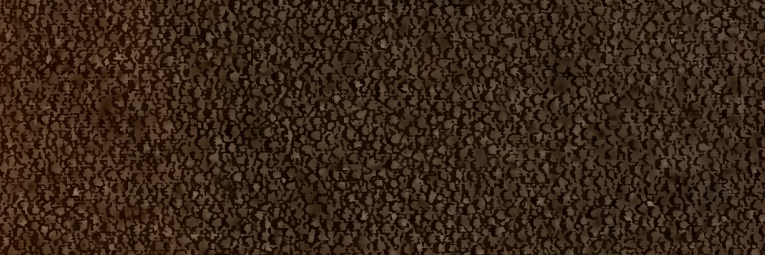

wholn

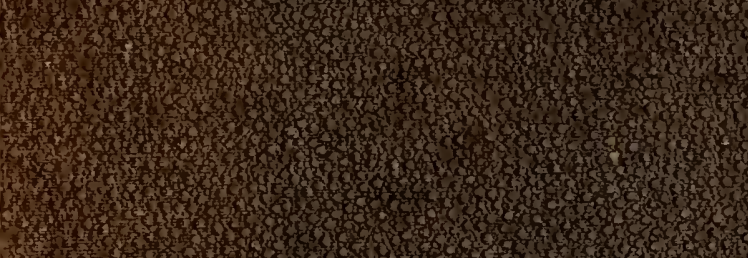
3.

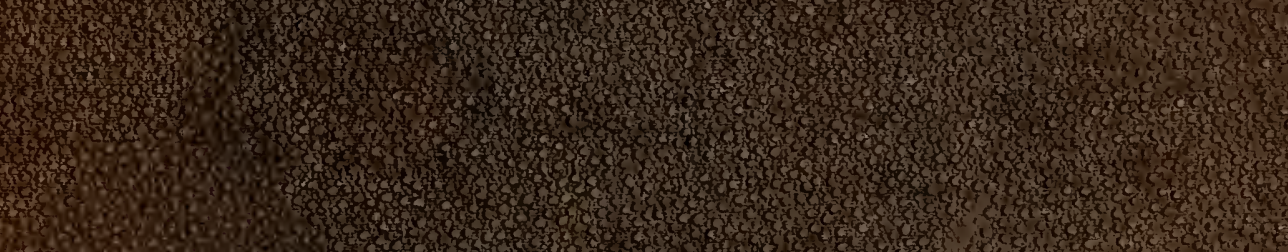
It ot. tin 


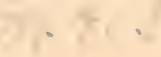




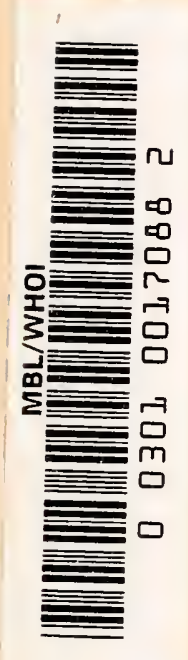





\title{
BUTTERFLIES AND MOTHS
}

OF

\section{NORTH AMERICA,}

WITH FULL INSTRUCTIONS FOR COLLECTING, BREEDING, PREPARING, CLASSIFYING, PACKING FOR SHIPMENT, ETC.,

\section{Complete Synonymical Catalogue OF}

\section{MACROLEPIDOPTERA,}

WITH

\section{A FULL BIBLIOGRAPHY,}

\author{
TO WIICH IS ADDEU
}

A GLOSSARY OF TERMS AND AN ALPHABETICAL AND DESCRIPTIVE LIST OF LOCALITIES.

\section{BY HERMAN S'TRECKER,}

Life Member of the Academy of Natural Sciences of Philadelphia; Member of the American Entomological Society, and of various other Scientific Associntions.

READING, PA.

PRESS OF B. F. OWEN, 1878. 




\title{
BUTTERFLIES AND MOTHS
}

oF

\section{NORTH AMERICA,}

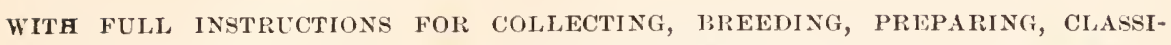
FYING, PACKING FOR SHIPMENT, ETC.,

Complete Synonymical Catalogue oF

\section{MACROLEPIDOPTERA,}

WITH

\section{A FULL BIBLIOGRAPHY,}

\author{
TO WHICH IS ADDED
}

A GLOSSARY OF TERMS AND AN ALPHABETICAL AND DESORIPTIVE LIST OF LOUALITIES.

BY HERMAN STRECKER,

Iife Member of the Academy of Natural Sciences of Philadelphia: Mamber of the American Entomologieal Society, and of various other Scientific Associations.

READING, PA. PRESS OF I. F. OWER, 1878. 
Entered according to Act of Congress in the year 1878, by Herman Stricken, in the office of the Librarian of Congress at Washington.

A2197 
eo

WILLIAM CHAPIAN HEWITSON

THIS VOLONE IS

WITH PROFOUND RESPECT

AND LOVING REMEMBRANCE

GRATEFULLY DEDIOATED. 


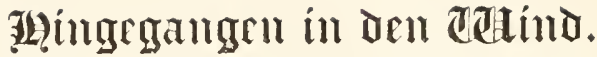

Salono! wo ist dein Thron hingegangen? in den Wind.

Lilie! wo ist deine Kron' hingegangen? in den Wind.

Predigest du in den Wind, Erdenweisheit! immer noch,

Seit der weise Salomon hingegangen in den Wind?

Bruestest du im Hauch des Glnecks dich noch immer, Erdenmacht !

Seit der maecht'ge sialomon hingegangen in den Wind?

Auf des Lebens Frnehlingsan'n draengen tausend Keimesich, Fragen nicht, ob tausend schon hingegangen in den Wind.

Fencht' einmal mit Wein noch an, Schenke! diesen durst'gen Stanb, Eh der nicht'ge Erdensoln hingegangen in den Wind.

Schenke! wie ein Traum der Nacht, wie ein Schatten auf der Flur, Ist das Leben mir entflohn, hingegangen in den Wind.

Hoffnungen, wie Spreu verweht, Wuensehe, Rosendueften gleich, Liebesseufzer ohne Lohn hingegangen in den Wind.

Falscher Schmeichelhanch der Huld, und des Hohnes kraenkender, Lieb' nnd Hass ist, Hnld und Hohn, hingegangen in den Wind.

Las der 'Thraenen letzten Rest mich rerweinen dieses Ang's, Bis die letate spur davon hingegangen in den Wind.

Lieht der Jugend! Sehoenheitsbild! kaum ersehienen bist du nir; Glenzend wie die Lilienkron', hingegangen in den Wind.

Lebenszierde! Schmuck der Welt! herrlich prangend, bist dn uns, Schoen wie Salomonis Thron, hingegangen in den Wind. L'm dein Angedenken soll ewig spielen Freimunds Lied, Bis davon der letzte Ton hingegangen in den Wind.

Fr. Rueckert. 


\section{CON'TENTS.}

PAGE

I. Preface,

II. Instructions for Collecting, Breeding, Preparing, Packing for 'Transportation, etc.

1. The Capturing of Day Butterflies (Rhopaloceres)-The Implenents Necessary,

2. The Modus Operandi of Using these Implements, . . . 8-10

3. The Capturing of Night Butterflies or Moths (Heteroceres), 11, 12

4. Preparing for the Collection, . . . . . . . 12,13

5. Cabinets, \&c., for containing Lepidoptera, . . . . 14,15

6. Entomological Forceps, . . . . . . . . 15

7. Entomological Pins, . . . . . . . . 16

8. The Arranging of Examples in the Cabinet, . . 16,17

9. Labeling the Examples, . . . . . . . . 17-19

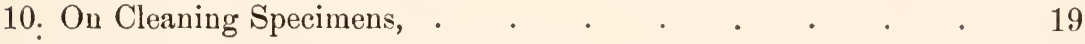

11. On Relaxing and Expanding Specimens, . . . . 20

12. Repairing Specimens, . . . . . . . . 21

13. Museum Pests, . . . . . . . . . . 21

14. Packing and Transportation, . . . . . . . 22, 23

15. Packing Specimens already expanded to place in the Collection, for Transmission to Foreign Parts; and as regards Foreign Express Cos., \&c., · • . • . . . . 24-28

16. The Rearing of Lepidoptera irom the Egg and Caterpillar, . 28-31

17. A few Final Remarks, . • • • • • . 31,32

III. Structure of Butterflies and Moths as shown on Plate 1, Figs. I-X, . • • • • 33,34

IV. The Terms and Abbreviations used in Works on Lepidoptera, 
V. An Alphabetical and Explanatory List of Localities of which the Lepidopterous Fauna is more or less known,

VI. Catalogue of the American Macrolepidoptera North of Mexico

VII. Corrigenda, 193,194

VIII. Index to Catalogue of Macrolepidoptera, Rhopaloceres,

IX. Bibliography-List of Authors and their Works cited; elucidating the abbreviations used in the Catalogue; with short biographical or autobiographical notes, 


\section{PREFACE.}

I would beg you friend not to pass this by, for, while that which follows may concern you the most, this is the part that relateth more particularly to myself and my wants, and it is human nature, you know, to think of ourselves first, last and always.

This Pamphlet is the result of numerous applications from beginners in many parts of the country, for information as to the methods of capturing, preserving, classifying, \&c., Lepidoptera (Butterflies and Moths); and I have endeavored to give such notes as lay in my power, the result of a lifetime devoted to sturlying and collecting in this branch of Natural Science.

Almost the first thing the beginner wishes to know, after he has made a few captures and finds butterflies are not all alike, and not confined to two or three kinds, viz., little yellow ones and big red or black ones, is whether they have numes and what those names are. In default of being able to obtain this information, ten to one he will give them names of his own invention, probably derived from some peculiarity, real or fancied, of form or colour. Then comes the desire to obtain literature on the subject; then to get specimens from other localities as sonn as he becomes aware that those of Calabar are not the same as those of Kentucky; and so one thing leads to the other until, from the little acorn sown by chance, a goodly tree doth grow and flourish.

To give some plain information that will tend a little to lighten the labor of the beginner, (perhaps far away from good collections, libraries and congenial companions, has been iny object, as also to increase my correspondence with many students and collectors, both new and old, in various parts of this country as well as abroad, with whom I bave not as yet had the pleasure of conmunicating.

I am not only anxious to secure correspondents in our own States and Territories, Canada and British America, but also in Mexico, Cuba, Brazil, New Granarla, Surinam, China, Amoorland, India, Japan, Algiers, Sierra-Leone, South and East Africa, Madagascar, Anstralia, Celebes, Moluceas, \&e.; and should this circular fall, perchance, into the hands of any one living in one or the other of these countries who is interested in the study of Butterflies (Lepidoptera), I would esteem it the greatest possible favour to receive a line on the subject.

Missionaries could do a vast deal if they would collect and transmit collections of these things; it is not at all necessary that they make the captures themselves; with a little instruction, natives will make very good collectors, and if a little pecuniary reward were in the perspective, they might accomplish wonders.

Soldiers stationed at various points in our Territories conld also do good work in the cause of seienre by devoting an occasional leisure hour to collecting these beantiful objects; to any such who feel interest enough to collect and send me examples, I would be happy to render an equivalent in any way desired. 
Any persons, here or in foreign comntries, willing to correspond with me or to exchange examples of either indigrenous or exotic species, will confer a great favour by sending me a line to that effect.

Also any one having undescribed or hitherto unfigured species, either buttertlies or moths, native or exotic, will confer a great favour by loaning them for the purpose of ilhstration and description in the work on "Lepidopter"a" which I am at puesent publishing in monthly parts; the greatest care will always be taken of all such examples intrusted to me, and they will be prompitly returned as soon ats described and figured, and a guarantee given to that effect whanever refuired; in such cases all credit, of course, will be duly given to the discoverer.

I will cheerfully anl gratuitonsly identify specimens of butterfies and moths sent to me for that purpose; where persons have them in duplicate the best plan is to put numbers on the specinens sent, corresponding with those on the specinens in their collections, and I need only write the manes aftor the numbers, thus: No. 7 is Papilin Enrymedon; you look at No. 7 in your collection and see in a moment that that is the species meant. Where you have only a single specimen, and wish it returned, it is of course unnecesiary to aflix any number, as I can write the name on a small slip of paper and stick it on the pin of the insect to be returned.

If I have in these parges failed to meet all the requirements of the case, I trust no one interested in the sucuce will hesitate to wite to me, for 1 am always equally as willing and glad to receive information as $I$ am at all times to imparc any, as far as lies within my power. It would be a churl indeed who would fail to answer an appeal fiom one who is traveling the same road that in bygone days he had traversed. I shall never forget when a little boy how my heart bounded when one day Prof. Jos. Leidy took me into the basement of the Philadelphia Academy of Natural Sciences, and pointing to the boeks on Entomology told me I had permission to examine their tontents. Great God what a Hearen opened to me! my books on natural history previously were sundry of the "l'eter Parley" suite; with what contempt I lnoked ever thereafter at the venerable Peter, as pictured on the first page, in knee breeches, surrounded by his nmmerous descendants who were suppored to he listening with eyes, mouths, ears all extended, to his accounts of vampyres, eockroaches half a foot long, and the inevitable tarantula, that after biting people looked at them till they danced themselves to death; but alas, the once treasured "Peter Parley" bonks hat served their time, and their phare knew them no more. How I now reveled in the treasures of old Cramer, in Donovan, in the wonderful Thesanrus of Mad. Merian, in indefatigable Hubner, and in dust ad libitum. How I gazed wonder-struck on the great African Saturnidae depicted by the old authors, never dreaming that 1 should ever become the happy posisessor of such traisures. Time in this respeet has dealt kindly with me, many of Craner's and Drury's species and many that Cramer and Drury doubtless never saw, now grace my calincts, and are things of beanty and to me things of endless joy. Oh! never my friend, give a cold look or a short word to those who hunger after the muth of sejence; foolish questions may be asked you, and your patience at times taxed, but remember the time, fir back, when you too were groping in the dark, vainly striving to find the path of which you could only eateh in the distance the fantent glimmer. Remember how a hand was reached ont to direct you aright from ghloom and uncertainty to light and knowledge; show now your gratitude for that kindness, in the only way in your power, by 
doing for some other one who is humbly striving, that which at a time long passed, was done for you. I have passed away from my subject entirely, but it seems as if it were but a few days since I was taken by the hand and led wondering, almost trembling into the presence of the grand old masters of natural science, those titans who laid the miglity ground work for all futurity to build upon. Lengths of crape were festooned across the Library, centred in the beak of a great condor, a tribute to the learning and worth of Dr. Morton, who had then just passed from his studies here to those in a land where alone perfect knowledge is attained; and further back peering out of the gloom, hideous in its frightful ngliness, was the head of Gorilla Caniceps, looming up like some Afrit or Gnome, the offspring of opium eating orientalism, and all alound and above were books, books. How I wished I could but spend my whole existence there, and I recollect staggering under the weight of an old volume, heavier almost than myself, to where Dr. Zantzinger was sitting, and asking him where the name of the huge moth there depicted could be found, and how I stared when he told me that in those days they had not yet named them, and how I wondered why Arlam had omitted naming such a vast number of beautiful things, or perhaps his renords and catalogues were lost in the deluge, (this latter was the most satisfactory conclusion I could at that time arrive at.) And when new wonders revealed thenselves at every page, how I wanted some one to talk to ahout them and to share my gieat happiness with me, but as I looked around I could see that all present were either reading or writing, perchance some one as he glanced up from his volume for a moment, met my enthusiastic craze, and gave the little sicklylooking boy a kindly smile ere he again resumed his book. Oh, those were golden days! How I treasured up the first poor battered specimen of the Enropean Peacock Butterfy, (Vanessa Io.,) for which I paid 25 cents to a venerable taxidermist, who thonght he might as well take my half-year's savings for it as to throw it away ; how I wondered if by any earthly possibility I should ever get another, in case accident by fire or flood shonld happen to this one. 'Then the first sphinx I ever captinred (Lineata I think was the species,) I kept him in a little box with a glass front, thinking that he would die before long, in which opinion he didn't appear in the least to agree with me, as his eyes shone like coals of fire night after night, and thinking it wonld overcome the little difference of opinion, I at last run a pin through his body and impaled him on a board with the innocent idea that it wonld kill him, and the stupid thing wouldn't die after all, and my conscience smote ne day by day, for a week nearly, as he jersisted in refusing to give up the ghost; and at last my futher, who couldn't beat to see the thing suffer any longer, unpinned it and despite the tears and appeals of his first-born, threw it into the great old-fashioned wood stove to get it out of its misery, as hesaid. This fixed that stove indelibly in my menory, it was a monstrous old thing, that either threw out a fearful heat or none whatever, no medium, if you let it burn, you had tolerably fair conceptions of Gehenna, if you Jowered the fire, lo! it wonld sullenly die away ; Darling \& Smith, Joanna Furnace," was the inscription borne by this household Moloch. Cireumstances have many years later brought me to my present home, not many niles from "Joanna Furnace." Since then on many an occasion I have met the "Darhing \& Smith," and their children and their children's ehildren, but it needs none of these to remind me of the ruin of my first great entomological capture, the recollection of which " only in death will die."

But I can almost imagine I: hear my reader's pshaw of impatience at my 
retrospective wanderings into the infant realm of bread-and-butter, nankeens, and credulity-in-perfection, and I may as well agree with iny readers as my recollections of infancy will only cost more printer's ink withont further enhancing the value of my pamphlet. The novelty of the first underwing moth (Catocala Amatrix) has passed away, nor can an old torn Telea Polyphemus longer hold me spell-bouml, and as the years of man are few, and time goeth far too swiftly, I may as well at once get out of the shadowy past into the real present, and make the most of it by endeavoring to obtain from those interested in onr beloved science, further material wherewiih to feast my eyes, and to give me greater opportunity of acquiring knowledge of there most lovely of all of nature's works.

As I continually have need of great numbers of examples of different species, I am always glad to exchange with parties having duplicates of Moths or Butterflies, either native or exotic. Of the N. American species I ran always use almost any number of perfect examples of all species, especially, Lycaenidae, Hesperidae, Sphingidae, Bombycidae, Catocalidae an! the Noctuac and Geometrae generally. Very rare species will be acceptable even if they be not perfect specimens, for of such we must be content to take the best we can get, without being too fastidions. I particularly want numbers of Sphingidae, (except Deil. Lineata, S. 5-Maculata aur S. Carolina,) also Aretidae, any species, Hem. Maia, Cith. Regalis, Eac. Imperialis, Aet. Luna, Cal. Angulifera, Debis Portlandia, Neonympha Gemna, Neo. Areolatus, Catoeala Coccinata, C. Villuata, C. Mulierenla, C. Amasia, C. Relicta, and in fact any others.

The following are a few particular desiderata of the N. American species, viz. :

Argynnis Nokomis, ơ 우

Argynnis Leto, 우

Lycaena Regia,

Colias Edwardsii, ㅇ

Macroglossa Flavofasciata,

Sesia Axillaris,

Proserpinus Gaurae,

Darapsa Versicolor,
Arctia Parthenos,

Platysamia Columbia,

Citheronia Sepulchralis,

Hepialus Purpuraseens,

Catocala Stretchii,

Catrocala Irene,

Catocala Zoe,

Catocala Consors.

For one or more of any of these I will give large exchanges or pay in money, as may be most agreeable.

I am also equally desirons of obtaining such exotics as I need from parties having duplicates from any locality.

The following species and varieties I would esteem above everything conld I but obtain them; and I insert this, not with any expectation of speedily getting them, but knowing that they are in the work, I hope that perhaps after many days or years some one or other of them ma come into my possession. I can only watch and wait, and heg that if any European firienl is fortunate enough ever to possess any of the following in duplicate he wonk remember then that there is one here who has grown grey trying to obtan then, who will give any exchange or pay in cash for then their price. That I should die withont beholding these would be, indeel, too liard a fitte, but I will not stop to contemplate so desolate a prospect, but will provecd to name the peerless things, which are as follows: 
Pap. Maackii, Men.

P. Radolei, Brem.

Thais Honoratii, B.

Parnassius Bremeri, Brem., $f$

“ Eversmannii, Men.

" Apollonius, Ev.

" Actins, Ev.

"Detphius, Ev.

"Tenedius, Ev.

Pieris Chieranthi, Hb.

Colias Aurora, Esp. ㅇ

Vanessa Testuda, Esp.

"Sardoa, Stg.

" F. Album, Esp.
Pyrameis Elymi, Rbr.

Chionobas Urila, Ev.

"Sculdia, Ev.

Smerinthus 'Tartarinovii, Brem.

" Maackii, Bren.

" Kindermannii, I al.

" Argus, Men.

"Tremulac, Tr.

" Dissimilis, Brem.

Saturnia Lunulata, Brem.

"Atlantica, Lue.

"Artemis, Brem.

I am particularly anxious to obtain Varieties Hybrids, Hermaphrodites and other aberrant and abuormal forms for which I am always ready to negotiate liberally.

I would like very much to secure correspondents in Boguta, Peru, Surinan and Rio Janiero. Should this meet the eye of any one at any of the above mentioned places, or any other part of S. Ameriea, I would esteem it the greatest favour if they wonld do me the hononr to communicate with me for purposes of exchange, de.

In eonclusion, I would repeat that I will always be delighted to hear firm Lepidopterists in any part of the world, and any one so favouring me will receive the promptest attention.

Ant should any Entomologist find himself in my neighborhood, I trust he will not slight me by neglecting to eall on me and allowing me the pleasure of showing him my collections.

I am always really to identify, for any one, Lepicloptera, native or foreign, Moths or Butterflies.

Always ready to exchange specimens from our own or other lands.

Parties either in the United States, or other entutries, having I cepidoptera or Coleoptera, of any country, that they would like to sell, would do well by placing them in my hands for that purpose.

Any persons wishing to purchase specimens, native or foreign, by sending lists of their desiderata, will be arcommodated promptly and satisfactorily, prices in accorlance with the rarity of the species and quntity desired. I will also firnish, when desired, Entomological Pins, Foreeps, Setting Blocks, \&c., \&e., also proenre books, pamphlets, \&e., either new or out of print, whenrer obtainable.

In writing, no matter low often you may have oecasion to do so, always jut under your signature your full aldress, No. of street or Post Office box ; city or town; comnty, shire or province; Slate, Empire, Kingdom, Country ; for it sares much time and tronble to have merely to stance at the bottom of the letter you have just answered, instead of having to hunt up some old letter to find the addiess, or else if you keep a list to have to go through the aldress of several hundred correspondents to find the one wanted. Always 
direct as below, and if you reside out of the United States, instead of Pa. spell Pennsylvania in full and add U.S. of N. America. Thus endeth the preface to these pages of

$$
\text { Yours, truly, }
$$

HERMAN STRECKER,

Box 111 Rearling P. O.,

Berks County,

$$
\text { Pre. }
$$




\section{TEFE CAPTURING}

\section{DAY BUTTERFLIES (RHOPALOCERES.)}

\section{THE IMPLEMENTS NECESSARY.}

The first and of conrse principal thing necessary is a bag-net, (See Fig. XI, Hate I, this can be made, to answer all practical purposes, as follows: the rim you can make by bending a piece of strong ibon wire to form a hoop, twisting the two ends together and filing them sharp that they may be driven into the end of a hantle, or, if the collector be inclined to luxuriousness, and does not wish to axcite the interest of the intelligent mob by carrying so cmrions an implement through the highways on his journey to the glades and wools, he can have the ends soldered fast to a ferrule of sheet iron or tin, which (an be put over the end of the handle when he gets without the eity precincts ; mitil that time the net can be earried under the coat, and the handle will serve conveniently for a walking stick, also as a preventative to the too close intimaer of canines. "To the iron rim there should be affixed a bag made of fine strong anuze-mosfuito nettiug from which the stiffening has been well washed will do; this bag should be eighteen to twenty inches long, and the bottom bound with a strip of muslin which is to he fastened to the iron rim, the diameter across this rim shonld be eleven or twelve inches. The handle should be about as long or a trifle longer than an ordinary walking-stick, if much longer it becomes mwieldy, though practice will make one perfect in anything, except living without food or sleep, and if a person should become handy with a long handle to the net, of eourse the advantage is obviolls.

Nets are made in varions other ways besides that described; in some the rim folds up in sections, in others it is male of steel and can be coiled up like a watch-spring, (re figs. XII, plate I,) all with the one object that they may be put in some big pocket to be out of sight until we are in the fiekls, for in this enlightened land a man can easily earn a reputation for lunacy if he lets it once be known that he is a buttertly hunter or any other kind of hunter except a money hunter; but if the collector be of moderate means, or of no means at all, as is the rase with the writer, then a home-made one consmoted as I have described will answer all purposes satisfactorily, and if he be ambitious to practice with a long handle, one of those fishing rods that are in sections, fitting into one another, will answer excellently.

Besides the net you should be provided with some strong pasteboard or light wooden boxes, lined at bottom with cork, of a size convenient to carry in the pocket; these boxes are to put your specinens in as fast as you catch them. 


\section{THE MODUS OPERANDI OF USING THESE IMPLEMENTS.}

In eatching hutterflies the net ean be put over them whilst sitting on flnwers, bushes, \&c., or with practice they ean be seenred whilst flying, by sweeping the net towards them and the moment they are in it giving it a quick turn that the upper end of the net which encloses the butterfly will hang over the rim, thereby preventing its escape before you have an opporiunity to secure it. If the net is put over the butterfly whilst at rest it is well to hear in mind that in ninety-nine eases out of a lundred the butterfly always thies upwark, so that by tiking the end of the net in the fingers and stretehing it upwards, the insect instead of creeping or flying out below as it might do if it hat decent instinct, will fly upwards to the end or point of the net where it will get imprisoned past all hope.

When they are in the net you can easily kill them by pressing the thorax between the thumb and index finger, (sce fig. XIV, plate I,) the wings being always folded hack; do this whilst they are in the net; in so doing the gauze of the net will be between your fingers and the butterfly, but that makes no difference; do not attempt to put your hand inside of the net and eommence a chase of the captive whieh will end either in its eseape, or what is equally as bad, in its tearing and ruining its beatuful wings; even in securing them through the net, in the manner I recommend, it requires some care and dexterity to do so without mutilating or rubbing off the scales whieh constitute the beanty of their eolouring, but with a little practice it is ealily done, for affer all experience is the best of all teachers, though withal at times a little expensive.

The large butterflies, such as the swallow-tails, (Papilio), mother-of-pearls, (Argynis), de, de., are easily killed, when in the net, with but little danger of dimaging them; but there is a class of most interesting little fellows yelept Skipper, (Hesperilae), so ealled from their jerking, short flight, which when they get into the net keep up a most intolerahle unisanee, not content to submit quietly to their fate, and with no appreciation of the fact that they are to serve the inreat ends of science, they do all to defeat those ends and exasperate the eollector hy flying and buzzing to a maddening extent; but, as says the German proverb, "there are more chains than bad dogs," the way to manage the little fellows is, the moment they are in the net, to hold it at both ends and stretch it auros the knee so that the butterfly is gently pressed between the tolds, then you can finish his existence by pressing the side of the thorax uppermost, the other side heing against your lear or knee, with your thumb nail; or what is a still better plan is to liave with you a small glass jar as wirle, or nearly so, at month as at bottom; it should be about 6 inches high and 3 in dianneter (see fig. XIII, plate I, whieh is a size convenient to carry in a tunch-coat porket; this jar should have a tin cover or top to it, and in the bottom you should have a lump of raw cotton saturated with chloroform; when you have the small hutterfly (Husperia) in the net, grasp the folds in which he is enclosed in a lump in pour hand, and hold them over, or if possible push them into the mouth of the jar ; the oxtor of the chloroform will produce a state of repose in the unruly butterfly in which condition you can take him out of the net and kill by pressure, but I would advise you not to deliy the killing too long, for it takes but a comparative'y short time for them to reeoser from the affeets of the drug-more tenaeious are they of their worthless lives than are we greater human things. 
Besides the butterflies proper there are various moths (Heterocera) that also fly in day time, among them the Humming-bird Hawk-moths (Sesice Thysbe, S. diffinis, S. Buffaloensis, \&c.); these must be treated in capturing the same way as the Hesperidae but as they are large waisted things pressure would spoil their beauty, therefore the killing is done by inserting a needle dipped in oxalic acid or Cyanide of Potash, thrusting it into the head, passing it lengthwise throngh the body once or twice, and they will fold their wings and silently go to rest.

In putting them in the temporary boxes (carried for the purpose) after they are killed, you can put as many on one pin as it will conveniently hold, but with the exception of the Hesperidae and Humming-bird Hawk-noths, all so far alluded to should be temporarily pinned through the side with the wings closed, which preserves the upper and more susceptible surface from being rubbed or scratched by the one pinned above it, as perhaps might accidentally happen if life were not quite extinct.

The Hesperidae and smaller butterflies as well as all night butterflies, (of which more hereafter, should be at once pinned through the middle of the thorax, from the back, and whenever practicable only one on cach pin.

The best time of the day for collecting is from early morning, when they may be picked off the leaves whilst their wings are yet heavy with dew, until two o'clock P. M., of course on clondy, windy or rainy days, you will get nothing lut disappointment and discomfort for your pains, but on a pleasant June, July or August day, with a clear sum and no air stirring, you may reap a rich harvest. If a desirable butterfly be hovering near you, it is ever better not to be too rash, for if you stand still he will flit here and there around you until finally he will come within the sweep of your net or alight, then if you don't secure him you scarcely deserve to, that's all, but to give chase and try to run them down under a July sun, with the occasional slight obstacles of fences, creeks, rocks, logs, furmer's dogs and farmers' boys, (just as bad,) and to find your expected prey wind up snngly in a grain or clover field within sight of the farmer's lonestead, firmer's self in shirt sleeves on porch, farmer's shot-gun within easy reach of farmer's fingers, forms a cumbination of circumstances by no means conducive to one's respecting the third commandment.

The best localities for finding butterflies are gardens in the country, marshes and meadows along the edges of woods, and above all wherever plenty of thistles and sumac are growing, but unfortunately these valuable plants are continually doomed to destruction whenever detected, because they will take passession of ground that some mulettered boor wants for cereals, just as if we couldn't get our wheat from California if the crops failed here, or if there wasn't room enough to grow it; why, you ean buy California flour here anytime at the same price as that ground from wheat raised east. But it is useless to complain, we must, alas, take things as they are, not as we would make them, as the milleninm is still a day or two distant.

Occasionally fine butterflies may be captured sitting in roads on the mud, especially if it be full of little puddles of water. I have often taken fine Swallow-tails, Limenitis, \&c., in such positions.

Cow-dung, decayed fish or a dead suake have a powerful attraction; I have often taken thrce or four at once that were enjoying themselves at such attractive objects.

Do not go on hills in dry, stony woods for butterflies; bear in mind always that swamps, meadows, woods near such, flower and vegetable gardens in the country, and pieces of waste land with creeks running through 
and on which are growing thistles, sumac, blackberry bushes, \&c., are their fivorite resorts, and there you will be rewarded for your pains. But alas, each year these Parradisiacal spots hecome more rare; it has eut me to the soul many a time to see just such places burut over, strewed with lime and plougher up to raise wheat to make bread, to keep the worthless souls in the worthless bodies of worthless beings which live and die without leaving the slightest vestige of a footstep "on the sands of time."

I would further add that for these excursions a coat made of some light woolen material is preferable: linen coats are abominable, as the suspenders, by the aid of perspiration, adorn the back of that garment with a St. Andrew's cross, which, though of no moment to our country cousins, is by no means desirable as we get within the city limits on our return homewarl, if it be still diaylight. This coat should be plentifully supplied with pockets, two inside breast-pockets, one of great eapacity to put the net, rim and all in, if you don't want to carry it in your hand, the other for your handkerckicf, segar-case, small glass jar, de.; it should also have two outside pockets near bottom of coat, the one to put your eollecting box in, and the other for lunch, which latter, although when you start you think your breakfist will last all day, becomes of vital inportance abont the time the sum is directly over your heald, when you will devour every erumb and, like poor Oliver, cly for more. Carry a little India Rubber, leather or tin drinking-cup will you but don't put much water inside of you-it is deleterious dluring these tramps; once give way to the temptation of guzzling ereek water and by the time you are ready to drag yourself home you will be as near a gone case of foundering as any undertaker need delight to see. If you feel thirsty smoke segars, if you can't smoke moisten your lips with a little lemon-juiee or whisky, but don't moisten with too much of the latter so that the last seen of you is adorning the corner of some fence, with the flies hovering around your mouth trying to ascertain whether it was "Mountain Dew" or "Lavan's best proof" that has put you in a position for your friends to be ashaned of you, sir.

It is alway's better on entomologrical excursions to go alone, but if yon must have a compranion let him be one likewise interested in the same pursuit, and when you arrive at the lunting grounds separate with the understanding that you are not to meet until the time arrives for returning home, and if your friend has a $(\log$, (which of course he has), which miserable lortate must of course accompany him on all possible and impossible occasions, (for who ever owned one of those wretehed curs thit did not have it forever walking at his own heels and snarling at every body else's), then in self-defenee, if you want to take a single butterfly that day, follow my advice-put as great a clistance between yourself and your friend as possible. By the way, in order to ward off the effects of the sun's rays on yourself, always arlopt the old plan of putting in your hat sone large leaves (oak, chestunt, ofe.) which have been previously immersed in water; this is a standard preventive of sun-stroke, nor will any one suffer from the effects of the sun's heat striking on the head if he adopts this plan; the leaves should be from time to time dipped in water as they become too dry. 


\section{THE CAPTURING OF NIGHT BUTTERFLIES OR MOTHS (HETEROCERES).}

For these a different mode is necessary; a glass jar like the one used in taking Hesperidae, but if a little wider it will be no disadvantage, slınuld be provided; in the bottom of this should be placed a number of pieces of $\mathrm{Cy}$ anide of Potash, over these plaster of Paris mixed with water to the consistency of molasses, shonld be poured to the depth of an inch or so until the Cyanide is just abont covered; in a short time the plaster will become set and the bottle or jar thus prepared will be fit for use for a long time. During the day many small moths may be detected on the underside of leaves, in shady corners on rocks, under the eaves of out-honses, de.; when one is detected hold the jar over him close to the object on which he is sitting, and he will hecome overpowered by the fumes of the drug and drop into the jar from whence he may be taken ont and killed. This mode is the best that can be nsed for taking Catocalas; these fine moths during the day sit on the trunks of trees, and are scarcely distinguishable from the bark thereof, as their grey lichen-looking upper wings entirely conceal the splendor of the searlet, or yellow under wings, but by looking carefully on the trunks of the trees from the roots up to as high as you can reach you may detect their presence, then eautionsly and earefully elap the poisoned jar over them; the noise caused by your tramping over the dead leaves will often rouse them from their hiding places, and when they again alight you will have opportunity to secure them. The Catocalac are always in much demand for exchanging, and whenever a a species is present you may look for it in numbers; they occur in oak and chestnut woods; \&c., some species are found where willows are abundant; all are conspicuous beautiful insects.

For niglit collecting a preparation of rum and sugar, or beer and sugar mixed to the consistency of sirup should be painted in patehes and strips on the trunks of trees, and other snitable places here and there but not laid on too thick; also you may soak pieces of dried apples and string them with a darning needle on pieces of twine and festoon the fences, trunks of trees and other places with them, this mess in either instance has a wonderful attraction for Noctuae and many will by that means be obtained which otherwise never would have the fortune to grace the naturalist's cabinet; the moths will fly to, and alight on this sweet and delusive mixture and by directing the light of a lantern on them and using your poisoned jar you can make many captures. It is not necessary to take every one out of the jar as fist as it falls in, get as many as it will hold without spilling, and then when the novelty has ceased, go into your quarters at some adjacent firm house and take them out at your leisure, in comfort. Do not be disgusted if your first nighth's experiment results in nothing but an army of ants or hundred-legged-bugs, lut perserere, for though the first or second or third night even may result in nothing, the fourth may pay for all of them; warm dark damp niglits are the most fuvourable, windy ones ain't worth anything; but as in everything clse experience will perfeet the knowledge of which I ean give you only the rudiments.

If arsenic be mixerl with the rum and sugar, it will facilitate matters, but in that ease an old sheet should be spread on the ground beneath the tree-trunk, fence or other object that is anointed with the potion, to receive those which fall overome by the poison.

Many moths may be captured in the evening in the country when they fly into the open windows attracted by your light, clap your jar over them as they 
alight on the walls or table and secure them, some of these small things are of great rarity, and it is among these we must look for new and hitherto unknown kinds, as the larger and more eonspicuous ones, are those to which the most attention has heretofore been given.

And finally in collecting, always bear the following directions in mind:

1st. Always retain a poor or damaged example until you get a better one of the same kind.

2d. Collect all kinds, large and small, beautiful and ugly, searee and common, those that fly by night (moths) as well as those that fly by day.

3d. Get as many different kinds as possible.

4 th. Get as many of each kind as possible.

5th. Recollect that no matter how common a species may be in one locality, there are other places where it is not found at all, and where naturalists wonld be glad to get it.

6th. Alway's endeavor to secure as many of the night butterflies (moths) as possible, hoth large and small, for these have been the most neglecterl.

Tth. Try your utmost to induce your friends in other loealities to collect, for many that may not be found in your neighiborhood, may occur in theirs; and bear in mind that every fifty miles produces variation in many speeies.

8 th. Should any species be taken in eopulation make note of the fact, as in some instances the sexes are very dissimilar, and this is generally a sure way of knowing if they be sexes of the same insect.

9th. Look particularly for varieties and aberrant forms of varions speeies, there occur sometines individuals presenting differences, and in some instances to such an extent as to almost force us to believe they are new species, as is the ease with the variety of Papilio Asterius called P. Calverleyi, of Argynnis Idalia called A. Ashtaroth, of Vanessa antiopa called V. Hygiaca (V. Lintnerii, Fitch), of Pyrameis cardui called P. Elymi, \&c., \&c.

10th. Bear it in mind that some species appear in abundance some years, whilst in others scareely one will be obtained; so in seasons of plenty prepare for dearth, and capture all you can; for should you get a thousand or more of a kind, it is a small number to supply the numerous entomologists in different parts of the world who may want them.

\section{PREPARING FOR THE COLLECTION.}

After you have returned home from the fields and fens with your aceumulated treasures, and have recruited yourself with food, rest you must not, (for if you thiuk of lying down for a few minutes or a half an hour, the demon of inertia will seize you, and your butterflies will lay till some other day, yon can immediately expand the larger examples; the smaller ones are probably too much dricd to attempt them at present, of which more anon ; for the purposing of expanding and drying your specimens you must have setting-bloeks or boards of various sizes (sce fig. I, plate II,) to suit the different examples; these blocks should be made of $\frac{3}{4}$ inch wood, with a groove cut in the middle about $\frac{3}{8}$ to $\frac{1}{2}$ inch deep for the large butterflies and moths, and $\frac{1}{4}$ inch for the smaller ones; the block should be thickest at the two outer edges and a little 
thinner in the middle at the groove, so that the butterflies' wings will stand, when dried, a little higher at the apices than at the base near the body; in course of time the wings will fall a little anyhow, and it they be set exactly horizontal at first, when they sink they will be below level, which finds no favour in the eyes of any except the English Lepidopterists who always set their examples with the wings deflexed. In the centre of the groove there should be a couple of little gimlet lıoles, about $\frac{1}{4}$ inch apart, bored througl! the block; behind these holes, on the back of the block, should be glued or tacked a strip of cork, around which (cork) should be tied a piece of coarse, soft thread long enough to wrap eight or ten times around the block from top to bottom ; now, having deseribed the block, I will tell you what to do with it if your own sagaeity (for which I would not give nuch if you were born in Berlis County, Penina.) has not already pointed out the method of using it. After seeing that the insect-pin is properly inserted in the middle of the thorax of the butterfly or moth, you then pass the point through the gimlet hole in centre of block into the cork fastened behind it where it will stick, of course; then talie the thread (that is fastened to the cork behind) and draw it close over the top of the block, and close, but not tight, over the wings of your specimen facing your left lund, then pass it bchind, across the back of the block, over the top and down the front over the wings ficcing your right hand, and secure the string in a noteh or slit made by a pen-knific on lower edge of block on side faeing your right hand; your butterfly is now secure, but his wings are not spread evenly; one is nearer, probably, the top edge of block than the other, one is nearer the body, perbays, than the other; to arrange this take an insect pin and insert it in the forewing right behind the costil, (the great fiont edge of the wing) one-third the whole length of the wing fiom the body, and draw the wing to the right position and keep it there by sticking (vithont withdrawing first) the pin into the block; do the same thing with the opposite forewing, then with one of the hind wings, then with the last hind wing, thus you will have the four wings properly placed and secured by the four pins sticking through them into the wood (see fig. E, plate II); then unloosen and nnwrap the string on the side facing your right hand and wrap it four times, abont, anound the side of the block, butterflies' wings and all, facing your left hand, then pass it crosswise belind the bluck to the sirle faring your right hand, then wrap it four times or so around that side, butterflies' wings and all, and secure the end in the slit or noteh in edge of block (see fig. F, plate II); then take ont the four pins that have so far secured the wings, as they liare donc their work and are now of no further use in that position, then stand yor block aside in a safe place, not exposed to much sunlight, to dry. If a small or medium sized butterfly it will take a weck to completely dry it that the wings will permanently retain their position, if a large butterfly, moth or Sphinx it will take from two to three weeks to attain that end.

The above method, with strings, will do admirably for day butterfies and the smaller moths, but for large moths, which have heavy fur on them and thick, downy wings, pieces of card bourd must be laid across the wings and secured with a pin in the block above the upper wing and below the lower one (see fig. G, plate II); each card board should be large enough to cover the two wings on one side, from where they join the body to their extremities, for if part of the wing only be eovered there will be a depressed line cut in the fur acruss the wings by the edge of the card. 
What I have tricel to make elear I might have told you my good reader, by word of mouth in a few minntes, but as that was impossible, owing to my not having the attribute of ulsiquitousness, I still hope I have made myself intelligible, but different species will want different little arrangements, which will suggest themselves as necessity requires their use.

\section{CABINETS, \&C, FOR CONTAINLNG LEPIDOPTERA.}

Varions Entomologists employ different kinds of receptacles for their examples.

The plan adopted by myself (see fig. $I I, A$, plate $I I$ ) is to arrange them in drawers which are eentatined in cabinets; the size of the drawers which I use are $19 \times 16$ inches in the clear and $1 \frac{3}{4}$ inches deep, they are made of $\frac{1}{2}$ inch stuff with soft pine bottoms, of course if you are wealthy (which few naturalists in this enuntry are) you can line the bottom of your drawers with eork which of eourse is an advantage, but soft pine will answer every purpose. These drawers have the groove, by which they slide into their places in the cabinets, in the middle of the side, which obviates the necessity of having strips between each drawer and thereby bosing space, in the height of the eabinets, that would hoid a couple of more drawers; in the tops of these drawer's fit narrow wahnut or other hard wood frames with grlasses puttied into them, (see fig. II, C, plate II,) these are removed by merely lifting up and laying aside when neessary; I have three rows of these drawers in each eabinct, the short sides of the drawers heing its front, that is when in the cabinet they are longer from front to back than they are wide. I paint the top edges of the drawer, where the frame and glass fit in, with creosote nceasionally, say whenever I have necessity to work at that drawer I put some on, with a large soft hair pencil or brush, the drug permeates the wood, and keeps away the Dermestes and Anthremus, the pests so destructive to collections of objects of natural history. The drawers shonld be papered insicle with white paper, such as periodieals and magazines are printed on does very well, it costs abont 60 cents a quire, and that quantity will paper at least fifty drawers.

The above plan of receptacle I consider the very best, and it is the one gencrally adopted for great collections all orer the world.

But the drawers shond be made to slide into their places very easily; give them a little play so that you may, when necessary, change them about; thus, we will say drawer No. 20 is the last containing swallow tails (Papilio) and drawer 21 is the first containing the white butterflies (Pieris). Now you get an accession in the Papilio, but your last drawer No. 20, devoted to that genus is full, well, instead of having to mpin your whole eollection to get drawer No. 21 empty for the occupancy of the new ones, you merely talie the last drawer in your eabinet, (which is empty) and pin your new examples in it, you then put the drawer that is next to the last one in the place from whence yon took the latter, and the drawer ahove that in its place and so on until you come to drawer No. 21 which you will then pat in the place of drawer No. 22 and in the space above formerly ocenpied by drawer 21 , you now put in the drawer which was the last in your cabinet and in which you have pinned 
your new Papilio, and the only trouble you had was to put your drawers, from No. 21 to the last, one drawer funther down which of course is a pleasure, for as you pull cach one out to change it to its place below you at the same time have the delight of feasting your cyes on its contents.

Another plan of receptacle is to liave boxes made in the form of books about $12 \times 9$ inches in the elear, and each half $1 \frac{3}{8}$ inches deep in the clear, the two are joined together at the backs by a piece of stout canvas being glued over it, which serves as a linge; when closed the clean sprace is $2 \frac{3}{4}$ inches and the specimens can be pinner on both sides; the superficial space thus occnpied in a double box of above size is $18 \times 12$ inches; the elges where they meet ean be painted oceasionally with creosote to keep out destructive vermin.

The principal objection to this plan of box is that if the greatest care be not taken always in opening and shutting, the force of the air is apt to loosen the wiugs of the examples, especially of the smaller frailer ones.

Ohers have the bottons of the drawers, in eabinets, glass as well as the top, and with little bits of cork gmmmed to the glass to pin the insects on, or else narrow strips of same material or soft wood fastened in, for same purpose, from one end of the drawer to the other; this method has the alvantage of allowing you to turn the lox around to see the under surfice of your examples, but the disadvantage when you want to add new material is fearful; this plan is only good for a finished collection where the owner intends to add nothing more, or for a local eollection wherc you know just how many species you can expect to get and can leave space for cach accoidingly.

But whatever manner of box or drawer is nsed, the great desiderata to be obtained is to keep them ont of the action of sunlight and dust, also do not keep them in a damp place which will engender mould, which ruins Lepidopterous examples past all redemption.

\section{ENTOMOLOGICAL FORCEPS.}

Having now your cabinet you will want foreeps with which to pin your examples into the drawers; these are absolntely indispensable; I wonld sooner do without my spectacles than my foreeps, and the only decent ones I have ever met with in this comntry are those made by Blake \& Co., No. 212 Chester Street, Philadelphia, Pa.; a pair of their make will last you a lifetime, and once in your hands you would as soon think of doing withont your night-cap as of trying to work in your cabinet without them; Mr. Blake, himself, is a practical Entomologist and well known through his writings on the N. Am. Nutilidae, \&c. 


\section{ENTOMOLOGICAL PINS}

are made of all requisite thieknesses, the German pins, which run from Nos. 1 to 5, are the most extensively used and are, withont donbt, the best; they range in prices from $\$ 1.00$ to $\$ 1.50$ per thousand.

The pins used by English Entomologists are much shorter, and the use of them is confined almost exclusively to the naturalists of that nation.

No. 3 German pins are best size for general use as they will do for a small fly and are strong enough for quite a large oue; but with Nos. 2, 3 and 4 you are fixed for any size of Lepidoptera.

\section{THE ARRANGING OF EXAMPLES IN THE CABINET.}

First sce that the examples are spread or expanded in a uniform style, wings of all in same position and all the same height on the pin, and not too high or too low, so that one-third of the pin shows above the insect.

In pinning the insect into the drawer or box, seize the pin, a little above the point, with the forceps which you hold in your right hand, (unless you be left-handed, then vice versa), at the same time whilst pressing the pin into the bottom of box with the forceps, hold the tip of the index finger of left hand gently on the had of the pin until it is firmly fixed and the forceps withdraw ; this will cause the pin to stand perpendicular, for if you fisten it without holding your finger on the haad of the pin you may find that when you remove the forceps your specimen will be leaning to the one side or other.

You begin of course to place your examples at the upper corner facing your left hand; some pin them in single rows up and down, for example we begin with Papilio Philenor, male, right below him we put the female, then below her the next species, Papilio Turnus, male and its female, and so on to the end of the row, and then begin the next, and so on ; of Lepidoptera, of the size of those just mentioned, drawers like those previously described will hoid four rows, of Vanessans, Coliades, \&c., six rows, and of Lycaenidae, \&c., cight to ten row's. This plan is cconomical as regards space, but terribly troublesome, when rou get new species which must be wedged $\mathrm{i}_{\mathrm{i}}$ between some of those already in, and necessitates the mpinning of half a drawer or hox perhaps, with beginners this may be pleasant, with old hands it is simply waste of time.

The plan which I have adopted and earried out in a eollection, embracing some forty thousand examples, is as follows: I place them in double rows, thus, we will take for example that wroup of Pieris of which P. Protodice is the common American representative, I have placed first a male of $P$. Protodice then right aside of it the female, then I place another male, with the under-surface turned up, directly under the first male, then a female showing the under-surface under the first female, then a male of $P$. vernalis with its female aside of it and below cach a reversed specimen and so on, the following will illustrate plainly my plan. 
Pieris Protodice, male.

$$
\text { " " male, reversed. }
$$

Pieris Vernalis, male.

$$
\text { " " male, reversed. }
$$

Pieris Callidice, male.

$$
\text { " " male, reversed. }
$$

P. Protodice, female.

$$
\text { female, reversed. }
$$

P. Vernalis, female.

" " female, reversed.

P. Callidice, female.

" " female, reversed.

and so on, ad libitum, if you have the specimens.

If I have but three examples of a species I place them thus:

Pieris Autodice, male. P. Autodice, female. P. Autodice, male, reversed.

putting the third, male or female as it may be, in the middle, below the two upper ones. When I acquire the fourth example I remove the third, and place it directly under the upper one of its own sex, and the newly-acquired fourth one under the other upper example.

If 1 have only a single example of a species I place it in the middle between the two rows, like $P$. Leucodice below:

$$
\begin{gathered}
\text { Pieris Callidice, male. P. Callidice, female. } \\
\text { P. Leucodice, male. }
\end{gathered}
$$

Pieris Autodice, male. P. Autodice, female.

When I get its mate I push the one I already have directly under the fly above, and put the new one aside of it.

This plan shows the whole insect-male, female, upper and under surfaceat a glance, and besides gives room for additions, for if I get an example of another species of the Pieris near $P$. Leucodice, before I get the second Leucodice, I can temporarily let it oceupy the position that the future $P$. Leucodice will have, until I have the good fortune to obtain the latter.

Of course, if you have varieties of the same species, or aberrant forms, or monstrosities, you place them under the examples of the normal form of whatever species they may have sprung from. Also, you can place below them the preserved larva, chrysalicts, as well as any parasites that infest the species, so far as you may be able to obtain them.

\section{IABELING THE EXAMPLES,}

which is of incalculable importance, can be done best as follows: you should have the labels of white card-board witls plain black borders printed on them, and three or four dotted lines within; on these you write, or print with pen and ink, the name, author's name, synonyms when necessary, name of work in which the species was first described, locality where found, and if it be a type specimen state the fact. Here are examples: 


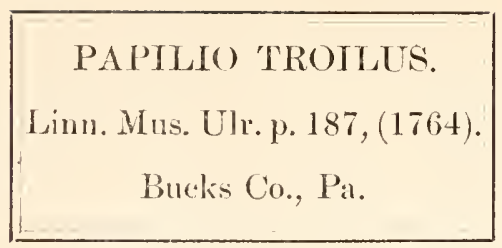

PAPILIO COPANA.

Reak., Proc. Ent. Soc., Phila. II, p. 141, (1863).

The above is the most exhaustive way of labeling, but will save rou much future trouble; you may, however, shorten it by leaving out the work in which it was first described, thus:

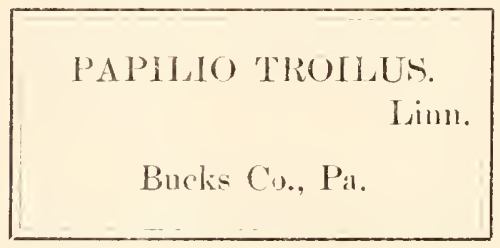

PAPILIO COPANT. Copan. Reak. (Original type).

Always remember that the name of the author is as necessary as that of the species.

If you don't know the name at all, never neglect to state the locality; when you have the same species from different localities you can have snaller labels for each locality, only using the large label with the name for the first two of a species, and giving each of the other localities one of the smaller labels, thus:

\section{PIERIS OLERACEA, Trenton, N. .I.}

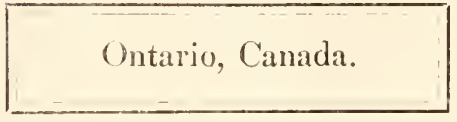

Lalvrador.
Great slave Lake.

Massachusetts.

'These labels are fastened to the bottom of the drawer or box, directly above the specimens of the insect designated, by a short pin at each end.

Many Lepidopterists collect the species of their own country or locality only, others, those having the greatest collections, place the species from ail comtries together, which I hold to be the only proper way, as nature has not set connty lines in such matters, and the species of all parts of the world are but links in the great chain, and by omitting those of some particular country you break the chain, and must produce discordancy. In my own collection, hefore referred to, I have placed those from all countries together, thus: in the nrange-colored forms of the Coliades I have them native and foreign arranged in the following manner: 
Colias Eurydice, $\sigma^{\lambda} \uparrow$, Cal.

" Cerbera, io , Bugota.

" Cosonia, o’ $\sigma^{7}$, Georgia, \&e.

"Aurora, o, A moorland.

" Eurytheme, o우, Cal.

" var. Kewaydin, o ${ }^{\prime}+, \mathrm{Cal}$.

"var. Ariadne, $\sigma^{\gamma} q$, Cal.

"Vauterii, ơ, Chili.

"Pyrothoe, ơ + , Brazil.

" Erythrogrammus, o 7 Bogota.

"Myrmidone, $\sigma^{\lambda}+$, Hungary
C. Chrysotheme, $0^{\lambda}+$, Hungary.

"Electra, o` $q$, Cape Good Hope.

" ? Fieldii, o", Himalaya.

"Edusa, ơ , Germany, de.

" var. Helice, Germany, \&c.

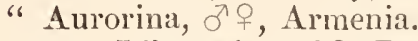

" var. Libanotica, $\sigma^{\nearrow}+$, Persia.

" var. Heldreichii, ठౌ, Greece.

"Sagartia, $0^{\top}+$, Persia.

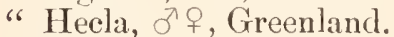

"Meadii, $\sigma^{\lambda}+$, Colorado.

-and so on, gromp after gioup, just as they seem nearest to eaeh other in structure, de, regardless of locality.

It is never amiss to have the same species represented by examples from various localities, as it is vastly interesting to see what changes may be produced by climatic and other causes, as for instance Limenitis Misippus, which is red in the northern States, the same colour as Danais Erippus, is very dark brown almost blackish in Florida, where it resembles auother species of Danais called Berenice; and the female of the Central American form of Papilio Asterius has a broad sub-marginal band or row of yellow spots on all the wings like the male, whilst the female in the common United-States form is almost altogether devoid of these spots; in the female of the same species from Labrador the vellow band is broader even than in those from Central America, which is still more curious when we consider that in those found in the United States, between the two extremes of Labrador and Central America, the female is destitute of the macular band, or has it represented only by a few small, half-obsolete spots.

\section{ON CLEANING SPECIMENS.}

Sometimes a butterfly or moth will be found to be more or less greased on body and wings, always starting at body and extending over the wings more or less, defacing and altogether hiding their beanty. This may be entirely removed by the following process: get a wide glass jar, need not be very deep, put a thin slab of cork in the bottom, the cork should be a trifte larger than the inside of the jar, so that it will take a little gentle squeezing to get it down to the bottom tight that it cannot move; pour the hest refined benzine into the jar to the depth of two inches or so, and pin your greasy specimen on the cork in the bottom of jar so that it will be entirely corered with the benzine, then cover the top of 'jar, and let it rest a longer or shorter time-a half an hour generally suffices, but if very bad they need a longer time; when you think the specimen was in long enough, take it carefully out by the pin, and pin it on a piece of cork, stand it in some safe place where it ain't dusty, and do not be frightened at the desolate, slunk appearance of your specimen, for no matter how bad it looks, depend on it, it will come all right; just let it alone ten or fifteen minutes, and you will find it beautiful, brilliant, and 
all the grease gone, or, if any traces of the latter still remain, give it another benzine bath; should the wings, after it is dry and the benzine evaporated, appear a little curled or bent, put it into the slack pot (hereatter described) from twelve to twenty-four hours, or longer if necessary, then tasten on setting block with eard board stretehed across the wings; let it remain on the block three or four days, then take it off and pin in its place in the cabinet, and you will have no cause to complain of the result of your labour.

\section{ON RELAXING AND EXPANDING SPECIMENS.}

Where speeimens are reeeived in papers, with the wings folded, or badly set, or on pins with the wings pointing four ways for Sunday, they should be treated in the following manner:

A large earthen pot is neerled, what the housewife ealls a butter-pot is the best; this is about 10 inches in diameter and 6 or 7 deep, and has a lid to eover it; of eourse if you can't get this kind any other eroekery-ware thing will do, but this is the most convenient in size and shape, being of as great diameter at bottom as at top. Into this you put 2 or $2 \frac{1}{2}$ inches of elean white sea sand, kept by the groeers and ealled silver sand; to not gret it too fine, it is better a little coarse, that which is used to saw marble is the best. Ponr in water enough to permeate through and through it, but not enough to make a slop or to stand on top of the sand,* then smooth the sand over and lay thereon two thicknesses of elean white paper, (don't use paper that is printed on). On this you lay or pin the examples that need softening, then put a couple of pieces of paper over the top of the jar or pot outside, and put the lid on, working it around a little that it squeezes the parper into the joint and fits tight, this paper under the lid is to make a tight joint, as the lids of erockery artieles are not proverbially tight fitting; stand the pot in a dry, cool place, (but not where it is eold enough to freeze); if it be too warm the examples are liable to monld, and to relieve speeimens of Lepidoptera of mould, without injuring them, is impossible; a pieee of gum camphor laid in the pot, or a small vial of ereosote stuek in it in the sand will aet as a partial preventive to mould. Let your pot stand twenty-four hours in peace, don't litt the lid and look in every half hour, but when twenty-four hours have elasped, look at the specimens, try gently if the wings can be moved in any position; if easily moved, take the exaniples out of the pot and expand on setting blocks, according to the same direetions previously given for expanding and drying specimens freshly canght; but with these dried specimens, it is not neceessar that they remain on the setting blocks more than two or three dlays to be fully dried and fit for the eabinet; in fiet, with the smaller ones you will lave to be quick while fixing them on the bloeks lest they dry before they ought to ; it is best to set them on the blocks in a cool room, a damp cellar would be excellent to expand such specimens in, but not to let them stand in after they are expanded; to dry properly they should be put in a dry moderately cool room in a closet with gauze over the doors or in a skeleton box covered with ganze or else merely set on edge

\footnotetext{
*You need not afterwards add iny more water for several months.
} 
on a table in a room where there is not mueh dust likely to be stirred if the specimens get dusty they ean be gently brushed off with a very soft long-haired eamels-hair pencil, but be careful you don't brush the antemua and little pieces ont of the edges of the wings along with it.

\section{REPAIRING SPECIMENS.}

Sometimes in transporation, or from other eauses valuable specimens become more or less broken, and in too unsightly a condition to be fit for the cabinet, but, with eare and patience, this ean be in a great measured remedied.

The best allie-ire to ho used is gum tragatanth mixed with water nntil it is of the eonsistency of jelly ; this adheres to the wings, dries quickly, and is by far the best thing for the purpose that can be used; don't mix gum arabie with it; and if it loes smell a little bad after stamding a week or two that don't hurt it, it will stick just as well as before nature perfumed it.

If the wings of your specimen be split or piees torn ont, you ean, with a small soft hair-peneil or lorush, put a little of the dissolved gum tragaeanth along the parts to be joined, and they will close together; if the pieee be entirely torn out, it is then necessary to back it up by pasting against the under surface a piece of wing taken from a worthless specimen of the same species, or in defanlt of that something that will come very elose to it; it takes practice to do this neatly, and the exigencies of the ase will at times tax your ingenuity to its ntmost.

Of course the less repairing that is done to specimens the better, but where the preservation from further injury depends in its being fixed, we had better take our choice of two evils, and select the least.

Never use glue; or gum arabic, but always gun tracracanth, which is the best; starch or even common flour paste is immeasurably to be preferred to glue, to use this latter is simply barbarous.

\section{MUSEUM PESTS.}

When Anthrenus or Dermestes (the small bectles that infest collections of Natural History) are in a speeimen, their presence may be deteeted by a fine dust on the bottom of the box around the pin on which the infected insect is; as soun as this is disoovered take ont the specimen with the forceps, and whilst holding the pin tight strike the forcops a couple of smart raps on the table; this will dislodge the robber, and you then put an end to his baneful existence in any way that your ingenuity or the magnitude of the offence may suggest. A constant surveillance should be kept over a collection, anointing the drawers with ereosote, de., de. On getting new examples from other parties, it is well first to put them in another box, that is strongly poisoned with creosote; let them renain there tightly elosed a week or so before placing them finally in your collection. 


\section{PACKING AND TRANSPORTATION.}

As no Entomologist is able to collect even in all parts of his own fatherland, let alone in foreign parts, he is obliged to get examples from other localities by exchanging duplicate examples of those found in his own neighborlood, and by purchasing; and, inasmuch as one fine, perfect specimen is worth any number of damaged or defective ones, it is requisite to pay particular attention to the packing for transportation.

We will begin first with the day butterflies (Rhopaloceres); these may be packed singly in papers without expanding; in using this method the butterfly should have the wings folded back, in the position that they oceupy when at rest, and should then be put in a paper folded in a three cornered envelope ; the locality and date of capture may be written on this envelope with lead pencil before putting the specinen in it; the paper used should be soft, not too stiff or heary, and care should be taken, in placing the butterfly in, that its wings or feelers (antenne) do not get eanght in the folds of the paper, and consequently broken or scratehed. The papers containing the butterflies may then be put in a flat segul-box-as many as it will hold; that is, they may be placed in the hox carefully until it is a little over full, so that in elosing the lid down gently it will jress them down and by that means they will not shuthle about loosely in the hox, but eare should be taken that it be not, on the contrary, too full, lest the pressure in closing the box might break them; keep a just medium; before fastening the lid down put in a little gumcamphor, in fine pieces or dust, (a large lump would damage the specimens) to keep vormin :avy until your box reaches its destination, and thereby probably save the contents from destruetion; in the absence of camphor, tobacco dust, will sage or other strong-smelling herbs will do as a substitute.

After the lid is down, it should be secured by having strong paper strips pasted over the edges all around, and if the side and bottom edres are also pasted over with paper it will be an inprovement in the way of keeping the contents safe from the access of vermin; if the paper used be such as is impervious to damp, so much the better, common boiled flour paste is better than glue or gum. Butterflies done up in this way neel no further packing, and may be sent by mail to any part of the United States or possessions, at letter rates of postage, 3 cents per $o z$ or fraction thereof. If the box be not pasted shut, but only tied tight with strong twine, and does not exceed $12 \mathrm{oz}$. in weight, it will go at sample pareel rates, which is much cheaper, being only 2 cents for every $20 \mathrm{oz}$. 1 fraction thereot, but the latter has the disadvantage of being opened by the Post ()ffice officials in the course of their duty, and as these gentlemen and ladies are not all naturalists, or acquainted with the mode of handling sucl objects, damage is sometimes unavoidable; it is best if the specimens are many and valuable to have the boxes pasted shut, even if the postage is higher. I certainly always would prefer that plan. For the arldres you must paste a clean piece ot yellow or white paper on the lid, and write on it always the full address, thus:

Same,

No. of Pust Uftice box, or street, as the case may be, City or town,

County, Shire or Province, State, Kingdom or Empire, Country.

$*$ See Plate 2, C 1, C 2. 
Do not give merely the man's name and town and imagine because he is a valued friend of yours, and known to naturalists, that he is by any means as equally well known to the Post-Office carriers, who have enongh to do without doing hours of work that you might perhaps save them lyy a seratch of the pen. I always direct all letters in full, and of the thousands I have written, I can recollect of but four failing to reach the parties addressed, and in the case of two of these it was owing to the parties having removed to parts unknown; bear these few hints well in mind, and you will save the Post-Office officials, your correspondents, and yourself much trouble and disappointment, and perhaps in some cases loss to yourself.

The packing of moths must be managed differently, for to fold their wings back like the div butterflies is unnatural and compresses the back of the thorax destroying much of the beauty; they should be put on pins; where it is absolutely necessary three or so may be put on one pin, leaving a little space between each; but I would advise this only where it is necessary to make the package containing them as small as possible; it is infinitely better to put but one on each pin; these can be pinned tightly into a that segarbox, lined with cork at the bottom; force the pins in with the forceps, force them through the cork into the wood of the box even, if you chonse, for if only one gets loose during transportation it will ruin probably the contents of the whole box ; before putting them in see that the abdomens are all tight; if 'one be loose put a little dissolved Gum Tragacanth on below where it is joined to the thorax, this you do of course with a small camels-hair pencil or toy paint brush. With the larger motls and Sphingidge it is necessary to secure the abdomen by a little raw cotton drawn over it and secured by pins forced into the botton of the box, so if the abdomen should gret loose from the thorax it cannot move from its position or do harm; I will allude further to this in my remarks on packing expanded and prepared specimens to send to foreign parts; when the specimens are all tightly pinned in the box, paste it shut. But in this case, where your examples are on pins, you must put your segar-box, containing them, into another larger box of light wood or stout pasteboard, and have the space between the two filled with raw cotton, fine marsh hav, tow or kindrerl soft material ; if you neglect this, your correspondent will have the mortification of receiving the examples without their antenne or abdomens, as it is the soft packing, between the inner and onter boxes, that acts like a spring and breaks the jarring that, of course, anything is subject to during transportation by railway or coach; the space between the box containing the Lepidoptera and the outer box should not be less than one inch. When all is packed, direct it, ask your Postmaster the amount of stamps requisite, see that he carefully weighs it, see that you rub the stamps tightly on with your thumb nail-don't just wet one corner and give them a dab with the end of your finger and let them go-these are trifles, you will say, but attention to then may save, perhaps, moch time and vexation. 


\section{PACKING SPECIMENS ALREADY EXPANDED TO PLACE IN THE COLLECTION, FOR TRANSMISSION TO FORETGN PARTS.}

For this purpose it is best to have boxes made of very stout paste-board, binders' board, or of light wood such as is used for segar boxes; these boxes shoulel be $10 \times 14$ inches and 13 inches deep in the clear, the lids should fit over them, the bottom of the box must be lined with cork or other soft material; cork is the best as it is tenacious and eloses on the pin when it is inserted into it, whilst in aloe pith and such like the pin breaks a hole into it, as it were, and jarring during a long journey may loosen the pin entirely, that it drops out; then the very mischief is loose, as the insect thus freed rolls from end to end of box enting furrows through the lines, of beautiful specimens, it is enough to burn one's heart even to think of it.

In the eentre of the lid of this box, cut a square hole, $3 \times 3 \frac{1}{2}$ inches, and on the outside of the lid, over this hole, lay a pieee of stont glass of about $4 \times 5$ inches, which you secure in its place by first fastening strips of stout paper along its eflges to the lid with gum arabic, (which adheres to glass), and then paste other larger strips over these with flour paste; this will secure the glass firmly in its place; this glass is, of course, only necessary to be put into boxes that have to pass through the hands of Custom House officers; they see through the glass that the contents are insects, and that ends the matter; but were the glass not in they would rip the boxes open where they are pasted shut, and in so doing damage the contents, besides they would not again be pasted shut, and I leave you to imagine in what state your butterflies will reach their destination.

The box just deseribed is the best I know of ; it is light in weight, sufficiently strong, and with eareful packing a great number of examples may be sately put away.

Never use a double box for transportation, in which the insects are to be pinned on both sides; such boxes are only fit to stand on the shelves of a closet, but never to send :iway.

After the bottom of the box has the cork glued securely in, paste clean paper over the cork, when that is dry put a thin layer of elean, raw cotton over the whole bottom; you can secure this by pushing a dull puneh or awl through the cotton into the cork, giving the awl a twist and then pulling it out-the cotton will stiek in the hole; do this here and there, at spaces of about two inehes apart, along the elges.

You are now all ready to put your speeimens into the box; you begin at the uppermost corner, facing your left hand, and pin a butterfly or moth in with the forceps, force the pin in tightly and see that the body is all tight and right, then take another butterfly and pin him aside of the first, letting his wings, facing your left hand, cover the wings of the first one you put in, facing your right hand, then take another, and so on until you get to the edge of the box facing your right hand; then begin a second row, at the same end of the box as you began the first, and when you place the first butterfly of this second row try to get the head and thorax between the hind wings of the Hy right above him, which will cause his front wings to partially eover the hind wings of the specimen right above him; after he is in place take another, and so keep on; Diagram III A, Plate 2, will make the above elear. This method is called shingling, and is used and probably originated with the German Lepidopterists, and a better or prettier way don't exist; it is best to lave 
the specimens in one row, as near of a size ats possible, and in the "ase of largebodied moths ahways secure the abdomen in the manner described on page 23.

Another plan, somewhat similar to that just described, is to begin at the upper corner, facing your left hand, as in previons instance, but, instead of pimning from left to right, to pin from top to bottom of box ; see Diagram III B, Plate 2; but the first plan will be found the hest, on trying.

If you wish to send the names of the examples along, the best plan is to put on the pin, near the point, of each specimen a little piece of paper with a No. corresponding to a No. on a list which you send by mail; thus, No. 5 is on the pin of a white butterfly-your correpondent looks on the list you have sent him, and finds that No.5 is Anthocharis Genutia. Here is the plan of making out lists:

(Ordinary Fory.

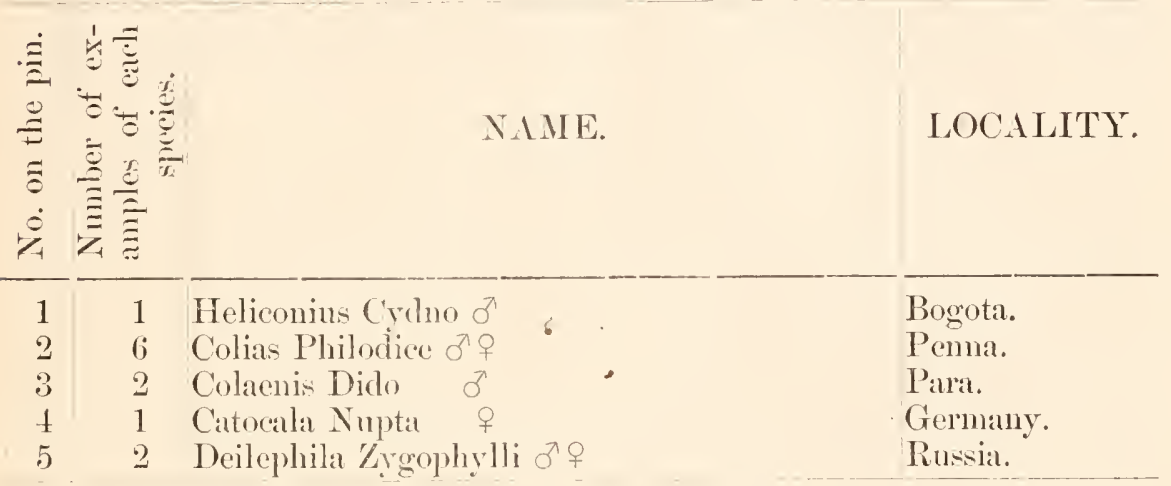

Form ix Which the Exchangixg is done ox a Monet Basis, each Example inatiga a Fixed Price.

\begin{tabular}{|c|c|c|c|c|c|}
\hline $\begin{array}{l}. \dot{\Xi} \\
\Xi \\
\Xi \\
\Xi \\
\dot{\Xi} \\
+\end{array}$ & 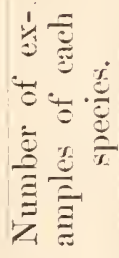 & NAME. & 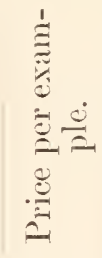 & 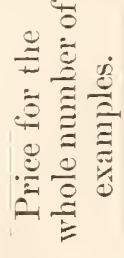 & LOCALITY. \\
\hline $\begin{array}{l}1 \\
2 \\
3 \\
4 \\
5\end{array}$ & $\begin{array}{l}1 \\
6 \\
2 \\
1 \\
2\end{array}$ & 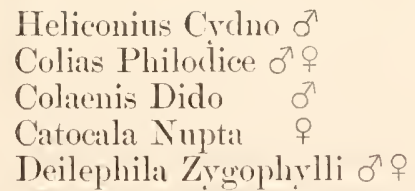 & $\begin{array}{r}80.75 \\
.05 \\
.50 \\
.15 \\
3.75\end{array}$ & $\begin{array}{r}\$ 0.75 \\
.30 \\
1.00 \\
.15 \\
7.50\end{array}$ & $\begin{array}{l}\text { Bogota. } \\
\text { Pemma. } \\
\text { Para. } \\
\text { Germany. } \\
\text { Russia. }\end{array}$ \\
\hline
\end{tabular}

Always kcep a copy of the list, so that if your letter containing it is lost, you can make out another for your friend.

Never send this list in the box or package which contains the butterflies, unless they are not going out of the country, for the revenue regulations are strict as regards sending writing in boxes of goods, and never, on any pretence, send a letter in a box that is to pass through the Customs; it not only 
would get you into tronble, but also your consignee, and the party or company who transport your packages; the penalty would be heavy fines and total confiscation of your box or package.

You now have your butterflies all pinned tightly in the box which presents a beatiful mosaic of tints and shades that the art of man is futile to imitate; after giving then a last admiring look, you may with a brush smear a little creosote on the inside of the lid here and there, not slop it on, but rub a little back and forward with the hair pencil till nearly dry, as it were; then put the lid on and paste it fast with strips of strong paper, so that neither vermin, dust, or anything else can get in-sceure every place; thus they are safely shut in, though you can still get a peep at a small portion of the contents through the glass placed in the lid for the delight of the Custom House officials.

You have now four of these boxes filled and pasted shut (the paste is entirely dry by this time); these, when plared on each other, make a bulk of 13 inches long, 10 inches wide, and $8 \frac{1}{2}$ hight, allowing for some fine hay or layers of old, soft paper to be placed between each. What you next require is a tight box, made of strong, light, $\frac{1}{2}$ inch wood, to be in the clear 16 inches long, 13 inches wide and 12 inches deep; in this you must put fine, dry marsh hay, tow or other soft, springy material, to the depth of $1 \frac{1}{2}$ inches, then place in one of your boxes of butterfices, all around which, after it is in, will be $1 \frac{1}{2}$ inch space; this space you fill with more hay-don't pack tight, only moderately, so that there is a little spring, as it were-then ptit on top of this box of butterfies, just packed in, a thin layer of hay or a few thicknesses of old, soft paper, and put in then your next box and pack hay around it, and so on until the four boxes are in; there will be then $1 \frac{1}{2}$ inches space between the last box of butterfies and the top of the wooden box enclosing them ; fill this with more hay-not too tight packed, yet not too loose-and screw on the lid of the wooden box; don't nail it, by any means-always serew it-do not use more screws than are necessary, but still enough, then direct plainly as follows :

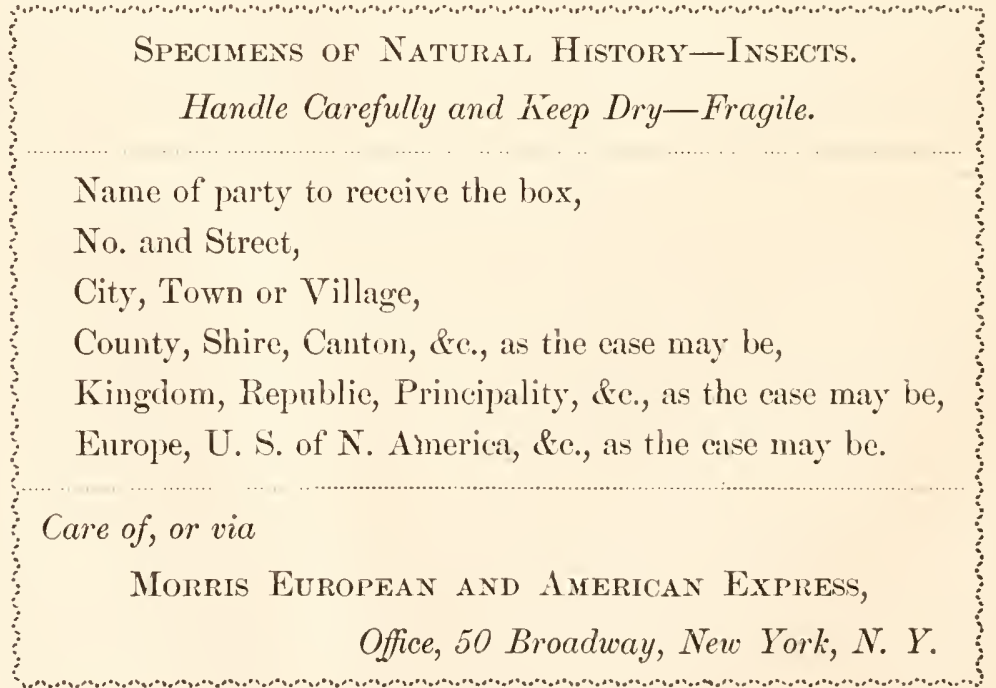


Do this and your box is bound to go safely.

You can also put in pamphlets and other printed matter along with your butterfly boxes, but in that case you must state so in the direction under "Specimens of Nat. History," thus, "Samples of Publication on Nat. History," or whatever it is; but be careful and, as I before cautioned you, never put any letter or other writing in, also put nothing more in than what you state on the outside of the box to be its contents.

You have now all reary for shipment, and though it has cost you trouble, it has been a pleasure to you nevertheless, and you anticipate many additions and new treasures for your collection as the result of this lot.

If you live in New York, you havê only to have your box delivered at the office of the Morris European and American Express, 50 Broadway, N. Y.; get it insured if you wish to-they will do that for you, too, at a moderate rate-and should the vessel go down taking your box with it you will receive its value in moner, which, of course, isn't as satisfactory by half as having your box reach its destination in safety, but, as "man proposes and God disposes," as our old copy-book headers used to say, it is still better than to get nothing at all.

Having paid your insurance and got the receipt therefor, and bill of lading, you have nothing further to worry about; your box will go safe and be delivered at the door of your consignee, be it in Liverpool or St. Petersburg, Alexandria, Bombay, Cape Town, or anywhere else.

There are also other trans-Atlantic Express Cos., but this is the one that has done my principal business, and has always done it well, safely and rapidly, in less time and at less cost than any other company. Their Central European Office is at present 7 Rue d'Antin, Paris.

Principal Office in Great Britain-London: Geo. IV. Wheatley \& Co., Globe Foreign Express-Chief Office, 156 Leadenhall Street. Branch Offices -33 St. Panl's Chmehyard; 23 Regent Street.

Liverpool: Geo. W. Wheatley \& Co., Globe Foreign Express, 10 North John Street.

Hamburg: P. Lehrs, 31 Kleine Reichenstrasse.

Bremen : Heinrich Becker, 39 Langestrasse.

If you live inland, your nearest Express or Transportation Co. will take your box to the nearest office of the Morris European and American Express, and give rou a receipt for its safe delivery; you can also, if necessary or desirable, write at time of shipment, to the Company's Otfice, arlvising of fact of shipment and giving or asking any information desirable.

If yon live in the United States, you can, through this company, have anything brought from Europe or elsewhere, by advising your correspondents to ship by them, as through them you can get a box from St. Petersburg to Sim Francisco and vice rersa.

A box of the size described will eost, to send from New York City to any part of Germany, $\$ 4.00$; this covers all expense except Custom Honse Duties, but objects of Natural History are exempt from all duties whatever.

For further particulars of rates, fe., the Morris European and American Express circulars furnish full details, besides much other valuable information ; these can be had on application, by mail or otherwise, at any of the Company's Otfices.

If you wish to send from the United States to Canada, or vice versa, the same.precantions are necessary and must be observed, as there are also Custom Houses on the Canadian line, but you can forward your boxes, \&re, to Canarla by the Central Express whose ageneies are almost everywhere in N. America. 
If you wish to send to California or far west, or the West, it takes longer and is as expensive, and there is more risk than in sending to or from Egypt. The very best way to get your specimens to or from there, if there be not too large a quantity, is to nse the mail, but if you have such quantity as will make a bulk of 1 to $1 \frac{1}{2}$ cubic feet, use the Express Cos-it will cost frightfully but can't be helped; or, if yet larger numbers that perhaps your boxes will fill an outer case of 24 ins. $x 18 \times 18$, or larger, then use the Freight lines, but when you deliver your box at the Railroad Freight office be sure to get a receipt and a duplicate receipt; the first you keep in some sufe place, the second you send by mail to your consignee, for you will probably, before the boxes reach their destination (if they have any great distance to go), have to begin to trace where they are from both ends of the line; I had the pleasure once of amusing myself for nearly six months that way; res, it actually took over five months to get a box from San Francisco to Riading, lut the box was a large one and only cost $\$ .5 .00$ freight; hat it came by express it would have cost about $\$ 50.00$.

Finally, never send or allow things to be sent by ailing-vessels when you can use steamers; if you do, the conserpunces are, that they are ten times as long on their was, and arrive at their destination puined by mould.

If you live in the United States, never have things sent to you that you will have to try to get out of the Custon IIouse vourself, for they will remain there till they rot, at fir as rou are concerned, for you can't get them out-you ean't do it, don't try it eiren; if ever such an aceident does oecur, apply directly to a Custom House broker and make up your mind it is going to cost you as much, at least, to get it out of the Custom House as it did to get there from any part of Euroje; he resigned, thank God, when after many days you get your hox, and gmand agumst the like occurring again in the futiure.

\section{THE REARING OF LEPIDOPTERA FROM THE EGG AND CATERIPILAAR.}

In order to get the ogos of day butterflies it is necessary to ronfine the live female along with the growing forkt-plant; this has lreen surecefully done by putting over the plant, if it be a snall one', a nail-keg or barel, ont of which the bottom has been knocked; the top' of the keg, after it is placod "rver the plant with the butterfly imprisoned, you cover with a eloth ; the fonmle thus imprisoned will deposit her egge, from which in a few days the young aterpillars will emerge; for there, alle muth be taken in froviding fresh fond

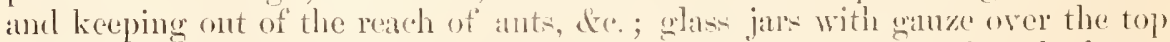

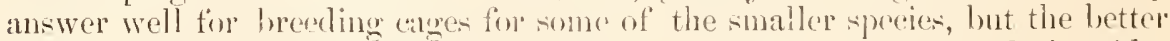
plan is to have lneerling alges, the skeloton of which is worn and the sides fine iron-wire ganze; within this an he stood flaskis of water in which the food-plant may be placed; keap your hreeding ages ont of the sum, the food fresh, and things generally in as near a state as posible to what they onght to be if the larve wore at larese; the size of these ages is not material, hut may

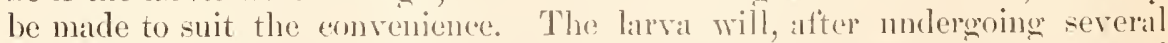
moults, or throwing off' of the old skin, trans form into naked chryalis athixed to the stems or leares of the fooll-plant, or to the sirles of breeding ange, ly 
the tail and a filament at each side, as do the Papilio, \&e., or suspended by the tail alone, head down, as do the Vanessans, \&e. ; in a eouple of weeks the butterfly will emerge and you will thus get specimens in the greatest perfection; to the entirely minitiated I might as well mention that the butterfly, on emerging, will have the wings exeedingly small, scarce one-fifth of the length that they will be when fully developed; all you will have to do is to let the butterfly alone-it knows its own business best-and, as soon as it finds a snitable place to hang on by, its wings will hegin to develop or grow under your eves, and in a short time, a quarter to a half hour or so, will reach their full size and beanty, but it takes an hour or so longer for them to get their strength.

It your larre be of the fall brood, the fly will not emerge until the following spring, remaining in the chrysalis all winter; but if you put the box containing the chrysalids in a warm room, you can thus force them out in a few weeks, but your specimens are apt to be deformed when this forcing process is used.

In obtaining eggs and rearing eaterpillars of moths, a somewhat different treatment is necessary.

The female, when eonfined in anything, will lay her eggs on the sides of her prison or in any other place, and no food-plant or other plant is necessary.

If you capture a viron female, or have one to emerge from the chrysalis for you, of the Satmrniclie or some of the Spangidie, de., seeure her alive in some convenient place ont-doors, and the males will be powerfilly attracted and come to her, from apparently a great distance; thereby she will become impregnated and you will get fertile egges, as well as at the time you may obtain good examples of the males that fly to her; often, when I have had it female come from the coroon, in the house, I have had the males to fly into the windows to her.

With the larva of the Saturnidie and other spinners you may pursue the same course of treatment as in the case of the day butterflies, but, instead of transforming into a naked chrrwalis like these latter, they will spin a silken cocoon and indergo their transtormation therein. But the Sphingidæe, Citheronia, Eacles, de., which undergo their metamorphosis under ground without spinning a cocoon, require more jurlgment and rare; for these, the bottom of the breeding atge should be furnished with 6 to 8 inches ground, moss, sawdust, dead laares, \&u., so that the worms, when they are realy, may go into it; after they have changed to the pupa state they may be put between layers of moss in an open box, alout 6 inches deep, and placed in the open air on a veranda or in a cool room, where they will remain until the following spring or summer, when the moths will emerge; it is necesiary to sprinkle the moss, covering the pupas, owasionally with water. or if there be drizzling rain that is not freezing, as sometimes oceurs, set your box out for awhile and let the contents have the benefit of it. Another way is to sink a halt barrel into the ground and put your moss and pupas in it and let them take eare of themselves; this is getting them into a position as near to nature as is posible, but you must proteet them from rats, de, by putting an old sieve over the sunken barrel; this also is necessary, in spring and summer, to prevent the escape of the moths as they emerge, otherwise they would leave with no thanks for what you have done for them.

Some larva hybernate over winter; these are the most difficult to deal with, for if the situation and concomitants are not just such as suits them they wither up and die. But the best rule to go by, in rearing larva, is to try, 
under all circumstances, to keep them as nearly situated, in all possible respects, as they would be in nature.

Some larva may be fed on the growing plant; if it be a tree, there can be a gauze bag tied over the branch on which they are to feed, and when they have stripped that branch, gently remove them to another by bending it towards them; when they have crawled on to the new branch put the gauze over it as before, and so on; of course, when nearly full-grown, the larræ will have to be removed to the breeding box to undergo their change into the pupa state.

The above plan may be adopted in forcing some species of Diurnals to lay their eggs; it is not convenient to get a puncheon big enough to put over ain apple tree, but you can enclose the end of a branch in a bag, inside of which the butterfly will lay its eggs.

In rearing larva, I would recommend the rearing of large numbers of even the common kinds, as it takes no more trouble to get food for a hundred than it does for a dozen, and not only can you use all the butterflies that result therefrom in perfect condition, but you may be rewarded with varieties, one alone of which might be sufficient reward for years of entomological labour; for instance, if you get from the willows, in June, the black spinecovered caterpillars of Vanessa Antiopa, and transfer them to your breeding cage and feed them a day or so-you need not trouble yourself to get them until they are nearly full-grown, nless yon wish to-they will transform, and in two weeks thereafter will emerge butterflies; now, what may be the result? Well, I will tell you what it was in my ease: one emerged with the yellow band of wings twice as broad as in the normal form, and with no vestiges of the band of blue, submarginal spots that are on the ordinary specimens; this was the rare var. Hygicea, Hdrch., (Lintnerii, Fitch), and any one who each successive season secures the larva of $V$. Antiopa will be sooner or later rewarded with examples of this variety; one friend got three, another one, so vou see the vahue of every season securing as many of the larva of $r$. Antiopa from the willows as possible, and imprison then in your breeding cage; if they all come out the common form no harm is done-you only need stand your cagre on the ledge of the open window, open its door and let them fly out -but if some wondrous variety is among them, how great the reward!

This species produces, besides other varieties, one in which the pale rellow covers the full outer half of all wings; another in which the marginal band of primaries, instead of being yellow, is dark like the rest of the wing.

Also secure all the larva of Pyrameis Cardui, which is found on the thistles; it is brown and yellow striped and covered with spines; though a common species, there sometimes occurs a marvelous variety in which the under side secondaries is plain white, and the upjer surfice is curionsly ornamented with white, wedge-shaped maks on the nervures and nerrules near and at their terminations on the exterior matrin of wings this is the rare Tanessa Elymi, Rbr., occurring both in Europe and $\mathbf{X}$. America.

Pyrameis Atalanta, also, though much more seldom, produres a variety entirely different from the ordinary form.

Argynnis Idalia produces the variety Ashtaroth, in which the upper side of secomblaries is plain black, devoid of " spots, and the under surface las only one great, silver spot; of this species, however, the larve is not ret known, but doubtless, in common with the other Argymidie, it ficeds on violets.

Papilio Asterius grives the splendid variety Calrerleyi, in which the basal half of all wings is black, and outer hatf rich orange. Rear all the larva of 
Asterius you can possibly find-it is a species subject to much variation; there is no trouble at all either to find or raise the larva; it is light-green, banded with velvet black, it feeds on the leaves of carrots, parsnips and allied plants ; if the worm be tomehed it sends, from behind it- head, a forked, yellow affair which hurts nobody.

I would also say of $P$. Turnus that it presents innumerable varicties; this species, as is well known, is dimorphic, having two kinds of females, one yellow like the male, and the other black, but there oceur forms between the two which are neither yellow nor black, but pepper-and-salt, mixed up of both colours; others there are where the upper surfice is black and the under yellow, others where the two wings of one side are black, female, and those on the opposite side yellow, female, others where one side is male (yellow), and the other is female (black).

'There are varieties of Colias Philodice grerish black on the whole npper surface.

Among the moths is also found much variation; Telea Polyphemus oceurs in many colonrs, greyish, brownish, reddish, bright yellow, and almost white, and varies in expanse from $2 \frac{3}{4}$ to over 6 inches.

Should any one, by following my suggestions, be fortunate enongh to breed any of the above or other curions varieties, I would hold it a great favour if they would communieate the intelligence to me with the full particulars.

I would also ask my friends to direct their attention to the raising of the larve of Smerinthus Myops, Sm. Astylus, Sm. Morlestes and Darapsa Versicolor, also to secure Catocala Relicta; these speeies are ahways in high demand, and will command splendid exehanges. In the appended synopsis will be found the names of the food-plants of the Smerinthii, as well as of many others, to which I beg the attention of the reader, as well as also to remind him once again that I need great numbers of all speeies, rare as well as the more common, whether butterfly or moth; every year I need and ean use thousands.

\section{A FEW FINAL REMARKS.}

Entomology, in common with every other earthly pursuit, whether of pleasure or business, requires the expenditure of some money for books, material, occasional specimens, \&c., \&c., and as these are often to be obtained from a distance, in the larger towns or cities, I would advise you never to send money loose in a letter; if it goes anywhere within the United States use a Post-Office money order, or if there is no money order system at your place, get the letter registered; in sending money to Canada, get the letter containing it registered. If you send money to Europe, and the amount be not too large, use the Post-Office money order system-it is admirable; the amount you deposit with your Postmaster is delivered into the hands of your European friend withont any trouble to yourself; if the amount you wish to send be large, then, of conrse, the better way is to get from the Messrs. Drexel, 3d Street, Philadelphia, or Exchange Place, New York, a gold draft payable to the order of your European correspondent, which you send him by mail.

In Continental Europe every species has its price, according to rarity or beanty, and in exchanging abroad it is almost invariably necessary to also affix a cash value to each species you send; as we have no fixed prices in this 
country, it is a little difficult to do so, but ly comparing our insects with the European species of like rarity or commonness, we can place to then the same or approximate prices.

Neatness in expanding and perfection of specimens have been too lightly heeded heretofore in this comntry, as the collector seemed to think if he had captured the insect it was all right, no matter how much it was battered or defaced; it is ever well to bear in mind that one fine, fanltess specimen is worth no end of rubbish, but still, as I have before remarked, in the rery rare species we must be satisfied to take the best we ean get; but if all our collector's would take heed and not put Sphinx pins in Geometrae, and some examples near the head of the pin and some two-thirds down, it wonld enhance the value of their eximples very considerably.

It must be borne in mind that manyspecies, especially Exotics, an only be gotten ly purchase; as the expenses of traveling and living in some comitries are very great, the products of the collector's labours must bring him money to meet those expenses, and as the major part of his collections are generally not the rarest species, it is but reasonable to suppose that the rare species will have to pay for what he loses by the small price of the commoner kinds. Though by purchasing a large number or quantity together, oftentimes rely great rarities are secured at a merely nominal figure; in the prices (except of the European species) there is no set value-the law of demand and supply regulating it; a species that you may get to-day for a dollar may be worth, in a week, five, or what may be five to-day may in a short time fail to one.

As a rule, the species of Siberia and Amoorland are the most expensive, then come certain splendid exoties, such as the glorious Agrias, many of the Papilio, Saturnidse, \&c. Papilio Antimachus, Dru., from II. Africa, of which but few specimens are known, all male, would bring, if it could be at all obtained, almost any price, and there are other species that would command any price. almost, if they could but be obtained.

Then again, many very handsome specics, such as Papilio Sarpedon, $P$. Agamemnon, P. Evemon, P. Phaeton, Callicore Clymena, Vict. Sthenales, Ageronia Arethusa, A. Feronia, \&e., de., \&e., ean be had at prices ranging from 25 cents to $\$ 1.00$ apiece. But as the student gets deeper interested in the study, and better acquainted with the various species through the figlires and descriptions of the different authors, he will better appreciate their value. 


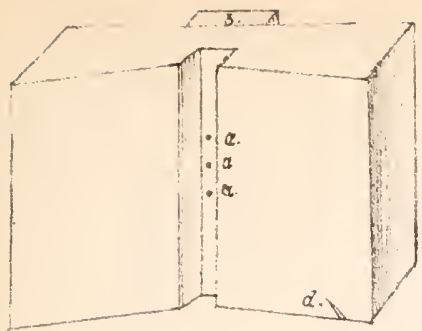

B.

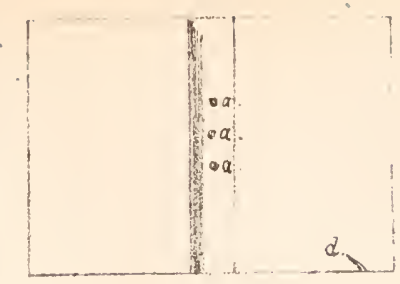

D.

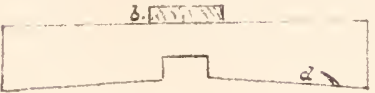

$\mathbb{G}$.
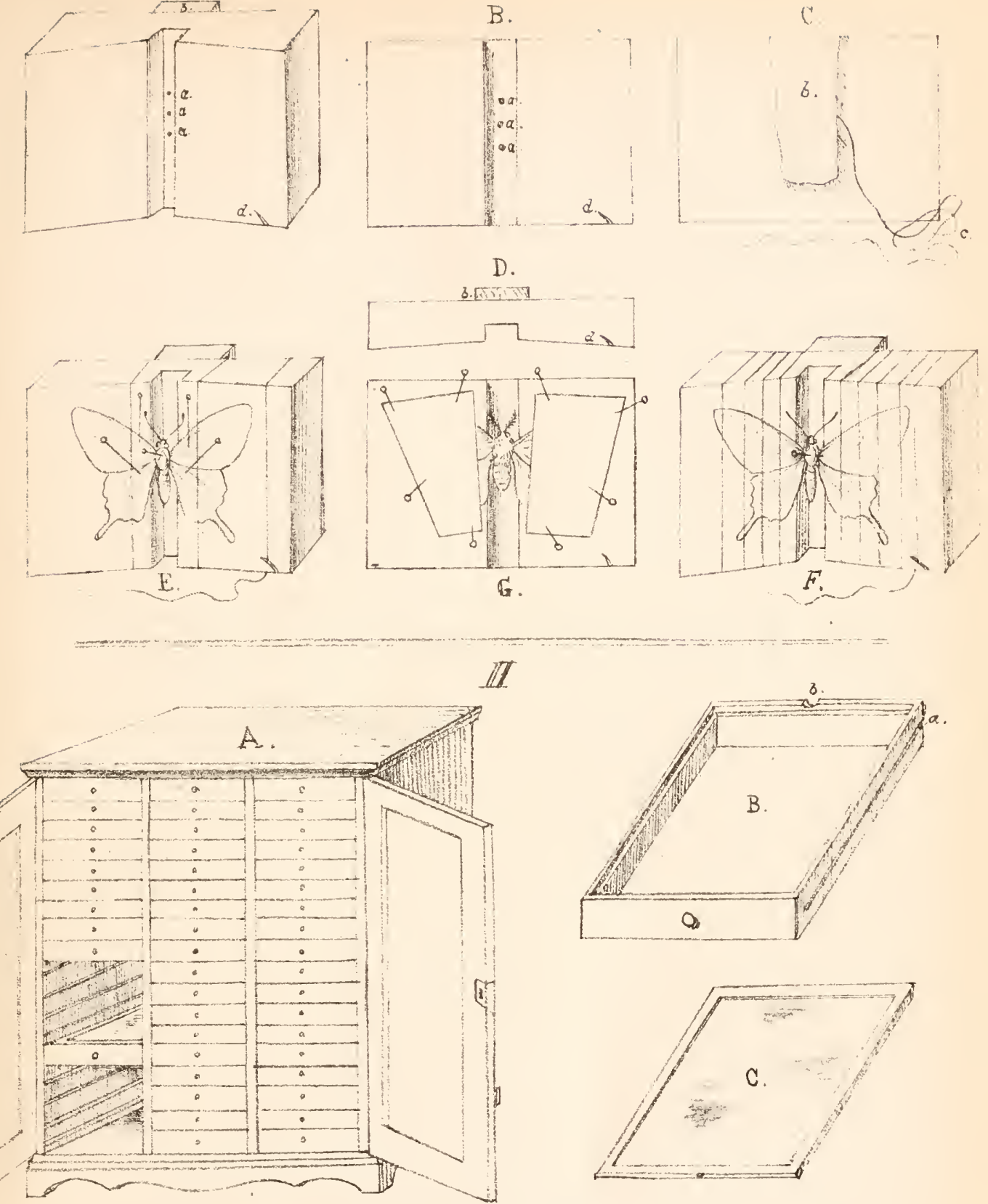

Hemar ?treeker De?

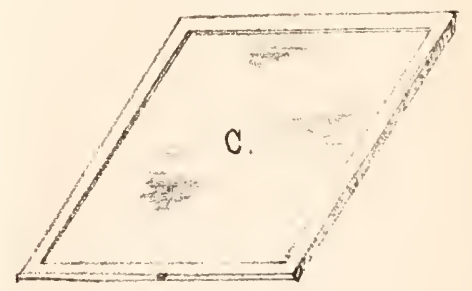

IIIII.
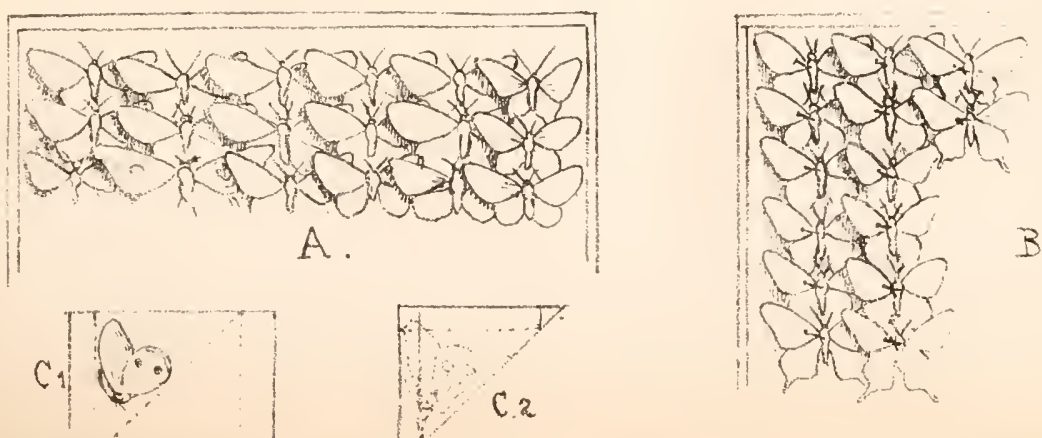




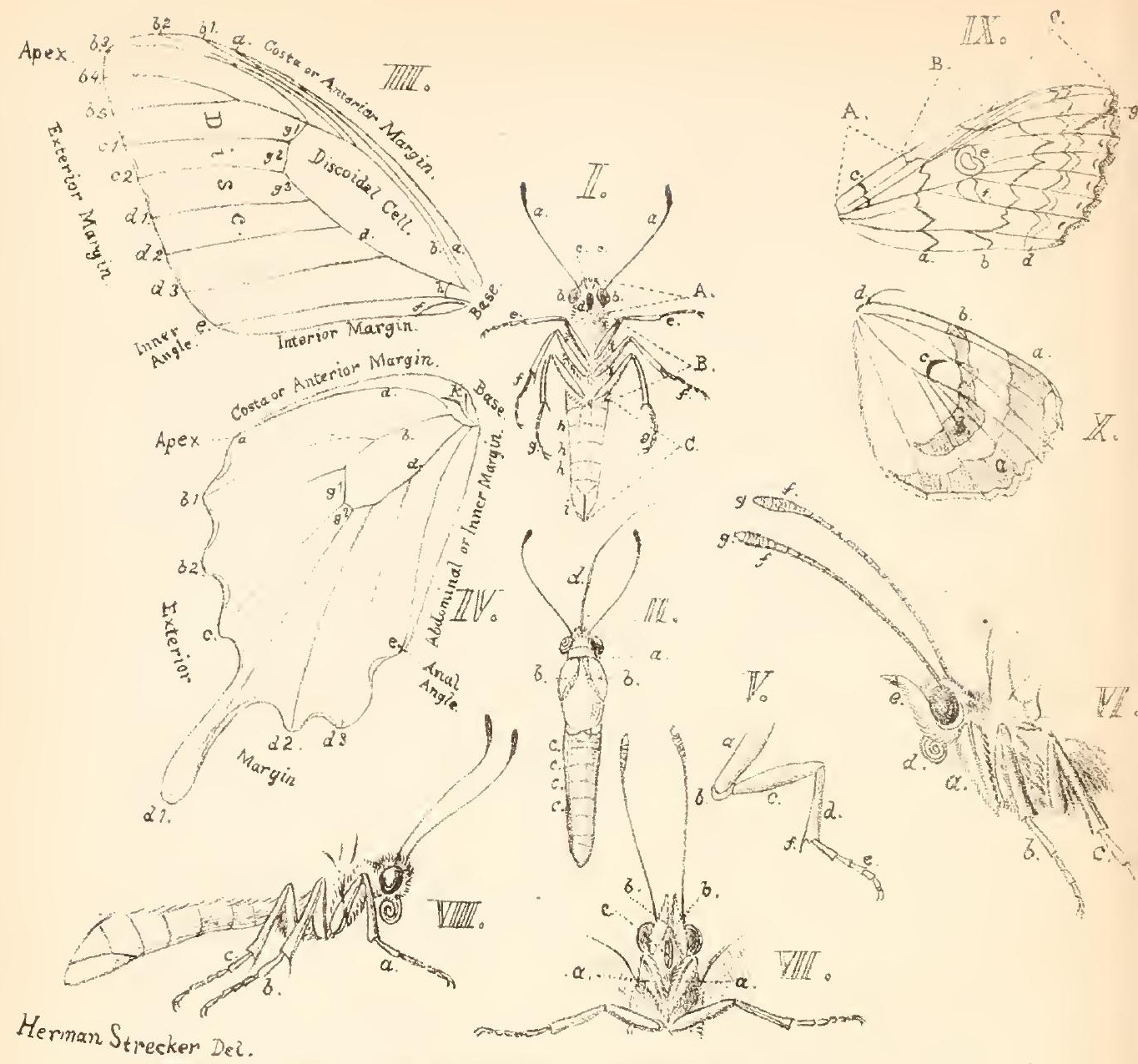

XI.

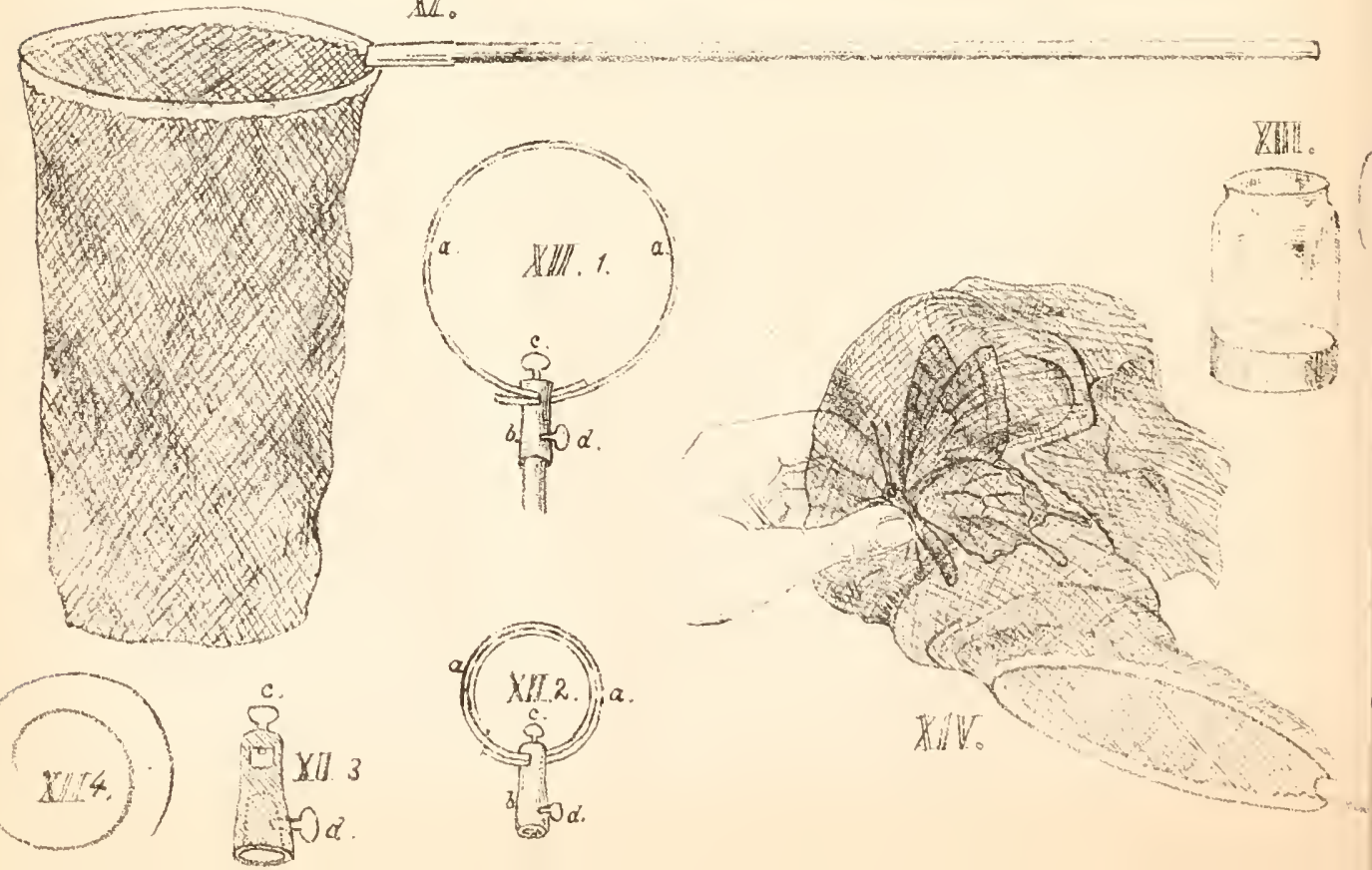




\section{STRUCTURE OF BUTTERFLIES AND MOTHS, AS SHOWN ON PLATE 1, FIGS. I-X.}

\section{Body, Unuer Side, (of Papilio Turnus).}

A. HeaD.

a, a. Antennie, or feelers.

$b, b$. Eyes.

c, c. Palpi.

d. Tongue, or Haustellum.

B. Thorax.

$e, e$. Pedes antici, fore legs.

$f, f$. Pedes medii, middle legs.

$g, g$. Pedes postici, hind legs.

C. Abdomen.

$h, h, h, h$. Segments, of which there are six or seven.

$i$. Anal extremity.

\section{Body, ABove.}

a. Collar.

$b, b$. Scapulie, Tegulie or Pterygodes, shoulder covers.

$c, c, c, c$. Abdominal segments.

III. Primary, or Fore Wing.

a, a. Costal nervure.

$b$. Sub-costal nervure.

$b 1, b \cong, b 3, b 4, b 5$. Sub-costal nervules.

c 1, $c$. D Discoidal nervules.

d. Median nervure.

$d 1, d \%, d \%$. Median nervules.

e. Sub-median nervure.

$f$. Internal nervure, confined almost solely to the Papilioujdat.

$g$ 1. Upper disco-cellular nervule.

$g$ :. Middle disco-cellular nervule.

g. Lower disco-cellular nervule.

$h$. Interno median nervule, found only in Papilionidæe and Morphidee.

IV. Secondary, Posterior or Hind Wing.

a. Costal nervure.

b. Sub-costal nervure.

$b$ 1, $b$ 2. Sub-costal nervules.

c. Discoidal nervule.

d. Median nervure.

$d /, d: d$ g. Median nervules.

e. Sub-median nervure.

g 1, g2. Disco-cellular nervules.

l. Pre-costal nervure. 33 

a. Coxa.
b. Trochanter.
c. Femur.
d. Tibia.
e. Tarsi.
f. Caleares, spurs.

VI. Side view of Head and Thorax of Vanessa (larger than in nature).
a. Abortive fore legs which lay against the breast.
b. Pedes medii.
c. Pedes postici.
d. Tongue.
e. Palpi.
$f, f$. Clubs of antennae.
$g, g$. Tips of clubs.

VII. Front View of Above.

a, a. Abortive fore legs.

$b, b$. Palpi.

c. Tongue.

VIII. Side View of Body of Papilio.

a. Fore legs.

b. Middle legs.

c. Posterior legs.

ix. Primary or Fore Wing of Catocala (C. Parta).

A. Basal area or space.

B. Middle area or space.

C. Limbal area or space.

a. Transverse anterior line.

b. Transverse posterior line.

c. Basal line.

d. Sub-marginal line.

e. Reniform spot.

$f$. Sub-reniform spot.

g. Sub-ipical sharle or dash.

X. Posterior or Hind Wing of Catocala (C. Parta). a, a. Marginal band.

$b, b$. Median or mesial band.

c. Discal lune or mark.

d. Frenulum, simple in male and forked or double in female. 


\section{THE TERMS AND ABBREVIATIONS USED IN WORKS ON LEPIDOPTERA.}

Abdomen. The hind part of the body. Vide Pl. 1, f. I, $c$.

Abdominal groore. The concave shape of the abdominal margin of the primaries, which enclose the abrlomen while at rest, in some families of the Rhopalocera, in the Satyridae and Nymphalidae, for instance.

Abdominal margin. The margin or edlge of wings nearest to abdomen. Vide Pl. 1, f. IV.

Abdominal pouch. In the females of Parnassius and Enryous, a corneons appendage attaehed to the under side of abdomen near the anal $\mathrm{ex}$ tremity.

Abdominal segments. The rings or annulations composing the abdomen. Vide Pl. 1, f. I, C, $h, h, h$.

$A b$.,

Aberration,

An example Aberratio, Lat. widely differing from the parent Abonderung, Ger. f form, as in the cases of the aberrant Vanessa $H y$ gicea (V. Lintnerii, Fitch), Pyrameis Elymi, Argynnis Ashtaroth, etc.

Aberrant form. See aberration. Acuminate. Sharply pointerl.

Alee anteriores. Fore wings.

Alce posteriores. Hind wings.

Alb.

Albus, White.

Alba,

Album.

Albino. Used to designate the white torms of some species, especially in the genus Colias, where, in addition to a female of the same colour as the male, there occurs in most species a white female: as $C$. Helice, which is the albino female of $C$. Edusa, $C$. Pallida of $C$. Erate, etc. These white varieties are always much scarcer than the normal females.

Albinism. The white state of some forms of insects.
Albinous. Relating to albino forms.

Anal. Relating to the hinder extremity of the abdomen.

Anal angle. The angle of wings nearest to extremity of abdomen.- Vide Pl. 1, f. III, IV .

Anal eye. An eye-like spot at or near anal angle of hind wings.

Anal extremity. Hind extremity of abdomen.

Anal ocellus. See anal eye.

Anal spot. A spot near the anal angle of hind wings, distinguished from the anal eve ly being plain and generally of but one colour, whilst the ocellus is formed of consecutive rings of various colours, thus forming an eye-like spot.

Anal segment. The last segment, ring or annulation of the abdomen.

Anal tuft. The brushes or tufts of hair or hairy seales which ornament the extremity of the abdomen in some species, most conspicuous in Maeroglossa and allies.

Anal valves. On the last segment of the abdomen, conspicuous in the males of the genus Papilio.-Vide Pl. 1, f. I, $i$.

Analogue., A species of one country that is analogous to that of another: thus, Colias Eurytheme is the N. American analogue of the European C. Edusa, or Papilio Zolieaon that of $P$. Mrachaon, etc.

Angulated. Where the exterior margin of the wings is dentated and pointerl, as in Grapta, Vanessa and Junonia.

Annulated. Ringerl.

Annulations. Rings or joints, as of the abdomen, antennae, etc.

Antenna. Feelers. - Vide Pl. 1, f. I, $a, a$.

Anterior wings. Sce alae anteriores. Vide Pl. 1, f. III. 
Apex,

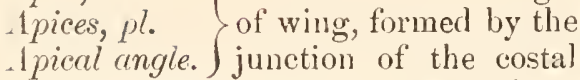

The outermost angle and exterior margins.- Vide Pl. 1, f. III, IV.

Apical. Relating to the apex.

Apical dash. A dark mark on primaries near the apex in many of the Noetuae, especially the Catocalae.

Arcuate, I Applied to the costa Arcuated. S of primaries when mueh rounded or curved in the forn of a bow, as in some of the Attaci.

irea. The surface or a part of the surface of the wing: as basal area or mirldle area.-Tide Pl. 1, f. IX, $\mathrm{A}, \mathrm{B}, \mathrm{C}$.

Argenteous. Silvery.

Articulations. Joints.

Apterous. Without wings, wingless.

Auroral spot. 'The bright orangecoloured spot on the apical part of primaries in the genus Anthocharis.

Band, I A rather even and someBar. $\}$ what broad stripe.

Base, (That portion of the wings Basis. for antennae which join the body or head.

Basal. Belonging to, or at the hase. Basal area. The area of the wing nearest the base. - Vide Pl. 1, f. IX, A.

Basal hairs. The hairs which elothe the parts of the wing nearest the body; in many of the Heteroeeres these are laid on very heavy and thick.

Basal line. The line on primaries nearest the base.

Basal patch. 'The patch of eolour nearest the base.

Bifid. Forked, or divided in two.

Blind-eye. A spot without a pupil.

Bloom. The tine violet dust-like appearance conspicuous on the pupas of Catocala, resembling that on plums and some other fruit.

Bloteh. A rather large, irregnlarformed pateh or mark.

Calcares. The spurs at the end of the tibiae.- Tide Pl. 1, f. V, $f$.

Caterpillar. 'The larval or embryonic state of I epidoptera.
Caudal. Appertaining to the tail.

Caudal horn. 'The horn on anal segment of the larva of 'Sphingidae.

Caudal appendage. 'Tail-like processes on the exterior margin of the hind wings of many species of butterfies and moths.

Caudate. Tailed.

Cells, I The spaces between the Cellulae, f nervures and veins.

Chrysalis, I The second tramsformaChrysalid. $\}$ tion of Lepidoptera. 'The pupa. A nummy-shaped affair, ineapable of feerling, suspended in some instances ly the tail; in others it lies concealed in the earth, or else is protected by a cocoon.

Cillia, , Fringes or hair-like seales Cillicue. fon the extcrior margius of the wings of Lepidoptera.

Ciliated. Fringerl.

Cinereuse, I Grey. Ashen col-

Cineraceous. foured.

Clavate. Club form.

Clavate antennae. Intennae terminating in a club.

Club. The heary terminations of the antemac of day butterflies.-Vide Pl. 1, t. I I, $f, f$.

Clypeus. Eront plate of the hear.

Cocoon. A ease formed by many of the larvae of the Heteroceres previous to their changing to the pupa state. They are sometimes all silk, more or less grummed, and sometimes the hairs of the caterpillar itself help' to form it, or bits of dead leaves, etc., enter into its composition.

Coll. Collectia, collection, museum.

Collai, I The part inmediately beCollare. hind the head.-Fide Pl. 1., f. II, $a$.

Common. Found in more than one species, or, if applied to ormamentation, when the same marks or colour: are "common to both wings, ete."

Concare. Exeavated or hollowed out in a curred form.

Concolor. The same color.

Concolorous. Of the same color.

confuent. Rumning into each other: as confluent spots, spots running into each other. 
Congener. Belonging to the same|Diaphanous. 'Transparent; as in the genus with other species.

congeneric. Of the same kind.

(ontiguous. Joining one another: as "contiguous spots."

('omergert. Direeted or tending towards one point.

(onvex. Curved outwarl.

rordate. Heart-shaped.

('oriaceous. Leathery, tough, stitt'.

(mneous. Horny, of horn-like substance.

comeous pouch. Ser abdominal pouch.

('osta. Front "r anterior' edge of the wing.

Costal. At the costa.

Costal nervure, The great vein on

('ostal rein. f the anterior margin. Vide PI. 1, f. III, IV, $a . a$.

coxa. 'The first joint of the leg which eonucets it with the borly.-Vide PI. 1, t. I, $a$.

Crenute. Having round teeth; scatloped.

rienulated. Havingsmall round projections.

Crescent. A mark the shape of the moon in her first quarter.

Crepuscular. Flying in the twilight, or just before dawn.

crepuscular Lepidoptera. Formerly nsel to designate the sphingidae, at family of Heteroceres that fly in the twilight or groaming.

('rested. Ornamented with a erest of raised seates on the back of the thorax, as in the carse of many of the Noctuas.

("urellated. Hooded.

cipreous. Copper-coloured, or of a roppery tinge.

Dentate. 'Toothed, serrated.

Dentuted. With teeth, as when the m:1rxin of a wing is "dentated" ol" wotherl.

Duticulate, I With small teeth or

Denticulated. f points.

Desideratum. Pl. Desiderara. Sonething that is lacking or wantiug; as "any new species of Colias or Algyrminis are always great desiderata with me. genus Ithomia, where the wings are clear, and nearly destitute of seales. Dilated. Expanded.

Dimorphic, Y Oceurring under two Limorphous $\}$ forms, as in the case of Prupilio Trurus, which has a yellow temale resenbling the male, and another female entirely black; or, as with the Coliades, which have, in addition to a normal-coloured female, anotlere that is quite white.

Dimorphism. The state of being dimorphous.

Disc, Iide Pl. 1, f. III.

Discal. Pertaining to the dise.

Discal bar. A bar or stripe on or very close to the disco-cellular nervules.

Liscal spot. A spot situated at the disco-cellular nervules.

Disco-cellular ceins.-Vide Pl. 1, f: III, IV, $g$ 1, $g$ ? . $g: 3$.

Discoidal idl-Vide PI. 1, f. III, IV.

Diumare. Dry butterflies, Rhopaloceres.

Inumal. Pertaining to day, as the butterfies that fly in the day time only are called diurnae.

bivergent. A plat from each other, as divergent rays.

Iorsal Pertaining to the back.

Dorsal brind or stripe. A band or stripe on the back.

Emarginate. Notehed.

Emarginutions. Notehes or indentations, as in the exterior margins of wings of many species of butterflies and moths.

Evitire. When used in connection with the wings, it means the edges are of an cren curve, without indentations or projertions.

Etc. Etratera, and so on ; in German u. s. w., und so weiter.

Ex., Example. S Speeimen.

Ex laria. From the larva; reared or raised firom the hava.

Lix ouc. From the egg; raised from the egar. 
Ex parte. One-sided; ex parte statement, a one-sided statement.

Expanse. The greatest width across from tip to tip of the expanted fore wings or primaries.

Exserted. Protruded, stuck out.

Externally, Outwardly ; towards

Exteriorly. $\}$ the exterior or outer margin, etc.

Exterior margin. 'The onter margin. Vide Pl. 1, f. III, IV.

Exuvia. Cast-off' skin, as of caterpillars when they molt.

Falcate. Hooked, sickle shaped, as in the primaries of some of the Attaci.

Falcated. Sickle-shaped.

Family, A A group of allied genera, Familia. $\}$ as the family Nymphalidae, etc., etc.

Fascia, A rather broad transverse band.

Fauna. The animals of any given territory; thus, the insect tauna of Labrador embraces all the insects found within the limits of that country.

Femur. Thigh, the third joint of leg. Vide Pl. 1, f. $\mathrm{V}, c$.

Fenestrated. Windowerl; used in connection with those I.epidoptera which have many transparent spots on the otherwise dark surface of the wings, as in case of Heleona Fenes. trata, an Australian species.

Ferruginous. Iron rust coloured, colour of burnt siemma.

F., Fig., $\{$ Figure; representation $f$. fig. $\}$ of an object or specimen.

Filiform. Thread-like.

ilazus,

Ilava, Yellow.

Flavum.)

Flavism. Yellowness; as in a vellow example of a butterfly in which the parent and normal form is some other colour; for instance, in the yellow females of Anthocharis, Sara, and Pieris Sisymbrii, which are exceptions to the ordinary colour of those species, which is white.

Flavescent. Of a yellowish cast, with a tendency towards yellow.
Flexuous. Sinuous, winding; as a flexuous line is a winding, irregular line.

Foliaceous. Leaf-like; as in the under surface of Gonepteryx Clorinde, Kallima Inachus, ete.

Fore wing. Primary, anterior or superior wing. - Vide Pl. 1, f. III and IX.

Fovea. A depression, like in the midrlle of the upper surface of hind wings of Tecophora Forea, from which peculiarity it has derived its name.

Fremulum. A strong nerve or bristle, emanating from the costa of hind wing near the root. This is only found in such Lepidoptera as fold their wings while at rest, like the Catocalae and other Noctuae; in the male it is single, in the fiemale double or bifid. - Vide Pl. 1, f. X, $d$.

$\left.\begin{array}{l}\text { Fringe, } \\ \text { Fringes. }\end{array}\right\}$ see cillia.

Fuligmous. Sonty, dusky, smokecoloured.

Fulvous. Brownish-yellow, tawney.

Furcate, Furcated. Forked.

Fuscous. Blackish brown.

Fusiform. Spindle-shaped, tapering at both ends; thus, fusiform antennae are antennae which are thickest near the middle.

Gamma. The third letter in the Greek alphabet. A silver spot in the shape of a gamma adorns the upper wings of several noctuae, among them Plusia Gumma, L., which has very appropriately received its name from that circumstance.

Ganglion. Pl. Ganglia. Centres of the nervous system, from which are thrown off the various nerves.

Geminate. Twin, in pairs; as gemimate spots are two spots nearly alike in size, and close togcther.

Generation. Biood.

Generatio prima. First or spring brood.

Generatio secunda. Second or summer generation or brood. 
Genital armour. The outer easing, Hirsute. Hairy; covered thickly with anal hooks, etc., of the organs of hair, as the larvae of the Aretiidae. generation.

Genus. Fl. Genera. A collection of allied species.

Glabrous. Smooth; devoid of hair or granulations.

Glaucous. Hoary, or grevish-blue or green.

Globose. Prominently round; like a globe ; crlobular.

Gramulated. Rough, like the grain of coarse stone, full of innumerable little prominences and wrinkles.

Griseous. Light grey, eomposed of a combination of black and white atoms ; grizzled.

Hab. Habitat. Locality, home.

Hyaline. Transparent like glass. See diaphanous.

Hybrid, I Mongrel, bastard. Hybridus, Lat. $\}$ Produced by the mixture of two species. - Vide Hybrida ex Sinerinthus, Ocellata et Smerinthus Populi. Humphreys Brit. moths t. 1. (1843). Lep., Rhop. et Het., Strecker, Vol. 1, t. VII.

Imago. The final and perfect state of an insect.

Immaculate. Spotless, pure; devoid of all spots or markings whatever.

Inferior's. Hind wings, Secondaries. Vide Pl. 1, f. IY and IX.

Inferior surface. Under surface.

Hastate. Shaped like the head of a Inferior wings. Sce inferiors. halberd or dart.

Hatched. Closely marked with numberless short, transverse lines.

Haustellum. Proboscis, sucker.-Vide Pl. 1, f. I, II, VI, d.

Haustellated. Having a proboscis-like tongue.

Hermaphrodite, I An example

Hermaphroditus, Lat. $\}$ which is both male and female, or partly each. Vide Angeronia prunaria, Nat. Lib. Vol. VII, Ent. t. 27. Papilio Castor, Wien. Ent. Mon., Vol. VII, t. 19. Papilio Asterius and Saturnia Promethea, Proc. Ent. Soc. Phil., Vol. IV, p. 390. In our own eolleetion are also a number of Hermaphrodite examples.

Heterocres. 'The second of the two great divisions of Lepidoptera, embracing the Sphinges, Bombyces, Noctuae, Geometrae, Pyralidina, Tortrieina, Tineina, Micropterygina, Pterophorina and Alucitina, the greater part of which fly at night.

Heterocerous. Pertaining to the Heterocera.

Hexapod. A six-footed animal, as the true insects.

Hexcopodous. Having six feet.

Hind wing. The inferior wing, or secondary. - Vide Pl. 1, f. IV and X.

In. Initio. In the beginning; eommencement.

Inner angle. Posterior angle, formed by the meeting of the exterior and interior margins. - Tide Pl. 1, f. III.

Inner margin. The margin or edge of wings nearest the abdomen. Iride Pl. 1, f. III, IV.

Internelly. Inwardly, towards the thorax.

Interior margin. See imner margin.

Intermuted. Broken; as, an interrupted line is a broken line, ete.

Iridescent. Showing the refleetion of the prismatic or rainbow colours.

Irrorate, P Powdered with minute Irroruted. $\}$ seales or dots.

Isoluterl. Alone, by itself; as, an isolated spot, mark or dash, ete.

Labial palpi. Small organs attached to the labium.

Labium. Lower lip.

Labrum. Upper lip.

Lamellate, I Formed of thin plates, Lamellated. $\}$ leaves or scales.

Lamelliforin. In the form of a plate or scale.

Lanceolate, I Drawn out to an acute

Lanceolated. $\}$ point; lance-shaped.

Larva. The first stage of an insect; the caterpillar.

Lateral. On the sides; pertaining to the sides. 
$\left.\begin{array}{l}\text { Lat., } \\ \text { Latimus. }\end{array}\right\}$ Latin.

Lepidopteia. The third great order of insects, according to Linnaeus. They were formerly rlivided into Papilio, or day butterflies, Sphinx, or those which flew at lusk and dawn, and Phalaena, or the nightfliers, but at present we recognize but two great divisions, the Rhopalocera and Heterocera; the former having clubbed or knobbed antennae and the latter with these organs of every form, as filiform, fusiform, pectinate, etc., etc.

Lepidoptere Rhopulor'sa. 'The butterflies that fly by day, and having knobbed antennae. Ferman, Tagfalter.

Lepidoptera Heterocera. Moths, night butterflies, comprising more than nine-tenths of all the Lepidoptera. German, Nachtfalter, or Nacht Schmetterling.

Lepidopteron. A buttertly or moth; a Lepidopterous insect.

Lepidopterous. Pertaining to Lepidoptera.

Limbal arce. 'The outer or marginal area or space of the wing. - Tirle Pl. 1, f. IX, C.

Lincat. Long and narrow, like a line.

L. coco citrito. $\}$ At the place cited.

Longitudinal. Lengthwise; from base to extremity of wing, from head to end of body, etc.

Lunc. A moon-shaped spot or mark. Soce crescent.

Limute. Crescent-shaped.

Lumule. A small erescent or moonshaped mark.

Lamuler', $\}$ Crescent-shaped.

Lamuletert. f

Luteous. Yellow.

Murvlar, \} Spotted; composed of

Merenlaterl. $\}$ spots; as, a macular band is a band formed of spots.

Mu(n)-Levidoptro. Great or large Lepidoptera, comprising all the Rhopalocera, and the Heterocera to Pyralidina.
Major. (Lat. comp. of Magmus, great.) Greater; as, the major part, the greater part, etc.

Mamlibles: Upper jaws.

Marbled. Variegated with irregular lines or blotches of two or more colours.

Margin. The edge.

Marginal. At or on the edges of the wings.

Marginal baud. The terminal band of the wing, extending to the exteriol margin or edge.

Marginal spots. Spots at the exterior margin of the wings.

Maxille. Lower jaws.

Mraxillary palpi. Minute organs attached to the maxillae.

Merlian. On or near the middle of the wing.

Metian cell. The space between the cross nerve and medians. Sometimes it is divided by a longitudinal nervure into two parts, which are called the unterion and inferion median cells.

Median mermese- Vide Pl. 1, f. IIJ, IV,$d$.

Median nerveles.-Iide Pl. 1, f. III, IV, $d 1, d 2, d 3$.

Mediran space. Middle field of wing. rirle Pl. 1, f. IX, B.

Iediun rein. Śce median nervure.

IClanism. In a black state, opposite of Albinism. Like the black female forms of Papilio Tumus.

Melano. A black form or variety.

Melemotic. Relating to melanism.

Mexial band. A band or stripe transversely crossing the middle of the wing, as in the hind wings of the Catocalas.

Mesothou'ax. Second or middle ring of thorax.

Metathorex. Third or last ring of thorax.

Micro-Lepidoptera. Little Lepidoptera or butterflies; commencing with the Pyralidina and continuing to and embracing the Alucitina, the last in the great order Lepidoptera. Middle area. sice middle space. 
Minor. Smaller; as in Asia-Minor, Obliterate. Very ficint. smaller or lesser Asia.

Moult. To cast off the skin; this is done by caterpillars a number of times before they change into the chrysalis, and in many instances each sucecssive moult results in great difference in their appearance.

MSS. Manuscript. Manuscript description; manuscript name; a name or description as yet mupublished.

Mucroncte. Terminating in a short, sharp process, as do the chrysalids of Eacles Imperialis, Anisotu Senatoria, etc.

Mus. Mfuseum. A collertion. Gerinan, Sammlung.

Nucred. Having iridescent, prismatic colonrs, like mother-of-pearl.

Nervures. The main ribs or veins that support the wings.

Neivules. Branches of the nervures; small nervures; veinlets.

Neuration. Arrangement of the nervures and nervules; nervation; venation.

Niger,

Nigrel, $\}$ Black.

Nigrum.

N. in litt.,

Manuscript names;

Nomen in litteris. unpublished name -names that have been only nserl in correspondence, or in a private collection, but not publisherl, and of course nut valid.

$\left.\begin{array}{l}\text { N., } \\ \text { Nomen. }\end{array}\right\}$ Name.

Nomenclature. The technical terms used in any particular branch of seience, or in any order, family or group, ete., in any branch of science.

Nov. sp. New species.

N., $\}$ Number.

Nio.

Nymph. The old term for pupa.

Obconic. Conical, but with the point reversed; inversely conical.

Oblique. Slanting; diagonal to longitudinal and transverse.

Obscurus,

Obscura, Obscure; dusky.

Obscurum.

Obsolete, Wanting, or scarcely Obsolescent. $\}$ discernable; obscured.

Obtuse. Blunted at extremity.

Occiput. The base or lind part of the head.

Occipital. Pertaining to the back of the head.

Ocelli. Simple eyes situated in the rear of the large, compound eyes.

Ocellus. An eye-like spot, like on the hind wings of Smerinthus Ocellata, s. Exececetu and Hypercheria Taria.

Ocellater. Marked with an eye-like spot, formed of concentric rings of various colours.

Ochraceous. Color of ochre or yellow elay.

Oculi. Large, round, contpound eyes, occupying a larese portion of the front part of the head.

Olivaceous. Olive colonr; a sort of greenish-brown, remarkable only for ugliness.

Omnis. All.

Onisciform. Shaped like a woodlonse, as are many of the larvae of the Lycaenidae.

Orbicular, In the Noctuae, a

Orbicular spot.) round spot in the median cell of the fore wings, interior to the reniform.

Original form. The parent form; stem form, from which aberrant or variable types may, in time, be developed.

Original type. The example or specimen frotn which a species was first described.

Oval

Ovate,

Ovoid,

Ovoidal.

Ovipositor. The organ used by insects for depositing their eggs.

Oviposition. Depositing of eggs.

Ovum. Pl. Ora. Egg.

$P$. Page. 
Palpi. Jointed organs attached to'Produced. Lengthened out; elongated. the head; in the Papilio they are Pro-legs. The fleshy legs of caterpilsmall and do not project, but in the Nymphalidae they stand out beyond the forehead, and in Libythea they are of enormous length. - Tide Pl. 1, f. VII, $b, b$

Palpuli. Appendages growing above the palpi in some of the Heterocera, but not present in all species.

Patagia. Shoulder tippets, covering the base of the wings.

Patch. A space or large blotch; as, "a patch of grey near the inner angle." Pectinate, Comb-like; like the Pectinated. $\}$ pectinated antennae of the Saturnidae, which are furnished with regular processes arranged as are the teeth of a comb.

Pedes antici. Fore legs.—Vide Pl. 1, f. VI, $a$.

Pedes medii. Middle legs.-Vide PI.1, f. VI, $b$.

Pedes postici. Hind legs. - Vide Pl. 1, f. VI, $c$.

Pilose. Covered thickly with down.

Planche, Fr. Plate; table.

$P$. Plate; table.

Plumose. Resembling a feather; feathery, plume-like.

Polymorphic. When several different forms oceur in the same species, as in the case of the E. Indian Papilio Memnon, $L$., which has many forms of the female, some with heavy tails, others tailless like the male, all differing more or less from each other in colour and ornamentation.

Porrected. Stretched, or pushed forth.

Posterior margin. Hind margin. See exterior margin.

Posterior wings. Secondaries; hind wings._Vide Pl. 1, f. IV and X.

Primaries. Fore or anterior wings; superiors. - Vide Pl. 1, f. III and IX.

Proboseis. See Haustellum._Vide Pl. 1, f. I, II, VI, d.

Process. A projection, as the fleshy processes on the larva of Papilio Philenor.

lars, sometimes called false legs.

Prothorax. First or front division of thorax.

Pruinose. Hoary; frosted.

Pscudo. Meaning false, as in Lyconca Pseudargiolus, false or counterfeit Argiolus, so named from its close resemblance to Lycana Argiolus.

Pterygodes. Shoulder covers, called also scapulæ. - Vide Pl. 1, f. $I, b, b$.

Pubeseence. Soft, fine hairs.

Pubescent. Covered with fine hair.

Pulcerulent. Dusty.

Pupa. Chrysalis; the second stage of an insect.

Pupil. The centre of an ocellus or eye-like spot.

Pupilled, \& Provided with a pupil; Pupillated. $\}$ as, "all the sub-marginal spots are pupilled."

Quadrate. Square.

Ray. Long, bright marks or streaks diverging from each other.

Recurved. Curved backwards.

Reniform, I A kilney-shaped Resiform spot. $\}$ spot, conspicuous on the wings of Tocture, especially on the Catocales.

Reticulate, Covered with fine lines Reticulated. erossing each other like net-work.

Retractile. Having the power of drawing in, or contracting.

Rhopalocera. The first of the two great divisions into which the Lepidoptera have been divided. They all fly by day, have the antenne terminated by a knob or club, and comprise the Papilionidæe, Pieridæe, Lycenidæ, Erycinidæ, Libytheidae, Nymphalidae, Acraeidae, Danaidae, Satyridae and Hesperidae, though the latter have strong claims to belong to the Heterocera.

Ribs. V'eins; nervtres. German, Rippe or Rippen.

$\left.\begin{array}{l}\text { Ruber, } \\ \text { Rubra, } \\ \text { Rubrum. }\end{array}\right\}$ Red. 
Rudimentary wings. Only partially developed or abortive wings which are stunted or imperfectly formed, and are incapable of producing flight, as in the females of the genus Ocnogyna and Hybernia.

$\left.\begin{array}{l}\begin{array}{l}\text { Rufescent, } \\ \text { Rufous. }\end{array}\end{array}\right\}$ Red ; reddish.

Rugose. Wrinkled.

Sanguincous. Colour of blood.

Seabrous. Covered with small rugged points.

Scales. The covering of the wings of Lepidoptera; it is these that give the beautiful colours and marks to the insect, as when they are detached there remains only the transparent membrane; some Lepidoptera are so sliglutly clothed with scales as to be diaphanous, and are called clearwings; prominent among these are the Sesiidae and Ithomidae.

Sealloped. The margin indented with segments of circles.

Scutate. Shield or buckler-shaped.

Scutellum. A small, triangular part of the mesothorax, situate at its hind end.

Secondaries. Hind wings, inferior wings or secondary wings. - Vide Pl. 1, f. IV and $X$.

Segments. Divisions or rings that compose the body.- Vide Pl. 1, f. I, $h, h, h, f$. II, $c, c, c, c$.

Segregated. Detached or scattered into groups; as, "segregated atoms," groups of loose or scattered atoms.

Semi. Half; and in some instances, partly.

Semi-lunate. Partly lunate, or with a tendency to being crescent-shaped.

Sending. A thing sent; as, a "sending of insects," or, "I received your sending in good order."

Sep. Separate.

Sep. Separatabdruck, German. Separate printed descriptions, etc.; advance sheets.

Series. A suite, row or line.

Serrate, Sharply toothed; as, a

Serrated. $\}$ serrated margin, a margin edged with teeth like a saw.
Setaceous. Like a bristle.

Setiform. Bristle-shaped.

Sctose. Covered with bristles; bristly.

Simple. Plain ; opposed to compound; as, "simple eyes."

Sinuate, Winding; waved; irreguSinuous. lar; sinuous lines; winding or undulating lines.

Simus. A deep indentation.

Spatulate. Spoon-shaped.

Sp., I A distinct kind, differing Species. $\}$ from others in the same genus. Sp. Darwin, \} Darwinian Species Darwiniana. $\}$ species. Species which, through climatic or other causes, have, in course of time, became entirely different from the form from which they had originally sprung.

Spiracles. Breathing holes, situated in the sides of the segments, in both larva and imago, and are connected with the two large traches, which extend aloug the sides of the body.

Spur. A small spine on the tibae. See calcares.-Tide Pl. 1, f. V, $f$.

Spurred. Furuished with spurs.

Squamose. Scaly, corered or clothed with seales.

Squamation. Scaliness.

Stumm, German. Stem.

Stcumform, German. Stem form ; parent form, from which other later forms have originated.

Stemmata. Simple eyes. See Ocelli. Sternum. The lower part of the thorax; the breast.

Streak. A narrow stripe.

Stria. Pl. Strice. A small line; properly, a depressed or indented line. Striated. Marked with tine lines.

Sub. Prefixed to other words, modifies or lessens their force; thins subhyaline means partially hyaline; sub-marginal, near the margin.

Sub-apical. Near the apex.

Sub-apical dash. A not very large dark mark starting from the exterior margin of primaries not far from the apex; most noticeable in the Catocalidae.

Sub-basal. Near the base. 
Sub-Costal. Near or below the costa. sub-hyaline. Partly hyaline or transparent.

Sub-marginal. Near the margin.

Sub-median. Below the middle of the wingr.

Sub-quadrate. Nearly square.

Sub-reniform, I A spot below the

Sub-reniform spot. $\}$ renitorm on the fore wings of the noctnae.

sub-terninal. Near the extremity or enrl, as a sub-terminal joint is the joint next to the last.

Sub-terminal band. The band nearest the last or marginal band, or near without being on the margin.

suffised. Clouded or obseured with a darker colour.

Suffused variety. A variety or form in which some one colour of the wing has predominated and obscured wholly or in past the other colonrs, as in the instance of Argynnis rer. Ashtaroth, Pyrameis rar. Elymi, and others; but it is a freak of great rarity.

Suitr. A large number or line of one speries; Sce series.

Superiors, $\}$ Uppe: or foreSuperior wings. $\}$ wings, primaries.Vind PI. 1, f. III and IX.

Superior Surface. Upuer side or surince.

suture. Indentation or joint between the segments.

Syn., A different name given siynomym. $\}$ to the same sprecies.

synonymous. Meaning the same; as, thus: "in Berks Connty, Pa., to be a scientist is synonymous to being a Iunatic."

Synopsis. A combined, condensed description of all the families, genera, et'., composing a whole order.

T., Plate; table.

Tabuta.

Tail. An elongation of the exterior nargin of hind wing.

Tailed. Provided with tail-like appendages to the hind wings.

Trilless. Withont tails.
Tarsus. Pl. Tarsi. The foot; the fifth and last division of the leg. Vide Pl. 1, f. T', $e$.

Tan'my. Buff; greyish-yellow.

Tegula. Shoulder eovers; Pterygodes. Vide Pl. 1, f. II, b, b.

Tentacle. A process proceeding from the head in some larva; it is either simple or branched. In the larva of the Papilionidae it is $\mathrm{Y}$-shaped, and eau be protruded or drawn entirely in, at the plersure of the animal.

Tentaculated. Prorided with Tentacles.

Terminal. Belonging or pertaining to the extremity or end.

Terminal joint. The last joint as " terminal joint of abromen."

Terminal segunt. The last anuulation or joint.

Terminal horn. A horn sitnate on the top of the last negment in some eaterpillars. See Caudal horm.

Tessellate, Checkered like a chessTessellated. $\}$ board.

Thoracic. Belonging to the thorax.

Thorax. The second great division of the body, situate between the head and abdomen. The legs are attached to this part.- Vide PI. 1, f. I, B.

Tibia, Pl. Tibice. The fourth joint of the leg.- Tide PI. 1, f. V, d.

Tips. The ends of the culus of the antenuae. - Vide Pl. 1, f. VI, g. g.

iboth. A prominence on the exterior margin of wings, generally a nore $o r$ less prolongation of the veins, the hollow spaces between such prominences are called emarginations.

Toothed. Provided with little projections.

Trichece. Air lubes; respiratory organs; these open by a number of breathing holes, called Spiracles, in the sides of the body of both larva and perfect insect; in the latter the principal of these are situated in the first abdominal segments and the 
thorax. In the larvae there is, on each side, one on each segment to the number of ten or eleven.

Transverse. Across the wing from costal to interior margin; or, the borly from side to side.

Transverse line. A line crossing the wing from costa to inner margin.

T. a. line, In the CatoTrunsterse anterior line. $\}$ callas, the line that divides the basal from the middle area on the fore wings. - Tide Pl. 1, f. IX, u.

T. p. line,

In the Cito-

Transverse posterior line. $\}$ ealis, the line that divides the median from the limbal or outer areal on the fore wings. - linle Pl. 1, f. IX, $b$.

Tri-tailed. With three tails on the exterior margin of sccondaries or hind wings.

Trochanter. The second joint of leg; it is between the (nxil and femur. Virle Pl. 1, f. V, b.

Truncate, $\}$ Terminating abruptly, Truncated. $\}$ as if ent squarely off:

Thiberclex. Small wart-like projections.

Tuberculose. Covered more or less with tubereles.

Type. $\}$ The example or

Type specimen. $\}$ specimen from which a species was first described.

Under surface. The under side, the inferior surface.

Lndulate. Wavy, sintious.
Unguis. A claw.

Unicolorous. Of one colour, as when an insect is all of one colour it is unicolorous.

Upper surfuce. Upper side, superior surface, the side exposed to view when the wings are spread.

V., T Species that from eliYar., mate, food or other influTraictas, ence, present differences Tariety, in colour, shape or size Variation from the typical form ; thus some butterflies that are tailed in India and China are levoid of those appendages in the Polynesian Islands, and some that are pale coloured become darker" as they occur further northward.

Veins. See nervures.

Veinlets. See Nerviles.

Vemation. See Nenration.

Tentral. Pertaining to the under side of body or abdomen.

Ventral band.) A longitudinal hand, Vential line. stripe or line on the Ientral stripe. $\int$ under side of the abmen.

Terracose. See tuberculose.

Tioluceous. Inclining to violet or purple.

rillose. Covered with long, soft hairs. Vitreous. Glassy; transparent. See diaphanous.

o. Male.

ค. Female.

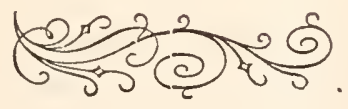




\section{AN ALPHABEITCAL AND EXPLANATORY LIST OF LOCALI- TIES OF WHICH THE LEPIDOPTEROUS FAUNA IS MORE OR LESS KNOWN.}

Abyssinia (Arabic). A country in East Africa, bordering on the Red Sea on the north-east, and on Nubia on the west.

ADELAIDE. The capital of South Australia.

Afghanistan. The eountry of the Afghans; lies between Persia and Hindostan, sonth of Turkistan, and north of Beloochistan.

Afr. Africa. Afrique.

AFrica CENT. Interior of A frica.

Africa mer. Soutl Africa.

Africa sept. North Africa.

Africa occ. West Africa.

A frica Or. Eastern Africa.

Alabama (Indian). One of the United States of $\mathrm{N}$. Am. ; it is south of 'Tennessee, east of Mississippi, and west of Georgia.

Alasisa. Formerly Russian America; the most north-western part of N. Am.

Albania. In the south-west of European Turkey.

A laiers, One of the Burbary Algiria. $\int$ States, on northern coast of A friea, between Muroeco and Tunis.

Alleghaxy (Indian). Alleghany River, Alleghany Mits., in western Pennsylvania and Virginia.

Aleutian Islands. A chain of islands between Alaska and Kamtschatka.

ALPS. Higher mountains of Europe. Alpine. Relating to the Alps.

ALT., Altai Mountains in S. W. Altar. $\}$ Siberia.

Amasia. A town in Asia Minor.

Amazon inf. Lower Amazons. Amazon sup. Upper Amazons. Ambala. North-west India, near the Himalayas.
Ambons, $\}$ One of the smaller of Amboriva. $\}$ the Moluccas, or Spice Islands, the home of Omithoptera Priamus.

Am. America. Amerique.

AMerica Bor. Arctic America.

America sept. North America.

America merid. South America.

Amooriand, Amur. Amurensis. Amurland. The country along the Amur river in the castern part of Chinese Tartary.

Andalusia. One of the southern provinces of Spain.

ANDES. High mountain ranges of $\mathrm{S}$. America.

ANDaman Islands. A number of islands in the Bay of Bengal south of Birmal.

Axiertium. One of the southern of the New Hebrides.

Anglia. England.

ANgola. On the west coast of Africa, below Loango. St. Paul de Loando is the principal settlement.

Anticostr Istand. A large island in the Gulf of St. Lawrence, south of Labrador.

AxTILLES. The great and lesser Antilles, the West Indian Islands.

Axtrocn, $\}$ A town in the northAntiocira. $\}$ west of Syria.

Apolobanba. A town in the province of Beni, in north-western Bolivia.

Appalachicola. (Indian). A town in west Florida at the mouth of the Appalachicola river.

Arabia. The country lying south of Asiatic Turkey, betwcen the Gulf of Persia and the Red Sca.

Ararat. A mountain in Eastern Armenia, 17,100 feet high.

Aral Sea. A large, inland sea in 
south-western Siberia; its southern shores are on Turan.

A RCTIC Regions. The region north of N. L. $60^{\circ}$.

Arizona (Indian). A Territory, bouncled on the west by California, on the south by Mexico, on the east by N. Mexico, and on the north by Útals.

Arkansas (Indian). One of the United States; it lies east of Indian Territory, and north of Louisiana.

Arm., $\}$ North-eastern part of Armenia. Asiatic Turkey.

Aru. Aru Islands. A crroup of islands sonth of the western end of New Guinea.

As. Asia.

Asra Mror. Little Asia; the northwestern part of Asiatic 'Turkey.

Asmañr. In north Guinea, on the west eoast of A firica.

Astrachas. South-eastem Russia; its principal town, of the same name, is at the mouth of the Volgat.

Assa.I. A district of N. E. Hindostan, adjoning Bimah. Also a settlement on the island of Bali.

Athantic States. Those of the United States bordering on the Atlantie Ocemn.

A ustria. The Empire of Anstria, in Germany, is morth of Turkey, west of Russia and south of Prussia.

Australia. The largest island in the world, it lies south of Papua. Its Iepidopterous fauna does not present the sime remarkable forms as in the larger animals, althongh there are inmense Cossidae, some expanding eight inches, besides curious Sphingidue, etc.

Australasia. Contrins Australia, New Guinea, New Zealand, Vandiemans' Land, Solomon's Islands, New Britain, New Ireland, and New Hebrides.

Azores. A group of small islands in the Atlantic, westward of Portugal.

BAHiA. A distriet of Brazil ; Bahia or Sansalvador, on the Bay of All
Saints on the eastern coast is one of the principal cities of Brazil.

BA H A AS. Bahama or Lucayan Islands, a number of small islands east and sonth-east of Florida.

BAfKAL LAKE. An inland sea in Irkoutsk, south-eastern Siberia.

Batcas, ? A triet of comntry, emBalkax. S braeing Dalmatia, European Turkey and Greece.

BALI, An island direct east of BAly. Java, lying between the latter and Lombok.

Banaxa Island. Near the coast of Sierra Leone, west Afriea. The locality of Drury's wondertinl, longtailed Saturnia Argus.

BAxca. A small island, N. E. of Celehes, from which it is separated by the Straits of Banca.

Baxda Istaxds. Some small islands of the Moluceas, lying between the latter and Ohi.

BAxkA. An island in the China Sea, close to and south-eastward of Sumatra, famous for its tin mines.

BARBARY, The north coast of BARBARIA. Afriea, embracing Moroceo, Algiers, Tunis and Tripoli.

Batavia. The eapital of fava.

Batcuiax. One of the Moluceas, near the southern extremity of Gilolo.

Benring's Strait. The namow strait that separates Asia from Ancrica; it is but 40 miles wide.

Belarum. Kingrlom of Belgium, nortli-east of France.

Beloocmistan. The country south of Afghanistan, and between Persia and Himclostan.

BexGal, Y That part of Hindostan Bexgalia. S that lies on the Ganges.

Bermudas. Small islands in the Atlantic, eastward from Georgia.

Beyrat, A town on the west Beyrout, $\}$ coast of Syria.

Bhotan. In the north-east of Hindostan, near Assam.

Brвман. A part of Farther India, lying hetween Hindostan and Siam, and bordering on the south on the Bay of Bengal. 
Bissao. Portugese possession on the coast of Senegambia, West Afriea.

Вітн. $\}$ North-western Asia

BrthyNiA. M Minor.

BoHenia. In the north-west of Austria, south of Saxony and east of Bavaria.

Bolrita. A republic of South America, north of Buenos Ayres and between Brazil and Peru.

Boybay. A district on the west coast of Hindostan. Its eapital bears the same name.

Bootan. See Bhotan.

Boothia-Felix. In Arctic Ameriea, north of Prince William's Land. The types of Colias Boothii were taken there by the 2d Ross expedition in 1832 .

Bor,
Boreals. Aretic.

Bonxeo. An immense island lying south-east of Farther India, north of Java, and south of the Philippines.

BourBon. Isle of Bourbon.

An Island in the Intian Ovean east of Madagascar.

Bouru. One of the Moluccis, lies west of C'erim and Amboina, and sontl of (Obi and Batchian.

Brazil, Empire of Brazil in Brasmla. SS. America.

Brisbane. A town on Moreton Bay, in New South Wales, East Australia.

Britannia. Great Britain.

Britisil Anerica, $\}$ The British Brmisi Columbia. possessions in N. America, eomprising, with the exception of Alaska, all that part north of $\mathrm{N}$. L. $49^{\circ}$.

British Guiana. Demerara, Essequibo and Berbice.

Buevos Ayres. That part of $S$. America east of Chili, south of Bolivia, and north of Patagonia.

Bulgaria. A territory in the eastern part of European Turkey, separated from Wallachia on the north hy the Danube River, while on the east it borders on the Black Sea.
Burias. A snall island, near the south-eastern extremity of the great island of Luzon.

BurmaH. See Birmah.

Butos. One of the Molurcas, close to and south-east of Celebes.

Caffraria. On the sonth-east coast of Afriea, east of Cape Colony. Tatal is its principal town.

Calabar. New and Old Calabar, two settlements on the coast of upper Guinea, West Africa.

Calabria. Extreme southern province of Italy.

Calcutta. The largest city in Hindostan, situated on the Hoogly river, one of the mouths of the Ganges

Califorsia. On west coast of $\mathrm{N}$. America, borders on the Paeific and is south of Oregon. The Lepidopterous Fauna of this state and.adjacent territories have a wonderful similarity to those of Europe.

Cambodi. In Farther Iullic, east of Siam.

Cameroons. In lower Guinea, west coast of Africa, below Calabar.

Chareta. A town in N. Brazil near the month of the Toeantins river.

Campenchy. On west coast of ' Yucatall.

Cixada. Dominion of Canada, part of the British possessions in North Anerica.

CANARA. A district on west coast of Hindostan.

Caxiries, $\}$ A group of

C.MNARY Islands. Sislands west of Nuroceo.

Cape Const. Coast around the Cape of Good Hope.

CAPE Coloxy. The southernmost part of Africa.

C.IPE of Good Hope. The most sonthern point of Africa.

Cape Tows. Capital of Cape Colony.

C.APE Tork. The northermmost point of Australia; it is the bome of the Ornithoptera eur. Fronomus.

CAPE Verde. On the coast of Senegambia, the most western point of Africa. 
Cape Verde Istaxis. A cluster Cumapas. The southernmost province of islands off Cape Verde.

CAprar. A small river which empties Crill. One of the South American into the Rio Para near its mouth, states, on the Pacific coast sonth of in Para district, north Brazil.

Carolisas. The States of North and South Carolina.

Caroline Islands. A number of small islands in Polynesia, north- Cmisd. Properly that portion of the east of New Guinea.

Caraccas. The calpital city of 'Venezuela; it is sitnated 3,000 feet above the sea; was almost entirely destroyed by an earthquake in 1812 , which buried 10,000 of its inhabitants.

CAshmir, $\}$ The most northern

Cashmere. district of Hindostan.

Caspiay Sea. Great inland sea, having Russia on the north-west, Turan on the east, and Persia on the south.

Catrar. China proper.

Catskilus. Catskill Mountains, on the borders of Greene and Ulster Counties, in eastern New York.

Castrle. Province of Central Spain. It is from here the peerless Saturnia Isabella comes.

Caucasus. Mountains in Georsia, south-east Russia, ranging from the Caspian Sea to the Black Sea.

Cayenne. French Guiana.

Cazamanca. River in Senegambia, west coast of Africa.

Cenebes. A large, very irregularshaped island, lying between Borneo and the Molnceas.

Cent. Am., \} The territory

Central America. $\}$ between Mexico and S. America, consists of the states of Guatemala, Honduras, Nicaragna and some smaller ones. This country is in the enjoyment of almost continual internecine war. Peru, and west of Argentine Republic or Buenos Ayres.

Chiloe. An island directly south of Chili.

Chinese Empire south of Tartary. east of 'Thibet, and north of Farther India.

Chinese Tartary. A great tract of country lying between the Amoor River and China. A part of the Chinese Empire.

Chmborazo. The second highest momtain in S. Am., is 21,427 feet in height. In the western part of Ecuador.

Chirreur. District in West Panama, adjacent to Costa-Rica. Marvelously rich in Lepirloptera. The locality of Dynastor Napoleon.

Chusan, or Tscinusas. A small island near the east coast of China.

Circumpolar. That portion north of N. L. $60^{\circ}$, surrounding the North Pole.

Cochrs Chisi. The part of Farther India on the west bordering on the China Sea.

Colorado Territory. South of Wyoming, east of Utah, north of N. Mexico, and west of Kansas; rich in a peculiar monntain fauna Columia. United States of Columbia, New Granada, the northwestern state of S. America.

Conxecticut. One of the New England States, east of New York and south of Massachusetts.

Conaro. In Lnwer Guinea, west coast of Aflica, between Loango and Anerola.

Ceram. One of the Moluceas, direct COPAx. The ruins of an ancient eity west of New Guinea, and south of in north-western Guatemala. NumGilola.

Caylon. A large island south of Hindostan.

Chatham Island. A small island east of New Lealand. bers of ronderfully carved sandstone idols and altars, of whose origin or history nothing is known, are there succumbing to the effects of time and quietly crumbling away. 
Cordularas. The Andes. A long claain of mountains extending along the whole western coast of South America, from north to south.

Corici. A peninsula X. E. of China, between the Yellow sea and the Sea of Japau.

Coromarnsis. South-east coast of Hindostan.

Corriextes. A cape on the coast of Mozambique, east Africa. Also a province and town in the east of Buenos Ayres, S. America.

Consrca. A large island in the Mediterranean Sea, west of France. The birth-place of Napoleon Bonaparte.

Costa Rich. The nost southern State of Central America, lying between Nicaragua and Panama. It has a glorious Lepidopterous fauna.

Crete. Candia. A large island in the Mediterranean Sea, south of Greece.

Croatia. The most north-western territory of European Turkey.

CuBA. Largest of the West India Islands, is the locality for the gorgeous and rare Papilio Gundlachiunus, P. Caignemabus, and other fine species which occur nowhere else.

Cunsca. A town in the southwestern part of Ecuador.

Curacos. Island north of Venezuela.

Crprus. A large island in the Mediterranean, near to and belonging to Asiatic Turkey.

DAHomer. East of Ashanti, in Upper Guinea, west coast of Africa. The pleasant place where on the death of one of its kings, a few thousands of his slaves and wives are inmolated at the burial of the dear departed.

DАкотА, ? Territory of the United

DAkotur. States, it is bounded on the north by British Columbia, on the sonth by Nebraska, east by Minnesota and west by Montana and Wyoming.
Dalmati. A narrow territory belonging to Austria; it adjoins on the east Croatia, in kur. Turkey, and on the west it coasts the Gulli of Venice.

DAunA-LANT). South-west coast of Africa, above Cape Colony.

DauAscrs. A city in the south-west of Syria.

Davis. Denmark.

DArrex. Tsthmus of Darien, the nariow neck of land that connects North and South America.

DarJielixg. In sikim, northeastern Hindostan.

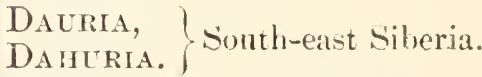

Deccas. Large district in southern Hindostan.

Derallatie. One of the United States, south of Penusylvania and New Jersey.

Delaware Riter. Runs between Pennsylvania and New Jersey, and between the latter and Delaware.

Deuni. A district in northern Hindostan, west of Nepaul and Oude; its capital city, of the same name, was the seat of govornment and residence of the Mroul dymasty.

Demera ra. British Guiana, lies lietween Venezuela and Surinani, ol Dutch Guiana, on the north coast of South America. Georgetown, its capital, is situated at the month of the Demerala Rivel.

DENMARK. Kingdom of Denmark.

Digne. A town in the lower Alps in south-east part of France ncar the borders of Italy; the heautiful and rare Thais var. Honoratii occurs in this locality.

DHaWALAghiri. The highest peak in the world; one of the Himalaya range in North Hindostan; it is 28,070 feet high.

Doner. A point on the north-west of New Guinea.

Dshilola. Gilolir.

Dutch Guiana. Surinam, on the northern coast of S. A merica, between British Guiana and Cayenne or 
French Guiana. It was here that Mad. Merian sojourned in 1699 and 1701 , for the purpose of collecting and studying the material for her great work, the "Metamorphosis Insectorum Suranamersium," which was one of the earliest illustrated works on Lepidoptera published. On the Zoellen plantation, in this district, the original of Cramer's figure of Eudomonia Semiramis was taken, one of the most remarkable moths in the world, having tails to the hind wings five inches long.

EAST Indies. East Indian Arehipelago; the islands in the Pacific; Malaysia, Australasia, and Polynesia.

Ecuador, I Territory in the west Equador. $\}$ of South America, between Columbia and Peru ; it contains the highest peaks of the Andes, Chimborazo and Cotopaxi; the former was ascended by the great Humboldt, in 1797, to the height of over 19,000 feet.

EGA. A town on the Amazon, in Solimoes district, north-irest Brazil.

Egrpt. The north-eastern territory of Africa. The land of the Pharaohs, but remarkably meagre in Lepidoptera, though a land of mighty wonders to the archrologist. ExG. England.

Eqratorial Arrica. That portion of Africa along the Equator, including Lower Guinea, Ethiopia, Zanguebar, ete.

Erie (Indian). Lake Erie, one of the five great lakes of North America, four of which-Superior, Huron, Erie and Ontario, lay between the United States and British Columbia.

Esineraldas. A town on the northeast coast of Ecuador.

Erisiopia. Athiopia, central Africa ; most of it unknown.

$\left.\begin{array}{l}\text { Eur., } \\ \text { Europa. }\end{array}\right\}$ Europe.

Euxine Sea. Black Sea, lying between Russia and Turkey.

Farther Ixdia. Includes Burmah,
Siam, Canbodia, Cochin China, Laos, Tonquin and Malaya.

Fensers. Feejee Islands; a cluster of small islands in Polynesia east of the New Hebrides; the two principal are Takanova and Amboo.

Fenvia. Finnland.

Fernando Po. An island near the northern part of the coast of Lower Guinea, W. Africa.

FEzZAN. Great oasis in Sahara, south of Tripoli.

Firus. The Feejee Islands See Feejees.

Fiximand. The country of the Finns, in north-west Russia, it borders on the north on Lapland, and on the west on the Baltic Sea.

FLA. Florida.

Flores. An island in Malaysia east of Java, between Sambawa and Timor, and south of Celebes.

Florida. The most souchern of the United States; it joins Georgia on the north, its west coast is on the Gulf of Mexico, and its est on the Atlantic Ocean.

Fonte BoA. A town on the Amazon River, in Solimoes distriet, northwestern Brazil.

Fommosa. A great island off the coast of China.

Fr. France. German, Frankreich.

Fresch Gutana. See Cayenne.

Friendey Istasts. A gromp of small islands in Polynesia, east of the Feejees, and sonth of Navigator's Islands.

Gaboon. A river on the Equator, in Lower Guinea, west Africa.

Galapagos. Some small islands on the Equator, west of S. America.

GAlicia. A northern province of Austria, bordering on Russia.

Gallia. France.

Gambia. A river in Senegambia, west coast of Africa.

Gebirge (German). Mountains.

Geniguen. In southern California.

Georgra. One of the United States of N. America; on its north is Tennessee, on the south Florida, on the west Alabama, on the east 
South Carolina and the Atlantic Herrides. Some islands north-west

Oce:tll.

Geongra. In Transcancasia; a tract of eountry separated from sonth-east Russia by the Caucasian Mountaius; on its south are Asiatic Turkey and Persia.

GY. Germany.

Germaxia. Germany.

Gilola. The largest of the Moluccas, lays between New Guinea and Celebes.

Gold Coast. Coast of Ashanti, W. Africa.

Goram. An island, in Malaysia, east of Ceram and west of New Guinea.

Graecia. Greece.

Grasada. Southern part of Spain, bordering on the Mediterranean Sea.

Great Slave Lake. In Northern British America.

Greenland. Polar regions nut theast of British America, it is here that Colies Hecla is found.

Guadaloupe. One of the Little Autilles, south-east from Porto Rico and Hayti.

Guatemala. In Central Ameriea, lies between Hondurats and Chiapas, and borders on the Pacific.

Guaraquil. A town in western Ecuador.

Guaxaca. Sce Oaxaca.

Grines. Upper and Lower Guinea, (') the west eonst of Africal the former embraces Islanti, Dillomey, ete., and the latter Loango, Angola, Bengnelat, tete.

Grlf of Guayadil. On the sonthwest coast of Ecualor.

Hartr. Mayti, or St. Domingo, with the exception of Cuba, the latgest of the West India Islands.

HAKODAII. A eity on the southern point of the island of Yesso, or Jesso, in Japan.

Halicia. See Galicia.

Hawall. Owyhee, the largest of the Sandwich Islands. Capt. Cook was killed there in 1779 .

Helvetia. Switzerland; Schweiz. of Scotland, sometimes called the Western Islands.

Hibenisia. Ireland.

Hmalaya. The great chain of mountains in the north of Hindostan, containing the highest peaks in the world.

Hixdostax. India, south of Tartary, and between the Arabian Sea and Bay of Bengal.

Hispania. Sprim.

Honduras. In Central America, east of Guatemala, and north of Nicaragrua and San Salvador.

Hong-Kong, A city on a little island at the mouth of the Si Kiang River, south-eastern coast of China.

Hudsox Bay. Tast borly of water in British Americi.

Huxgary. Ungarn. A kingdom of Austria, south of Galicia.

Huros. Lake Huron; one of the five great lakes of $\mathrm{N}$. America ; its western shores are on the state of Michigan, and its eastern on Canada. Ib., Peninsula of Spain and Iberia. $\int$ Portugal.

Iceland. A large, Arctic island, northwest of Great Britain, and to the east of Greenland.

IDAHO (Indian). One of the western Territories of the U. S.; it borders on the west on Washington Territory and Oregon, on the east on Montana and Wyoming, on the south on Utah and Nevada, and on the north on British Ameriea.

I.,

ILE.,

IsLe,

Is.

IIl. Indian). One of the Illinois. United States of N. Am.; it is south of Wisconsin, and is bonnded on the east by Indiana, on the west by Iowa and Missouri, and south by Kientucky.

Imertia. Western Transeaucasia. IND., Hindostan and Farther INDIA. $\}$ India.

IndaA Istands. Malaysia, Poly- 
nesia and Australasia.

Ixpiaxa. One of the United States of N. Am., south of Michigan, north of Kentucky, west of Ohio, and east of Illinois.

Indus. A large river in the northwest of Hindostan; it empties into the Arabian Sea.

Insagasuga. The emerald mine district of New Granala ; the home of the glorious Morpho Cypris, of which the matives have a pretty legend that the souls of these most lovely butterflies pass into the emeralds, or vice-versa, I forget whieh.

Ixs. Island.

INS. AND. Anclaman's Islands.

Ins. DARnier. Darnley's Islands.

INs. IND. Indian Islands.

Ixs. KE. Ke Islands.

Ins. Pelcew. Pelew Islands.

Ins. VAx. Vancouver's Island.

INs. WOODLARK. Woodlark Island, one of the Louisades.

Inver. The mouth of ; as, Inverary the mouth of the Ary.

Ionian Islands. Cephalonia, Zante, Santa Maura, Ithica, Corfu, Paxo and Cerigo, all islands belonging to, and west of Greece.

Iow A (Indian). One of the U. S. of $N$. A meriea, lying south of Minnesota, east of Tebraska, west of Illinois, and north of Missouri.

Iran. Persia.

Ireland. One of the British Islands; part of the kingdom of Great Britain.

Irkutsk, T Territory in S. E. Si-

Irkootsk, beria. Its eapital city,

Irkoutsk. bearing the same name, is the emporium of Eastern Siberia.

IRRAWADDI, \{ A large river run-

IRRAWADDY. $\}$ ning through Burmah from north to south.

IsLaNdia. Iceland.

Isle of Bourbon. See Bourbon.

IsLE of MAN. An island in the Irish Sea, south of Scotland, north-west of England.

Iste of Pines. A West Indian Island, south of western Cuba.

IsLe of IVIgHT. In the British Chan- nel directly south of Hampshire.

IsPaHAN. A city in the eentre of Persia, of which kingdom it was formerly the Capital; it is still one of the finest cities in western Asia.

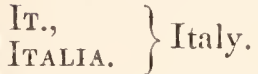

JakuTsk. Territory in eastern Siberia, on the Lena River, which permeates through it, is the town of Jakutsk, or Yakoutsk, one of the principal depots of the fur trade.

Jallore Pass. A pass in the momntains of Koolloo, one of the northern provinces of Hindostan.

JAMAIOA. The third largest of the West Indian Islands; it lies south of eastern Cuba.

JAPAN, \} The Japanese Empire, JaPONIA. $\}$ ennsisting of a ehain of large islands east of Tartary and China. fava. One of the large islands of Malaysia ; it lies south of Borneo and south-east of Sumatra, from whieh latter it is only separated by the Straits of Sunda.

JEDDO, The capital of the Japanese JEDO. Empire, is situater on the east coast of the Island of Niphon, and is one of the most populous cities in the world.

Jerusalem. 'The Holy City, is in the sonthern half of Palestine, between the Dead Sea and the Mediterranean Ocean, and both wouderful and rare to relate, it is equally the Holy City of Israelite, Christian and Moliammedan.

Jilola. See Gilola.

Juar Ferraxdez Islands. Masafinera, Masatiera and Goat Is.; three small islands in the P'aeific, west of Chili, rendered fimous through Dofoe's story of Robinson Crusoe, (Alexander Selkirk, who was left there to take eare of himself for ever so long, and who was, if a tithe of what was said about him be true, a most fortunate and ingenious gentleman.

JUTIA, \} The northern and JUTLAND. $\}$ greater part of Deumark. 
KAmAmazoo. A town in the south west of Michigan.

KАмтспатка, \& A penimsula of KAмтьснаткі. Siberia, between the Okhotsk and Kamtehatka Seas.

KANAWHA. A connty in West Virginia. The home of the peerless Argynnis Diana.

Kiniwha River. A branch of the Ohio River, in west Virginia, running through the comnties of Mason, Putnam, Kanawha and Fayette, and between Raleigh and fireenbrier, and Mercer and Mlomroe.

KANGAROO ISLAND. An island near the south coast of $X . S$. Wales Australia.

Kaxsas. One of the United States, south of Nebraska, north of Indian Teritory, east of Colorado, and west of Missouri.

KE Istands. Directly south of western New Guinea.

K nxTUCKY. One of Uuited States of $\mathrm{N}$. Am., divided by the Obio River on the north from Illinois, Indiana and Ohio, on its east is Virginia, and south of it is Tennessee.

Kers County. In Southern California, lying north-west of San Bernardino, and south of Tulure comnties; it contains a river and a lake of the same name.

This is a sort of a memorial definition; as probably very few yersons now living know, and still fewer care, why it was so named, but inasmuch as the three persons to whom this county, river and lake were dedicated, were own brothers to the writer's matemal relative, he of course feels it incumbent to write these few facts. In Philadelphia were three brothers hearing respectively the names of Ben., Richard and Edward Kern, and they were sons of a certain John Kern, who was a "man in place," having for many years, "1 to the time of his death, which event was caused $b y$ the falling of a derrick in the Philadelpilia Nay Yard, enjoyed the comforts and emoluments arising from the collectorship of the Port of Philadelphia. The eldent of these brothers, Ben., was a doctor, and the other two, Richand and Edward, were artists-all three were naturalists; many years since, when Californis was a terra incognita, these brothers accompanied Fremont on his pioneer expedition over the Rocky
Mts., where Ben. had his career rather summarils ended by either the arrowa of the noble $\mathrm{Im}$ dian or from the slower but less painful effects of cold and starvation, which was the proximate cause, has I believe, never been definitely re1tled, neither at this late date can it be of an material inportance. Some years later, in 1853 , the second brother, Richard, was masiacred along with Gunnison's furveviug party on the Sevier river, by Ltah Indians, who by these sanguinary means became the joyous possestors of sundry mules, arms and engineering instruments. The roungest and surviving brother, Edward, accompanjed Perry's Expedition to Japan, and shorlly after the return of the expedition to the United States, he died of heart-sickness, ol starvation, or something of the sort, which, however, is also at this late date of no particnlar import. Whether the name of these hrothers was bestored on the desolate earth and water in question, by Fremont, or them. relves, or whether it was an honor conferred ly the administration, is a point I am not able to decide, neither does this much matter now, though we will trust it was thelatter, as we have no record of any further or olher acta of munificence done by a grateful government in acknowledment of their services and the sacrifice of their lives. Reyuiescant.

N. B. Capt. Gunnison's name is also rendered immortal by an island in the northern part of Great Salt Lake, which, on a very large map, is represented by a sjot or two quite the size of a speck of fly dint.

Kinchit. A town on the Selinga River in Irkutsk, south east Siberia.

Kirgh.,

Kirrahis,

Kincinus Steppes, $\}$ deserts sontinRiver.

Kholissex, \} North-eastern Persia, Kondskx. $\}$ bordering on Afghanistan and Turkistan.

KonIk. An island sonth of A laska.

Koolison. A mountainous distriet of northern Hindostan.

KORDOFAN. A territory in easteru Africa, south of Nubia, west of Senmal and Abyssinia, and south-east of the Libyail Desert.

KoORILE I-LANDs. A chain of small islands, running from near the south point of Kamtrhatka to near Jesso. one of the Japanese Islands.

Koordistax. 'The territory of the Kurds, a monntainous district (m) the borders of Asiatic Turkey and Persia.

Kuma. A river south of Astrachan, 
in south-east Russia.

Kindistax. See Konmlistan.

Kurntes. See Knorile Islands.

LABRALAIR. The part of British Anerion bordering on the Atlantiv, snuth-west of Grecnlamel. It has a Lepidopterous fauna in which are species found nowhere else on earth, among them Colius Tastes, Aryynnis Poluris, etc. ; these are fomm at I. I. $57^{\circ}$.

LABLAx. A small island near the north-ivest of Borneo.

IA1 $1 \mathrm{~K}, \quad$ A town in north-west IAnAkI. S Thibet.

LAHorit. A city in the Punjat, in north-west Hindostan.

Lake Hate. Se Eric.

L.Ikf MICHicax. One ot the five great lakes of N. Am.; it lies beiween the States of Michigan and Wisconsin, and south of Lake Nuperiol.

Lake Huron. See Huron.

LAKE N'G.ıni. Great lake in the interior of eastern Africa west from Lauzibar.

lakE ONTARIO. One of the great liskes of $\mathrm{Y}$. Am. ; it lies north-west of State of New York.

hAKE Superior. The largest of the five great lakes, it lies betwen the State of Michigan and Canarla West.

LAkE l'cuss. A great inlaul soa in Bornu, Central Africa.

lake Winneper. A lake in the southern part of British America, north-west of Lake Superior.

LAns. A part of Farther India, having Tonquin and Coehin China (1) the east, China on the north, Burmah and Siam on the west, and Cimbolia on the south.

L.t P.x. One of the wenteru districts af Bolivia, the principal town of which bears the same name. Also a town in the sonthern part of lower California.

LAPPLAXN. I The most worth-

LAPPNAA, f western part of Russia, alowe the Arctic liue; it borders on the nortl on the Arctic Ocean.
La Punlua. One of the Mexiean States; its north coast is on the Gulf of Mexieo, and its south on the l'acific Ocean. Its eapital city bears the same name.

LITIXIA. A province in western Russia

Lanco. Distriet of Lower Guinea, west coast of Africa.

Loмвok. One of the chain of islands directly east of Java; it lies between Bali and Sumbawa. Bali is the island immediately next to Java, aud separated from it by the Siraits of Bali or Baly.

La) Cinc Istixds. Off the east roalst of China, and south of Japan.

Los Angelos. A town in the southern part of California, in the comnty of the same name. It was in the latter" that the types of Hymenites c'aliforniea, Lygerna Tejua, Lyecenet Monica, ete., were taken.

Lotisiana. One of the southern United States of N. Am. ; originally sotiled by the French; it is south of Arkansas, west of Mississippi, east of 'Texas, and borders the Gulf of Mexico on the south.

Lovis.me Archipelago. A numbee of small islands near the eastern extremity of New Guinea.

Lustraxia. Portugal.

LUzON. The largest of the Philippine Islands, it lies east from Cochin China and south of the island of lormosa, which latter is off the roust of China.

LYurs. IVest and south-west Asiatie Turkey.

MANsir. A town on south-west end of Celebes.

Macissir Srratts. Run between Bornen and Celebes.

M.seso. An island and town on the estuary of the Si Kiang River, southeastern eoast of China.

MACKexzie's River. A large river in north-western British America.

MAInguicar. A great island off the soutli-cast coast of Mozambique, Africa, from which it is separated by the Mozambique Channel. It is 
here that Thaliura Rhipheus, the most splendid of all known Lepidopterons, is found.

MadeIRA Islands. Some small islands west of Moroceo.

Madjica-Sina. Some small islands inorth-east of Formosa and south of the Loo Choo Islands.

Madras. The capital of the Presidency of Madras, on the Coromandel coast, south-east Hindostan.

Madura. An ishund in the Java Sea, north of the eastern end of Java.

Mageldax. Straits of Magellan, between Patagonia and Terra-delFinego.

MAINE. The most north-eastern of the United States of $\mathbf{N}$. America.

MaLAliar. The south-western coust of Hindostan.

Manacca, The southernmost part MALAYA. $\}$ of Farther India, and is a peninsula south of Siam, on the west the straits of Malacea divide it from Sumatra, and on the east it coasts the China Sea.

Mataysia. The Asiatic Islands, embracing Sumatra, Java, Borneo, Philippines, Celebes and Moluceas or Spice Islands.

Mavada. See Menardo.

MANILLA. The eapital eity of the Philippines, is in the sonth-western part of the island of Luzon, the largest of that group.

Mantehoomi, I North-eastern part Mantenura, of the Chinese emMandshooria. pire; Amoorland.

Maracaibo. A eity of Venezuela, on Maracaibo lake near its outlet.

MArocco. One of the Barbary States, the most north-western part of Africa.

Mamaniayr. An important commereial town on an isiand at the mouth of the Maranham River, in the distriet of same name in the north-east of Brazil.

Marquesas Islanits. One of the more eastern of the groups of Polynesia, they are in the same latitude as the south-eastern end of $\mathrm{New}$ Guinea.

Martinique. One of the lesser Antilles.

Mariland. One of the United States of N. America, south of Pennsylvania and north and northeast of Virginia.

MAss.,

One of the New

Massacinusetts. England States, it lies cast of New York, and south of Vermont and New Hanıshire, north of Connecticut and Rhode Islant, and on the east it fronts the Atlantic.

Matabella. An island south of Goram, and south-west of New Guinea.

Matanzas. A eity on the northern const of western Cuba.

MaUna RoA. A volcano in Owhyhee, Sandwich Islands.

MaUn, I North-west Africa.

Manretania. Algiersand Moroceo.

MAUritues. An island in the Indian Ocean, east of Madlagasear and north-east of Isle of Bourbon. Thaline Rhipheus has also been found on this island.

Mo. Maryland.

Metbourne. The capital of Victoria the south-eastern province of Australia.

MENado. Town on the north-east of Celebes.

Merida. The capital of Iucatan, is in the north-west of that state, about 25 miles from the eoast.

M.,

Mer.,

Mieridionalis.

MEx., I The comntry of the MonMexico. $\}$ tezumas, or rather what is left of it; what still remains is bunnded on the north and northeast by New Mexieo and Texas. The principal pastime of the inhabitants is to cont each other's' throats. They have rery frequent changes of the administration, sometimes being blest with several in one day. The 
Emperor Maximilian endeavored to establish order and suppress anarchy, but through the interference of the United States, which wanted Mexico for itself, his efforts were rendered abortive, and he shared the fate of other reformers, being ruthlessly murdered by the miserable ruffians who now enaet the faree of governing that unhappy country. No measures were taken to avenge his death, and it was with difficulty that the body could be saved from desceration and given up to his fimily for interment. The fauma of Mexico is beatutiful, especially towards the south, but it is worth a man's life to travel through it, as each inhabitant eonsiders him or herself a self-constitnted committee of one to murder and rob whoever Providence sends in their way.

Micmigax. One of the United States of America, its northern boundary is Lake Superior, its eastern Lake Huron, its western Lake Michigan, and on its south are the states of Indiana and Ohio.

Mixas Geraks. A district sonth of Bilhia in south-east of Brazil.

Mrndanan. The seeond in size, and the most sonthern of the Philippine Islands, it lies north of Celeies and nortli-east firom Borneo.

Mrsdora. One of the Philippine Islands, it lies south of Luzon.

Minnesota (Indian). One of the Uniter States, its northern border is on British Ameriea, to its east is Lake Michigan, on its sonth is the State of Iowa and on its west, Dakotah Territory.

Mississirpi. One of the southern United States; it is bounded on the north by Tennessee, east by Alabama, on the west the Mississippi River separates it from Lonisiana and Arkansas, and on its south lay Florida and the Gulf of Mexieo.

Missouri. One of the United States; it lies south of Iowa, west of Illinois, east of Kansas, north of Arkansas.
Moldavia. An eastern province of Austria, north-east of Wallachia.

Molvecas. Spice Islands, a group of islands in Malaysia; they lie south-east of the Plilippines, and between New Guinea and Celebes; they consist of Gilola, Morty, Batehian, Mysol, Ceram, Bouru, and a number of smaller islands. These are the homes of the splendid Ornithopteras.

Moxgolia. The north-western part of the Chinese Empire; west Tartary; its northern boundary is the chain of the Altai Mountains, which separates it from sonth Silveria ; eastwardly it is bounded by Mantehooria, to its south are China and Thibet.

Montasa. Territory of the United States of North America; it joins British Ameriea on the north, Dakotah on the east, Wyoming on the south, and Idaho on the west.

Morea. Southem Greece.

Moretor BaY. On the eastern coast of New Sonth Wales, Australia.

Mommor Laxd. Utah, the land of the Salt Sea and Latter-Dar Saints, where polygamy is allowed by law, and though it is one of the Territories of the United States of North Ameriea, that great govermment has been unable to enforec the federal laws against a plurality of wives, for when the United States troops were sent to enforee those laws, the army of saints vanquished them-yex, hip and thigh-and Unele Samnel could but weep in silence and let his degenerate children in Utah go to perdition the quickest way possible, i. e., in the arms of as many wives as they could feed or starve.

Monty. The most northern of the Molnecas or Spice Islands, it is separated from Gilola on the northeast by Morty Straits.

Moulaiern. A town near the month of the river Martaban in eastern Martaban, India.

Mozambique. Territory on the sonth- 
east coast of Africa; between it and the great island of Madagascar runs the channel of Mozambique. It was in this Territory that the resplendent Thuliura Cimsus was diseovered.

Mit. Bireid. In Amoorland.

Mr. Drabio. A mountain in ContraCosta County, west California, it is ilere that the most beautitul of the iN. American Lycænidæ, Lyecena Regia, is taken.

Mit. Gothard. One of the peaks of the Swiss Alps, 9,975 feet high.

Mr. Trw. One of the White Momtains of New Hampshire.

MT. Masmagrox. The highest peak of the White Mountains of New Hampshire, 6,226 feet in height. On this monntain is found (hionobus Semideu, Arctia Quenselie, Anarta Cordigera, and uther Arctic or Alpine species.

Mundus. The world.

Mrsol. One of the Moluceas or Spice Islands; it is south-east of Gilola, east of Oby, north of Ceram, and west of New Guinea.

Mísore. A district in which is also a town of same name, in south-west Hindostan.

Mrsory. An island near the northwest const of New Guinea.

N. Air., T North America, em-

N. Aser. J bracing British Columbia, Alaska, United States and Mexico.

Naxkix. One of the prineipal eities of China, is near the mouth of Yangtse-Kiang River, in easterm China.

Natal. Port Natal, on the southeast coast of Africa. Many beautiful Saturnidae are found here, among them Gynanissa Isis, Actias Mimosu', Antherea Menippe, A. Arata, Myalophora Mythimnia, etc.

NAPA. A county in western California. One of the principal localities for that most beautiful of all kuown Coliades, C. Eurydice.

NApo. A branch of the Amazon, running through central Ecuador.

Nauta. On the Amazon, near the southern boundary of Ecuador.
Nebraski. One of the United States; it lies south of Dakotah, east of Colorado and II yoming, north of Kansas, and west of Iowa, from which latter it is separated by the Mississippi River.

Neelghetri, ) Blue Hills, in

Neelgherises, the sonthern part

Neilgherries, fof Mysore and ad-

Nilgerrates. f jacent districts of Hindostan.

N'GAMI. See Lake N'Gami.

Nepax, \& One of the north-eastern

NEPAUI. districts of Hindostan, bordering on the north on the Himalayas.

NEVADA. One of the United States of N. Am. ; it lies east of Califormia, south of Oregon, and west of $\mathrm{Utah}$ and Arizona.

New Brituis. An island north-east of New Guinea, separated from it by Dampier's Straits.

New Brusswick. A province of British America, east of the State of Maine.

New Ciledrnta. An island in Australasia, east of Australia, south of New Hebrides, and north-west. of New Zealand.

New Exglaxy, JThesix UniNew Exglaxd States. Sted States east of New York; they are Maine, New Hampshire, Vermont, Massachusetts, Connecticut and Rhode Island.

Newfousnlasi, A large island in the Atlantic Ocean; it is separaterl from sonth Labradior by the Straits of Belle Isle.

New ifreiburg. A settlement in south-east Brazil. Eudcmonia Derceto, of Maassen, one of the most wonderful of known Heteroceres (moths), was discovered here; there are so far but three species known to this grenus, viz.: L. Semiramis, Cram., E. Derceto, Maussen, and $E$. Jchovah, Strecker, distinguisher by the immense length of the tails of the hind wings, which in Semiramis o measure five inches. 
New Graxada. See Columbia.

New Gunea. One of the largest of the Pacific islands; is in Australasia, north of Australia, from which it is separated by Torres Straits; its inhabitants are oriental negroes; the flora and Lepidopterous fauna are exceedingly rich.

New Hampsure. One of the New England States; it lays west of Maine, east of Vermont, and north of Massachusetts; in this state are the White Mountains, having a curious Aretic and Alpine fauna.

New Heberoes. A group of islands in Australasia; they are north-east of Australia, north of New Caledonia, south-east of New Guinea, and west of the Feejee Islands.

New Hollano, Australia.

New Irer.axp. An island in Aus tralasia, north-east of New Guinea.

New JERsex. Although not generally so considered by Amerieans, really is one of the United States of N. Am. ; it lies south of New Lork, east of Pennsylvania, and its eastern shores are on the Atlantic Ocean. In its swamps are good collecting grounds for the Lepidopterist.

New Mexico. Territory of the United States of N. Ain., lying north of Mexico, east of Arizona, west of Texas, and south of Colorado. It is the locality of the splendid Papilio Pilumnus and $P$. Daunus, and other fine speeies.

New Orledxs. The capital of the State of Lonisiana; it is situated on the left bank of the Mississippi, about a hundred miles from the sea.

New Soutu Walds. The eastern district of Australia; it lies south of North Australia, east of South Australia, and north of Vietoria. Sydney, the capital of Australia, is on its east coast.

New York. One of the United States; it lies west of the New England States, south of Canada, and north of Pennsylvania; its principal city - of the same name- on its south-eastern point, is the metropolis of eastern N. A merica.

New Zesuaro. A large island, or rather two contiguous, large islands, divided by Cooke's Straits; the northern part is called New Ulster, and the southern New Munster; it lies sonth-east of Anstralia. One of the principal articles of export is the embalmed heads of the natives; these are splendidly tattooed, and when one chief overeame another in war, the head of the vanquished party was beautifully embalmed, but the demand for the article among civilized collectors beeame so large that a domestic market was established, by tattooing the faces of slaves and subjects, then slaughtering them and passing their heads oft on the nnsuspicions customer as those of genuine chiefs. This is, or was, also where those missionaries, who were emulous to obtain the crown of martyrdom, went for that delectable purpose, when the oblioing natives speedily fulfilled their pious wishes by butchering and afterwards foasting on them.

Nras. An island off the north-west of Sumatra.

Niciragua. One of the states of Central America; it has Costa Rica on its south, the Gulf of Mexico on its east, Honduras on its north, and the Pacific Ocean on its sonth-west.

NICOBAR, Islands in the

Nicobar Istandes, Indian Ocean,

Nikobali IsLands. north-west of Sumatra, west of Malacca, and sonth of Andaman Islands.

Niger. One of the great rivers of Africa; flows through the eastern part of Upper Guinea, and ihence into Sondan.

Nile. A large river, rising in Central Africa, where it has the name of the White Nile, running northward, through Nubia and Egypt, and emptying into the Mediterranean Sea.

Ning-Po. A city in the province of Che-Kiang, on east coast of China. 
Niphon. The largest of the islands comprising the Japanese Empire. Jeclio, the capital of the empire, is on the calst coast of this island.

North Australia. The northeastern part of Australia; its northern and castern shores are on the Pacific, on the west it is bounded by West Australia, and on the south by New south Wales and South Australia.

Nonth Carolina. One of the southern United States of $\mathrm{N}$. Am.; its eastern shore is on the Atlantic Ocean, on the north it is bounded by Virginia, and its south by South Carolina.

Norv.,

The north-western Norvegis, frart of Europe, borderNonfar. J jng on the Northern Ocean.

Tova Hollande. New Holland, Australia.

Nova Scoria. The most southeastern of the provinces of British America; it is a peninsula, connected with the south-eastem part of New Brunswick, and separated from the south of it, and from the State of Maine, by the Bay of Fundy.

Nova Zembea. A large island in the Aretic Ocean, north of Russia.

Nubra. A country in East Afirica, lying sontl of Eigyt, north of Abyssinia, east of the Libyan Desert, and with its western shore on the Reil Sea.

Nukahiva. One of the Marquesas, or Walshington Isles.

OAXACA. Une of the most southern divisions of Mexico; its south coasts on the Parcific Occan, to its east is Tehuantepec, on the north Vera. Cruz, and on the west La Puebla.
Ochotsk. Territory of eastern Siberia, bordering on the Ochotsk Sea ; its principal settlement-of the same name-is one of the great fur-trade depots.

OcEanica. The islands in the Pacific Ocean, comprising Malaysia, Australasia and Polynesia.

Oesterieich. Austria.

Onio. One of the United States of N. Am.; it lies south of Lalic Erie and Michigan, West of Pennsylvania, east of Indiand, and north of Kentucky and Viroinia.

OKFAK. A station on the nortl-east coast of Labrador.

Orhotsin. See Ochotsk.

Old Calabar. A setulement, east of New Calabar, in eastern part of Ulper Guinea, W'est Africa.

Ontario. See Lake Ontario.

Or., Eist; eastern ; per-

Orikntais, taining to the east; as,

Oruental. Europe or., eastern Europe.

$\left.\begin{array}{l}\text { Orb., } \\ \text { Orisis. }\end{array}\right\}$ The world.

Oregon. One of the most western of the United States of N. America; the Pacific washes its western shore, on its north is Washington Territory, to its east is Idaho, and on its south California and Nevarla.

Orinuco. A large river, lmmning through Tenezuela from cist to west.

Orizalsa, A n nountain prak on ORIzara. the westem bolder of Vera Cruz, Mexico; it is 17,370 feet highl.

Ost, (ie). East.

Ostuich, Ger. Easteru.

OTAFiEITE. The largest of the siociety. Islands.

Oвi, I One of the Moluceas, or Otromax Emplat. The Turkish OBr. S Spice Islands; it lies south of Empire-European and Asiativ Gilula, west of Mysol and New Turliey, and the Baschalice of Egypt. Guinca, and north of Ceram.

Obroos. A town on the upper Anazons, north-west Brazil.

Oude. A district in northern Hindostan; it lies south of Nepaul and east of Delli.

Oc., Western; to the Oratau. One of the Fiji Islands. Occidentanis, $\}$ west; belonging to Owhs's Lake. In Inyo County, Occunental. $\int$ the west. southern California. 
Owhymee, One of the Sandwich Paraxa. A district in the south of Islands. See Hawaii.

Palemibang. A settlement in the southern part of Sumatra.

Pa. Pennsylvania.

Pachacamac. A small town not far from Lima, Peru. It was the scene of some of the depredations of $\mathrm{Pi}$ zarro; in the time of the conquest it was the site of a great temple to the god Pachacamac, part of the ruins of which still remain.

Pagosa. A village and springs in $\mathrm{S}$. IV. Colorado.

Palanow. A district in the Presidency of Bengal, Hindostan.

Palengue. A village in Chiopas, near which are the wondrous ruins of ancient palaces, idols, ete, which, be it spoken to the shame of the United States, are, along with those of Copan, allowed to deeay in the wilderness whilst a little energy, and a trifle of the moner annually scandalonsly squandered by Government, would transmit them to a place of safety in some public institution.

Pacific Const. West coast of $\mathrm{N}$. Americal.

Pacific Siope. That part of the United States wert of the Rocky Mountains.

Palawax. An island in Malaysial, north-east of Borneo and sonth-west of Mindora and Luzon.

Palestine. The Holy Lamd; in the sonth-western part of Asiatic 'Turker.

Panama. The narrow tract of country which comnects North and Sonth Ameriea.

Papua. See New Guinea.

PARA. A district in the north of Brazil; a city near the mouth of the Para River, in northern Brazil. This region is enormonsly rich in Lepidoptera and other order's of insects.

Paraguar. One of the States of S. America; it is south of Bolivia, and north-east of Buenos Avres.

Brazil ; its eastern boundary is the Atlantic.

Patagonia. The southernmost part of $\mathrm{S}$. America.

Pebas. A town on the Amazon, in the sonth-east of Ecuador.

Perin. The capital city of the Chinese Empire, is in the north-east of China proper, near the Great Wall. Pencew Islandos. A group of small islands in Polynesia, northward of New Guinea, and eastward of the Philippines.

Penang. See Pulo Penang.

Pexra, \} One of the UniPenserylania. $\}$ ted States of $\mathrm{N}$. Am.; it is sonth of New York, west of New Jersey, north of Maryland, and east of Ohio.

Pernambuca. One of the northeastern provinees of Brazil; its principal city - of same name-is of considerable commereial importance.

Pers., I Lies east of Asiatic TurPersis. Jkey, north of the Persian Gulf-which separates it from Arabia-west of Afghanistan and Beloochistan, and south of Georgia and Turan, or Turkistan.

P'Eru. One of the western of the Sonth American States, bordering on the Pacifie; it lies south of Ecuador, and west of Brazil and Bolivia.

PhiL.,

Philda.,

Prima delpha, United mimaderia. United States of N. America; situated on the Delaware River, in the sonth-eastern part of Pennsylvania. It is here that the Phila. ACademy of Natural Sciences, and the AmERICAN Entomological Society are located, and have built and sustained themselves, anidst all sorts of difficulties, entirely by the means and exertions of their members; for to look for aid to the United States Government, in anything that is great or good, would be as fruitless as to look to the Government of Dahomey. 
Philippines, $\quad$ A group of Philippine Islands. $\}$ large islands in Malaysia, lying north-east of Borneo, and eastward of Farther India; the largest of them are Lnzon, Mindanao, Mindora and Samar.

Piemonont. In the north-western part of Italy, separated from Switzerland on the north by the Pennine Alps.

Pike's Peak. One of the highest of the Roeky MIts. in Colorado, and ahout 11,500 feet high.

Pilution. A small town in Putnam Comnty, Florida.

Poland. Once independent, now a part of the Russian Empire, is in the western part of Russia, adjoining Prussia.

POL., $\}$ Polar ; pertaining to the Polaris. $\}$ Arctic regions.

Polar-land. See Aretie regions.

Poly'sesia. That portion of Oceanica east of Malaysia and Australasia, contains Navigator's Is., Friendly Is., Marquesas Is., Sandwich Is., Ladrone Is, ete., etc., etc.

Pomerania. A northern Provinee of Prussia.

Pondicherry. A Freneh Settlement in Coromandel, Hindostan.

PonT., Y North-east Asia Minor, Pontus. Amasia and Tokat.

Pooxar. Distriet in the Presidency of Bombay, India.

Port Dennison. In eastern Australia; the locality of Ornithoptera var. Cassandra.

Port Natal. see Natal.

Porto Rico. The fourth in size of the West Inlian Islands; it is directly east of Hayti, or St. Domingo.

Posen. One of the eastern provinces of Prussia, formerly a part of Poland.

Po YANG. A great lake in Kiangse, China.

Preussen. Prussia.

Prince of Wales Island. Pulo Penme.

Pulo Penang. Or Prince of Wales' Island; an island near the west coast of Malaya, in the Straits of Malaeca, between Malaya and Sumatra.

Pyrenees. Chain of mountains between south France and north Spain. Quiso. The eapital city of Eeuador, is in the western part of that state, on the side of the voleano Pichincha, 9,500 feet above the sea.

Quenssland. A distriet of Australia.

RADACK IsLANDs. In Mulgrave's Arehipelago, north-east from New Guinea.

RAJAHMUNDRY. A town near the mouth of the Godavery River, eatst coast of Hindostan.

ReG. Arot.,

The Aretic

Regrones I RCTICA. f regions; north of the Aretic Circle.

REG. IND., I Hindostan and Regio Indico. $\}$ Farther India.

Repulse Bay. A small bay on the Arctic Cirele, below Melville Peninsula, in British Ameriea.

RHode Istand. The smallest of the United States of N. Am.; it lies east of Comnecticut and south of Massachusetts.

RHodes. An island near the west coast of Asiatic Turkey.

Riesex Gebirge. A range of hills in eastern Saxony, and between Saxony and Silesia.

Rio. River.

Rio JANiero. The eapital of Brazil, situated on a fine harbor on the sonth-east coast.

Rio Napo. A branch of the Amazon, in central Ecuador.

Rio NEgro. The north-western provinee of Brazil ; its principal river - of the same name-is a branch of the Anazon.

Rock Y Mountaiss. The great ehain of mountains running from north to sonth through the whole western part of North America.

Rodragez. A small island east of Mauritius.

Ronol. One of the Philippines, north of Mindamao. 
Ross.,

$\left.\begin{array}{l}\text { Rossia, } \\ \text { Russiani, Gier. }\end{array}\right\}$

Russia.

RuperT's Hotse.

A fort, formerly on the south-east shore of Hudson's Bay.

RuperT's LAND. The territory in British America, to the south and south-east of Hudson's Bay.

Saghalien. A long, narrow island, east of Mantehooria and separated trom it by the Gulf' of 'Tartary.

SAHARA. The immense desert ocenpying the great part of northem Africa.

Sali Lake City. The capital of Utah, on the River Jordan, near Great Salt I sake.

Samar. One of the Philippine Islands.

Salwater. An island to the extreme west of New Guinea, from which it is separated by a narrow strait.

Samarcand. On the Kohuk River, in Bokhara, southern Turkistan; was one of the most noted cities of Asia.

Gambang. A settlement near the western coast of Borneo.

Sayod. One of the Shifler Islands, north-east of the Friendly and Fiji Islands.

SANDAL-WOOD Islatin. An island of Malaysia, sonth of Flores, southeast of Java and Sumbawa, and west of 'Timor'.

SAx Diego. Thesouthermmost county of California. One of the localities of Lycuna Regia and Arthocharix Cooperi. Its principal town-bearing the same name-is on San Diego Bay, on the west coast.

SANTwICH Istaxis. A group of islands in the north-east of Polynesia; ther comprise Oahu, the residence of their king, Hawaii and some smaller ones.

SAN,

SANCTA, Saint.

Santa.

San Francisco. The eapital of California and the metropolis of the western United States of N. Am., is situated on a neck of land on the west coast.

Sax Salvador. A state of C'entral Ameriea, east of Guatemala, sonth of Honduras, and with its south bordering on the Pacifie Ocean. Bahia, a city of Brazil, is also sometimes called San Salvador.

Santa Lrora. One of the Lesser Antilles, directly south of the Island of Martinique.

Saxta Marta. One of the mortlern provinces of Columbia. The town of Santa Marta is at the mouth of the Magdalena River.

Santareis. A town on the Amazon, in Para Distriet, northern Brazil.

SARAWAK. North-western coast of Borneo. One of the localities of the splendid (mithoptera Brookiame.

S.ARDINIA. 'The kingrlom of' Sardinia - the north-western part of Italy. Also a large island in the Mediterianean, south of Corsica and northivest of Sicily.

SAREPTA. The somth-east deserts of Russia.

SAx.. I kingdom of Germany,

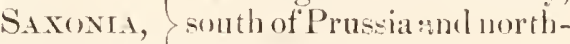
SAxONY. west of Austria.

Scandindia. Swelen and Norway. Schmarafoex-lant. Utopia, Fools' Paradise.

ScruwerT\%. S'witzerland.

Sootia. Seotland.

SENGgal. The most western Sexeg mara. J part of Africa, south of "Great Desert and west of Soudan. $\left.\begin{array}{l}\text { Sept., } \\ \text { SEPTENTRIONALis. }\end{array}\right\}$ North.

Serex. A town on the Guadiana Kiver, in sonthern Portugal. Also a town on the Upper Amazon, northern Brazil.

SEYchelis, I A cluster of Serchelle Istands. small islands in the Indian Ocean, easi of Zanunebar, Africa, and north-east of Madagasear.

Shangmal. A city in the Kiang-Son District, on the east coast of China. 
Sherborodgh Istand. Near the coast of Sierra Leone, west Africa.

SiAM. A kingdon of Farther India, bordering on the south on the Gulf of Siam, on its east is Cochin China, and to its north is Laos.

Srao. A small island, morth of the north-east point of Celebes.

Sireria. The Russian possessions in Asia, eomprising all that part north of the Chinese Empire and Turkistan, and east of Russia proper.

Srcilia, A large island, southSrcms. $\}$ west of Italy, from which it is separated by the Straits of Messina.

Sinrras. Momntains.

Srerra LeONe. A small distriet on the west coast of Africa, south of Senegambia and north of Liberia.

Sierra Nevada. The snowy mountains of California, rumning north and south along the west coast.

Srkim. A small province in northeast of Hindostan, between Bhotan and Nepanl.

Silesia. The sonth-eastern province of Prussia, adjacent to Poland.

Srmao. A small island in Malavia, directly west of the island of 'Timor.

Sinr.a. An English sanitory station on the lower Himalavahs.

Sixar. A monntain in Arabia Petrea, mortb-west Arabia ; its height is 7,500 feet.

Shyapore. A town and islaud directly south of Malaya.

Smrria. The chief emporium of the Levant-is a city on the west coast of Asiatic 'Turkey.

SocueTy Istands. A group of islands in Polynesia; they are east of the Friendly Islands, south-east of the Navigator's, and sonth-west from the Marquesas.

Solor. Island in Malaysia, adjacent to Timor.

Songaria. Territory south and sonth-west of the Aitai Momntains.

Sonora. One of the north-western states of Mexico; its west is on the Gulf of California.
Sooloo IsLands. Three islandsTalyabo, Mangola and Bessy-between Celebes and Molnems, northwest of Bouro.

South Cape. The sontherumost point of Van Dieman's Land.

South Carolnsa. One of the United States of N. Am.; its cast is on the Atlantic Ocean, its morth on North Carolina, and its soutb-west on Georgia.

SPICE Islayds. See Moluceas.

Spain. The south-western peninsula of Enrope.

Stante (German). A city.

Śt. Domngo. See Haiti.

S'r. Paulo. A town on the Amazon, in the north-west of Solimoes district, west Brazil. Also a town on Joannes Island at the mouth of Para River, on northern coast of Brazil.

Sü̃ (German) Sonth.

Suecra. Sweden.

Sumbawa. Island in Malaysia, lies between Lombok and Flores, and sonth-west from Celebes.

Sumatia. An immense island, south of Malaya, west of Bormeo and north-west of Java.

Surinax. Duteh Guiana; its morth is on the Atlantic; it is separated from British Guiana, on the west, by the River Corentrn, and on the east, firom Cayenne, by the Maroni River. A country witis a most marvelous Lepidopterous fauna.

Sway River. On the enast of southwestern Australia.

Switzerlano. A momntainous country north of Italy, east of France and sonth and west of Germany.

Swiss Alps. The mountains of Switzerlaud.

Sroxey. On the south-east "nastis the capital of Austrilia.

Syria. South-western Asiatic Turkey.

Tabatinga, OR JABATINGa. A town on the Amazon, in the extrene south-west of Rio Negro distriet, north-west Brazil.

Taiti, or Otaheite. The largest of the Society Isles. 
Tal-wan. See Formosa.

TAPAJOs. One of the great arms of the Amazon, in Para, northern Brazil.

'Tar'Taria Chinesis. Clinese 'Tartary-includes Mantchooria, Mongolia, ete.

'Tasmania, or Van Dieman's Land. A large island, south of New South Wales, Australia.

'l'enasserm. A district on the west coast of Farther India, above Malaya.

Tenerifre. The largest of the Canary Islands; its peak is over 12,000 feet high.

TrNnEssez. One of the United States of N. Am.; it lies south of Kentucky and north of Mississippi, A labama and Georgia.

Teriolis. 'Tyrol.

Ternate. One of the Moluccaswest of Gilola.

'Terra del Fuego. Land of Fire; south of Patagonia, from which it is separated by Magellan's Strait.

'Texas. The largest of the United States of N. Am, ; it joins Mexico on the south-west, Indian 'Territory on the north, Louisiana on the east, and its south-east border's on the Gulf" of Mexico.

'Thibet. Part of the Chinese Empire; lies north of eastern Hindostan, west of China proper and south of Mongolia.

Truor. An islaud in Malaysia, sontlwest of New Guinea, south of Moluccas and south-east of C'elebes.

'Tocantrus: A large river in northwesteru Brazil.

Tondaxo. An island near Celebes.

Trianciucasia. The country lying between the Caspian and Black Seas, south of the Caueasian Mountains and north of Asiatic 'Turkey and Persia.

Trinidad. An island near the northeast of $V$ enezuela.

'Tulbagi. A town in Worcester, Cape Colony, southernmost part of Africa; named after the old colonial governor, Ryk Van 'Tulbagh, who was much devoted to Natural History.

lurciA. Turkey; the Turkish Empire.

Turan, Independent 'TarTurcomania, tary; lies south-west 'TuRkis'TAN. $\int$ of Siberia, west of Chinese Tartary, east of the Caspian Sea and north of Persia and Afghanistan; its northern part is oceupied by the Khirguis and its southern by the petty kingdoms of 'Bokhara, Klookan and Khiva, each ruled by a Tartar chief or king. It is here that the rare and gloomy-looking Axiopena Maura, one of the largest of the Arctiidae, is found.

Ty. Territory.

'TyroL. The most western province of Austria, bordering on north-east Italy.

UCAYAII. A district in the northeast of Peru; it is watered by a branch of the Amazon, of the same name.

UkraInE. Regions on the River Dnieper, Little Russia.

Unio Amer. United States of Nortl America.

Ural Mountains. Great range of mountains in east Russia, and betiveen Russia and Siberia.

Uruguar. A state of $\mathrm{S}$. America, south of Brazil and east of Buenos Ayres.

U. S. Abbreviation of United States of N. America; also of Uncle Sam, the familiar name by which the people of the United States designate their government.

UTAH. See Mormon Land.

Valais, I One of the southern Valesia. $\int$ Cantons of Sivitzerland.

VAlparaiso. The most noted port of Chili, on the west coast of South America.

Vancouver's IstaA ND. A large island south-west of British America and north-west of Washington Territory. Van Dieman's Land. See Tasmania. Vanna Valara. One of the Fiji Islands. 
VARINAS. A town in north-western Venezuela.

Venezuela. One of the northem states of S. America; it lies on the north on the Caribbean sea, to its west is New Granada and to its east British Guiand.

Vera PAy. One of the Central American States; it is north of Guatemala and west of Balize.

Vermont. One of the New England or Eastern United States; it is east of New York, west of New Hampshire, sonth of Canada and north of Massachusetts.

VIlla Nova. A town near the mouth of Amazon, in Para district, morthern Brazil.

Virginia. One of the Southerm United States of $\mathrm{N}$. Am., is south of Maryland and north of North Carolina.

Virginia Citr. A eity in extreme western part of Nevadia.

WAIGIor. An island neal the northwest point of New Guinea.

WALES. Part of the British Kingdom.

WAILACHIA. A distriet in the northeast of European 'Turkey, south of Moldavia and north of Bulgaria.

Wallis (Germun). Valais, Yalesia

W ashington Ciry. 'The capital of the United States of N. Americais on the Potomac River, in the District of Columbia.

Washingron. Territory of the United States of $\mathrm{N}$. Am., on the Pacitic eoast; it lies north of Orearon, south of British Americal and west of Idaho.

Wes'T Indiks. Great and Lesser Antilles; a great number of large and smal! islands south and southeast of the United States, and worth and north-east of S. A merica. The four principal ones ale Cuba, Jamaica, Haiti and Porto Rico, but there are as many smaller ones as there were saints in the calendar to name them after.

Wes' Y'IRGINIA. 'The western part of the old State of I'irginia, which was separated from the latter during the late war; it lies east of Ohio and Kentucky, south of Pennsylvania and north-west of what is left of the old Virginia.

White Mountains. In the State of .New Hampshire; the principal ones are Mt. Madison, 5,420 feet high, Mt. Jefferson, 5,660 feet high, Mt. Adams, 5,760 feet high, and Mt. Washington, 6,226 feet high.

IVII'Te Nile. The lower Nile.

Wincepeg Lake. A lake in British Anerica, north-west of Lake Superior.

Wisconsin. One of the United States of N. Am.; it is north of Illinois, west of Michigan, east of Minnesota.

WOODLARK Isisaxl. One of the Louisarles.

W Yomsic: 'Territory of the United States of N. Am.; south of Montana, east of Iclaho, west of Dakota and Nebraska and north of Colorado.

Ykoutsk. A great trat of east Siberia; its ehief town is of the same name, and is a great fur depot on the Lena River.

Yendo, OR JEIno. The capital of Japan.

Yelaowstone. A branch of the Missouri River, rumning through the eastern half of Montaua.

YLoE. ( ne of the Philippine Islands, west of Mindor"a.

Yosmates. Mountains and Valley in Mariposa County, California : in the high monntains of this range are foumd the dark-green Colias, Behrii, and the rare Aroynmis Leto.

Yucatan. A peninsula of Central Ameriea.

'/AMBEsi. A river in eastern Africa, between Mozambique and Sofala.

hambongu. A town on the west point of Mindanoa.

'/ANTes. One of the Ionian Isles.

'LAN\%[BAR. An island off the coast of Kanguebar, east Africa.

\%WELLENDAM. The southernmost part of Cape Colony-rontains a town of the same nante. 


\section{CA'TALOGUE}

OF THF

\section{AMERICAN VICROLEPIDOPTERA} NORTF OF MEXICO. with a

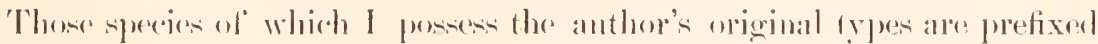

Those that ale moknow to mo in mature aro demoted be a to

Fucle as are wanting to me collection ale designated by a *.

\section{RHOPALOCERA.}

\section{FAMIIT I. PAPIIIONIDE. (IBNES I. PAPILIO I.}

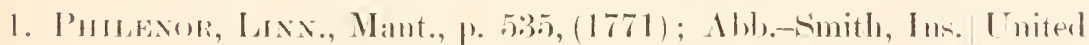
(xa., I, t. :, (1797); Gorlt., Enr. Meth., IX, P. 40, Ntates and (1819); Say, Int. Fut., t. I, (1824); Brll.-I dere, Torritories I.p. Am. Sept., 1. 29, t. 11, (18.3.3); Bull., Sp. from Itlan-

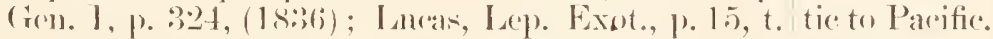
8, (18:.5); Morris, Srm., p. (i, (1862); Kirly, (at., Mexieo. 1. $521,(1871)$.

Astinous, Ihury, III. Hx. Eut., I, t. 11, (177:); ('rall., Pap). Ex., I II, t. 208, 1, P, (1752).

Princeps dominams I'hilenor, Hïb., Exot. Sibmett., I., (180(i-1):24).

I allvil on Aristolochia.

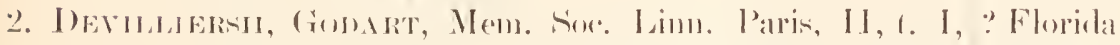

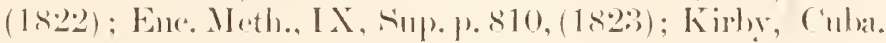
(:it. 1). 5201), (1851).

Tilliersii, Bdl.-Lec., Ixp. In. Sept., p. :36, t. 14,

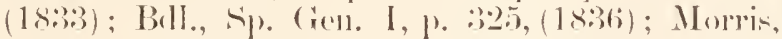

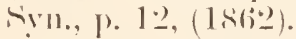

If found at all in the $\left[\begin{array}{r}\mathrm{r} \\ \text {. S. }\end{array}\right.$

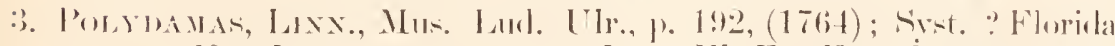

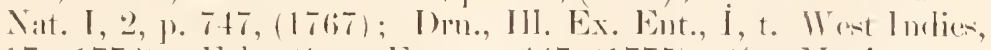
$17,(1773)$; Fal)., Firt. Fint., \%. 447, (1775); Ky. Mexico, Ins., II, 1. \&, (1781); Mant. Ins., II, p. t, (1787); ('ont. Im. Ent. Fist., V, p) 14, (17!): ) ( 'ram., Pap. Ex., III, l. 33 , t. 2221, (1782); (iolt., Enc. Meth., LX, p. 39, (1819); Bill.-Leе., [жер. Аm. kept., 1. :37, t. 15,

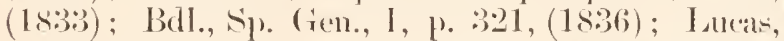
I.p. Exot., p. 3:3, t. 17, (1835); Morris, Nyn., 
p. 1:3, (1862); Kirh, ('at., 1. 521, (1871); Merian, Ins. Sur., t. 31, (1705); Melsa, Thes., IV, t. 39 , $(1765)$.

Princeps dominans $P$., Ḧ̈̈b., Ex. Solhmett.,(1806-1824).

Iarva fommd on rarious plants of the genus Aristolochir.

1. Mreotes, Bates, Trans. Ent. Sine, Ser. III, Vol. V, p. S. Califomia 3 thi, (1861); Kirlor, (at., 1). 53:30, (1871).

Mrxicon,

Tw fornia, and receiverl from Dr. Heerman in 1862.

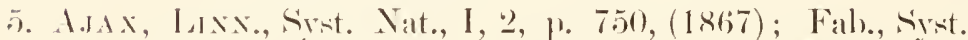

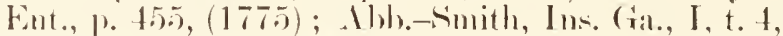
$(1797)$; (rolt., Enc. Meth., IX, p. 5:3, (1819); Bill.-

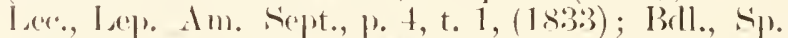

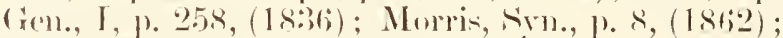
Kirhr, (at., 1. 55s, (1871).

Panama, Nicalanglat.

[initre]

States alst of

Texils, ex"ejeting the New Fincrlamd Stater.

Varcellus, Cram., Pap. Fx., II, t. 98, F. (x., (1779). Ajax var. Walshii, IT. H. Edueds., Butt. X. Am., I, t. I, Pap., (1871).

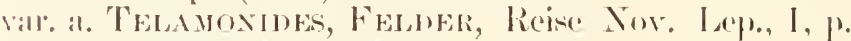
60, $(1865)$; IV. H. Fdwds., Butt. Х. Am., 1, t. II, Pap., (1871); Kirhy, ('at., p. 558, (1871).

A form of gen. I intermediate hetween Ajax (gen. I) and Marcellus (gen. II).

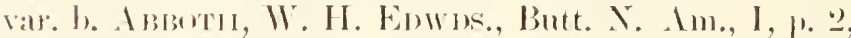
t. II, Pap., (1871).

Like Ajax, hut with the lower half of mesial har strongly suffused with erimson on upper surface of secondaries.

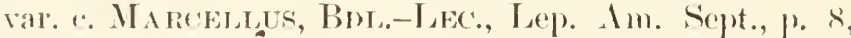
t. 2, (18:33); BAll., Sp. Genl., I, J. 2:37, (18:36); Murris, sirn., \%. 9, (1862); W. H. Erlwrls., Butt. N. Im., I, t. III, Pap., (1871); Kirbs, Cat., p. 55.8, $(1.871)$.

I'. Ajax, Esper, Nolmett. I, t. 51, (1780).

Princeps heroicus Ajax, Ḧ̈b., Sam. Ex. Sithmett., (1806-1824).

Ipliclides Ajax, Hïb., V'e\%. Bek. Sishmett., p. \$2, (1816)

The second brool; larger; tails much longer, and heavily edged with white nearly their whale length; at anal angle of inferiors a crimson spot, sometimes two, instead of the bar of gen. I.

Ialra fereds on pawpaw (Asimina trilobre, (rray).

6. Sinox, Fabr., Syst. Ent., p. 452, (1775); Sip. Ins., II, 1. : Florida

15, 11. 59, (1781); Mant., Ins., II, J. \&, n. fiт, Intilles.

(1757) ; Ent. Srst., [II, 1. 24, n. 75, (179:3); ('ram.,

I'ap. Ex, IV, t. :317, C, D), (1782); Golt.,

Enr. Meth., IX, 1. 53, (1819); Bell.-leer., Irl).

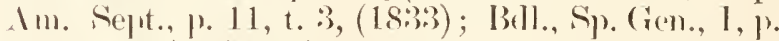

26(1), (18:36); Morris, Syn., 1). 9, (1862); Kiplor,

('at., p. 557, n. 269, (1871).

I'. Protesilaus, Dru., Ill. Ex. Ent., I, 1. 57, t. 22, t. $: 3,4,(1773)$. 
P. Zonaria, Butler, Ent. Mo. Mag., V, 1. 271 (1869); Kirby, Cat. p. 557, 11. 267, (1871).

This species has been from time almost immemorial confounded with its ally (or perhaps var.) Celadon, Lucas. ('ramer figured on t. 317 , (Vol. IV), four figures, C, D, E, F, which purporter to show both surfaces of the two sexes of Sinon, hut E, F, which he represents as the +9 is Celadon. Drury's name, Prolssilaus, would have held for this species (Sinon) had it not heen given previously by Lin. to another insect. Fabricins in Syst. Ent., (1775), first designated Drury's " P. Protesilaus, Dru., I, t. 22, 3, 4," as Sinon. Later, in his Sp. Ins., (1781), he mixed up with it and quoted P. Policenes, Cram., (I. t. 37, A, B, ) a W. Afr. Sp., as a synonym of Sinon, (Protesilaus, Iru. nec Lin.) In his Mantiska, (1787), he confounds Sinon and Coladon as Cramer had ilone, "Papilo Sinon, Cram., Ins., 27 , tah. 317, fig. C, D, E, F." In the Ent. Sy+t., (1793), he repeats the error, "Cram., Ins., 27, tah. 317, fig. C, D, E, F, P. Protesilaus. Dru., I, tah. 22, fig. 3, 4." Celadon is more frergently represented in N. Am. collection as Sinon than is the trie Sinon itself, in fact the latter is very rare and the few examples I have seen in cahinets have no certain localities cited. Boisduval, in the Sp. Gen., gives Jamaica, Florida and Cuba, as its habitat, and I have little doubt but that it really does occur in the southermmost part of peninsular Floridi, the Lep. Fauna of which is clecidedly W. Indian.

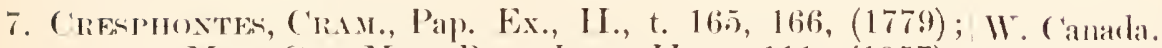
Men., Cat. Mus. Petr. Lel., II, p. 111, (1857); U. S. cast of Feld. I'erh. \%ool. Bot. Ges., XIT, p. 310, n. 294, the Rorkr 1). $357,11.168,(1864)$.

Heraclides Oxilus, Hïb., Ver\%. Bek. Schmet., 1. 83, except the (1816).

Papilio Thoas, var., Bdl.-Lec., [4ep. Am. Sept. p. :31, lamd Sitates. t. 12, 13), (1833); Morris, syn., 1. 7, (1862). Texas.

P. Thoas, rar. b, Cresphontes, Kirhy, Cat. p. itt, Mexion. (1871).

Larva on orange in Floricla, on an-h in the more norCentral thern states.

Rare in the north; common south of Virgini:t.

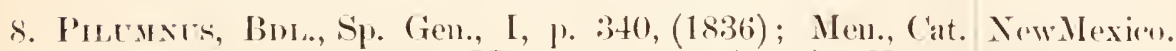
Mus. Petr. Ieps, II, p. 110, t. 7, (1857); Kirby, Mexieo. (at., ). 564, (1871); Ntreck, Lep., Rhop., Het., p. C'entral 13, t. II, :3, 4, ठ, (187:3).

Ameriari.

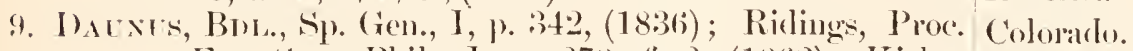

Ent. Soc., Plil., I, ]. 278, f. 2, (1862); Kirly, New.Мxi(n).

(at., p. 564, (1871); Streck., Lep., Rhop., Het., p. Mexico.

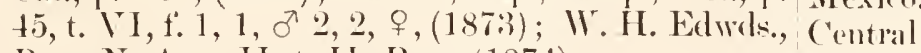
Butt. N. Im., II, t. II, Paj), (1874). America.

I allva on a species of wild eherry.

10. Trixrs, Laxx., Mant., p. 536, (1771); Fabr., Syst. Ent., British ('op. 452, (1775); Nן. Ins., II, 1. 16, (1781); Esp., lmmbia, (anlus. Sechmett., t. 48, t. 1, (1785-1798); (rodt., Enc. arla, [initer] Meth., IX, p. 5j, (1819); Say, Am. Eut., III, t. States fiom 10, (18.2s); Bd1.-Lec., Lep. Iin. Sept., p. 19, t. 6, the Itlantic: 7, (18:33) ; Bdl., Sp. (ien., I, ]. 3:38, (18:36); Laneas, to the Rocky Lep. Exot., 1. 35, t. 18, (18.35); Harris, Ins., Mountains. Flint's Ed., 1. 268, f. 97, $(1862)$; Moris, Syn., Gmamaxuata, p. $2,(1862)$. Mexico. 
.Jasoniades Turnus, Hüb., Verz. Bek. Schmett., p. 8.3, (1816).

Pap. Alcidamus, Cram., Pıр. Ex., I, t. 38, A, B, (1776).

Pap. Antilochus, Linn., Mus. Iud. I†r., p. 207,

(1764); Syst. Nat., 1, 2, 1) 751, (1767); Cateshy,

Nat. Hist. (arolina, IJ, t. s:), (1771); Bdl., Sip.

(ien., I, \}. 340, (1836).

(atesbr's figure represents either a monatrosity or is a palpable exaggeration; the primaries are acutely falcate and many other points show the most liberal exercise of artistic license.

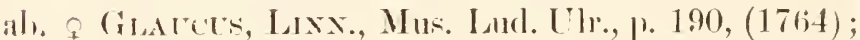
Sirit. Nat. I, 2, p. 746, (1767); Clerek, Icones, t. $24,(1764)$; Fabr., Syst. Wut., 1. 445, (1775); Cram., Palp. Ex., I I, t. 139, (1779); Goult., Euse. Motlı, IX, 1. 60, (1819); Brll.-Iec., Lep. Anr. Sept., 1) 22, t. 8, 9, (183:3); Bull., S̈p. (ien., I, 1. 33.5, (18:36); Morris, Syu., \%. 2, (1862); Kirhy, (at. p. 565, (1871).

Euphocades Glaucus, Hüh., Varz. Bek. Schmett. 1. S:3, (1816).

This common species is polymorphic, having a yellow $?$, like the $\delta$, and another ( $a b$. Glaucus) entirely black and between these every intermediate gradie; some are black above and rellow beneath; others have the wings of one side yellow $q$ and those of the other black $q$, and the body also half yellow and half black.

latra on plum, apple, cherry, wild cherer, tulip trees.

11. Rutelots, Bul.., Ann. Soc. Ent., Fr., 1. 279, (18.52); Lue., (alifornia,

Rev. Zowl., p. 138, (1852); Morris, Syll., p. 3, ()regon and $(1862)$; Kirby, (at., p. 565, (1571); Hỵ. Eswak., adjacent terProc. (al. Arad. Sco, (187:3). ritury.

12. Errsymox, Bur., Ann. Soc. Eut., Fr., 1. 280, (1852); (alifirnia,

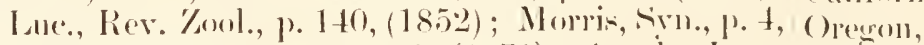
(1862); Kirly, ('at., p. 565, (1871); strock., lepe, Vamonver's Rhop., Het., $\% .25$, t. IV, (1873); Hy. Edwols., [slamel. Prece. (al. Acarl. Sic., (1873); W. H. Ediwlis., Butt.

N. Am., II, t. I, Pap., (187t).

Iarva ou Frangula Californica.

valr. a. Irastis, Felder, Reise, Nov. Jep., I, p. 93, 11. $71,(1865)$.

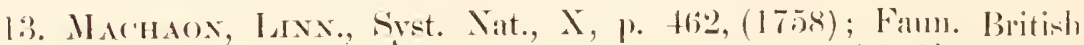
Suec., p. 2667, (1761); Syst. Nat., I, 2, p. 750, (1767); ('olumbia, S̈.ha, Thes., IV, p. g(), t. XXXII, (176.j); Esp., Mlaka, sichmett., 1, 1, t. 1, (1777); Hïl., Fur. S'clmett., ()regrms. 1, f. 390, 391, (1798-180:3); Wilhelu, Int. Nit., Europe, I-ia II, 1. 21, t. III, (1797); Golt., kine. Meth., IX, 1. $57,(1 \times 1 !)$; Duncan, Xat. Iil., Wut., III, 1). !4, t. 1, (18:35); Bull., Sן. Gell., I, p. 328, (18:36); Morric, Sivo, p. 12, (1862); Standingere, ('at., p. 1,

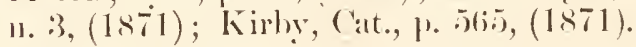

(18] $1 \mathrm{i})$.

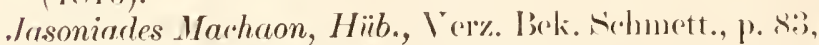
Pap. Regine, Retzius, (iesu. et. sp. Ins., 1).30, (178:3). 
P. Aliaslia, Scudder, Ent. Notes, II, Pruc. Bost. Soe.

Nat. Hist., (1869); Kirlw, Cat., p. 566, (1871).

The N. Am. examples are a little darker in the yellow of ground colour, resembling in this the form occurring in Sicily, Turkev, etc.* Its larva bas not vet been found in this conntry, but of conrse it feeds on the ITmbelliferce.

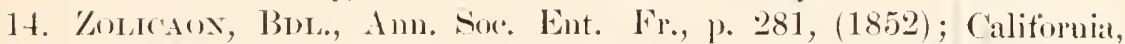

Morris, syn., 1\% t, (1862); Kirhy, Cat., p. 566, Utah,

(1871); streck., I sep., Rhop., Hot., p. 46, t. I I, f. :), Colorado, $\because,(187:)$; Hy. Edwds., Proc. Cal. Acad. So, (187:3); Oregon,

II. H. Wlwels., Butt. N. Im., JI, t. V'I, Pap., V'ancouver's $(1875)$.

Zelicaon, Lue., Rev. '/ul., p. 1:36, (1852).

Island.

Machaon var. Californica, Men., ('at. Mus. P'otrup', 1.]. I, 1. 69, (1855).

I sarva on mmbelliferoms plants, carrot, cte.

+15. Ixura, Reak., Proc. Ent. Soc., Phita., VI, p. 12:3, (1866); Cohorado.

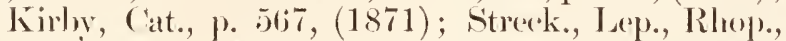

Het., p. 9, t. II, t. 1 o', (1873); Proc. Acatl. Natt.

si., Phil., p. 150,(1876); Putman, Proc. Davenport

Acat. Sc., I, p. 18, t. XXXV, t. jo $(1876)$.

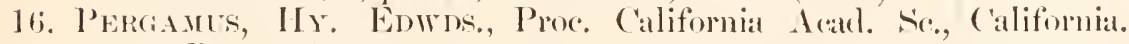
(1)ec., 1874).

According to its author close to Indra, lut has tails as long as Asterius. Described from one $\delta$ taken in Santa Barbara, California, May, 1873.

17. Asterus, ('ma., Pap. Exot., I 1 , t. 385, (1782); Es]., [united Aus., Nolmott., t. 11, f. 1, 2, t. 40, f. $6,(1785-1798)$; States and Euphoeades A., Hüb., Ver\%. Bok. Sehmett., 1. s:i, Territories (1s16).

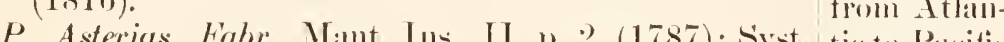

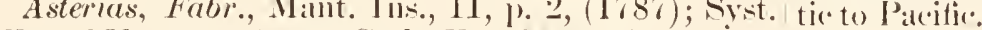

Ent., III, p. 6, (1793); Gollt. Enc. Meth., IX, 1). js,

(1819); Bdl.-Lec., Lep. Am. Sept., t. t, (18:3:);

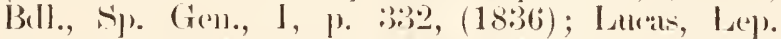

Exot., p. :38, t. 20, (18:35); Momris, Syn., p.5, (1860);

Harris, lns. Inj. Yeg., Flint's Eil., p. 205, t. IV, $(1862)$.

Aja.e, Clerek, (nec Linn.), I (onses, t. :3:), (1764).

Troilus, Drury, (nec Linn.), I11. Exot. Ent., I, t. 11, f. 2., 3, 5, (177:3) ; Falor., Ent. Syst., III, 1. 4, (179:3); Abh.-Smith, Ins. Cia., 1, t. 1, (1797); ('ram., Palp. Exit., I]I, t. 207, (1782).

Polyxenes, Fabr., Syst. Knt., 1) H4, (1775); Kirby, ('at., 1). $5666,(18>1)$.

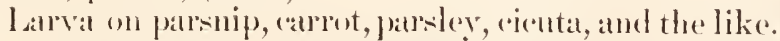

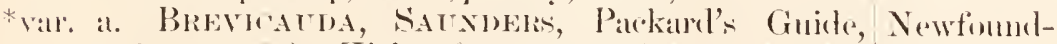
p. $245,(1869)$; Kirts, ('at. 1). 567, (1871); II. H. land.

Edwlis., Butt. X. An., II, t. VIII, Pay)., f. :", t, 5, (1875).

The macular bands of upper smrface of wings fulvous instead of yellow; tails very short.

* P. Machaon var. Sphyrus, Hub., Sam. Ex. Schmett., f. 775, 776, (1818-1824). 
tvar. b. Antrostrexsis, STreck., I sep., Rhop., Het., I, South Iap. 10, t. II, \%. 68, t. VIII, (Lava), (187:3); W. H. brator, Edwds., Butt. N. Am., t. VIII, Palp., f. 1, 2, (1875). Anticusti,

The macular bands on wings of $q$ are as broad and broader :' ('anarla. than in $\delta^{\top}$; tails short. Larva on Archangelica purpurea.

*al. “. Calvelifeyt, Grotes, Proc. Ent. Sic., Phila., 11, 1. \$1, t. 10, (186t); Kirby, Cat. p. 5666, (1871).

Basal or inner half of wings black; outer half orange coloured, devoid of ornamentation; nearly alike on upper and under surface. But two examples so far known, one (ठ) captured un Long Island, X. Y., the other (i) taken on St. John's River, Florida.

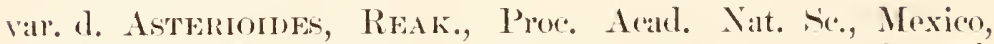
Phila., p. :3:31, (1866); Kirlsy, Cat. 1'.567, (1871); ('entral Streck, Isep., Rhop), Itet., p. 47, t. VI., f, (187:;). America.

Macular bands of upper surface alike in both sexes; narrower than in common form of rasely any indications of yellow within discoidal cells.

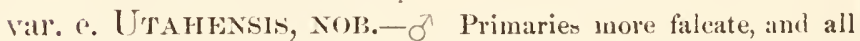
wings somewhat narrower than in the common form. Pate yellow stripes on each side of head and prothorax; tegula also pale yellow; usual lateral rows of yellow dots on abdomen; anal valves pale yellow; macular bands and submarginal lunules on wings pale yellow on both surfacen, devoid of the orange colour beneath so conspicuous in the eastern examples; anal eye orange popilled with black, said pupil extending in a line to and (connecting with the black of at). dominal margin. of with the macnlar bands rednced to a series of more or less obsolete spots.

*17 a. Bande, W. H. Enwis., Proc. Ent. Soc., Phila., VI, Arizona. р. 200, (1866); Kirly, ('at., p. 5) 67 , (1871).

I saw the type of this some years since, and, it my recollection serves me right, it is very near or perhajs the same as var. Asterioides, above cited.

18. Tromst, Laxs., Mus. Iml. Ulric, p. 187, (1764), Sist. Inited Nat., I, 2, p. 746, (1767); ('ram., Pap. Kxot., I] I, States from t. $207,(1782)$; Golt., Enc. Meth., JX, 1) 60, the Atlanti.

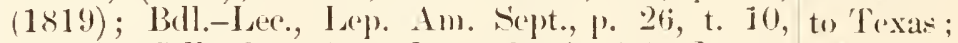
(18:3i) ; Bull., Sp. (ien., I, 1) :3:3t, (18:36); Lulats, ? ('alifornial. lep. Fxot., t. 19, o (1835); Morris, Nym., 1. 5, (186.) ; (Euphoades T.), Hüb., Ver\%. Bek, Schmott., 1. 8\%, (1816), Sam. Ex, S(chmott., (1816-1824).

P. Llioneus, Abb.-Smith, Ins. Georgial, I, t. 2), (1797); Fold., I (erh. Kool. Bot. Ges., XIV, p. :31;, u. :3(i⿱丷), p. 2364, 1. $210,(186 t)$.

Lalrva on sassafras (Laurus Sassafras).

al. a.-with the submarginal lunules of secondaries prolonged inwardly towards hase, forming dashes or rays. One example in coll. Peale.

tals. b. - with, on under surface of hind wings, a narrow yellow band which crosses the wing nearly parallel with abdominal margin, running from near anal angle to costa a short distance from base, the same as is always found in Palumedes. One example in coll. Strecter. 
19. Palamedes, Dru., III. Ex. Ent., I, t. 19, (177.3); Cram., Southern Pap. Ex., I, t. 93, (1779); Kirloy, Cat., p. 543, United (1871).

States from

Chalcas, Fabr., Syst. Eut., P. 453, (1775); Herbst, Virginia Nat. Schmett., III, t. 42, (1788); Morris, Syil, p. sonthward, 7, (1862); (Eupherades C.), Hïb., Ver\%, j. 8:3, and south(1816).

Calchas, Godt., Fuc. Metlı., IX, p. 59, (1828); Bdl.- isiana. Lee., Lep. Am. Sept., p. 17, t. 5, (1833); Bdl., S'p. Gell., I, p. 3:37, (18:36).

Larva much resembles that of Troilus, and feeds on various species of Laurus.

\section{GENUS 2. PARNASSIUS, LATR.}

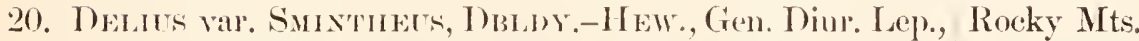
t. 4, (1847); Reak., Proc. Ent. Soc., Phil., II, p. of Colorado, 127, (1866); Kirly, (it., 1. 512, (1871); W. H. Montana,ete. Edwds., Butt. N. Inı., I, t. II-I I, Parn., (1872). Sayii, W. H. Eduds., Prox. Ent. For., Phil., II, p. 78, (1863) ; Butt. X. Am., I, t. II, t. 2, Parn., (1872); Kirly, ('at., 1. 511, (1871).

var. a. Behri, IT. H. EnWrs., Trams. Am. Ent. Soc., I I I, p. 10, (1870); Butt. N. Am., I, t. II I, l'illı., (1872); Kirloy, ('at., p. 514, (1871).

This form has yellow spots instead of red.

I all'vil on Sedum.

21. ('uodus, Mex., (at. Mus. P’etr., I, 1). 73, (1855); Bdl., California ; Lep. Cal., p. 29, (1870); W. H. Edwds., Butt. N. Oregon.

Am., t. I, Pam., (1871); Kirhy, (at. p. 513, (1871).

Clarius, Bdl., Aun. Fin. Ent., Fr., 1. 28:3, (1852);

II. H. Edwds., Butt N. Inı, t. I, Parı., (1871).

*.2. Eversmaxi, Mex., Cat. Mus. Petr., I, 1. 7:, t. 1, f. 1, Alaska;

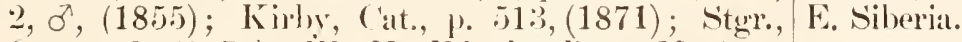
Cat., p. 2, (1871); II. H. Wdwds., Butt. N. An., t. IY, Paun., (187'2).

Hosnesenskii, Men., ('it. Mus. Petr., I, p. 74, t. 1, f.: : +,$(1855)$.

\section{FAMILY II. PIERIDA. GENUS 1. LEP'TALIS, DaLMaN.}

23. Mrutee, Lixx., (Pap. M.), syst. Nit., I, 2, 1) 755, (1767); New MexClerek, Ienes, t. 44, (i764); (ram., Pay. Fx., I I, ino; Mexico. t. 153), (1779); Fab., Ent. Syst., III, p. 160, (179:3); (Pieris M.) Godt., Enc. Meth., IX, 1) 165, (1819); (Licinia M.) Swails., Kool. Ill., I, t. 22, (18201821); (Leptalis M.) Bill., Nंy. (ien., I, I. 422, (1836); (Dismorplia M.) Kirlw, ('il., 1) 4:36, (1871). 


\section{GENUS 2. NEOPHASIA, BeHR.}

24. Mexapla, Jenner, (Pieris M.), Wien. Fut. Mon., III, California,

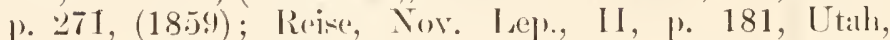
t. 25, (1865); Kibly, (at., ). 450, (1871); (Neo- ( )regon, phasia M.), Wr. H. Edwrls., Bntt. X. Am., t. 1, Vamenuver's Pieris, on, (1871); Streck., I tep., Rhol.-Het., t. Il, Jisurl. f. 4 , + , 1. $14 ;(187: 3)$.

Pieris Tau, scud., Proc. Bost. Sim. Nat. Hist., VIII, 1. 18:3, (1861); Morris, Nivn., p. 322, (186:2). Pieris Ninonia, Ball., Lep). ('al., p. :38, (1869).

Hy. Edwds. says, "Chrysalis is attached to the trunks of pine and fir trees. "The caterpillar donbtless feeds on the spruce fir (Abies Douglassi), and shonld be sought in the early part of July.'

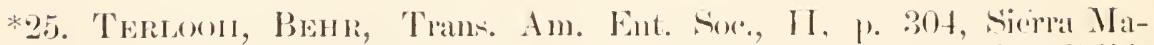
(1869;) Kirlyy, ('it., p. 450), (1871). Are', ('alifil.

\section{GFNTS 3. PIERIS, SCHRANCK.}

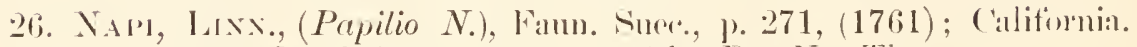
Syst. Nat., 1, 2, p.760,(1767); Selat, Rer. Nat. Thes., IV, t. 2, (1765); Esper, Schmett., I, 1, t. 3, (1777); Hïh., Enr. S(hmett., I, t. 406, 407, (179:3-1827); (Pieris N.) Cont., Enc. Meth, IX, p. 161, (1819); Bull., sir. (иен., I, p. 518, (18:36); Stgr., (at., J.:), (1871); Kirlyy, Cat., p. 45:3, (1871); Strerk., Lep., Rhop.-Het., t. VIII, 1. 61, (187:3); (Pontia N.) Duncan, Nat. Ijil., Ent., III, 1. 121, t. 4, (18:35); (Tachyptera N.) Berget, Schmett., 1. 94, t. :30, (1842).

Pieris Venosa, Scud., Pror. Bust. Sur.. Nat. Hint., I'] II, j. 182, (1861); Morris, sin., 1) :320, (1862); Kirly, ('at., J. 454, (1871); II. I. Helwhk, Nyo. X. Ain. I'1., I. 4, (187:).

Pieris Nasturtii, Bdl., Lep. ('al., p. :38, (1869).

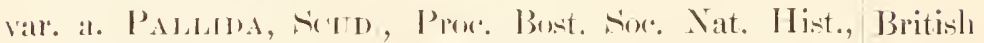
VIII, 1. 18:3, (1861) ; Molris, Syon., p. 3:21, (1860); Colnul,ial,

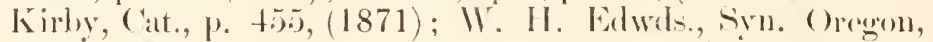
X. Am. Isep., p. t, (187:); Strok., Ixep., Rhop.- ('alifornia. Het., t. IIII, 1) 6:2, (187:3).

Pieris Iberidis, Bdl., Lep. ('ill., 1. :3!), (186!)).

+ Pieris Castoria, Reak, Proc. Ararl. Nat Ne., Phila., P. 238, (18615); Kirly, ( at., 1) 45)t, (1871); IV. II.

Edwds., Syn. N. Ain. Lep., 1) 1, (187:).

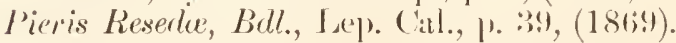

Paler form of the preceding. $\sigma^{7}$ sometimes with a more n less distinet black spot in middle of superiors towards outer unargin, and sometimes entirely destitute of such spol. 
var. h. (),erices, Harris, (Pontia O.), New Eng. ('anada, New Farmer, VIII, \%. 402, (1829); I gass., Lake Supe- England, rior, p. 38s6, t. 7, (1850); (Pieris O.) Bdl., Sp. Cren., Middle and I, p. 518, (1836); Seurl., Proc. Bost. Sore Nat. Western Hist., VIII, 1. 178, (1861); Harris, Ins. Inj. Veg., Sitates to Flint's Ed., p. 270, fig. 99, (1862); Morris, Syn., p. Colorado. 315, (1862); Kirly, ( :at., l. 454, (1871); IT. H.

Edwats., Sinn. N. Am. Lepr., p. 4, (1872).

l'ieris Cruciferarum, Bull., Np. Gen., I, 1. 519, (18366). Pontin Casta, Kirby, Famm. Bor. Am., IV, p. 288, t. $3,(1837)$.

An almost immaculate form, - a little greyish at hase of wings and on costa and apex of primaries heing all the decorations.

I alrva om ("ab)age, turnips, etr.

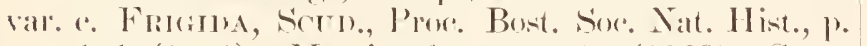
181, (1s61); Morris, Syn., 1.:31s, (1862); Stgr., ('at., \%. 3, (1871); Kirly, (at., 1). 454, (1871);

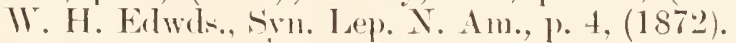

L'ieris Oleracea var., Bull., Sp. Gen., I, p. 518, (1836).

Ganoris Oleraceu var. Borralis, Grote, Bull. Buff: Sor., I, l. 185, (1873).

A form having the veins of under surface of secondaries accompanied with dark xcales.

var. 1. Husba, W. H. Enwss., Trams. Am. Ent. Sore, Konliak.

II, 1. 370, (1869); Kirhy, Cat., p. 453, (1871).

veins of under surface so heavily accompanied by blackishgreen scales that but litule of the pale yellow ground colour of the wing is visible.

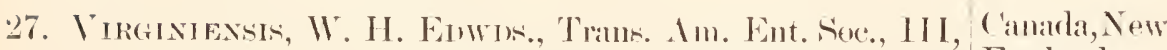
P. 13, $(1870)$; Butt. N. Am., t. I], Pieris, (1871); England, Kirby, Cat., 1. tist, (1871).

28. Rarde, Laxy., (Propilio R.), Syst. Nat., El. X, I, l. 4tis, Europe, Ni(1758); Fann. Siner., p. 270, (1761); Syst. Nat., heria, British Ed. XII, p. 759, (1767); Esper, Sehunett., 1, t. 3, Columbia, (1777); Häh., Eur. Sorbuett., I, 404-10.5, (17.9s); Oregon, Cal-

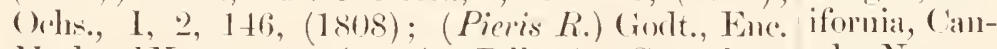
Mcth., IX, 1. 161, (1819); Bull., sir. Cren., 1, J. ada, New 520, (1836); (Pontia R.) Duncan, Nat. Lil., IJI, England, ). 117, t. T, $(1835)$; (Tachyptera h.) Berere, Mirlille amd

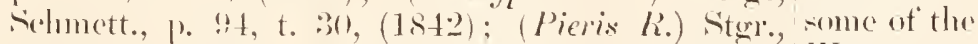

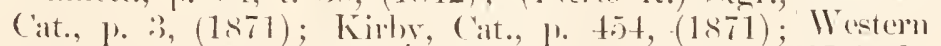

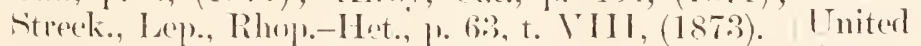

P'ieris Margimalis, Scurl., Proc. Bost. Sim. Natt. Hist., Stater.

IIII, 1. 18:), (1861); Morris, S'rn., 1. :321, (1862); Kirloy, Cat., \%. 4.5t, (1871); II. II. Edwhls., Syrn.

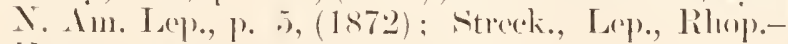
Het., p. 6i:3, t. VIII, (1873).

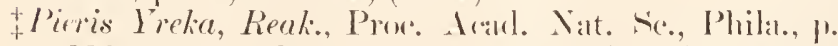
238. (1866); Kirbr, (at., 1. 4is), (1871); II. H. Edwds., Sym. I m. N. Am., p. 4, (1872); Streck., Lej', Rhoj)-Het., 1. 6i3, t. VIII, (187:3). 
Larva the ton well-knomm ablhage-worm; is also found on turnips, migmomette, and some other plants.

var. a. Novanglde, Sivo., ('an. Hut., IV, p. 79, Canarla, New (1872).

ơ eutirely lemon yellow on both surfaces.

England and N'dlestater.

29. Monuste, Linx., (Pap. M.), Mus. Lad. Ulr., p. 237, Southern $(176+4)$; Syst. Nat., I, 2, p. 76(6), (1767) ; Fabr., U. Statew, Syst. Ent., 1) 470, (1775); (Pieris Mr.) Godt., Enc. W. Indier, Nieth., IX, p. 141, (1819); Ball., Sp. Gen., I, p. Cent. Am., 495, (1836); Kirbs, (at., p. 458, (1871). Cayenne, Pap. Monusta, Crami., Pap. Ex., II, t. 141, (1779); Brazil, V'm(Pieris H.) Morris, Svru., p. 16, (186\%). ezuelat.

Mylothris Mippomonuste, Hïl., V er\%. Bek. Sehmett., 1., $91,\left(1816^{\circ}\right)$.

Pieris Cleomes, Bdl.-Lec., Lep. Am. Siept., I, 1. 43, t. $16,(1833)$.

Pieris Orseis, Godt., En!. Meth., 1X, 1. 141, (1819).

Pap. Albusta, Sepp, Surin. Vlind., III, t. 1+1, $(1855)$.

ab. a. Phineta, Fabr., (Pap. P.), Syst. Ent., p. 471, (1775); Kirby, Cat., p. 458, (187i).

Pieris Philete, Bdl., Sy. (ien., I, 1. 550), (1833i).

Pieris Suasa, Bdl., 1. (., 1. 549, (1836).

Phileta is a smoky or melanotic $q$ form.

Larva, acoording to Bdl., on Cleome Pentaphylla.

30. Protonter, Brts.-Lec., Lep. Amer. Sept., p. 45, t. 17, Camarla, (1833) ; Sp. Gen., I, p. 543, (1836); Scoud., Proe. United Bost. Sor. Nat. Hist., VIII, 1. 180, (1861); Morris, States and Syn., p. 17, (1862); Kirlor, (at., p. 451, (1871); Territorico, II. H. Edwdi., Sin. N. Am. Butt., p. 4, (1872); from AtSaunders, Can. Enit., V, p. 42, (1873). lantic to the

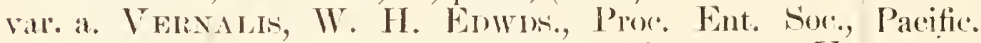

Phila., II, p. 501, (186t); Butt. N. Am., t. II, Pieris, (1871); Kirby, Cat., p. 463, (1871).

This is the first or spring generation of Protodice.

Larva on Cruciferce.

31. Ocenentalis, Reak., Proc. Fint. Soc., Phila., VI, p. 133, colomato, (1866) ; Kirby, Cat., 1. 462, (1871); W. H. Edwrts., Nevala. Syn. Butt. N. Am., p. 5, (1872).

Closely allied to the preceding.

32. Sisturetr, Bot., Am. Soc. Ent., Fr., p. 284, (1852); Califormia Morris, Syn., p. 17, (1862); Kirby, Cat., p. 451, and adjacent (1871); W. H. Edwds., Syu. Butt. N. Am., p. 5, territory. (1872).

33. Culoriderce, Hurs., (Papilio C.), Eur. Schmett., I, f. 712- Nevada, 713, (1803-1818); (Pieris C.) Ochls., Schmett. Eur., Utah,S.RusIV, p. 154, (1816); (Pieris C.) Dup., Lep. Fr. sia, Sarepta, Suppl., I, t. 4, (1832); Bdl., Sp. Gen., I, p. 543, Tureomania, (1836); Stgr., (at., p. 3, (1871); Kirby, Cat., p. Siberia, 451, (1871); Streck., Jep., Rhop.-Het., p. 70, Persia. (1873). 
Papilio Daplidice var. Russice, Esp., Schmett., I, 2, t. 90, (1784).

Pieris Beckerii, W. H. Erhods., Butt. N. Am., t. 1, Pieris, (1871); Hy. Eilwels., Proc. Cal.Acad. Sc. V II,(1876)

34. Calyce,W. H. Edwds., Trans. Am. Ent. Soc, III, p. 189, Nevada, (1870); Hy. Edwds, Proc. Cal. Acad. Sc.VTI,(1876) California.

\section{GENTS 4. ANTHOCHARIS, BiL.}

35. Aunonia, Hub., (Pap. A.), Eur. Schmett., I, 582-583, Gr. Slave L. (180:3); Ochs., I, 2, 1. 164,(1808); Godt., II, 6, 3, Brit. Col., S. 4, (1822); Bdl., Amm. Soc. Ent. Fr., p. 68, (1845); Eur., MorocStgr., Cat., p. 4, (1871); (Euchlee A.) Kirby, Cat., co, Syria, 1. $506,(1871)$. Armenia.

var. al. Ausonordes, Bdu., Amn. Soe. Ent., Fr., 2me Ser. California X, 286, (1852); Lucas, Rev. Zool., p. 340, (1852); and adjacent W. H. Edwds., Proc. Eut. Soc., Plilia., II, p. 81, territory. (1863); Syn. N. Am. Butt., P. 5, (1871); (Euchloe A.) Kirby, Cat., p. 506, (1871); (Anth. A.) W. H. Edwels., Butt. N. Am., II, t. I, Anth., (1874); Hy. Edwels., Proc. Cal. Acad. Sc., V, (1874); Mead, Whecler's Rep., V, p. 747, (1875).

Larva on Cruciferce.

36. Creusa, Dbldr.-Hew., Gen. Diur. Lep., p. 56, t. 7, Nevada, (1847); (Euchlee C.) Kirby, Cat., p. 506, (1871); Utah. (Anth. C.) IV. H. Edwds., Srrn. N. Am. Butt., p. 5, (1871); Hy. Edwds, Proc. Call.Acarl. Se. VII, (1876).

A. Hyantis, W. H. Edwds., Trans. Am. Ent. Soc., III, p. $205,(1871)$.

37. Laxceolata, Bdi., Ann. Soe. Ent. Fr., 2 me Ser. X, 284, California. (18.52); Luc., Rev. Zool., p. 338, (1852); Morris, Syn., p. 21, (1862); Scud., Proc. Bost. Soc. Nat. Hist., Vol. XII, 1. 406, (1869); (Midea L.) Kirby, Cat., p. 509, (1871); (Anth. L.) Streck., Lep., Rhop.Het, p. 49, t. VI, (1873); Hy. Edwrls., Proe. Cal. Acarl Se., VII, (1876).

A. Eitrardsii, Behr, Trans. An. Ent. Soe., II, p. 304, (1869) ; (Euchlee E.) Kirloy, Cat., p. 508, (1871).

38 Genutia, Fabr., (Pap. G.), Ent. Srst., III, 1, p. 198, U. S. east of (1793); Don., Ins. Ind., t. 27, (1800); (Pieris G.) Texas, (? exGodt., Ene. Meth., IX, p. 168, n. 165, (1819); cept New (Anth. G.) Bull., Sp. Gen., I, p. 565, (1836); Morris, England Syn , 1. 20, (1862); (Hidea G.) Kirby, Cat., p. 508, States). (is71).

Mancipium vorax Hidea, Hüb., Sam. Ex. Schmett., (1806-1816).

Pieris L'herminieri, Godt., Enc. Neth., IX, n.164,(1819) Donovan's figure is incorrectly represented with long palpi like Libythea.

39. Sara, Bdu., Amm. Soc. Ent. Fr., 2 me Ser. X, 285,(1852); California, Luras, Rev. Zool., p. 21, (1852); Morri, Syn., p. 21, Oregon. (1862); (Euchloes.) Kirby,Cat., p.508,(1871); (Anth.

s.) W. H. Edwds.. Butt. N. An., t. II, Anth., (1871). var. a. Reakinti, W. H. Enwds., Trans. Am. Ent. 
Soc., II, p. 369, (1869); Butt. N. Am., t. I, Anth., (1870); (Luchloe R.) Kirby, Cat., p. 50s, (1871); Hy. Edwels., Cal. Acad. Nat. Se., VII, (1876).

Smaller than Sara, and $f$ is always white, never yellow, as in some instances in the former. Probably the first generation of Sara.

40. Centhura, Feld, Reise Nov. Lep., II, 11. 182, t. 25. (1865); (Euchloe C.) Kirby, Cat., p. 508, (1871).

Mt. Diablo, Sim Diego, A.Cooperi, Behr, Trans. Am. Ent. Soc., II, p.30t,(1869); Catifornia.

W. H. Edwd.., Bntt. N. Am., t. I, Anth., (1870). A. Angelina, Bdl., Lejr. Cil., p. 40, (1869).

41. Julia, IT. H. Eowds., Trans. Am. Ent. Soc., IT, p. 61, (1872); Streck, Lep., Rhop.-Het., p. 50, t. V'I. J, , Utah.

(187:3); Mear, Wheeler's Rep., V, p 748, (1875).

42. Oltupia, W. I. Edwos., Trans. An. Ent. Sinc, II I, p. 266, Ya., Kan., (1871); Streck., Lep., Rhop.-Het., p. 6t, t. VIII, o?, (1874); W. II. Edwds., Butt. N. Am., II, t. I. Anth., (1874); Hy. Edwds., Cal. Acad. Nat. Sc., VII (1876) Belongs to the group separated by Rimbur in to the genus Zegris.

Colorarlo, Ya., Kan
Tex. and donbtless other partsol the $\mathrm{L}$. s.

\section{GENUS 5. NATIIALIS, BDL.}

44. Iole, Bot., Sp. Gen., I, p. 589, (18:36); Morris. Syn., p. Colorado, 22, (1862) ; Reak., Proc. Ent. Soc., Phil., VI, p. 134. California, (1866); Kirly, Cat., „. 501, (1871); Hy. Edwds., Texas, MexProe. Cal. Acerl. Se., VII, (1876).

Felicia, Poey, Mem. Cuba, I, p. 44:3, t. 18, (18.51). Irene, Fitch, 3 d Rep. X. I. State Agr. Soc., Snppl., p. $485,(1856)$.

†Luteolus, Real., Proc. Ent. Soc., Phil., II, 1. 350 , (1863); Kirby, Cat., p. 504, (1871).

The original type of Lutenlus is in my possession; it is merely a little darker yellow than is eommonly the case.

\section{GENUS 6. GALLIDRYAS, BUL.}

45. Argante, Fabr., (Pep. A.), Syst. Ent., p. $170,(1755)$; Ent. Florila, Syst., III, 1, 1. 189, (1793); (Wrncipium fuga.x A.) Texas, МexḦ̈b., Sam. Ex. Schmett., (1806-1816); (Col. A.) ico, II. InGodt., Enc. Meth., IX, p.92, (1819); Swains., Kool. «lies, Cent. Ill., I, t. 52, (1820-1821); (Cullidryas A.) Bdl., Sp. Am., BoliGen., I, 1). 622,(1836); Lucas, Lep. Exot., p. 81, t.40, via, Brazil, (1835); (Catopsitia A.) Kirby, Cat., 1). $484,(1871)$; ate.

(Call. A.) Butl., Lep. Exot., p. 119, t. 11, (1872)

ơ Pap. Hersilia, Cram., Pap. Ex., II, t. 173, (1779);

Herlsst, Nat. Schmett., V, p. 192, t. CX, $\left(\sigma^{7}\right)$, p. 197, t. CXI, (f), (1792); (Call. H.) Butl., Lep). Exot., p. 106, t. $39,(1872)$.

Pap. Cypris, Cram., Pap. Ex., II, t.99,(1779); (Phorbis

C.) Ḧ̈l., Sam. Ex. Schmett., (1806-1s16).

Pap. Pallideflavus, Groeze, Ent. Bert., III, 1, 1. 185, 11. $9 \bar{T},(17 \overline{7} 9)$.

Pre. Lrura, Fubr., Ent. Syst Snppl., p. 423, (1793);

(Col. I.) Grodt., Enc. Meth., IX, p. 94, (1819).

Pap. Toloanica, Perry, Areani, (1811).

Col. Cnidia, Godt., Enc. Meth., [X, p. 9):3, (1819).

Pap. Tenthe, Sepp, Surin. Vlime, II, t. 75, (1818). 
46. Erbuta, Iaxx., (Pap. E.), Syst. Nat., I, 2, 1. 764, (1767); U. S. ex(ram., Pap. Ex., II, t. 120, (1779); Abb.-Smith, cepting New Lep. (kiı., I, t. 5), (1797); (Callidryas E.) Bdl.-Lec., England and 1.1. Am. Sept., 1). 74, t. 24, (18:33); Bdl., Sp. Gen., the north1, p. 613), t. 6, f, (18:36); Duncan, Nat. Lih., Ent., western Y, 1. 122, t. VIII, (18:37); Morris, Syn., 1). 25, States, (onl1(1862); (Catopsilia E.) Kirby, Cat., P. 482, (1871). monest Pap. Marcellina, Cram., Pay. Ex., II, t. 163, south. Mex(1779) ; (Col. M. et Eubule) Godt., Ene. Meth., IX, ieo, W. In1. 92, (1819); Don., Nat. Rep., 1, t. 6, (1823); dies, Cent. (Callidryas II.) Bdll., Si. Gen., 1, 1) 615, (1836); and S. An. Bates, Jul. Ent., I, 1. 2:38, (1861); Morris, Syn., p. $26,(1862)$.

Pap. Drya, Habi, syst. Ent., p. 478, (1775).

: val. Pap. Senne, Linn., Nyst. Nat., 1, 2, p. 764, (1767).

Larva on Cassia.

17. ('urls, Fdir., (Pap. C.), Ent. Syst., 1II, 1, p. 212, (179:3); S. Texas, Don., Nat. Rep., II, t. 40, (1824); (Colias C.) " N. Mexien, Gort., Enc. Meth., IX, p. 91, (1819); (Catopsilia Mexion, C.) Kirlw, (at., p. 484, (1871).

Callidryas Cypris, Bdl., Hp. Gen., I, 1) 62:), (1836). Brazil, "to. Colias Neocypris, Ḧ̈l., Sim. Ex. Schmett., (1816$1836)$.

千 Callidiyas Bracteolata, Butler, Proc. 'mol. S'oc., p. 458, t. 26, (186ij).

Hind wings of this species prolonged at the anal angle into a tail.

\section{CIENUS 7. KRICOCONIA, REAK.}

48. Ixistre, Gont., (Colius L.), Ene. Meth., IX, 1. 98, (1819); \&. Florida,

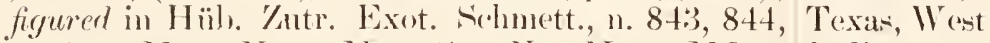

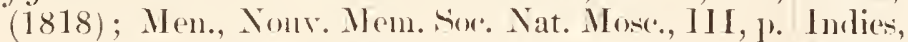
119, (18:34); (Rhodocera L.) Bdl., Sp. ('xn., I, p. Mexicn. 60:3, (18:36); Morris, Syn., 1). 24, (1862); (Gonepteryx L.) Dhldy.-Hew., Gen., I, p. 71, (1847); (hic. L.) Reak., Proc. Hint. Ser., Phil., I I, ]. 356;, (186:3); Kirly, ( at., p. :387, (1871).

\section{GENUS 8. GONEPTERYX, TEACH.}

49. Marted, Fabr., (Pup. M.), Frst. Ent., p. 479, (1775); Florida, Ent. S., I II, 1, 1. 212, (1793); Don., Ins. Ind., t. W. Indies, $27,(1800)$; (Col. M.) Golt., Ene. Meth., 1X, p. 89, Mexien. (1819); (Rhodocera M.) Bdl.-Iec., Lep. Im. Á(.pt., p. 71, t. 2:), (183:); Bdl., Sp. (Gen., I, 1. 60), (18:36); Morris, Syn., j. 2:3, (1862); (Gion. M.) Kirly, ('at., \%. 488, (1871).

Pap. Licclipsis, Cram., 1'aj. Ex., 11, t. 129, (1779). 
50. Cuonnde, Gont., (Colias C.), Ene. Meth., IX, Sup., p. S. T'exas, 813, (1823); (Call. C.) Lucas, Pap. Ex., p. 8:3, t. N. Mexico, 42, (1835); (Rhodocera C.) Bdl., Sp. Genl., I, J. Mexico, II. 599, (1836); Morris, Syn., p. 350, (1862) ; (Gonep- Inties, ('ent. teryx C.) Dbldy.-Hew., Gen., 1, 1. 71, (1847); Am., N. Kirloy, Cat., p. 487, (1871). Giranadi, Anteos Mferula, Häb., Sam. Ex. Schmett., (1806- Bolivia, dete. 1824).

Amynthia et Cynthia Swainsonia, Swains., Kowl. Ill., 2, Ser., t. 65, (1832).

Colias Godarti, Perty, Del. Animal, 1. 152, t. 29, (1834).

\section{GENUS 9. MEGANOSTOMA, REAK.}

51. Eurydice, Bdi., (Col. E.), Amm. Soce. Ent., Fr., p. 32, California. (1852); Lep. Cal., P. 40, (1869); W. H. Eslwet., Butt. N. Am., I, t. V, (ol., (1869); (Meg. E.) Kirby, Cat., p. 490, (1871).

Col. Wosnesenskii, Men., Cat. Mus. Petr. Lep., I, p. 77, t. I, (1855); Morris, Syn., p. 32, (1862).

q Rhodocera Lorquini, Bdl., Aim. Sioe. Eut., Fr., p. 52, (1855).

\$Meganostoma Helena, Reak., Proe. Kint. Soc., Phil., II, P. 358, (1863); Kirlo, Cat., p. 48!), (1871).

Larval food-plant, Amorpha Californica, Torr.

52. ('esonia, Stenta, (Pap C.), Sup. (Tram., t. 41, (1787- Sonthern $1791)$; (Kerene C.) Hïl., Sim. Ex. Schmett., (1806- and W' estern 1824); (Colices C.) Godt., Ene. Meth., IX, p. 98, U. s. firm (1819); Ball.-Lee., Lep. Am. Aept., 1). 157, t. 22, Atlantic to (1833); Lucas, Pap. Ex., p. 79, t. 39, (1835); Bell., Pacific"; sp. Gen., I, p. 6835, (1836); Dbldy.-Hew., Gen., Mexico, p. 74, (18+7); Morris, Syn., p. 27, (1862); ( Meg.C.) ('entral Reak., Proc. Ent. Soc., Plila., 11, p. 358, (1863); Amerinat. Kirloy, Cat., p. 489, (1871); Hy. Ekwds., Prece. (al. Acarl. Sc., (1874).

Pap. Garoliniana, Petiv. (iazoph., 1. 2, t. 7, (176; ).

Latrva on various speries of clover (Trifolium).

\section{GENUS 10. COLIAS, FABR.}

53. Padano, Laxw., Fam. Suee, p. 272, (1761); Syst. Nat., Brit. CoI, '2, p. 764, (1767); Fabr., Syst. Lint., 1. t76, lumbia, (1775); Eut. Syst., III, p. 207 , (179:3); Ochs., Aretio reSchmett., I, 2, 184, (1808); (Colias P.) Godt., Enc. gions of Meth., IX, p. 101, (1819); Bdl., sp. (ien., I, P. Americat and 645, (18:36); Stgr., Cat., 1. 5, (1871); Kirlsy, (ait., Lurepr. p. $49: 3,(1871)$.

Pap. Luropomene, Esp., Schmett., I, t. 42, (1778);

Hïl., Eur. Sillmett., 434, 435, (1793-1827).

Pup. Philomene, Hüb., І. (., 602, 60:3, 740), 7.11;

(Col. P.) Dup., L.e., Sup)l., I, t. 47, (1832). 
Col. Palono var. Lapponica, Stgr., Cat., p. 5, (1871).

Col. Werdandi, H.-S., Schmett. Eur., f. 403, 404, ㅇ, (1848).

Col. Helena, W. H. Edwds., Proe. Ent. Soc., Phila., II, p 80, (1863); Butt. N. Am., I, t. I, Col., (1868).

Col. Chippewa, W. H. Edwds., l. c., last page Vol. I; Kirby, Cat., p. 495, (1871).

The N. Ans. $\sigma^{7}$ examples are generally paler than the common European form, assimilating more to the var. Lapponica, Stgr. Edwds.' types (Helena et Chippewa) were taken at M'Kenzie's River, British Columbia, N. L. $61^{\circ}$, abont. I received examples from the region soutl-west of New North Wales, B. C. It is a common species in central and northern Europe and Siberia

54. Pelidne, Bdl., Icones, t. 8, (1832); Sp. Gen., I, p. 644, N. E. Lab(1836) ; Dup., Suppl., I, t. 15, (1832); Bdl.-Lec., rador, Lep. Am. Scpt., p. 66, t.: 21, (1833); Herr.-Sch., Brit. ColumSchmett. Eur., t. 7, f. 35, 36, t. 8, f. 43, 44, (1843); bia, Colorado Freyer, Nene. Beit., VI, t. 511,(1831-1858); Men., Cat. Mus. Petr. Lep., I, p. 84, (1855); Mosch., Wien. Monat., IV, p. 349, (1860); Morris, Syn., p. 30, (1862); Kirby, Cat., p. 493, (1871); W. H. Edwds., Butt. N. Am., II, t. I, Col., (1874).

Col. Anthyale, Stgr., Cat., p. 5, (1871).

Col. Labradorensis, Scud., Proc. Bost. Soc. Nat. Hist., p. 107, (1862) ; 1. c., XII, p. 406, (1869); Kirby, Cat., p. 493, (1871).

Col. Scudderii, Reak., Proc. Ent. Soc., Phil., IV, p. 217, (1865); Kirby, Cat., p. 496, (1871); W. H. Edwds., Butt. N. Am., I, t. VIII, Col., (1872); Mead, Wheeler's Rep., V, p. 749, (1875).

Differs in nothing of any importance from the Labrador examples.

var. a. Interior, Scud., Proc. Bost. Soc. Nat. Hist. IX, p. 108, (1862) ; Kirby, Cat., p. 493, (1871).

+Col. Pelidnevar., Streck., Lep., Rhop.-Het., p.69,(1873).

Col. Philodice var. Laurentina, Scud., Proc. Bost. Soc.

Nat. Hist., p. 4, (Oct., 1875).

A form found in S. Labrador and in the Lake Superior region, in which the is in the majority of instances yellow like the $\sigma^{?}$.

var. b. Christixa, WV. H. Edwds., Proc. Ent. Soc., Phil., Brit. ColumII, p. 79, (1863); Butt. N. Am., I, t. II, Col., (1868). bia.

A form of great size, $\sigma^{7}$ of often $2 x$ inches in expanse; the $\sigma^{7}$ is sometimes partially suffused with orange, like Eurytheme, as in the examples figured by Edwds, which were taken at Slave River, B. C. In the examples from N. S. Wales, B. C., the males are lemon yellow, like the typical Labrador form; the females are both yellow and white, the latter greatly in excess of the former. Above Lake Athabasca both the orange and yellow $\sigma^{r}$, and the yellow and white $q$ forms occur. All four exceed in size those from $\mathrm{N}$. E. Labrador.

55. Alexandra, W. H. Edwds., Proc. Ent. Soc., Phil., II, Colorado.

p. 15, t. 11, (1863); Butt. N. Am., I, t. I, Col.,

(1868) ; Reak., Proc. Ent. Soc., Phil., VI, p. 135, (1866) ; Kirby, Cat., p. 494, (1871) ; Mead, Wheeler's Rep., V, p. 749, (1875).

ab. a. $\&$ ALBA, - a white $\&$ form of rare occurrence. 
var. b. Edwardsi, Behr; W. H. Edwds. Butt. N. Nevada. Am., I, t. 6, Col., (1870); Kirby, Citt., P. 494. (1871); Mead, Whecler's Rej., V, 1. 749, (1875).

What little difference there is between this and Alexandra is easier seen than described, being mainly in the presence of more dark scales on margin of primaries in + .

†*56. Emilia, W. H. Edwds., Trans. Am. Ent. Soc., III, p. Olegon. 12, (1870); Kirby, Cat., p. 494, (1871).

†*57. Barbara, Hy. Edwds., Proc. Cal. Acad. Nat. Se, V'II, California. (1877).

58. Philodice, Godt., Enc. Meth., IX, p. 100, (1819); Camalat, (Eurymus P.) Swains., Zool. Ill., 2, Ser. II, t. 60, United (1831); Bdl.-Lce, Lep. Anl. Sept., p. 64, t. 21, Staltes cant (18:3:3); Bdl., Sp. Gen., I, 1. 6.77, (1836); Lneas, of Texas, Isep. Exot., p. 78, t. 39, (1835); Hamis, Ins. Inj. Kamsis, Veg., p. 272, f. 100, 102, (1862); Morris, Syn., p. ? Nevala. 29, (1862); Reak., Proc. Ent. Soc., Phil., IV, P. 218,(1865), VI, p. 135, (1866); Simuders, Can. Ent., I, p. 54, (1869); Kirby, Cat., p. 494, (1871); Mead, Wheeler's Rep., V, p. 748, (1875); W. H. Edwds., Butt. N. Am., II, t. II, III, Col., (1876).

Pap. Palceno, Cram., Pap. Exot., I, t. 14, (1775).

Zerene Anthyale, Hüb., 'Zutr. Ex. Schmett., f. 307, $308,(1823)$.

Col. Europome, Steph., Ill. Brit. Ent. Haust., 1, p. 10, t. 1, (1828); (Eurymus E.) Swains., Zool. Ill., 2d, Ser. II, t. 70, (1831); (Col. E.) Humph., W est. Brit. Butt., p. 17, t. 3, (1848).

Col. Chrysotheme, Nastes et Santes, Fitch, Rep. N. Y. State Agr. Soc., VIII, 1. 378, (1854).

ab. a. ㅇ Alba, W. H. Edwds., Butt. N. Am., II, t. 11, Col., f. 6 , t. III, f. 5, 6, (1876).

The common white 우 form.

Larva on clover (Trifolium) and pea (Astragalus).

ab. b. ठ ठ Nig.-First figured by Glover in his unpublished plates from a unique example taken near Palmyra, N. Y. Thi figure was copied in Edwds.' Butt. N. Am., II, t. III, Col., f. \&, $9,(1876)$. Another example, now in my possession, was taken near Montreal, Canada; it is wholly smoky black on upper surface save the fringes, which are pink. Under surface dull green, with a large inky patch on inner half of primaries.

łab. c. $\sigma^{\lambda}$ VIRIDA.-One example taken at same time and place as the preceding. Upper surface dull dark green, with usual black border. Under side much as in preceding.

ab. d. or Hybrida ex C. Pinloden et C. Chriso- Illinois, Theme, figured in W. H. Edwds.' Butt. N. An., Geororia. II, t. III, Colias, (1876).

Suffused with pale orange.

var. e. Occidentalis, Scud., Proc. Bost. Soc. Nat. Hist., M'Kenzic's IX, p. 109, (1862); W. H. Edwds., Butt. N. Am., I, River, Britt. VII, Col., (1871); Kirlyy, Cat., 1) 493, (1871). ish ColumCol. Chrysomelas, Hy. Edwds., Proc. Cal. Acad. Nat. bia; Oregon, Sc., VII, (1877). California. 
? var. f. Eriphyle, W. H. Edwds., Trans. Am. Ent.'British CoSoc. $\mathrm{V}$, p. $202,(1876)$.

lumbia.

†*59. Astrea, W. H. Edwds., Trans, Am. Ent. Soc., IV, p. Montana. $61,(1872)$.

Described from one $\delta^{7}$ taken near the Yellowstone River Montana, by the Hayden Ex., 1871.

60. Chrysotheme, Esp., (Pap. C.), Schmett., I, 2, t. 65, Rare in Ca(1777); Hüb., Eur. Schmett., I, f. 426-428, (1793- nada, New 1827) ; Ochs., Schmett. Eur., I, 2, 1. 178, (1808); Eng. and (Col. C.) Godt., Enc. Meth., IX, p. 103, (1819); Mirldle Bdl., Icones, t. 9, (1832) ; Sp. Gen., I, p. 643, t. 6, States; com(1836) ; Morris, Syn., p. 28, (1862); Stgr., Cat., p. mon in 6, (1871); Kirby, Cat., p. 493, (1871); Streck., Southern Lep., Rhop.-Het., p. 100, (187t).

Col. Ariadne, W. H. Elwds., Trans. Am. Ent. Soc., III, p. 12, (1870); Kirby, Cat., p. 494, (1871). var. a. gen. 2. Eurytheme, Bdr., Ann. Soc. Ent., Fr., p. 286, (1852) ; Morris, Syn., p. 29, (1862); Reak., Proc. Ent. Soc., Pliil., II, p. 136, (1866); W. H. Edwds., Butt. N. An., I, t. III, Col., (1869); Kirby, Cat., p. 493, (1871) ; Hy. Edwds., Proc. Cal. Acad. Sc., V, p. 162, (1873) ; Mead, Wheeler's Rep., V, p. $748,(1875)$.

Col. Chrysotheme, vai. Bdl., Sp. Gen., I, p. 644, (1836). Col. Amphidusa, Bdl., Ann. Soc. Ent., Fr., p. 286, (1852).

Col. Edusa, var. Californiana, Men., Cat. Mus. Petr. Lep., I, p. 80, (1855).

ab. b. क Alba. W. H. Edwds., Butt. N. Am., t. III, Col., f. 5, 6, (1869).

fab. c. I FLAVA,-rlestitute of every trace of orange. Mus. Streck. var. d. Kenwaydin, W. H. Edwds., Butt. N. Am., I, t, IV, Col., (1869); Kirby, Cat., p. 491, (1871); Mead, Wheeler's Rep., V, p. $748,(1875)$.

Forma intermedia Chrysotheme et Eurytheme.

ab. e. क Alba. W. H. EDWds., l. c., f. 8, 9.

ab. f. Harfornit, Hy. Edwds., Proc. Cal. Acad. Nat. California. Se., VII, (1877).

Col. Kecuaydin, var., A, ơ, W. H. Edwds., Butt. X. An., I, t. I I ${ }^{r}$, Col., f. 7, (1869).

Destitute of all orange, lemon yellow like Philodice.

Larva on bufflalo grass (T. reflexum) and other species of Trifolium.

61. Meadi, W. H. Edwds., Trans. Am. Ent. Soc, III, p. Rocky Mts. $267,(1871)$; Butt. N. Am., I, t. VIII, Col., (1872); of Col. ; 10Mear, Wheeler's Rep., V', P. 750, (1875). 12,000 f'eet

So close to C. Hecla, Lef br., that I almost doubt its being distinet. above the sea

62. Hecta, Lefrir., Amm. Soc. Ent., Fr., p. 38:3, t.9, (18:36); Greenland, Kirby, Man. Eur. Butt., p. 17, (1862); Stgr., Cat., Iappland. 1. 6, (1871); Kirby, Cat., p. 492, (1871).

Col. Boothii, Bdl., (nec (urtis), Gen. Ind. Meth., p. т, (1840); IIerr.-Sch., Schmett. Eur., I, f. 459, 460, (1843); Walleng., Skand. Dagf., p. 139, (185:3). 
63. Boothin, Curtis, App. to Narr. Ross' 2d Voy., Nat. Hist., Boothiap. 65, t. A, (1835); Herr.-Seh., Sehmett. Eur., I, Felix.

f. 39, 40, (1813); Gn., Ann. Soe. Ent. Fr., p. 198, (1861); Stgr., Stett. Ent. Z., p. 47, (1866); Cat. Eur. Lep., p. 5, (1871); Kirby, Cat., p. 493, 1871).

ab. a. Chione, Curtis, App. Ross' 2d Voy., Nat. Hist., p. 66, t. A, (1835); Stgr., Cat., p. 6, (1871); Kirby, Cat., p. 493, (1871).

Devoid of the black discal spot on primaries; marginal border narrow and obscure.

64. Nastes, BdL., Ieones, t. 8, (1832); Godt., Dup. Suppl. N. E. IabLep., I, t. 15, (1832); Bdl., Sp. Gen., I, p. 648, rador.

(1836); Herr.-Seh., Schmett. Eur., I, t. 7, f. 37, 38, (1843), t. 84, f. 401, 402, (1843); Walleng., Skand. Dagf., p. 142, (1853) ; Moseh., Wien. Ent. Monat., IV, p. 354, t. 9, (1860); Morris, Syn., p. 30,(1862); Stgr., Cat., p. 5, (1871); Kirby, Cat., p. 494, (1871); W. H. Edwds., Butt. N. Am., II, t. I, Col.,(1874).

This is the Labrador form of the Lappland $C$. Werdandi, Zett., (Ins. Lapp., p. 908, (1828).

*var. a. Rossir, Gr., Ann. Soc. Ent. Fr., p. 199, (1864); BoothiaStgr., Cat., p. 5, (1871); Kirby, Cat., p. 495, (1871). Felix.

Yellow form.

65. Behri, W. H. Edwds., Proe. Ent. Soc., Phil., VI, p. Mts. of Cal., 201, (1866); Butt. N. Am., I, t. 2, Col., (1868); 10,000 ft. Kirby, Cat., p. 495, (1871). above the sea

\section{GENUS 11. TERIAS, SwaINs.}

\section{$\left\{\begin{array}{l}\text { Xanthidia, Bdl. } \\ \text { Eurema, Hüb. }\end{array}\right\}$}

68. Nicippe, Cray., (Pap. N.), Pap. Exot., III, t. 210, From Penn(1782) ; Herbst, Nat. Schmett., V, p. 176, t. CVII, sylvania f. 3, 4, (1792). Enc. Meth. Ins. Plates, t. 15, f. 2, sonthward (1797) ; Fabr., Ent. Syst., III, p. 208, (1793); figured in Hüb., Zutr. Ex. Schmett., n. 819, 820, ó, (1818); (Colias N.) Godt., Ene. Meth., IX, p. 103, (1819); Say, Am. Ent., II, p. 70, t. 30, (1825); Lncas, Pap. Exot., p. 76, t. 38, (1835); (Tanthidia N.) Bdl.-Lee., Lep. Am. Sept., p. 55, t. 20, (1833); Mexico, Cen(Terias N.) Bdl., Sp. Gen., I, p. 653, (1836); Mor- tral Am., W. ris, Syn., p. 33, (1862); (Eurema N.) Kirby, Cat., p. Indies. 141,(1871); Mead, Wheeler's Rep., V, p. 750,(1875); Hy. Edwds., Proc. Cal. Acad. Sc., VII, (1876).

ab. a. $\sigma^{7}+$ F FAVA.-Citron yellow without any traces of orange. $\sigma^{7}$ very rare, + more frequent.

Larva on Cassia and Trifolium.

69. Proterpia, Fabr., (Pap. P.), Syst. Ent., p. 478, (1775); Texas, MexSp Ins., II, p. 50, (1781); Mant. Ins., II, p. 24, ico, Cuba, (1787); Ent. Syst., I!I, 1, p. 210, (1793); (Col. P.) Cent. Am., Golt., Ene. Neth., IX, p. 91, (1819); (Ter. P.) Bolivia, Bdl., Sp. Gen., I, p. 654, (1836); Lucas, Lep. Exot., Venczuela. p. 74, t. 38, (1835); Morris, Syn., p. 35, (1862); (Eurema P.) Kirby, Cat., p. 441, (1871). 
70. Gundlachia, Poex, Mem. Nat. Hist., Is. Cuba, I, p. 246, 'Texas, t. 24,(1851); (Eurema G.) Kirby, Cat., p.441,(1871). Mexico, Ter. Proterpia var., Bdl., Sp. Gen., I, p. 655, (1836). Cuba.

71. Mexicana, Bdu., Sp. Gen., I, p. 655, t. 19, + , (1836); 'Texas, Dunean, Nat. Lib., Ent., V, p. 125, t. 8, ơ, (1837); Louisiana, (Eurema M.) Hüb., Zutr. Exot. Schmett., f. 917, Mexico. 918, (1837); (Ter. M.) Morris, Syn., p. 36, (1862); (Eurema M.) Kirloy, Cat., p. 441, (1871).

Ter. Boisduvaliana, Feld., Reise Nov., II, p.200,(1865).

72. Westwoodi, Bdi., Sp. Gen., I, p. 666, (1836); (Eurema 'Texis, W.) Kirby, Cat., p. 445, (1871).

Eurema Dina, Hüb., Zutr. Ex. Schmett., f. 951, 952, (1837).

73. Elathea, Cram., (Pap. E.), Pap. Exot., II, t. 99, (1779); : Florida, Fabr., Sp. Ins., II, p. 44, (1781); Ent. Syst., III, Mexico, 1, p. 196, (1793); (Pieris E.) Godt., Ene. Meth., Cent. Am. IX, p. 136, (1819); (Ter. E.) Lucas, Lep. Ex., p. 76, t. 39, (1835); Bdl., Sp. Gen., p. 664, (1836); Bates, Jul. Ent., I, p. 242, (1861); (Eurema E.) Kirby, Cat., p. 444, (1871).

74. Palmira, Poer, Mem. Nat. Hist. Is. Cuba, I, p. 249, t. : Florida, 24,(1851); (Eurema P.) Kirby, Cat., p. 444,(1871). Cuba.

Ter. Lydia, Feld., Wien. Ent. Mon., V, p. 87, (1861);

Reise Nov. Lep., II, p. 206, (1865).

75. Delia, Cram., (Pap. D.), Pap. Exot., III, t. 273, (1782); Sonthern (Xanthidia D.) Bdl.-Lee., Lep. Am. Sept., p. 49, United t. 18, (1833); (Ter. D.) Bdll., Sp. Gen., I, p. 663, States. (1836); Morris, Syn., p. 34, (1862); (Eurema D.) Kirby, Cat., p. 444, (1871).

Eurema Demoditas, Hüb., Verz. Bek. Sehmett., p. 96, (1816).

Pieris Daira, Godt., Ene. Meth., IX, p. 137, (1819).

Larva on "Trifolium, Cassia and Glycine," Bdl.-Lec.

76. Lisa, BdL.-Lec., (Tanthidia L.), Lep. Am. Sept., p. 53, Canada, U.

t. 19, (1833); (Ter. L.) Bdl., Sp. Gen., p.661, t. 2, S. east of the (1836); Morris, Syn., p. 34, (1862); (Eurema L.) Rocky Mts., Kirby, Cat., p. 443, (1871). 'Texas,

Pieris Śmilax, Godt., Enc. Meth., IX, p. 136, (1819). Mexico. ah. a. + $\mathrm{ALBA},-$ entirely white instead of yellow.

Larva food same as the preceding.

77. Jucunda, Bnt.-Lec., ( Tanthidia J.), Lep. Am. Sept., p. Habitat 52, t. 19, (1833) ; (Ter. J.) Bdl., Sp. Gen., I, p. 665, same as (1836) ; Morris, Syll., p. 35, (1862); (Eurema J.) T. Delia. Kirby, Cat., p. 445, (1ऽ71).

Ter. Ebriola, Poey, Mem. Nat. Hist., Is. Cuba, I, t.

$24,(1851)$.

o Ter. Albina, Poey, l. c.

\section{FAMILY III. LYCANIDA. GENUS 1. THECLA, FABR.}

†78. Crysalus, W. H. Edwds., Trans. Am. Ent. Soc., IV, p. Colorado, 344,(1873); Mead, Wheeler's Rep., V, p. 777,(1875). Utah. 
Hypaurotis Chrysalus, Scud., Buff. Bull., III, p. 113, (1876).

*79. Putnami, Hx.Enwds., Proe.Cal.Aead. Nat.Se., VI,(1876). Utah.

80. Grunus, Bdr., Ann. Soc. Ent. Fr., 2me Ser. X, p. 289, California.

(1852) ; Lep. Cal., p. 43, (1869); (Dipsas G.) Hew.,

Ill. Diur. Lep., 67, Supp., 16, t. 6; (Thecla G.)

Morris, Syn., p. 100, (1862); (Zephyrus G.) Kirby,

Cat., p. 403, (1871); (Habrodais G.) Scud., Buff.

Bull., III, p. 113, (1S76).

81. Halesus, Cram., (Pap. H.), Pap. Ex., II, t. 98, (1779); Southern

(Hesperia H.) Fabr., Ent. Syst., III, p. 273, (1793); States from (Atlides H.) Hüb., Verz. Bek. Schmett., p. 80, Atlantic to (1816); (Polyommatus H.) Godt., Enc. Meth., IX, Parific.

p. $626,(1823)$; (Thecla H.) Bdl.-Lec., Lep. Am.

Sept., p. 83, t. 25, (1833); Morris, Syn., p. 91,

(1862) ; Kirby, Cat., P. 383, (1871); Mead, Wheeler's Rep., V, p. 777, (1875); (Atlides H.) Seud., Buff. Bull., III, p. 112, (1876).

Atlides Dolichos, Hïb., Zntr. Exot. Sehmett., f. 219, 220, (1818).

Atlides Dolichus, Hüb., Vevz. Bek.Schmett., p.80,(1816)

Thecla Juanita, Scud., Proc. Bost. Soc. Yat. Hist., XI, p. 435, (1868); Kirby, Cat., p. 383, (1871).

Larva on Quercus Cinerea and other oaks.

82. M-Albuir, Bds.-Lec., Jep. Am. Sept., p. 86, t. 26, Sonthern (1833); Morris, Syn., p. 92, (1862); Kirby, Cat., States.

p. 390, (1871); (Eupsyche M.) Soud., Buff. Bull., III, p. 112, (1876).

T. Psyche, Bdl.-Lec., Lep. An. Sept., p.88, t.27,(18:3);

Morris, Syn., p.93,(1862); Kirby, Cat., p. 390,(1871).

Larva on Astragalus and Quereus.

83. Melinus, Hub., (Strymon M.), Zutr. Ex. Schmett., f. 121, Canada, 122,(1818); (Thecla $M$.) West.,Gen. Diur. Lep., p.486, United (1852) ; Mead, Wheeler's Rep., V, P. 778, (1875); States and (Uranotes M.) Scud., Buff: Bull., III, p. 107, (1876). Territories T.Hyperici, Bdl.-Lec., Lep.Im.Sept., p.90, t.28,(1833); from AtlinMorris, Syn., p.94,(186.2); Kirby, Cat., p. 396,(1871). tic to Pacific. T. Favonius, Ball-Lec., Lep. Am. Sept., p. 95, t. 30, (1833); Morris, Syn, p. 95, (1862).

T. Humuli, Harris, Ins. Inj. Veg., 1st Ed., p. 215, (1841), 2d Ed., p. 235, (1852), 3d Ed., p. 276, t. 4, (1862); Kirby, ('it., 1. 395, (1871).

T. Pan, Harris, Hiteh. Rep. Geol., Min., etc., Mass., $590,(1833)$.

T. Silenus, Dbldy., List B. M., 2, p. 31, (1847).

T. Melinus var. Pudica, Hy. Edwds., Proc. Cal. Anad. Nat. Se., VI, (1876).

Larva on Humulus Lupulus, Crategus.

84. Cecrops, Fabr., (Hesp. C.), Ent. Syst., III, I, 1. 270, Southern (1793); ('Polyom. C.) Godt., Ene. Meth., IX, p. 6:36, United (1819); (Thecla C.) I)bldy.-West., Gen. Dinr. Lep., States, Wrest 485, (1850-1852); Kirby, Cat., p. 386, (1871); Indics, (Calycopis C.) Scud., Butf: Bull., III, p. 108, (1876). Cent. Am. 
Rusticus Armatus Poeas, IIï., Sam. Ex. Schmett., 1, (1806-1824); (Thecla P.) Bell.-Lee., Lep. Am. Sept., p. 111, t. 35, (1833) ; Morris, Syn., p. 103, (1862); Kirby, Cat., p. 395, (1871).

Strymon Beon, Ḧ̈̈b., Verz. Bek. Schmett., p. 75, (1816).

85. Hugon, Gont., (Polyom.), Fine. Meth., IX, p. 640, Florida, $(1823)$.

W. Indies.

Thecla Hugo, Dbldy.-I'est.-Hew., Gen. Diur. Lej., t. 74, f. $4,(1852)$.

86. Favonius, Abb.-Smith, (Pap. F.), Ins. Ga., I, p. 27, S. Carolina, t. 14, (1797); (Polyom. F.) Godt, Enc. Meth., IX, Genrgia, 1). 635, (1823); (Thecle, F.) Dbldy., List Ins. B. Florida, M., 2, 31, (1847); Kirby, Cat., p. 395, (1871); Alabama. Scud., Buft: Bull., III, 1. 111, (1876).

Larva on black oak.

87. Autolycus, W. H. Enwds., Thans. Am. Ent. Soc., III, Texas, p. 271. (1871); Seud., Buff. Bull., III, p. 111, Kansats. $(1876)$.

var. a.- with the orange pateh on primaries obseured or represented by only a small spot.

Larva on Quercus Obtusiloba.

88. Alcestis, II. H. Edwus., Trans. Am. Ent. Soc., III, p. Texas. 271, (1871); Send., Buff. Bull., II I, p. 111, (1876).

89. Calanus, Hub., (Rustious Armatus C.), Sam. Ex. Canada, Schmett., 1, (1806-1824); (Strymon C.) Ind. Ex. United Lep. 2, (1821); (Thecla C.) Dbldy., List Lep. B. States east of M., 2, p. 30, (1847); Dbldy.-W' est.-Hew., Gen. the Rocky Diur. Lep., II, p. 486, (1850-1852); Kirby, Cat., Mountains. p. 395, (1871); Scudl., Buff. Bull., III, p. 110, (1876).

Polyommatus Falacer, Godt., Enc. Metlı., IX, p. 633, (1819); (Thecla F.) Bdl.-Lee., Lep. Am. Sept., p. 92 , t. 29, (1833) ; Morris, Syn. p. 95, (1862).

Thecla Inorata, G. \&. R. Trans. Am. Ent. Soc., I, p. 323, (1868) ; Kirby, Cat., p. 395, (1871).

Larva on various oaks.

ab. a. Lorata, G. \&. R., Trans. Am. Ent. Soe, I, p. 171, Virginia. (1867) ; Kirby, Cat., p. 396, (1871) ; Seud., Buff. Bull., III, p. 110, (1876).

Differs from the preceding in having a pale subbasal line on under surface of both wings.

90. Auretorum, Bdu., Ann. Soc. Ent., Fr., 2me Ser. X, p. California. 288, (1852); Morris, Syn., p. 99, (1862) ; Kirby, Cat., p. 396, (1871).

91. Liparops, Bdu.-Lec., Lep. Am. Sept., p. 99, t. 31, Can., N. E., (1833) ; Morris, Syn., p. 96, (1862); Kirby, Cat., M'dl, Sotl'n, p. 396, (1871); Send., Buff. Bull., III, p. 111, and West'rn (1876). 
T. Strigosa, Harris, Morris, Syn., p. 101, (1862); Ins. Inj. Veg., Flint's Ed., p. 276, (1862); W. H. Edwds., Butt. N. Am., I, t. II, Theela, (1869); Kirby, Cat., p. 396, (1871).

Larva on oak.

†*92. Acis, Dru., (Pap. P.), Ill. Ex. Ent., I, t. I, (1773); Florida, (Thecla $a_{s}^{3}$.) Kirby, Cat., p. 398, (1871); (Uranotes W. Indies. A.) Scud., Buff. Bull., III, p. 108, (1876).

Pap. Mars, Fabr., Gen. Ins., p. 268, (1777); Ent. Syst., III, 1, p. 265. (1793) ; (Polyom. M.) Godt., Ene. Meth., IX, p. 635, (1823); (Strymon M. Hüb., Sam. Ex. Schmett., II, (1806-1824).

†*93. Ninus, W. H. Edwds., Trans. Am. Ent. Soc, III, p. Colorado. 270, (1871); Mead, Wheeler's Rep., V, p. 778, (1875) ; Scud., Buff. Bull., III, p. 109, (1876).

*94. Ontario, W. H. Edwds., Trans. Am. Ent. Soc., II, p. Canada. 209, (1868); Butt. N. Am., I, t. II, Theela, (1869); Kirby, Cat., p. 396, (1871); Scud., Buff. Bull., III, p. 111, (1876).

$\dagger * 95$. Tetra, Behr, MSS. W. H. Edwds. Trans. Am. Ent. California. Soc., III, p. 19, (1870); Kirby, Cat., p. 401, (1871) ; Seud., Buff. Bull., III, p. 111, (1876).

96. Sxpium, Bdu., Ann. Soc. Ent., Fr., 2me Ser. X, p. 288, Californii. (1852) ; Morris, Syn., p. 99, (1862); Kirby, Cat., p. 396, (1871) ; Scud., Buff. Bull., III, p. 109, (1876); Mead, Wheeler's Rep., V, p. 779, (1875).

T. Chalcis, Behr, MSS. W. H. Edwds., Trans. Am. Ent. Soe., II, P. 376, (1869); Kirby, Cat., p. 400, (1871).

†*97. Adenostomatis, Hr. Edwds., Proe. Cal. Acad. Se., California. YI, (1876); Scud., Buff. Bull., III, p. 111, (1876).

98. Edwardsit, Saunders, MSS., Can. Ent., I, p. 98, Camada, New (1869); G. \&. R., Trans. Am. Ent. Soc., I, p. 172, England and 173, (1867); Seud., Butf. Bull., III, p. 110, (1876). Middle

T. Falacer, Harr., (nec Godt.), Ins. Inj. Veg., Flint's States, WesEd., p. 276, (1862).

teru States to

T. Calanus, G. \& R., (nec Hüb.), Trans. Am. Ent. Texas and Soc., I, 172, 173, (1867).

T. Fabricii, Kirby, Cat., p. 654, (1871).

Larva on Quercus Ilicifolia.

99. Acadica, W. H. Edwds., Proc. Acad. Nat. Se., Phil., Camadia, New p. 55, (1862); Butt. N. Am., I, t. I, Theela, (1868); England and Kirby, Cat., p. 396, (1871) ; Scud., Buff. Bull., p. Micldle 109, (1876\%. States;

T. Californica, W. H. Edwds., Proc. Aead. Nat. Se., Western Phil., p. 223, (1862); Kirby, Cat., p. 396, (1871); States and Mead, Wheeler's Rej., V, p. 779, (1875). Territories

T. Souhegan, Whitney, Proe. Bost. Soe. Nat. Hist., to the Pacific XII, p. 162, (1868); Kirby, Cat., p. 401, (1871).

T. Borus, Bdl., Lep. Cal., p. 43, (1869).

T. Dryope, W. H. Edwds., Trans. Anı. Ent. Soc., III, p. 19, (1870); Kirby, Cat., p. 400, (1871); Scud., Buff. Bull, III, p. 109, (1876). 
T. Cygnus, II. H. Edurds., Trans. An. Ent. Soc., III, 1. 207, (1871); (T. Cyenus) Scud., Buff. Bull., ITI, 1. 109, (1876).

Laviva on willow.

A species subject to some variation, more particularly in the extent of the reddish colour near the inner angle, etc., on upper surface of wings.

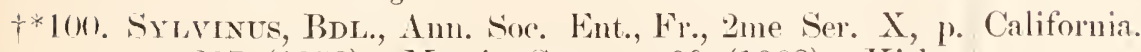
287, (1852); Morris, Syn., ). 99, (1862); Kirloy, Cat., 1. :396, (1871); Mead, Wheeler's Rep., V, p. $778,(1875)$; Sieud., Buff. Bull., III, p. 109, (1876).

101. Nersone, Bde., Lep. Cal., p. 43, (1869); Kirby, Cat., California. p. 399, (1871); Soud., Buft. Bull., III, p. 109, (1876).

102. Damon, (rou., (Pap. D.), Pap. Ex., TV, t. 390, C, D, Uniterl

(1782); (Thecla D.) Hew., III. Diur. Isep., t. 37, States, from (1867); Harr., Hitch. Rep., 1st Ed., p. 590, (1833); the Atlantic Kirlıy, Cat., 1. 387, (1871); Send., Buff. Bull., III, westward to p. 108, (1876).

Lycus Gryneus, Hüb., Verz. Bek. Schmett., 1. 74, (1816).

Polyommatus Ilamastus, Godt., Enc. Meth., IX, p. 640, (1823); (Thecla D.) Morris, Syn., P. 110 , (1862).

Papilio Simcethis, I)ru., Ill. Ex. Ent., I, t. 1, (1773); (Polyom. S.) Godt., Enc. Meth., IX, p. 643, (1823); (Lycus S.) Hüb., Sam. Fx. Schmett., (1806-1824); (Thecla S.) Kirby, Cat., p. 398, (1871).

Thecla Smilacis, Bdl.-Lec., I «ep. Am. Sept., p. 107, t. 33, (183.3); Morris, Syn., p. 98, (1862).

T. Auburniana, Harris, Ins. Inj. Veg., Flint's Eil., p. 277, (1862): Morris, Sivu., P. 101, (1862).

T. Castalis, J. H. Eduds., Trans. Am. Ent. Nor., III, p. 208, (1871).

I arva on smilex.

†* 103. Siva, W. H. Ermms., Trans. Am. Ent. Sor., V, p. 110, Arizolla.

(1874); Mearl, Wheeler's Rep., V, p. 778, (1875);

Soud., Butf: Bull., III, p. 109, (1876).

Perhaps identical with the preceding.

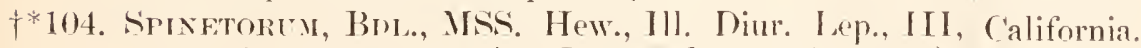
p. 94, t. 45, (1867); Глер. Cal., P. 42, (1869);

Srud., Buff. Bull., III, J. 109, (1876).

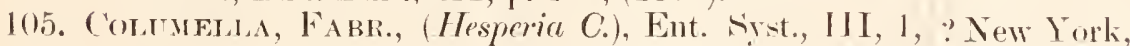
1. 282, (1793); (Polyom. C.) Godt., Euc. Neth., ? Florida, IX, p. 6388, (1823); (Callicistr C.) Scudl., Butf. Cuba, Mex., Bull., IIJ, p. 107, (1876).

Tholus Eurytulus, Hüb., Sam. Fx. Schmett., II, Veneznela, (1806-1824); (Thech E.) Kirhy, Cat., p. 395, etc. (1871).

L.yerrna Modestu, Maynard, Am. Nat., VII, 1. 178, (1873); (Lycoma M.) Morrison, Buff. Bull., I, p. $188,(1874)$. 
Callicista Ocellifera, Grote, Buff'. Bull., I, p. 178, (1873).

The foundation for placing this in our fauna rests on one $\gamma^{7}$ said to have been takell near Aurora, New York, in .July, 1873.

†*106. Spamix, Hr. Enwds., l'me. Cal. Acarl. Nat. Sir., VI, California. $(1876)$.

†*107. Benrit, W. H. Edwis., T'rans. Am. Ent. Sor., III, p. California ; 18, (1870); (Callipxyche B.) Soud., Buff. Bull., JII, Mazatlan, p. $107,(1876)$.

Mexim.

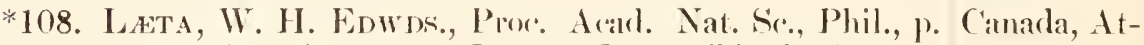
$56,(1862)$; Butt. N. Am., I, t. I, Theela, (1868); lantic I. S. Kirby, ('at., p. 4t)1, (1871); (Erora L.) Srund., Buff., from Maine Bull., p. 106, (1876).

\& Thecla C'lothilde, IT. H. Edurds., I'rox. Eut. Sor., Phil., II, 1. 15, (1863); Send., Proc. Bost. Soc. Nat. Hist., XI, 1. :377, (186s).

109. 'Titus, Fabr., (Hesperin T.), Ent. Syst., III, 1, p. 297, Canarla,

(17.93) ; (Polyom. T.) Gorlt., Eur. Metlı., IX, United P. 688, (182:3); (Lycona T.) Dbldy.-Hew., (ren. States and Diur. Lep., p. 494, (1850-1852); (Theclı T.) Kirby, Territories Cat., p. 399, (1871); (Strymon T.) Seurl., Buff. Bull., from the AtIII, ए. 105, (1876).

S'trymon Mopsus, Mïb., Verz. Bek. Schmett., 1. 74, Pacific.

(1816); (Chrysophamus M.) /sutr. Ex. Sehnett., f. 135, 136, (1818); (Thecla M.) Bdl.-Lee., l sep. Am. Sept., p. 109, t. 34, (1833); Morris, Syn., p. 102, (1862); Harris, Ins. Inj. Veg., Flint's Fd., p. 278,(1862); Mearl, Wheeler's Rep., V, 1). 779,(1875). I sarva on oak and Fupatorium Coelestiuum.

110. Fumisinosa, W. H. Fowns., Proc. Acad. Nat. Sc., California. Phil., p. 164, (1861): (Cupido F.) Kirby, Cat., p. 364, (1871); (Lyc. F.) Streck., Lep., Rhop.-Het., p. 89, (1874); (Śatyrium F.) Sourl., Butf. Bull., III, p. $106,(1876)$.

Lycena Suasa, Bdl., Lep. (al., 1. 51, (1869).

111. Niphon, Hur., (Licus N.), Kutr. Ex. Schmett., t. 203, Canada, 204, (182:3); (Thecla N.) Bdl.-Lec., Lep. Am. Sept., United p. 105, t. 33, (1833); Morris, Svn., p. 98, (1862); States and Harris, Ins. Inj. Veg., Flint's Ed., p. 278, (1862); 'Territories Kirhy, Cat., p. 399, (1871); (Incisalia N.) Seud., from the AtButf. Bull., III, p. 104, (1876). lantic to the T. Nephon, Hest.-Hew., Gen. Diur. Iep., p. 486, Pacific. (1850-1852).

T. Eryphon, Bdl., \nи. Sinc. Ent., Fr., 2 me Sier. X, p. 289, (1852); Kirby, Cat., p. 399, (1871); Mearl, Wheeler's Rep., I, i). 780, (1875); (Incisalia E.) Send., Buff. Bull., III, p. 104, (1876).

T. Eriphon, Morris, Syn., p. 100, (1862). Larva on varions species of Pinus. 
112. Ires, Gont., (Polyommatus I.) Enc. Meth., IX, p. 674, Oecupies the (1823); (Thecla I.) Bdl.-lee., Lep. Am. Sept., p. same territo101, t. 31, (1833); Kirly, Cat., 1. 399, (1871); ry as Niphon (Incisalia 1.) Scud., Buff'. Bull., III, p. 104, (1876). and Titus.

T. Iris, Morris, Syn., p. 97, (1862).

val. a. Arsace, BDL.-lew., Lep. Am. Sept., p. 103, t. 32, (1833); Murris, Syrt., p. 97, (1862); Kirby, ('at., p. 399, (1871).

Median lines wanting the distinct white at termination on costa of both wings and on inner margin of secondaries.

val. b. Hexricr, G.-R., Trans. An. Ent. Suc., I, p. $174,(1867)$.

Sualler. Inferiors tailless.

Larva on Vaccinium Corynbosum.

113. Algistes, Kirbs, Faluma Bor. Am., IV', p. 298, t. 3, Found in (18:37); Morris, Syn., p. 103, (1862); Harris, Ins. same territoInj. Veg., p. 279, t. 108, (1862); (Incisalia A.) ry as the Scud., Buff: Bull., III, p. 104, (1876).

T. Augustinus, West., ( 1852); Kirby, Cat., p. 395, (1871).

T. Iroides, Bdi., Ann. Soc. Ent., Fr., 2nue Ser. X, p. 289, (1852); Morris, Syn., 1. 100, (1862); Kirby, Cat., p. 399, (1871); I Iead, Wheeler's Rep., V, p. $780,(1875)$.

11. Drmerorim, But., Anu. Soc. Ent., Fr., 2me Ser. X, p. Nevada, Cal291, (1852); Morris, Syn., p. 100, (1862); Kirby, ifornia and Cat., 1. 398, (1871); (C allophrys D.) Soud., Buff: Oregon. Bull., III, p. 105, (1876).

T. Viridis, W. H. Lidwels., Proce Acad. Nat. Se., Phil., p. 223, (1862); Kirby, Cat., 1. 402, (1871).

T. Affinis, Wr. H. Eiluris., Proce. Acad. Nat. Sc., Phil., p. 223, (1862).

Larvil on Hoscachia.

'This is the American form of ' $T$ '. Rubi, I., from which it differs so little, if any, as scarce to deserve a separate designation.

\section{GENUS 2. LYCENA, FABR.}

\section{(I'olyoumatus, Latr.)}

\$115. 'Teula, Reak., Proc. Acad. Nat. Si., Phil., p. 245, Southern (1866); (Cupido T.) Kirlsy, Cat., p. 356, (1871); California. (Lycana T.) Streck., Lep., Rliop.-Het., p. 82, t. X, (1874); (Everes T.) Scud., Buff: Bull., III, 1. 113, (1876).

\$116. Moxica, Reak., Proc. Acad. Nat. Sc., Phil., p. 244, Southern (1866); (Cupido M.) Kirby, Cat., p. 356, (1871); California. (Lycena M.) Streck., I.ep., Rlıop.-Het., p. 82, t. X, (1874). 
117. Comyxas, God's., (Polyom. C.), Ene. Meth., IX, p. 660, Canada, (1823); (Argus C.) Brll.-Lec., Lep. Am. Sept., p. southward to 120, t. 36, (1833); (Polyom. C.) Morris, Syn., p. Gulfo of Mex8:3, (1862); Harris, Ins. Inj. Veg., Flint's Fd., p. ier,and west275, (1862); (Cupido C.) Kirby, Cat., p. 356, ward from (1871); (Lycana C:) Streek., Lep., Rhop.-Het., p. the Atlantic: 82, (1874); Mead, Wheeler's Rep., I, p. 783, to the Rocky (1875); (Everes C.) Sond., Buff. Bull., III, p. 114, Monntains. $(1876)$.

Larva on Phaseolus Perennis, Lespedeza ('apitata.

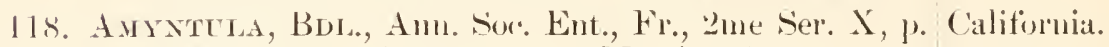
294, (1852); (P'olyom. A.) Morris, Sirn., p. 87, (1862); (Lycuna A.) Streck., Lep., Rhop.-Het., p. 82, (1874); (Everes A.) Send., Buft. Bull., III, p. $114,(1876)$.

Cupido Comyntas var. Amyntula, Kirby, Cat., p. :i56, (1871).

+*119. Marixa, Reak., Proc. Acad. Nat. Sc., Phil., p. 87, Southern (1868); (Cupido M.) Kirls, Cat., p. 351, (1871); C'alifornia, (Leptoles M.) Scull, Buff: Bull., III, p. 124, (1876). Maxiro.

Lampides Cassius, Butl., P'or. Yool. Sime, Lom., P'. $354,(1874)$.

Lyc. Cassioides, Bdl., Lep. Guat., p. 16, (1870).

+*120. Theosis, I re., Sagra Hist. Nat. Cuba, V [1, 1. 611, Key West, t. 16, $(1856)$; (Cupido T.) Kirby, Cat., p. 351, Florida. (1871); (Leptotes T.) Sund., Buff'. Bull., III, p. 124, (1876).

Lye. Cassiusvar. Floridensis, Morrison, Buff. Bull., I, 1. $187,(1874)$.

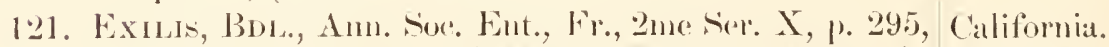
(1852); (Polyom. E.) Morris, Syll., p. 87, (1862); Arizona, (Cupido E.) Krirby, Cat., J. 357, (1871); (Lycena Utalı, E.) Streck., Lep., Rhop.-Het., 1). 83, (1874).

Brephidium Exile, Scud., Buff: Bull., I I 1, p. 124,(1876). Texas. Lyc. Fea, W. H. Eduds., Trans. An. Eut. Soc., III, 1. :11, (1871); (Brephidium F.) S.'ud., Buft. Bull., III, 1. 12:3, (1876).

122. Isoptratima, H-s., (onr.-Blatt. Kool. Min. Ges. Re- r'orida, genshero, X VI, p. 141, (1862); Ftett. Ent. /eit., p. Cubat. 73, (1869); (cupido I.) Kirby, C'at., p. 350, (1871); (Brephidium I.) Soud., Buft. Bull., III, 1. 12:3, (1876).

1.yc. I'seurlofea, Morrison, Buff: Bull., I, 1. 181;, (1874).

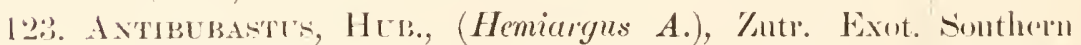
Schmmett., 1. 19, f. 9!), 100, (1818); (Thecla A.) States, West I)blily.-Hew., Gixn. I)iur. I dep., II, 1. 486, (1850- Indie's. 1852); (Cupido A.) Kirby, Cit., p. 350, (1871);

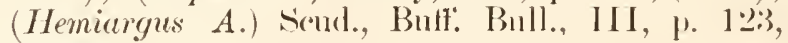
(1876). 
Rusticus Adolescens Hanno, Hïb., Sam. Exot. Schmett., 1, (1806-1816); (Cupido H.) Kirhy, Cat., p. 350, (1871); (Lycana H.) Streck., Lep., Rhop.-Het., J. 83, (1874).

Lyc. Hamo, Luc., Sigra Hist. Nat. Cuba, VII, 1.61\%, $\left(1856^{\circ}\right)$.

Polyom. Filenus, Poey, Cent. Lep. Cuba, t. II, (183:3); (Argus F.) Boll.-Lee,, І сер. Aı. Sept., p. 114 , (1833); Morris, Syn., p. 82, (1862).

Argus Pseudoptiletes, Bull.-Lec., Lep. Am. N'ept., p. i14, t. 35, (1833).

l.ye. Astenidas, Ball., MSS. I આu., Silg. Hist. Nat.

( 'ubal, V'II, p. 61:3, (1856).

+*124. Amuon, Lue., Sig. Hist. Nat. Cuha, V'I1, p. 612, t. Sonthern $16,(1856)$; (Cupido A.) Kirby, Cat., p. 351, (1871); Florida,

(Hemiargus 4.) Simul., Butf.' Bull., III, 1. 122, West Iudies. (1876).

125. Isola, Reak., Proc. Acad. Nat. Sc., Phil., p. 332, Texas, Co](1866) ; (Cupido I.) Kirly, Cat., p. 376, (1871); orado, Kan(I.yc. I.) Strerk., lep., Rhop.-Het., J. 84, (1874); sals, Arizona, Mead, Wheoler's Rep., V, p. 783, (1875); (Hemi- New Mexargus 1.) Sent., Butl. Bull., IIJ, 1. 123, (1876). ien, M(exico,

I.yc. Gyas, II'. H. Eduds., T'ralus. An. Ent.šoc., IIJ, Cent. Am.

p. 210, (1871); Nitreck., I('p., Rhoj)-Het., p. 84, (1874).

I.yc. Alce, II. H. Eduds., 'Trans. Am. Ent. Soc, III, p. 272, (1871); Ntreck., luep., Rhop)--Het., p. s8, (18T4).

126. Acrox, I)nLwy.-Hkw., ( Ken. Dinr. Lep., 11, p. 294, t. California, 76, (1852); (P'olyou. A.) Morris, Cat. Lej. N. Am., Nevada, 1. 12, (1860); (Cupido A.) Kirly, Cat., p. 3358, Itah, Ari(1871); (Lycana A.) Streck., Lep., Rhop.-Het., p. жmat. s8, (1874); Mear, W'hwer's Rop., V', p. 782,

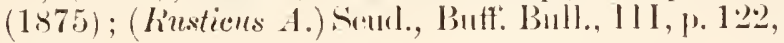
(1876).

Lyc. Antegon, Bdl., Aun. Soc. Ent., Fr., 2nme S'r. X, 1. 295, (1852); (Polyom. A.) Morris, ('at. Isep. N. Ant., 1. 12, (1860); Sivi., ). 87, (1862); (('upielo A.) Kirby, Cit., p. 335, (1871).

lal'val on Hosackio.

127. Melsisa, W. H. EDwus., Trans. Am. Ent. Soc, IV, Ltalı, Ari1. 346, (1873); Streck., I ، p., Rhop.-H(.t., p. 88, t. zona, Colo10, (1874); Mead, Whiceler's Rej., V, p. 78:, t. rado, New XXXVI, (1875); (Rusticus M.) Suud., Buff. Bull., Mexico. III, p. 122, (1876).

128. Axra, W. H. Edwos., Proc. Acall. Nat. Sc., Plhil., p. California, 163, (1861); Morris, Syn., p. 329), (1862); (('upielo C'olorado, A.) Kirby, Cat., p. 358, (1871); (Lyc. A.) Strerek., Ltah, NeLep., Rhop.-Het., J. 88, t. X, (1874); Meall, valal.

Wheeler's Rep., V, p. 782, (1875); (Rustiou. A.)

sicud., Butf. Bull., III, p. 122, (1876). 
+Lyc. Cajona, Reak., Proc. Ent. Soc., Phil., VI, p. 147, foot-note, (1866).

Lyc. Argyrotoxus, Behr, Proc. Cal. Acad. Nat. Sce, III, p. 281, (1867).

Lyc. Philemon, Bdl., Lep. Cal., p. 47, (1869).

12y. Scudperi, W. H. Edwds., Proc. Acadl. Nat. Se, Phil., S. Labr., p. 164, (1861); Morric, Syn., p. 329, (1862); (C'u-Canada, pido S.) Kirby, Cat., p. 358, (1871); (Lyc. S.) New York, Streck., Lep., Rhop.-Het., p. 87, (1874); (Kusticus Michigan. S.) Scud., Buff: Bull., III, p. 122, (1876).

Larvil on Lupinus I'erennis.

130. Optilete, KNoch, (Pap. O.), Beitr. Ins., I, p. 76, t. Alaska, 5, (1781); Esp., Schmett., I, t. 79, (1782); Fabr., Kodiak, Mant., I1, 74, (1787); Hüb., Eur. Schmett., I, f. Scaudlinavia, 310, 312, (1793-1827); Ochs., I, 2, p. 51, (1808); Germany, (Yolyom. O.) Godt., Enc. Meth., IX, p. 686, (1823); Russia, (Lyc. O.) Frey., Neu. Beit., 451, 2, 3, 656, (1831- Siberia. 1858); (Cupido O.) Kirby, (at., 1. 359, (1871); (Lyc. O.) Stgr., Cit., p. 10, (1871); Streck., Lep., Rhop.-Het., p. 120, (1876).

A number of examples from Alaska presented not the slightest point of distinction from the many European examples with which I have compared them.

131. Battondes, Behr, Proe. Cal. Acad. Natt. Se, III, p. Mountains 282, (1867); (C'upido B.) Kirby, Cat., 1. 360, of Colorado, (1871); (Lyc. B.) Streck., Lep., Rhop.-Het., p. 87, Nevada and (1874); Nead, Wheeler's Rep., V, p. 782, (1875); California. (Rusticus B.) Scull., Buff'. Bull., III, p. 122,(1876).

Isyc. Glaucon, W. H. Edwds., 'Trans. Am. Ent. Soc., III, p. 210, (1871); Streck., Isej., Rhop.-Het., p. s8, (1874); Mrat, Wheeler's Rep., V, 1. 78:, $(1875)$.

132. Shasta, W. H. Enwus., Proc. Acad. Nat. Sc., Phil., p. Oregon, Cal$224,(1862)$; (Thecla S.) Kirby, Cat., p. 401,(1871); ifornia and (Lyc. s.) Streck., Lep., Rhop.-Het., p. 83, (1874); adjacent ter(Rusticus S.) Scond., Buft. Bull., III, 1. 121, (1876). ritory.

Lyc. Zelmiva, Feld., Reise Nov. Lap., II, p. ״82, t. 35, (1865); (('upido Z.) Kirly, ('at., J. 359, (1871).

Lyc. ('alchas, Behr, Proce Cial. Acad. Nat. Sc., III, p. ㅁo1, (1867); (Cupido (') Kirby, ('at., p. 358, (1871); (Lyc. (:) Streek., Lep., Rhop.-Het., p. 88, (1874); Mead, Wheeler's Rep., V, 1. 78:2, (1875).

Lyc. Nivium, Bdl., Lep. Cal., p. 47, (1869).

†*133. Enoptes, Bul., Ann. Soc. Ent., Fr., 2me ser. X, p. California, 298, (1852); (Polyom. E.) Morris, Sinn., p. 89, A rizona, (1862); (C'upido E.) Kirby, Cat., 1. 363, (1871); Nevardal. (Lyc. E.) Streck., Lep., Rhop.-Het., p. 89, (1874); (Rusticus E.) Sicud., Buff: Bull., III, 1. 122, (1876). 
134. Lupixi, BDi.., Iep). Cal., p. 46, 11. 2): (1869); ( ('upido California, L.) Kirby, Cat., p. 358, (1871); (Lye. L.) Streck., Montana.

Lep., Rhop.-Hot., J. 88, (1874); (Rusticus I.)

Seud., Butf. Bull., III, p. 121, (1576).

Agriades Minnehaha, scurl., Proe. Bost. Sor. Nat.

Hist., XVII, 88.

13\%. Psevdargiolus, Bd.-Isrc., (Argus P.), Isep. Am. Camarla,

Sept., p. 118, t. 36, (183:3); Morris, Syn., p. 82, U. S. cast of (1862) ; (Iolyom. I'.) Harris, Ins. Inj. Ieg., Flint's Texas.

Ed., 1. 2Т4, (186\%); (Lycona P.) W. H. Edwds.,

Proc. Ent Soc., l'hil., VI, p. 204,(1867); Butt. X.

Am., I, t. II, I ymena, (1869); Streck., Lep., Rhop.-

Het., p. 82, (1874); ('yaniris I'.) Scud., Buff'. Bull., III, p. 114, (1876).

I'ap. Argiolus, Abb.-Smith, Ins. Ga., I, t. 15, (1797).

Lyc. Neglecta, Wr. H. Edwods., Proc. Acarl. Nat. Se.,

Phil., p. 57, (1862); Butt. N. Anı., I, t. II, I yc.,

(1869); Parkard, Cunide, P. 265, (1869); (Cyaniris

N.) Scud., Buff. Bull., III, p. 115, (1876).

Cupido Pseudargiolus et Neglecto, Kirby, Cat., p. 371 , (1871).

Iarvi on Actinomeris.

135 a. Prasus, Bnl., Ann. Sor. Ent., Fr., 2me Ser. X, p. Califoruia, 299, (1852); (Polyom. P.) Morris, Syn., \%. 89, Oregon and (1862); ('upido P.) Kirby, Cat., p. 363, (1871); adjacent ter(Lye. P.) Streck., Lep., Rhop.-Het., p. 82, (1874); ritorv.

Mear, Wheeler's Rep., V, p. 785, (1875) ; (ryaniris P.) Srud., Butf. BulI., III, p. 114, (1876).

Lycona Echo, I'. H. Edurls., Prore. Ent. Sorc., Phil., II, p. $506,(1864)$.

136. Lecra, Kirpy, Fann. Bor. Anr., IV, p. 299, t. 3, Labrador, (1837); (Polyom. L.) Morris, syn., p. 90, (1862); Canada, eastHarris, Ins. Inj. Veg., Flint's Ed., p. 275, f. 105, ern U. S. to 106, (1862) ; (Lyc. L.) Streck., Lep., Rhop)--Het., Virginia. 1. $82,(1874)$.

Lyc. Tiolacea, W. H. Edwds., P'roc. Ent. Suc., Phil.,

VT, p. 201, (1866); Butt. N. Am., I, t. 1, Isrc., (1868).

('upido Inciu at Violacer, Kïby, Cat., p. :368, (1871). Lyc. Pseurlargiolus var. Lucia, Mead, Whecler's Rep., $\mathrm{T}, \mathrm{p} .785,(1875)$.

(yaniris Jiolncea et Lucia, scued., Buff. Bull., III, p. 114, 115, (1876).

The type form has a large dark brown patch on dise of under side of secondaries. S.ee Kirhy's and Harris' fignres.

ab. a. 9 NiG., figured in W. H. Edwrk. Butt. N. Anı., Virginia.

I, t. I, f. 4, Lye., (1868).

The prevalent $q$ form in Virginia, upper surface entirely dark brown.

ab. b. I INTERMFIHA,-a form intermediate in colour of upper surface between the blue and brown female, neither one nor the other but partaking in a measure of the characteristics of both. Rare. 
137. Fonoressis, Fead., Reive Nov. Lep., II, p. 281, t. 35, Mt. Diablo, (1865); (Cupido S.) Kirby, Cat., p. 354, (1871); Slasta, San (Lyc. S.) Streek., Lep., Rhop.-Het., p. 105, (1875). Diego, S.

Iyc. Regia, Bdl., Lep. Cal., p. 46, (1869); (' upido California ; R.) Kirbr, (at., p. 366, (1871); (Lyc. R.) Streck., Sonora. Lep., Rhop.-Het., p. 87, (1874); IV. H. Edwds., Butt. N. Am., II, t. I, Lyc., (1875) ; (Philotes Regia et Sonorensis) Scud., Butf. Bull., III, p. 116, (1876).

138. Sagitergera, Feld., Reise Nov. Iep., II, p. 281, t. I dos Angeles, 35, (1865); (Cupido S.) Kirlsy, Cat., P. 354, (1871); S. Cala., (Phedrotes S.) Sculd., Buff: Bull., III, p. 116, Colomadı, $(1876)$.

Sonora.

${ }_{+}^{+}$Lyc. Catilina, Reak, Proce Acad. Nat. Sc., Phil., p. 244, (1866); (cupido (:) Kirlsy, Cat., ). 376, (1871); (I.yc. (') Streck., Lep., Rhop.-Het., pp. $86,105,120,(1874-1876)$, t. X, f. 1, 2, (1874).

lyc. Lorquini, Behr, I’roc. Cal. Acad. Nat. Sc., III, p. 280, (1867); ('upido L.) Kirby, Cat., p. 377, (1871); (Lyc. L.) Streek., Lep., Rhop.-Het., p. 90, (1874), 1. 120, (1876).

Iyc. Rhrea, Brll., Lep. Cal., 1. 51, (1869); (('upido R.) Kirlyy, Cat., 1. 367, (1871); (Iyc. R.) Streck., I sep., Rhop).-Het., p. 88, (1874), p. 105, (1875).

Lye. Viaca, IT. H. Ellwds., Trans. Am. Ent. Soc., III, p. 209, (1871); Streck., I,ep., Rhop.-Het., p. $89,(1874)$.

lyc. Donnin, W. H. Edwds., Trans. Am. Ent. Sior., III, P. 272, (1871) ; Mear, Wheeler's Rep., I, p. $78.5,(1875)$.

139. I vradurs, Intar., (Polyom. L.), Entom., P. 209, Atlantir

$(18+2) ;($ I.yc. L.) W. H. Eilwds., Butt. N. Im., I, Statre from t. I, Isre, (1868); ('upido I.) Kirby, Cat., 1. 368, New York (1871); (Lyye. L.) Streck., Lep., Rhop.-Het., p. 84, to Creorgia ; (1874); Mead, Wheeler's Rep., I', p. 784, (1875); Indiana, (Nomiarles L.) Sirud., (an. Ent., VIII, 1).2:3, (1876), (Ohio, MirllButt: Bull., III, p. 117 , (1876).

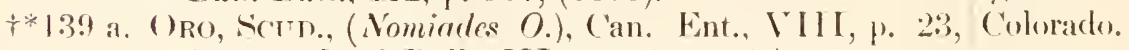

(1876); Buff: Bull., III, 1) 117, (1876).

I'robably a val'. of the preceding.

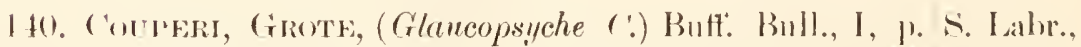
185), (1874); (Nomiades (:) Somd., Can. Ent., VIII, Inticosti, 1. 22, (1876); Buff: Bull., III, p. 117, (1876). I ake Winlyc. Pembina, W. H. Edwels., Syn. X. An. Butt., p. nipeg. $37,(1872)$; Streck., Lejo., Rliop.-Het., pp. 69, 81, t. $\mathrm{X},(187+)$.

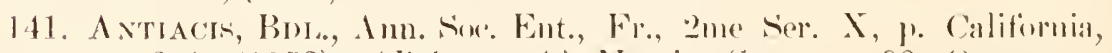
300), (1852); (Jolyom. A.) Morris, Syll, J. 90, ()recon, (1862); (cupirlo A.) Kirly, (at., ). :itl, (1871); Br. Col, (Lyce. I.) Streek., Lep., Rliop.-Het., p. st, (1874); Mearl, Wheeler's Rej., I', p. 785, (1875); (Nomiades A.) Somul., ( an. Ent., VIII, 1. 22, (1876); Butt. Bıll., III, I. 117, (1876). 
Lyc. Mertila, If. H. Edwods., Proe. Ent. Soc., Phil., YT, p. 206, (1866); Streck., Lep., Rhop.-Het., p. 85, (1874).

142. Behri, W. H. Enwos., Proc. Acarl. Nat. Se, Phil., p. Califormia. 224, (1862); (Thecla B.) Kirby, Cat., p. 400, (1871); (Iyc. B.) Streck., Lep., Rhop.-Het., p. 84, (1874); (Nomiades B.) Send., Can. Ent., VIIT, p. $23,(1876)$; Buff: Bull., III, p. 117, (1876).

I.yc. Polyphemus, Bdl., Lep. Cal., p. 49, (1869); ( ('upido P.) Kirly, Cat., p. 373, (1871).

113. Xfarces, Bnt., Am. Soe. Ent., Fr., 2me Ser. X, p. 296, California. (1852); (Polyom. X.) Morris, Syn., p. 88, (1862); (Cupido ..) Kirhy, Cat., p. 373, (1871); (Lyc. X.) streck., Isep., Rliop.-Het., ๒. 86, (1874); (Nomiades X.) Scud., Can. Ent., VIIJ, p. 21, (1876); Buff. Bull., III, 1. 117, (1876).

144. Pheres, Bot., Ann. Soc. Ent., Fr., 2me Ser. X, p. 297, California, (1852); (Polyom. P.) Morric, Syn., p. 89, (1862); Oregon.

(Cupido P.) Kirls, Cat., p. 362, (1811); (Iyc. P.) Streck., Iep., Rhop.-Het., p. 85, (1874), P. 120, (1876); Mead, Wheeler's Rep., V, 1. 785, (1875); (Cupido P.) Senrl., Buff. Bull., III, p. 118, (1876).

var. a. Evits, Bds., I.ep. Cal., p. 49, (1869); (Cupido N.California, E.) Kirby, Cat., 1. 363, (1871); (Lyc. E.) Streck., Nevada.

J sep., Rhop)-Het., ए. 89, (1874).

Differ mainly in the shape of the median row of black spots on unter side of primaries.

ab. b. Irdea, W. H. Enwds., Trums. Am. Ent. Soc., Nevada.

III, p. 209, ठ7, (1871); Streck., I sep., Rhop.-Het.,

p. 86. (1874); (('mpido A.) Scud., Buff. Bull., III,

l. 118, (1876).

Tnder surface of secondaries levoid of the row of median spots, and with a large white spot near middle.

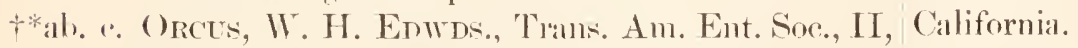

ю. 376, (1869); (Cupido O) Kirby, Cat., p. 377,

(1.871); (Lyc. ().) Strock., I sep., Rhop.-Het.. p. 85,

(1874): (Cupido O.) Srond., Butf. Bull., TII, p. 118, $(1876)$.

Under surface, with the exreytion of faint discal bars, inmaculate.

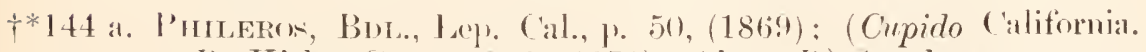
P.) Kirhy, Cat., p. $366,(1871)$; (Lyc. I'.) Sitreck., Lep., Rliop.-Het., p. 87, (1874); (Cupido P.) Śend., Buff.'Bull., III, ). 118. (1876).

Lyr. Helios, W. H. Eduds., Trans. Am. Fint. Soc., III, p. உos, (1RT1): Streck., Lep., Rhop.-Het., p. $89,(1874)$.

Probably a var, of Pheres.

145. Futla, W. H. Edmos., Thans. Am. Ent. Soc., III, p. Califormia. 194, (1870); ('Pebeius f.) Kirbr, Cat., 1) 653, (1871); (Lyc. H.) Streck., Lep., Rhop.-Het., p. 89, (1874); (Cupido F.) soud., Buff: Bull., III, J. 11s, (1876). 
Lyc. Fuliginosn, Streck., (noc Eduds.), Lep., Rhop.Het., 1. 89, (1874).

146. Seprolus, But., Ann. Soc. Ent., Fr., 2me Ser. X, p. California, 297, (1852); (Polyom. S.) Morris, Syn., p. 88, Nevada, (1862); (Cupido s.) Kirlw, (at., p. 373, (1871); Colorado. (Lyc. S.) Streck., I tep., Rhop.-Hot., p. 90, (1874); Mead, Wheeler's Rej., I, p. 784, (1875); (Cupido S.) Scud., Buff. Bull., III, p. 119, (1876).

ab. a. $f$ Aend.lA, Beir, Proc. Cal. Acarl. Nat. Se., III, 1. 280, (1867); (Rusticus A.) S(・ud., Buff. Bull., III, p. 121, (1876).

Cupido Achaja, Kirby, Cat., 1. 366, (1871); (Iyc. A.) Streck., Lep., Rhop.-Het., p). 89, (1874).

Lyc. Rufescens, Bdl., Lep. Cal., J. 48, (1869); Mead, Wheeler's Rep., I, 1. 784, (1875).

A o form, dark fulvous on upper surface and brown beneath.

147. Icarioides, Bdu., Ann. Sor. Fut., Fr., 2me Ser. X, p. California, 297, (1852); (Polyom. I.) Norris, Syvl., p. 88, Oregon, (1862); (Cupido I.) Kirhy, (at., p. 366, (1871); Colorado, (Lyc. I.) Streck., Lej), Rhop.-Het., p. 87, (1874), Nevacla, P. 120, (1876); (Cupido I.) Siend., Buff. Bull., III, Brit. Col., p. $119,(1876)$.

Iyc. Lycea, WT. H. Eduds., Proc. Ent. Soe., Phil., II, J. 507, (1864); Tran.. Am. Ent. Soc., III, 1. 273, (1871); (Cupido I.) Kirby, Cat., p. 377, (1871); (Lyc. L.) Streck., Lep., Rhop.-Het., p. 88, (1874); Mear, Wheeles's Rep., V, 1. 785, (1875).

†Lyc. Rapahoe, Reak., Proc. Ent. Soc., Phil., VI, p. 146, (1866); (Cupido R.) Kirby, Cat., p. 377, (1871); (Lyc. R.) Streek., Lep., Rhop.-Het., p. 87, t. X, f. 14, 15, (1874), p. 120, (1876); Mead, Wheeler's Rep., V, p. 784, (1875).

Lyc. Docdalus, Behr, Proc. Cal. Arad. Sr., IIJ, p. 280, (1867); (('upido D.) Kirby, Cat., P. 366, (1871); (Lyc. D.) Streck., Lep., Rhoj.--Het., p. 90, (1874).

Lyyc. Kodiak, W. H. Edurls., 'T'ans. Im. Ent. Soc., III, p. 20, (1870); (('upido k.) Kirly, Cat., p. 376, (1871) ; (Lyc. K.) Streck., I tep., Rhop.-Het., 1). 87, (1874); (Cupido K.) Send., Buff: Bnll., III, J. 120 , (1876).

var. a. Maricopa, Reak., Proc. Acad. Nat. Sr., I'hil., p. 245, (1866); (Cupido H.) Kirby, Cat., p. 377, (1871); (Lyc. M.) Streck., I Lep., Rhop.-Het., p. 85, (1874); (Ciupirlo M.) Seud., Buff'. Bull., III, P. 119, (1876).

Lyc. Pardatis, Rehr, Pror. ('al. Laud. S̀c., I11, p. 279, (1867); (Cupido 1'.) Kirby, Cat., P. 374, (1871); (Lyc. P.) Streck., Lep., Rhop.-Het., 1. 89, (1874);

(Cupido P.) Seurl., Buff'. Bull., III, p. 119, (1876). Lyc. Erymus, Bdl., Isep. Cal., p. 18, (1S69); (Cupido 
E.) Kirby, Cat., p. 366, (1871); (Lyc. E.) Streck., Lep., Rhop.-Het., p. 86, (1874).

Iyc. Wintha, W. H. Edwds., Trans. Am. Ent. Soc., III, p. 194, (1870); Streck., Lep., Rhop.-Het., p. 89, (1874); (C'upido M.) Scud., Buff. Bull., III, p. $119,(1876)$.

Plebeius Mincha, Kirby, Cat., 1. 653, (1871).

A darker form.

The above synonymy of Icarioides I trust may prove correct. Mr. Reakirt's original types of Rapahoe, both 우, (though erroneously determined $\delta q$ in the original description), are in my possession. Dodalus and Pardalis I received from their author, Dr. Behr. Kodiak I likewise received from that gentleman, who also had supplied Mr. W. H. Elwds, with the examples on which the latter based his description. The types of Iycea, Marienpa and Mintha I have not seen.

Mr. Edwds. says that Maricopa and Mintha are the same as the var. Pardalis.

Mr. Scudder tells is that Pardalis o is possibly identical with Maricopa, which latter he pronounces distinct from Fcarioides, and that Pardalis 0 , to which he places Erymus as a synonym, is distinet from both Maricopa and Icarioides.

Dr. Behr believes Rapahoe to be identical with his Deedalus. Mr. Edwds. says Dredalus is a synonym of Icarioides, and that Rapahoe is the same as Lycea. Mr. Scudder informs us that hoth Rapahoe and Lycea are synonyms of Edwds.' Pembina, whilst Mr. Edwds. holds Pembina to be a distinct species and one that has not yet been barnacled with aliases.

+*148. Pembina, W. H. Edwis., Proc. Arad. Nat. Sc., Phil., Slave Lake, p. 224, (1862); (Thecle P.) Kirby, Cat., 1. 401, Brit. Col. (1871); (Lyc. P., incorrectly determined as identi(a] with Couperi,) Strerk., Lep., Rhop.-Het., p. 88, (1874) ; (Cupido P.) Send., Buff. Bull., III, p. 119, (1876).

149. Orbitulus, DePruxrer, (Pap. O.) Lep. Pieclmontana, Colorada, p. 75, (1798); Esp., Schmett., t. 112 , (1800) ; Ochs., Nevada, Schmett., I, 2, 43, (1808); Hiib., Em. Schmett., I, California. f. 841, (1818-1827); (Agriades O.) Hüb., Terz. Bek. Schmett., p. 68, (1816) ; (Polyom. O.) Godt., Enc. Metl., IX, 1). 688, (1823); (Lyc. O.) Stgr., Cat., p. 11, (1871); (Cupido O.) Kirby, Cat., p. 363, (1871); (Lyc. O.) Streck., Lep., Rhop.-Het., p. 86, t. X, $(1874)$; (Agriades O.) Scud., Buff. Bull., III, p. 121, (1876).

Papilio Neleager, Hüb., Eur. Sehmett., f. 52.2-525, (1798-1803), f. 761-762, (1803-1818).

Iyye. Rustica, W. H. Edwds., Proc. Ent. Soc., Phil., IV, p. 203, (1865); (('upido R.) Kirby, Cat., p. 377, (1871); (Iyc. R.) Mead, Wheeler's Rep., $\mathbf{V}$, p. $783,(1875)$.

Lyc. Podarce, Feld., Reise Nov. Lep., II, p. 28:, t. 35, (1865); (Cupido P.) Kirby, Cat., p. 36:3, (1871); (Agriades P.) Scud., Butf. Bull., III, p. 120, (1876). +Lyc. Tehama, Reak., Proc. Acad. Nat. Sc., Phil., p. 246, (1866); (C'upido T.) Kinly, Cat., p. 377, (1871). 
Lyc. Cilla, Behr, Proc. Cal. Acad. Tat. Se, III, p. 281, (1867); (Cupido (:) Kirby, Cat., p.363, (1871).

Lye. Nestos, Bdl., Lep. Cal., p. 50, (1869); (Cupido N.) Kirby, Cat., p. 363, (1871); (Lyc. N.) Sitreck., Lep., Rhop.-Het., 1. 87, (1874).

150. Aquilo, Bde., (Argus A.), Icones, I, p. 62, t. 12, (1832); Labrarlor, Dup., Hist. Nat. Lep., Supl., I, 47, 6, 7, (1832); Arotic (Lyc. A.) H-S., Schmett. Em., I, t. 24, 25, (1843), Amrrica. t. 343, 344, (1847); Walleng., Fkand. Dagt., p. 211, (1847); Mosch., Wien. Ent. Mon., IV, p. 343, (1860); (Lyc. A.) Streck.. Lep., Rhop.-Het., p. 86, (1874); (Agriades A.) Send., Butf: Bull., III, p. $120,(1874)$.

Lyc. Orbitulus var. Aquilo, Stgr., (iat., 1. 11, (1871).

cupido Orbitulus var. Aquilo, Kirby, Cat., p. :36:3, (1871).

Lyc. Franklinii, Curtis, App. to Narr. Ross' ed Toy., Nat. Hist., p. 69, t. A, (1835).

+*151. Amica, IV. H. Edwds., Proe. Ent. Sox., Phil., II, p. MrKenzie's 80, (1863); ('upido A.) Kirly, Cat., 1. :376, (1871); River, Brit.

(Lyc. A.) Streck., Lep., Rhop.-Het., p. 85, (1974). Col.

Agriades: Orbitulus, Scud., Buff: Bull., III, p. 121, $(1876)$.

†*15\%. Speciosa, Hr. Emwor., Proe. Cal. Acad. Nat. S'r., V, KernCounty p. $6,(1876)$.

California.

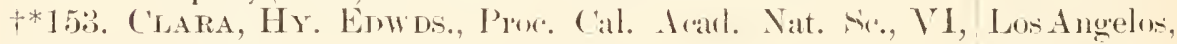
$(1877)$.

Califormial.

154. Héteronea, Bdu., Ann. Soc. Ent., Fro, 2ume Ser. X, California, p. 298, (1852); (Holyom. H.) Morris, Syru., p. 89, Colorada, (1862); (Cupido H.) Kirly, ('at., ). 363, (1871); Ctal. (Lyc. H.) Strock., Lep., Rihop.-Het., p. 92, t. I, (1874); W. H. Edwds., Butt. N. Anı., II, t. I, Lycena, (1875); Mead, Wheeler's liej., I', p. 781, (1875); ( 'upido H.) Sindl., Bufl: Bull., III, 1). 120, $(1876)$.

\section{('Trysophanus, Müb.)}

155. Sirius, W. H. Evwos., (Chrysoplanus st.), Trans. An. Colorado. Ent. Sox., III, 1. $270,(1871)$; Butt. N. AuI., II, t. I, Clirysophanms, (1874); (I.yc. s.) strek., Lep., Rlıop.-Het., p. 92, t. X, (1874); ( ('lerysophanus st.) Meal, Whoeler's Rep., I', 1). T81, (1875); ( halceria s.) ș.ud., Butt. Bull., [II, 1). 126, (1876).

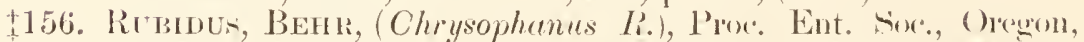
Phil., VI, p. 208, (1866); W. H. Edwols., Butt. N. Montana, Am., H, t. I, Chrysophanus, (1874); (Iye. R.) Nevala.

Kirby, Cat., p. 345, (1871); Streck., Lep., Rhop.Het., p. 92, (1874).

('halceria Rubida, Scud., Butl. Bull., I11, 1. 1:6, (1876). 
†*157. Cupreus, W. H. Edwds., (Chrysophanns (:), Trans. Olegon.

Am. Ent. Soc., III, p. 20, (1870); Butt. N. Am., II, t. I, Chrysophanus, (187t); (Lyc. C.) Kirby, Cat., p. 345, (186.) ; Strerk., Lep., Rhop.-Hot., p. 9.), (1874).

('latceria Cuprea, Scud., Buff: Bull., III, p. 125, $(1876)$.

158. Phimeas var. Ayericaxa, D’Urbax, (an. Nat., V', Camala, 1. 246, (1857); Harris, Ins. Inj. Veg., Flint's Wel., L. S. and 1. 273, (1862); Kirby, Cat., 1. :44, (1871); Strerk., Territories lep., Rhop.-Het., P. 91, (1874); (Polyom. A.) firm AtlanMorris, Svn., 1. 91, (1862). tir to Pacific.

Polyommatus Hypophkeas, Bdl., Amr. Sor. Ent., Fr., ¿me Ser. X, p. 293, (1852); Morris, Syrn., p. \&4, (1862); Kirby, Cat., ए. 344, (1871); (Heorles II.) soud., Buff. Bull., III, p. 128, (1876).

talb. a. F FAsciata, NOB.-All the black spots on upper surface Florida. of primaries, save the one within the discoidal cell, are enormously enlarged and confluent, forming a broad, sonewhat irregular, black band extending from costa to inser margin. Under surface exactly as in common form.

I arvi on Rumex Acetosella.

159. 'Thus, BDL., (Polyommatus T.), (ray. Gritt. An. King., (anada, New t. 58, (18:32) ; Bell.-Ier., Lep. Am. Sept., p. 125, t. England 38, (18:3:3); Guér., Irom. Regg. An., t. 81, (18+4); States, New (chrysophanus T.) West.-Hew., Gen. Dim. I tep., York, PennI1, p. 498, (1852); (I'olyom. T.) Morris, Syrt., p. sylvania, st, (1862); (Lyc. T.) Kirly, (at., p. :34:), (1871); Ohio, MichStreck., Lep., Rhop.-Het., j. 91, (1874); ('hryso- igan, Mimmephanus T.) Send., Butt. Bull., II I, p. 127, (1876). sita, Kansis. Lill'via on Polygonum.

160. Epraxthe, Bdi.-Lec., (Polyommatus E.), Lep. Am. British CoSept., p. 127, t. 38, (1833); Morris, Syrn., p. 85, lumbia, New (1862); (Lyc. E.) Harris, Ins. Inj. Vege, Flint's England Eel., 1. 274, (1862); ('olyom. L.) Morch., Nitett. States, New Ent. 'Leit., 1) 114, (1870); Stgr., Cat. Eur. Ixp., p. York, Mich8, (1871); (Lye. E.) Kirhs, Cat., p. 343, (1s71); igan, WisStreck., Lep., Rhops.-Het., p. 90, (1874); (Epidemia comsin, Towa. E.) Srud., Buff: Bull., I II, 1. 128, (1876).

Iyecena Doreces, Kirby, Fam. Bor. An., IV, 1. 299, t. 4, (1837); ('hrysophanus I).) l)hlily.-Hew., Gen. Diur. Lep., 498, (1850-1852); (Lyc. L.) Kirby, Cat., 1) 343, (1871); (Nolyom. D.) Morris, Syn., p. 90, (1862); (Epidemia D.) Śmol., Buft: Bull., III, p. 128, (1876).

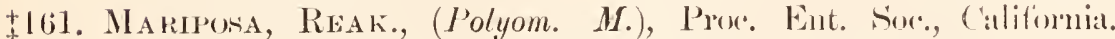

Phil., VI, p. 149, foot-note, (1866); (Lyc. M.) Kirby, Cat., p. 342, (1871); Streck., Lep., Rlwop.Het., p. 91, t. X, (1874); (Epiderinia M.) sicud., Buff: Bull., 1II, p. 127, (1876).

Polyommatus Nivalis, Bdl., Lep. Cal., p. t4, (1869). 
162. Helloides, Bdu., (Polyommatus H.) Ann. Soe. Ent., Califormia, Fr., 2ne Ser. X, 1. 292, (1852); Morris, Syn., p. Oregon, Col86, (1862); (Lyc. II.) Kirby, Cát., j. 342, (1871); orado, ctr. Streck., I epp., Rhol.-Het., p. 91, t. X, (187t); (c'hrysophanus H.) Mead, Whecler's Rep., V, p. 780, (1875) ; (Epidemia. H.) Scud., Buft: Bull., III, 128, 1876$)$.

$\$$ P'olyommatus Castro, Reak, Proc. Ent. Soc., Phil., I'I, 1. 148, (1866); (Lyecenre (') Kirby, Cat., p. 342, (1871); (chrysophanus C.) Mead, Wheeler's Rep., I, p. 781, (1875).

163. '/eroe, But., (Yolyommatus Z.), I sep. Cal., p. 45, (1869); California, (Epidemia Z.) Scud., Buff. Bull., III, p. 127, (1876). Colorado, Chrysophanus Ianthe, W. H. Edwels., Trans. An. Ent. Nevada, etr. Sot., III, p. 211, (1871) ; (Lyc. I.) Streck., Lep., Rhop.-Het., p. 91, t. X, (1874); ( 'hrysophanus 1.) Mead, Wheeler's Rep., Tr, p. 781, (1875).

164. Xaxinomes, Bdi., (Jolyom. X.), Ann. Soc. Ent., Fr., California. ?ne Ser. X, p. 292, (1852); Lep. Cal., p. 45, (1869); Morris, Syr1., p. 86, (1862); (Lyc. X.) Kirby, Cat., p. 343, (1871) ; Streck., Lej., Rhop.Het., p. 92, t. X, (1874); (G'reides X.) Scond., Buff: Bull., III, p. 126, (1876).

"Food-plant: Hemizonia."

vall. a. Droxe, Sucd., (chrysophanus D.), Proc. Bost. Wisconsin, soe. Nat. Hist., XI, p. 401, (1868); 'Trans. Cluieago Iowa, MisAcal. Sc., I, p. 330, (1869); (Lyc. I).) Kirby, Cat., souri, Kan1. 343, (1871); Streck., I sep., Rhop.-Het., p. 92, sits.

(187t); (Gaeides D.) Scoud., Buff. Bull., III, p. 126, $(1876)$.

biffers in of lyeing uniformly tame colour above an the $\sigma^{3}$.

165. Gorgox, Bur., (Polyom. G.), Ann. Soc. Ent., Fr., 2mac Ser. X, p. 292, (1852); Morris, Syn., p. 86, (1862); (Lyc. G.) Kirby, Cat., p. 343, (1871); Streck., Lep., Rhop.-Het., p. 90, t. I, ơ, (187t); (Gacides (r.) Sc(ud., Butf'. Bull., I [I, 1). 126, (1876).

*\$166. Hermes, W. H. EDwds., (chrysophanus H.), Trans. Californial. An. Ent. Soc., III, 1).21, (1870); (Lyc. H.) Kirby, (at., 1. :345, (1871); Streck., Lep)., Rhop.-Het., p. 91, (1874); ('Tharsalia H.) Ścul., Butt: Bull., I1I, 1. 125), (1876).

167. Arota, Bur., (I'olyom. A.) Ann. Soc. Ent. Fr., 2me ('alifornia. Ser. X, p. 293, (1852); Morris, Srn., 1. $86,(1862)$; (Lyc. A.) Kirbr, Cat., 1. 34:3, (1871); Streck., Lep., Rhop.-Het., \%. 91, t. X, (1874); (Tharsalia A.) Sorucl., Butt. Bull., I I , p. 125, (1876).

168. Virgixinssis, W. H. Enwds., (('hrysophstus V.), Nevada and Trans. An. Ent. Soc., II I, 1). 21, (1870); (Lyc.V.) adjoining Kirby, Cat., 1. :345, (1871); Streck., lep., Rlıp.- territory. Het., p. 91, t. X, (1874); ('Tharsalia I.) Soud., Bufl: Bull., 1II, p. 105, (1876). 
In Kirhy's Catalngue are citer the following apocryphal species : (On 1. 376, No. 306, "Cupido Clam, Eilw. (Iyc. C.) Trans. Amer. Ent. Soe. 1870. California." On p. 6553, No. 42, "L. Nais, Edw. (Chrys. N.) Trans. Amer. Ent. Soc. 1871. Inio Amer." No. 326, "Plebeius Embla, Edw. (Lyc. E.) Trans. Amer. Ent. Soe. 1870. California." No. 328, "Plebeius Eunomia, Edw. (Iyc. E.) Truns. Amer. Ent. Soc. 1870. California."

These four have no existence in nature nor are their descriptions to be found in the work referred to. Mr. Scurder says "These names were sent to Mr. Kirly as abont to be published, and by accident were never cancelled." Buff: Bull., III, p. 124 .

\section{(BENUS 3. FWNISECA. (iROTE.}

169. 'Tarquints, Eabr., (Hesperia T.), Ent. Syst., I II, 1, 1. Canala ; 319, (1793); (Pap. T.) Don., Ins. Ind., t. 4t, Enited $(1800)$; Herbst, Natursyt. Ins. Schmett., XT, p. Staten from $376,(1804)$; (Erycina T.) Godt., Ence Meth., IX, Atlantir to p. 580, (1819); ("hrysophanus T.) 1)bldy.-Hew., the liowly

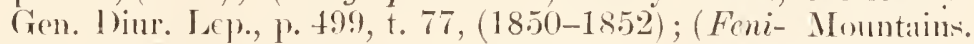
seca T.) (irote, Trans. An. Ent. Soc., II, p. 307, (1869) ; (? Lyc. T.) Kirhy, Cat., p. 345, (1871); (Fenesece T.) Saud., Buff: B̈ull., III, 1. 129, (1876). Polyommatus ('ratcegi, Bdl.-Lee., Lep. Am. Sept., p. 128, t. :27, (1839); Morris, Nyn., v. 85, (1862).

Polyommatur' Porsenna, Scud., Proc. Escex Ins., III, p. 163, (1862); (' Lyc. P.) Kirly, Cat., 1. 345, (1871).

Larva on Alnus, Vrecinium, Viburnum.

\section{GENUS 4. EUMALS, HUR.}

170. Atata, Poer, (Eumenia A.) Cent. Lep. (uha, t. 2, (1832); Floriola, Guerin, Icon. Reg. An. Ins. textu, p. 489, (1844); (uba.

(Eumceus A.) I)lıldy.-Hew., Gen. D)iur. Isp., t. 74, (1850-1852); Kirby, Cat., 1. 426, (1871); Sicud., Buff: BulI., III, \%. 103, (1876).

Eumenea Toxea, Gray, Gritf. An. King., XV, t. 4:3, (1832); Guerin, Iron. Reg. An. Ins., t. 80, (1844).

Larva on Zamia Pumila.

171. Minvas, Hrb., (Rusticus Adolescens M.), Sam. Ex. S. II. T'exas, Schmett., I, (1806-1816); (Eumceus M.) Verz. Mexico, Bek. Schnott., 1) 67, (1816); Kirby, Cat., p. 426, Panama. (1871).

Eumenia Minijas, Bdl., Al. Gen., I, t. 21, (18:36); C'ur., Reg. An. Ins., [1, t. 141, (1836); (Eumceus M.) Scurl., Buff: Bull., III, p. 103, (1876).

Eumenia Toxea, Crodt., Eus. Meth., IX, 1. 826 , (1823); Lлие., Іер. Ex., t. 7!), (1835). 


\section{FAMILI IV. ERYCINIDE.}

\section{(AENUS 1. APODEMIA, FELA.}

172. Morus, Ferd., (Lemonias M.), Wien. Ent. Mon., III, Itah, Ne1. $271,(1859)$; (Apod. M.) Reise Nov. Lep. II, p. vada, A rizo302, t. :37, (1865); (Lemonias M.) Morris, Syn., p. na, New 104,(1862); (Apod. M.) Kirby, Cat., p. 324, (1871); Mexion. (chrysobia M.) Ścud., Buff.' Bull., III, p. 103, (1876).

Nemeobius Dumeti, Behr, Proc. Cal. Arad. Nat. Se., III, \%. 178, (1865) ; (Lemonias D.) Mead, Wheel(r's Rep., I', p. 786, (1875).

('hrysobia Mormonia, Bdl., I wep. Cal., p. 52, (1869).

var. a. Virgutiti, Behr, (Nemeobius V.), Proc. Cal. S.California, Acarl. Nat. S(.., III, ). 178, (1865); (Apodemia V.) Arizona. Kirby, Cat.. p. 324, (1871); (Chrysobia V.) Scud., Buff. Bull., III, p. 102, (1876).

Apodemia Sonorensis, Feld., Reise Nor. Lej), II, 1). $30: 3,(1865)$.

Lemonias ('ythera, W. H. Eduds., Tran-. Am. Ent. Soc.. IV, 1. 845, (187.3); Mead, Wheeler's Rep., Y, p. 786, t. XXXVI, o, (1875); (chrysobia (.) scrutl., Buff: Bull., III, p. 103, (1876).

This form is a little smaller and differs further in that the median row of spots on upper surface of secondaries is confluent, forming a band, the inner edge of which is very irregular, having a deep sinus opposite the middle cell; this band is fulvous, elged more or less with white on its inner margin.

\section{GENUS 2. LEMONIAS, WEST.}

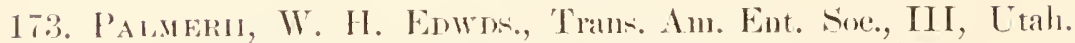
1. 195, (1870); Kirly, Cat., p. 652, (1871); (Chrysobia. P.) Scutl., Butt: Bull., II I, 1. 1(1), (1876).

\section{GENTS 3. CHARIS. HUB.}

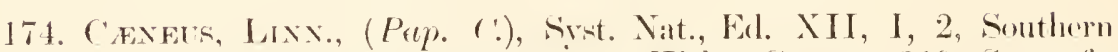
1. 796, (1767); (('haris (:) Kirhw, Cat., ). 319, States from (1871); (c'alephelis (') send., Butfi. Bull., I1I, p. Virginia to $102,(18 \div 6)$.

Texas.

l'olystichtis r'erea, M̈̈b., V'r\%. Bek. Sirhmott., J. 1s, (1816).

Erycina Virginimsis, Bdl., (iritl., ('us. In. King., ㄱ, t. 58, (18:32); (ruer., I (m). Rex. In. Ins., p. 189, t. 81, (1844).

Nymphidia Pumila, Bell.-Lec., I. 1. An. S'(pt., p. t:31, t. $37,(183: 3)$; Morris, Syll., 1. 104, (1862); (calleplectis l'.) (irote, Cin. Ent., I, 1). 14t, (1873).

('haris ('ereus, I)bldy., l ist Lep. B. M., II, p. 16, $(18+7)$. 
('haris Caenius, G.-R., Trans. Am. Ent. Sor., II, l. $310,(1869)$.

175. Borkatis, G.-R., (Nymphidia B.), Amm. N. Y. Tye. Nidalle and Nat. Hist., VIII, 1). 351, (1866); (Charis B.) Western 'Trans. Am. Ent. Soc., II, p. 310, (1869); (Charis States fiom B.) Kirloy, Cat., p. 319, (1871); (Calephelis B.) N. York to Grote, Can. Ent., Yr, p. 144, (1873); Send., Buff. Illinois. Bull., III, p. 102, (1876).

†*176. Nemrsis, W. H. EDwds., Thans. Am. Ent. Soc., 1II, Arizona. 1. 212, (1871); (Calephelis N.) Ścud., Butt. Bull., II I, p. 102, (1876).

\section{FAMILY V. LIBYTHEIDA. GENUS 1. IIBYTHEA, FABR.}

177. Bachmaxi, Kin'Tlav1, sill. Jn]. S‘., 2, Ed. XIII, p. Camada, U.S. 336, (1852); Morris, Syn., 1) 63, (1862); Saund., from AtlanCan. Ent., I, p. 25, f. 1, (1868); W. H. Edwds., tie to Texis Butt. N. Am., II, t. I, I iby., (1874). and Kansits

Hypatus Bachmanii, Scud., Butf: Bull., II, 1. 269, inchusive; (1875). rare north,

Lib. Motya var. a. Bachmani, Kirby, Cat., p. 283, commoner" (1871).

IAlrva on Celtis Occidentalis.

178. Carinexta, Cram., (Pap. C.), Pap. Exot., II, t. 108, Arizona, X. (1779); (Lib. C.) Godt., Ene. Meth., IX, p. 170, Mex., Mex., 1819); Mearl, Wheeler's Rej., V, p. 772, (1875); C'ent. Am., (Hypatus (:) Sond., Buft. Bull., II, p. 269, (1875). Surinim.

\section{FAMILY YI. DANAIDA. \\ GENUS 1. DANAIS, LATR.}

179. Plexippts, Lrxx., (Pap. P.), Syst. Nat., Ed. X, p. Canada; 471, (1758); Nus. Lad. Uir., p. 262, (1764); U. S. and C'ram., Pap. Ex., III, t. 206, E, F, (1782); Territories JeBeauv. Ins. Afr. et Am., p. 172, t. IV, f. 1 a, from Atlan1 b, (1805); (Danaida P.) Latr, Hist. Nat. Coust. tic toPacitie; et Ins., XIV, p. 108, (1805) ; (Danaus P.) I attr., Antilles; Gen. Crust. et Ins., IV, p. 200, (1809); (Idea P.) Mex.; Cent. Eseh., Kotzeb. Reise, III, p. 209, t. 7, (1821); Am.; N.Gra(I)anaus P.) Say, Am. Ent., III, t. 54, (1828); nada ; VenPeale, Lep. Am., I, t. 7, (1833); (Danaida P.) ezuela; Scud., Buff: Bull., II, p. 245, (1875).

(illiana;

Papilio Erippus, Cram., Pap. Ex., I, t. 3, A, B, Australia. (1779); (Danais E.) Kirby, Cat., p. 7, (1871).

Papilio Archippus, Fabr., Ent. Syst., III, 1, p. 49, (1793); Abb.-Sm., Ins. Ga., I, t. 6, (1797); Brown, Const. Mis. Butt., I, p. 156, t. 23, (1832); (Denais A.) Bdl.--Lec., Lep. Am. Sept., p. 137, t. 40, (1833); Morris, Syn., p. 38, (1862); Harris, Ins. Inj. Veg., 
Flint's Ed., p. 280, (1862); Samnders, Can. Ent., V, pp. 4-s, f. 1-5, (1873); W. H. Edwds., l. c., p. 9,(1873); Mead, Wheeler's Rep., I', p. 750, (1875).

Danais Archippe, Godt., Enc. Meth., IX, p. 184, (1819).

Anosia Megalippe, Hïb., Sam. Exot. Schmett., II, (1806-1824).

Anosia Menippe, Häl., I 1 \%. Bel. Schmett., p. 16,

$\frac{(1816) .}{1703) .}$, Petiver, Mns., 52, 11. 527, (1696-

t. $88,(1743)$.

val. a.-Generally maller. Gromd colour chll, much suffinsed with black, espeeially on primaries,

tab. b. J-Black marginal band destitute of all white spots; the white spots of snbapical band minute, almost obsolete. Mus. Streek.

var. c.-Not bright; more the colonr of Berenice, but not so dark.

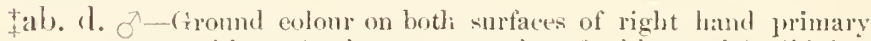
pure white. Aualogons examples of this partial albinisin are not unfrequent among the copper Lyetenidie. Mus. Streck.

Apatathicela, Floridis. Baltinure', Md.

Iallat on valuous species of milkweed (Asclepias); also on bitter root (Apocynum Androscemifolium).

('itesby's figure, which is cited by Limm. in the Srst. Nitt, Ed. $X$, ant oller editions, also in Mus. Lud. Uir., is, thongh rende, a fair representation in form and colour, and is the earkest reliahle figure I have been ahle to examine of our species. Under Plexippus Linn. also eites fig. 5, 6, t. 239, in Sloane's Jamaica. 'These figures, however, do not represent this speeies at all, but the npper and under surfices of $D$. Berenice.

I have strong dunbts if Cramer's Erippus, fig. A, B, t. 3 , in Iol. I, Pap. Ex., represents our species at all, but think it more likely to have been meant for the allied Brazilian Plexuare, Godt., at least to judge ly the white which aceompanies the venation of under side of secondaries.

Perhaps one of the moit remarkable occurrenes in eomneetion with this, the commonest of all onl $\mathrm{N}$. Am. butterflies, is that within the has few years it has appeared in great numbers in Anstratia, and bids fair to be, if not already, as plentiful there als with us. It is worthy of some thought, "not that it is curious or mire, but how the devil it got there?" possibly and probably the ehryatis or larva, or even the perfect inseet, through commeree was earried from sim Franciscos to some not very distant point in the Pacific, and in due time from thenee further, and so on.

180. Berented, Crair., (Pap. B.), Pap. Exot., III, t. 205), E, F, (1782); (I)anuix B.) Bdl.-Ler., L Lej. Am. Sept., 1. 134, t. $39,(1833)$; Morris, Syn., 1). $37,(1862)$; Mearl, Whoceler's Rep., V, p. 750, (1875); (Anosia b.) Scud., Buft: Bull., II, 1. 246, (1875).

Pap. Erippus, Fabr., (nee Cram.), Mant. Ins., II, p. $27,(1787)$.

Anosia kipippe, Mïb., V'erz. Bek. Sohmett., p. 16,

(1816); (Danais E.) Grodt., Enc. Meth., IX, p. 186 , (1819).

S. Carolinat, Gerorgia, thr. Gulf States ; II. Indies, Mexico. 
Papilio Gilippus, Abb.-Smith, (nec Cram.,t.26, $\left.f_{\bullet} C, D\right)$, Ins. Ga., I, t. 7, (1797); (Danais G.) Kirby, Cat., p. $7,(1871)$.

t. 239, f. $5,6,(1725)$.

Larva on milkweed (Asclepias).

var. a. Strrigosa, Bates, Ent. Mon. Mag., I, p. 32, Texas; Mex(1864) ; (Anosia S.) Scud., Buff. Bull., II, p. 246, ico; Cent. $(1875)$. Am.

Dan. Gilippus var. Strigosa, Kirby, Cat., p. 7, (1871).

I Differs only in that on upper surface of secondaries the veins as far as to the black margin are narrowly elged with obscure whitish grey.

Vinceloxici, (Limnas ferruginen et Anosia), of Hubner is not our species, but the Gilippus of Cram., a S. Am. insect paler in colour and with more white spnts.

\section{GENUS 2. CERATINIA, FABR.}

181. Lycaste, Fabr., (Pap. L.), Ent. Syst., III, 1, p. 161, Los Angelos, (1793) ; (Ceratinia L.) Reak., Proe. Eut. Soc., Phil., California.

V, p. 218-219, (1865); (Dynothea L.) 1. c., p. 222 ;

(Ithomia L.) Kirby, Cat., p. 26, (1871); (Dynothea

L.) Send., Buff. Bull., II, p. 246, (1875).

†var. a. Negrèta, Reak., Proc. Ent. Soc., Phil., V, p. 220,

(1865); (Ithomia N.) Kirby, Cat., P. 26, (1871);

(Dynothea N.) Scud., Buff. Bull., II, p. 247, (1875).

Differs principally from the type form in the presence of a black spot in end of cell of secondaries.

This var, is elose to var. Panamensis, Bates, but differs from it in the presence of the black in middle cell of secondaries and in the absence of the three white submarginal spots on same.

\section{GENUS 3. MECHANITIS, FABR.}

¡182. Califorvica, Reak., Prom. Ent. Sor., Pliil., I, p. 223, Lus Ingelos, (1865); Kirby, Cat., p. 24, (1871); Seud., Buft. California. Bull., II, P. 247, (1875).

\section{FAMUA VII. HELT(ONII)A. GENUS 1. IIHLICONILS, LATR.}

18:3. Charefhoxia, Lixx., (Pap. C.), Sist. Nat., Ed. XII, Flopida, 2, p. 757, (1767); (Hel. (') Kirby, Cat., 1. 141, West Indies. (1871).

Pap. Charitonia, Fabr., Syst. Ent., 1. 462, (1775);

(ram., Pap. Ex., II, t. 191, (1779); (Apostraphia

(:) Hiil., Ver\%. Bolk. Sohmett., p. 13, (1816);

(Heliconir (:) Golt., Enr. Meth., IX, p. 210, (1819); Bill.-Lee., Lep. Ans. Sept., p. 140, t. 41, 11830): Lucas, Pap. Ex., 1. 95, 1. 50, (1835);

Morris, Syu., p. 39, (1862) ; (.1postraphia C.) Scud., Buff. Bull., II, p. 247, (1875).

$15,16,(1725)$.

Sloane, Hist. Jamaica, II. t. 289, t. 


\section{FAMILY VIII. NYMPHALIDA. GENUS 1. COLANIS, Hub.}

184. Julia, Fabr., (Pap. J.), Syst. Fint., p. 509, (1775); Texals, Mex(Dryas phalerata J.) IIÏ̈b., Sam. Ex. Schmett., ico, Cent. (1806-1816); (Cokenis J.) Verz. Bek. Sehmett., Am., Brazil. 1. 32, (1816); (C'ethosia J.) Grolt., Enc. Meth., IX, p. 24, (1819); Lucas, p. 102, t. 53, (1835); (Colennis .J.) Kirby, Cat., P. 147, (1871); Seull., Buff. Bull., II, p. 257, (1875).

Pap. Alcimea, Cram., Pap. Ex., III, t. 215, f. A, F, (i, , (1782).

Pap. Alcyonea, Herbst, Natursyst. Schmett., t. 67, (1783-1804).

185. Dewat Feba, Then, IV, t. 4, f 19, 20, (1765). Texis, Mex(Cokrnis D.) Hül,., Verz. Bek. Schmett., p. 32, Cent. Am., (1816); (Cethosic D.) Godt., Ene. Meth., IX, p. Surinam. 244, (1819); (Colconis D.) Kirby, Cat., p. 147, (1871); Scud., Buff: Bull., II, p. 257, (1875). Pap. Cillene, Cram., Pap. Ex., III, t. 215, f. I), E, (1782).

$21,22,(1725)$.

\section{GENUS 2. A(XRAULIS, BDL.LEC.}

186. Vanille, Linvo, (Pap. Y.), Syat. Nat., Ed. X, p. 482, United (1758) ; Mus. Lnd. Ulr., p. 306, (1764); Srst. Nat., States from El. XII, I, 2, p. 787, (1767); Clerek, Icones, t. Virginia 40, (1764); Sulzer, Abg. Gesch., t. 18, (1776); southward, Cram., Pap. Ex., III, t. 212, (1782); Fabr., and from the Mant. Ins., II, p. 64, (1787); Stoll., Suppl., t. 1, f. Itlantic to 7 A, 7 B, Lar. et Pnp., (1787-1791); Herbst, Na- the Pacific; tursust., t. 254, (1783-1804); DeBeauv., Ins. Afr. Antilles; et Ani., p. 208, t. 11 c, f'. 2 al, 2 h, (1805); (Inyas Mexiro; Phalerata I.) Hïb., Sam. Ex. Schmett., I, (1806); Cent. Am.; (Dione V.) Hüb., Ver\%. Bek. Schmett., p. 31, (1816); N. Gramarla; (Argynnis V.) Godt., Ene. Meth., IX, p. 262, Venezuela; (1819); Bdl.-Tee., Lep. Am. Sept., p. 143, t. 42, Guiana; Br:i(1838); (Agraulis V.) Morris, Srn., p. 40, (1862); ril ; Bolivia. Kirloy, Cat., p. 148, (1871); Hy. Edwals., Proc. Cal. Acad. Nat. Sc., Larr., (July, 1874); Soud., Buff: Bull., II, p. 255, (1875).

P'ap. Passaftore, Fabr., Ent. Syst, III, 1, p. 60, (1793) ; Abb.-Sm., Ins. Gia., I, t. 12, (1797).

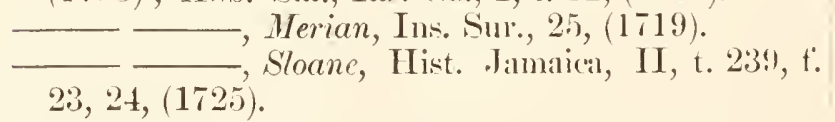

ab. al.- Ground colour of upper surface olivaceous instead of red.

Larva on bhe and scarlet passion flower (Passaford ('erulea et Incarnata). 


\section{GENLS 3. EUPTOIE'TA, DBLDY.}

187. Cluadia, C'ram., (Pap. C.), Pap. Ex., I, t. 69, f. E, F, U. S. from (1779); (Dryas fucata (.) Hiib., Samm. Ex. Penna.

Sehmett., I, (1806-1816); (Rrenthis C.) V er\%. Bek. soutliwarl

Sehmett., 1. 30, (1816); (Argynnis C.) Dbldy., and fiom the List Lep. B. M., I, p. 67, (184t); Dbldy-Hew., Atlantic to Gen. Diur. Lep., p. 170, (1850-1852); Chenn, Pap. the Rocky Diur., f. 192, (1851-1857); (Eup. (') Reak., Proe. Mt-. ; IriEnt. Soe, Phil., VI, p. 136, (1866); W. H. Edwds., zona; New Can. Ent., II, p. 163, (1870); Kirhy, Cat., p. 154, Mexieo. (1871) ; Mearl, Wheeler's Rep., V, p. 750, (1875); Scull., Buff. Bull., II, p. 258, (1875).

Pap. Clausius, Herbst, Natursvit. Ins., IX, p. 189, t. $257,(1798)$.

Argynnis Columbina, Godt., (nec Fabr.), Ene. Meth., IX, p. 260, (1819); Bull.-Lee, Lep. Am. Sept., p. 153, t. 44, (1833); Morris, Syn.. p. 44, (1862).

Larva on violets, Podophyllum, Sedum, Passiflora, ?Portulacer.

188. Hfaesia, Cram., (Pap. H.), Pap. Ex., III, t. 209, E, S. Calitomia, F, (1782); (Eup. H.), Kirby, Cat., 1). 154, (1871). Mexico, II. P'ap. Columbina, Fabr., Ent. Syst., III, 1, p. 148, Indies, C'ent. (1793); (Arg. C.) Godt., Ene. Meth., IX, p. 260, Am., Chili. (1819).

Pap. Daunius, Herbst, Natursyst. S'chmett., IX, P. 184, t. $256,(1798)$.

Argynnis Hortensia, Blanch., (iay, Fall1. Chil., VII, P. 23, (1852); Kirby, Cat., 1. 159, (1871).

\section{GENUS 4. ARGYNNIS, FABR.}

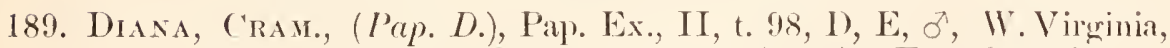
(1779); Fabr., Sp. Inr., p. 110, ơ, (1781); Ent. Creorgia, Syst., III, p. 145, (1793); (Arg. D.j Crodt., Enc. Kentucky, Meth., IX, y. 257, (1819); Say, Am. Ent., I, t. 17, 'Tennexiece, ठै, (1824); Herbst, Natursyst. Gohmett., IX, p. 169, Irkansils. t. 25:), (1798) ; Bdl.-I.ec., L.ep. Am. Sept., \%. 149, (1833); Morris, Syn., ए. 42, ơ, $(1862)$; II. H. Ellwds., Proc. Enit. Soce, Phil., III, P. 431, +, (1864); Bıtt. N. Ain., I, t. 1, Arg., ơ I. c., II, t. VII, Are: ()v. I Alll. et Pup., (1876); Can. Ent., VI, p. 121, (1874); Feld., Reise Nov. Lep., III, p. 394, t. 50,(1867); Kirby, Cat., 1. 155, (1871); (Semnopsyche I).) Seud., Butf: Bull., II, 1). $258,(1875)$.

Larva on the varions species of violets, both wild and cultivated.

190. Inalia, Dru., (Pap. I.), Ill. Ex. Ent., I, t. 13, (1773); I'. S. firom Cram., Pap. Ex., I, t. 44, (1779); Fabr., Syst. Ent., Mass. toWir. p. 516, (1775); Ent. Syst., III, p. 145, (1793); Arkansas \& Ionisiana. 
Herhst, Natursyst. Schmett., IX, t. 252, (1798); (Acirlalia I.) Hüb., Verz. Bek. Schmett., p. 31, (1816); (Arg. I.) Godt., Enc. Meth., IX, p. 263, (1819); Brll.-Lee., Lep. Am. Sept., P. 147, t. 43, (18.3); Lucas, Pap. Ex., p. 108, t. 56, (1835); Morris, Sirn., 1. 41, (1862); Harris, Ins. Inj. Veg., Flint's Ed., p. 285, f. 110, (1862); Kirby, Cat., p. 156, (1871); (Speyeria I.) Scud., Butf. Bull., II, J. 258, (1875); (Pap. I.) Brown, Constable's Mis., III, Butt., p. 40, t. 2, (1834).

ab. a. F A-mearowh, Fismer, Proc. Acad. Nat. Sc., Schooley's Phil., p. 352, (1852); Morris, Syn., p. 47, (1862); Momntain, Kirloy, Cat., p. 157, (1871).

Arg. Astarte, Fisher, Proc. Acad. Nat. So., Phil., p. 179, t. 2, (1858); (Speyeria A.) Scoul., Butt. Bull., II, J. 258, (1875).

Above tlie spots and marks of primaries suffused and confluent, forming heary black streaks between the veins and connecting with the black outer margin. Secondaries destitute of the two rows of white spots. Beneath primaries marked ats ahove and with the black streaks in the rells heavilysufluked with silver. Seeondaries with the batsal half silver and the onter half dark hown with blackish streaks between the veins; five snbmarginal silver spots, two only at all conspicuntis, the others merely a few seales. Mus. Streck.

Fisher changen the name Astarte, muder which it was originally described, to Ashtaroth, owing to the former beingr preocempied by a slecies in Dbldy.-Hew., linr. Lep., t. 23, f. 5.

Iarval fool is, probably, in common with that of the other speries, varions kinds of violets.

†191. Fow rosit, Reak., Proc. Ent. Soe, Phil., VI, p. 137, colorale.

(1866); W. H. Edwls., Butt. N. Am., I, t. 11,

Arg., (1s69); Kirls, Cat., p. 160, (1尺i1); sंeud.,

Buff. Bull., II, J. '260, (1875) ; Mead, Wherler's

Rej., I, ]. 754, (1875).

Arg. Aglaia, W. II. Edreds., Proc. Ent. Sire, Phil.,

II, p. $504,(1864)$.

var. a. Nevinfasis, W. H. Enwes., Trans. Am. Ent. Montana, Sox., III, p. 14, (1870); Butt. N. Am., I, t. 14, Nevalla, Arer., (1871); Kirby, Cat., p. 6.t7, (1871); Sond., Itah, CaliButf. Bull., II, p. 260 , (1875). formia.

Wings sonewhat broader. Under surface of seeondaries in of not greenish; generally with the space between the two onter rows of silver spots pale bufl' colour in both sexes.

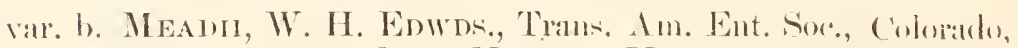
IV 1 . 67, (1872); Butt. N. Am., II, t. 2, Arg., M(n)tana. (1875); Noud., Butf. Bull., II, p. 260), (1875);

Mard, Whecer's Rep., T, p. 755, (1875).

smaller. Green of under side of secondaries brighter.

192. Nokems, W. H. EDwds, Proc. Acal. Nat. Se, Phil., Arizoma. 1.. 221, (1862); Butt. N. An., I, t. 4, Are., (186is); Reak., Proce. Fut. Soc., Phil., VT, p. 136, (1866); Kirly, Cat., p. 157. (1871) ; Soud., Buff. Bull., II, 1. 259, (1.875); Mearl, Whoeler's Rop., V, l. 751, t. $35,(1875)$. 
193. Cruele, Fabr., (Pap. ('), Syst. Ent., p. 516, (1775) ; Camada, U.S. Ent. Sist., III, p. 145, (1793); Herbst, Natursyat. from Maine Schmett., I X, p. 178, t. 25.5, (1798); (Acirlalia (.) to Virvinial Hül., Verz. Bek. Schmett., p. 31, (1816); (Arg. C.) and west(rodt., Enc. Meth., IX, p. 260, (1819); Bdl.-Lec., ward to lep. Am. Asept., p. 151, t. 45, (1833); Kirby, Faun. Kantis. Am. Bor., IV, p. 289, (1837); Morris, Syn., p. 42, (1862); W. H. Elwds., Butt. N. Am., I, t. 2, Aro., (1868); Can. Ent., I'I, p. 121,(1874); Kirbr, ('at., 1. 157, (1871); Siunders, Can. Ent., IV, p.

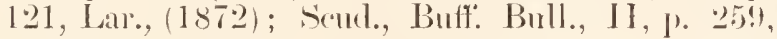
$(1875)$.

Ary. Duphnis, ('rum., (I'ap. I).), P'al). Ex., 1, t. 5̄, $(1779)$.

I sillit on violets.

fal. a. O BAAL, Nob.-Upper surface primaries, subnarginal ()hio. lamules confluent with the row of round black spots interior to them. Secondaries, submargina! line wanting, submarginal lunules connerterl and suffused, forming an irregular jagged line; the row of spots interior to this almost obsolete, other marks suffised. Ender surface primaries, all hlack marks increased and more or less confluent. Secomtaries, were one-third of wing (hasal part) silver, rest reddish brown, paler towards exterior margin; an irregular, rather broad, sulmarginal band formed of conllnent silver lumules and spots. Mus. streek.

vall. b. I eto, Benr, Proc. Cal. Acad. Nat. Sir., IJ, p. ()renon, Cal17:3, (1858-186\%); W. H. Elwdi., !'me. Ent. Sor., ifmonia.

Phil., l, 4:34, (1864); Butt. N. An1., I, t. X, Aro., (1869); Kirby, (at., p. 157, (1871); Streck., lep., Rhop-Het., p. 106, (1875); Soud., Buff. Bull., I I, 1. $259,(1875)$.

Arg. ('ybele, Bdl., Lep. Cal., p. 60, (1869).

Upper surfice, groumd colour of $\sigma^{7}$ same red as the normal form or a liule darker, of $f$ pale vellow or yellowish white, which colour is however confined mainly to the outer third of wings, the latsal and discal parts being black or blackish brown. $o^{7}+t$ with silver spots of under side of secondaries very mall.

+*194. Nitocras, Ut. H. Evwds., Trans, Am. Ent. Soc., V, p. Arizona.

15, (1874); Meal, Wheeler', Rej., T, 1. 751,

(1875); sund., Buff: Bull., II, 1). 259 , (1875).

†*195. Carpexterin, W. H. Enw1m., Thans. An. Ent. Sox., I, p. $204,(1876)$.

196. Aphronfte, FAbr., (l'ap. A.), Mant. Ins., II, p. 62, Camida, U.S. (1787); Ent. Syst., III, 1, 1. 14t, (1793); (Arg. A.) from Mane Godt., Enc. Meth., IX, 1). 264, (1819); Morris, to Viryinia Syn., p. 43, (1862); Hamris, Ins. Inj. Veg., Flint's and we'stEd., p. 285, 286, f. $111,(1862)$; W. H. Edwd-.., witrl to (ool-

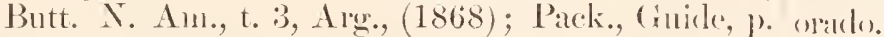
25:3, f. 18:3, (1869); Kirby, Cat., p. 157, (1871); Can. Ent., II, 1. 121, Lair., (187t); Mead, Wheeler's Rep., V, p.75:2, (1875); Foud., Buti: Bull., II, 1. $259,(1875)$. 
Pap. Daphnis, Martyn, Psyche, t. 3, f. 7, t. 4, f. 9, $(1797)$.

Larva on violets.

var. a. Alcestis, W. H. Evwds., Trans. Am. Ent. Soc., Y, p. 289, (1876).

$\delta$, ground colour under surface all wings miform cimmamon brown, seldom much inlication of the buff space between the last row of silver spots and the submarginal lunules. + ground colour under side secondaries uniform very dark ferruginous.

al). b. \&.-Whole upper surface obscured with blackish brown; no defined marks visible save one in cell of primaries. Under surface primaries, all black nuarks very much enlarged, in many parts confluent. Secondaries with very dark ground colour, silver spots as in usual form.

†*197. Halcrone, W. H. Enwds., Butt. N. Am., I, t. 9, colomado. Arg., (1868); Kirby, Cat., p. 158, (1871); Scud., Buff. Bull., II, p. 260, (1875); Mead, Wheeler's Rep., V, p. 75t, (1875).

From Mr. Edwds.' figure should suppose this to be the sane as Aphrodite.

198. Atrlantrs, W. H. Enwos., Proc. Acad. Nat. Sc., Phil., S. Labrartor, 1. 54, (1862); Butt. N. Am., I, t. 5, Arg., (1869); Can., Lake Can. Ent., IX, p. 35, (1877); Pack., Guide, p. 252, Sup. Region, (1869); Kirly, Cat., p. 158, (1871); Mead, Wheel- N. E. States, er's Rep., V, p. 754, (1875); Seud., Buff. Bull., II, X. Y., Pa., p. $260,(1875)$.

Larva on violets. west'n States to Roc'y Mts.

+*199. Nausica, W. H. Enwos., 'Trans. Ant. Ent. Soc., V, p. A rizona. 104, (1874); Meur, Wheeler's Rep., V, 1. 752, (1875).

†*200. Columbia, Hy. Edwiss., Proc. Cal. Arad. Nat. Sec., British CoVI, (1877).

lumbial.

†*201. Lildana, Hy. Euwds., Pror. (al. Aeul. Nat. Sc:, V1, Calitomia. $(1876)$.

202. Comoxis, Behr, Proc. Cal. Acad. Nat. Sc, II, p. 173, California. n. 2, (1858-1862); W. H. Edwd., Proc. Ent. Soc., Phil., III, p. 435, (1864); Kirby, Cat., J. 158, (1871); Scurl., Buff. Bull., II, p. 260, (1875). Arg. Juba, Bdl., Lep. Call., p. 60), (1869).

203. Callippe, Bdu., Ann. Soe. Ent. Fr., 2 me Ser. X, p. California. 302, (1852); Morris, Syn., p. 46, (1862); Behr, l'roc. Cal. Acad. Nat. Sc., II, p. 17\%, n. 1, (18581862); W. H. Edwds., Proe. Ent. Sor., Phil., III, p. 434, (1864); Butt. N. Amı, I, t. 6, Are., (1868); Kirby, Catt., 1. 158, (1871); S'cul., Buft. Bull., II, p. $260,(1875)$.

204. Brementi, W. H. EDwds, 'Trams. An. Eut. Soe, Vanconver's IV, p. 63, (1872); Butt. N. Am., II, t. 4, Arg., Is., Wasl. (1874); Scud., Buff. Bull., II, p. 260, (1875). Ty, Oregon. 205. Montrolda, Benr, Proe. Cal. Acad. Nat. Sc., II, p. Cálifomia, 175, (1858-1862), l. e., III, p. 84, (1863); W. H. Oregon. lidwols., Pron. Ent. Soc., Phil., III, p. 4i36, (1864); 
Butt. N. Am., I, t. 8, Arg., (1868); Kirby, Cat., ю. 158, (1871); Ścull., Buff. Bull., II, p. 261, (1875). -Arg. Zerene, Bal., Am. Soc. Ent., Fr., 2 me Ser. X, p. 303, (1852); (Melitaa /.) Morris, Syn., 1). 53, (1862).

var. a. Rhodope, W. H. Edwds., Trans. Am. Ent. Brit. Col., Soe., V, p. 15, (1874); Butt. N. Am., II, t. 6, ()regon, Arg., (1874) ; Scud., Buff. Bull., II, p. 260, (1875). Califimin.

I)iffers in the under surface of secondaries being darkel" coloured; sometimes obscured with blackish on disc between the second and third row of spots. In $0^{2}$ the spots are more or less silvered; in of the submarginal lunules sometimes silvered, sometimes pale yellow; all the other spots pale yellow.

var. b. Benrensit, IV. H. Lowos., Trans. Am. Ent. Mendocino, Soc., II, p. 370, (1869); Butt. N. Am., I, t. 12, Shasta, Arg., (1870) ; Kirby, Cat., p. 163, (1871); Soml., California. Butf: Bull., I I, 1). 260, (1875).

Under surface of secomblaries in both sexes deep forruginous with more or less of a paler greyish tint hetween the onter row of spots and the submarginal lumles; all the spots brilliant silver. The greatest difference between this and the preceding variety is in the females; between the males it is not much.

f*var. e. Purpurascens, Hy. Emwus., Proc. Cal. Acarl. Oregon. Nat. Sr., VI, (1876).

This may prove to be one or the other of the alove forms.

206. Hesperis, IV. H. Edwds., Proc. Ent. Soc., Phil., II, Colorado, p. 502, (1864); Reak., l. c., VI, p. 139, (1866); Utah.

W. H. Edwrk, Butt. N. Am., I, t. 7, Are., (1868); Kirloy, Cat., p. 158, (1871); Send., Bufr. Bull., II, p. 261, (1875); Mead, Wheeler's Rep., V, p. 75t, $(1875)$.

f*207. Inornata, W. H. Edwos., Trans. Am. Ent. Soc., IV, Califormia. p. ${ }^{*} 64,(1872)$; Butt. N. Am., II, t. 5, Are., (1876); Scud., Buff. Bull., II, p. 261, (1875).

208. Zerene, Bnt., Amn. Soc. Ent., Fr., 2 me Ser. X, 1. California. 303, (1852); Behr, Proc. Cal. Acad. Nat. Sc., II, p. 175, n. 9, (1858-1862); W. H. Edwh., Proe. Ent. Soc., Phil., III, p. 436, (1864); Butt. N. In., I, t. 13, Arg., (1870); Kirloy, Cat., p. 158, (1871); S.ull., Butt: Bull., IT, p. 261, (1875).

Arg. Hydaspe, Bdl., Isep. Cal., p. 60, (1869).

Under the name of Zerene Dr. Boisduval in 1852 placed loth this and "the species afterwards deseribed by f)r. Pellor as Monticola. In 1869 , premising that he had confomnled two species, lie renamed this me IIydaspe and retained Zerene for the species which in the interin (1863) Dr. Behr lad sepatrated as Monticola; of course Dr. Behr's uame will stant for the latter and Dr. Boisduval's for the present, whilst Mydaspe sinks into a synonym.

var. a. Inene, Bdi., (Arg. Egleis var. Irene), Lep. Cal., California. p. $59,(1869)$.

Ary. Montivago, Kirby, (nee Behr), Cit., p. 159,(1871). 
Arg. Irene, Scud., Buff. Bull., II, p. 261, (1875).

Submarginal limules on under surface of secondaries in both sexes silver; all other spots whitish yellow as in Zerene.

var. b. Mormonia, Bdu., Lep. Cal., p. 58, (1869); California. Sind., Buff? Bull., II, p. 261, (1875).

Arg. Montirago, W. H. Edwds., Proc. Ent. Soc., Phil., III, 1. 435, 11. 5, (1864).

Arg. Nenoquis, Kirby, (nec Reak.), Cat., p. 160, (1871).

All spots on under side of secondaries silver.

vall. e. Montryago, Behr, Proc. Cal. Acarl. Nat. Sc., Califomial. II, p. 174, n. 4, (18.58-1862), l. c., III; p. 84, (1863);

Kirby, Calt., p. 159, (1871); Scud., Buft: Bull., II, 1). $261,(1875)$.

Arg. Egleis, Bdl., Lep. Cal., p. 59, (1869).

Very chose to Mormonia, if not, as I believe, identical. Gromud colonr of under surface appears to be paler than in that form, and in some instances with only the submarginal lunules of secoudaries silver.

?var. d. Rupestris, Benr, Proc. Cal. Acatd. Nat. Sc., California.

II, P. 175, n. 6, (1858-1862), I. e., III, p. 84, (186:3); W. H. Edwels., Proce Ent. Soc., Phil., III, p. 435, (1864); Butt. N. An., II, t. 7, Arg.,(1876); Kirby, Cat., p. 159, (1871); Scud., Buff. Bull., II, p. $261,(1875)$.

Black markings heavier, with a tendency to suffusion. Submarginal ] nuules of under side of secondaries partly silver, sometimes all the spots nore or less silvered.

209. Euryome, W. H. Edwds., 'Trans. Am. Ent. Soc, IV, Colorado.

p. 66, (1872); Butt. N. Am., II, t. 1, Arg., (1875);

I cad, Wheeler's Rep., V, p. 755, (1875); Scuul.,

Buff: Bull., II, p. 260, (1875).

?Arg. Astarte, W. H. Edwds., (nec Dbldy.), Proc. Ent.

Soc., Phil., I, p. 221, (1862).

This is not the "n. 4 Astarte" of Elwds. in Proe. Ent. Soe., Phil., III, 1. 435, which is species (No. 210) described below as follows:

+210. A RGE, NOB.-This name I have given to a smaller allier] species from California, which has been sometimes mistaken for Montivago, and which may be a Pacific coast var. of Eu-

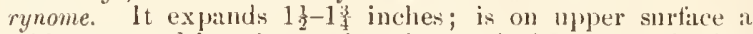
trifte more red in colour, otherwise much the same as in that species. Beneath the primaries, except along the costa and towards the apex where they are buft; are tinged with rel; in some cases the three or four marginal Junules nearest alpex are silver, oftener not. Secondaries reddish buft, palest between the marginal Lunules and the last row of silver spots, but nowhere dark; spots all silvered, no tinge of grten whatever in any example of the very many I have examined. When compared with Eurynome, beneath the latter is much paler, is yellowish and generally mottled or shaded more or less with greenish, whilst the present species is darker, is of at ferruginous buff' and never with the slightest indication of green; the spots are also comparatively smaller and not as heavily silvered as in Eurynome. This is the species cited as Astarte, Dbldy., by W. H. Edwds., Proc. Ent. Soe., Phil., III, 1. 435, (1864), and later considered by the same author ats illentical with Eurynome, from which, however it is I helieve, distinct, as shown above. 
211. Adnan'te, Bdu., Lep. Cal., p. 61, (1869); Kirby, Cat., California.

p. 157, (1871); Seurl., Buff. Bull., II, p. 261, (1875).

Arg. Adiaste, (Bdl. MSS.), Behr, Proe. Cal. A cal.

Nit. Se., II, p. 175, (1858-1862), l. c., III, p. 84,

(1863); W. H. Edwds., Proe. Ent. Soe., Phil., III, 1. $436,(1864)$.

Arg. Adruste, Kirby, Cat., p. 160, (1871).

†*212. Clio, W. H. Edwos., Trans. Am. Ent. Soe., V, p. 106, (1874).

*213. Biscuoffir, W. H. Edwos., Trans. Am. Ent. Soc., III, p. 189, (1870) ; Butt. N. Am., II, t. 3, Arg., (1875); Scull., Buff. Bull., II, p. 260, (1875).

var. a. (opts, W. H. Enwos., Trams. Am. Ent. Soc., V, Cariboo,

p. 105, (1874); Butt. N. Am., I I, t. 3, Arg., (1875). Brit. Col.

No silver on spots of under surface.

214. Mrrixa, Cram., (Pap. M.), Pap. Ex., II, t. 189, (1779); Canada, sou(Arg. M.) Hüb., V erz. Bek. S.limett., p. 30, (1S16); thern part of Say, Am. Ent., III, t. 46, (1828); Bdl.-Lee., Iep. Brit. Col., Am. Sept., p. 155, t. 45, (1833) ; Kirby, Fann. Am. New EngBor., IT', p. 290, (1837); Harris, Ins. Inj. Veg., land, Middle Flint's Ed., p. 286, f. 112, (1862); (Brenthis M.) and Western H-S., Prodr. Lep. Reg. Corr.-Blatt, 1. 91, (1865); States to the (Arg. M.) Morris, Syn., p. 43, (1862); Samnd., Can. Rocky Mts.

Ent., I, p. 55, Lar., (1868); Kirby, Cat., p. 162,

(1871); (Brenthis M.) Scud., Buff. Bull., II, p. 262,

(1875); (Arg. M.) W. H. Edwds., Can. Ent., VIII, p. 161, (1876).

Pap. Myrinus, Herbst, Natursyst. Ins. Sehmett., IX, p. 178, t. 255, (1798).

Arg. Myrissa, Godt., Ene. Meth., IX, pp. 266, 806, (1819).

Lallva on violets.

215. Aphirape var. 'Tricluars, Hub., '/ntr. Ex. Sehmett., Lahrador,

II, (1818-1824) ; Mosch., Wien. Ent. Mon., IV, p. British Co334, (1860) ; Stgr., Cat., p. 20, (1871) ; Kirby, Cat., lumbia, p. $162,(1871)$.

Arg. 'Tricluris, Meud, Wheeler's Rep., V, p. 757,

(1s75); (Brenthis T.) Seud., Buff. Bull., II, 1. 262, $(1875)$.

Arg. Ossiamus, Bdl., (nec Herbst), Ie. Iep., t. 19, (1832) ; Bdl.-Ice., Lep. Am. Sept., p. 157, (1833); Morris, Srnn., p. 48, (1ฐ62).

216. Helena, W. H. Edwos., Trans. Am. Ent. Soe, TII, Colorado, 1. 268, (1871); Mead, Wheeler's Rep., V, p. 757, Montana. (1875); (Brenthis M.) Send., Buff. Bull., II, 1). 262, (1875).

217. Charicilia, Schineider, (Pap. C.), Neu. Mag., V, p. Iabrador, $588,(1794)$; Herbst, Natursyst. Ins. Schmett., X, Brit. Col., t. 272, $(1800)$; Hïb., Eur. Schmett., I, f. 769, 770, Greenland, (1824-1826); (Arg. C.) Ochs., Schmett. Eur., I, p. I atppland. 66, (1807), IV, p. 114, (1816); Treits., X, 1, p. 15, (1834); Dup., I, p. 34t, t. 48, (1832); (Brenthis C.) H-S., Prodr. Syst. Lep. Reg. Corr.-Blatt, p. 91, 
(1865) ; (Arg. (.) Bull.-Lec., Lep. Am. Sept., p. 161, (1833) ; Bdl., Sp. Gen., I, t. 11, f. 2, (1836); Send., Proc. Bost. Soc. Nat. Hist., XVII, p. 40, (1875); Mosch., Wien. Ent. Mon., IV, p. 338-342, (1860); Morris, Syr1., p. 49, (1862); Stgr., Cat., p. 20, (1871); Kirly, Cat., 1. 161, (1S71); (Brenthis C.) Send., Bufr. Bull., II, p. 262, (1875).

Arg. Arctica, Zett., Ins. Lapp., p. 899, (1840).

var. a. Boisduvali, Dup., Sup., I, t. 20, (1832); Sommer, Bdll., Ic., I, p. 98, t. 20, (1832); Hüh.Gey., Eul'. Schmett., I, f. 1020-1022, (1827-1841); Mosch, Wien. Ent. Mon, IV, p. 341, 342, (1860); Sterr., Cat., p. 20, (1871); Kirlyy, Cat., p. 161, (1871); Scoull., Butf: Bull., III, p. 262, (1875).

I estitute, or nearly so, of the white basal nurks on under side of secondaries.

var. b. Montinus, Siens., P'one. Ess. Hus., III, p. 166, White Mts. (1862); Bost. .Jnl. Nat. Hist., VII, P. (326, (1863); of New (Brenthis M.) IBuff. Bull., II, p. 26:3, (1875); (Ar\%. Hampshire. M.) Kirby, Cat., p. 161, (1871).

Prevailing eolonr of under side of secondaries much more reddish or rust coloured.

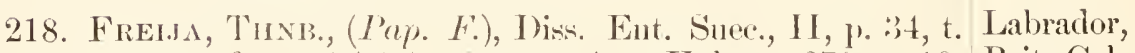
5, f. 14, (1791); Quens., Act. Hol., p. 276, t. 10, Brit. Col., (1791); Ilerbst, Natursyst. Ins. Schmett., X, t. 272, (1800); Esp., Schmett., I, 2, t. 109, (? 1790); Hiib., Eur. Schmett., f. 55, 56, (1793), 771, 772, (1807); Ochs., Schmett. I, 1, p. 78, (1807); (Arg. H.) Hüb., Verz. Bek. Schmett., p. 30, (1816); Godt., Enc. Moth., IX, 1. 27:3, (1819); Meigen, Eur. Sohnett., t. 14, (1829-1832); Frever, Neu. Beit., t. 295, (18:1-1858); Dup., Supl., I, 11, t. 19, (1832); Bull. Tcon., I, t. 19, (1832); Kirby, Fann. Am. Bor., IV, p. 291, (18.37); Zett., Ins. Lapp., p. 897, (1S40); II-S., Eur. Schmett., I, p. 36, (1843); Evermin., Ent. Russ., V, p. 61.t. 7, (1851); Moseh., Wien. Ent. Mon., IV, p. 338, (1860); Morris, Syn., p. 46, (1862); S'rud., Proc. Bust. Soc. Nit. Hist., X VIT, p. 299, (1875); Ster., Cat., 1. 20, (1871); Mear, Wheeler's Rep., V, 1. 750, (1875); (Brenthis F.) S(cud., Buft: Bull., I I, p. 262, (1875).

Brenthis Freya, $\Pi-S$., Prodr. Isep. Reg. Corr.-Blatt, p. 91, (1865).

Pap. Dia Lapponica, Esp., Solmett., I, 2, t.97,(?1790.)

Arg. Lapponica, Kirby, Cat., p. 161, (1871).

Boothiavar. a. 'Tarqunius, Cur't., (Melitea), Ross' 2ł Toy., Ipp. Felix.

Nat. Hist., p. 68,(1835); Kirby, Cat., p. 161, (1871);

(Brenthis T.) Scud., Buft. Bull., II, 1). 262, (1875).

219. Polakis, Bnt., Ind. Meth., p. 15, (1829); Ieon., t. 20, Iabrador,

(18:3); Sp. Gen., I, t. 11, t. 1, (1836); Bdl.-I uec., Aretic A 11.

Lep. Am. Sept., p. 159, (1833); Dup., Supl., 1, 11, t. 20, (18:32); Freyer, Neu. Beit., V, t. 439, (18311858); H-S., Eur. Schmett., I, p. 32, (1843); 
Eversm., Ent. Russ.. V, p. 65, t. 7, (1851); Wallengr., Skand. Dagf., p. 91, (1853); Mosch., Wien. Ent. Mon., I V, p. 342, (1860); Morris, Syn., p. 48, (1862); Sent., Proc. Bost. Soc. Nat. Hist., XVII, p. 303, (1875); Stgr., Cat., p. 20, (1871); Kirby, Cat., p. 161, (1871); (Brenthis P.) Scuul., Buff. Bull., II, p. 263), (1875); (Papilio P.) Hüb., Eur. Schmett., I, f. 1016-1019, (1827-1811).

220. Frigga, Tinnb., (Pap. F.), Diss. Ent. Suec., II, p. 33, Iabrador, (1791, Dee. 10); Quens., Act. Hol., t. 19, f. 6, Brit. Col., (1791); Hiib., Eur. Sohmett., I, f. 49, 50, (1793); Colorado, Ochs., I, 1, 1. 74, (1807); (Arg. F.) Hïh., Ver\%. Lappland, Bek. Schmett., p. 30, (1816); Goutt., Enc. Meth., N. IV. SibeIX, p. 272, (1819); Dup., Supl., I, t. 19, (1832); ria, N. Rus(Brenthis F.) H-S., Prodr. Syst. Lep). Rex. Corr.- sia.

Blatt, 1. 91, (1865); (Ar\%. F.) Eversm., Eilt. Russ., $\mathrm{V}$, p. 59, (1851); Mosch., Wien. Ent. Mon., IV, p. $337,(1860)$; S.tgr., Cat., p. 20, (1871); Kirby, Cat., p. 160, (1871); (Breathis F.) Scud., Butf: Bull., II, p. 263, (1875).

var. a. SAGA, KADEN.-Where deseribed I canuot at present ascertain. It is a little smaller than the normal Frigga. On upper surface the basal half of secondaries cutirely suffused with black; beneath the basal half of secondaries, except the large white spot at costa near bise, are dark rust red, the usual marks but dimly discernible.

221. Beldona, Fabr., (Pap. B.), Syst. Ent., 1. 517, (1775); Canada, New Ent. Syst., III, 1, 1. 148, (1793) ; (A.\%. B.) Hüb., England, Zutr., p. 42, f. 975, 976, (1818-1837); (rodt., Enc. Middle anıl Meth., IX, 1. 271, (1819); (Brenthis B.) H-S., Western Prodr. Syst. Lep. Reg. Corr.-Blatt, P. 91, (1865); States to the (Arg. B.) Bdl--Lec, Lep. An. Sept., p. 164, t. 45, Rocky Mts. (1833) ; Harris, Ins. Inj. V'eg., Flint's El., p. 287, f. 113, 114, (1862); Molris, Srn., P. 45, (1862); Pack., Guide, p. 25:), (1869); Kirby, Cat., 1. 159, (1871); (Brenthis B.) Sent., Buff. Bull., II, 1. 26:?, (1875).

Papilio Myrina, Martyn, (nec (nam.), Psyche, t. 1, t. $2,3,(1797)$.

Larva on violets.

var. a. EPITHore, Bdi., MSS. Edwals., Proc. Ent. Soc., California, Phil., II, p. 504, (1864); I tep. Cal., p. 58, (1869); Oregon.

Kirby, Cat., p. 160, (1871); Mead, Wheeler's Rep., V, p. 756, (1875); (Brenthis E.) Secul., Butt'. Bull., II, p. 263, (1875).

Fore wings not produeed so much apically. Not as much dirk suffusion on basal half of upper surface as is generally the ase in Bellona. Markings of under surface of secondiries somewhat more distinet.

var. b. $9 .-$ It is difficult to saly if this example belongs to Epithore Utal. or Frigga, but probably to the first. The upper surtace is nearly is in Epithore. "The whole under surface is paler than either of these species. The broad irregular mesial hand amd basal spots of secondaries are all uniform clear yellow, and all save one, basal spot at costa, elged with at sharp black line. 


\section{†*222. Improba, Butl., Ent. Mon. Mag., X'III, 206, (1877). Cambridge Bay, Aretic An.}

+Morrisii, Reak., Proc. Acad. Nat. Sc., Phil., p. 245, (1866), was descriled from an example of Arg. Euphrosyne, L., which Mr. Reakirt received from M. Lorquin the younger, with California erroneously given as its locality.

Nenorpuis, Reak, Proc. Acad. Nat. Se., Phil., p. 247, (1866), is Dia, L., received by Mr. Reakirt under the same circumstances.

The Argynnides of the western slope, or Pacific side of the Rocky Mts., are without doubt, if we except perhaps the Coliades, the most difficult of all the N. Am. Diurne to deal with, as they not only run into certain variations, but again into sulwariations, and even further; the two species Monticola and Zerene, first considered identical by Dr. Boisduval, are perhaps the most perplexing; each of these bears the same relation to some of their varieties as does Niobe to its var. Eris and Adippe to Cleodoxa, but presenting by no means the stability of form of these European variations, but branching out into endless and endless varieties until the student is completely at a loss to know where or to what they may beiong. The presence or absence of silver spots is not of the slightest specific importanee, for the same species may he with or withont them, or one sex of the same species is with them silvered and in the other they are devoid of it, or again the silver is eonfined to a single row of spots, or even to part of a row, or to one or two spots only. Edwardsii and Nevadensis are so close as to searce deserve even a varietal name. Nokomis may be and I believe is a form of Cybele, coming at it does from Arizona, which for its Ley. Fauna is the wonderland of $\mathrm{N}$. Am., we neet scarce be astonished at its remarkible aherrancy. Brcmuerii may he a form of Monticola. Nos. 194, 195, 197, 199, 200, 201, 205 var. c., 207, 212 and 222 are entirely umknown to me in nature; the majority of them I feel assured will prove to be varieties of some of the older species.

The lately described Alcestis is a var. of Aphrodite; Mr. Edwds. informed me that the larva is different; in my estimation the difference in the appearance of the larva amounts to very little; for if the perfect insect varies fron the normal form, why may not then the larva likewise vary? In fact, I doubt if there can be much variation in the imago mnless it existed in the earlier stages. Too much stress by far is laid on the cireumstance of whether the latra differs or not from that of the ordinary form. If this were so conclusive, why is it then that the green and brown larve of Cer. Imperinlis, both bring precisely the same form of moth, or the tawny and green larva of Thyreus Abbotii, prodnce the same results? No; if we have a varietal form or subsuecies in the last stage of the inseet we must just as reasonably expect to find it in the earlier stages. Is the Albino offspring of negro parents black when a child or with black or brown eves? Certainly not; as an infant it has the same abnormal white cutiele to its body and the same fiery iris to the eye as when it becomes an adult. Again, would the child born with six toes or fingers on each foot or hand have but five to each extremity on attaining maturity? 


\title{
GENUS 5. MELITAA, FABR.
}

\author{
( Phyciodes, Ilïl. ) \\ \{ Liesia, Brll. \}
}

223. Hermas, Hew., (Eresir II.), Ex. Butt., III, Eres., t. Las Angeles, 5, f. 32, (1864); (Phyciodes II.) Kirby, Cat., p. Califi., ; 174, (1871); Soul., But1: Bull., II, p. 268, (1875). Mexicu. †Eresia Genigueh, Reak., Proc. Ent. Soc., Phil., V, p. $225,(1865)$.

The fignre of (under side) Hermas agrees with the original type of Genigueh, Reak., in every respect except that the pround colour of the former hats a little more of a reddish tinge, not so muteh of an ochres.

224. Texana, W. H. Eowns., Proc. Ent. Soe., Phil., II, p. Texas, Lon81, (1863); (Ercsia 7.) Roak., I. r., V, p. 226, iwiani, Flor(1865); (Ihyc. T.) Kirloy, Cit., p. 17t, (1871); ida, Mexiro. (Anthenetsos T.) Scoul., Buff: Bull., I I, p. 26s, (1875). Eresia Cincta, W. II. Etherds., Proc. Ent. Sox., Plhil., II, p. 502, (1864); (I'hye. (') Kirby, Cilt., p. 177, (1871).

Eresia Smerdis, Hew., Ex. Butt., III, Eres., t. 5, t: 33, 34, (1864); Reak., Proce. Ent. Sore, P'hil., II, 1. $226,(1865)$.

†*225. I’unctata, W. H. Enwns, (Eresic P.), Trans. An. Arizona, Ent. Soc., III, p. 191, (1870); (Pliyc. P.) Kirby, New Mexien Cat., p. 647, (1\$71); (Anthenassa P.) Scurl., Buit?. Bull., If, 1. 268, (1875).

226. Frisia, Poer, Cent. Lep. Cular, p. 9, t. 2, (1832); Jlorida (Melithere F.) ('alt., Met., ete., Mem. Soc. Eeon. Keys; Cuha. Hab., 2 Ser. II I, 125, (1846); (Melitece H.) La Sitg., Hist. Cul. Anim. Art., p. 535, (1857); (Eresia F.) H-S., Schmett. Cula Reg. Corr.-Blatt, 1) 162, (1864); Reak., P'roe. Ent. Soe., Phil., II, 1. 226, (1865); (Phyc. F.) Kirhy, Cat., p. 173, (1871); Sond., Butt: Bull., I1, p. 267, (1875).

Eiresia Gyges, Hew., Ex. Butt., III, Eres., t. 6, f. 45, $46,(1864)$.

227. Pieta, W. H. Enwdos, Proe. Ent. Soc, Phil., IV, p. Colorado, 201, (1865); (Eresin I’.) Reak., Proc. Ent. Sor., Neluraska, Phil., V I, p. 141, (1866); (Mel. P.) Kirby, Cat., p. Arizona, 171, (1871); Streck., Ieep., Rhop.-Het., p. 65, t. 8, Mexico. f. 10, (1873); (Pllyc. I’.) Sond., Buff. Bull., I I, p. $267,(1875)$.

†*228. Canace, W. H. Edwds, (Phyc. (!), Trans. Am. Eut. Southern Soc., III, p. 206, (1871); Scull., Buff. Bull., II, p. California. 267, (1875); Nead, Wheeler's Rep., V, p. 764, (1875).

This is only known to me through Mr. Edwds.' deseription, which, however, seems equally applicuble to M. I'ictu, but whether it be identieal with that species I an of course at present unable to determine; or again, it may he only another of the endlesis variations of $M$. I'ratensis. 
229. Phand, W. H. Emwos, Proc. Ent. Soc., Phil., II, p. Ga., Fla. and $505,(1864)$; Kirlsy, Cat., 1). 171, (1871); (1'hyc. P.) Gulf States Scurl., Bufl. Bull., J I, 1). 268, (1875).

230. Vrist, W. H. Ebwds, Trans. Am. Ent. Soc, II, p. 371, Texas. (1869); Kirby, Cat., p. 171, (1871); (Phyc.V.) Scud., Buff: Bull., II, p. 266, (1875).

2:31. Thakos, Dru., (P(p). T.), Ill. Ex. Ent., I, p. 43, t. 21, f. S. Labrador; 5, 6, $(1770)$; Cram., Pap. Ex., II, t. 169, E, F, Canada ; (1779); Hhit., IX, t. 260, 4, 5, (1798); (Eres. T.) United States Stepli.., Ill. Brit Ent. Haust., I, 150, (1828); (Mel. east of Rocky T.) Bdl.-Leer, Lep. Am. Sept., p. 170, t. 47, (1833); Mts.

Morris, Srn., 1. 51, (1862); (Eies. T.) Reak., Proc. Ent. Sox., Plnil., Vl, 1. 142, (1866); (Phyc. T.) Kirby, Cat., p. 172, (1871); Scud., Buff: Bull., II, p. $267,(1875)$; Mcatl, (an1. Eint, V I1, J. 161, (1875). P'ap. Horpheus, Fabr', Sist. Fut., p. 530, 11.370, $(1775)$; IIordst, Natursyt. lns. Sdmett., IX, 1). 20) 1 , t. 2650, f. 1, 2. (1798).

Ary. Morphea, Godt., Enc. Meth., IX, p. 289, (1819). P'ap. Cocyta, ('ram., Pap. Ex., II, t. 101, A, B, (1779); Bill., Lep. Cal., p. 5.3, (1869).

Pap. Euclea, Bergs., Nom. u. Besch. Ins., IV, p. 23,

t. $79,(1780)$; IHLt, X, t. 27t, 9, 10, (1800).

Arg. Tharosse, Godt., Enc. Mcth, IX, p. 289, (1819).

Mel. Selenix, Kirby, Fann. An. Borl., IV, 1. 289, (18:37).

Mel. I'haros, Emmons, Agr. Nat. Ilist. N. Y., V, p. 212 , t. 43, (1854); Hamris, Ins. Inj. V'eg., Flint's Ei., 1. 28\%, f. $116,117,(1862)$.

Eresia Gorgone, II-S., Ind. Srrt., Reg. Corr.-Blatt, 1. $104,(18655)$.

f. 30 al, $30 \mathrm{~h},(1779)$.

rar. a. Marua, W. H. Edwds., Tialls. Am. Eint. Sor., II, p. 207, (1868); (Ihyyc. M.) Kirly, Cat., p. 172, $(1871)$.

P'ap. Cocyta, Crem., I’ap. Ex., II, t. 101, f. C, (1779).

Whole under surface of secondaries mottled and shaded with brown and grey.

ah. b. P'Ackarbit, Sauxd., P'ack. Guide, p. 256, (1869); Ontario, (I'hyc. P.) Kirhy, Catt., 1. 172, (1871); Scud., Buff: Can. liull., II, P. $2688,(1875)$.

latrvit on Actinomeris Melianthnides.

The dark colour predominating and the normal style of ornamentation alnusst entirely changed.

In IInbner's Sam. Ex. Schmett., I, on first page in the index is citerl "Dryades A. Reticulatix, al. Liriope, b. (iorgone," on the plate of "Dryades A. reliculate :I.," which is the fortieth in the vol., though nome are numbered, are four good figures of Liriope, designated by that name (Dryades reticulata Liriope). 1)r. Ilerr.-Sichaef., in his Ind. Syst., p. 104, Reg. Corr.libalt, (186.5), quotes this by the index name (Gorgone) as a synonym of Tharos, which is curions, its said Gorgone of index-Liriope of plite - is a quite distinet $\mathrm{s}$. Ameriean spe- 
cies, bearing no resemblance to Tharos in particular; on the same page he cites, under its name Liriope, Cramer's f. C, D, t. 1, (Vol. I), as a separate species from Hubner's, above quoted, when it is apjarent that both authors represented the same insect and also denoted it by the same name, Liriope. Hubner's figures are, as usual, good, and Cramer's are recognizable, and both are so good that any one at all acpuainted with the common tropical species Liriope could immediately idenlify it from either. Mr. Scudder cites two of the figures of Huluner's plate $($ Nos. 1, 2) as representing Ismeria, (Carlota, Reak.), from which they are even farther removel than from Tharos, and the other two (Nos. 3, 4) he regards as distinet and retains for them Hubner's index name of Gorgone.

232. Batestr, Rfak., (Eresia B.), Proc. Fint. Sor., Plil., V, p. Mid'le States $226,(1865) ;($ Phyc. B.) Kirly, Cat., p. 172,(1871); Scudl., Buff. Bull., II, p. 268, (1875).

Ohio, Mil., $\mathrm{V}$ a.

233. J'ratensis, Behr, Pror. Cal. Acad. Nat. Sre, IJ I, p. 86, (186i:); (I'hyc. P.) Kirby, Cat., p. 173, (1871); Scucl., Buff. Bull., II, p. 267 , (1875).

f Mel. Campestris, Behr, Proc. Cal. Acad. Nat. Se., III, p. $86,(1863)$; (Eresice (:) Reak., Proc. Ent. Soc., Phil., I'I, l. 142, (1866); (Phyc. C.) Kirlyy, Cat., 1. 173, (1871).

Mrt. Pulchellu, Brll., Am. Soc. Fnt. Fr., 2me Ser. X, p. 306, (1852); (Phyc. P.) Scurl., Buff. Bull., II, p. $266,(1875)$.

var. a. Palmon, W. H. Enwos., Proc. Ent. Soe., Phil., Colorado, II, p. 505, (1864); (Eresia P.) Reak., Proc. Ent. 'Texas, KanSoc., Phil., VI, r. 142, (1866); (Phyc. P.) Kirby, sas, Utah. Cat., p. 174, (1871); Sond., Buff. Bull., II, p. 267, (1875); Mead, Whecler's Rep., V, p. 763, (1875).

o' Phyce Camilhe, W. H. Eduds., Trans. Am. Ent. Soc., III, p. 268, (1871); Mead, Wheeler's Rep., V, W. $764,(1875)$.

ot 9 Phye. Emissu, IV. H. Edurds., 1. c., p. 269, (1871).

Mesial band broader and in conmon with the marginal lunules, above and below, on all wings pale yellow or whitish, more especially so in the $f$. secondaries beneath pale.

fab. b. क Mata, Reak., (Eresia M.), Proc. Ent. Soc., Colorado.

Phil., II, I. 142, (1866); (Phyc. M.) Kirbs, Cat., ю. 177, (1871); (.Mel. M.) Streck., Lep., Rhop.Het., p. 65, t. VIII, t. 11, (1874); (Phyc. M.) Mead, Whecler's Rep., V, p. $763,(1875)$.

$\Lambda$ white or Albinons aberration of the var. Pallida. Analogons examples sometimes occur of the European M. Cinxia in which the fulvons is entirely replaced on both surfaces by rellowish white.

var. c. Orsers, W. H. Enwps., Trans. Am. Ent. Soe, Sierra YeIII, p. 206, (1s71); (Phyc. O.) Send., Buff. Bull., varla, CaliII, P. $267,(1875)$.

[pper surface very heavily suffused with blackish ; reticulalions of under surface more sharply rlefined than is generally the case with Pralensis.

234. Montana, Behr, Proc. Cal. Arad. Nal. Se., III, p. 85, (1863); (Hhyc. M.) Kirby, Cat., p. 173, (1871). fornia; : Or-

Sierra Nevada, California. egron. 
Mel. Orsa, Bdl., I.ep. Cal., p. 55, (1869); (Phyc. O.) Kirby, Cat., p. 173, (1871).

Phyc. Pratensis, Scud., (nec Behr), Butr. Bull.,. I I, p. $267,(1875)$.

235. Mrgitta, W. H. Eowos., Proe. Acad. Nat. Sc., Phil., California; p. 160, (1861); Proc. Ent. Soc., Phil., II, p. 504,? Mexico. (1864); Morris, Syn., p. 324,(1862); (Eresia 1I.) Reak., Proe. Ent. Soc., Phil., VI, 1). 142, (1866); (Phyc. M.) Kirby, Cit., p. 173, (1871); Hy. Edwrl.., Proe. Cal. Acad. Nat. Sic., V', I alr., (1873); Mead, Wheeler's Rep., V, p. 764, (1875).

Mel. Collina, Behr, Proc. Cal. Arad. Nat. Sc., III, p. $86,(1863)$.

Mel. Callina, Bdl., I.ep. Cal., 1. 54, (1869); (Phyc.

(.) Scurl., Buff: Bull., II, 1). 267, (1875).

Mel. Epula, Bdl., I Lej. (al., J. 54, (1869).

Pliyc. Pulchella, Scud., (nec Boll.), Buft. Bull., II, p. $266,(1875)$.

Inarva on various speeies of thistle (c'arduus).

236. Nyoters, 1)broy.-Hew., Gen. Diur. Lep., p. 181, t. 22, ('anarla, New f. 3, (1846-1850); Chenn, Pap. Dinr. f. 20), Lum. States; (1851-1852); Morris, Syn., p. 325, (1862); (Eres. New York, I.) Reak., I'roc. Ent. Sor., Pliil., VI, p. 141,(1866); I'enn'a, Vir(Jhyc. N.) Kirby, Cat., ). 173, (1871); (chari- winia, thenew dryes N.) Seurl., Syst. Rev. Am. Butt., p. 26, (1872); westwand tu (iVel. N.) I int., 23d Rep. N. Y. State Cal). Nat. the Rorlky Ilist., J. 158, Lar., (1872); (Phyc. N.) W. H. Monntaino : Edwrls., Can. Ent., V, 1. 224, (1873); Riles, Pros. Colorata ; Am. Ass. Adv. So., p. 108, (1874); (Charidryas N.) Texat. Sirud., Buff. Bull., II, p. 266, (1875); (Phyc. N.) Mead, Wheeler's Rep., V, p. 762, (1875).

Mel. Oenone, Scud., J'roc. Essex Ins., III, 1. 166, $(1862)$.

Mel. Nyctis, Bdl., Isep. Cal., p. 53, (1869).

IIcl. Harrisii, W. H. Edwds., Can. Ent., II, p. 163, (1870); Saund., 1. c., IV, 1. 161, (1872).

Lal'va on Helianthus Divaricatus (-m11-flower), Actinomeris Helianthoides, A. Squarrosa.

237. Ismeria, Bdu.-Lec., Lep. Am. Sept., p. 168, t. 46, (18:33); From Vir(Mel. I.) Dbldy., Gen. Diur. Lep., I, \%. 181, 11. 22, ginia moutl(1846-1850); Morris, Syn., p. 50, (1862); (Phye. I.) wirl to the K'irby, Cat., p. 174, (1871); Send., Can. Fut., IV, Gultof Mex. p. 85, (1872); (Charidryas I.) Buff: Bull., II, and wostp. $266,(1875)$. warel to the

Mel. Nyctris, W. H. Edwols., Proc. Acarl. Nit. Sc., Rock! Mts. P'hil., p. 161, (1861).

Evesia Carlota, Reak., Proc. Ent. Soc., Phil., VI, p. 141, (1866); (Phyc. C.) Kirby, Cat., p. 173, (1871); Mead, Itheeler's Rep., V, p. 762, (1875). Larva on Helianthus Trachelifolius. 
'There has been some uncertainty as to what Bdl.-Lec.'s figures really represent. These $\mathrm{Mr}$. Scudder ascertained were copied from Abbot's unpublished drawings, and poorly enough copied at that. No one will dispute that they are caricatures, but nevertheless there can no longer be any doubt that they were intended to illustrate this species.

238. Harrisu, Ścud., Proc. Essex, Ins., III, p. 167, (1862); Canada, Pack., Guide, p. 257,:(1869); (Plyc. H.) Kirby, New Eng. Cat., p. 174, (1871); (Limncecia H.) Scud., Syst. States, New Rev. Am. Butt., p. 27, (1872); (Cinclidia H.) Buff. York. Bull., II, p. 266, (1875).

Mel. Ismeria, Harris, (nec Bdl.-Lec.), Ins. Inj. I'eg., Flint's Ed., p. 288, (1862).

I surva on Diplopappus l mbellatus.

The figure (187 on p. 258) in Packarl's Guide, murporting to be the larva of this insect, does not represent the larva of any species of diurnal Lepidoptera.

Messis. W. H. Elwds, and LScudder both cite the Ismeria of Harris (p. 288, Ins. Inj. ; Veg.) as a synonym of Nycteis, bhldy. Botl anthors" are in the wrong. First, Harris' description plainly and unmistakably applies to the specie snbserpuently deceribed by Scudder as Harrisii, and not at all to Nycteis. Dr. Harris remarks, after his deseription, "the only specimen which I have seen was sent to me by Dr. D. S. C. H. Snith of Sutton." I liave seen this specimen, which is still in the Harris collection" (now in the keeping of the Boston Mus. Nat. Hist.). It is a specimen of Harrisii, Scucl., and is. No. 514 in the collection. On referring to Dr. Har'is' MSs. catalogue, which is with the collection, I formol No.514 to be "Melitac, Sutton, Dr. Smith."

2:39. Minuta, W. H. Edwds., Proc. Acad. Nat. So., Phil., p. Texas, Col161, (1861); Morris, Syn., p. 325, (1862); Kirby, orado, New (at., p. 171, (1871); Mead, Wheeler's Rep., V, j. Muxico.

761, t. 36, (1875); (Schoenis M.) Soud., Buff. Bull., II, 1. $265,(1875)$.

Mel. Arachne, W. H. Edwds., Trans. Am. Ent. Soc., II, I). 372, (1869); Kirloy, Cat., p. 171, (1871); Mead, Wheeler's Rep., V, p. 760,(1875); (Schoenis A.) Soud., Buff.' Bull., II, p. 265, (1875).

240. Palla, Bdi., Amm. Soc. Ent. Fr., 2 me Ser. X, p. 305, California. (1852); Morris, Syn., p. 52, (1862); Behr, Proc. Cal. Acad. Nat." Sc., III, p. 88, (1863); Reak., l'roc, Ent. Soc., Phil., VI, p. 139, (1 866); Kirby, Cat., p. 170, (1871); Hy. Edwds., Proe. Cal. Acad. Nat. Sc., V, p. 167, Lar., (1873); Mead, Wlieeler's liep, V, p. 759, (1875); (Lemonics P.) Scurt., Buff: Bull., II, p. 264, (1875).

I alrva on ('astelejia Brevifiora.

var. a. Helcita, Bul., Lep. (al., p. 55, (1869); (Lemonias $H$.) Sutud., Buff: Bull., II, p. 264, (1875).

var. b. Ga Bвir, Benr, Proc. Cal. Acad. Nat. Sc., III, Southern p. 89, (1863); Kirby, Cat., p. 171, (1871); (Lemo- California. niess G.) S.ond., Buffi. Bull., II, p. 264, (1875).

Mel. Sonorce, Bell., Lep. Cal., p. 56, (1869).

subnarginal lumules, and sometimes mesial band of under side of recondaries, silver or silvery white. 
var. c. Hofmanni, Benr, Proe. Cal. Acad. Nat. Se, California, III, p. 89, (1863); Reak., Proc. Ent. Soc., Phil., Colorado, VI, p. 140, (1866); Kirby, Cat., p. 171, (1871); Nevarla.

Mead, Wheeler's Rep., V, p. 760, (1875); (Lemonias H.) scud., Buff. Bull., II, p. 264, (1875).

'The black lines on onter half of uppersurface of primaries partially obsolete, the red ground colour prevailing. On under side of secondaries the small ocelli in the space between the marginal lunules and mesial band is wanting.

?var. d. Whitreyi, Bemr, Proc. Cal. Acald. Nat. Sc., MountainIII, p. 88, (186:3); Kirby, Cat., p. 170, (1871); ous regions (Lemomias WV.) Scud., Buff: Bull., II, p. 265, (1875). of Colorado, Yaler on both surfaces, black lines less diffuse; the small round Nevada and spots on space between marginal lunules and mesial hand of Califormial. under side of secondaries obsolete or nearly so.

†*240 a. Pola, Bin., lep. Cal., p. 56, 1. 44, (1869); Kiplsy, Ṡ.Califormia. Ciat., p. 171, (1871); (Lemonies P.) Send., Buff. BulI., II, J. 265, (1875).

Not known to be in any $\mathrm{N}$. An. collection, and doubless is one or the other of the above cited forms of Pralla.

†*241. Acastus, W. H. Enwds, Trans. Ant. Ent. Soc., V, p. 16, (1874); (Lemonius A.) Seud., Buff: Bull., II, p. $265,(1875)$.

Montalla, Nividia, Utal.

I am entirely unacruainted with this insect in nature, but from the description I should surely suppose it to be identical with M. Whitneyi.

†*242. Sterope, II. H. Enwos., Trans. Am. Ent. Soc. III, Oregon.

p. 190, (1870); Kirly, Cat., p. 647, (1871); (Lemonias S.) Serud., Butf: Bull., II, p. 265, (1875).

This is also unknown to me, but from the Jescription it seems imposible that it can be anything else than the black oform of M. Pulla.

243. (Quno, Benk, Proc: Cal. Acald. Nat. Sto, III, p. 90, Californiat. (1863) ; Kirby, ('at., p. 164, (1871); (Lemonias (?.)

seud., Buff: Bull., 11, p. 2064, (1875).

244. Axiria, J)blwr.-Hew., (ien. Diur. Lep., p. 179, t. 2:3, Mts. of Cal-

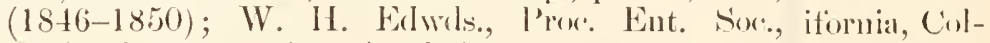
Phil., I, p. 22:3, (1862); Betr, P'rex. Cal. Acad. mado, NeNat. Sc., I11, p. 91, (186i3) ; Reak., Proc. Ent. Soc., varlat.

Phil., VI, p. 140, (1866); Kirlsr, (at., 1. 164, (1871); Mead, Wheeler's Rep., V, p. 758, (1875); (Lemonias A.) Srud., Butl. Bull., II, p. 264, (1875). vall. a. Nibiciexa, Behr, P’rox. Call. Aral. Nat. Sic., III, P. 91, (1863); Kirby, Cat., P. 161, (187I); Mead, Wheeler's Rep., I, 1.758, (1875).

An $\mathrm{Al}_{\text {pine }}$ variety presenting no very consid rable differences from the stem form.

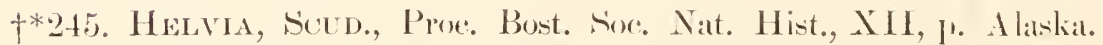
405, (1869); Kirby, Cat., p. 164, (1871); (Lemonias H.) Scud., Buft: Bull., I1, 1. 264, (1875).

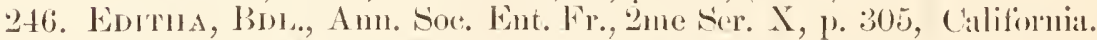
(1852); Morris, Syn., p. 51, (1862); Hy. Eilwds., P'oc. Cal. Acad. Nat. Sc., V, P. 167, Isar., (1873). 
Mel. Anicia var. Editha, Kirby, Cat., p. 16t, (1871).

Lemonias Anicia, scul., Buft. Bull., II, p. 264, (1875).

Larva on "Erodinm Cicutarium, various speriess of"

Trifolium and Viola." Hy. Elwets.

247. Coopert, Benr, Proc. Cal. Arad. Nat. Sc., III, p. 90, California.

(1s63); Kirbs, (at., J. 164, (1871); (Lemonias (':)

S'rud., Butt. Bंull., 1I, p. 264, (1875).

Larva on Scrophularia.

248. Chalcedoxa, Dibdx.-Hew., Gen. 1)im. Lep., I, 1. 180, (álifornia,

t. 23, (1847); Reak., Proc. Ent. Soc., Phil., VI, p. ()regon.

140, (1866); Kirby, Cat., p. 164, (1871); (Lenonias (:) Scud., Buti: Bull., II, p. 264, (1875).

Mcl. Chalcedon, W. H. Eduds., Proe. Ent. Soc., Plit.,

1, p. 22.2, (186:); Butt. N. Am., I, t. I, MЩ.,

(1.871); Bebr, Proc. Cal. Acarl. Nat. Sc., I1I, p. 89,

(1863); Mearl, Wheeler's Rep., V, p. 757, (1875).

Iarva on "Scrophularia Marylandica, Diplacus

Glutinosus, Mimulus Lutens, Lonicera and varjonspeeies of ('astelejia." Hy. Edwds.

249. Pheton, Dru., ('ap. P.), Ill. Ex. Ent., I, t. 21, (1767); Camada;

Fabr., Syst. Ent., 1. 481, (1775); Eut. Syst., III, New Eng.

p. 46, (1793); C'ram., Pap. Ex., 111, t. 198, C, 1), and Middle

(1782) ; Herbst, Natursyt. Ins. Schunctt., VI, J. States and

111 , t. 142, (1793); (1/el. P.) Bell.-Lece, p. 167, t. others of the

47, (183:3); Bdl., Sl). (ien., t. 11, (1836); Enmm., more morth-

Agr. N. Y., V, p. 212, t. 43, (1854); Morris, Syn., ern states

1. $50,(1862)$; Harris, Ins. Inj. Veg., Flint's Ed., east of the

p. 288 , t. $115,(1862)$; Kirby, Cat., 1). 164, (1871); Rorky Mts.

IV. H. Elwds., Butt. N. Am., II, t. 1, Mel., (1875);

(Euphydryes I’.) Sind., Syst. Rev. An. Butt., p. 27,

(1872); Buff: Bull., II, j. 263, (1875).

Mel. Pluctaenr, Häl., Y' (1\%. Bek. Solnmett., p. 28,(1816).

Arg. Phatontea, Gorlt., Hin. Math., IX, p. 28s, (1819).

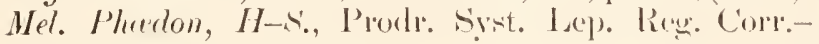

Blatt, 1). 105, (186.5).

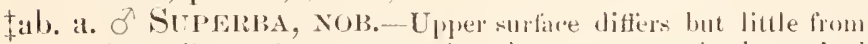

the ordinary form, except lhat the two rows of sllmarginal while spolis of secondaries are contluent, furming but one row of werlge-shaped marks with the points towards the baste. inderneath the wholes spare, comprising the greater part of the wing, between the ferruginums hatwal patches and narrow margin of same eoforr, is pure white, wilh the venalion biack. Taken by Mr. (ieo. 1). Hulst on Long Islauml, N. Y., in 1875. Mus. Sireek.

Larvia en Chelone Gilabiet, Lonicera Ciliala.

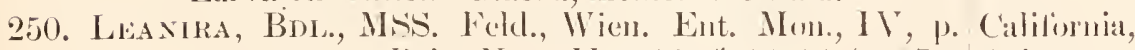
106, (1860); Reice Nor., II, t. 50, 1: 1:3, 14,(1867); Arizunit.

Behr, Proc. Cal. A(aul. Nitt. Sc., III, p. 9)1,(1863:); Bdl., Lep. Cal., p. 57, (1869); Kirby, Cat., 1'. 171, (1871); Mead, Wheeler's Rep., V, ]. 759, t. :37, (1875); ('Thessalie L.) Seud., Butl: Bull., II, p. $265,(1875)$.

var. a. Obliterata, Hy. Eumins, Proe. (ál. Acad. California. Nat. Sc., VI, (1876). 
Under surface of primaries without the abbreviated apieal black submarginal band. Inder side of secondaries uniform whitish yellow, destitute of all the black marks and bands of normal form.

Ialrva on Cordylanthus Pilosus.

251. 'Theoxa, Men., En. An. Mus. Petr. Ieep., I, p. 86, t. S.California; 2, (1855); (Phyc. T.) Kirby, Cat., 1) 17:3, (1871); S. W. Texals; ('Thessalia T.) Send., Buff. Bull., II, p. 265, (1875). Cent. Am. +*252. Theкla, W. H. Enwds., Trans. Am. Ent. Sor., III, S. Califomia, p. 191, (1870); (Thessulia T.) Si.ud., Buff. Bull., Arizuna. II, 1. $265,(1875)$.

The first lifteen species constitute a group unknown to the old world fama, but abounding in tropical America where many of the forms are most remarkable, wonderfully comnterfeiting in alpearance the varions Acreide and Heliconide, with which they associate. Various anthors have placed them in IInbuser's genus Phyciodes, equivalent to Bdl.'s Eresia, but I think the grounds are too insufficient to entitle them to any lighler position than that of a group.

M. Ilarrisii form a very natural transition from this to the Athalia group here represented by Palla and varieties. $M$. Whitneyi has an amazing resemblance to the S. Eur. Dejone, 11-(i. Minuta is exceedingly close to the Russian Arduinna, Esp., v. Atherie, Hub., and allied species.

Anicin, Quino aud Chalcedona are near to Maturna, L., Artemis, llub., etc.

Leunira and allies have no old world representative, though in appearance, especially of under surface, M. Iduna, Ditm., bears a close resemblance indeed in the disposition of the markings.

The group of Tharos, etc., is represented most abundantly east of the Rocky Mts., whilst of the group of Anicia ant Chal. cedona we have only the one enstern representative, Thoton.

1. Eurytion and M. Calydon, mentioned by Mr. Mead on [r]. 759, 760 of Wheeler's Rep., V, (1875), were from MSS. of W. II. Edwds., lut the description has never been published. Lurytion-Nubigena, and Calylon = some one of the forms of Pilla.

\section{GFNes. STNCHLOE, Bus.}

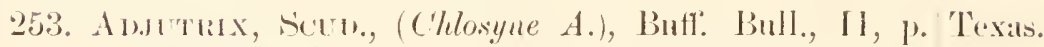
$269,(1875)$.

Syn. Lacinia, W. H. Eiluods., (nec Hül.), Butt. I. Al1., 1, Sir1., p. 18, (157\%).

254. Menhatrix, Fend), Reise Non., II, 1. 395, n. 584, Texis, Bu(1867); (Coatlantona M.) Kirby, ('at., J. 178, goti.

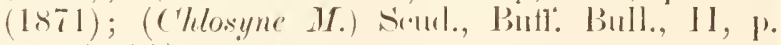
$269,(1875)$.

Syn. Saundersii, W. H. Eduds., (ne: 1)hly.), Butt. N.

Am., I, Syr1., 1. 18, (1872).

lietween Saundersii, Dbldy., and Lacinia, heyer.

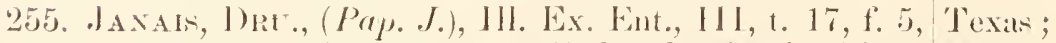

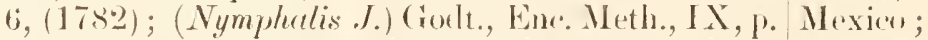

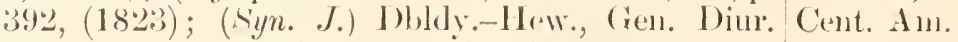
Lep., I, P. 186, (1846-1850); (Coullantona J.) Kirlsy, Calt., p. 178, (1871); (Chlosyne J.) Scoul., But1: Bull., II, p. 269, (1875). 
256. Fronyte, Bol., Bater, Ent. Mom. Mang., I, p. 84, (1864); Trxas; (ent. Dbldy-Hew., (ren. I)im. Iep., 1) 186, (1846- Amerim; 1850); (Contlentone E.) Kirby, (at., 1. 178, (1871); ? Mexiro.

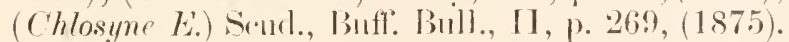

257. ('rocate, IF. H. Fowis., Trans. Am. Ent. Soc., V, p. Arizona.

17, (1874); Meate, Wheclex's liep., Y, p. .765, t. :37, (1875); (C'hlosyne C.) Send., Buff. Bull., Il, P. $269,(1875)$.

\section{GENUS 7. FURENA, UBLDI.}

258. I, etruf, Fabr., (I'up. L.), Fint. Syst., II I, 1, p. 80, (1793); 'Texas; MexInon., Ins. Ind., 1. 2:), (1800); (Trenesse L.) Godt., ion ; ('int. Enc. Meth., IX, Sul)., p. S18, (182:); (Eur. L.) Am., Brazil,

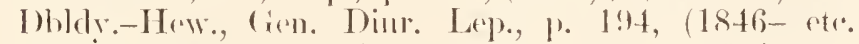
$1850)^{\circ}$; (Iypanartia. L.) Kirhy, Cat., p. 180, (1871); Sirurl., Butt: Bull., 11, p. 20̃)1, (1875).

Myp. Jemonicen, Hïb., Sam. Ex. Schmett., I I, f. 1, 2, (1806-1827); fign. 3, 4 on sane plate represent kabulina, Gorlt.

\section{GENTS R. VANESSA, FABR.}

\section{(Grapta, Kirlyy, Faun. Am. Bor.)}

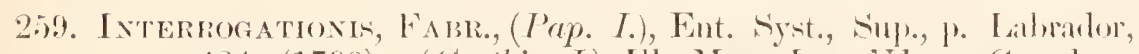
124, (1798); (cynthice I.) IHI. Mag. Ins., V1, p). Camada, 281, (1807); (Tomesser I.) Godt., Enr. Meth., IX, I niterlstater Suppl., p. s1!), (182:); Halris, Hiteh. Rep. (xeo. ratst of the Min., etc., Mass., Wel. 1, 1.590, (18:33); (Frapta I.) Rocky Mts.

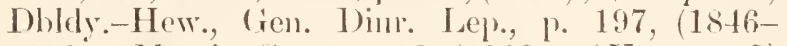
1850); Morris, Syn., 1. 53, (1862); (Vunessa I.) Harris, Ins. Inj. I'w., Flint's Ed., p. 29s, f. 124, (1862); Pack., (Guide, p. 259, (1869); (Crapta I.) lint., Trans. Am. Ent. Soc., II, p. $317,(1869)$; 1. «., III, \%.197, $(1870)$; IV. H. Edwds., Butt. N. Inl., I, t. I, Ciriptal, (1871); (Tanessa l.) Kirloy, (at., p. 181, (1871); (Polygonire I.) Seurl., Syit. Rev. Am. Butt., 10, (1872); Butf. Bull., II, I. $251,(1875)$.

Grapta Fabricii, W. H. Edurds, Trans. An. Ent. Sioc., III, P. 5, (1870); I int., l. c., p. 1!7, (1870); (Van. H.) Kirby, Cat., 1. 181, (18-1).

Grapta Interrogationis var. Fabricii, it. II. Eduds., Butt. N. Im., I, t. V, (imipta, (1871).

var. a. Imbrosa, List., (Crepte l.), Trans. Am. Ent. Soc., II, p. 31:), (186!) ; W. H. Edwels., Butt. X. Im., I, t. 4, Graptal, (1871); (Ian. L.) Kirby, Cat., p. 648, (1871); (Polygonia U.) Scurl., Buff: Bull., II, p. 251, (1875).

Pap. (' Aureum, ('ram., P'Il). Ex., I, t. 19, E, F, (1779); Herbst, Natursyst. Ins. Schmett., YII, t. 
162, f. 1, 2, (1794); \b.-Sm., Ins. (Ka., I, 1. 22, t. 11, (1797); (Polygonia C A.) Hüb., Sam. Ex. Schmett., II, (1806-1824); Verz. Bek. Srhmett., p. 36, (1816); (Van. ('A.) Bill.-Lee., Iep. Am. Seput., p. 192, t. 51, (1833).

Van. Internogutionis, Godt., Ene. Meth, IX, p. 301, (1819); Fmtn., Igr. Nat. IIist. N. Tork, p. 207, t. $: 35,(1854)$.

Gropte ('romeri, seud., Proc. Bost. Sox. Nat. Hist., XIII, 1. 276, (1871); (Nymphalis C.) Kirby, Cat., 1. 648, (1871).

Upper surface of inferiors liluish black.

Larva on nettle, hopss, elut.

There has been any amount of confusion in regarl to this speries, all evidently laving its origin in the fact of Fabricius' apparent non-itequaintance with the true $C$ A tureum of tinn. (Angrlica, Cram.), Linn.'s diagnosis of the latter speeies in sym. Nat, is "C auremu, 169, I", N, alis angulatis fulvis nigro-natulatis: postieis subtus $\mathrm{C}$ anreo notatis.

Habitat in Asit.

Simillimus $P$. Calbo, sed duplo major, subtus magis luten nebulosis Cuureo minori notutis."

This is ulain enough; neither Interrogationis nor var. Umbrose are elondy yellow heneath, but $C$ Aureum most undoubtedly is.

Fahricins in Syst. Ent., p. 506, cites $C$ Awreum as the Asiatic spercies from Liun., Syst. Nat., p. 778, Ed. 12.

In the Sp. Ins., II, p. 94, he again gives it as I.inn.'s Asiatie specier from Syst. Nat., p. 778 , (Angelica, Cran., t. 388, Vol.

- IV), and (ites as a synonym (ramer's other figure (C Aureum, Cram., t. 19, Vol. 1), which represents the var. of the N. Anı. Interrogationis, now known as Umbrosa.

In Mant. Ins., II, p. 50, he again quotes from the syst. Nat. linn.'s deseription of the Asiatie species, snlustituting, however, the words "alis dentate candatis" for "alis angulatis."

In Ent. Syst., III, 1, 1. 78, he 'protes Linn. altered in the same way, and refers again to Cramer's N. Am. CAtureum (t. 19, Vol. 1) as a synonym.

C'ramer in lis text to the figure of our N. Am. species (t. 19) also makes the same mistake and eites it as Linn.'s Asiatic speeies, i. e., "Linn., Syst. Nat., XUI, p. 778, n. 169 Pap. Nymph. phalerat. C anreum," whilst the real speeies described by Linn., in the foregoing, Cramer figured on his t. 388 as another species ander the name of Angelica.

Herlst in Vol. 7, t. 142, has ropied Cramer's figure of our $\mathrm{N}$. Am. sprecies, but in the text he quotes Linn.'s diagnosis of the Asiatic species as altered by Fabrieins in the Mant. Ins. and Ent. Syst. He also eites Fibricins' various works and Cramer's i. 19. Its fatherlanil he gives as Asia.

Abhot's upper figure (t. 11, Vol. I) C Auream is I'mbrosa withont donlt. The lower figure will do for either Linbrosa or Interrogationis equally as well, as it is equally as like and molike either.

Hulmer's fignres (II, Sam. Exot. Schmett.) are first-rate reprerentations of Trmbrosa.

Bdll.-Lec.'s figure 1 represents a form between Interrogationis and its var l'mbrosa, of which I have an example that is as near one als the other.

In Constable's Miss. Butt., III, t. I1, is figured the "American Commd buttertly, Papilio C anrenm. Virginia." It is evidently an atrocious figure of Faunus, or perhaps of Comma, "crtainly not Interrogationis. He cites "Ablot, 1. 11," but there is no resemblance to the latter ligure. 
260. Comma, Harris, Ins. Inj. Vege., Ed. 1, p. 221, (18+2), Canada, Flint's Ed., 1. 300, t. 4, (1862); (Grapta C.) British CoDhlıly.-Hew., Gen. Dinr. Lep., I, 197, (1846- lımbia, N.

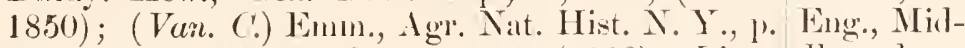
208, (1854); Morris, Svn., p. 54, (1862); Lint., dle and Proc. Ent. Soe., Phil., III, 1). 55, (1864); (crapte IVestern (?) Reak., Proc. Ent. Soc., Pliil., VI, 1. 148, (1860); States, cast W. H. Edwds., I. e., I, p. 182, (1862); Butt. N. of the Rouky Am., I, t. 2, Graptı, (1871); (Holygonic (:) Seurt., Mts.

Sist. Rev. Am. Butt., 10, (1872); Buff: Bull., JI, p. $251,(1875)$.

Van. C'Album, Bdl.-Lec., Lep. Ans. Sejut., p. 1!n, (1833); Fitch, N. Y. State Agr. Soc., p. 4:30, (185(5). Grapta Harisii, W. H. Edwds., Can. Ent., I, P. 181, (1873).

vall. a. DrYas, W. H. EDWus., Trams. Am. Ent. Sor., IIJ, P. 17, $(1870)$; Butt. X. An1., I, t. 8, Grapta, (1871); (Nymphulis D.) Kirly, Cat., 1. 64\%, (1S71); (Polygonia D.) Seul., liult. Bull., II, P. 251, (1875).

Upper surface inferiors blackish.

Iarvat on hops, elm, nettle.

261. C-Albur, LiNx., (P'ap. (.), Syst. Nat., EJ. X, 1) 477, Canada;

(1758), Ed. XII, I, 2, p. 778, (1867); Fann. Surc., British Cop. 279, (1761); Socop., Ent. Carn., p. 146, (1763); lmmbiatu the

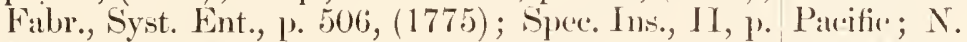
93, (1781); Mant. Ins., II, p. 50, (1787); Ent. Eng., Midlle Syst., III, 1, 1. 124, (1793); Esp., Silmett., I, 1, ant Atlantic t. 13, (1775), I, 2, t. 59, (: 1780); Bergs., Nour., t. States south 38, (1779); Brk., Nitur. Selunett., I, p. 15, 203, to the Caro(1788); Hïb., Eur. Solnuett., I, f. 92, 9:3, (179:3), linas, west to also in another vol. larval and pupa, but not num- the Rocky bered ; Herbst, Natursyst. Ins. Sclmmett., VII, p. Mts.; Hii50, t. 161, (1794); Wilh., Unterl. Natture. Ins., I1, rope, Silseria, p. 109, t. 13, (1797); Don., Brit. Ins., VI, J. 45, Ja!ra11.

t. 199, (1797); (1'ap. Nymph. C.) Schatef., Iron., I I, t. 147 ; vol., text, p. $140,(1804)$; (I'ap. (.) Ochis., Schmett., I, 1, 125, (1807); (Van. ( $)$ Cionlt., Enc. Meth., IX, p. 302, (1819); Hist. Nit. Lepiel., I, p. 85 , t. 5, f. 3, t. 5 tert. f. 1, (18:1); Steph., Ill. Brit. Ins. Halst., I, 1) 42, (1828); I3ll.-I Lex',

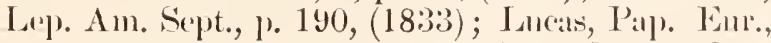
p. 60, t. 2, (1834); Dun., Nit. Libr. Ent., III, J. 160, t. 17, (1835); Humpl.-West., Brit. Butt., 1) 50, t. 13, (1841); (Tachypter (') Berge, Silnuct.buelı., p. 98, t. 44, t. 4a-4d, (1842); (Vun. (:) H-s., Solnmett. Eur., I, f. 159, 160, (1844); I)up., I (con. Ilist. Nat., 1, 1. 102, t. 11, Isall., (1849); (Crropla (.) Chenu, Pap. Diur., 1, t. 26, f. 5 d f. 206, p. 99, (1851-1853); Morris, Syl1., ए. 55, (1862); ( I'un. c.) Stgr., (at., 1) 16, (1871); Kirlsy, Calt., p. 182, (1S71). 
Pap. G album, Fourc., Ent. Paris., II, p. 235, (1785). I'an. Comma alba, Mill., Brit. Ent., t. I, (1821).

Grapta Faunus, Wr. H. Edwds., Proc. Acad. Nat. Sc., Phil., p. 222, (1862); Proc. Ent. Soc., Phil., I, p. 183, (1862); Butt. N. Am., I, t. 1, Grapta, (1869); (Tan. F.) Kirby, Cat., p. 182, (1871); (Grapta F.) Caulfield, Can. Ent., VII, ). 49, (1875); (Polygonia F.) Seud., Syst. Rev. Am. Butt, 10, (1872); Buff: Bull., I I, p. 252, (1875).

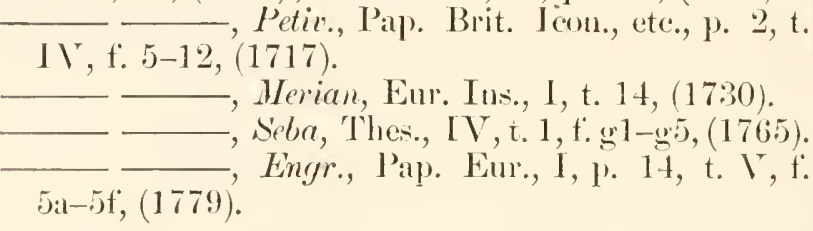

After continned and most carefinl examination of great numbers of $C$ Album from various parts of Europe, and also of the so-called species Fannus from the United States and Canada, as well as examples from the Amoor region and Japan, I cannot pronounce them distinct. The American examples are apparently less subject to variation than their European congenors, but there is no certain point of sufficient stability to emitle them to specific distinction.

The dark exterior border on upper surface of wings is generally deeper in colour and more inclined to blackish in the N. Am. examples, and the spots enclosed in that of secondaries are inclined to be smaller, but neither of these are constaut distinctions, as those of the European examples having the borders of onter margins darkest are precisely identical with those of the American examples in which said borders are lighter than the average.

The examples from Japan are notably like the average of those from Canada and $\mathrm{N}$. Tork, all having that same greenishblue tinge of under surface which is more peculiar to the latter.

My hope was that Faunus might prove constant enongh in depth of colour of outer margins of upper surface to allow its being cited as a form or variety of $C^{\prime}$ Album, bnt, as $\mathbf{I}$ before said, when the darker European examples are placed aside of the paler American ones, this ceases to be a distinetion at all, as we know not where $C$ Album ends or Faunus hegins. Besides, there are in Europe forms of ' $C^{\prime}$ Album that are yellow below, presenting far greater differences from the darker forms of the same than do the most aberrant of the latter from the $\mathbf{N}$. American examples; these yellow examples have analogues in some of the variations of Comma and Salymu, which on under side are vellow of varions shades from pale othre to dark orange tiwny. As to the before mentioned Japanese examples, they are almost fac-similes of those from America save that they are of average larger size thongh not larger than the largest of the latter.

Larva un willow (Salix Humilis).

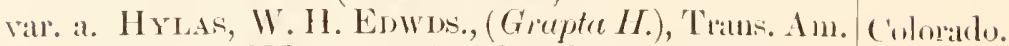
Eut. Soc., IV, p. 6s, (1872); Butt. N. An., II, t. I, (irapta, (1875); Mead, Wheeler's Rep., V, p. $768,(1875)$.

Polygonia Zephyrus, Sicud., Buff'. Bull., II, p. 25:, (1875).

Sunaler; otherwise differing little from the Eastem form 
†*261 a. Rusticus, W. H. Edwds., (Grapta R.), Trans. Am. California, Ent. Soc., V, p. 107, (1874).

I cannot, by the description, separate this from the preceding Island. species, with which it is probahly identical.

262. Satryus, W. H. Enwds., (Grapta S.), Trans. Am. Colorado, Eut. Soc., II, p. 374, (1869); Butt. N. Am., I, t. Califoruia, 6, Grapta, (1872); Hy. Edwds., Proc. Cal. Acad. ()regon, Nat. Sc., V, p. 168, Lar., (1873); Pearson, Can. Brit. Col., Ent., VII, 1. 216, (1875); Mearl, Wheeler's Rep., Canadla. V, p. 767, (1875); (Nym. S.) Kirby, Cat., p. 648, (1871); (Polygonic S.) Scud., Buff. Bull., II, P. 25:, (1875).

var, a. MArsyas, W. H. Edwns., (Grapta M.), Trans. Rocky Mts. Am. Eint. Soc., IIJ, p. 16, (1870); Butt. N. Am., II, t. 2, Grapta, (1875); (Nym. M.) Kirby, Cat., p. 648, (1871); (Polyg. M.) Scud., Buff. Bull., II, 1. $252,(1875)$.

Under surface dark reddish.

Larva on nettle (Lrtica).

263. (Oreas, W. H. Enwos., (Grapta O.), Trans. Am. Ent. California, Sox., II, p. 373, (1869); 1. с., V, p. 109, (1874); Oregon, (Van. O.) Kirby, Catt., 1. 183, (1871); (Polyg. O.) Vancouver's Simul., Buff: Bull., II, p. 252, (1875).

Grap. C-Album, Behr, Proc. Cal. Acad. Nat. Sc., III, p. $123,(1864)$.

Grap. Silenus, W. H. Edwds., Trans. Am. Ent. Soc., III, p. 15, (1870); Butt. N. Am., II, t. 1, Grapta, (1874); (Nym. S.) Kirlyy, Cat., p. 648, (1871); (Polyg. S.) Siend., Buff. Bull., II, p. 252, (1875).

Larva on Letica.

†*264. Silvius, W. II. Enwos., (Grapta S.), Trans. Am. Fit. California. Soc., V, p. 108, (1874).

265. Zephyres, W. H. Enwns., (Grapte Z.), Trans. Am. Colorado, Ent. Soc., III, p. 16, (1870); Butt. N. Am., I, t. Nevalla, 6, Grapta, (1872); (Nym. Z.) Kirby, Cat., p. 648, Montana, (1871); (Crap. Z.) Hy. Edwds., Proe. Cal. Arad. California, Nat. Sc., V, p. 169, Lar., (1873); Mead, Wheeler's Oregon, Rep., V, p. 769, (1875); (Polyg. Z.) Seud., Buff. Utah. Bull., II, p. 2.52, (1875).

Polyg. Thiodamas, Scud., Buff. Bull., II, p. 252, (1875).

Ialrva on Azalea Occidentulis.

var. a. Gracilis, G.-R., (Grepta G.), Amn. N. Y. Lye. Canatil, Nat. Hist., VIII, p. 432, (1867); (Van. C.) Kirly, Maine, Cat., 1. 18\%, (1871); (Grap. C.) Streck., Lep., White MIts., Rhop.-Het., p. 68, t. 8, (1873).

Grap. C-Argenteum, Scud., Proc. Eiss. Inst., III, p. shire. $169,(1862)$.

Grap. Fennus, Scud., Buft. Bull., II, p. 252, (1875).

Larva on willow (Salix Humilis).

Basal third of under surface of wings deep reddish brown or charet coloured. 
266. Progne, Cran., (Pap. P.), Pap. Ex., I, t. 5, (1775); Fabr., Northem Gen. Ins., 1. 264, (1777); Sp. Ins., II, p. 93, IT. S. to the (1781) ; Ent. Syst., III, 1, 1. 124, (179:3); Herbst, Rocky Mts.; Nitursyst. Ins. Solmett., VII, p.61, t. 163, (1794); Canaila, (Polygonia I'.) Hüb., Verz. Bek. Selnmett., 1. 36, Labrador, (1S16); (Tun. P.) Godt., Func. Meth.. IX, p. 304, British Co(1819); Bill-Iser., I жер. Am. Sept., p. 188, t. 50, lumbia, (18:3:3); (trapta P.) Dhldy.-Hew., Gen. Diur. KamtselatLefe, I, p. 197, (1846-1850); (I'an. P.) Emm., ka, Siberia, Aer. Nat. Hint. N. York, p. 207, (1854); Fitch, Japan. liep. N. Tork State Aerr. Sox., 1) 428, (1856); Morris, Nyn., p. 56, (1862); Harris, lns. Inj. Vea., Flint's lid., P. 301, (1862); (roupte P.) Lint., Prox. Ent. Sore, Phil., III, \%. 58, Iar., (1861); Kark., Proc. Ent. Sore, Phil., VI, p. 143, (1866i); l'ark., (inide, 1. 260, t. 188, (1869); (Van. I'.) Kirls, (at., p. 182, (1871); Ster., (at., ). 16, (187i); (I'slygonia I'.) Send., Syst. Rev. Am. Putt., 10, (1872); But7. Bull., II, p. 253, (1875).

I'mp. (roogne, Fabr., Mant. Iıs., II, 1. 50), (1787).

Cirepter ('Argenteum, Kirby, Fanm. Bor. Am., IV, p. 292, t. : , f. $6,7,(1837)$.

var. a. I-Argexteur, S(Ub., (Poiygonia L.), Buff. Bull., I1, 1. 25:3, (1875).

Cpleer surface of secondaries mostly blackish.

latra on coltivated and wild corrant, and will gooseherry (Ribes Rotundifolintm).

267. Val-Misum, Wiex. Ver\%, (Pap. V.), 1) 176, (1776); Northorn (Vom. T.) Kirby, Cat., p. 184, (1871).

I'(1). V. Album, F́abr., Mant. Ins., II, ). 50, (1787); cast of the

Ent. Syst., III, 1, p. 122, (179:3); Hïb., Eur. Rocley MIts.;

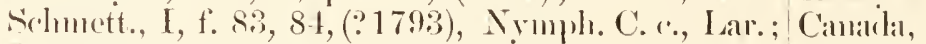

().+1.:., Schmett. Eur., I, 1, 1. 112, (1807); (Eugonia Labrador ;

I.) IIïh., Verz. Bek. Schmett., 1. :36, (1816); British Co-

(Fin. V.) Grolt., Enc. Moth., IX, H. 306, (1819); lumbia to the

Mup., ITist. Natt. Isep., I, 2:3, 1, 2, (18:32); Bull., Pacitic ; SiIron., I, 24, (18.32) ; Sp. Cron., I, t. 10, f. 1, (1836): heria, RusIsuas, Pap. Eur., 1. 59, t. 3, (1834); (Techyptera sia. Hun-

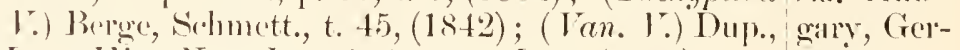
Iron. Ilist. Nat., I, p. 1014, t. 11, Ialr., (1849). maily.

l'up. I, Album, Lsp., Schmett., I, 2, t. 62, (1780);

sillı., Syst. Bowdh., I, p. 163, (178t); Bkh., Nat. shmett., I, 1) 1 17, 204, (1788); Herhst, Natursist. Ins. Schmett., VII, J. 56, t. 162, (1794); H-S, Syst. Barth. Schmett. Eur., r. 40, (18.43); Stgr., (iti., 1). 16, (1871).

l'ap. Polyrhlomes, Cram., (nec L.), Palp. Ex., IV', t. $330,(1782)$; (Van. I’.) Emm., Ierr. Nat. Hist. N. Y., T, p. $208,(1854)$.

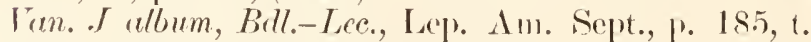
$50,(18: 33)$; Morris, Syn., 1). 56, (1862); Harris, lus. Inj. Veg., Flint's Ed., p. 29s, (1862); (Crapta 
.J.) Lint., Proc. Ent. Sox., Phil., II I, p. 58, I ar., (1864); (Nymphalis .J.) Somrl., Syst. Res. Am. Butt., 11, (1872); (Eugonia .J.) Sicurl., Buff. Bull., II, p. 25.3, (1875).

Van. Lrticer, IIarris, (nec J.), Hitch. Rep. (reo). Min., etc., El. 1, p. 520, (18333).

Larva on willow.

There is a slight tendency to suffusion in the black marks of upper surface in the American examples; and towards the exterior margins of upper surface of secondaries the colour is a litule paler, but these trivial and scarce constant differences can be considered by no means sufficient to separate them specifically from the European examples.

268. Califorvica, Bol., Anm. Sox. Fint. Fr., 2 me Ser. X, p. California, 306, (1852); Morric, Syn., r. 58, (1862); Behr, Oregen.

Proc. Cal. Arad. Nat. S'Sc, III, p. 12:), (1864); Pack., Fuide, p. 259, (1869) ; Kirby, Cat., P. 184, (1871); Hy. Eilwels., P'roe. Cal. Acad. Nat. Sir., V, 1. 171, Iar., (1875); Mearl, Wleoler's Rep., V, p. 769, (187.5); (Eugonia (¿) Scurl., Buff. Bull., II, P. $253,(1875)$.

Larva un C'cenothus Thyrsiftorus.

269. Milberti, Gont., Ene. Meth., IX, p. 307, (1819); Bil.Lee., Lep. Am. Sept., p. 187, t. 50, (1893:3); [H,lely.Hew., Gen. I)iur. Isep., I, 1. 201, t. 26, (18i6- Brit. Colum$185(0)$; Harris, Ins. Inj. Veg., Flint's El., p. 302, bia, N. Eng. f. $125,(1862)$; Morris, Syn., p. 56, (1862); I int., States, Proce Ent. Soc., Phil., III, 1. 61, Iar., (1864); N. Jork, Reak., I. '., VI, p. 148, (1866); Samnd., Can. Ent., Penna., I, p. 76, (1869); Kirly, Cat., 1. 143, (1871); Hy. Erlwrk., Proce. Cal. Acad. Nat. Sre, Lar., (Oet. 6, 1873 ) ; (Aglais M.) Sornd., Srst. Rev. Am. Butt., p. 21, (1872); Buff: Bull., I I, 1) 251, (1875).

Van. Furcillata, Say, Am. Fint, II, t. 27, (1825); (Pap. K.) Brown, Const. Mis. Butt., I, 1. 180, t. 40, (18:32); Kirby, Famm. Bor. Am., IV, 1. 292, (18.37).

Ohir, Michigan, Incl. III., Missonri, Wisconsin, Iowa, Colorarlo, Montana, Nevarla, Van. Wibertii, Pack., Guide, P. 259, (1869) ; Mearl., California, Whereler's Rep., V, P. 769, (1875).

I arval on nettles (Urtica).

Emmons, in Agr. Nat. Hist. N. X., V, p. 209, t. 46, (185.1), describes and figures 1 . Trticor, stating that it occurred in $\mathrm{N}$. Iork,- of course erroneously, as no anthenticated instance of its capture in this country is known.

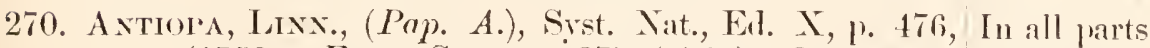
(1758); Faun. Suec, p. 277, (1761); Syst. Nat., of N. Im. Ed. XII, I, 2, p. 776; (1767); Porl., Ins. Mus. except the (irace., p. 71, (1761); Seop., Ent. Carn., P. 148, Polar regrion; n. 419, (1763); Fabr., Srst. Ent., p. 503, (1775); Europe, Sp. Ins., II, 1. 89, (1781); Mant. Ins., II, p. 48, Siberia. (1787); Ent. Syst., III, 1, 1. 115, (1793); Esp., Sehmett., I, 1, t. 12, (1777), t. 29, (1778); Bergstr., Nom., t. 39, t. 112, (1779); Brk., Natur. Schmett., 
I, pl. 11, 195, (1788); Hiih., Eur. Schmett., I, f. 79, 80, (1793), on t. Nym. C a., also Lar. ; Herbst, Natursist. Ins., VII, p. 96, t. 166, (1794); Don., Nat. Hikt. Brit. Insects, II I, p. 45, t. 8!, (1794); Wilh., Unt. Nat. Ins., II, p. 91, t. 12, (1797); (Nymph. A.) Latr., Hist. Nat. Crust. et Ins., XIV, P. 83, t. 105, (1805) ; (Pap. A.) Ochs., Schmett., I, 1, 110, (1807); (Eugonia A.) Hül)., Verz Bek. Schmett., p. 37, (1816); (Aylris A.) Dalm., Vetensk. Acarl. Handl., 64, (1816); (Van. A.) Gorlt., Hue. Meth., IX, p. 308, (1819); Steph., Ill. Brit. Ent. Haust., 1, 1. 45, (1828); (Pap. A.) Brown, Const. Mis. Butt., Vol. I, p. 160, t. 26, (1832); (Fan. A.) Bill.-Lec., Lep. Im. Sept., 1. 173, (18.3.3); Imeas, Рap. Eur., 1. 58, t. 1, (1834); Duncan, Nat. Lib. Ent., III, 1. 168, t. 18, (1835); Kirlsy, Faun. Bol. Am., I V, p. 293, (1837); (Tachyptera A.) Berge, Selimett., \%. 99, t. 4t, (1842); (Van. A.) Emm., Agr. Nat. Hist. N. York, V, p. 20, t. 6. (1854) ; Humplseys, Brit. Butt., p. 53, t. 14, (1841); Harris, Ins. Inj. Veg., Flint's Ed., p. 296, f. 121, 122, (1862); Morris, Syn., p. 57, (1862); Behre, Proc. Cal. Arad. Nat. Sc., III, p. 125, (1864); Lint., Proc. Ent. Soc., Phil., III, P. 59, Lar., (1864); Reak., 1. c., VI, P. 143, (1866); Jack., Guide, p. 258, (1869); Saund., Can. Ent., I, 1. 75, I ar., (1869); Stgr., Cat., P. 16, (1871); Kirly, Cat., p. 183, (1871); Hy. Erlwds., Proc. Cal. A art. Nat. Ac., J ar., (C)t. 6, 1873); Mcal, Wheeler's Rop., V, P. 76!, (1875); (Pap. A.) Sicul., Butf: Bull., II, ю. 254, (1875).

Pap. Pompadonr, P'oll., Bemerk. Churpf. Ock. Cies., (1779).

Pap. Morio, Liun., Faun. Suec., Ed. 1, 1. 232, (1746);

Retz., Gen. et Sp. Ins., 31, (1783); (Van. M.) Goult., Hist. Natt. Ixep., 1, p. 93, t. 5, (1821).

$(1765)$ , seba, Thes., IV, p. 39, t. 32, f. 1, 2, Engr., Palp. Eur., I, p. 1, t. 1, (1779).

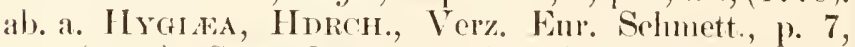
(1851); Stgre, Cat., p. 17, (1871); Kirly, Cat., p. 183, (1871); (Р(t). H.) S'cutl., Buff. Bull., II, p. $254,(1875)$.

Pap. Antiopa, Hüb., Enr. Schmett., I, f. 993, (18291841); (Ían. A.) Frey., Neu. Beit., II, 1. 145, (? 18:35)

Ian. Antiopa var., Mill., Icon. Chen. et Lep., X, p. 420, t. 94, (1868).

Tin. Lintnerii, Fitch, Bol Rep. Trans. N. York Sitare Agr. Soe., p. 48.), (1856); Morris, Syn., \%. 57, (1862); Niterk., Lep., Rhop.-Het., p. 7, (1872); Bunker, Can. Ent.. I'III, P. 240, (1876). - Engr., Lap. Eur., I, t. 1, f. 1f', (1779). 
The yellow border much broader, extending over the space that in the normal form is uccupied with the row of blue spots, these latter either entirely wanting or else faint traces of them are on the secondaries only, as in Hubner's and Milliere's figures. In one example I have seen the yellow border encroached to such an extent as to cover nearly the whole outer half of all wings.

${ }_{+}^{+} \mathrm{al}$, b. 으 With the border on upper side of primaries black instead of yellow. Mus. Streck.

Herbst, on t. 168, Vol, VII, fignres another aberration of great size with white border to the wings and the blue spots enormously large.

In Seba, Vol. IV, (1765), t. 32, f. 5, 6, another is represented in which the white marks on outer part of primaries at costa are entirely wanting, and on the under surface the dark colour of all wings is iniform, devoid of all marbling or reticulation; this example is, I believe, still in existence in the St. Petersburg Museum.

Larva on willow, elm, poplar.

\section{GENUS 9. PYRAMEIS, Hus.}

271. Atalanta, Linn., (Pap. A.), Syst. Nat., Ed. X, P. 478, Whole of (1758), Ed. XII, I, 2, p. 779,(1767); Fann. Suec., N. America 1). 279, (1761); Pod., Ins. Mus. Girace, p. 72, except the (1761); Scop., Ent. Carn., p. 148, (1763); Fabr., Polar region; Syst. Ent., p. 504, (1775); Sp. Ins., II, p. 90, Eumpe, (1781); Mant. Ins., II, p. 49, (1787); Ent. Syst., N. Africa. II I, 1, p. 118, (1793); Esp., Schmett. Eur., 1, 1, t. 14, (1777); Bergs., Nom., t. 20, (1779); Brk., Natur. Schmett., 1, 1p. 12, 196, (1788); Hïb., Eur. Srhmott., I, f. 75, 76, (" 1793), Nymph. C a., f. a, b, Latr.; IJerbst, Nitursyst. Ins. Schmett., VII, p. 171, t. 180, t: 3, 4, (1794); Wilh., Unt. Nat. Ins., II, p. 118, t. 15, (1797); Don., Brit. Ins., VIII, p. 19, t. 260, (1794); (I'ap. Nym. A.) Scharef., Icon., II, t. 148, vol. of text, p. 14l, (1804); (Nymph. A.) I atr., Hint. Nat. C'mst. et Ins., XIV, l. 86, (1805); ('Pap. A.) ().hs., Schmett. Fur., I, 1, 104, (1807); (Pyram. A.) Hïb., Verz. Bek. Schmett., 1. 33, (1816); (Aglais A.) Dalm., Yetensk. Acad. Handl., 55, (1816); (Libythea A.) Istmarck, Hist. Anim. sans Vert., IV, 29, (1817); (Van. A.) Godt., Ene. Meth., 1X, p. 319, (1819); Hist. Nat. I sep., 1, p. 99, t. 6, (1821); Steph., III. Brit. Ent. Haust., 1, p. 46, (1828) ; (I'un. A.) Bull.Jec., Lep. An. Sept., p. 175, (18:33); Istas, Pap. Eur., p. 57, t. 1, (1834-35); (Cynthia A.) Harris, Hitch. Rep. Min. Geo., ete., Masss., Eil. 1, 1) :390, (1833); (Van. A.) Duncan, Nat. Lib. Ent., III, I. 170, t. 20, (1835); (Tachyptera A.) Berge, s'.lnnett., p. 100 , t. $45,(18+2)$; (Van. A.) Emm., Agr. Nat. Hist. N. York, V, p. 209. (1854); (C'ynthia A.) Humpl., Brit. Butt., p. 55, t. 15, (1841); Harris, Ins. Inj. I' eg., Flint's El., p. 294, f. 120, (1862); 
(Pyram. A.) Morris, Syn., p. 58, (1862); Behr, Proc. Cal. Acal. Nat. Sc., III, 1. 125, (1864); Pack., Guide, p. 261, (1869); Kirby, Cat., p. 185, (1871); (Van. A.) Stgr., Cat., 1. 17, (1871); (Pyram. A.) My. Edwds., Proc. Cal. Acad. Nat. Sc., V, Laur., (Oct. 6, 1873) ; Meal, Wheelor's Rep., I, p. 770, (1875); (Van. A.) Send., Buff. Bull., II, p. 251, $(1875)$.

Pap. Amiralis, Retz., (ien. et Sp. Ins., :31, (178:3).

- - Meriun, Eur. Ins., t. 91, (1730).

$4,(1765)$.

1. Engr., Pap. Eur., p. 17, t. (6, (1779).

Larva on nettles (Urtica), lops (Iurnulus Lupulus), Boehmeria Cylindrica.

This species is very seldom sulject to any great variation. I have seen no example in this country showing any remarkable aberiancy.

On t. 86, f. 4, Esper figures a most wonderful variety which was taken in 'Tyrol. 'This figure luas been copied by Herbst in his Vol. VII, t. 180, and also by other European authors. Herr-Sch. also figures a most extraordinary form (in Vol. I, f. 547,548$)$. In the figures above cited the whole style of ornamentation is changed.

Milliere, in his Icon.. X, t. 88, (1867), figures a curious form in which all the bands that are orange, normatly, are here brownish or greyish white and semidiaphanous.

272. Cardul, Imxx., (Pap. (.), Syst. Nit., Ed. X, p. 475, X. America (1758), Ed. XII, p. 77f, (1767); Jaun. Snce, p. except the 276, (1761); Scop., Ent. Cinn., p. 150, (1763); Polar region; Falsr, Syst. Ent., j. 499, (1775); Sp. Ins., 1I, 1. India, Asia 82, (1781); Mant. Ins., I1, J. 45, (1787); Ent. Minor, EuSirst., II I, 1, p. 104, (179:3); Esp., Sichmett., 1, 1, rope, Africa. t. 10, (1777); Bergstr., Nom., t. 62, (1779); Brk., Natur. Sichmett., I, p. 199, (1788); IÏ̈b., Em. Schmott., I, 1: 7:3, 74, (: 179:3), Nymph. C a, f. 1a, b, c, Latr.; Wilh., Unt. Nat. Ins., II, p. 77, t. 9, (1797) ; Don., Brit. Ins., IX, 1).9, t. 292, (1800); (Pap. Nymph. (!) Sohace., Icones, I, t. 97, vol. of text, p. 108, (1804); (Nymph. (!) Laitr., Hist. Nat. ('rust. et Ins., XIV, 1). 87, (1805); (C'ynthia C.) Falır., IIl. Mag. Ins., VI, 281, (1807); (Van. (!) ()hs., Schmett. Eur., I, 1, 102, \{1807); Hüb., V'ё. 13ek. Sohmett., p, 33, (1816); (Ayluis (!) Dalu1., V'otensk. Acull. Handl., 65, (1816); (Libythea (:) Ianmarek, Hist. Anim. sans Vertehr., IV, 29, (1817); (Van. ( .) Godt., Ene. Meth., IX, p. 32:3, (1819); (Cynthia (:) Steph., Ill. Brit. Ent. Haust., I, p. 17, (1828); (Vur. C.) Bdl.-Lee., Lер. An. S(ept., ю. 178, (1833); Bal., Fatun. Ent. Mad., 1. 4:, (1834); (Cynthia C.) Don., Nat. I ib. Ent., [11, p. 174, t. 19, (1835); Kirby, Fann. Bu. An., IV, 1. פ95, (18:37); Hmmph., Brit. Butt., p. 56, t. 15, (15+1) ; ('T'achyptera (:) 
Berge, Schmett., p. 100, t. 15, (1812); (Van. C.)

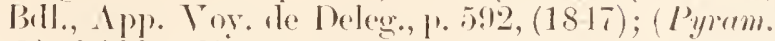

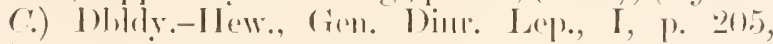

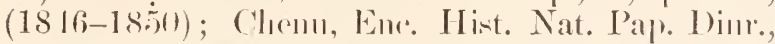
I, f. $215,(1 \times 50)$; ( Van. C.) Bill., Anu. Ent. Fr., 2me Ser. X, p. :307, (1852); (cynthice (') Emm., Igr. Nalt. Ilist. N. York, V, 1. 210, 1. 16, (1854); Staint., Man. Brit. Butt., I, 1. 37, (1857); (I'yrom.

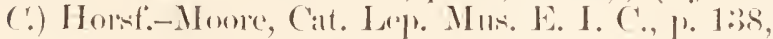
(1857); (cynthice (') Hatris, Ins. Inj. Vom. Flint's Fil., 1. 291, f. 118, (1862); (I'yrem. (c) Norric, sym., p. 59, (1862); 'Trim., Rhor. Ifr. Instr., 1,

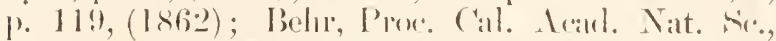

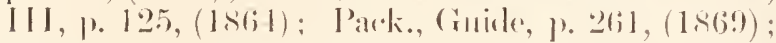

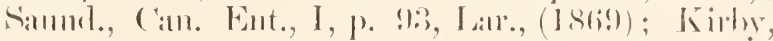
(at., p. 185. (1871); (J'an. ( .) Nterr., (att., ). 17,

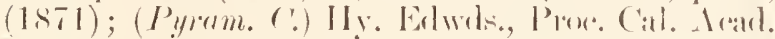

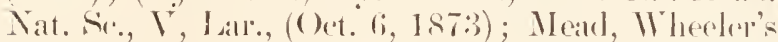
Rep., V, 1. 770, (1875); (lim. (.) Serrl., Bull: I311., II, 1. 251, (1855).

P'ap. Bellurlomma, J'etir., Pap. Jirit., p. 2, t. 1, (1717);

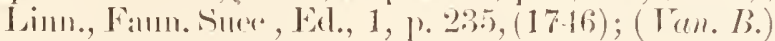

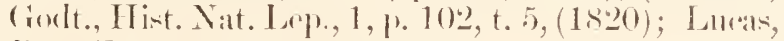
Pap. Eur., p. 57, t. 3, (1851).

Pap. Carductis, seba, Thes., IV, ]. 6, t. 1, (17655);

('ran., l'ap. Exot., I, t. 26, f. F, F, (1779).

$$
\begin{aligned}
& \text { Merian, Eur. Ins., t. } 116,(1730) . \\
& \text { Engr., I'ap. En1., 1). 20, t. 7, (1779). }
\end{aligned}
$$

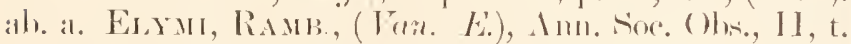
5, f. 1, 2, (1829): Kirlw, (att., 1) 186, (1871); Nter., (:it., P. 17, (1871).

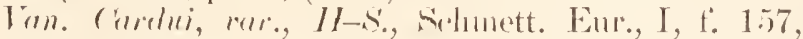
$158,(1849)$.

Normal form of ornamentalion obliterated. I'pler side of primaries has the hawal half covered with an orange yellow blotch; subapical white spots eouflnent. Seeondaries orange yeliow; on costal parts lulackish, this colonr extending along the veins to onter margin; before it reatches the latter this colour broadens into diamond-shaprel marks; a submarginal rew of white spols. Toder side of primaries molh as alove, Tut will a broal white submarginal hame. Seromelaries motthed pale greevish, wilh a loroad white marginal hand; in some inst:mees neirly the whole surface of secondaries beneath is white, in others the while predominates on the upper surfice to the greater exchsion of the hlaek. Two examples, Mhs. Mrs. Siridgham, taken in N. Jersey.

fab. h. ATE, Nob.--I Pres surface primaries suffised heavily with blackish, the normal markings entirely gome, the orange eonfined to a bloteh on dise on half of wing towards the imner margin, said bloteh merging into the blackish on all sides; the large snlapieal white har entirely wanting. Secondaries ohsomred with backish, the row of black spots faimbly discernible and pupilled with white points. Cnoler side primaries much as on upper sile, secondaries hatk excepl along the ahdominal margin where the ordinary colonaation and marking is retained; vein. white; the six ocelli as in ordinary form; a narrow yellowish or clay colonred margin exteriorly. Body white beneath. Mus. Streck. Taken in Summit Co., Ohio. 
Trimen, in Rhop. Afr. Anstr., p. 1st, cites an example laken at King Willian's Town, S. A fr., which, according to his deseription, agrees with the ahove var, in almost every particular.

I arva on thistles (cieduess, ('nicus, (ircium), nettlo (Urtica), Althere Roser, ILelianthus, Mralraces, and some other plants.

273. Carye, Ilers, (Hemeadryas decore (:), Samm. Ex. California, Sehmett., I, (1806-1816); (Vun. (:) Hüb., Verz. Nevarla, Bek. Selumett., p. 3:), (1816); (Pyrum. (') Dlu]dy.- Arizonil,

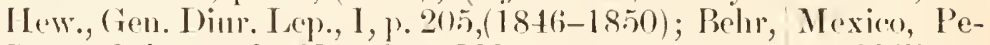
Proce Cal. Acal. Nat. Sic., III, p. 125, (1864); ru, Chili. Kirhy, Cat., p. 186, (1871); Hy. Elwrik., Broe. (al. Nout. Nat. Sic., IV, p. 32!), Lar., (July 6, 1874); (Van. (.) Scoul., Buff. Bull., II, p. 255 , $(1875)$.

Ten. Charie, Blanch., ( Wily, Fann. (hil., VII, 1. 26, t. 2, Atlas, (1852).

Larva on Maliener and litico.

274. Huntera, Fabr., (I'ap. II.), Syst. Eint., p. 499, (1775); Sp. Ins., II, p. 8:3, (1781); M:ıt. Ins, JI, p. 15, (1787); Ent. Srst., III, 1, 1. 101, (1793); Herhst, Nitursest. Ins. Solmett., VII, p. 165, t. 178 o , 179 \%, (1794); N1.--S., Ins. (iil., I, t. 9, (1797); (Van. H.) Hül., Samm. Ex. Schmett., III, (1806$1816)$; Cindt., Enc. Weth., IX, p. 324, (181!); Bill.-Lee., Lepr. Am. Sept., 1). 180, t. 48, (18:3:3); (Cynthice H.) Hatris, Hitch. Rep. Geo. Min., etc., Jass., Ed. I, 1. 590, (1833); Humph., Brit. Butt., p. 57, t. 15, (1841); (Pyram. H.) Dhldy.-Hew., (xoll. I)iur. Lep., I, 1. 2015), (1846-1850); (c'ynthice II.) Emm., A Awr. Nit. Hist. N. Y., V, p. 210, (18.54); Harris, Inc. Inj. Vex., Flint's Eal., 1. 292, f. 119 , (1862); (Pyram. II.) Morris, Srn., p. 60, (1862); Lint., l'roe. Ent. Sox., Phil., I I J, j. 6i3, Latr., (1861); Saund., Can. Ent., I, p. 105, Larr., (1869); Pack., (inide, 1). 261, (1869); Hy. Edwds., Prox. Cal. Acad. Natt. Sce, V, (1873); (Van. H.) Scud., Buff. Biıll., II, p. 254, (1875).

Pap. Belladonna virginiana oculis suhtus minoribus, Petiv., (iazoph., I T, t. 33), f. 5, (1711).

Pap. Cardui Virginiensis, Diu., Ill. Ex. Ent., I, t. 5, (1770).

Prip. Iole, ('ram., Pilp. Ex., 1, t. 12, (1779).

I'en. Hunteri, Hüb., Verz. Bek. Schmett., p. 33, $(1816)$.

Pyremeis Virginiensis, Kirby, Cat., p. 186, (1871).

Larval on the varions specier of Cinaphalium.

\section{GENUS 10. JUNONIA. HuB.}

275. Ceris, Hub., Samm. Ex. Silmett. II, (1816-1824); M., S. and

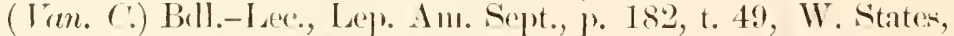
(1833); (Jun. (') Morris, Sroll, p. 61, (1862); from At. to Bochr, Proc. Call. Acad. Nat. Sce, III, p. 126, (1864); Par.; Mex.; Parek., Guide, 1. 261, (186:1); Kirly, Catt, p. 188, Cent. Am. 
(1871); Hy. Elwrls., Proc. Cal. Acarl. Nat. Si., V, Lar., (Oct. 6, 187:) ; Simul., 13ulf. Bull., 1], 1. 255, $(1875)$.

P'ap. Oiythia, Abb.-S., Ins. Gis., I, t. 8, (1797).

Vanessa Larinia, Goelt., Enc. Math., IX, p. :318, (1819).

Cynthia Lavinia, Harr., (nec Cram.), Hitch. Rep. (ien. Min, ete., Mass., Fil. 1, p. 500, (183:3); lıs. Iıj. Veg., Flint's Eil., 1. 243, (1862).

Lavia on I'lantago Lanceolata, Gerardia Purpurea, Antirohinum Canadensis.

Subject to much variation on under side, especially of secondaries, some examples being whitish ochraceous, others claret coloured, some immaculate, others reticulated and with ocelli.

Pap. Lavinia, Cranı., I, t. 21, C. D, (1779), is the form found in S. Am. and the Antilles. I'ap. Lvarete, III, t. 2013, C, 1), (1782), is another S. Am. var. of the same. Pap. Genoreva, IV, t. $290, \mathrm{k}, \mathrm{F}, \mathrm{i}$ al also as. Am. form of same. Hamadryas decora Etarete, Hul., Sam. Ex., I, is the same S. Am. form as Cram.'s Ecurete, I, t. 21 . The fig. 26,29 , t. 2:39, Sloane's Jamaica, (1725), represents the same form, or something near it at least, is the one ahove cited in C'ram., I, t. 21.

\section{GENUS 11. ANARTIA, IIUl,}

276. Jatrophe, Laxs., (Pap. J.), Mus. Lmd. Ulr. Rong., p. S. Florida, 289, (1764); Syst. Nat., El. XII, I, 2, 1.779, W. Indies, (1767); doh., Ammon. Aral., VI, p. 408, (1764); 'Texas, Fabr., Syst. Ent., 1. 493, (1775); Sp. Ins., II, p. Mexi(0), 75, (1781); Mant. Ins., II, 1. 37, (1787); Eut. Cent. Anı, Syst., III, 1, p. 98, (1793); ('ram., Palp. Ex., III, Surinam, t. 202, (1782); Herlst, Natursert. Ins. Solnuct., Brazil. VII, p. 1:34, t. 172, (1794); (Ilemadryas decora J.) Iül., Simmm. Ex. Solımett., I, (1806-1s16); (Anartia .J.) Ver\%. Bek. Selmett., p. 3\%), (1816); (Tan. J.) Godt., Enc. Metl., IX, p. 297, (1819); (Anartia .J.) Inbldy.-How., (ion. Dinr. Lep)., 1, p. 216 , (1846-1850); Morris, Sirt., 1). 62, (1862); Kirbs, Cat., 1. 194, (1871); Sciut., Butt. Jull., I1, l. $255,(1875)$.

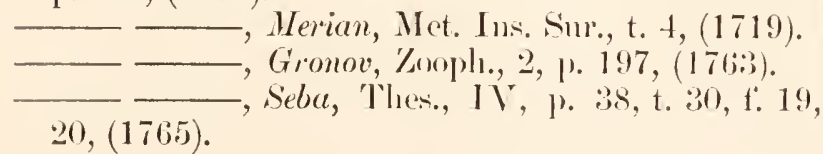

\section{GENTS 12. AGERONIA, MUB.}

277. Feronia, Imxn., (Pap. F.), Syst. Nat., Eil. X, p. 473, S. W. Texas, (1758); Mus. Lad. Ulr. Reg., p. 28:, (1764); Syst. Mexico, Nat., Eil. X I I, 1, 2, p. 770, (1767); Clerek, lorines, Cent. Am., t. 31, (1764) ; Drı., Ill. Ex. Ent., I, t. 10, (1770); S. Am. Fabr., Syst. Ent., p. 491, (1775); Spec. Ins., 11, p. 71, (1781); Mant. Ins., II, J. 36, (1787); Ent. 
Syst., III, 1, 1. 226, (179:3); Cram., Pap. Ex., I I, t. 192, (1779); Herlst, Nitursyst. Ins. Sichmett., VIII, ]. 258, t. 225, (1796); (Hamadryas decora r.) Hül, Simm, Ex. Sehmett., 1, (1806-1816); (Ager. F.) Ver\%. Bek. Selnuett., P. 42, (1816i); (Nymph. F.) Gorlt., Hne. Meth., IX, 1. 128, (182:3); (Ager. F.) Chenu, Iay. Diur., 1. 151, (1852); (Am-

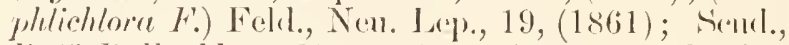
liuf1: Bull., 11, 1. 256;, (1875); (Ayer. IF.) Kirbs, (

—_- Suba, Thes., IV, p. 46, t. 38, f. 10, 11, (1765)).

('ram.'s ligures $\mathrm{A}, \mathrm{B}, \mathrm{t}$. 362 , Vol. IV, which he has cited as Feronit, are not that species, but Ferentina.

278. Fomax, Hrm., Samm. Ex. Solmett. I1, (1816-1824); S. W. Texas,

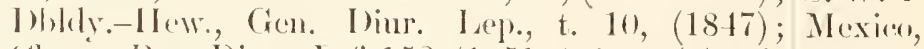
('henil, Pap). Dinr., 1, t. ]52, (1851-185:); (Amph. Cont. An.; F.) Feld., Nin. Ixp., 19, (1861); (Ager. F.) Kirler, S. Am. to s.

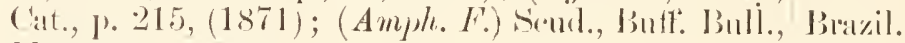
II, 1.2.56, (1875).

\section{GENES 13. EUNIGA, IIUB.}

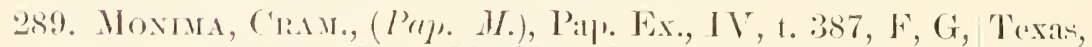

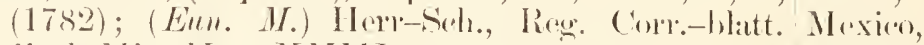
\%(x)l. Min. Ver., XVIII, 1) 162, (1864). Florida, $\because$ Nymph. Myrta, Codt., Euc. Meth., IX, 1) 1]8, (182::); Antilles, (Eun. M.) Hïh., V'r\%. Bek. Sohnett., p.ti1, (1816). ('ent. Am. Em. Modesta, Butes, Eut. No. Mag., I, J. 11:3, (1864); Kinly, ('at., p. 200, (1871).

Enn. (I'tp.) Orphise, Cran., I, I. 12, f. E, F; Eun. Hyperipte, Huh., Simm. Lix.; ind E. (Libythea) C'uvierii, Lncise, l'alp. Ex., t. bil, are all diflerent species from ours, nome being identival, als hais been sometimes supposed.

\section{GENTS 14. CALLICORE, HUB}

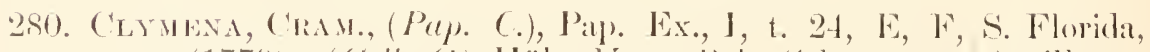

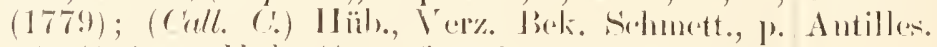

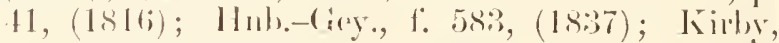

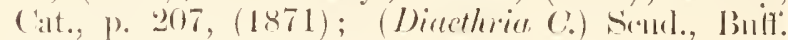
liull., II, 1. 2055, (1875).

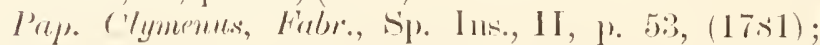

Mant. Ins. II, 1. 206, (17s7); Ent. Syst., III, 1. 4:), (17:3:3); (Nymph. (!) Goult, Em. Moth., IX, J.

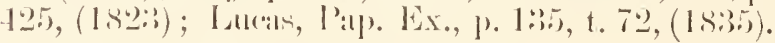

In the coppos of Incas that I have seen, the extrat discal hamd on mpere side of primaries is painted erimson, which of conrse wats a diverwion of the colourist's, as nothing in nature or the text witrants it.

\section{(AENTS 15. CIS'PINEURA, BUL.}

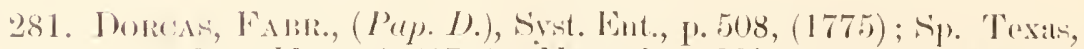

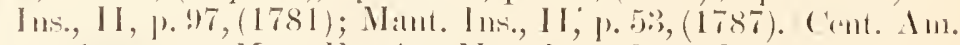

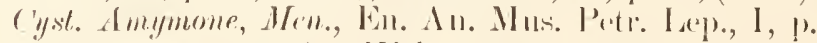

1.:, 1. 9, (1857); Kins, (ait., 1. 217, (1871);

(Mestra A.) Sicul., Butr. Bull., II, 1. 256, (1875). 
GENUS 16. TIMETES, BuL.

282. Chrox, Fabr., (Pap. C.), Syst. Ent., p. 452, (1775); Sp. Texals, Ins., II, p. 16, (1781); Mant. Ins., II, 8, (1787); Mexico, Ent. Syst., II I, 1, p. 26, (1793); Herlust, Natur- West Indies, syst. Ius. Schmett., III, ). 222, t. 52, (1788); C'ent. and s'. (Nymph. C.) Godt., Fine. Meth., IX, p. 359, (1823); Anerica.

(Megulura C:) Kirlyy, Cát., p. 221, (1871).

Pap. Marius, Cram., Pap. Ex., III, t. 200, (1782); Stoll, Suppl. Cram., t. 30, (1791).

Marpesia Chironias, Hub., Ver\%. Bek. Schmatt., p. $47,(1816)$.

$(1725)$

, Sloane, Hist. .Jamaica, t. 2:39, f. 1, 2, Seba, 'Thes., IV, p. 42, t. 34, f. 13 ,

14, p. 4:3, t. 35 , f. $3,4,(1765)$.

283. Coresia, Gon't., (Nymphulis C.), Ene. Meth., IX, p. 359, Texals,

(1823) ; Megalura (!) Blanch., Hist. Nat. Ins., I I1, Mexien, 1. 447, (1840); (Timetes C:) Dlildy.-Hew., Gen. Cent. Am. I)iur. Lep., II, p. 263, (1850-1852); W. H. Edwds., Proc. Ent. Soc., Pliil., I, p. 224, (1862); (Meg. (') Kirly, Cat., P. 220, (1871); (Tim. C.) Ścnd., Butf. Bnıll., II, 1. 256, (1875).

Marpesia Zerymthia, Hub., Samm. Ex. Schmett., II, $(1806-1824)$.

Pap. Sylla, Perty, Del. Anini. Art., 1. 151, t. 29, (1830-1834).

284. Eifedcilka, Hur., (Mrapesin Li), Simm. Ex. Schmett., II, (1816-1824); Verz. Bek. Sehmett., P. 47, (1816); '/utr. Ex. Schmett., f'. 197, 198, (1818); H-S., Reg. Conr.-blatt Zool.-Min. V'er., XVIII, p. 161, (1864).

Timetes Eleucha, Dbldy.-Hew., Gen. Diur. Lep., II, 1. 263, Atlati, t. 33, (1850-185.2); (Megulura E.) Kirloy, Cat., 1. 222, (1871).

Nymphialis Pellenis, Godt., Ene. Meth., IX, p. 359, (1823); (Athena P.) Soud., Butt: Bull., 11, p. 255, (1875).

Hubner's figures 197,198 , in the /utrag, evidently represent a different species, or at least a variety. I have not seen in nature anylhing that resembles it.

285. Peinus, Sulz., (I'ap. P.), Alug. Gesch. Ins., t. 13, f. 4, S. W. Texas,

(1776); (Meyalure P.) Kirby, (at., 1).222, (1871); Mexico, (Athenc P.) Sund., Buft: Bull., I I, 1. 256, (1875). Cent. An1., Pap. Thetys, Fabr., Gen. Ins., 1) 26t, (1777); Sp. S. An. Ins., II, 1. 87, (1781); Mant. Ins., II, p. 47, (1787); Ent. Syst., III, 1, p. 77, (1793); (Marius T.) Swains, Kool. I11. Ins., I I, t. 59, (1832).

Pap. Thetis, Debeauv., Ins. Afr. et Am., p. 18!), 1. 5, (1805).

Athence Thetis, Hüb., Verz. Bek. Sohmett., p. 36, (1816); (Nymphalis T.) Godt., Enc. Meth., IX, p. 
358, (1823); (Marius T.) Dun., Nat. Lib. Ent., V', p. 164, t. $19,(18: 37)$.

Pap. Petreus, Crum., Palp. Ex., I, t. 87,(1779); Stoll, Sup. Cratu., t. 2, f. 2:il, 2b, 2ec, Larr. et Pıp., (1791); Hurhst, Natursist. Ins. Schunctt., WV, 1. 87, t. 67, $(1790)$.

Latrvil on the Cissuew (Anacardium Occidentale).

\section{GENUS 17. VICTORINA, Blanch.}

286. Stelenes, Linn., (Pap. S.), Syst. Nat., Ed. X, p. 465, S. W. Texas, (1758), El. XII, p. 750, (1767); Mus. Lud. Ul1. Mexico, Rey., p. 218, (1764); Clerck, Icon., t. 35, (1764); Cent. Am,, Fabr., Sist. Ent., p. 456; (1775); Sp. Ins., II, pp. S. Am. 23, 92, (1781); Mant. Ins., II, 1p. 12, 108, (1787); Ent. Srst., III, 1, p. 84, (1793); Cram., Palp. Ex., I, t. 79, (1779); Herlst, Natursyst. Ins. Schmett., III, 1. 188, t. $4 \bar{\imath},(1788)$; DeBaluv., Ins. Afi. et Am., P. 18s, t. V, (1805); (Najas hilaris S.) IIïb., Samm. Ex. Schmett., (1806-1824); (Nymph. s.) Godt., Enc. Meth., IX, p. 378, (1823); Lucas, Pap. Ex., p. 125, t. 69, (1835); (Vict. s.) Dbldy.Il'w., (Gen. Dinr. Lap., IJ, 1. 265, Atlas, t. 33, (1850-1852); Gusse, Ann. Nat. Hist. Ser., 2, Vol. II, p. 268, (1848); Clentu, Enc. Hist. Nat. Pap. I)iur., 1. 126, f. 241, (1851-185.3); S'mul., Buft. Bull., II, p. 257, (1875).

Metamorpha Sthenele, Häl., V'er\%. Bak. Schnnott., p. $43,(1816)$.

Vict. Steneles, Blumch., Hist. Nat. Jus., III, p. 447, (1840); Kirly, Cat., 1. 223, (1871). Petiv., (iazoph., 20, t. 13, (:' 1702).

239, f. . $4,10,(1725)$.

P'ap. Lavinia, Fubr., Ent. Syst., III, 1, p. 22, (1793).

\section{GENUS 18. LIMENITIS, FABR.}

287. Mismpus, Linx., (Pap. M.), Mns. Lud. Uhr. Reg., p. Camada; 264, (1764); Syst. Nat., Ell. XII, p. 767, (1767); United Fabr., Syst. Ent., 1) 481, (1775) ; Sp. Ins., II, 1). States east 55), (1781); Mant. Ins., I1, p. 27, (1787); Ent. of the Rorky Syst., III, 1, p. 50, (1793); Herhst, Natursyst. Ins. Mts. Sichnett., VII, p. 30, t. 158, f. 3, 4, (1794); (Lim. M.) Eimm., Agr. Nat. Hist. N. York, p. 202, t. 47, (1854); Parck., (inide, p. 261, f. 189), (1869).

I'ap. Archippus, ('rom., I'ap. Wx., I, t. 16, A, B, (1779); (Lim. A.) Kirby, Cat., 1. 237, (1871); (Basilarehia A.) Sond., Sist. Rev. Am. Butt., 8, (1872); Buff: Bull., II, 1) 250, (1875).

Anosia Archippe, Hiib., V $\mathrm{er}$. Bak. Simnett., p. 16. (1816). 
Nymph. Disippe, Fodt., Enc. Meth., IX, 1. 39:3, (182.3) ; Harris, Ins. Inj. Veg., Flint's Ed., 1. 281, f. $109,\left(1866^{\circ}\right)$.

Nymph. Disippus, Pill.-Lec., I Lep. Am. Sept., p. 201, t. 55, (1833); Morris, Srn., J. 6i5, (1862); (Jim. D.) Doldy.-Hew., (ien. Diur. I dep., p. $276,(1850-$ 1852); Lint., Proce. Ent. Sine., Phil., III, p. 6i:, (1864); Samul., ('an. Ent., I, p. 94, (1869); Riler, Bd Ent. Rep. State of Misismur, p. 15:?, f. 68, 69, 70, Im., Lall. et [’up., I. ‘. p. 171, (1871).

var. a. Fionempisis, Nob.-The form found in Florida and other parts of the extreme south. Whilst our more northern form is of the same colonr as Danais Plexippus, this soutlern variety exactly mimies in its dark colouration Danais Berenice, with which it associates.

+al). b. O Nu(i,- Whole upper surface deep, hackish l,romn, the venation only a sharle darker and only distinguishable from rest of ground colour on close inspection; the nanal submarginal row and other white spots conspicuously visible $\mathrm{hy}$ contrast with the blackness of rest of wings. Linder surface hut a trifle less dark thin the upper. Taken hy Mr. Jacob Doll in Florida in 1874. Mus. Strecker.

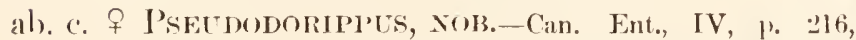
(1872). The mesial black stripe of sccondarics wanting; darkish shade devoid of the usual three white spots. Under surface same as above, save that the submarginal row of white lunules have no intervening black line between them and the reddish ground colour. Taken in Catskill Mts., $N$. York, in 1872, by Mr. T. L. Mead, in whose musenum it now is.

I have alio an example which differs from the above in the total olsolescence of all white lunules in margins of both surfaces; in this the mesial line of secondaries is very faintly visible, in all other points it agrees with the other example just described. It is a $\delta^{7}$ and was taken near IJolyoke, Misss., iu 1871 , by Mr. Jos. E. Chase.

Latrva on various species of willow (Solix), plum (Prunus), joplar (Populuss) and uak (Quereus).

288. Epheston, Stom, (Pap. E.), Suppl. ('mam., 1. 121, t. United 25, f. 1, 1a, (1790); (iodt., Enc. Meth., IX, p. t2, States from (1819); (Nojas turbida E.) In̈̈h., Samm. Ex. the Atlantic Schmett., I, (1806-1824); (Nymph. E.) Harris, Ins. to the Rocky Inj. Vea., Flint's Ell, \%. 283, (1862); (Lim. E.) Mts.; AriPack., Cinikle, 1) 262, (1869).

Pop. Astyanax, Fabr., Srst. Ent., 1. 4t7, (1775); Sir. Ins., II, ґ. 7, (1781); Mant. Ins., II, リ. 4, (1787); (Lim. A.) Kirlyy, Cat., p. 237, (1871); (Basilarchia A.) Scmul., Sist. Rev. Am. Butt., s, (1872); Buff. Bull., II, j. 249, (1875).

Pap. Wrsula, Fabr., Ent. Srst., III, 1, p. 82, (179:3); Ab.-S, Ins. (ia., I, t. 11), (1797); (Nymph. U.) Godt., Eue. Meth., IX, 1. :880, (1823); Bil.-Ler., Lep. Am. Sept., p. 199, t. 5i3, (1833); Morris, Syn., l. 64, (1862); (Lim. U.) Riley, Cim. Ent., I II, p. 52 , Lar., (1871); W. H. Edivls., l. c., V, p. 10, $(1873)$. 
Callianira, Ephestiraena, Hüb., Verz. Bek. Sehmett., p. $38,(1816)$.

var. a. VIRIDIs.--The blue of upper surface replaced ly green. ah. h. Rubints.-Blue of upper surface replaced by fulvous. Under inrface suffised with fulvons. Deseribed by T. L. Mead in Can. Ent., IV, p. 217, (1872).

Jarva on willow, will guoselnerry, wild cherry, apple, plum, hawthorn, aik, Vaccineum stramincum, Carpinus Americana.

\begin{abstract}
Fabrieins, in his Syst. Ent., (1775), had used for this insect the name of Astyunax, but in the Ent. Syst., (1793), lue ehanged it in Ursula in enserpuence of the previoms name alrearly having been used to designate one of the o rarietieslof Pap. Pammon (figured in Don., Ins. Ind., t. 19), both insects being in the genus 1'apilio as then definal; his action in making this change, and thas, as he sulpposed, avoiding synonyty, was of course right, and his later name would have stood had not Stoll, (in 1790), in his Supplement to Cram., three years prior to this elrange, figured and eiterl the speeies as Ephestion, and as, at the time of his so doing, Astyanax was a synonym, his name will have to be retained, and the later one of Ursu. la, even though applied by Fabrieius, shonld be dropped.
\end{abstract}

289. A rтukmis, Dre., (Pap. A.), Ill. Fx. Ent., II, t. 10, (177.3); (Lim. A.) Siv, Am. Ent., II, 1. 2:3, (1825); (Nymph. A.) Bell.-Lier., Le'. Ali. S'pr., 1) 202, t. 5̆t, (1833); (I.im. A.) Dhbly.-Hew., Gen. Diur. Lep., II, p. 276, (1850-1852); Emm., Agr. Nat. Hist. N. York, p. 211, t. 4.3, (1854); (Nymph. A.) Harris, Ins. Inj. V'eg., Flint's El., p. 243, t. 1, (1862); Morris, Sin., p. 6.5, (1862); (Lim. A.) Lint., Proc. Ent. Sinc., Phil., IIJ, P. 62, (1864); Reak., I. r., VI, 1. 14:, (1866(i); Park., (ruirle, ). 262, (1869) ; Samml., (an. Ent., I, P. 95), (1869); (Brasilurdin A.) Soudl, Syst. Rev. Am. Butt., 8, (1.572); Buff: Bull., I], 1. 24!), (1875); (Lim. A.) IV. II. Edwls., C'an. Ent., V, p. 232, (1873); Mead, l. ․, VII, 1. 162, (1875).

Nymph. Altemis, I)bldy., (at. Lep. B. M., I, 96, (1844); (Lim. A.) Kinhy, Cat., p. 2:37, (1871).

I'ap. Lamina, Folon., Ent. Sist., I I I, 1, 1. 118 , (17.98); (Nymph. L..) (ienlt., Ene. Meth., IX, p. 380, (1823). rat. a. Proserpixa, IT. H. Euwns., Proc. Ent. Soc., l'hil., V, p. 148, (1865); Trans. Am. Ent. Sinc., 1, p. 286, t. Y, (1867); Butt. N. Am., 1, t. 1, Lim., (1868); Kirby, Cat., p. 237, (1871); Strerk., I rep., New. Eng. $S$ attes, $N$. York, Penna. Rhop.-Het., p. 70, (1873); II. II. Ekwols., Can. Ent., V, 1. 23:2, (187:3); (Basilarchior I'.) Crote, ('au. Ent., V, 1. 143, (1873); Soud., Buft. Bull., I1, 1). 249 , (1875).

On upper surface the white hand of primaries either partially obsolete or entirely so; on secondaries entirely wanting. Below sometimes obsolete on all wings and somelimes partially present.

latra on willow and hatworn. 


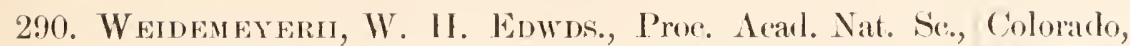
Phil., ю. 162, (1861); Butt. N. Am., I, t. 2, L.im., Montana, (1869); Morrik, Syn., p. 327, (1862); Reak., P'roc. Utalı.

Fint. Soc., I’hil., VI, 1. 143, (1866); Kirlsy, Cat., P. 236, (1871); Mead, Wheeler's Rep., V, 1. 770, t. 38, (1875); (Bresilarchia W.) Send., Buff. Bull., I I, 1. 249, (1875).

291. Lorquixi, Bdi., Ann. Soc. Ent. Fr., 2ne Ser. X, p. 301, California, (1852) ; Morris, Sytr, p. 66, (1862); Behr, Pror. Oregon.

(al. Acarl. Nat. Si., III, p. 127, $(1864) ; \mathrm{W}$. H. liwhls., Butt. N. Am., I, t. 3, Lim., (1869); (Adelthe L.) Kirby, Cat., p. 2:35, (1871); (Lim. L.) Hy. Edwols., Proce. Cal. Acad. Nat. Sc., V, p. 171, Iar., (1873); Manl, Wheeler's Rep., I, p. 770, t. 38, (1875); Sंcul., Buft: Bull., II, 1. 250, (1875).

Iarva om willow (Salix).

292. Bredowir, Hub., (Adelpha B.), 'Mutr. Ex. Schmett., f. California, 8.5, 826, (18:57); (Lim. I3.) W. H. Fdwds., Butt. Arizona, \. Am., I, t. 4, Lim., $(1870)$; (Adelpha B.) Kirloy, Oregon, Cat., p. 235, (1871).

Mexico.

Lim. Eulalia, Dbldy.-Hew., ('мn. Diur. Lep., t. 36, (1850-1852); Bill., Imn. Soc. Ent. Fr., 2me Ser. X, P. 301, (1852); W. H. Edwds., Proe. Aral. Nat. Sc., Phil., J. 225, (1862); Behr, Proc. Cial. Ararl. Nat. Se., I11, p. 127. (1864).

Heterochrou Californica, Butl., Proe. Zool. Soe. I und., ア. 485, (1865); (Adelpha C.) Kirly, Cat., ए. 235, (1871); (Lim. C.) Mr. Edwds., Proc. Cal. Aral. Nat. Sc., V, p. 171, (1873); Mead, Wheeler's Rep., I, p. 770, t. 38, (1875); Sevul., Buft. Bull., II, P. $250,(1875)$.

This species connects Limenitis with the subgenus Heterochroa, Bdl., (Adelpha, Hub.)

GENL'S 19. APATURA, FABr.

293. Celtis, Bnd.-Lec., Lep. Am. Sept., p. 210, t. 57, (18:3); Wentwarl Morris, Srn., p. 68, (1862); Kirly, Cat., p. 262, from Vir(1871); Ii. H. Filwds, Butt. N. An., II, t. 1, ginia to Аp., t. 1, 2, 3, (1875). Texas,southPap. Lyycaon, Fubr., Ent. Syst., I II, 1, P. 228, (1793); ward to the Herbst, Natursyt. Ins. Sehmett., VIII, p. 295\%, (mulf of (1796); (satyrus ? I.) Dbldy.-Hew., Gen. Dinr. Mexico.

Lер., II, p. 392, (18.50-1852); (Doxocopra L.) houd., Syst. Rev. Am. Butt., 9, (1872); (ipature L.) Riley, Trans. St. I muis Acad. Se., I II, 1. 193, $(1873)$; bth Ent. Rep. State of Missomi, p. 187, f. 39, 40, (1874); (Chlorippe L.) Sent., Buff: Bull., II, 1. $249,(1875)$.

ab. a. Of Alb., figmed in W. H. Wilwds.' Butt. N. Am., II, t. 1, A 1., f. 4, 5, (1875).

A form occurring sometimes, in first generation, with the ground colour of both surfaces white. 
var. b. Alicis, W. H. Enwos., Jint. N. Am., I; t. 1, Ginlf States Ap., $(1868)$.

from Flarida

Much larger. Ground colour of upper surface inclined to rerl- to I antisiana. dish tawny.

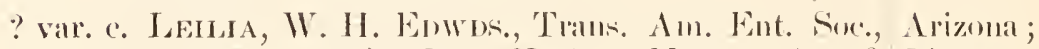

V, 1. 10:, (187.1); Butt. N. Im., 1], t. 1, Ap., f. LAano $6,7,(1875)$.

Estraciato.

More reddish in tint of apper surface than the preceding, less fuscous on apical parts of primaries, and with three ocelli on upper and under surface of primaries insteal of but two as in all the other fornss.

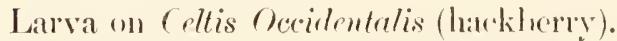

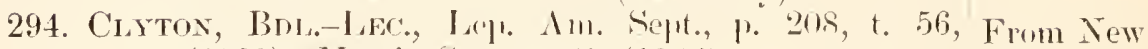
(183.3); Monris, Syn., p. (is, (1862).

Ap. Clyton, ear. Oicellate, II. H. Lidurls., Butt. X. A แ1., II, t. 2, A 1., f. 1, 2, 3, 1, (1876).

Pap. Herse, Fabr., Ent. Syst., I II, 1, p. 2.2!, (17!:3);

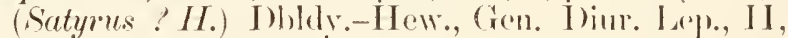
392, (1850-1852); (Doxocopa H.) Reud., Syst. Rev.

An. Butt., 9, (1872) ; (Apatura H.) Riley, Trans.

St. Lomis Acad. Sc., III, 1). 198, (1873); 6th Ent.

Rep. State of Mismomi, 1). 140, t. 41, 42, (187t);

(Chloripye H.) Sirurl., Buff. Bull., II, 1. 24s, (1875). Apatura Idyja, Kirby, Cat., ए. 262, (1871).

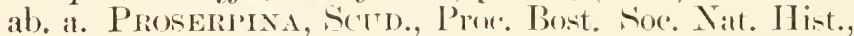

XI, p. 401, (186s); Trans. Chicango A (adl. Nat. Sur.,

I, 1. 332, (1869); W. H. Elwrls., Butt. N. An.,

II, t. 2, I I., f. 5, 6, (1876).

Entire upper surface of secondaries obscured with blackish, ocelli olssolete.

fab. b. O NIG. - Tpper surface of all wings obsemed with l,ackish. Mus. Streck.

Berks Co., l'enna.

var. c. Fions, IT. H. Emwds, Butt. N. Ans, II, (1876i). Florida.

of large size. Upper surfice bright orange-fermginous. Under surface strongly ferruginous.

Latrva on ('eltis Occidentalis.

There is strong doubt as to whether Fabricius' descriptions of Lycaon and Herse were meant to apply to the species since designated as Celtis and Clyton hy Bdl. ats there is disagreement in many particulars; besides it woulet appear that the said deseriptions of Fabricius were not taken from real insects, but from the pictures of inscets, in which case all claims to priority for his names would fall; and, at any rate, as the species have been known by Ball.'s names for over forty vears, there can be nothing gained by suppresing them in favor of those of Fabricins.

Fabricius' Ilerse I really believe to be identical with Idyja, Hub., a Cuban species.

\section{GENUS 20. AGANISTHOS, BHL.}

295. Orios, Fabr., (Pap. O.), Syst. Ent., p. 485, 11. 185, :- S. Florida, (1775); Sy. Ins., II, l. (it), (1781); Mant. Ins., II, Antilles, 1. 29, (1787); Ent. Syyt., III, 1, 1. 5), (179:3); C'ent. and (Nym. O.) Ciodt., Enc. Meth., IX, 1. 368, (1803); S. Im. 
(Ayan: O.) Ball.-Isec., Lep. An. Sept., 1) 195, t. 52, (1833); Bull., Sp. Gen., t. s, (1836); (Nym. O.) Lnals, Pap. Ex., p. 12t, t. 66, (1835); (Agum. O.)

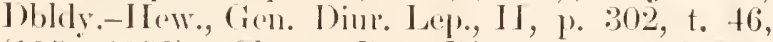
(1850-1852); Chenn, Iay. I)inr., p. 148, f. 264, (1851-1853); (Historis ().) Srrul., Butl. Bull., II, 1. $248,(1875)$.

Pap. Odius, Fabr., Syst. Ent., 1. 457, n. 60, (1775); Sิ). Ins., I I, 1. 2.:3, n. 9.5, (178]); Mant. Ins., II, l) 12, 11. 111, (1787); Sill., Gresch. Ins., t. 13, (1776); Herbst, Natursyst. Ins. Solmett., [I], p. 100, t. 35, (1788); (Hamad. undata O.) Hïl.,

Simmm. Ex. Shhnett., I, (1806-1816); (Ayan. O.)

Kirly, Cat., 1. 26:3, (1871).

Pap. Denuë, Ciem., I, t. 84, (1779).

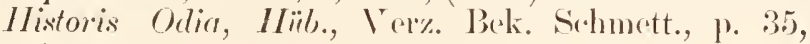
(1816).

\section{GENUS 21. MEGISTANIS, WESTW}

296. Acheronta, FalsR., (I'lp. A.), Srst. Eut., p. 501,(1775); ? Texas,

Sp. Ins., II, p. 87, (1791); Mant. Ins., II, ». 47, :S. Florida, (1787); Ent. Syst., III, 1, p. 76, (1793); (Coed A.) Antilles, Iliih., Verz. Bek. Solnmett., p. 4\$, (1§16); (Nym. Mexico, A.) Cinelt., Ene. Meth., IX, 1. 3558, (182:3); (Agan. Cent. and A.) Kinls, (att., 1. 264, (1<7) ; Sicul., Buff. Bull., S. Am., to II, 1. $247,(1875)$. Brazil.

Pap. Ciedmus, Cram., Paj. Ex., I, t. 22, (1779);

Herlst, Natursyst. Ins. Selumett., I V, p. 24, t. 57, f. 1, 2, (1790); (Megis. C.) Dhldy.-Hew., Gen. Dinr. Lap., II, 1. :311, t. 36, (1850-1852).

Pap. Pherceydes, Crum., Pay. Wx., IV, t. 330, (1782);

Herlst, Natursyst. Ins. Arehnucte, IV, p. 26, t. 57, f. 3, 4, $(1790)$; (coea f’) Hïl., V'r\%. Bek. Sehmett., (1816).

\section{GENUS 2.2. PAPHIA, W WATW.}

297. Trogiconyta, Farz., (I'upilio T.), Syst. Ent., P. 502, n. S. Illinois, 250, (1775); Sp. Iı., II, 1.87, (1781); Mant. Kentucky, Ins., II, 1. 17, (1787); Ent. Syst., III, 1, 1. 77, M issonil, (1798); (I'aphice T.) J)blely.-IIew., Gen. I)iur. Kansas, Ley., II, p.::18, (1850-1852); (Anace T.) Kirls, Texas. (at., 1. $276,(1871)$; Sicul., Bull. Bull., II, 1. 248, $(1875)$.

Ancer Troglodita, Miib., Verz. Bok. Silnmett., p. 48, (1816).

Papilio Astinux, Cram., Pap. Ex., IV, t. 397, A, B, o, (1782); Ilerhst, Natursist. Ins. Schmett., IV', 1. 28, t. 57, (1790).

Pripilio Astina, Fabr., Ent. Syst., I II, 1, P. 81, (1793); (Hamadryas undatr A.) Hïh., Samm. Ex. Sichmett., (1806-1816). 
Paph. Glycerium, Riley, (nec I)bldy.), Am. Ent., II, p. 121, f. 81-83, (1870); W. H. Edwrls., Butt. N. Am., t. 1, Paphia, (1870); Morris, Syn., p. 67, (1862). Anace Andria, s'cud., Buft. Bull., II, 1. 248, (1875). I firvat on wild sage (Croton ('apitatum).

Pup. Glycerium, Dbldv., (in Gen., II, p. 319, 1. 10, t. 50, f. 1, 1850-1852), is a Mexican species, differing decidedly, not only in markings but even in shape of wings, especially of the primaries.

Pap. Astinax of Cran.'s t. 337 recognizably rejresents the of of our species, though the tails are a little exaggerated in length and the red colour of upper side is too deep for the $q$, being nearer that of the male. Cram. say's the original of his figIres was from the island of St. Thomats, in the W. Indies.

Herbst's fig. (vol. IV, t. 57) is a copy of Cramer's.

IIamadryas undata Astina, in Ex. Schmett, I, also represents, I think, the f of our species, though it differs in some slight resieets from Cram.'s figure.

\section{FAMILY IX. SATYRIDE. GENUS 1. PRONOPHILA. WEsTW.}

298. Tritonia, W. H. Edwos., (Geirocheilus T.), Trans. Am. Arizona. Eut. Six., V, p. 1s, (1874); (Gyrocheilus T.) ścut., Butf: Bull., II, p. 241, (1875).

\section{GENUS 2. DEBIS, W ESTW.}

999. Pontlanina, Fabr., (Pap. P.), Sp. Ins., II, 1. 82, (1781); Camala, lint. Sist., III, 1, 1. 10:3, (179:3); Herbst, Natur- IT. States syst. Ins. Sohmett., VIII, 1. 285, (1796); (Satyrus east of the I’.) Brll.-Lec., Lep. Am. Sept., p. 220; t. 58, (1833); Rucky Mts. (I)ebis P.) Dbldy.-Hew., Gen. Diur. I sep., II, p. 360, (1850-1852); (Lethe P.) Butl., Cilt. Satrr. B. M., 1. 114, (1868); (Euptychice ? P.) Kirby, Cat., 1. 55, (1871); (Enodia P.) Send., Syst. Rev. An. Butt., 5, (1872) ; Buff.'Bull., II, 1. 241, (1875).

Pup. Iortlundia, Fabr., Mant. Ins., II, p. 45, (1787). ()rerss Marmorea Andromacha, Müb., Simm, Kx. Sichmott., I, (1806-1816); (Mipparchia A.) Say, An. Ent., II, t. 30, (1825); ('́ap. A.) Brown, (onst. Mis. Butt., I, p. 195, t. 44, (183:); (Hip). A.) (umse, Can. Nat., 1) 246, (1840); (I)ebis A.) Morris, Syru, p. 78, $(1862)$.

I sillvil on entalis.

fal. a. $\sigma^{\lambda-S}$ pots on upeer surface of primaries yery small and al- Texils. most olsolete, the transverse lines entirely wanting. In the (rells (exeepting the discoidal) accompanying the veins are hroal furry fuscons lines conneded inwardly, open outwardly, leaving sagittate spaces of the brown ground colour in the inillate of each cell. Mus. Streeker.

\section{GENUS 3. NEONYMPIIA, HUB.}

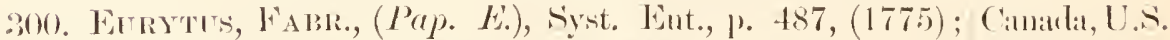

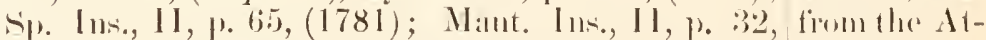
(1787); (Euptychice E.) Butler, Proc. Kool. Soce, lantireto Lombl., p. 165, (1866); Kirlyy, Cat., p. 4s, (1871); Kinl., Nab. and 'Texals. 
(Megisto E.) Seud., Syst. Rev. Am. Butt., 7, (1872));

(Cissia E.) Buft. Bull., I I, 1. 245, (1875).

Pap. Eurytris, Fabr., Ent. Syst., III, 1, P. 157,

(1793); Herlst, Natursyst. Ins. Schmett., V'III, p.

96, t. 196, (1796); (Neon. E.) Dhbly.-Iew., (ien.

Diur. Lep., II, p. 375, (1850-1852); Chenu, Pap.

I)iur., p. 281, (1851-1853); (Hipparehice L.) Harris, Ins. Inj. Veg., Flint's Ed., 1). 306, 1. 129,

(1862); (Noon. E.) Patck., Guicle, 1). 264, (1869).

Satyrus Eurythris, Godt., Enc. Meth., IX, p. 494,

(182:3); Bdl.-Lec., Lej. An. Sept., t. 61, (1833);

(Neon. E.) Morris, syn., 1. 73, (1862); Samul,

(an. Ent., II, 1) 139, (1870).

Pap. (ymela, ('ram., II, t. 132, (1779).

Megisto ('ymclia, Hül., Ver\%. Bek. Schmett., p. 5t, (1816).

fab. a. - With all the ocelli of enormous size.

Florida.

Lalva on grass.

301. Rubricata, IT. H. Enwds., Trams. Am. Ent. Soc., III, Texas.

1. 212, (1871); (cissia R.) Scurl., Butf: Bull., II,

P. $245,(1875)$.

302. Sosvbius, Fabr., (Pap. S.), Ent. Syrst., IT1, 1, p. 219, Southem (1798); Herlst, Natursyst. Ins. Sehmett., VIII, 1\% laalf of the 148, (1796); (Satyr. S.) Godt., Ene. Meth., IX, P. U. States 495, (1823); Bal.-Lec., Iep. Am. Sept., t. 63, finm the At(1833); (Neon. S.) Dobldy.-Hew., Gen. I)iur. I sep., lantic west to 1], 1. $375,(1850-1852)$; Morris, Syn., J. 74, 'Texas incln(1862); (bupt. S.) Butl., Proc. 'lool. Soc., Iond., sive; Mexр. 474, (1866); Kirly, Cat., p. 49, (1871); (Cissia ieo; Cent.

S.) Soud., Buff. Bull., II, 1. 245, (1875). Aı.; S. An.

Prap. Camerta, Cirm., Palp. Ex., IV, t. 293, F, (1782);

(Neon. (') Dbllly.-Hew., Gen. Diur. I sep., II, ). 375, (1850-185.2); ( Hupt. (:) Kirloy, Cat., 1). t8, (1571).

Prip. Cimertus, Herbst, Natursyt. Ins. Solnuett., VIII, 1!. 91, t. 195), (1796).

303. Phorion, Fabr., (Pap. P.), Sp. Ins., II, p. 138, (1781); Southem Mant. Ins., II, 1. 92, (1787); Wut. Syst., II I, 1, 1). U. States 218, (1793); Herhst, Natursyst. Ins. Solmett., p. firom the At147, (1796); (Neon. P.) Dhldy.-Hew., Gen. Diur. lantic to lete., II, 1. 375, (1850-1852); (Eupt. l') Kirlyy, 'Texals.

('at., p. 55, (1871); (Megisto P.) Soud., Syst. Rev'. Am. Butt., 7, (1872); (Neon. P’.) Buff. Bull., I I, ]'. $244,(1875)$.

Pap. Areolatus, Abb.-S., Ins. Ga., I, 1). 25, t. 13, (1797); (Satyr. A.) Godt., Enc. Meth., I X, 1. 494, (1823); Bell.-Lec., Lep. An. Sept., t. (3:3, (18:3:3); (Neon. A.) Dbldy.-Hew., Gen. Diur. Lep., Il, l). 375, (1850-1850); Morris, Syn., [. 74, (1862).

Euptyc. Areolete, Kutl., Proc. 'Kool. Soc., Lonel., p. $498,(1866)$. 
Oreas fimbriata Helicta, Hïb., Samm. Ex. Schmett., I, (1806-1816); (Neon. H.) Verz. Bek. Schmett., p. $65,(1816)$.

Larva on Audropogan Nutans, Panicum Sanguinale.

Fabr.'s diagnosis in the Sp. Ins. is not so plain, bnt in the Ent. Syst. it is more to the point: "Alis integerrimis supra fuscis immaculatis, posticus subtus strigis flavis ocellisque trihus oblongis. Habitat, $-\longrightarrow$. Mus. Britam. Parviss. Alae omnes supra fuscae, immaculatie. Subtus anticae fuseae, immaeulatae, posticae strigis quatuor flavis, quarum 2-3 utringue coennt \& inter has ocelli tres valde oblongi, atri iride Hava punctisqne plurimus pupillaribus, argenteis."

Also Herlst's version from Vol. VIII, p. 147: "Die Fluegel sind oherhalb braun, ungefleckt; unten sind die Obertluegel gleichfalls ungefleckt braun, die Unterfluegel aher haben vier gelbe linien, von welchen die zweyte und dritte an beyden Seiten zusammenstossen, und zwischen diesen sind drey sehr langlich runde schwarze Augen mit gelben Ringen und mehreren silbernen Pupillen."

These lescriptions point undeniably to this species, and loth as we are to ignore the more familiar name of Areolutus, we must nevertheless allow that, according to the law of priority, it is untenable.

304. Gemma, Hur., (Neon. G.), Zutr. Ex. Schmett., I, f. 7, 8, Sonthern (1818); Ver\%. Bek. Schmett., p. 65, (1816); (Satyr. States from G.) Bdl.-Lece, Lep. Am. Sept., t. 62, (1833); the Atlantic (Neon. G.) Dbldy.-Hew., Gen. Dim. Isep., II, p. to Texas. $375,(1850-1852)$; Morris, Syn., p. 73, (1862); (Eupt. G.) Butl., Proc. \%ool. Soc., Loml., 1. 500, $(1866)$.

Satyrus Cornelius, Gorlt., Ene. Meth., IX, p. 493, (1823); (Eurygona C.) D)bldy.-Hew., Gen. Diur. Lep., II, p. 438, (1850-1852); (Eupt. (') Kirloy, Catt., 1. 55, (1871); (Neon. ( () Sentl., Butr. Bull., II, 1. $244,(1875)$.

larvil on grass.

Whether this be identical with the Cornelius of Fabr. I am nnable to determine from the cloubtful and unsatisfictory diagnosis of the latter; thongh it is possible that such may be the ease. But as Hubner las given most excellent figures, and moreover it is snpposed that Fabr. was unacquainted with the insect in nature and that he drew his deseription from a picture, it is probably licst to retain IInbner's name of Gemma, by which the species las so long been generally known.

I here append Fabricius' description of Cornelius, also the same from Herbst published three years later.

Fabr., Ent. Syst., III, 1, 1. ¿20, n. 689, (1798): "Alis integerriunis olscure enereis; posticis ocellis quatuor approximatis. Habitat - Dom. Drury. Medius alae supra obecure einereae, anticae immaculatae, posticae vcellis quatuor approximatis, marginalibus, fuscis, snbtus paullo pallidiores, fuseo undatae, posticis ocellis quatuor uarginalibus, approxi. matis, atris pupilla argentea."

Herbst, Nat. Ins. Schnett., VIII, p. 139, (1796): "Pap. Cornelius. Er ist von mitlerer Groesse. Oberhalt, sind die Fluegel dunkel aschgran, die obern ungefleck, die untern haben vier dicht neben eiramler stehenle, Augen, sie stehen :m Aussenrande und sind bram, unten sind die Flnegel etwas blasser brann, wellenfornig; die vier Augen anf den Unterflnegeln sind anch hier, aher schwarz mit einer silbernen Pupille. Das Vaterlanl ist mubek:mnt." 
†*305. Henshawi, W. H. Euwbs., Trans. Am. Ent. Soc., V, A rizona. 1. $205,(1876)$.

\section{GENUS 4. ERERIA, DALM. (ITniola, schrli.)}

306. Tyndaris, Esir., (Prp). T.), Schmett., I, 2, 1. 97, t. 67, Colorado ; (1781); ()hs., Sidmett. Eur., I, 1, p. 299, (1807); Swiss Alps, Iiib., Eur. Sehmett., I, f. \, 971-974, (1829- IIungary, 1841); (Hipp. T') Frever, Nen. Beit., I, t. 80, f. 2, Italy, (1833); (Mamiole T.) Kilby, Cat., P. 63, (1871); France. (Ereb. T.) Stgri., Cat., P. 25, (1871).

Pap. Herse, Brk., Natut'. Sehmett., I, p. 94, (1788).

Pap. Cossionides, Esp., Solumett. Eur., I, 2, t. 103, f. 2, $:,(1790)$.

Pap. Dromms, Fabr., Eut. Nyst., I I I, 1, 1. 221, (1793); (Satyr. 1).) Godt., Ene. II (th., IX, 1. 528, (1823); Lucas, Pap. Eur., p. 85, t. 39, (1834); (Ereb. D.) H-S., Schunctt, Eur., I, p. 59, t. :37, f. 169, 170, (1843); Inbldy.-Hew., Gen. I)im. Le]., II, ए. $379,(1850-1852)$.

Pap. Tymdarellus, Merbst, Natursist. Ins. Sehmett., VIII, p. 135, t. 202, (1796.).

Prop. Clco, Müb., Eur. Schmott., I, f. 209-212, $(\because 1796)$; Gorlt., Hist. Nat. Lep. Fr., II, 17, 5, 6, (1821-1824).

Hipparchia Nelens, Freyer, Neu. Beit., I, t. 80, f. 3, 4, (18:33).

Erebia Callias, W. II. Edreds., 'Trans. Ant. Ent. Soe, III, J. 27 t, (1871); sicurl., Buff. Bull., II, p. 243, (1875).

Eireb. Tymdarus, var. ('ullius, Mead, Wheeler's Repr,

$\mathrm{V}$, 1. $775,(1875)$.

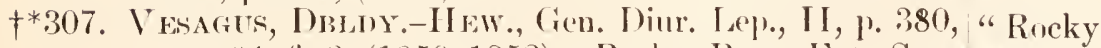
t. 64, f. :3, (1850-18.52) ; Reak., Proc. Hut. Soc., Mts."

Phil., VI, I. 143, (1866); (Maniola I.) Kirby, Cat., P. 64, (1871); (Lieb. I:) Scond., Butf. Bıll., II, 1. $243,(1875)$.

The locality is given in Dhldy, as "? Rocky Mountains." The figure represents only the upper surface and is entirely unlike any known N. Am. species, nor do I helieve it was ever captured in this comntry, unless possibly in Arizona; the figure resembles more in appearance some of the species of the S. Am. genus Lymanopoda than any of the N. Am. Satyridae.

308. Emipsoden, Butr., Cat. Sat. B. M., p. 80, t. 2, f. 9, Colorado.

(1868); (Maniola E.) Kirly, Cat., P. 65, (1871); (Ereb. E.) Scud., Butf: Bull., II, 1). 24:3, (1875); Mead, Whecler's Rep., I', p. 775, (1875).

Ereb. Rhodia, W. H. Eiluds., Trans. Am. Ent. Soc., III, P. 27?, (1871).

†*309. Ha roexin, U. H. Eowns. Hayden's Rep. Exp. Mon- Montana. tana, p. 467, (1872) ; Soud., Buff. Bull., II, p. 243, $(1875)$. 
+*310. Rossit, Curt., (Hipp. R.), App. Nat. Hist. Ross' 2d BonthiaVoy., p. 67, t. A, f. 7, (1835); (Ereb. R.) Dhldy.-Felix. Hew., (ien. Diur. Isep., II, J. :380, (1850-1852); (Maniola R.) Kirly, Cat., p. 67, (1871); (Ereb. R.) Seud., Buff. Bull., II, p. 243, (1875).

This is probably a form of Embla, Thun.

†*311. Disa, Var. Maxcixus, Dridy.-Hew., (Erebia Mrencinus), (ten. Diur. Lep., II, 1. 380, Atlas, t. 5t, Columbia ; (1850-1852); Reak., l'roe. Eut. Soc., Phil., VI, p. Alaska. 149, (1866); (I)isa, var. M.) Butl., Cat. Sat. B. M., p. 89, (1868); (Maniola M.) Kirloy, Cat., p. 67, (1871); (Ereb.M.)Send., Buff.Bull., II, p. 2t3,(1875).

312. I) Iscomder, Kirby, (Hipparchic T).), Fann. Bor. British Am. Im., IV, p. 298, t. 3, f. 2, 3, (1837); (Ereb. D.) Doblaly.-Hew., Gen. Diur. I,ep., II, p. 380, (18501852); Morris, Syn., p. 75, (1862); (Maniola D.) Kivly, ('at., p. 67, (1871); (Ercb. D.) Stgr., Cat., 1. 26, (1871); Scud., Buff. Bull., II, p. 243, (1875).

†*313. Fasciata, Butl., Cat. Sat. B. M., 1. 92, t. 2, t. 8, Aretie Am. (1868); (Maniole F.) Kirby, Cat,, p. 63, (1871); (Ereb. F.) Scmrl., Buff. Bull., II, 1. 243, (1875).

This may be identical with Discoidalis, but I have had no op. portunity of examining Butler's figure, hence cannot speak with any certainty.

\section{GENUS 5. CHIONOBAS, BuL. (Eneis, Hüb.)}

314. Jutra, IIrb., (Pap. J.), Eur. Sichmett., f. 614, 615, Lahrador, (1800-1s23); (Chion.J.) Bdl., Icones, t. 38, f, 1-t, Canada, (1832); (Sutyr. J.) Dup., Lep. Sup., I, t. 40, f. 3- Norway, $5,(18: 2)$; Kett., Ins. Lap., 1.902, (1840); (Chion. Istppland, J.) H-S., schmett. Eur., !, f. 116-118, (1843) ; Sweden, I)hldy.-Hew., Gen. Diur. Lep., II, p. 382, (1850- N. Rusia, $1852)$; Wallengr., Skand. Dagí., 1) 46, (1853); Siberia. Mush., Wien. Fnt. Mon., VII, p. 201, (1863); Scul., Proc. Ent. Soc., Phil., V, p. :), (1865); l'akk., Guirle, 1. 26:3, (1869); Monch., Stett. Ent. \%eit., 1. 122, (1870); ((Encis .J.) Kirby, Cat., p. 68, (1871); Sterr., Cat., p. 27, (1871); Scud., Buft. liull., I1, 1). 2+1, (1875).

P'ap. Norna, rar., Ochs., Schmett. Eur., I, 1, p. 202, (1807), IT, 1. 134, (1816), X, p. :31, (18:34).

('hion. Brilder, Bdl., Icon., I, 18!), t. 39, 1'. 1-3, (18:32);

Icon. du Reg. An. par Guer. Ins., t. 80, f. 1, la, (1529-1844); (Satyr. B.) Dup., I.p., I, t. 49, f. 4, 5, (18:32); (Chion. B.) Bell.-Lec., Lep. Am. sept., 1. 216, (18:9:3); (Satyr. B.) \%ett., Ins. Lalp., p. 902, 11. 6, (1840); (Chion. B.) H-S., Schntet. Eur., I, f. :3s4-386, (184:3); Morris, Syn., p. 71, (1862).

Enmenis Balderi, Hüb., '/utr., f. $981,982,(1837)$.

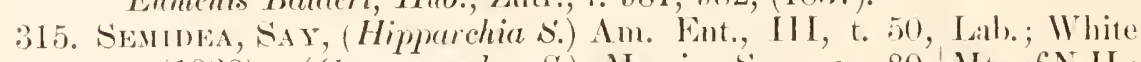
(1828): (Cocnonympha S.) Morrin, sinn, ए. 80, Mts.of N.H.; (Chion. s.) 1. $351,(1862) ;$ (Ilip). S.) IIarris, Ins. IIts. of Col. 
Inj. Veg., Flint's El., p. 304, f. 126, (1862); (Chion. S.) Seurl., Brst. Jnl. Nat. Hist., VII, p. 621, t. 14, t. 2-8, (1863); Proc. Ent. Soc., Phil., V, p. 20, (1865); Pack., Guide, p. 263, f. 190, (1869); Mosch., Stett. Ent. Zeit., p. 123, (1870); (Oeneis S.) Sterr., Cut., p. 27, (1871); Kirby, Cat., p. 70, (1871) ; Seucl., Buff. Bull., II, p. 240,(1875); (Chion. S.) Mearl, Wheeler's Rep., V, p. 776, (1875).

Chion. Oeno, Bdl., Ieones, Hist. Lep., I, 1. 195, t. 39, f. 4-6, (18:32); (Satyr. O.) Dup., Hist. I rep., I, t. 49, f. 1-3, (1832); (Cliion. O.) Bdl.-Lee., Lep. Am. Sept., p. 220, (18:3); H-S., Sehmett. Eur., I, p. 71, f. 59,60 . f. 123,124 , ab. with ocelli, (18431856 ); Mosch., Wien. Ent. Mon., VII, p. 211,(1863).

Chion. Also, Bdl., Ieones, Hist., I, p. 197, t. 40, f. 1, 2, (1832) ; H-S., t. 78, f. 381, (1843-1856).

I alva on Carex Rigida.

316. Crambis, Frey., (Pap. C.), Neu. Beit., T, t. 440, f. Labrador. 3, 4, (1845); (Chion. C.) Dblly.-Hew., Gen. Diur. Lep., I I, p. 38:3, (1850-1852) ; Mosch., Stett. Ent. Zeit., p. 12:, (1870); (Oeneis (!) Stgr., Cat., p. 27, (1871).

Chion. Also, Morris, Syn., p. 71, (1862); Moseh., Wien. Ent. Mon., VII, p. 205, (1863).

Hipp. Subhyalina, Curt., App. Ross' $2 \mathrm{~d}$ Yoy., p. 68, (1835); ((Eneis S.) Kirby, Cat., p. 70, (1871).

Chion. Taygete, H-S., Schmett. Eur., I, p. 70, t. 24, f. 112-115, (1843) ; Leler, Ver\%. Zool. Bot. Ver., $24,(1862)$.

Chion. Oeno, Scud., Proc. Ent. Soc., Phil., T, \%. 13, (1865) ; Buff. Bull., II, p. 240, (1875).

(Eneis Oeno, var. b. Crambis, Kirby, Cat., 1. 70, (1871).

Oeneis Assimilis, Butl., Cat. Sat. B. M., 163, t. 2, f. 10, (1868); Kirly, Cat.. p. 70, (1871).

317. Taygete, Hub., (Oeneis T.), Samm. Ex. Schmett., III, Labrador.

Nymph. IX, Oreal. D. Nubilace, 4, f. 1-4, (18161824); (Chion. T.) Ibbldy.-Hew., Gen. Diur. Lep., II, 1. 383, (1850-1852); (Chinobas T. ㅇ) W. H. Eilwels., Proc. Acarl. Nat. Se., Phil., p. 57, (1862); Mosch., Wien. Ent. Mon., VII, p. 213, (1863); (1Eneis T.) Kirby, Cat., 1. 70, (1871).

('hion. Bootes, Bdi., Icon. Hist., p. 191, t. 37, f. 1-6, (1832); (Gatyr. B.) Dup., Lep., I, t. 32, f. 3-5, (1832); (Hipp. B.) Ochs-Treit.., Schmett., X, 1, 1. 32, (1834); ('hion. B.) Bull., Sp. Gen., I, t. 13, f. :3, (1836); (Eumenis ?'B.) Hül., Eur. Sehmett., I, f. 1025-1028, (?. 1841); (Chion. B.) H-S., Shomett. Eur., I, P. 69, t. 80, f. 391, 392, (1843$1850)$; Leeler, V'ers. Zool. Bot. Ver., (1852); Wallengr., Skand. I)agf., p. 46, (1853); Morris, Syn., 1. 72, (1862); Mosh., Stett. Ent. Keit., 1. 124. (1870); (Cineis B.) Kirby, Cat., p. 70, (1871). 
('hion. Bore, Scud., Proc. Fint. Sor., Phil., V, p. 10, (1865).

(Eneis Bore, var. Tayyete, Sterr., ('at., p. 27, (1871).

Chion. Calais, Scud., Proc. Hut. Soc., Pliil., V, p. 7, (1865).

Moschler gives this and Bore as varieties of one species (Wien. Mon., YII, p. 213). Staudinger also cites Taygele as the Labrador form or var. of Bore (Cal., $\%$. 27). Scudder and W. H. Elwards consider them is iclentical and that Taygete is hut a synonym of Bore. I an constrined to aglee with the first two authors lhat there is at least a varietal difference between the Lapland examples and those from Labrador. I here append the nomenclature of the European form for the better convenience of the interesterl reater.

Bore, Esp., (Pap. B.), Silnmett., I, 2, t. 100, Cont. 55, f. 1, t. 108, f. 1, (1790); Sehn., Nen. Mag., p. 415, (1792) ; Hub., Eur. Schmelt., I, f. 134-136, 756, (1793-1794); Ochs., Schmett. Eur., I, 1, p. 205, (1807); (Erebia B.) Dalm., Pap. Suec, 80, (18:1); Meig., Eur. Schmetı., t. 31, f. 1, (1829$1832)$; (Chion. B.) B.ll., leon. Hist., t. 37, f. 1, (?2, 3), (1832); (Satyr. B.) Dup., Lep., I, p. 209, t. 32, f. 1, 2, (1832); '/ett., Ins. Lalp., p. 902, n. 7, (1840); (Chion. B.) H-S., Schmett. Eur., t. 26, f. 119-122, (1843-1856); Dbldy.-Hew., Gen. Diur. Lep., II, p. 383, (1850-1852); (Oeneis B.) Stgr., Cat., p. $27,(1871)$.

Chion. 'Taygete, var. Bore, Mosch., Wien, Fnt. Mon., VII, P. $214,(1863)$.

Pap. Norna, Quens., Act. Hol., t. 10, f. 1, 2, (1791).

Pap. ? Fortunatus, Fabr., Ent. Syst., I11, 1, p. 214, (1793).

Pap. Melissa?, Fabr., Syst. Ent., p. 513, (1775); Sp. Ins., II, p. 104, (1781); Mant. Ins., II, 1. 57, (1787) ; (Eneis M.) Kirhy, Cit., p. 70, (1871).

Pap. Polixenes?, Fabr., Syst. Int., 1. 484, (1775); Sp. Ins., II, 1. 59, (1781); Mant. Ins, II, 1.28, (1787); (Neonympha? P.) Dhbly.-1lew., Gen. Diur. Lep., II, p. 376, (1846-1850); (Gneis P.) Kirby, Cat., 1. 70, (1871); Scud., Buff. Bull., II, p. "210, (1875).

318. Chryxhs, Driny.-Hew., (ion. Diul. lep., II, p. 38:3, Rocky t. 64, (1851); W. H. Elwds., Proe. Ent. Soe, Mts. of Phil., II, 1. 82, (186.3); Soud., I. (.., V, p. 5, (1865); Montana and Keak., l. (., II, 1. 145, (1866); ('Eneis (') Kirby, Colorado. ('at., 1. 69, (1871); Scull., Buff. Bull., II, \%. 240, (1875); (chion. C.) Maral, Wheeler's Rep., I, p. 777, (1875); J'utuam, Pror. Davenport Arad. Nat. Sc., I, \%. 189, (1876).

Chion. Chrixus, Pack., (Huirle, l. 26:), (1869).

Very close to the Lappland Norna, Thub.

\$319. Uineri, Rfak., Proc. Ent. Soc, Phil., VI, p. 143, Rocky (1866i); ((Eneis U.) Butl., Cilt. Sityr. B. M., 163, Mts. of (1868); Kinlsy, Cat., p. 69, (1871); (Chion. U.) Colorarlo. Streck., Lер., Rhop.-IHet., p. 2s, t. 4, f. 5, 5, (1873); Mead, Whecler's licp., V, リ. 776, (1875); (Cencis L.) Scuul., Butf: Bull., II, P. 240, (1875).

Very closely allied to the Siberian Sculda, Ev.

320. Nevanfasis, Bul. MSs., Feld., Reise Nov. Lep., p. Califumia, 489, t. 69, f. 4, 5, (1867); Belre, Pror. Cal. Mrad. ()regon, Nat. S., III, 1. 16:3, (186-1); (Oeneis N.) Butl., Vamcouver's Cat. Satrr. B. M., p. 161, (1868); Kirhy, Cat., p. Island. 69, (1871); Seud., Bufl: Bull., I1, 1. 240, (1875). 
(Eneis Gigas, Butl., Cat. Satyr. B. M., p. 161, t. 2, (1868); Kirby, Cat., p, 69, (1871); (Chion. C.) W. H. Elwals., Butt. N. An., II, t. 1, ('hion., f.5, 6 , \&, (1874), l. c., t. 2, Chion., f. 1, 2, ఠ, (1875); (Oeneis G.) Sculd., Buft: Bull., II, p, 240, (1875).

Chion. Colifornica, Ball., I, Cal., P. 62, (1869); ((Eneis C.) Kirby, Cat., p. 69, (1871); (Chion. C.) IV. H. Elwds., Butt. N. Anı., II, t. 2, Chion., f. 3-6, (1875).

Chion. Iduna, W. H. Eduds., Butt. N. Am., II, t. 1, Chion., f. 1-4, (1874); (Deneis I.) Scud., Buff: Bull., II, p. 240, (1875).

It is nearer to Aello than any other old-world species.

There are no possible grounds for consirlering Gigas, Californica and Iduna as distinct species from Neradensis. Mr. W. H. Elwds, in his Butt. N. Am. dwells at considerable length on what lie imagines are many differences of speeific value, but which I consider nothing more than the slight differences usually found between diflerent individuals of the same speeies. Much stress has been laid by both Scudder and W. I. Edwds, on the shape of the discal band of under side of secondaries in the various species of this genus. To show the fallaciousness of any distinction fommderl on such a basis, I would say that on one of the seven original examples that furnished W. H. Edwds.' lypes of Iduna, received by ne from Jas. Behrens, the inner edge of this hand is not at all like the figures in W. II. Edwile.' work, but is almost the same as in the flgure of Nevadensis in the great work of the Novara. Farther, Scudder in Proc. Phil. Soe, 1865, held Chryxus and Calais as different species, attempting to prove their distinctness by the different ontline of the liscal hands, of which he gave fignres. Nevertheless, he himself afterwards (though wrongly) united the two, placing Calais as the O of Chryxus; Calais, however, really is Taygete, IInb., from which Seudder in same article also separated it hy outlines of diseal band. This same Taygete, in a long snite of examples now before me, presents as great differences in the ontline of the diseal bands as is seen between iny of the fignres of Iduna, Gigas, Californica and Nevadensis. In varions eximples of Uhleri the difference is yet greater; in some the band is distinetly defined on its outer edge, in others it has no limit, but the marbling eontinues indiseriminately to the onter margin of the wing.

The number of ocelli or spots on upper side vary in different examples of the same species very much; of Norna I have examples with two spots on primaries and none on secondaries, with two on primaries and one an secontlaries, with one on primaries and one on secondaries, with one on primaries and none on secondaries, and with three on primaries and two on secondaries; of Uhleri one of the types hits three on primaries and four on secondaries, the other has four on primaries and five on secontaries, one of which (the subapical) is quite small and was overlooked by lieakirt in his description; other examples have only one spot on primaries and two or three on secondaries. Chryxus I have with one spot on primaries and none on secondaries, and another with two on primaries and one on secondaries.

Chion. Tarpeia, an Altaian species, has been by some authors plaeed with the N. Am. fauna, but without donbt erroneouss ly ; I do not believe it ever has been or ever will be fonnd to ocenr in this country; but as some may feel further interested in the matter, I here give its nomenclature.

Tarpeia, Pali., Reis., I, p. 18, n. 59, (1771); Esp., Schmett., I, 2, p. 190, t. 83, (1783); Brk., Sclumett., 1, p. 101, (1788); 
Ochs., Schmett., I, 1, p. 203, (1807) ; Hub., Eur. Sclnnett., I, f. 779-78:, (1824-1826) ; Meigen, Eur. Schmett., I, 1). 128, t. 30, (1829); (Satyr. T.) Dup., [ep., J, 1. 207, t. 31, (1832); (Chion. T.) H-S., Schmett. Eur., 1, ). 67, f. (11-64, (18431844) ; Frr., Nen. Beit., V, t. 427, (1845); Musch., Wien. Ent. Mon., VII, p. 184, (1863); (Oeneis T.) Butl., (at.Satyr. B. M., p. 161, (1S68); Stgr., Cat., p. 27, (1871); Seud., Bufl. BuH., 11, p. 239, (1875).

Pap. Tarpejus, Fabr., Mant. Ins., I1, p. 32, (1787) ; Ent. Syst., III, 1, p. 214, (1793); Gmel., Syst. Nat., I, 5, 2255, 498, (1788); Herhst, Natursyst. Ins. Schmett., VIIJ, p. 210, t. $213,(1796)$.

Satyr. Tarpeius, Godt., Enc. Meth., IX, 1. 519, (1823).

Pap. Celimene, Cram., Pap. Ex., IV, t. 375, (1782); (Eneis C.) Kirlsy, Cat., P. 69, (1871).

\section{GENUS 6. SATYRUS, LATR.}

321. Ridingsit, W. H. Edwos., Proc. Ent. Soc., Phil., IY, p. Colorado, 201, (1865); Reak., I. c., VI, p. 145, (1866); Montana, (Hipparchia R.) Kirby, Cat., p. 82, (1871); (Satyr. Nevada, R.) Streck., Lep., Rhop.-Het., p. 29, t. 4, (1873); Utal. Mead, Wheeler's Rep., V, p. 774, (1875); (Neominois R.) Scud., Buff. Bull., II, 1. 241, (1875).

Chionobas stretchii, W. H. Edwds., Trans. An. Ent. Soc., III, p. 192, (1870).

322. Sthenele, Bdi., Ann. Soe. Ent. Fr., 2 me Ser. X, p. 308, California. (1852); Morris, Syn., p. 77, (1862); Behr, Proe. Cal. Acad. Nat. Se, III, p. 161, (1864); (Hipp. S.) Kirby, Cat., p. 81, (1871); (Satyr. S.) Streek., Lep., Rhop.-Het., p. 30, t. 4, (1873); (Cereyonis S.) Scud., Buff. Bull., 1I, p. 242, (1875).

323. Sinvestris, W. H. Edwins., Proe. Acall. Nat. Se., Phil., California. p. 162, (1861); (Satyr. Syl.) Behr, Proe. Cal. Acad. Nat. Sc., III, p. 16:3, (186t) ; (Enodia syl.) Reak., I'roc. Ent. Soe., Phil., V I, p. 145, (1866); (Hipp. Syl.) Kirlsy, Cat., ]. 81, (1871); (Cercyonis S.) Scud., Buff. Bull., II, p. 242, (1875).

324. Charox, W. H. Enwos., Trans. Am. Ent. Soe, IV, p. Colorido, 69, (1872); Mead, Wheeler's Rep., V', 1. 773, Muntama, $(1875)$.

Cercyonis Oetus, Scud., (nec Bdl.), Buff: Bull., II, p. S. Cillifornila $2+2,(1875)$.

†*325. (Oetres, Bdt., Lep. Cal., p. 63, (1869); (Cercyonis O.) California. Seull., Buff: Bull., II, p. 242, (1875).

Hipp. Sylvestris, Kirby, Cit., p. 81, (1871).

There is some confusion in regard to Oetus. Kirby, in his Cal. places it as a synonym of Silvestris, W. II. Eihwds., whilst Scurder in Buff. Buill. provisionally cites Charon, W. H. Edwds., as a synonym of Oetus. No Americun lepidopterist, als far as I an aware of, is accuainted in nature with Oetus, Bdl.; but I feel fully assured that the three names, Silvestris, Oetus and Charon, lielong to two speeies only; but whether Oetus be a synonym of Silvestris, or Charon of Oetus, ean only be known by comparison of types.

326. Meadn, W. H. Euwds., (Erebia M.), Trans. Am. Ent. Coloralu, Soc., IV, p. 70, (1872); (Satyr. MI.) Mead, Wherl- Utah, er's Rep., V, p. 774, (1875); ('ercyonis M.) Send., Arizonis. Buff: Bull., 11, p. '242, (1875). 
327. Pinoces, W. H. Eowss., Trans. An. Ent. Soc, V, p. 14, Brit. Col., (187t); (Cereyonis I’.) Scud., Buff. Bull., 11, p. ()regon, $242,(1875)$.

Montanal.

328. Nepintee, Kirby, (Hipparchia N.), Fann. Am. Bor., Camada, IV, p. 297, (18:37); (keb. N.) Dbldy.-Hew., (ren. Britisl Dim1. Lep., II, 1). 380, (1850-1852) ; (Hipp. N.) Columbial; Emm., Agrr. Nat. Hist. N. Y., 1. 213, t. 33, (1854); uortlern (Ereb. N.) Morric, Syn., p. 76, (1862); (Hipp. N.) U. S. aast of" Harris, Ins. Inj. Veeg, Flint's El., p. 306, t. 1:30, Rorky (1862); (Sirtyr. N.) W. H. Edwds., Pror. Ent. Soc., Mts. Phil., p. 195-200, (1866); (Hipp. N.) Kirlyy, Cat. 1. 81, (1871); (Minois N.) Sreid., Syst. Rer. N. Am. Butt., 6, (187.2), ('ercyonis N.) Bitf.' Bull., II, J. $242,(1875)$.

l allvat on gratss.

var. a. Ariane, Bor., Ann. Soc. Ent. Fr., 2 ne Ser. X, California. p. 307, (1852); Morris, Syn., p. 77, (1862); (Enodia A.) Reak., P'roc. Ent. Soc., Phil., V1, P. 145, (1866); (Hipp. A.) Kirloy, Cat., p. 81, (1871); (Cercyonis A.) Sucl., Buff. Bull., II, 1. 242, (1875).

With the exception that the under side is a little paler :nd the stria not as sharply defined, this presents searcely any difference from the steni form. Sometimes the black spot at in ner angle on upper side of primaries is accompanied by a contiguous smaller one.

var. b. Boorers, Berre, Proce. Cal. Acart. Nat. Se., ITI, Oregon, p. 164, (1864); W. H. Eswds., Prore. Ent. Sore, Montama, l’il., VI, p. 196, (1866); (Hipp. B.) Kirby, Cat., C'alifornia. 1. 81, (1871); (Cercyonis B.) Scul., Buff. Bull.. II, p. $242,(1875)$.

Devoid of ocelli on under surface of secondaries.

†*var. c. Gabmi, W. H. Enwss., Trams. Am. Ent. Soc., Oregon.

III, p. 19:3, (1870); (Hipp. G.) Kirlsy, Calt., J. 641, (1871); (Cercyonis G.) Scud., Buff.' Bull., 11, 1). $242,(1875)$.

I have had no opportunity of examining the types of this inseet; from the description I cannot separate it from Nephele or Ariane.

var. d. A tope, Fabr., (Pap. A.), Ent. Syst., III, 1, p. Midlle and 229, (1793); Herbst, Natursyst., VII1, p. 296, Western (1796); (Satyr. A.) Golt., Fue. Moth., IX, p. 52t, States fiom (182:3); Bdl.-Ler., Lep. Am. Sept., p. 228, Atlantic to (18.33); (Mipp. A.) Marris, Hitcl. Rep. Geo. Min., the Rereky ete., Mass., E.l. 1, p. 590, (1833); (Enodia A.) Mt.s.

1Mldy., list Lep. B. M., I, p. 136, (184t); J)llly.IIew., Gen. Diur. Iже., I1, p. 392, (1850-1852); (Mipp. A.) Emm., Agr. Nat. Hist. N. Y., p. '21:', t. 33:, (185t); (Satyr. A.) Morris, Syn., 1. 76, (18(;2); (Hipp. A.) Harris, In.s. Iıj. Veg., Flint's Ell, p. 305, f. 127, (1862); (Enodia A.) Reak., Proc. Ent. Soc., Plil., VI, 1. 145, (1866i); (Satyr. A.) W. 11. Edwals., l. '., p. 196-200, (1866); (Hipp. A.) Kirloy, (at., 1. 81, (1871); (Minois A.) Send., Syst. 
Rev. N. Am. Butt., 5, (1872); (Cercyonis A.) Buff. BıIl., II, 1. 242, (1875).

latria on gratss.

With a broal buff or oeluraceons yellow band across onter half of primaries on both surfaces; within this band are the two blick ocelli.

fab. a. $\sigma^{\lambda}-()_{n}$ the upper surface of primaries there are not the Maryland. slightest traces of the two ocelli, neither any evidence of the one usually on secondaries not far from anal angle. Beneath, on the primaries the ocelli are indicated ly two mere points, on secondaries there is only one small one not far from the anal angle. Mus. Streek.

falb. b. $\sigma^{7-W}$-With three ocelli on npper side of seeondaries, otherwise Marylamt. normal. Mus. Streek.

var. ๔. Peralat, Fabr., (Pap. P.), Syst. Ent., p. 494, Southurn (1775); Sy. Ins., II, p. 76, (1781); Mant. Ins., II, State from 1. $38,(1787)$; Ent. Syst, III, 1, p. 230), (17983); Cicorgia to (satyr. P.) Coolt., Ene. Meth., IX, p. 524, (1823); 'T'xats.

Dhbly.-Ilew., Gen. Diur. I גep., II, J. 398, (18501852); Morris, Sym., 1). 7T, (1862); W. H. Edwels., Proc. Ent. Soc., Phil., YT, p. 195, (1866); (Hipp. P.) Kirby, ('at., p. 81, (1871); (Cereyonis 1 .) S'mul., Bufl: Buil., II, 1. 241, (1875).

I'ap. Pegula, Herbst, Natmssist. Ins. Schmott., VIII, 1. 2.!ล, (1796).

o Satyrus Alope, Bdl.-Lee, Ixep. Ant. Sept., t. 59, (18:3:3).

Larger size than any of the preeding forms. O with only one ocellus on primaries (towarls the apex); o with two ocelli. On under surfitce of secondaries the ocelli are large and conspicnous; the striation of under surface sharply definet.

Bull,-Lee.'s figures undonbtedly represent of of this form, and not Alope as they have citel it.

valr. f. Whemeler, W. H. Eowss., Trans. An. Ent. S.California, Sor., IV, p. :34:3, (187:3); Mcal, Ithecler's Rep., Arizna.

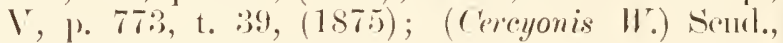

Butf: Bull., I I, 1. 242. (1875).

Satyrus Iotfimani, Streck., L(')., Rhop.-Het., p. 31, t. t, ㅇ, 1. 66, t. 8, o , (187:).

This is one of those wonderful aberrant forms peruliar to Arizona and alljatcent region. The of is dark, much the same colour as Nephele, Boopis, ete., but the o (which Mr. W. H. Edwds, so curronsly mistook in his deseription for the $\delta^{7}$ ) is very pale on upper surface and white beneath. Both sexes are devoid of the broad yellow hand of Alope and Pegala, but have two ocelli on primaries, the one nearest the apex is always donble; on under side of secondaries are six ocelli in two different rows of three each, the midlle one of the three nearest to apex oblong and sharply pointed outwarlly.

The of fignre in Wheeler's 5th Rep. is far too pale in colour.

Ir. Behr, speaking of Sat. Ariane, siays in Proc. ('al. Acal., IIl, p. 164: "I confess I rannot find any constant matk of difference between this species and $S$. Alope, Nephele, and Pegala, however different at first glanee their forms may appear, $1 \mathrm{am}$ very much inclined to consirler thom loeal aberrations of one far spread species that gradually slopes from S. Pegala, Fahr., throngh S. Ariane, bill., to $S$. Nephele and 
S. Alope, Falor., in a simila way as the (ierontogeie P. Egcria, L., looks very different from its African form $P$. Niphia, Falp, wih which, nevertheless, it is insensibly united by its intermeliate form P. Meone." I differ fron the above only in that l think the more northern Nephele was the stem form from which originally emanated Ariane and Boopis in the west and Alope in the east, and through the latter the splendid Pegalu in the sonth, whilst acclinatization in the dry salt regions of Utah aud Arizona resulted in the widely aberrant Whecleri.

\section{GENUS 7. PARARGE, IIUB.}

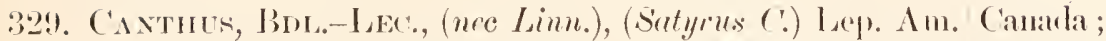
Sept., t. 60, (183:3); (Noon. (.) Morris, Syrl., p. New. Eng. $74,(1862)$; (Eupt. (.) Kirhy, Cat., p. 55), (1871). States, $\mathrm{N}$. Mipperchie Tionsmontena, Cosse, Newm. Wut., p. York, N. $1: 38,(18+1)$.

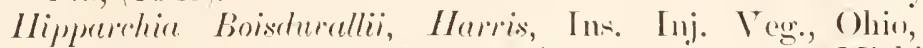
Flint's Fd., p. :305, f. 128, (1862).

Mirhigan, Argus Eurydice, send., (nec Limn.), Syst. Rev. N. Indiana, Am. Butt., 6, (1872); (Satyrodes E.) Butt: Bull., Illinois. II, J. 24:, (1375).

I atrva on glats.

The Eurydiee, L., (Amon. Acull. Cent. Ins., V1, 1). 406, 11. 65 , 1764), of which Canthus, L., (Sy.st. Nat., Eil. X11, 1.768, 1767), is a synonym, seems to be an enitirely different insect from this, and is mo:s probally I'ap. Arganthe, Cram., (['ap. Ex., Ill, t. 204, C, D), a S. Ams species which is on the upper surface uniform brown devoid of all spots. The following is all the description of Canthus given by Limn, in the Syst. Nat. (Wol. XII): "Alis integerrimis fuscis: subtus prinoribus ocellis (1uatuor, posticis senis. Amon. Acad., 6, p. 406, n. 65. P'apilio Eurydice. IIabilat in America septentrionalis."

The deseription of "Eurydice" in Amcen. Acad., referred to in the preceding, is:

"Papilio Eyrydice D. alis fuscis: sultum primoribus ocellic rutituor, posticis sex.

lialvitit in Philadelphia. De Geer.

Similis Pap. IIyperante. Mlae inteyerrime, supra fuscae; postiear. obsoletus oetlatae. l'rimores subtus ad maryinem posteriorum oecllis quatuor nigris pupilla alba. Postiete ocellis quinque intra. marginem posticum, disexto remotiori."

Herbil (Natursyst., VIII, p. 70, t. 192) has figured as Canthus C'ramer's Arganthe, which he also refers to Eurydice, Lim.

Also Fabricins in Eut. Syst., III, p. 157, gives Eurydiee, Canthus, L., ind Argenthe, Crim., as synonymical.

\section{GENUS 8. COENONTIPHA, HUB.}

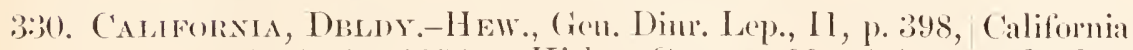

t. $197,(185(1-1852)$; Kirhy, (at., 1. 99, (1871); and adjacent

S'(ud., Buft. Bull., II, p. 난, (1875).

Satyrus (aliformins, Brli., Aun. Soe. Ent. Fr., 2ne

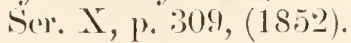

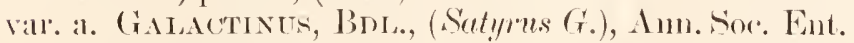
Fr., 2ne Ser. X, 1. :309, (1852); (Coen. G.) Kirly. Cit., 1). 99, (1871).

Coen. Gulactina, Morris, Syn., p. 8(), (1802); Belur, Proc. Cal. Acad. Nat Sice, III, p. 164, (186t).

val. l. ('eres, Butr., Ent. Mom. Mag., IV, ]). 7s, (1866). 
var. c. Eryxert, Hy. Eowns., Proc. Cal. Acal. Nat. Si:., Y, 6, (1876).

This $i$ a very variable species on the under side, in some instances being yellowish white, in others obscured or dusted heavily with grey. It is one of the eommonest of the Californian butterflies.

331. Ixorxata, W. H. Euwns., Proc. Acad. Nat. Sc., Phil., Nevada, p. 16:, (1861); Morric, Syn., p. 828, (1862); Sond., Montana, Buff: Bull., II, p. 241, (1875).

(. Typhon, var. h. Inornata, Kirby, Cat., 1). 100, (1871).

Oregron,

Vaneo. Isid.,

Brit. Col.

392. Amperos, W. H. Edwds., Trans. Am. Ent. Soc., III, Oregon. 1. 21:;, (1871); Sind., Buff. Bull., 11, p. 24t, (1875).

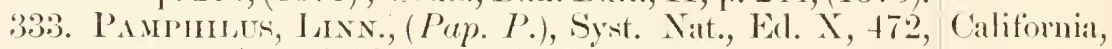

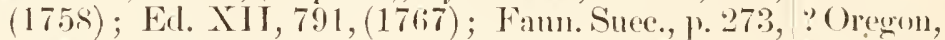

(1761); Fahr., Syst. Ent., P. 529, (1775); Sp. Ins., Eurne,

II, 1.66, (1781); Fint. Syst., I I I, 1, 1. 221, (1793); Siberia.

Esp., Schmett., I, 1, t. 21, (1777), t. 7s, f. 4, val.,

(1782) ; Beress., Nomı., t. 88, (1779); Herbst, Natmlsyst. Ins. Sohmett., VIII, p. 40, t. 186, f. $7,8, \mathrm{t}$.

187, t. 1, 2, f. 3, 4, ab., (1796); Ochs., Schmett.

Eur., I, 1, p. 305, (1807); (Satyrus P.) Crorlt., Enc.

Moth., IX, p. 549, (1823); (ITipp. P.) l)uncan,

Nat. Lih. Ent., III, p. 207, t. 26, (1835); (Cren. P.)

Kirly, Cat., p. 99, (1871); Sterr., Cat., 1. 32, (1871).

Pap. Menalcas, Poda, Mus. (iriee, P. 78, (1761);

Siop., Ent. Carn., 1) 458, (1763).

I'ap. Nephele, Hufn., Berl. Mag., II, p. 78, (1766);

Brk., Nat. Sehmett., I, 1. 87, (1788); Hiil., Eur.

sichmett., I, f. $237-239$, (? 1797).

P'(p). Gardetta, De Loche, Mém. Acc. 'Tor., VI, 2, p.

$1+6$, t. $7,(1801)$.

f.Cen. Pamphiloiles, Real., Proc. Ent. Soc., Phil., VI,

1. 146, foot-note, (1866); Butl., Cat. Sat. B. M., P.

14, (1868); Sond., Butf. Bull., II, 1. 24:), (1875).

Cren. Prmphilus, rar. b. Pamphiloilles, Kirby, Cat., 1).

9) (1871).

I posiess Reakirt's original type from California, which differs in now ise from the ordinary European form.

331. ()mided, W. H. Edwos., Proc. Arad. Nat. Sc., Phil., Montama, \%. 16:), (1861) ; Morris, Srn., 1. 328, (1862); Reak., Tow Mexico, Proc. Ent. Soc., Phil., YI, 1). 145, (1866); Kirhy, Arizoma, ('at., p. 100, (1871); Mead, Whecler's Rep., V, p. Brit. Col. 772, (1875); Scucl., Buff. Bull., II, 1. 24t, (1875).

I have no doubt but this is a variety of Tiphon, Rott., (Naturf., VI, P. 15, 1775), a species ranging all over Europe and Northorn Asia, and of which Davus, Fabr., is a symonym.

†*335. Brexta, W. H. Eowns., Trams. Am. Ent. Sox., TI, \%. Mas Angeles, $: 35,(1869)$; Kirby, Cat., 1). 100, (1871); Soud., Calal.

13ufl: Bull., 1I, p. 过3, (1875).

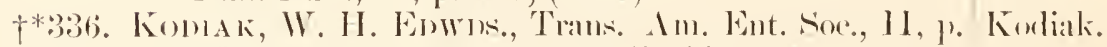

$375,(1869)$; Sout., Butl: Bull., 11, p. 244, (1875).

C'en. Kodiah, Kirby, Cat., 1. 100, (1871). 


\section{FAMILY X. HESPERIDA. \\ GENUS 1. EUDAMUS, Swarns. \\ $\left\{\begin{array}{l}\text { Goniurus, Hüb. } \\ \text { Goniuris, West. } \\ \text { Goniloba, West. }\end{array}\right\}$}

337. Proteus, Linn., (Pap. P.), Syst. Nat., Ed. X, p. 484, Sonthem (1758) ; Mus. Lud. Ulr., p. 333, (1764) ; Syst. Nat., United Ed. XII, I, 2, p. 794, (1767); Clerck, Icones, t. States, W. 42, (1764); Fabr., Syst. Ent., p. 532, (1775); Sp. Indies. Ins., II, p. 132, (1781) ; Mant. Ins., II, p. 85, (1787); Ent. Syst., III, 1, p. 331, (1793); Cram., Pap. Exot., III, t. 260, D, E, (1782); Abb.-Sm., Ins. Ga., I, t. 18, (1797) ; (Urbanus fortis P.) Hüb., Samm. Exot. Schmett., I, (1806-1816); (Goniurus P.) Verz. Bek. Schmett., p. 104, (1816); (Hesp. P.) Latr., Enc. Meth., IX, p. 730, (1823); (Eudarus P.) Bdl.-Lee, Lep. Am. Sept., t. 69, (1833); (Goniuris P.) Dbldy.-Hew., Gen. Dinr. Lep., II, p. 511, t. 79, var., (1850-1852); (Eud. P.) Chenn, Pap. Diur., p. 224, f. 374, (1851-1853); La Sagra, Hist. Cuba, An. Art., p. 622, (1857); (Hesp. P.) Morris, Syn., p. 106, (1862); (Goniur. P.) H-S., Reg. Corr--blatt, p. 56, (1865); (Thymele P.) Kirby, Cat., p. 570, (1871); Scud., Syst. Rev. Am. Butt., p. $69,(1872)$. , Merian, Met. Ins. Sur., t. 63, (1719). Larva on Clitoria Mariana, Phaseolus Odoratus.

338. Simplicius, Stold, (Pap. S.), Suppl. Cram., t. 39, 6, 6 E, Texas, Ari(1791); (Goniurus s.) Hüb.,V Verz. Bek. Schmett., p. zona, Mexi104, (1816); (Goniuris S.) Dbldy.-Hew., Gen. co, Cent. Diur. Lep., II, p. 511, (1850-1852); (Eud. S.) Am., Brazil, La Sagra, Hist. Cuba, An. Art., p. 622, (1857); Surinam. (Thymele S.) Kirby, Cat., p. 569, (1871); Scud., Syst. Rev. Am. Butt., p. 67, (1872).

Hesp. Eurycles, Latr., Ene. Meth., IX, p. 730, (1823).

339. Lycidas, Abr.-Sx., (Pap. L.), Ins. Ga., I, t. 20, (1797); Pennsylva(Hesp. L.) Latr., Ene. Meth., IX, p. 751, (1823); nia south(Eud. L.) Bdl.-Lee., Lep. Am. Sept., t. 71, (1833); ward to the (Hesp. L.) Dbldy.-Hew., Gen. Diur. Lep., II, p. gulf, west527, (1850-1852); Morris, Syn., p. 106, (1862); ward to Lon(Eud. L.) Send., Proc. Ess. Ins., III, p. 170, (1862), isiana and Proc. Chicago Acad., p. 334, (1868); (Thymele L.) Texas. Kirby, Cat., p. 571, (1871); (Achalarus L.) Send., Syst. Rer. Am. Butt., p. 71, (1872).

Proteides Lyciades, Hüb., Verz. Bek. Schmett., p. 105, (1816); Geyer, Zutr. Ex. Schmett., p. 10, f. 621, $622,(1832)$.

Larva on Desmodium. 
340. 'Tityrus, Fabr., (P'up. T.), Syst. Ent., p. 532, (1775); Canata ; Sp. Ins., II, p. 132, (1781); Mant. Ins., II, p. 85, UnitedStates (1787) ; Ent. Syst., III, 1, p. 331, (1793); Abl.- and territoSm., Ins. Ga., I, t. 19, (1797); (Hesp. T.) Latr., ries from AtEne. Meth., IX, p. 743, (1823); (Eud. T.) Bdl.- lantie to PaLee, Lep. Am. Sept., t. 72, (1833); (Goniloba T.) eifie; AntilDhldy.-Hew., Gen. Diur. Lep., II, p. 512, (1850- les; Cent.

1852); (Eurl. T.) Emmons, Agr. Nat. Hist. N. Y.,'Am. p. 215, t. 38, (1854); (Gon. T.) La Sagra, Hist. Cuba, An. Art., p. 632, (1857); (Eud. T.) Harris, Ins. Inj. Veg., Flint's Ed., p. 310, f. 133, 134, t. 5, f. 1, $(1862)$; (Goniloba T.) Morris, Syn., p. 112, $(1862)$; (Eud. T.) Send., Proc. Essex Ins., III, p. 170), (1862), Proe. Chicago Acarl., p. 334, (1868); Pack., Cinide, p. 269, (1869); (Thymele T.) Kirby, Cat., p. 571, (1871); (Epargyreus T.) Send., Syst. Rev. Am. Butt., p. 70, (1872); (Goniloba T.) I'ntnam, Proc. Dav. Acad., I, p. 197, (1876).

Pap. Clarus, Crom., Pap. Ex., I, t. 41, E, F, (1779); (Epargyreus (:) Hïb., Verz. Bek. Schmett., p. 105, (1816).

Larvi on Robinia Psendacacia, R. Viscosa, R. Hispida.

341. Celuds, Bde-Lec., (Eudanus C.), Lep. Am. Sept., t. From Vir73, (18:33); (Hesp. C.) Dbldy.-Hew., Gen. Diur. grinia nouthLep., II, p. 526, (1850-1852); Morris, Syll., p. ward to Gulf 105, (1862); (Spathilepia C.) Kirby, Cat., p. 578, of Mexico. (1871).

Cecrops Festus, Hüb.-Gey., Zutr. Ex. Sehmett., 1. 27, f. 907, 908, (1837); (Hesp. F.) Dbldy.-Hew., Gen. Diur. Lep., II, 1. 526, (1850-1852); (Thymele F.) Kirby, Cat., p. 571, (1871).

†*342. Erigexa, Butr., Trans. Ent. Soe. Lond., p. 493, 'Texat, Mex(1870) ; (Thymele E.) Kirby, Cat., p. 655, (1871). ico.

Eud. Orestes, Lint., MSS. W. H. Edwds., Trans. Am. Ent. Soc., VI, (1877).

343. Bathylues, Aвb.-Sir., (Pap. B.), Ins. Ga., I, t. 22, Penmsylvi(1797); (Eucl. B.) Latr., Ene. Meth., IX, p. 764, via soith to (1823); Bdl.-Lec., Lep. Am. Sept., t. 74, (1833); the Gulf of (Hesp. B.) Morris, Syn., p. 106, (1862); (Eud. B.) Mexieo, and Send., Proce. Ess. Ins., III, p. 170, (1862), Proc. west to the Chicago Acad., p. 335, (1868); Paek., Guide, p. Pacific; An269, (1869); (. Ethilla B.) Kirlw, Cat., p. 578. tilles.

(1871); (Thorybes B.) Seud., Srst. Rer. Mun. Butt., p. 71, (1872).

Gon. Bethyllus, Dbldy.-Hew., Gen. Diur. Lep., II, p. $514,(1850-1852)$, (Buthyllus, I. (., p. 534); La Sitgral, Hist. Cubal, An. Art., p. 638, (1857).

Larva on wild bean, Desmorlium Dillenii.

vall. a. Pradade, Scend, Proce Bust. Soc. Nat. Hint., Camadal U. XIII, p. 207, (1870); (Ethilla P.) Kirby, Citt., p. S. and Ter. 578, (1871); (Thorybes P.) Scud., Syst. Rev. Am. from AtlanButt., p. 71, (1872). tie to Pacific. 
Eud. Bathyllus, Harris, (nec Abb.-Sm.), Ins. Inj. Veg., Flint's Ed., p. 312, f. 135, (1862).

Thorybes Nevada, Scud., Syst. Rev. N. Am. Butt., 1. $71,(1872)$.

Larva on various species of Glycine and Hedysarum.

The white marks on primaries much smaller, sometimes obsolete.

344. Amyntas, Fabr., (Pap. A.), Syst. Ent., p. 533, (1775); Sp. Ins., II, p. 133, (1781); Mant. Ins., II, p. 86, (1787); (Pamphila A.) Kirby, Cat., p. 605, (1871). Amazons.

Polygonus Lividus, Ḧ̈b., Samm. Exot. Schmett., II, (1816-1841) ; (Astraptes L.) Ver\%. Bek. Schmett., p. $103,(1816)$.

Hesp. Savignyi, Latr., Ene. Meth., IX, p. 741, (1823); (Gon. S.) Dbldy.-Hew., Gen. Diur. Lep., II, p. $512,\left(1850-1852^{\circ}\right)$; I a Sagra, Hist. Cuba, An. Art., p. 631, (1857); H-S., Reg. Corr.-blatt, p. 54, (1865); (Acolastus S.) Scud., Syst. Rev. Am. Butt., p. $71,(1872)$.

345. Inesus, Dbldy.-Hew., (Goniloba H.), Gen. Diur. Lep., Texas, MexII, p. 513, t. 78, f. 5, (1850-1852); (Thymele H.) ico, Cont. Kirby, Cat., p. 574, (1871); (Epargyreus H.) Send., Am., AmaSyst. Rev. Am. Butt., p. 70, (1872).

\section{GENUS 2. PYRRHOPYGE, Hub.}

346. Araxes, Hew., (Eryc. A.), Deserip. Hesp., p. II, n. 3, Arizuna, (1867); (Myscehs A.) Kirlyy, Cat., p. 587, (1871). Mexioo.

\section{GENUS 3. ERYCIDES, HuB.}

347. Batabaxo, Lef., (Eudamus B.), La Sagra, Hist. Cuba, S. Florida, An. Art., p. 624, (1857); (Eryc. B.) H-S., Reg. Cuba. Corr.-blatt, XIX, 1. 56, (1865); Kirby, Cat., p. $589,(1871)$.

Erycides Mancinus, Herr-Sch., Regensh. Corr.-blatt, XVI, p. 143, (1862).

348. Urania, West., Dbldy.-Hew., Gen. Dimr. Lep., II, Texas, p. 510 , t. 79 , f. 1, (1850-1852); Kirby, Cat., p. Mexico, 587, (1871); Scud., Syst. Rev. Am. Butt., p. 67, Cent. An. (1872).

+*349. Saxtunfea, Scud., Syst. Rev. Am. Butt., p. 68, (1872). Texas. +*350. 'T'uxana, Scub., Syst. Rev. Am. Butt., p. 68, (1872). 'T'exis.

\section{GENUS 4. RGIALE, Feld.}

(Megathymus, Scud.)

351. Yurcis, Bd.-Ifec., (Eudamns? Y.), Lep. An. Sept., Southern t. 70, (1838); (Castniu Y.) Walker, List Lep. B. States from M., VII, 1. 158., (1856); (Goniloba Y.) Morris, S. Carolinato Syn., 1. 113, (1862); (Egiule? Y.) Kirby, Cat., 1. the Gulf of" 608, (1871); (Megathymus Y.) Seurl., Syst. Rov. Mexico. 
Am. Butt., p. 82, (1872), Hist. Sketch Gen. Names for Butt., p. 213, (1875); Grote, Can. Ent., VII, p. 173, (1875) ; Riley, 'Trans. Acad. Sc., St. Louis, III, p. 323, (1876), 8th Mo. Ent. Rep., p. 169, (1876), 9th Mo. Ent. Rep., p. 129, (1877); (Egiale Y.) Streck., Proc. Acad. Nat. Se., Phil., p. 149, (1876).

Larva lonrrows in the stems of Yucca Aloifolia, $Y$.

Gloriosa and $Y$. Filamentosa.

†352. Cofacui, S'rreck., Proc. Acarl. Nat. Sc., Plil., p. 148, Georgia; $(1876)$.

Llano Estacado, 'Texas.

\section{GENUS 5. PAMPHILA, FABR.}

353. Hurox, W. H. Edwos., (Hesp. H.), Proc. Ent. Soc., Plil., II, p. 16, t. 1, (1863); Reak., l. c., VI, p. 150, (1866); (Pam. H.) Kirby, Cat., p. 600, (1871); (Atulopedes H.) Send., Syst. Rev. Am. Butt., p. 78, (1872).

var. a. Camiestris, Bdu., (Hesp. C.), Ann. Soc. Ent. Fr., 2me Ser. X, p. 316, (1852); Morris, Syn., p. 108, (1862); (Pam. C.) Kirby, Cat., p. 602, (1871); (Atalopedes C.) Scud., Syst. Rev. Am. Butt., p. 78, (1872).

354. Pintlaus, Drurt, (Pap. P.), Ill. Ex. Ent., I, t. 13, (1770); (Hesp. P.) Latr., Enc. Meth., IX, p. 767, (1823); (Hesp. Phyleus) Bull.-Lec., Lep. Am. Sept., t. 78, (1833); (Pam. Phylaeus) Dbldy.-Hew., Gen. Diur. Lep., II, p. 522, (1850-1852); La Sagra, Hist. Cuba, An. Art., 1. 645, (1857); Kirby, Cat., 1. 600, (1871); (Pam. Phyleus) Morris, Syn., p. $118,(1862)$; H-S., Reg. Corr.-blatt, XIX, p. 53, (1865); (Euthymus Phylceus) Scul., Syst. Rev. Am. Butt., p. 77, (1872).

Thym. Augias, Hüb., Zutr. Ex. Schmett., f. 227, 228, (1823).

Pam. Bucephalus, Steph., Ill. Brit. Ent. Haust., p. 102, t. 10, + , (1828), Cat. Brit. Ins. Haust., p. 28, (1829) ; Humph.-West., Brit. Butt., p. 126, t. 40, 万, (1841); Wood, Ind. Ent., p. 10, (1845).

Pam. Phylous, Emm., Nat. Hist. N. York Agr., V, 1. 215, (1854).

I doubt if Emmons was acquainted with the true Phyleus, from his asserting that it "is a very common butterlly in western Massachusetts," so I merely ald his citation for what it may be worth.

Isarva on Panicum Sanguinale.

In Dbldy.-Hew., Gen., Pap. Colon, Fabr., is cited with a ? as a synonym of Phylaeus, also in La Sagra, Hist. Cub. An. Art., on what grounds 1 do not know; Fibr.'s description does not

U. S. and Territories from the Atlantic to Arizona. California,

'Texas.

From Maryland south to the Gulf of Mexico and west to the Pacific; W. Indies; Cent. and S. Am., to S. Brazil. 
agree with Phylaeus, and he further says Colon is from India, though this locality with Fabr. might have meant indifferently either the West or East Indies. I append here the description of Colon from Syst. Ent., p. 531, (1775):

"Alis divaricatis, fulvis: macula media margineque striato fuscis.

Habitat in India. Mus. Tottianum.

Summa affinitas P. Commatis. Antennæe nigro fulvoque annulatæ, clava uncinata, basi fulva, apice nigra. Alæ omnes fulvæ, anticis, macula magna inedia margineque postico fuscis. Postice margine exteriori et postico fuscis ; subtus alæe fulvæ, immaculatæ."

It is also cited in Sp. Ins., II, p. 131, (1781), Mant. Ins, II, p. 84, (1787), Ent. Syst., III, 1, p. 327, (1793).

355. Napa, W. H. Edwds., (Hesp. N.), Proc. Ent. Soc., Colorado. Phil., IV, p. 202, t. 1, (1865); Reak., I. c., VI, p. 150, (1866); Scud., Proc. Chicago Acad., p. 335, (1868); (Pam. N.) Kirby, Cat., p. 602, (1871); Scud., Syst. Rev. Am. Butt., p. 77, (1872).

Hesp. Dacotah, W. II. Edwds., Trans. Am. Ent. Soe., III, p. 277, (1871).

+*356. Draco, W. H. Edwos., Trans. Am. Ent. Soc., III, p. Colorado. $274,(1871)$.

357. Otroe, IV. H. Enwds., (Hesp. O.), Proc. Ent. Soc, Kansas, Phil., VI, p. 207, (1867); (Pcmı. O.) Kirby, Cat., Iowa, Ne1. 602, (1871); Scud., Syst. Rev. Am. Butt., p. 78, brasba, Ind. (1872), Mem. Bost. Soc. Nat. Hist., II, p. 348, t. Ty. 10, f. $6,(1874)$.

†*358. Yuma, W. H. Enwns., (Hesp. Y.), Trans. Am. Ent. Arizona. Soc., IV, p. 346, (187:3).

359. Brettus, Bnt.-Lec., (H九sp. B.), Lep. Am. Sept., t. Southern 75, o, (1833); (Pam. B.) Dhldy.-Hew.. Gen. Diur. States from Lep., II, p. 523, (1850-1852); La Sayra, Hist. Georgia to Cuba, An. Art., p. 646, (1857); Morris, Syn., p. Texas; 118, (1862); Kirby, Cat., p. 600, (1871); (Hedone Antilles. B.) Scurl., Syst. Rev. Am. Butt., p. 79, (1872).

o Hesp. I'inginu, Scud., Proc. Ess. Ins., III, p. 173, (1862).

Bdl.'s figures 3,4 are incorrectly cited as males; all three of his figures are females.

360. Sassacus, Harris, (Hesp. S.), Ins. Inj. Veg., Flint's Atlantic El., p. 315, (1862); Morris, Syn., p. 110, (1862); States from Scud., Proc. Ess. Ins., III, p. 173, (1862), Proc. MassachuChicalgo Acad., p. 335, (1868); (Pan. S.) Kirby, setts to GeorCat., p. 599, (1871); Seud., Syst. Rev. Am. Butt., gia. p. 77, (1872), Mem. Bost. Soc. Nat. Hist., II, p. 346 , t. $10,(1874)$.

Larva on Panicum Sanguinale.

361. Mrstic, W. H. Eowns., (Hesp. M.), Proc. Ent. Soc., Canada, New Phil., II, p. 15, t. 1, (1863); Scud., Proc. Ess. Ins, England and III, p. 172, (1862); Saund., Can. Ent., I, [1.66, Micllle I ar., (1869); (Pum. M.) Kirby, Cat., J. 599, (1871); States. (Limochores M. I.) Scudl., Syst. Rev. Am. Butt., p. 80, (1872). 
362. Peckius, Kirby, (Hesp. P.), Fann. Bor. Am., IV, p. Canada, New 300, t. 4, (18:37); Emm., Nat. Hist. N. York Agr., Engr., Mirktle V, p. 216, t. 32, f. 8, (185t); Harris, Ins. Inj. Veg., and Westem Flint's Ed., p. 315, f. 139, +, (1862); (Pam. P.) States to Kirby, Cat., p. 600, (1871); (Polites P.) Scud., Iowa and Syst. Rev. Am. Butt., p. 78, (1872).

Pam. Peckii, Morris, Syn., p. 120, (1862).

o Hesp. Wamsutta, Harris, Ins. Inj. Veg., Flint's Ed., p. 318, f. 141, (1862); Morris, Syn., p. 111, (1862); Seud., Proc. Ess. Ins., III, p. 174,(1862); Saund., Can. Ent., I, p. 66, Lar., (1869); Patck., Guide, p) 270, f. 198, (1869); (Pam.W.) Kirlsy, Cat., p. $600,(1871)$.

Larva on grass.

363. Nemorum, Bdy., (Hesp. N.), Ann. Soc. Ent. Fr., 2 me California. Ser. X, p. 314,(1852); Morris, Syn., p. 107,(1862); (Pam. N.) Kirby, Cat., p. 602, (1871); (Ochlodes N.) Scnd., Syst. Rev. Am. Butt., 1. 78, (1872).

Hesp. Yreka, II. H. Edwds., Proe. Ent. Soc., Phil., VI, p. 207, (1866); (Pam. Y.) Kirby, Cat., p. 602, (1871).

†*364. Aqricola, Bdi., (Hesp. A.), Ann. Soc. Ent. Fr., 2 me California. Ser. X, p. 314,(1852); Morris, Syn., p. 108, (1862); (Pam. A.) Kirby, Cat., p. 602, (1871); (Ochlodes A.) Seud., Syst. Rev. Am. Butt., p. 78, (1872).

†*365. Cruusca, W. H. Edwds., (Mesp. (.), Trans. Am. Ent. Arizona. Soc., IV, p. 346, (1873).

366. Sylvanus, Esp., (Pap. S.). Schmett., I, 1, f. 36, California; (1777); Brkh., Schmett., I, 1. 180 \& 285, (1788), Europe, 1. c., II, p. 2:36, (1789); Fahn., Mant. Ins, II, p. Northern 84, (1787); Ent. Syst., III, 1, p. 326, (1793); and Western Iewin, Pap. Gt. Brit., 1. 96, t. 46, f. 1-3, (1795); Asia. Don., Nat. Hist. Brit. Ins., VIII, p. 8, t. 254, f. 2, ơ, (1799); Hüb., Eur. Schmett., I, f. 482-484, (1798-1803); Ross, Faun. Etr., II, p. 158, (1790), Ed. 2, 1I, p. 251, (1807); Ochs., Schmett. Eur., I, 2, 226, (1808); (Hesp. s.) Godt., Lep. Fr., I, t. 12 , sec. f. $2 \sigma^{2}$, t. 12 , tert. f. $3 \sigma^{7},(1821)$; (Augiardes S.) Hïlo., Ver\%. B(ek. Schmett., 1). 112, (1816); (Hesp. S.) Latr., Ene. Meth., IX, p. 770, (1823); (Pom. S.) Steph., Ill. Brit. Ent. Haust., p. 101, (1828), Cat. Brit. Ins. Haust., p. 28, (1829); (Hesp. S.) Meigen, Handbuch, p. 79, (18:27), Eur. Schmett., II, p. 67, (1830); Dunc., Nat. Lib. Ent., IV, p. 117, t. 2, (1836); (Pam. St.) Woorl, Ind. Ent., p. 9, t. 3, f. 80, (1845); Inbldy.-Hew., Gen. Diur. Lep., II, p. 522, (1850-1852); (Hesp. S.) Chenu, Pap., p. 226, f. 382, (1851-1853); Bdl., Ann. Soc. Ent. Fr., 2me Ser. X, p. 313, (1852); Morris, Sym., p. 107, (1862); Stgr., Cat., p. 17, (1871); (Pam. S.) Kirby, Cat., p. 602, (1871); (Augiades S.) Scud., Syst. Rev. Am. Butt., 1. 79, (1872). 
Pap. Melicerta, Brk., Eur. Sehmett., I, p. 180 \& 285, (1788).

Pap. Minor ex aureo \& fusco mixtus stria nigra; Streakt cloudy Hog. of, cloudy Hog. \& ; Petiv., Gaz., t. 4, f. 7, 8, (1702); Pap. Brit., p. 2, t. 6, f. $16,17,(1717)$.

I have never seen an American example of this species, but have placed it in our fauna on the authority of Dr, Boisduval.

367. Symaxomes, Bnt., (Hesp. S.), Ann. Sog. Ent. Fro, California. 2me Śer. A, p. 313, (1852); Morris, Syn., p. 107, (1862); (Pam. S.) Kirby, Cat., P. 602, (1871).

Ochlodes Sonork, Scurl., Syint. Rev. Am. Butt., 1) 78, $(1872)$.

1*368. Ruricola, Bul., (Hesp. R.), Ann. Soc. Eut. Fr., 2 me California. S.r. X, P. 315, (1852); Morris, Syn., p. 108, (1862); (Pam. R.) Kirloy, Calt., p. 602, (1871).

†*369. Pratrixcola, Bol., (Mesp. P.), Amn. Suc. Ent. Fr., California. 2 me Ser. X, p. 315, (1852); Morris, Srn., p. 108, (1862); (Prom. I.) Kirly, Cat., p. 602, (1871); Send., Srst. Rev. Am. Butt., p. 83, (1872).

370. P'awree, Dodre, (Hesp. P.), Can. Ent., I'I, 1. 44, Nebraska. $(1874)$.

371. Comma, Linn., (Pap. (.), Syst. Nat., Ed. X, P. 484, Colorado, (1758), El. XII, I, 2, p. 793,(1767); Famn. Suce., Utah, Monp. 285, (1761) ; Seop. Ent. Carn., p. 181, n. 463, tana, Cali(1763); Wiens, V, P. 160; Fibr., Syst. Ent., fornia, p. 531, (1775); Sp. Ins., II, p. 131, (1781); Nevada, Mint. Ins., II, 1. 84, (1787) ; Ent. Syst., III, 1, p. Oregon, 325, (1793); Esp., Schnett. Enr., I, 1, t. 23, (1777); Arizona ; Eng, Pap. Eur., I, p. 194, t. 45, f. 95 d, (1779); Brit. Col., Brk., Selumett., I, 1) 179 \& 2st, (1788); Ross, Siberia, EuFaun. Etr., II, 1). 158, (1790), 1. c., El. 2, II, p. rope. 251, (1807); Iewin, Pap. Gt. Brit., p. 94, t. 45, f. 1, 2, (1795); Don., Nat. Iist. Ins., IX, p. 17, t. 295, ㅇ, (1800); Hül., Eur. Schmett., I, f. 479481, Lar. Lep. I, Pap. II, Gens. E, f. 3 a, (1798180:3); Fabr., Ill. Mag. Ius., VI, 287, (1807); Ochs., Schmett., I, 2, p. 224, (1808); Godt., Hist. Nat. Lep. Fr., I, t. 12 tert. f. 4, (1821); (Augiades C.) Hüb., Verz. Bek. Schmett., p. 112, (1816); (Hesp. C.) Latr., Enc. Meth., IX, p. 769, (1823); Meig., Handbuch, p. 78, t. 8, f. 8, (1827), Eur. Schmett., II, 1. 66, (1830); (Pam. C.) Steph., III. Brit. Ent. Haust., I, p. 102, (1828), Cat. Brit. Ins. Maust., 1. 28, (1829) ; Mun., Nat. Lib. Ent., IV, ). 119 , t. 2, (1836); West.-Hum., Brit. Butt., p. 128, t. 41, (1841); Wood, Ind. Ent., p. 10, t. 3, (1845); (Hesp. C.) Bdll., Amn. Soe. Ent. Fr., ?me Ser. X, p. 313, (1852); Dbldy.-Hew., Gen. Diur. Lep., II, 1. 522, (1850-1852); Chenu, Pap., p. 226, f. 383, (1851-1853); Momis, Syn., p. 109, (1862); Stgr., Cat., P. 35, (1871); (Pam. C.) Kirby, Cat., 
p. 602, (1871) ; Send., Mem. Bost. Soc. Nat. Hist., II, J. 350, t. 10, f. 13, 14, (1874).

Pap. Virgula, Retz., Gen. Spec. Ins., p. 31, 1. 7, (1783).

Pam. Nevado, Scud., Mem. Bost. Soc. Nat. Hist., II, p. 347 , t. 10 , f. 1-4, (1874).

Pam. Colorado, Scud., l. e., 1. 349, t. 10, f. 16-18.

Pam. Manitoba, Scud., 1. c., p. 351, t. 10, f. 8-11.

- — Kaj., Hist. Ins., 125, (1710).

- - Merian, Eur. Ins., 15, t. 48, (1717).

- Schuef., Icon., III, t. 260, f. I, II,

274, f. I, II, (1804), Hesp. Uib. Comma, Nom.

Panz., p. 208, \& Hesp. rur. C., p. 215, (1804).

Larva on Coronilla Varia in Europe.

var. a. CAtesa, Strtr., (Hesp. C.), Stett. Ent. Zeit., p. N. Ialuardor, 357, (1861), Cat. Lep. Eur., p. 35, (1871); (Pam. Iaplaud.

C.) Kirhy, Cat., p. 602, (1871); Scud., Mem. Bost. Soc. Nat. Hist., II, t. 10, f. 12 \& 15, (1874).

Under surface secondaries very dark greenish, spots conspicuous and of silvery whiteness.

var. b. Juba, Scud., Syst. Rev. Am. Butt., p. 77, (1872), Mem. Bost. Soc. Nat. Hist., II, p. 349, t. 10, f. 19, $20,(1874)$.

California, Arizona,

Somewhat larger ; less obscured with fuscous on upper surface, espeeially in of.

? var. c. Coldubia, Scud., Syst. Rev. Am. Butt., p. 77, $(1872)$.

Pam. Sylvanoides, Scud., (nec. Bdl.), Mem. Bost. Soc.

Nat. Hist, p. 351, t. 10, f. 21, 22, (1874).

Smaller; $\delta^{7}$ has on upper surface a brown furry patch joining the inner side of the discal dash. Silver marks of under side of secondaries in both sexes small and placed somewhat differently from any of the above forms; they consist of a chevron-shaped diseal spot, an abbreviated mesial bar, formed of eonfluent spots, with a small isolated spot near its apieal end, but not in a line with it, being somewhat interior thereto.

This may perhaps be a distinct species.

4372. Kundisir, Reak., (Hesp. R.), Proc. Ent. Soc, Phil., Colorado.

VI, p. 151, 우, 1866); Kirby, Cat., 1.615, (1871).

Only known by the unique of type formerly in Mus. Reak. Though of greater size, it approaches Comma somewhat in the markings, espeeially of under surface; and it may possibly prove to be a melanotic aberration of that species.

It bears also, on both surfaces, more particularly the lower, a striking resemblanee to Metea $\delta^{\top}$.

373. Sabuleti, Bdu., (Hesp. S.), Ann. Soc. Ent. Fr., 2ne California. Ser. X, p. 316, (185.2); Morris, Syn., p. 109, (1862); (Pam. S.) Kirluy, Cat., \%. 602, (1871); (Polites s.) Scud., Syst. Rev. An. Butt., P. 7s, $\left(187^{\circ}\right)$. 


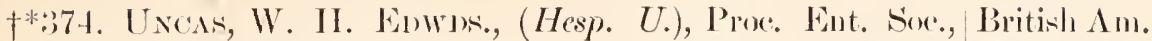
Phil., II, p. 19, t. 5, f. 3, ơ, (1863); (I'tem. U.) Mirl. \& Wes. Kirlw, Cilt., p. 600, (1871); (Athonaster I.) Srurl., States to ColSrst. Rev. Am. Butt., 1. $78,(1872)$. arado.

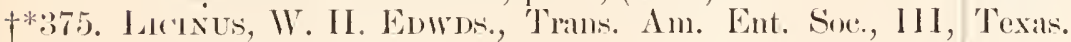
1. $275,(1871)$.

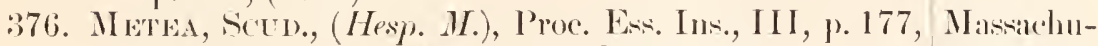
(1862): (I'cm. H.) Kirly, Cat., P. 607, (1S71); setts, Con(Ocytes M.) Scurl., Syst. Rev. An. Butt., p. 76, necticut, $(18 \div 2)$.

N. York.

377. ATratum, W. H. Enwhs., (Hesp. A.), Trans. Am. Ent. Texas. soc., III, 1. 276, (1871).

vall. a. Simuxole, Sivo, (Oeyles S.), Syst. Rev. Am. Floridil. Butt., 1. 76, (1872).

Darker on murler surface. Pale spots of upper surface all smaller.

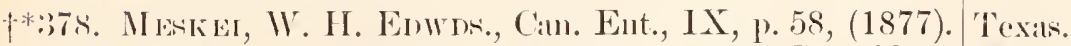

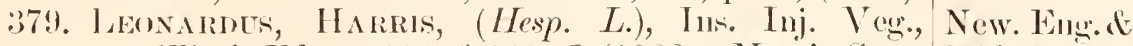
Flint's Erl., 1. 314, f'. 1:38, ơ, (1862); Morris, Syn., Mid. States; p. 110, (1862); Scud., Proc. Esis. Ins., III, p. 172, IV. Via., (1862), Pror. Chicago Aard., p. 3.35, (1868); (I'cm. O)hio, Ind., L.) Kirhy, Cat., p. 599, (1871); (Athomaster L.) Ill., Ark., Soud., Syst. Rev. Am. Butt., 1). 78, (1872).

Kan.

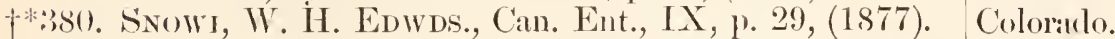
381. Pontac, II. H. Howns., (Hesp. P.), Proc. Ent. Soc., New York, Phil., I1, l. 17, t. 11, t. 5, ठ’, (1863); (Pam. P.) Ohio, Inl., Kirly, Cit., 1) 600, (1871).

Hesp. Conspicua, W. H. Eduds., Proc. Ent. Sor., Jowa, Minn., Phil., II, p. 17, t. 5, f. 5, +, (186:3); Send., Prox. Neb.

Chicaggo Arad. Nat. Se, p. 336, o’. (1868); Parkicr, ('in. Ent., 1II, p. 51, ơ, (1871); ('Pum. C.) Kirly, (iit., p. 606, (1871); (Atrytone C.) Sudl., Syst. Riv. Am. Butt., 1). 77, (1872).

Medone Orona, Scud., Syst. Rev. Am. Butt., J. 79, (1872).

352. Cerses, Bnd.-Iec., (Hesp. C.), Jep. Am. Fept., t. 76, Canada ; f. 1, 2, (183:3); (Pam. (!) Dbldy.-Hew., Gen. United Diur. Lep., II, p. 523, (1850-1852); Kirby, Cat., States and p. 599, (1871).

Hesp. Arogos, Bdl.-Lec., I.ep. Am. Sept., t. 76, f. 3, 4, 5, (1833); (Pam. A.) Jobldy.-Hew., Gen. Diur. Lep., II, 1. 523, (1850-1852); Morris, Syrl., p. 118, (1862); Kirby, Cat., 1). 600, (1871).

Ilesp. Ahaton, Harris, Ins. Inj. V'eg., Flint's Esl., p. 317, f. 140, ㅇ, (1862); Morris, Syn., p. 111,(1862); Scud., Proc. Ess. Ins., III, 1) 176, (1862), I'roc. Chicago Acad., p. 335, (1868); (Pam. A.) Kirby, Cat., 1). 600, (1871).

Pap. Taumus, Fabr., Mant. Ins., II, p. 84, (1787); Ent. Syst., III, 1, p. 327, (1793); (Hesp. Th.) Latr., Enc. Meth., IX, p. 766, (1823); (Pam. Th.) Dbldy.-Hew., Ger. Diur. Lep., II, p. 522, (1850- 
1852); Morris, Sirn., p. 117, (1862); Kirlyy, Cat., 1. 5.99, (1871); (Limochores T.) Send., Syst. Rev. Ain. Butt., p. 80, (1872).

Pap. Origenes?, Fabr., Ent. Syst., III, 1, 1. 328, (1798); (I'ap. O.) Don., lus. Ind., t. 48, f. 2, (1800); (Pam. O.) Morris, Syn., 1. 117, (1862); Kirby, Cat., p. 599, (1871).

I am doubtful whether Origenes be the same as our species. Neither Fabricius' deseription nor Donovan's figure agree with it in several respects, but we must bear in mind that Donovau was somewhat careless in his delineations, often depending on rough sketches or even his memory in finishing his figures.

Fabricius' description is :

"Alis divaricatus concoloribus fuscis: striga punctorum alborum, anticis basi testacis.

Pap. Origines. Jon. fig. pict. 6, tab. 74. f. 2.

Habitat in Indiis, Dom. Jones.

Statura omnino praecedentium. Alate omnes fuscae striga punctorum alborum. Anticae basi oblique testaceae."

383. Manatanuua, Scud., (Hesp.M.), Proc. Ess. Ins., III, p. Camada; U. 175, 11862); (Pam. M.) Kirloy, Cat., p. 599, (187.1); (Limochores M.) Send., Syst. Rev. Am. Butt., p. $80,\left(187^{\circ}\right)$.

Hesp. C'ernes, Harris, Ins. Inj. Vex., Flint's Ed., p. $316,(1862)$.

384. Oтно, Aвr.-Sir., (Prp. O.), Ins. Ga., I, p. 31, t. 16, (1797); (Pam. O.) Kirby, Cat., p. 603, (1871).

Larvil on P'anicum Sanguinale.

S. and 'T'er.

firom Atlantic to Pacific.

val. a. Hesl. Egeremet, S'un., Proc. Ess. Ins., III, Camada;

p. 174, (1862); (Pam. E.) Kirby, Cat., P. 603, United (1871).

Hes.). Otho, Ball.-Lec., (nec Abb.-Sm.), I.ep. Am. Sept., t. $77,(1833)$.

Hedone Etna, Seud., Syst. Rev. Am. Butt., p. 79, (1872).

In both sexes the entire ground colour above and below is dark hrown.

385. Bumactia, Gri-Rom., (Hesp. B.), Anu. N. Y. Iye. Nat. Mass., N.

Hist., VIII, ). 433, (1867); (Pam. B.) Kirby, York, Ohio, Cat., 1. 603, (1871); (Limochores B.) Śeut., Syst. Ind., Ill., Rev. Am. Butt., p. 80, (1872).

Iowa, Ark.,

Hesp. Aconootus, Scud., Proc. Bost. Soc. Nat. Hist., Neb.

XI, p. 3.s1, (1868).

Ilesp. Illinois, Dodge, Can. Ent., I V, p. 217, (1872).

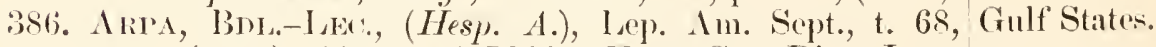

(183:3); (Iam. A.) Dbldy.-Hew., Gelı. Diur. Lep., II, p. 528, (1850-1852); Morris, Syru., p. 117, (1862); Kirbr, Cat., p. 597, (1871); (Limochores A.) Srud., Nyst. Rev. Am. Butt., p. 80, (1872).

387. Butenta, Bib.-Lec., (Hesp. B.), Ixp. Am. Sept., t. 67, Gulf States. (1833) ; (I’am. B.) Dhldy.-Ilew., Gen. Diur. Lep., II, p. 52:;,(1850-1852); Morris, Syn., p. 117,(1862); Kirby, Cat., 1. 597, (1871).

Mesp. Pilatka, H. H, Edwds., Trans. Am. Ent. Soo, I, p. 287, (1867). 
Pam. Pilalka, Kirby, Cat., p. 602, (1871).

Limochores Palatka, Scud., Syst. Rev. An. Butt., p. 80, (1872).

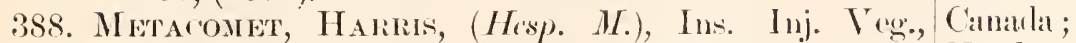
Flint's Ed., 1. 317, (1862); Morris, Syn., 1) 111, Northern (1862) ; Senl., Prox. Chicateo Acad., p. 3935, (1868); Inited (Pam. M.) Kirby, Cat., 1).600, (1871); (Euphyes States from M.) Scud., Syst. Rev. Am. Juutt., T. $80,(1872)$; (I'rem. Maine to M.) Putnam, Proc. Dav. A caut., I, 1. 186, (1876). Katmsas. Pam. Rurea, W. H. Ldwds., Proc. Acatl. Nat. S'., Plil., p. 58, (1862); (//esp. R.) 'Trams. Am. Ent. Soc., II, 1. $288,(1867)$.

\$389. Kunah, Reik., (Iеsp. K.), Proe. Ent. Sor., Phil., "Rocky VI, p. 150, (1866); (P'cm.K.) Kirly, Cat., p. 600, Mts." (1871).

Only known throngh the mique ơ type which passed into my keeping. It is the size and colour of Metacomet, but the infiriors are smaller and botll surfaces of all wings aremiform blackish brown, totally devoid of every vestige of marking save the black discal line on upler sille of primaries.

†*390. Osceola, Lint., MSS. IV. H. Elwds., Trans. An. Mendocino, Ent. Soc., VI, (1877).

Califa.

391. Ar'ius, Abr.-Su., (Pup. A.), Ins. (ri., 1, t. 2:, (1797); (Aulf States. (Pam. A.) I)bldy-IHew., (xen. I)iur. Ix), II, P. 523, (1850-1852); Kirky, Cit., p. 5!7, (1871); (Lerema A.) Scud., Syst. Rev. An. Butt., 1) 82, (1872).

Ilesp. Monoco, Scurl., Proc. Ess. Ins., III, 1. 178, (1862); (Pam. M.) Kirly, ('it., P.600, (1871).

Hesp. Nortonii, W. H. Eiliods., Trans. Am. Ent. Sor, I, p. $287,(1867)$.

Hesp. Punctella, G.-R., Trams. A m. Ent. Soc., I, p. 1, (1867); (Pam. P.) Kirlsy, Cat., p. 600, (1871).

Larva on Indian eorn, Wistarie Frutescens.

†*392. Deva, W. H. Edwds., (Hesp. 1).), Trans. An. Ent. Arizona. Soc., V, p. 292, (1876).

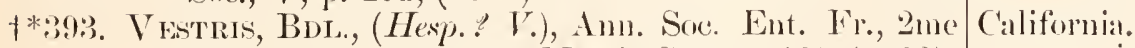
Ser. X, p. 317, (1852); Morris, Syn., 1) 109, (1862); (Pam. V.) Kinlyy, Cat., p. 597, (1871); (Euphyes V.) Ricud., Syst. Rev. Am. Butt., p. 80, (1872).

1*394. Horus, W. H. Howns, (Iesp. H.), Trans. Am. Fut. Tuxas. Soc., III, p. 277, (1871).

395. Varsa, W. H. Edwos., Prox. Acad. Nat. Se., Pliil., J. Pa. south to the 57, (1862); Kirby, Cit., ). 5!99, (1871); (Euphyes V.) Seud., Syst. Rev. Am. Butt., 1. 80, (1872).

396. Hianxa, Scud., (Hesp. M.), Proe. Bost. Suc. Nat. New. Eng. Hist., XI, p. 382, (1868); (I'cm. II.) Kirloy, Cat., States, N.York p. $600,(1871)$; (Levema H.) Scmel., Syst. Rev. Am. Wis., Neb. Butt., 1. 82, (1872).

397. Viteldius, Fabr., (Pap. V.), Ent. Syst., III, 1, P. Pa. sontl to 327, (1793); Hew. in Tram. Ent. Sor. Loml., I, 1. Gulf of Mex.

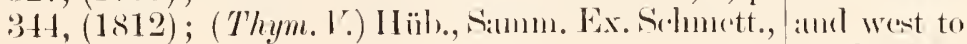


II, Jер. I, Pap). II, Gent. VI, Astyei G., vig. 6, (1816-1844); Ver\%. Bek. Schmett., p. 113, (1816).

Hesp. Delaware, IV. H. Edwols., Proc. Ent. Soc., Phil., II, p. 19, t. V, f. 2, ot, (1863); Send., Proc. Chicago Acad., p. 336, (1868); (Thym. I).) Kirly, Cilt., P. 610, (1871).

Mesp. Logan, W. H. Edwds., Proc. Ent. Soc., Phil., II, p. 18, t. 1, f. 5, , (1863); 'Trans. An. Ent. Soc., II, p. 288, (1867); Scnd., Proc. Chicago Acad., p. 336, (1868); (Ium. L.) Kinby, Cat., p. 607, (1871); (Atrytone L.) Sund., Syst. Rev. Am. Butt., 1) $77,(1872)$.

398. '/abuidon, Bdu-Lec., (Hesp. Z.), Lep. An. Sept., t. 76, Pa. southf. $6,7,(1833)$; (Pam. Z.) Dhldy.-Hew., Gen. Dinr. wand to Gulf Lep., II, p. 523, (1850-1852); Morris, Syu., p. of Mexico, $116,(1862)$; Kirby, Cat., 1.603, (1871); (itrytone west to \%.) Scul., Syst. Rev. Ant. Butt., p. 77, (1872). 'Texas.

IIas been frequently confounded with Hobomok, Harr., lut is entirely distinet.

399. Iовонок, Harris, (Hesp. H.), Ins. Inj. Vegog. Flint's Canada ; kd., p. 313, f. 187, (1862); Morris, Syn., p. 110, United (1862); Soud., Proc. Ess. Hus., III, p. 171, (1862), States from Proc. Chicago Acad., p. 335, (1868); Sammd., Can. Atlantic to Ent, I, P. 66, Larr., (1869); (Pam. M.) Kirby, Cat., 1). 6(1), (1871). the Rockiy

Atrytone Zabulon, Scurl., (nec Bell.-Lee.), Syst. Rev. Mts.

An. Butt., p. 77, (1872).

Latrva on grisis.

var. a. (QUADAqUINA, Ścud, (ITesp. ().), Proc. I'ost. Sor. Nit. Hist., XI, 1. 381, (186s); (' 'am. ().) Kirlyy, Cat., p. 603, (1871).

This and the following are melanotic forms of Ilobomok, having both surfaces obsented with dark brown.

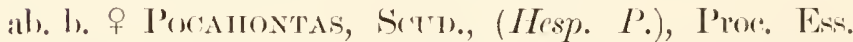
Ins., III, p. 171, (1860); Proce. Bust. Sow. Nat. Hist., XI, P. 381, (1868); (I'am. I’.) Kirly, Cat., р. 60:3, (1871); (Hexp. P.) Streck., L(p), Rihop.Het., p. 7, (1872).

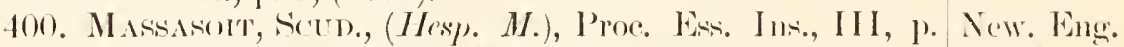
171,(1S62); (I'am. M.) Kirluy, ('at., p. (i)7, (1s71); and Mirllle (Poemes M.) Sounl., Syst. Rive Am. Butt., 1) T6, States. $(187 \cdot 2)$.

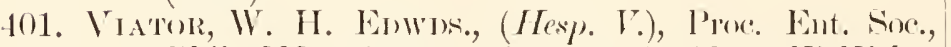
l'hil., I V, P. 202, t. 1, f.5, (1s6.5); (P'm. V.) Kirhy,

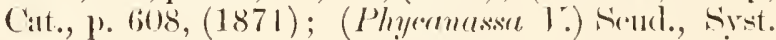
limv. Am. Butt., p. 77, (1572).

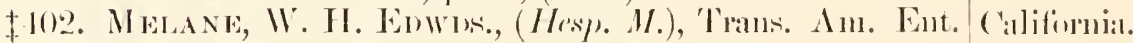

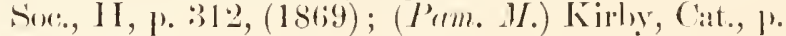
(60), (1571).

Mr. W. H. Helwds. in Trans. An. Bnt. Soc. Y'I, Feh., 187t, rites this as a "dim. val. f" of Norpe. This is curions, as 
he described Melane himself from "1 $\sigma, 1 \%$, collection 'Tryon Reakirt, Esq." There are in this coll., including Edwds.' types, $3 \delta^{2}, 1$. all of which are now in my possession. They are indubitably $\sigma^{2}$ and $q$; in that there is no mistake, and Edwds. properly described both sexes in Trans. II, 312 ; and what makes it still more strange that he shonld later place it as a var. of Napa, is that the on is entirely destitute of the raised diseal bar or stigma so conspicnons in Napa ơ ind allies.

Melane is a dark brown species. Napa a yellow one.

403. Iowa, Scun., (Hesp. I.), Trans. Chicago Acad., p. 336, Gulf States; (1868); (Atrytone I.) Syst. Rev. Am. Butt., p. 77, Low:1, Ne(1872); (Thym. I.) Kirby, Cat., p. 610, (1871). brakka.

Pap. Vitellius, Abb.-Sm., (nec Fabr.), Ins. Ga., I, 1).

34, t. 17, (1797); (Pam. V.) Dbldy.-Hew., G(n.

Diur. Lep., II, 1. 52, (1850-1852); Morris, Syn.,

p. 120, (1862); Kirly, Cat., p. 603, (1871).

Latra on Punicum (inus-galli.

404. Panoevin, Scud., (Hesp. P.), Proc. Ess. Ins., III, p. 178, Gulf States.

(1862); (P'am. P.) Kirlsy, Cat., p. 608, (1871);

(Prenes 1'.) Scudl., Syst. Rev. Am. Butt., p. \$1, $(1872)$.

Hesp. Ophis, W. M. Edwods., Trans. Am. Wint. Sox., II, 1). 216, (1871).

405. ()ond. W. H. Enwds., (Hesp. O.), Proc. Ent. Sor., Phil., Gulf States.

II, p. 20, t. 11, f. 4, (1863); (Pam. O.) Kirlyy,

Cat., p. 607, (1871); (Prenes O.) Sond., Syst. Rev.

Am. Butt., p. 81, (1872).

406. Eтuluus, Cran., (Pup. E.), Pap. Ex., IV, t. 392, A, B, Gulf States;

(1782) ; (Calpodes E.) II iib., V'er\%. Bek. Schmett., S. Am. to

p. 107, (1816); (I'rem. L.) Kirloy, Cat., p. 596, Bunuó

(1871); (C'alpodes E.) Send., Syst. Rev. Am. Butt., Ayres.

l. $82,(1872)$.

Hesp. Chemnis, Fabr., Ent. Syst., III, 1, p. 331,

(1793); (Hesp. (․et Ethl.) Laitr., Hne. Meth., IX,

1. $746,(1823)$; (1'tp. (!) Dom., Ins. Ind, t. 4!), t:

$1,(1800)$.

Eudcamus? Olymthus, Bell.-Lec., Lep. Ams. Sept., t. 75,

f. 1, 2, (1833) ; (Goniloba ().) Morris, Syn., p. 113, (1862); (14m. O.) Kirlyy, Cit., p. 5!)(i, (1871).

A single example of this sonthern species was taken in West Farms, N. Y., by James Angus some ycars since.

for. Maudata, W. H. Eowns., (Mesp. M.), Prow. Ent. Soc, Sonthem Plil., IV, P. 20\%, t. 1, f. 6, (1865); ('Prm. M.) States, Gil.

Kirby, (at., 1). 599, (1871); (Oligoria M.) Scud., to 'Fexas.

Syst. Rev. Ant. Butt., 1. 81, (1872).

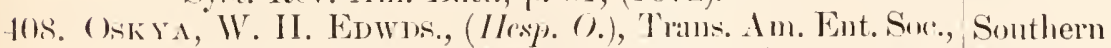

I, p. 288, (1867); (P'em. O.) Kirby, Cat., P. 607, States;

(1871); (Euphyes O.) Soul., Syst. Rev. Am. Butt., Goorgia to 1. $79,(1872)$.

Mrsp. Enfule, Wr. II. Eduds., Trans. Am. Ent. Soc., Jexis.

II, 1). 311, (186!)); (l'um. L.) Kirlyy, Cat., 1) 606, (1871); (Lerorde E.) Serul., Syst. Riev. Am. Butt., 1. $79,(157 \%)$. 
Eufala was sent to me from Apalachicola, Fla., by Dr. A. W. Chapman, who also furnished Mr. W. H. Edwds. with the example from which the latter made his description. Later I obtained examples of Oskya taken in 'Texas and identified hy Mr. Fdwds. himself, and I cannot, with my best will, find any characteristics by which to separate them into two species.

409. Conus, W. H. Enwos, (ILesp. C.), Trans. Am. Ent. Texas. Soc., V, p. 206, (1876).

410. Vialis, W. H. Evwis., (Hesp. T.), Proc. Acad. Nat. L. S. from Sc., Phil., P. 58, (1862); (I'cm. V.) Kirby, (at., P. Atlantic to 608, (1s71); (Amblyscertes I.) Seml., Syst. Rev. Mississippi Aı. Butt., J. 75, (1872).

Vallev.

411. Simoste, Sivd., (Hesp. S.), Proc. Eis. Ins., III, p. 176, New Eng.

(1862); (Amblyscirtes S.) Syrt. Rev. Am. Butt., and Midulle 1. $75,(1872)$. Mesp. Megon, Scud., Proc. Fss. Ins., III, p. 176, Iowa, Wis(1862); Korloy, Cat., p. 613, (1871). States, Mich.

Hesp. Nemoris, W. H. Edurds., Proc. Ent. Sixe., Phil., II, P. 507, (1863); I. c., IV, t. I, (1865).

Ilesp. Alternata, G.-R., Tran.. A m. Ent. Soc., I, p.:3, (1867); (Pam. A.) Kirby, Cat., [). 606, (1871).

Latrvi on Androporgon Arenaceum.

412. Fusci, G.-R., (ILesp. F.), Trans. Ani. Ent. Soc, I, p. Sonthern

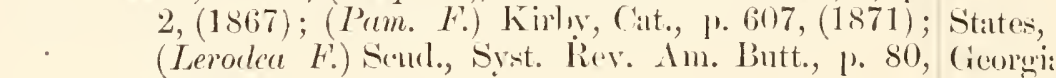

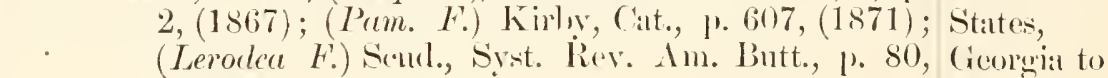
$(1872)$. conisin. Texils.

413. Traxtor, Hub., (Pyrgus T.), '/utr. Ex. Schnett., f. 515, Sonthem 516, (1825); I)bly.-Hew., ('on. Diur. Lep., II, p. States, 518, (1850-1852); (P'am. T.) Kirby, Cat., P. 606, Georgia to (1871); (Stomyles T.) Scull, Syst. Rier. Am. Butt., Texas. 1. $76,(1872)$.

Hesp. Onelo, Scud., Proc. Esis. Ins., III, 1. 176, (1862); Kirby, Catt., 1. 6113, (1871).

Hesp. Wakulla, W. H. Edwds., T'rans. Am. Ent. Soc,, II, ]. : :11, (1869).

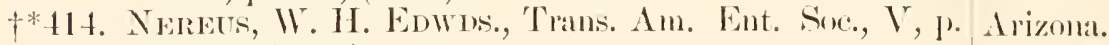
$207,(1876)$.

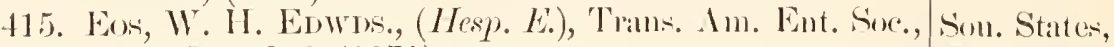
JlI, p. $286,(1871)$.

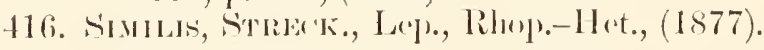

The earlier stages of but fesw of the species of Pamplita are (iil. to 'T'ex. Sill Antonio, 'T'xils.

known, but it is presumed that the larva of most of them feel on gratss.

\section{GENUS 6. ANCYLOXYPIIA, FEm.}

417. Procris, W. II. Enwos., (Meteropterus l'.), 'T'rans. Am. 'Texas.

Ent. Sox., I11, 1. 215, (1871).

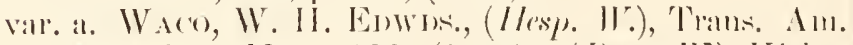
Ent. Sior.. I1, J. 122, (1stis); (Pram. IT.) Kirly,

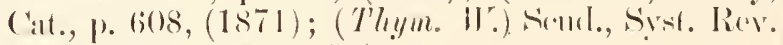
A11. Bull., 1). 71, (1ST2). 
IIesp. Minima, W. II. Edturds., Trans. Am. Ent. Sore, III, p. 196, (1870); (Thym. M.) Kirly, Cat., p. 656, (1871).

Destitute of the white streak which runs from base to middle of outer edge on under sicle of seeontaries in Procris.

†*418. Arene, W. H. Edwds., (Ieteropterus A.), Trans. Am. Arizonia. Eint. Soc., III, I. 214, (1871); (Thym. A.) Scurl., Syst. Rer. Am. Butt., p. 75, (1872).

419. Numitor, Fabr., (Ilesp. N.), Euit. Syst., III, 1, p. 324, Camada ; (179:3); (Pap. N.) Don., Ins. Ind., t. 44, (1800); United (Iesp. N.) Latr., Ene. Meth., IX, p. 776, (182:3); States from (Pam. N.) Dbldy.-Hew., Gen. I)iur. I sep., II, p. the Atlautic 523, (1850-1852); Morris, Syn., p. 120, (1862); to the Rosky (Thymelicus N.) Kirlw, Cat., j). 609, (1871); (An- Mts. $c y l$. N.) Seudl., Syst. Riev. An. Butt., p. 74, (1872).

Thymelicus Puer, IÏ̈̈b., Ver\%. Bck. Schmett., 1. 113, (1816); Zutr. Ex. Solunett., f. 275, 276, (1823).

Heteropterus Marginatus, Ilarris, Ins. Inj. V'eg., Flint's Ed., p. 308, f. 131, (1862); (Thym. M.) Kirlor, Cat., p. 610, (1871).

+200. Garita, Reak., (Hesp. G.), Proce Ent. Soc., Phil., VI, (oloramlo, p. 150, (1866); (I'am. G.) Kirby, Cat., p. 607, N(braklial, (1871); (Ilesp. G.) Streck., Lep., Rhop.-Ilet., p. Illinois. $93,(1874)$.

Ilesp. Powesheik, Parker, Am. Ent., II, p. 271, (1870);

(Oarisma I'.) Scul., Syst. Rev.Am. Butt., p.75,(1872).

? var. a. Hylax, W. H. EDwds., (Thymeticus 11.) T'inn. Colorado. Am. Ent. Soc., I I I, 1) 274, (1871).

\section{GENUS 7. CARTEROCEPHALUS, LEn.}

421. Mandan, W. H. Edwos., (IIssp. M.), Proce Eut. Soes, White Mts. Phil., II, P. 20, t. 5, f. 1, (1863); (Ileteropterus of New M.) Kirby, Cat., P. 624, (1871); (Cyclopides M.) Ilampshire; Send., Syst. Rev. Am. Butt., p. 75, (1872).

IJesperia IIesapano, Scud., Prore. Bost. Soc. Nat. Hist., British

XI, p. 383, (1868); (IItetopterus M.) Kirby, Catt., Columl ria, p. $624,(1871)$.

Cyclopides Skada, IV. II. Eduds., Trans. Am. Ent. Soc., III, p. 196, (1870); (IIeteropterus S.) Kirby, Cat., p. 656, (1871); (Cyclopides S.) Soud., Syst. Rev. Am. Butt., 1. 75, (1872).

†*422. (Omana, W. H. Eiwns., (Ilesp. O.), Proe. Ent. Soc., West Vil., Phil., II, P. 21, (186:3); Reak., l. c., VI, p. 150, Coloradu, (1866); (I'am. O.) Kirby, Cat., 1. 607, (1871); California. (Potanthus O.) Scud., Syst. Rev. Am. Butt., 1. 75, (1872).

Hesp. Mingo, W. H. Edwds., Proc. Ent. Soe., Phil., VI, p. 207, (1866); (Y'am. M.) Kirloy, Cat., 1. 607, (1871).

Potanthus Californica, Scud., Syst. Rev. Am. Butt., p. $75,(1872)$. 


\section{GENUS 8. PYRGUS, Hub.}

429. Srrentus, Fanr., (Pap. S.), Syst. Ent., p. 534, (1775); Unitedstater Sp. Ins., I I, ». 1:37, (1781); Mant. Ins., I I, p. 90, and 'T'(rrito(1787) ; Ent. Syst., III, 1, p. 349, (1793); (Pyrg. ries fiom s.) Hïb., Verz. Bek. Schmett., 1) 109, (1816); Atlantic to (Hesp. S.) Latr., Enc. Meth., IX, 1). 785, (182:3); Pacific; (I'yrg. S.) Dbldy-Hew., Gen. Diur. Lep., II, p.' Cent. and s. 518, (1850-1852); (Hesp. S.) Kirhy, Cat., p. 616, Am. to (1871); Scul., Sy-t. Rev. Am. Butt., p. 73, (1872). Bucmos Pap. Orcus, Cram., Palp. Fx., IV, t. 33t, I, K, L, Ayres. (1782).

Pyr\%. Oileus, West.-Mumph., (nec Limn.), Brit. Butt., t. 38, f. 14, 15, (18+1); Reak., Proc. Ent. Soc., Phil., VI, p. 150, (1866).

Syrichtus Oilus, Morris, Syn., 1). 121, (1862).

Ṕap. Tartarus, Müb., Eur. Schmett., f. 716, 717, (1808-1818).

Mesperia Tessellata, Soud., Syst. Rev. Am. Butt., p. 7:), (1872); Can. Ent., IY , 1. 77, (1872); (I'y\%. T.) Putnam, Proe. Dav. Acad., I, p. 197, (1876).

Syrichtus Communis, Grote, Can. Ent., IV, 1. 69, (1872); (Hesp. (¿) 1. c., p. 220, (1872).

I arva on wild tea (Serla).

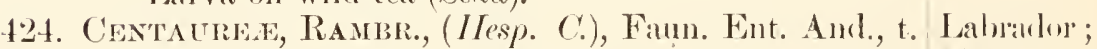
8, f. 10, (1839); Bdl., (ren. et Ind., p. 36, (1840); New York, I-S., Schmett. Eur., I, Hesp., t. 1-?, (1845); Virginia, Wallerr., Skand. Dagf., p. 265, (1853); (Scel. C.) Cololado; Raunbr., Cat. Lep. And., I, p. 78, (1858); (Syr. C.) Norway, Moseh., Wien. Ent. Mon., VIII, 1. 193, (1864); Iapland. Stgrr., Cat., 1. 34, (1871); (IIesp. (') Kirloy, Calt., 1. 614, (1871); Scull., Syst. Rev. Am. Butt., 1. 7t, $\left(187^{\circ}\right)$.

Syr. Ruralis, Brll., Amn. Soc. Ent. Fr., 2me Ser. X, p. 311, (1852); Morris, Syn., p. 121, (1862); (IIesp. R.) Kirly, Cat., 1. 616, (1871).

Mesp. Wyandot, W. H. Edwds., Proe: Ent. Soc., I'hil., II, 1. 21, t. 5, f. 4, (1863); Kirly, Cat., p. 614, (1871).

425. Ricalia, W. H. Edwos., (ITesp. R.), Proc. Ent. Soc., Nevadil, Phil., IV, p. 203, t. 1, (1865); (Pyrg. R.) Reak., California. 1. c., VI, p. $150,(1866)$; (IIesp. R.) Kirby, C'it., 1. $614,(1871)$.

Mesp. Ruralis, Scud., (nec Bdl.), Syst. Rev. Am. Butt., 1. 74, (1872).

Syr. Petreius, W. II. Edwds., Trams. Am. Ent. Soc., III, p. 195, (1870).

†*426. Caspritalis, BDi., (Syr. C.), Amn. Soc. Ent. Fr., 2me Califomia. Ser. X, 1. 312, (18.52); Morris, Syn., p. 121, (1862); (Hesp. C.) Kirly, Cit., p. 616,(1871); Seud., Syst. Rev. Am. Butt.o, p. 7t, (1872). 
†*427. Scriptura, Bnl., (Syr. S.) Ann. Soc. Ent. Fr. 2me California. Ser. X, p.31:, (1852); Morris, Syn., p. 121, (1862); (Hesp S.) Kirby, Cat, p. 616, (1871); Send., Syst. Rer. Am. Butt., p. 7:, (1872).

428. Ericetorum, Bdl., (Syr. E.) Anm. Soc. Ent. Fr. 2me Oregon, Ser. X, 1).313, (1852); Morris, Syn., p. 121, Callifornia. (1862); (Leucochitones E) Kirby, Cat., 1). 617, (1871); (Leucoscirtes E.) Scud., Syst. Rev. Am. Butt., 1) 72, (1872).

Syr. Alba, W. H. Edwds., Proc. Ent. Soc. Phil. VI, p. 206, (1866); (Hesp. A.) Kirby, Cat., p. 614, $(1871)$.

中*429. Oceanus, Wr. H. Edwds., (Syr. O.), Trans. Am. Ent. Arizona, Soc. III, 1. 213, (1871); (Leucoscirtes O.) Scud., syst. Rev. Am. Butt., p. 72, (1872).

\section{GENU's 9. SPILOTHYRUS, DUP.}

430. Notabilis, Stracck., Lep. Rhop.-Het., p. 131, (1877). San Antonio, Tex.

\section{GENUS 10. NISONIADES, Hub.}

\section{(Thanaos, Bdl.)}

431. Juvenalis, Fabr., (Hesp. J.) Ent. Syst. III, 1, p. United 339, (1793) ; (Pap. J.) Abb.-Sm., Ins. Ga. I, t. 21, States from (1797); (Hesp. J.) Latr., Enc. Meth. IX, p. 789, the Atlantic (1823); (Than. J.) Bell.-Lec., Lep. Am. Sept., t. to the 65, (1833); (Nis. J.) Dbldy.-Hew., Gen. Diur. Mississippi Lep. II, p. 519, (1850-1852); (Than. J.) Harris, Villey. Ins. Inj. Veg., Flint's Ed., p. :309, (1862); (Nis. J.) Morris, Srn., p. 114, (1862); Scud.-Burgess, Proc. Bost. Soc. Nat. Hist. XIII, p. 297. (1870): Kirby, Cat., p. 629, (1871); (Erynnis J.) Scud., Syst. Rev. Am. Butt., p. 72, (1872).

Nis. Jurenis, Hüb., Verz. Bek. Schmett., p. 108, (1816). Nis. Costalis, Dbldy.-Hew., Gen. Dinr. Lep. II, 1) 519 , t. 79, f. 3, (1852).

Nis. Terentius, Scud.-Burg., Proc. Bost. Soc. Nat. Hist. XIII, p. 292, (1870); Kirbr, Cat., 1. 629, (1871) ; (Erynnis T.) Soud., Syst. Rev. Am. Butt., p. $71,(1872)$.

Nis. Ovidius, Scud.-Burg., I. c., p. 295, (1870); Kirby, ('at., p. 629, (18:1); (Erynnis O.) Seud., Syst. Rev. Am. Butt., 1. 71, (1872).

Nis. Ennius, Scud.-Burg., l. c, p. 296, (1870); Kirls, Cat., 1. 629, (1871) ; (Erynnis E.) Seud., Syst. Rev. Am. Butt., p. 71, (1872); (Nis. E.) Putnam, Proc. Dar. Acad. I, p. 186, (1876).

Nis. Horatius, Scud.-Burg., 1. c., p. 301, (1870); Kirby, Cat., p. 630, (1871); (Erynnis H.) Scud., Syst, Rev. Am. Butt., p. 71, (1872). 
Nis. Virgilius, Scud.-Burg., 1. c., p. 302, (1870); Kirby, Cat., 1. 630, (1871); (Erynnis V.) Scucl., Syst. Rev. Am. Butt., 1) 71, (1872).

Larva on various oaks, Wild Indigo, Glycine, Lathyrus.

†*432. Planute, Sudd-Burg., Proc. Bost. Soc. Nat. Mist. Floridit.

XIII, p. 304, (1870); Kirby, (at., p. 630, (1871);

(Erynnis P.) Seud., Syst. Rer. Am. Butt., 1. 71, (1872).

43:3. Propertius, Scud.-Burg., Proc. Bost. Soc. Tat. Hist. California.

XIII, p. 299, (1870); Kirly, Cat., 1. 6:30, (187]);

(Erynnis P.) Seurl., Syst. Riev. Am. Butt., p. 71, (1872).

Nis. Tibulhus, Scud-Burg., Proc. Bost. Soc. Nat. Hist.

XIII, 1. 298, (1870); (Erynnis T.) Scud., Syst.

Rev. Am. Butt., 1. 71, (1872).

434. 'Tristis, Bdi., (Than. T.) Ann. Soc. Ent. Fr. 2 me Ser. Califonnia

X, p. 311, (1852); (Nis. T.) Morris, Syrn., p. 115, and alliacent

(1862) ; Scud.-Burg., Proc. Bost. Soc. Nat. Hist. territory.

XIII, p. 303, (1870); Kinlsy, Cat., p. 6:30, (1871);

(Erynnis T.) Seud., Srst. Rev. Am. Butt., p. 71, (1872); (Nis. T.) Putnam, Proe. Dar. Acad., p. $186,(1876)$.

435. Funeralis, Scud.-Burg., Proc. Bost. Soc. Nat. Hist. 'Texis.

XII, p. 293, (1870); Kintr, Cat., 1. 629, (1871);

(Erynnis F.) Scud., Syst. Rev. Am. Butl., 1. 71, (1872).

†*436. Pacuvius, Lint. MSS., W. H. Edwds., Tians. Im. Arizona. Ent. Soc. VI, (1877).

4:7. Persius, Scud., Proc. Fss. Ins. III, p. 170, (1862); New Eng., Scud.-Burg., Proc. Bost. Soc. Nat. Hist. XIII, J. Middle and 286, (1870); Kirloy, Cat., P. 629, (1871); (Erymis, Wrestern P.) Send., Syst. Rev. Am. Butt., p. 71, (1872); States to the (Nis. P.) Lint., Ent. Cont. 2:3 I Rep. N. Y. State Paleific. Mus., t. 7, f. 3, 4, (1872).

var. a. Lucilius, Lint., Ent. Cont. 23d Rep. N. Y. State Mus., p. 164, t. 7, f. 1, 2, (1872); Scud.Burg., Proe. Bost. Soc. Nat. Hist. XIII, p. 287, (1870); Kirby, Cat., 1. 630, (1871); (Erynnis L.) Send., Syst. Rer. Am. Butt., p. 71, (1872).

Ground colour not so dark; the marks on upper surface primaries more distinet.

Larva on Scarlet Columbinc, (Aquilegia Canadensis).

4:38. Martialis, Scud., Trans. Chicago Arad. Nat. Sc. I, p. From Mass. 3:35, (1869); Somd.-Bure., Proc. Bost. Soc. Nat. south to the Hist. XIII, 1. 291, (1870); Kirby, Cat., p. 629, Gull :mb (1871); Iint., Ent. Cont. 23d Rep. N. Y. State wert to Mus., t. 7, f. 7, 8, (1872); (Erynnis M.) Scud., Texas and Syst. Rev. Am. Butt., p. 71, (1872).

Lava on Ceanothus Americanus. Nebriskia. 
439. Ausonius, Lint., Ent. Cont. 23d Rep. N. Y. State Mid. States, Mus., p. 166, t. 7, t. 11, 12, (1872). O., Md., Va.

440. Brizo, Bde-Lec., (Than. B.) Lep). Am. Sept., t. 66, Canada; U. (18.33) ; Bdl., Amn. Soc. Ent. Fr. 2me Ser. X, p. S. from the 310, (1852); (Nis. B.) Dbldy.-Hew., Gen. Diur. Atlantic Lep. II, p. 520, (1850-1852); (Than. B.) Harris, west to Ins. Inj. Veg., Flint's Ed. p. 309, f. 192, (1862); ( Nis. Kansas and B.) Morris, Syn., p. 114, (1862); Scud.-Burg., Texas.

Proe. Bost. Soe. Nat. Hist. XIII, p. 289, (1870); Kirby, Cat., p. 629, (1871); Lint., Ent. Cont. 23d Rep. N. Y. State Mns., t. 7, f. 9, 10, (1872); (Erynnis B.) Scud., Syst. Rer. Am. Butt., p. 71, (1872).

Larva on Oaks, Wild Indigo.

441. Icelus, Lint, Ent. Cont. 23A Rep. N. Y. State Mus., Can., N. E. p. 162, t. 7, f. 5, 6, (1872); Scud.-Burg., Proce and Middle Bost. Soc. Nat. Hist. XIII, 1. 288, (1870); Kirby, States, Ohio, Cat., 1. 630, (1871); (Erymnis I.) Scud., Srst. Rev. Ind., Ill., Am. Butt., p. 71, (1872).

Nich.

442. Tages, var. Cervaytes, Grasl., (Than. (.) Amu. Soc. California. Ent. Fr. p. 558, t. 17, B, f. 1, 2, (1836); Bdl., 1. c., 2 me Ser. X, p. 310, (1852); (Erynnis C.) Ranb., Cat. Lep. And., p. 83, (1857); (Nis. v. C.) Kirby, Cat., p. $628,(1871)$.

†*443. Zanpa, II. H. Edwos, (Hesp. Z.) Trans. Am. Ent. Arizona. Soc. V, 1. 207, (1876); (Lintneria Z.) l. e. VI, (1877); (Systasec Z.) Cim. Ent. IX, p. 120, (1877).

444. Catulleus, Fabr., (Hesp. C.) Ent. Syst. III, 1, p. 348, United (1793); (Pap. C.) Abb.-Sn., Ins. Ga. I, t. 24, States from (1797); Don., Ins. Ind., t. 50, (1800); (Hesp. C.) the Atlantic. Latr., Ene. Meth. IX, 1). 77 , (1823); (Nis. C.) to the Roeky Morris, Syn., p. 115, (1862); Reak., Proe. Ent. Mts. Soe. Phil. V1, p. 150), (1866); Kirby, Cat., p. 630, (18i1); (Pholisora C.) Scud., Srst. Rev. Am. Butt., p. $72,(1872)$.

Larva on Pigweed, Monardo Punctata.

The Pup. Catillus, Cram., t. 260, f. F, G, which has been cited by W. H. Erwds. and others as this species, is an entirely different insect, being tailed like Proteus and belonging to the genus Eudamus.

445. Haymursti, W. H. Eidwes, (Hesp. H.) Trans. Am. From Mrd. Ent. Soc. III, p. 22, (1870); (Nis. H.) Kirly, Cat., sonth to Gulf p. 631, (1871); (Pholisora C.) Sendl., Syrt. Rev. and west to Am. Butt., 1. 71, (1872). Rocky Mits. †*146. Alpheus, W. H. Eowds., (Than. A.) Trans. Am. Ent. New Mexico Soc. $V$, p. 206, (1876).

†*447. Pinus, ${ }^{*}:{ }_{w}$ H. Livds., Field and Forest III, p. 119, Colorado. $(1877)$.

†*448. Nessus, W. H. Edwds., Can. Ent. IX, p. 192, Sam Antonio, $(1877)$. 


\section{GENUS 11. ACHLTODES, IlUB.}

449. 'Thraso, Hur., (Urbanus vetus T.) Samm. Ex. Sohmett. Texas, I, (1806-1816); (Achl. T.) Verz. Bek. Schmett., p. Mexico, 108, (1816); (Erntis T.) Bull., Sp. Cren., t. 1:), t. 6, Cent. An. (18:36); (Achl. T.) Kirby, Cat., p. 631, (1871); Scud., Syst. Rev. Am. Butt., p. 70, (1872).

Hesp. Tamenund, W. H. Ealods., Trans. Am. Ent. Soc. III, p. 215, (1871). 


\section{APPENDIX.}

Since the precerling has goue through press, the following additional citations have been noted and new species described:

\section{GENUS PAPILIO, L.}

1. Philenor, L. (p. 67); Fabr., Srst. Ent., p. 445, n. 12 , (1775); Spee. Ins. II, 1). 4, n. 15, (1781); Mant. Ins. II, p. 2, 1. 15, (1787); Ent. Srst. III, \%. 6, 11. 18, (1793); Goeze, Ent. Bert. III, P. 39, n. 2, (1779); Herbst, Naturst. Sehmett. II, p. 271 , t. XIX, f. 2, 3, (178t); Shaw-Nodd., Nat. Miss. XXIII, t. 1010, (1790-1813); (Laertias P.) Hüb., Verz. Bek. Schmett., p. 84, 1. 858, (1816); Emm., Agr. Nat. Hist. N. I., V, p. 201, (1854).

3. Ponvoamas, L. (p. 67) ; Srst. Nat., El. X, p. 460, 1. 11, (1758); Herbst, Natursyst. Sehmett. II, p. 91, t. X, f. 6, 7, (1784); Goeze, Ent. Beyt. III, 1). :34, 1. 12, (1779); (Ithobalus P.) Hüb., Verz. Bek. Sehmett., 1. $88,11.91: 3,(1816)$.

I have on p. 68 cited Merian's upper fig. plate 31 to thin species, inasmueh as Linne himself refers to the same figure in Syst. Nat., Ed. X; but on re-examination of said figure I am filly assured that it does not represent Polydamas, or even agree with 'imme's short diagnusis, but represents $P$. Androgeos, Cram., which is 8 form of $P$. Polycann, Cram.; the latter' is also represented on the lower part of the same plate.

5. A.JAx, L. (p. 68) ; Srst. Nat., Ed. X, p. 462, n. 26, (1758); Fabr., Sp. Ins. II, p. 20, 11. 79, (1781); Mant. Ins. II, p. 10, n. 90, (1787); Ent. Syst. III, ?. 33, 1. 97, (1793); Goeze, Ent. Beyt. III, p. 55, 11. 32, (1779); Herbst, Natursst. Schmett. II I, p. 114, t. XLII, f. 5, 6, (1788); Shaw-Nodd., Nat. Miss. XXIV, t. 1024,(1790-1813).

On t. XLIV, vol. Il I of Herhat's Natursyt. the figures $(1,2)$ of $P$. Milliades, eopied from Anhenton, had for their original an example of Demoleus in which the hinel wings had been replaced by those of $A j a x$.

Pup. Marcellus, Goeze, Ent. Bert. III, p. 81, n. 56, (1779).

Papilio caurlatus Carolinianus, Cutesby, Car. II, 1). 100, t. 100, (17:31); also same p. and t. in Ed. of 1754 and of 1771 .

6. Sinos, Fabr. (p. 68); (Tphiclides S.) Hïb., Verz. Bek. S.hmett., p. 82, n. 8:38, (1816).

7. (resphontes, Cras. (p. 69); Goeze, Ent. Beyt. III, p. 86, II. 64, (1779); Herbst, Natmsyst. Schmett. III, p. 
121, t. XXXIX, (1788); Glov., U. S. Agr. Rep. p. $264,(1858)$.

P. Thoas, Shau-Node, Nat. Miss. IX, t. :331, (1790-1813).

10. Tulinus, Lrnn. (p. 69); Fabr., Mant. Ins. II, p. 9, 11. 76, (1787); Ent. Srst. III, p. 29, n. 86, (179:) ; Groeze, Ent. Beyt. III, 1, p. 71, 1. 5, (1779); Herbst, Naturisst. S(hmett. III, J. 136, t. 41, f. 3, 4, (1788); Gosse, Can. Nat., p. 18., fig. (1840); Emm., Agr. Nat. Hist. N. Y., Y, p. 201, (1854); Seud., Proc. Bost. Soe. Nat. Hist., Tol. XII, p. 406, (1869); Saunders, Cint. Ent. VI, p. 2, f. 1, 2, (1874).

Pap. caudatus max. etc., Catesby, Car. II, t. 83, (17:31).

Pap. Antilochus, Limn., Syst. Nit., Ed. X, p. 46:3, 1. $28,(1758)$; Falbr., Ent. Syst. III, 1, p. 24, 11. 70, (179:3).

P. Thersitrs, Lee, Coloured Spec. Ill. Nat. Hist. Butt. t. $2,(1806)$.

Pap.diurna, primaetc., Catesby, Carol., p.97,t.97,(1731) P. Alcidamas, Goese, Ent. Bert. III, 1, 1) 77, 11. 27, (177!). Ray, Hist. Ins., p. 111, n. 98, (1710). ab. F (ilducus, Lixs. (p. 70$)$; Syst. Nat., Ed. X, p. 460, 11. 9, (1758); Falı., ș. Ins. II, 1). 5, n. 18, (1781); Mint. Ins. II, p. 2, 1. 18, (1787); Ent. Syst. II I, 1, 1. 4, 1. 11, (1798); Herlst, Natursyst. Sichmett. 1II, 1. 229, t. XVII, t. 1, 2, (1788).

Herbst's tigures represent one of those curious of aberrations that are intermediate between the black and yellow formsneither as dark as one nor as light as the other.

11. Rutulus, BdL. (p. 70); ठ var. or ab.? Streck., Lep. Lrizona. Rhop.-Het. I, p. 128, (1877).

13. Machaon, Lisx. (p. 70); Ray, Hist. Ins., p. 111, (1710); Merian, Ins. Eur., t. 38, (1730); Wood, Ind. Ent., p. 1, t. 1, f. 1, (1745); S(o)., Ent. Carn., 1) 166, n. 44. (1763); Fabr., Syst. Ent., p. 452, 11. 42, (1775); ث̈pec. Ins. II, 1. 17, 11. 67, (1781); Mant. Ins. II, 1. 9, 11. 77, (1787); Hnt. Syst. I I I, 1, 1. 30, n. 37, (179:3) ; Herbst, Natursyst. Schmott. III, p. 162, t.

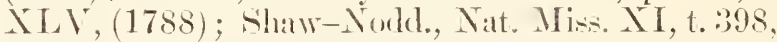
(1790-1813); Lewin, Pap. (Er. Brit., p. 72, t. 34, (1795). Hne. Meth. Ins. Plates, t. 49, t. 4, 5. 6, (1797); Don., Nat. Hist. Brit. Hns. VI, p. 75, t. 211, (1797); Schatef, lon. I, t. 45, 1. 63 in vol. of text, (1804); Hïb., Kur. Schmett., l’ap., n. 775,

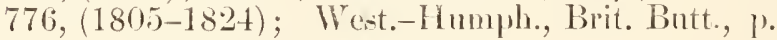
8, t. I, (1841); I)bldy.-Hew., Gen, Vol. I, 1. 16, 11. $158,(18+6-1850)$.

Papilio major caudatus, the Royal Willirm, Pet. Mus., p. 35, 1. :328, (1695); T’ap. Brit., P. 1, 1. 5, t. 2 , f. $5,(1717)$.

I'. Aliesker, seud., I'roe. Bont. Soc. Nat. Hist. XII, J. $407,(1869)$. 
14. \%olicaos, BDL. (p. 71).

val. a. Oregoxia, II. H. Eowds., (P. Hippoerates var.

Oregonia) Trims. Am. Ent. Soc. Y, p. 208, (1876).

Differs from the normal form mainly in the anal ocellns.

17. Asterius, Crair. (p. 71); Guste, Cam. Nitt., p. 184, (1840).

P. Asterias, Emm., Agr. Tat. Hint. ‥ Y', 1. 200, (18.5).

P. Polyxenes, Herbst, Natursyt. Schmett. II, 1. 253, t. 18, f. $1,\left(\sigma^{7}\right),(1784)$.

Troilus, Herbst, 1. e., p. 242, t. 17, f. 3, 4, ( ) ; ShawNodd., XXIII, t. 100:3, (1790-1813).

valr. e. ITtaheNsis, Streck., I גep. Rhop.-Het. I, p. 128, (1877).

18. 'Tronlus, Lixx. (1. 72) ; Syrt. Nit., I, Eil. X, p. 459, n. 5, (1758); Herbst, Natmisyt. Schmett. II, p. 291, t. XX, f. 2, (o7), (1784); Glover, Agrr. Rep., 1) 548 , (1864), 1. c., p. 314, (1868).

19. Palamedes, Dru. (1. 7:3).

P. Chalcus, Fabr., sp. Ins. II, p. 18, 11. 70, (1781); Mant. Ins. II, 1. 9, 11. 80, (1787); Herbst, Nat. Schmett. III, p. 139, t. 42, (1788).

P. Chalcas, Fabr., Ent. Srst. III, 1, p. 31, 11. 90,(1793). Pap. Flavomaculatus, Goere, Ent. Bert. IJ I, 1, p. 87, n. $72,(1779)$.

$(1765)$

fig. 1, (1797).

\section{GENUS PARNASSIUS, LATR.}

20. var. Smintheus, DBLdy.-Hew. (p. 73 ).

val. a. Behri, IV. H. Enwos., Hy. Edwds, Proc. Cal. Acad. Sc. VI, (1876).

21. Cuonuss, Mex. (p. 73); Hy. Edwds., Proc. Cal. Acad. Ne. VI, (1876).

var. Mrantriesin, Hy. Eowds, Proe. Cal. Acad. Se. Califil.; Mt. VI, (1876).

Smaller, and with the red spots of secondaries very small.

22. Eversmaxni, Men. (1. 73); Seud., Proc. Bost. Soc. Nat. Hist., Vol. XII, p. 407, (1869).

\section{GENUS NEOPHASIA, BEHR.}

24. Mexapa, Femo. (p. 74); W. H. Elwds., Trms. Am. Ent. Soc. IT, 1) 6i: (1872-1873).

\section{GENUS LEPTALIS, DALM.}

25. Melite, Linn. (p. 73); Amoen. Acal. VI, p. 403, n. 56, (1763); Fabr., Syst. Ent., p. 460, n. 71, (1775); Spec. Ins. II, p. 27, 11. 108, (1781); Mant. Ins. II, 
p. 13, n. 126, (1787) ; Herhst, Nat. Schmett. IV, p. 165, t. LXXVI, t. 3, 4, (1700). Enc. Meth. Ins. Plites, t. 21, f. 10. (1797).

Pap. Versicolor, Goeze, Ent. Bert. III, 1, 1) 123, 1. $7:,(1779)$.

$(1765)$.

\section{GENUS PIERIS, SCHRANCK.}

26. NApi, Imxx. (p. 7t); Srst. Nat., Ed. X, I, p. 468, n. 60, (1758); Fabr., Syst. Ent., p. 469, 1. 112, $(1775)$; Sp. Ins. II, p. 99, n. 163, (1781); Mant. Ins. II, 1. 18, n. 185, (1787); Ent. Syst. III, 1, p. 187, 11.576, (1793); Herlest, Nat. Schmett. Y', p. 89, t. XCII, (1792). Enc. Meth. Ins. Plates, t. 52, f. 2, (1797); (Pieris N.) Hy. Edwds., Proc. Cal. Acad. Se. VI, (1876).

Pieris Yenosa, Scud., Proc. Bust. Soc. Nat. Hist., Tol. XII, p. 406, (1869).

Pieris Oleracea, Glover, Agr. Rep., p. 79, f. 37, (1870). Pontia Brassicae?, Rath., Igr. Rep., 1). 592, f. 7, 8, (186i).

Pap. Alba, etc., Pet., Pap. Brit., 1. 1, 11. 15, 16, t. 2, f. $15,16,(1717)$.

28. Rape, Lixx. (1. 75); Fabr., Syit. Ent., p. 469, n. 111, (1775); Sp. Ins. II, 1. 39, n. 162, (1781); Mant. Ins. II, p. 18, n. 18t, (17!3); Ent. Syst. III, 1, p. 186, n. 575, (1797); Herbst, Nat. Schmett. V, p. 64, t. LXXXVII, (1792). Ene. Meth. Ins. Plates, t. 52, f. 6, (1797); (Pieris R.) Hy. Edwds., Ploc. Cal. Acad. Se. TI, (1876); Glover, Agr. Rep., p. 78, f. $36,(1870)$.

Pap. Alba, te, Pet., Pap. Brit., 1. 1, 11. 7, 8, t. 1, f. $7,8,(1717)$.

rar. a. Novanglie, Scodo, (1. 76); Bull. Soc. Ent.

Fr. (5) III, P. 57, (1873).

30. Protodie, Bnd.-Lec. (1. 76); Glover, Agrr. Rep., p. 79, f. 38, (1870).

3.). Chlorodice, Hub. (p. 76).

Pieris Beckeri, H. H. Eduds., Proc. Cal. Acad. Se. VI, (1876).

3t. Calyee, W. H. Edwos. (p. 77); Hy. Edwds, Proc. Cal. Acad. Sc. VI, (1876).

There is very little doubt that this is the first or spring generation of P. Occidentalis, Reak. (No.31).

\section{GENUS ANTHOCHARIS, BDL.}

†*4:). Thoosa, Scud., (Synchloe T.) Hayden's Bull. U. S. Geo. Arizona. Sur. IV, 1). 257, (1878).

Evidently allied to Cethura, Feld.; perhaps a var. of that species, or else = to A. Julia, W. II. Eduds. 
GENUS CALLIDRYAS, BDL.

46. Eubula, Linn. (p. 79); (Pap. E.) Shaw-Nodd., Nat. Miss. XXIII, t. 1018, (1790-1813); (Call. E.) Hy. Edwils., Proe. Cal. Acall. Sc. VII, (1876).

Pap. Marcellina, Herbst, Nat. Schmett. V, p. 189, t. CX, f. 1, 2, $\left(\sigma^{\top}\right),(1792)$. Enc. Meth. Ins. Plates, t. 13, f. 4-6, (1797).

Pap. Eubule, Herbst, 1. c., p. 202, t. CXII, f. 3, 4 (우). 47. Cirris, Farr. (p. 79); (Call. C.) But., Lep. Ex., p. 69, t. $26,(1871)$.

\section{GENUS GONEPTERYX, LEACH.}

49. Merrula, Fabr. (p. 79); Spec. Ins. II, p. 51, u. 222, (1781) ; Mant. Ins. II, 1. 24, 11. 255, (1787).

Pap. Eclypsis, Herbst, Nat. Schmett. V, p. 157, t. CIII, (1792).

\section{GENUS MEGANOSTOMA, REAK.}

51. Eurydice, BdL. (p. 80); Streck., Lep. Rhop.-Het. I, p. $6,(1872)$.

val. a. Amorphe, Hy. Edwds., Proc. Cal. Acad. Se. VII, (1876).

\section{GENUS COLIAS, FABR.}

53. Palmono, Linn. (p. 80).

Pap. Europome, Herbst, Nat. Schmett. V, 1. 217, t. CXV, (1792).

\section{GENUS TERIAS, SWAINS.}

71. Mexicana, Bde. (1). 85); Hy. Edwds., Proc. Cal. California. Acad. Sc. TII, (1876).

73. Elathea, Cram. (p. 85); Fabr., Mant. Ins. IT, P. 20, n. 209, (1787); Herlst, Nat. Sehmett., p. 229, t. CXYII, f. 5, 6, (1792).

75. Delia, Cram. (p. 85); Herbst, Nat. Schmett. T, p. 230, t. CXVII, f. 7, (1792).

\section{GENUS THECLA, FABR.}

81. Halesus, Cram. (p. 86); Habr., Sp. Ins. II, p. 116, 11. 517, (1781); Mant. Ins. II, p. 67, n. 638, (1787). Enc. Meth. Ins. Plates, t. 40, f. 4, (1797); Herbst, Nat. Schmett. X, p. 322, t. CCXCV, (1800).

84. Cecrops, Fabr. (p. 86); Herbst, Nat. Schmett. XI, p. $144,(1804)$.

$\dagger^{*} 8$ 12. Clyte, W. H. Euwds., Fieldand Forest III, p.88,(1877) San Antonio,

Seems to be close to Beon, Cram. Texas.

92. Acis, Dru. (p. 88); Cram., II, t. 175, f. C, D, (1779). Hesp. Rur. Ixion, Fabr., Syst. Ent., p. 523, n. 340, 
(1775); Sp. Ins. II, p. 121, n. 540, (1781); Mant. Ins. II, p. 71, n. 671, (1787); Herbst, Nat. Sehmett. X, p. 280, t. CCLXXXIX, f. 1, 2, (1800).

96. var. a. Fulvescens, Hy. Eiwds., Proe. Cal. Acad. Sc. Harilah, VII, (1876).

$101 \frac{1}{2}$. Kali, Streck., Lep. Rhop.-I Let. I, p. 129, (Sept., 1877). Arizona. 102. Danon, Cram. (p. 89); Herbst, Nat. Schmett. XI, p. 2t, t. CCXCIX, f. 9, 10, (1804). Enc. Neth. Ins. Plates, t. 41, f. 14, (1797).

Pap. Simcethis, Fabr., Syst. Ent., p. 523, n. 338, (1775); Sp. Ins. II, p. 120, n. 537, (1781); Mant. Ins. II, p. 70, n. 668, (1787); Ent. Syst. III, p. 286, n. 97, (1793); Herbst, Nat. Schinett. X, p. 282 , t. CCLXXXIX, f. 3, 4, (1804).

113. Augustus, Kirbi (p. 91).

Incisalia A.var. Crocsioides, Scud., Buff. Bull. III, p. $104,(1876)$.

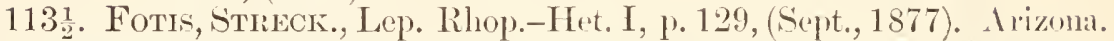

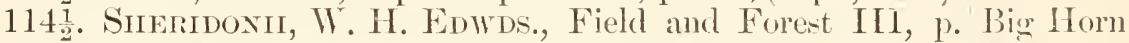
$48,(1877)$.

The naming of this insect after a military celebrity is a most lamentable piece of sycophancy which cannot be too much deplorel. Lient.-Gen. P. H. Sheritlan may have been and doubtless was a good soldier and an efficient officer-though being nothing of a politician myself, and consequently not interested in the late war, I am not likely to be much of a judge as regards the question of his military greatness-but I think I may safely venture to doubt whether the General knows more of entomological science than does the horse he rides; and the designating of an insect by his name is under such eircumstances in insult instead of an honour-an insult to the General and a greater one to science.

\section{GENUS LYCANA, FABR.}

125. Strriata, IT. H. Edwds., Field and Forest III, p. 88,

130. Optilete, K

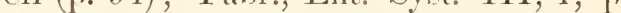
297, n. 131, (1793); Herbst, Nat. Schmett. XI, p. 255 , t. CCCA VI, f. 8, 9, 10, (1804).

136. Lucia, Kirby (p. 95); Scult., Proe. Bost. Soe. Nat. Hist. Vol. XII, p. 406, (1869).

\section{GENUS FENISECA, Grote.}

169. Tarquinius, Fabr. (p. 103); Herlost, Nat. Schmett. XI, p. 376, (1804).

\section{GENUS EUMELS, HUB.}

170. Atala, Poex (p. 103); (Eum. A.) Scud., Mem. Bost. Soe. II, P. 413-419, t. 14, (1875).

\section{GENUS CHARIS, HUB.}

174. Ceneus, Lmin. (p. 104); Syst. Nat., Ed. X, I, p. 487, 1. 181, (1758). 
176․․․ Guadeloupe, Streck., Lep. Rhop.-Itet. I, p. 131, San Antonio, (Sept., 1877).

Texals.

Char. Australis, W. H. Edwds., Field and Forest III, p. 87, (Nov., 1877).

\section{GENUS LIBYTHEA, FABR.}

178. Carinenta, Cram. (p. 105); Ene, Meth. Ins. Plates, t. 37, f. t, (1797); Fabr., Sp. Ins. II, p. 10t, 1. 455, (1781); Mant. Ins. II, p. 56, n. 554, (1787); Ent. Syst. III, 1, p. 139, n. 428, (1793); Herbst, Nat. Schmett. VII, p. 85, t. CLXV, f. 8, 9, (1794).

178 ‥ Larvata, Streck., Lep. Rhop--Het. I, p. 130, (Sept., San Antonio, $1877)$.

\section{GENUS DANAIS, LATR.}

179. Plexippus, Linv. (p. 105); Syst. Nat., Ed. XII, I, 2, p. $767,(1767)$; Herbst, Nat. Schmett. VTI, p. 19, t. CLVI, f. 1, 2, (1794); Fabr., Srst. Ent., p. 481, n. $170,(1775)$; Sp. Ins. II, p. 55, 11. 243, (1781); Mant. Ins. II, p. 27, n. 281, (1787).

Pap. Arehippus, Shaw-Nord., Nat. Miss. XXIII, t. $1006,(1790-1813)$.

180. Berexice, Cray. (p. 106); Merlst, Nat. Sehmett. V'II, p. 22, t. CLIII, f. 1, 2, (1794). Ene. Meth. Ins. Plates, t. 3:3, f. 3, (1797).

Pap. Erippus, Fabr., Ent. Syst. III, 1, 1. 49, n. 152, (1793).

\section{GENUS HELICONIUS, LATR.}

18:3. Cimarithonia, Lixx. (p. 107).

Pup. Charitonia, Fabr., Sp. Ins. II, p. 30, n. 126, (1781); Mant. Ins. II, p. 15, n. 147, (1787); Ent. Syst. III, 1, p. 170, n. 528, (1793); Herbst, Nat. Schmett. IV, p. 163, t. IXXVI, f. 7, (17!0). Enc. Meth. Ins. Plates, t. 19, f. 1, (1797).

\section{GENUS COLANIS, Hub.}

184. Julia, Fabr. (p. 108); Fabr., Sp. Ins. II, p. 99, n. 4:35, (1781); Mant. Ins. II, p. 54, n. 529, (1787).

P'ap. Luteus, Goeze, Ent. Bert. III, 1, p. 119, 11. 45, (1779).

P. Nigromarginatus, Goese, 1. c., p. 122, 1. 64, (1779). re Seba, Thes. IV, t. IV, f. 19, 20, t. XXVIII, f. $13,14,(1765)$.

185. DelitaA, Fabr. (p. 108); Sp. Ins. II, p. 100, $n$. 439, (1781): Mant. Ins. II, p. 54, 11. 534, (1787); Ent. Syst. II I, 1. 57, n. 176, (1793).

I'ap. Cillene, Herbst, Nat. Schmett. IV, p. 93, t. LXVII, f. 8, 9, (1790). 
GENUS AGRAULIS, BDL.-LEC.

186. Vanilla, Linn. (p. 108); Fabr., Syst. Ent., p. 518, n. 319, (1775); Sp. Ins. II, 1). 111, n. 486, (1781); (Agr. T.) Glov., Agr. Rep., p. 106, t. IX, (1855); l. c., p. 43, (1866); Hy. Edwds., Proc. Cal. Acad. Sc. VII, (1876).

\section{GENUS EUPTOIE'TA, DBLiy.}

187. Claudia, Cram. (p. 109).

Pap. Daunius, Herbst, Nat. Schmett. IX, p. 1St, t. CCI VI, f. 1, 2, (1798).

Pap. Nigrosignatus, Goese, Ent. Beyt. III, 1, p. 183, 11. 87, (1779).

Argyn. Columbina, Glov., Agr. Rep., 1. 61, (1854); 1. c., p. 66, 105, t. IX, (1855).

188. Hegesia, Cram. (p. 109).

Pap. Columbina, Herbst, Nat. Schmett. IX, p. 182, (1798); (Eupt. H.) Hy. Edwds., Proc. Cal. Acad. Sc. VII, $(1876)$.

\section{GENUS ARGYNNIS. FABR.}

189. Diana, Cram. (p. 109); Fabr., Mant. Ins. II, p. 63, n. 594, (1787). Enc. Meth. Ins. Plates, t. 35, t. 2, $(1797)$.

190. Idalia, Dru. (p. 109); Falor., Sp. Ins. II, p. 109, n. 478, (1781); Mant. Ins. II, p. 6:3, n. 593, (1787); ShawTodd., Nat. Miss. XXIV, t. 1035, (1790-1833). Ene. Meth. Ins. Plates, t. 37, f. 1, (1797).

Pap. Cytherea, Wuell., Voll. Niturs. I, p. 619, t. 19, (1774).

Pap. Huttuinus, Goeze, Ent. Beyt. III, 1, p. 362, n. $5,(1779)$.

193. C'rbele, Fabr. (p. 111); Sp. Ins. II, p. 109, n. 477, (1781); Mant. Ins. II, p. 62, n. 592, (1787).

196. Aprnodite, FABr. (p. 111); Herhst, Nit. Sehmett. IX, p. $181,(1798)$.

198. Atrantis, IV. H. Edwos. (1. 112); Mosch., Stett. Ent. Keit., p. 156, (1874).

214. Mrtima, Cram. (1. 115); Fabr., Sp. Ins. II, p. 109, n. A lakkil. $476,(1781)$; Mant. Ins. II, 1. 62, n. 591, (1787); Ent. Syst. III, P. 145, 11. 44 , (179:3); (Mel. M.) Hy. Eilwds., Proc. Cal. Acad. So. VII, (1876).

215. Apminape var. Trictaris, Hub., (p. 115); (Brenthis T.) Scud., Proc. Bost. Sor. Nat. Hist. XVII, p. 294, $(1875)$.

217. Cimaricteli, Schnemper (p. 115); (Bienthis C.) Seud., I. (.., 1. 297, (1875).

218. Freita, Thxis., (p. 116); (Pap. F.) Schuncidel, Neu. Mig. IV, p. 420, (1792).

Pep. Tullia, Fabr., (Otto) Fann. Groen., p. 192, 1. $14:),(178(1)$. 
220. Frigga, Thnb. (p. 117); (Pap. F.) Schneid., Nen. Mag. IV, p. 416, (1792), V, p. 587, (1794); Herbst, Nat. Schmett. X, p. 135 , t. CCLXXIII, f. 1, 2, (1800); (Brenthis F.) Seud., Proc. Bost. Soc. Nat. Hist. XVII, p. 306, (1875).

221. Bellona, Fabr. (p. 117); Sp. Ins. II, p. 111, 11. 484, (1781); Mant. Ins. II, p. 64, 11.600, (1787).

$\dagger^{*} 222 \frac{1}{4}$. Macaria, W. H. Edwos., Field and Forest III, y. Havilah, $86,(1877)$.

†*2221. Columbia, W. H. Edwds., 1. e., p. 102, (1877).

California.

British Col.

\section{GENUS MELI'TAA, FABR.}

2:31. 'Tharos, Dru. (p. 120).

Pap. Morphius, Fabr., Sp. Ins. II, p. 62, n. 278, (1781).

Pap. Morpheus, Fabr., Mant. Ins. II, p. 30, n. 321,

(1787); Ent. Syst. III, 1, 1. 155, n. 479, (1793).

$\$ 280 \frac{1}{4}$. Imitata, S'treck., Lep. Rhop.-Het. I, p. 130, (Sept., San Antonio, 1877).

Texas.

Mel. Ulrica, W. H. Edwds., Can. Ent. IX, p. 189, (Oet., 1877).

$\$ 230 \frac{1}{2}$. Manunda, Strreck., Lep. Rhop.-Het. I, p. 130, (Sept., Sim Antonio, $1877)$.

Mel. Dymas, W. H. Edwds., Can. Ent. IX, p. 190, (Oet., 1877).

24!. Pinteron, Dru. (p. 125); (Pap. P.) Fabr., Sp. Ins. II, p. 54, n. 237, (1781); Mant. Ins. II, p. 26, n. 275, (1787). Enc. Meth. Ins. Plates, t. 38, f. 3, (1797); (Mel. P.) Gosse, Can. Nat., p. 227, fig., (1840); Packard, Guide, p. 255, f. 181, (1869).

$\$ 252 \frac{1}{4}$. Alma, Streck., Lep. Rhop.-Het. I, p. 135, (1877). Ariz'a, Utah $+* 252$. Bolli, W. H. Eowds., Field and Forest III, p. 101, San Antonio, $(1877)$.

\section{Texas.}

\section{GENUS VANESSA, FABR.}

259. var. a. UMrrosa, Lint.

Pap. C-Aureum, Shan-Nodd., Nat. Miss. XXIV, t. $1045,(1790-1813)$.

261. C-A libur, Linn.

Le, P. Gamma, Ene. Meth. Ins. Plates, t. 54, f. 9-11, (1797).

265. var. a. Gricilis, G.-R. (p. 131); Seud., Proc. Bost. Soc. Nat. Hist., Vol. XII, p. 405 , (1869).

270. Antiopa, Linn. (p. 133); (Pap. A.) Shaw-Nodd., Nit. Miss. X VIII, t. 744, (1790-1813); (Van. A.) Glov., Agr. Rep., p. 37, (1865); (Pap. A.) Sent., Syst. Rev. An. Butt., p. 22, (1872).

P. Morio, Enc. Meth. Ins. Plates, t. 55, f. 4-7, (1797). 
GENUS PYRAMEIS, HuB.

271. Atalanta, Linve. (p. 135); (Pap. A.) Shaw-Nodd., Nat. Miss. V, t. 157, (1790-1813). Enc. Meth. Ins. Plites, t. 29, f. 1, (1797); (Tan. A.) Send., Srst. Rer. Am. Butt., p. 42, (1872). (Hybrid bet. $\dot{P}$. Atalunta and P. Carye, Hy. Edwds., Proc. Cal. Acad. Se. VII, (1876).

P. Iulcuin, Enc. Meth. Ins. Plates, t. 59, f. 1, (1797). 272. Cardui, Lisrs. (p. 136); (Pap. C.) Shaw-Nodd., Nat. Miss. XI, t. 430, (1790-1813). Enc. Meth. Ins. Plates, t. 28, f. 6, (1797); (Vun. C.) Scud., Syst. Rev. Am. Butt., p. 43, (1872).

274. Huntera, Fabr. (p. 138); (Pap. II.) Shaw-Nodd., Nat. Wiss. XXIV, t. 1050, (1790-181:3); (Van. II.) Suud., Syst. Rev. Am. Butt., p. 43, (1872).

\section{GENUS JUNONLA, HUB.}

275. Censta, Hub. (p. 188); Seud., Syst. Rer. Am. Butt., p. $4:,(1872)$.

\section{GENUS CALLICORE, IIUB.}

280. Clymena, Crani. (p. 140).

Najas hilaris Chlymene, Häb., Samm. Ex. Schmett. i, $(1806-1816)$.

\section{GENUS TIMETHS, BDL.}

285. Pellets, Sulz.

Pap. Petreus, Enc. Meth. Ins. Plates, t. 11, f. 4, (1797).

\section{GENUS IIMENITIS, FABR."}

288. Fipinestrion, Stoll (1) 143 ).

Lim. Ursula, Emm., Lgr. Nat. Hist. N. York, p. 20:3, t. 3:3, $(1854)$.

289. Irtinemis, Diru. (1. 144); Gosse, Can. Nat., p. 220, fig., $(1840)$.

291. Torquin, BDi. (p. 145); Hy. Eilwds., Proc. Cil. Acart. Se. III, (1876).

\section{GENUS APATURA, FABR.}

2!3. Celtis, Bol.-Lec. (p. 145).

var. d. Axtoxia, IV. II. Enwdo, Field and Forest III, Sun Antonio, 1. 10:3, (1877).

Ap. Celtis ear. Streck., Ruther's Annual Rep., Dep. Missonri, 1. 142, (1876).

\section{GENTS EREBIA, DALM.}

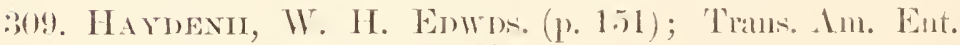
soc. V, 1. 19, (1874). 
310. Mancinus, Dreny.-Hew. (1. 152); Scud., Proc. Bost. Soc. Nat. Hist., Y'ol. XII, p. $405,(1869)$.

312. Discoidalis, Kirbe (p. 152); Send., Proc. Bost. Soe. Nat. Hist., Tol. XII, p. 405, (1869).

\section{GENUS SATYRUS, FABR.}

$321 \frac{1}{2}$. Asimtaroth, Streck., Lep. Rhop.-Het. I, p. 129, Arizona. (Sept., 1877).

Neominois Dionysus, Seud., Hayden's Bull. U. S. Geolog., Geograph. Surver IV, p. 254, (Feh., 1878).

\section{GENUS COFNONYMPHA, HuB.}

334. Ochracea, IV. H. Enwos. (p. 160); Send., Hayden's। Bull. Geo. sur. IV, 1. 254, (1878).

\section{GENUS EUDAMUS, SWAINS.}

340. Titraus, Fabr. (p. 162); (Epargyreus T.) Seud., Hayden's Bull. Geo. Sur. IV', p. 257, (1878).

342. Epigexa, Butr. (1. 162); Lep. Ex., p. 65, t. 25, (1871).

\section{GENUS AGIALE, FELD.}

351. I uccae, BdL.-Lec. (p. 163) ; (Megathymus Y.) Riley, Trans. Aead. Se. of St. Louis III, p. 566, (1877); West., Trums. Linn. Soc. 2d Ser., Y'ol. I, p. 205,(1875). var. a. Coloradensis, Rilex, (Megath. C.) 1. c., p. Colorado. $567,568,(1877)$.

Much smaller and paler coloured.

352. Cofaqui, Stricck. (1). 164); Rufliner's Ann. Rep. Dep. Missomi, p. 1429, (1876).

\section{GENUS PAMPHILA, FABR.}

371. Comma, Linn. (p. 167).

var. a. Catten., Meyer-Dur., Schmett. Schweisz., p. $217,(1852)$.

†*371 $\frac{1}{2}$. Morrisoni, W. H. Edwds., Ficld and Forest III, p. Colorado. $116,(1877)$.

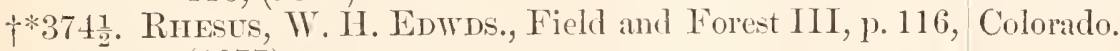
(1877).

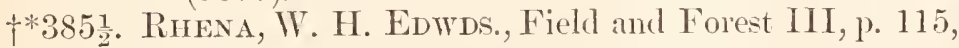
(1877).

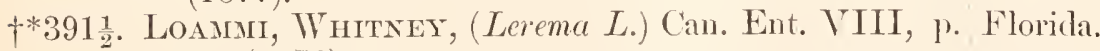
$76,(1876)$.

$\dagger^{*} 408 \frac{1}{2}$. Phillace, IT. H. Edwds., Field and Forest III, p. Colorado. $117,(1877)$.

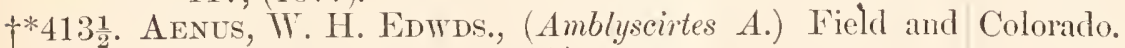
Forest III, p. 118, (1877).

416. Simlis, Streck. (p. 174).

Amblyscirtes Nysa, W. H. Edwds., Can. Ent. IX, p. 191, (Oct., 1877). 
$\dagger^{*}+16 \frac{1}{2}$. Nilus, W. H. Edwds., (Amblyscirtes N.) Field and San Antonio, Forest III, p. 118, (1877). Texas.

\section{GENUS ANCYLOXYPHA, FELD.}

†*4201. Libra, Sevd., (Heteropterus L.) Hayden's Bull. U.S. Irizona. Geo. Sur. IV, p. 258, (1878). 


\section{CORRIGENINA.}

In alluding to "sixth line," "eleventh line," etc., etc., it is (with the exception of the first correction of all-on p. 3) always to be understood as counting from the name that eomes after the No., and under which the correction is to be made, and not from the top of the page.

Page

3. On termination of tenth line read "Gorilla Castaniceps" instear of "Gorilla Caniceps."

22. In regard to the Post-Office regulations alluded to on lower half of this page, I would say these are constantly undergoing changes; even since the foregoing was printed the weight allowed for packages has been increased from $12 \mathrm{oz}$. to $4 \mathrm{Ht}$.s.; in order to keep informed on these points it is always best to inquire at your Post-Office for particulars.

67. No. 3. Polydamas. On sixtl line real "Cram., Palp. Ex. III, p. 33, t. 211," instead of "t. 221." On fiftl line after "Ent. Syst." rear "III" instead of " $\mathrm{V}$."

68. No. 5. A.jax. On first line read "AJax, Lisx., Syst. Nat. I, 2, p. 750 , $(1767)$, " instead of " $(1867)$. "

70. No. 13. MAcmán. The "(1816)" that comprises the eleventh line should terminate the twelfth, which latter would then properly read "Jasoniades Machaon, Hüb., Verz. Bek. Schmett., p. 83. (1816)."

71. On seeond line from top of page, add after first two words "Vol. XII, p. 407," so that it reacls " Nat. Hist., Vol. XII, p. 407, (1869)."

71. No. 17. Asterius. The last word on the fiftl line, and the first on the sixth line, should be transposed to read "Ent. Syst." instead of "Syst. Ent."

80. No. 50. Clorixde. On beginning of fourth line after "599," place "t. 19, f. 4," so that it will read " 599 , t. 19, f. 4, (1836)."

80. No. 52. Casonia. End of eleventh line "(1702:)" instead of "(1767)."

80. No. 53. Palmono. On first line after "Paleno, Linn." place "(Pap. P.)."

95. No. 134. Lupini. Add to the end of the sixth line, "(1874)."

96. No. 138. SAgitTigerA. On commencement of fifth line read "Catalina" instead of "Catilina."

96. No. 139. LrgDamus. Make first word on second line "(1841)" instead of "(1842)"

99. No. 149. Orbitulus. Read last word on first line "Pedemontana" instead of "Piedmontana."

100. No. 150. Aquilo. End of eightl line read "(1876)" instead of "(1874)."

100. No. 152. Speciosa. Rearl "Proc. Cal. Acad. Nat. Sc. VI, (1876)," instead of "Proc. Cal. Acad. Nat. Sc. V, p. 6, (1876)."

102. No. 165. Gorgon. The locality of this species, which was accidentally omitted, is California. 
Page

108. No. 184. Julia. On tenth line, after "Sehmett." place "IV;" and on eleventh line place "(1790)" instead of "(1783-1804)."

108. No. 186. Vanilla. On eighth line, after "Natursyst." place "IX ;" and in place of "(1783-1804)" read " $(1798)$."

109. No. 187. Claudia. Place "Pap. Daunius, Herbst," as a synonym of this species instead of as a synonym of "188. EUPT. HEGESIA, Cray.," as I have it on sixth line from No. 188, same page.

110. No. 190. ab. a. Ashta roth. On second line after "Phil., p. 352," read "(1859)" instead of " (1852)."

111. No. 193. CYmele. After "Schmett., IX," on third line read "p. 176 " instead of "p. 178."

111. No. 196. Aphrodite. On eighth line insert at beginning " $\mathbb{W}$. $\mathrm{H}$. Edwds.," so as to read "W. H. Edwds., Can. Ent. VI, p. 121 ," etc.

117. No. 221. var. a. Epitirore. On second line place "Bdl.," in front of "Lep. Cal.," so that it reads "Bdl., Lep. Cal.," etc.

120. No. 231. ab. b. PACKAndi. The fourth line, which reads "Larva on Actinomeris Helianthoides," should be taken out and replaced below the next two lines (which begin, "The dark colour," etc., etc.), as the food-plant designated is not meant to be that of ab. Packardii, but of the stem forms Tharos and Marcia.

125. No. 250. Leaxira. On eighth line read "var. a. Obsoleta," instearl of "var. a. Obliterata."

129. No. 260. After "var. a. Drras, W. H. Edwos.," place "(Grapta)." 140. No. "2s9" should be "279."

160. No. 330. (Californica) var. e. Eryngir. On seeond line read "Se. VI, (1876)" instearl of "Sc. V, 6, (1876)."

190. No. 285. After "Peleus, Sulz.," place "(141)."

190. To. 288. "Ephestrion" should be "Ephestion." 


\section{INDEX}

TO

\section{CA'TALOGUE OF MACROLEPIDOP'TERA.}

\section{RHOPALOCERES.}

Species and varieties are in Roman letters.

Genera are in Roman capitals.

Synonyms are in italies.

The No. immediately following the name, and preceding the No. of the page, corresponds with that prefixed to the same name in the Catalogue; thus, "Acadica 99, 88," meaus that Acadica is No. 99 on page 88.

The synonyms are numbered with the same numbers as the species with which they are identical.

To each species or variety is always affixed the name (abbreviated) of the author of the species.

To each species is affixed the name (abbreviated) of the genus to which it belongs, regardless of that in which it may have been first placed by its author; thus, "Arthenis Dru. Lim." is Limenitis Arthemis, Drury, although Drury placed it in Papilio.

The generic names attached to the synonyms are always those in which the authors of said synonyms originally placed them; thus, "Argiolus Abb.-S. Pap." does not mean that Argiolus belongs to Papilio (Pap.), but ouly that it was placed there by Abbott and Smith when they published the species.

\begin{tabular}{|c|c|c|c|}
\hline & Page & & Page \\
\hline Edw. Pap. 5 b. & 68 & Ahaton Har. Hesp. 382, & 169 \\
\hline ica IV. Edw. Th. 99, & 88 & Ajax Lin. Pap. 5, & 68,181 \\
\hline stus W. Edw Mel. 241, & 124 & Ajax Cl. Pap. 17, & 71 \\
\hline us Abb.-S. Pam. 391, & 171 & Alb. ab. Ap. 293 a. & 145 \\
\hline Achaja Kby. Cup. 146 a. & 98 & Alba Col. ab. 55 a. & 81 \\
\hline Fab. Meg. 296, & 147 & Alba col. ab. 58 a. & 82 \\
\hline DES HUB. & 180 & Alba Col. ab. 60 b., e. & 83 \\
\hline 1. 92, & 88,185 & Alba etc. Pet. Pap. 26, 28, & 184 \\
\hline H. Iyc. 126 , & 93 & Alba Ter. ab. 76 a. & 85 \\
\hline ud. Hesp. 385 & 170 & Alba W. Edw. Syr. 428, & 177 \\
\hline H. Edw. Th. 9 & 88 & Albanus Feld. Pap. 12 a. & 70 \\
\hline $\operatorname{lrg} .211$ & 115 & Albina Poey, Ter. 77, & 85 \\
\hline 211 & 115 & Albusta Sepp, Pup. 29, & 76 \\
\hline 253 & 126 & Alce H. Edu. Lyc. 125, & 93 \\
\hline 211 & 115 & Alcestis WV. Edw. Arg. 196 a. & 112 \\
\hline ELD. & 163,191 & tis IV. Edw. Th. 88, & 87 \\
\hline Lyc. 146 a. & 98 & Alcidamas Goeze, Pap. 10, & 182 \\
\hline Edw Pant. $413 \frac{1}{2}$ & 191 & Alcidamus Cr. Pap. 10, & 70 \\
\hline ud. Hed. 384 a. & 170 & Alcionea Cr. Pap. 184, & 108 \\
\hline Edw. Th. 114, & 91 & Alcyonea Hbst. Pap. 184, & 108 \\
\hline THOS BDI & 14 & indra W. Edw. Col. 55, & 81 \\
\hline NIA HUB. & & Aliaska Scud. Pap. 13, & 71,182 \\
\hline Edw. Arg. 191, & 11 & Alicia W. Edw. Ap. 293 b. & 146 \\
\hline DL-LEC. & 108,188 & trk. Mel. 2521, & 189 \\
\hline Agricola Bdl. Pam. 364, & 166 & Alope ab. Sat. 328 a. & 158 \\
\hline
\end{tabular}


Alope ab. Sat. 328 b.

Ardea W. Edw. Lyc. 144 b

Alope Fab. Sat. 328 d.

Arene IV. Edw. Auc. 418,

Alope Bdl.-L. Sat. 328 e.

Alpheus IV. Edw. Nis. 446,

175

157

Also Bdl. Ch. 315,

179

Also Mor. Ch. 316,

Alternata G.-R. Hesp. 411,

153

153

174

Americana var. D'U. Lyc. 158, 101

Amica W. Edw. Lye. 151, $\quad 100$

Amiralis Retz. Pap. 271,

136

Ammon Luc. Lyc. 124,

93

185

Ampelos IV. Edw. Coen. 332, 160

Amphidusa Bdl. Col. 60 a.

Amymone Men. Cys. 281,

Amyntas Fab. Eud. 344,

83

140

163

Amyntula Bdl. Lyc. 118,

Amyntula var. Kby. Cup. 118,

ANARTIA HUB.

ANCYLOX YPHA FELD. 174, 192

Andria Scud. An. 297,

148

Andromacha Hub. Or. M. 299, 148

Angelina Bdl. Anth. 40,

Anicia Dbl.-H. Mel. 244,

Anicia Scud. Lem. 246,

124

125

Anicia var. Kby. Mel. 246,

Anna IV. Edw. Lyc. 128,

Antcegon Bdl. Lyc. 126 ,

ANTHOCHARIS BDL.

Anthyale Hub. Zer. 58,

Anthyale Stgr. Col. 54,

Antiacis Bdl. Lyc. 141,

125

93

93

77,184

82

81

96

Antibubastus Hub. Lyc. 123,

Anticostiensis Strk. Pap. 17 b.

Antilochus Lin. Pap. 10,

Antiopa L. Van. 270,

79

Antiopa ab. Van. 270 b.

70,182

133,189

135

Antiopa var. Mill. Van. 270 a. 134

Antonia W. Edw. Ap. 293 d.

190

APATURA FAB.

145,190

A phirape var. Hub. Arg. 215, 115, 188

Aphrodite Fab. Arg. 196, 111, 188

Aphrodite ab. Arg. 196 b.

APODEMIA FELD.

112

104

Aquilo Bdl. Lyc. 150,

100

Aquilo var. Kby. Cup. 150,

100

Aquilo var. Stgr. Lyc. 150 ,

100

Arachne W. Edw. Mel. 239,

123

Alaxes Hew. Pyr. 346,

Archippe God. Dan. 179,

163

106

Archippe Hub. An. 287,

142

Archippus Cr. Pap. 287,

142

Archippus Fab. Pap. 179,

105

Archippus Shaw-Nod. Pap. 179, 187

Arctica Zett. Arg. 217,
Areolata Butl. Eup. 303,

Areolatus Ab.-S Pap. 303,

Argante Fab. Call. 45,

Arge Strk. Arg. 210,

Argiolus Ab.-S. Pup. 135,

ARGYNNIS FAB.

Argyrotoxus Behr, Lyc. 128,

Ariadne W. Edw. Col. 60,

Ariane Bdl. Sat. 328 a.

Arogos Bdl.-L. Hesp. 382,

Arota Bdl. Lyc. 167,

Arpa Bdl.-L. Pam. 386,

Arsace Bdl.-L. Th. 112 a.

Artemis Dbl. Nym. 289,

Arthemis Dru. Lim. 289,

Ashtaroth Fis. Alg. 190 a.

Ashtaroth Strk. Sat. $321 \frac{1}{2}$,

Assimilis Butl. Oen. 316,

Astarte Fis. Arg. 190,

Astarte W. Edw. Arg. 209,

Astenidas Bdl. Lyc. 123,

Asterias Fab. Pap. 17,

Asterioides Reak. Pap. 17 d.

Asterius Cr. Pap. 17,

Astina Fab. Pap. 297,

Astinax Cr. Pap. 297,

Astinous Dru. Pap. 1,

Astrea W. Edw. Col. 59,

Astyana.x Fab. Pap. 288,

Atala Poey, Eum. 170,

Atalauta L. Pyr. 271,

Ate Strk. Pyr. 272 b.

Atlantis W. Edw. Arg. 198,

Attalus W. Edw. Pam. 377,

Auburniana Har. 'Tl. 102,

Augias Hub. Thy. 354,

Augustinus West Th. 113,

Augustus Kby. Th. 11:,

Auretorum Bdl. Th. 90,

Ausonia Hub. Antl. 35,

Ausonius Lint. Nis. 439 ,

Ausonoides Bdl. Anth. 35 a.

Australis W. Edw. Ch. 1761,

Autolycus W. Edw. Th. 87,

149

149

78

114

95

109,188

94

83

157

169

102

170

91

144

144,190

110

191

153

110

114

93

71

72

71, 183

147

147

67

83

143

13,186

135,190

137

112,188

169

89

164

91

91, 186

87

77

179

77

187

87

\section{B}

Baal Strk. Arg. 193 a.

111

Bachmani Kirt. Lib. 177,

Bachmani var. Kby. Lib. 177, 105

Bachmonii Scud. Hyp. 177,

Bairdii W. Edw. Pap. 17 a.

105

Balder Bdl. Ch. 314,

Balderi Hub. Eum. 314, 
Bathat Page

Bartara H. Edw. Col. 57

Batabano Lef. Ery. 347,

Batesii Reak. Mel. 232,

Bathyllus Ab-S. Eud. 3 43 ,

Bathyllas Har Eud. 343 a.

Battoides Behr, Lyc. 131,

Beckerii 川 Edw. Pier. 33,

Behrensii W. Edw. Arg. 205 b. 113

Behrii W. Edw. Col. 65,

Behrii WV. Edw. Lyc. 142,

Behrii W. Edw. Parn. 20,

Behrii W. Edw. Th. 107,

Belladonna Pet. Pap. 272,

Belladonna virgin. Pet. Pap. 274, 138

Bellona Fab. Arg. 221, 117, 189

Bellona var. 221 b.

117

87

Beon Hub. Str. 84,

Bereniee (r. Dan. 180, Bethyllus Dbl.-H. Gon. 343,

Bimacula G.-R. Pam. 385,

Bischoffii W. Edw. Arg. 213,

Boiscluealiana Feld. Ter. 71,

Boistuvalii Dup. Arg. 217 a.

Boisduvalii Hur. Hip. 329,

Bollii W. Edw. Mel. 252?,

Boopis Behr, Sat. 328 b.

Bootes Bull. Ch. 317,

Boothii Curt. Col. 63,

Boothii Bal. Col. 62,

Bore Esp. (Pap.)

Bore scud. Ch. 317,

Bore rar. Stgr. QEn. 317,

Borealis G.-R. Cha. 175,

borealis Gr. Gan. 26 c.

Borus Bdl. Th. 99,

Bracteoluta But. Call. 47 ,

Brassicae Rath. Pont. 26,

Bredowii Hub. Lim. 29:,

Bremnerii W. Edw. Arg. 204,

Brenda IV. Edw Coen. 335,

Brettus Bdl.-L. Pam. 359,

Brevicauda Saun. Pap. 17 a.

Brizo Bdl.-L. Nis. 440,

Bucephalus Steph. Pam. 354,

Bulenta Bdl.-L. Pam. 387,

\section{$\mathrm{C}$}

Cadmus Cr. Pap. 296,

Caenens L. Cha. 174,

Cuenins G.-R. Cha. 174,

Cæsonia Stoll. Meg. 52,

Crespitalis Bdl Pyrg. 426 ,

Cajona Reak. Lyc. 128,

Calais Scud. Ch. 317 ,

Calanus G.-R. Th. 98,

Calanus Hub. Th. 89,
106,187

162

170

115

85

116

159

189

157

153

84

83

154

154

$15+$

105

75

88

79

184

145

112

160

165

71

179

164

170

147

104

10.5

80

176

94

154

88

87
C Album Bdl.-L. Van. 260,

(-Albun Behr, Grap. 263,

C-Album L. Van. 261,

Calchas Behr, Lyc. 132,

Calchas God. Pap. 19,

Californiana, Edusa var. Men. Col. 60 a.

Califorica Bdl. Ch. 320,

Californica Butl. Het. 292,

Californica BdI. Yan. 268,

California Dbl.-H. Coen. 330,

Califormica Men. Pap. 14,

Californica Reak. Mel. 182,

Californica Scud. Pot. 422,

Culiforuica II. Edu. Th. 99,

Californius Bdl. Sat. 330,

Callias var. Mead, Ereb. 306,

Cullice H:. Edw. Ereb. 306 ,

CALLICORE HUB.

CALLIDRYAS BDL.

Callina Bdl. Mel. 235,

Callippe Bdl. Arg. 208,

Calverleyi Gr. Pap. 17 e.

Calyce IV. Edw. Pier. 34,

Calydon W. Edu. Mel.

Camerta (r. Poy). 302,

Camertus Hbst. P'ap. 302,

C'amillus II. Edw. Phy. 233 a.

Campestris Bdl. Pam. 353 a.

Campestris Behr, Mel. 233,

Canace IV Edw. Mel 228,

Canthus Bdl.-L. Par. 329,

Carduelis Seba, Paj). 272,

Cardui L. Pyr. 272,

Cardui virgin. Dru. P'up. 274, 138

C-Aryenteum Kby. Grap. 266, 132

C-Argenteum Scud. Grap. 265 a. 131

Carinenta Cr. Lib. 178,

Carlota Reak. Eres. 237,

Curoliniana Pet. Pap. 52,

105,187

122

80

Carpenterii WV. Edw. Arg. 195, 111

CARTEROCEPHALUS LED. 175

Carye Hub. Pyr. 273.

Cascioides Bdl. Lye. 119,

Cassiovides Esp. Pup. 306,

Cussius Butl. Lam. 119,

Cus.ius mar. Mor. Lyc. 120,

C'uste Kby. Pont. 26 b.

Castalis II. Edw. Th. 102,

Castoria Reak. Pier. 26 a.

Castro Reak. Poly. 162,

Catalina Reak. Lyc. 138,

Catena Stgr. Pam. 371 a.

Catillus Cr. Pap. 444,
138

92

151

92

92

75

89

74

102

96

168

179 


\begin{tabular}{|c|c|c|c|}
\hline & Page & & Page \\
\hline Catteua M-D. Pam. 371 a. & 191 & Clara H. Edw. Lyc. 153, & 100 \\
\hline Catullus Fab. Nis. 444 , & 179 & Clarius Bell. Parn. 21, & 73 \\
\hline Candatus Carolimiamns. Cat. Pap. & $.5,181$ & Clarns Cr. Pup. 340 , & 162 \\
\hline Caudatus Mar: etc. Cut. Pap. 10 & $0, \quad 182$ & Claudia Cr. Eup. 187, & 109,188 \\
\hline C-Aureum ('r. Pup. 259 a. & 127 & Clausius: Hbst. Pap. 187, & 109 \\
\hline (-Aureum Sh.-_oul. P'ap. 259, & 189 & Cleo Hub I'up. 306, & 151 \\
\hline Cecrops Fab. Th. 84, & 86,185 & Cleomes Bdl.-L. Pier. 29, & 76 \\
\hline Celimene Cr. Pap. & 156 & Clio W. Edw. Arg. 212, & 115 \\
\hline Cellus Bdl.-L. Eud. 341, & 162 & Clodius Men. Parn. 21, & 73,183 \\
\hline Celtis BdI.-L. Ap. 29:3, & 45,190 & Clorinde God. Gon. 50 , & 80 \\
\hline Celtis var. Strk. Ap $293 \mathrm{~d}$. & 190 & Clymena Cr. Call. 280, & 140,190 \\
\hline Ceneus I. Ch. 174, & 186 & Clymems. Fab. P(1). 280, & 140 \\
\hline Centaurea Ram. Pyr. 424, & 176 & Clytie W. Edw. Th. $84 \frac{1}{2}$, & 185 \\
\hline CERATINIA FAB. & $10 \bar{T}$ & Clyton Bdl-L. Ap. 294, & 146 \\
\hline Ceren Hub. Pol. 174, & 104 & Clyton var. W. Edu. Ap. 294, & 146 \\
\hline Ceres Butl. Coen. 330 b. & 159 & Chidia God. Col. 45, & 78 \\
\hline Cereus Dbl. Cha. 174, & 104 & Coeyta Cr. Pap. 231, 231 a. & 120 \\
\hline Cernes Bdl.-L. Pam. 38:, & 169 & Coenia Hub. Jun. 275 , & 138,190 \\
\hline Cernes Har. Hexp. 383 & 170 & COENONYMPHA HUB. & 159,191 \\
\hline Cervantes Grasl. Nis. 442, & 179 & Cofaqui Strk. Aig. 3.52, & 164,191 \\
\hline Cethura Feld. Anth. 40, & 78 & COLENIS HUB. & $108,18 T$ \\
\hline Chulcu. Fab. Pap. 19, & 73,183 & COLIAS FAB. & 80,185 \\
\hline Chalcedona Dbl.-H. Mel. 248, & 125 & Collina Behr, Mel. 235, & 122 \\
\hline Chalcedon W. Edw. Mel. 248, & 125 & Colom Fub. Pap. & 164,165 \\
\hline Chalcis Beho', Th 96, & 88 & Colorudo Scud. Pam. 371, & 168 \\
\hline Chalcus Fab. Prip. 19, & 183 & Coloradensis Riley, Ag. 351 a & 191 \\
\hline Chariclea Sch. Arg. 217, & 15,188 & Columbia H. Edw. Arg. 200, & 112 \\
\hline Charie Blan. Fan. 273, & 138 & Columbia W. Edw. Arg. $222 \frac{1}{2}$ & 189 \\
\hline CHARIS HUB. & 04,186 & Columbia sicud. Pam. $371 \mathrm{c}$. & 168 \\
\hline Charithonia L. Hel. 183, & $0 \bar{\tau}, 18 \bar{\imath}$ & Colrmbina Gloe. Argyn. 187, & 188 \\
\hline Charitonia Ful. Pap. 183, & 07,187 & Columbina Gorl. Arg. 187, & 109 \\
\hline Charon IV. Edw. Sat. 324, & 156 & Columbina Hbst. Pap). 188, & 188 \\
\hline Fub. Hesp 406 , & 173 & Columbina Fab. Pap. 188, & 109 \\
\hline Curt. Col. 63 a. & 84 & Columella Fab. Th. 105, & 89 \\
\hline CHIONOBAS BDL. & 152 & ue ulba Mill. Van. 261, & 130 \\
\hline Chiron Fab. Tim. 282, & 141 & Conmma Har. Van. 260, & 129 \\
\hline Chironias Hub. Mar. 282, & $1+1$ & Comma L. Pam. 371, & 167,191 \\
\hline Chippewa II. Edu. Col. 53, & 81 & mis Gr. Syr. 423, & 176 \\
\hline Chlorodice Hub. Pier. 33, & 76,184 & Comus W. Edw. Pam. 409, & 174 \\
\hline Chlymene Hub. Naj. hil. 280, & 190 & Comyntas God. Lyc. 117 , & 92 \\
\hline Christina W. Edw. Col. 54 b & 81 & Comyntas var. Kby. Cup. 118, & 92 \\
\hline Chrixu. Pack. Ch. 318, & 154 & Conspicure W. Edu. Hexp. 381 & 169 \\
\hline Chrysalus Seud. Hyp. T8, & 86 & Cooperi Beler, Anth. 40 , & 78 \\
\hline Chrysomelas $H$. Eilu. Col. 58 & 82 & Cooperi Behr, Mel. 247, & 125 \\
\hline hanus Hub. & 100 & Coresia God. Tim. 283, & 141 \\
\hline theme Esp. Col. 60, & 83 & Comelin. God. Sat. 304, & 150) \\
\hline Chrysotheme Fitch. Col. 58, & 82 & Coronis Behr, Arg. 202, & 112 \\
\hline Chrysotheme var. Bdl. Col 60 a. & 83 & Costalis Dbl. $-H$. Nis. 431 , & 177 \\
\hline is Dbl.-H. Ch. 318 & 154 & Couperi Grote, Lyc. 140 & 96 \\
\hline Chusea W. Edw. Pann. 365, & 166 & Crambis Fr. Ch. 316 . & 153 \\
\hline Cillu Behr, Lyc. 149, & 100 & Crameri Scud. Gropp. 259 a. & 128 \\
\hline Cillene Cr. Prip. 185, & 108 & C'ratagi Bdl.-L. Poly. 169, & 103 \\
\hline Cillene Hb.t. Pap. 185, & 187 & Cresphontes Cr. Pap. 7 , & 69,181 \\
\hline Cineta W. Edu. Eres. 224, & 119 & Creusa Dbl.-H. Anth. 36 , & $7 \tau$ \\
\hline Cipris Fab. Call. 47, & 79,185 & Crocale W. Edw. Syu. 257, & 127 \\
\hline
\end{tabular}


Page

Cruciferamm Bdl. Pier. 26 b. Crysalus IV. Edw. Th. 78,

Cupren Scud. Ch. 15\%,

Cupreus IV. Edw. Lyc. 157,

Cuvierii Luc. Lib. 279,

Cybele Fab. Arg. 193,

Cubele Bdl. Arg. 193 b.

Cygnus W. Edwe. Th. 99,

C'ymela Ci. P'up. 300,

Cymelia Hub. Meq. 300 ,

Cypris (1). Pup. 45 ,

('ypris Bill. Call. 47,

C'NTINEURA BDI,

Cythera II. Edw. Lem. 172 a.

C'ytheren Muel. P(1). 190,

\section{$\mathrm{D}$}

Ducotah W. Edu. Hesp. 355,

Deedalus Behi, Lyc. 147,

Duira God. Pier. 75,

Demastus: God. Poly. 102,

Damon Cr. Th. 102,

Dance ( $i$. Paj) 29.5,

DANAIDE,

DANAIS LATR.

Daphnis Cr. Pap 193,

Daphnis ILar. Prep. 196,

Daplidice var. Exp. P(1). 33,

Danni" W. Edu. Lyc. 138,

Dammins Hbst. Pap. 187,

Daumus Bdl. Pap. 9,

DEBIS WESTIV.

Delevare H. Edu. Hexp. 397 ,

Delia Cr. Ter. 75,

Delila Fah. Col. 185,

Delius Parn. 20,

Demoditas Hub. Eur. 75,

Demomien Hub. Hyp. 258,

Deva W. Edw. Pam. 392,

Devilliersii God. Pap. 2,

Diana Cr. Arg. 189,

Dia Lappomica Esu. Pap. 218,

Dina Hub. Eur. 7:,

Dione Scud. Lyc. $16+$ a.

Dionysus ścud. Neom. 3211,

Disa var. Dbl.-H. Ereb. 311,

Dixippe God. Nym. 287,

Disipuns: Bdl.-I. Nym. 287,

Dolichos Hub. Atl. 81,

Dolichus Hub. Atl. 81,

Dorcas Fab. Cys. 281,

Doreas Kby. Lyc. 160,

Draco IV. Edw. Pam. 356,

Dromus Fab. Pap. 306,
108, 187
Drya Fab. Pap. 46,

Page

Dryas IV. Edw. Grap. 260 a. 129

Dryope W. Edu. Th. 99,

Dumeti Behr, Nem. 172,

Dumetorum Bdl. Th. 114,

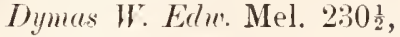

88

104

91

189

\section{E.}

Ebriola Poey, Ter. 77,

Evelipsis Cr. Pap. 49,

Echo H. Edw. Lye. 135 a.

Eclypsis Hbst. Pap. 49,

Edtith" rar. Kby. Mel. 246,

Eduse rer. Men. Col. 60 a.

Edewedsii Behr, Anth. 37,

Edwardsii Behr, Col. 55 b.

Edwardsii Reak. Arg. 191,

Edwardsii Saund. Th. 98,

Egeremet Scud. Pam. 384 a.

Eglei: Bdl. Arg. 208 c.

Elathea $\mathrm{Cr}$. Ter. 73 ,

170

114

85,185

Eleuche Dbl.-H. Tim. 284, 141

Eleuchea Hub. Tim. 28t, 141

Elymi Ram. Pyr. 272 a.

137

Enilia IV. Edw. Col. 56,

Emisse W. Edw. Phy. 233 a.

Emmius Scud.-B. Nis. 431,

82

121

177

Enoptes Bdl. Lye. 1:38,

Eos W. Edw. Pam. 415,

Ephestiaena Hub. Call. 288 ,

Ephestion Stoll, Lim. 288,

Epigena But. Eud. 342,

Epipsodea Butl. Ereb. 308,

Epixanthe Bdl.-L. Lyc. 160, EREBIA DALM.

Eresia Bdl.

101

Ericetorum Bdl. Pyrg. 428, 175

Eriphon Mor. Th. 111, 90

Eriphyle W. Edw. Col. 58 f. $\quad 83$

Eripue Hub. An. 180, 106

Erippus (1. Pap. 179,

Erippus Fab. Pap. 180,

105

Erodyle Bdl. Syn. 256,

106,187

ERYCIDES HUB.

127

163 ERYCINID A, 104

Erymus Bdl. Lyc. 147 a. $\quad 98$

Eryngii H. Edw. Coen. 330 c. $\quad 160$

Eryphon Bdl. Th. 111, 90

Ethlius Cr. Pam. 406,

Eubule Lin. Call. 46,

Eubule Hbst. Pap. 46,

79,185

Euclea Bergs. Pap. 231, 
Page

EUDAMUR SWAINA.

Eufalu W. Edu. Hesp. 408,

Evilalia I)bl-H. Lim. '292,

EUMAUS HUB.

EUNICA HUB.

EUPTOIETA DBLDY.

EUREMA DBLDY.

Eurema $I$ uub.

Europomene Esp. Pap. 5:3,

Europome Stuh. Col. 58,

Eurycles Latr. Hexy. 338,

Eurydice Bdl. Meg. 51,

Eurydice L. P'ip. 329,

Eurydice Scud. Árg. 329,

Eurymedon Bal. Pap. 12,

Eurynome W. Edw. Arg. 209

Eurytheme Butl. Col. 60 a.

Everythris Crod. Sat. 300,

Eurytion W. Edu. Mel.

Eurytris Fub. P(t)). 300 ,

Eurytulus Hub. Tho. 105,

Eurytus, ab. Neo. 300 a.

Eurytus Fab. Neo. 300,

Eversmanni Men. Parn. 22,

Evius Bdl. Lyc. 144 a.

Exile Scud. Brep. 121,

Exilis Bal. Lye. 121,

\section{F}

Fabricii Kby. Th. 98,

Fabricii var. W. Edw. Grap. 259, 127

Fabricii II. Edhe. Grap). 259, 127

Falacer God. Poly. 89,

Falacer Har. Th. 98,

Fasciata Butl. Ereb. 313,

Fasciata Strk. Lye. 158 a.

Faumes Scud. Grap. 26.5 a.

Faunus W. Edw. Grap. 261,

Favonius $\mathrm{Ab}-\mathrm{S}$. Th. 86 ,

Favonius Bdl.-L. Th. 83,

Fea IT. Edw. Lyc. 121,

Felicia Poey, Nat. 44,

FENISECA GROTE,

Feronia L. Ag. 27

Festus Hub. Cec. 341,

Filemus Poey, Poly. 123,

Flava Col. ab. $60 \mathrm{c}$.

Flava Ter. ab. 68 a.

Flanomarulutus Goez. Pap. 19, 183

Flora W. Edw. Ap. 294 c. $14 t^{\circ}$

Floridensis Strk. Lim. 287 a. 143

Floridensis, ver. Mor. Lyc. 120,

Foruax Hub. Ag. 278,

Fortumetus Fab. Pap.

Fotis Strk. Th. $113 \frac{1}{2}$,
161,191

173

145

103,186

140

109,188

127

84

80

$8 \cdot 2$

161

80,185

159

159

70

114

83

149

126

149

89

149

148

$73,18 \%$

97

92

92

88

127

88

152

101

131

130

87

86

92

78

103,186

139

162

98

83

84

92

140

154

186
Frenklimii Curt. Lyc. 150,

Freija Thn. Arg. 218,

Freyre H-S. Bren. 218,

Frigga Thn. Arg. '220,

Frigila Scud. Pier. 26 c.

Frisia Poey, Mel. 226,

Fuliginose Strk. Lye. 145,

Fuliginosa W. Edw. Th. 110,

Fulla IV. Edw. Lyc. 145,

Fulvescens H. Edw. Th. 96 a.

Funeralis foud.-B. 435 ,

Fureillate Say, Van. 269,

Fusca G.-R. Pam. 412,

\section{G}

Gabbii Behr, Mel. 240 b.

Gabbii W. Edw. Sat. 328 c.

Galactina Mor. Coen. 330 a.

Galactinus Bdl. Sat. 330 a.

Galbum Fourc. Pap. 261,

Gurmma, Enc. Meth. P(1) 2(i1,

Gurdettu DeL. Pup. 333,

Garita Reak. Anc. 420,

Gemnia Hub. Neo. 304,

Geniqueh Reuk. Eres. 223,

Genutia Fab. Anth. 38,

Gigas Butl. Gin. 320,

Gilippus Ab.-S. P'ip. 180,

Gilipuns var. Kby. Dan. 180 a. 107

Glaucon II. Eelue. Lye. 131,

Glaucus Lin. Pap. 10 a.

Glycerimm Riley, Paph. 295,

Codarti Perty. (ol. 50,

$12: 3$

157

159

159

130

$18 ?$

160

175

150

119

77

15.5

107

94

70

148

GONEPTERTX IEACH,

Gomiloba Westu.

Gomineis Hestu.

Gominuses $H u b$.

Gorgon Bill. Lye. 165,

Gorgone H-S. Eres. 2231,

Gracilis G.-R. Vau. 2(i.j a.

Grapta Kirby,

Grogne Fab. Pap. 266,

Grumus Bill. Th. 80,

Gryneus Hub. Lyye. 102,

Guadeloupe Strk. Ch. $17 t_{2}^{2}$,

Gundlachia Poey, Ter. 70,

Gyas W. Edw. Lye. 125,

Gyges Hex. Eres. 2o,

\section{H}

Haleyone WV. Edw. Arg. 197,

Halesus Cr. Th. 81,

Hamo Lue. Lyc. 123,

Hanno Hub. Rust. Ad. 123,

Harfordii H. Edw. 60 f:
80

161

161

161

$10^{\circ} 2$

120

131,189

127

132

$\mathrm{Sti}$

89

187

85

93

119

112

86,185

93

93

83 
Page

Warisii W. Edw. Grup. 260, 129 Harrisii Śeud. Me]. 23s, 123

Hurvisii W. Edw. Mel. 236, 122

Haydenii WV. Edw. Er. 309, 151, 190

Hayhurstii W. Edw. Nis. 445, 179

Heela Lef. C'ol. 6\%,

Hegesia Cr. Eup. 188,

Heyon sond. Hesp. 411,

Helcita Ball. Mel. 240 a.

Helema Reak. Meg. 51,

Helena W. Edw. Arg. 216,

Helena W. Edwo. Col. 53,

HELICONIDA,

HELICONIUS LATR.

Helicta Hub. Or. fim. 30:3,

Helios W. Edw. Lyc. 144 a.

Helloides Bdl. Lyc. 162,

Helvia Seud. MIel. 245 ,

Henriei G.-R. Th. 112 b.

Henshawi IV. Jdw. Neo. 305,

109,188

83

174

$12 \%$

80

115

81

107

107,187

1.50

97

102

124

91

1.51

119

102

151

146

78

161

113

163

100

171

185

76

172

$15 \mathrm{~s}$

124

177

109

171

87

87

75

86

138,190

138

$16+$

188

77

82

113

134

130

17.5

86

140

101

\section{I}

Ianthe W: Edw. Chr. 16\%,

Iberidis Bdl. Pier. "26 at.

Icarioides Bdl. Lyc. 147,

Icelus Lint. Nis. 441,

Idalia Dru. Arg. 190,

Idunu II. Edw. Ch. 320,

Idyja Kby. A p. 294,

Illinois Lood. Hesp. 385,

Hionens Ab.-SS. Pap. 18,

Imitata Strk. Mel. 2301,

Improba Butl. Arg. 2202,

Indra Reak. Pap. 15,

Inomata G.-R. Th. 89,

Page

Inornata W. Edw. A r.g. 207, 113

Inornata W. Edw. Coen. 331, 160

Interior Scud. Col. 54 a.

Internerlia ab. Lye. $136 \mathrm{~b}$.

Iuterrogationis Fab. Van. 259,

Interrogationis Gorl Van 259 at

Interrogation is ar. W. Edw. Grap. 259,

Iole Bdl. Nat. 44,

Iole (r. I (ip). 274,

Iortlandia Fab. P'up. 299,

Iowa Scud. Pam. 403,

Irene Bill. Arg. "208 a.

Irene Fitch, Nat. 44,

Irene Scud. Arg. 208 a.

Iris Mor. Th. 112,

Iroides Brll. Th. 113,

Irus God. 'Th. 112,

Isneria Bdl.-L. Mel. 237.

Ismeria Har. Mel. 238,

Isola Reak. Lye. 125,

Isopthalma H-S. Lye. 122,

Ixion Fab. Hesp. 92,

\section{.}

J album Bdl.-L. Van. 267,

Janais Dru. Syn. 25.,

Jatrophæ L. 276 ,

. Juanita Seud. 'Th. 81,

Juba Seud. Pam. $371 \mathrm{~b}$.

Jueunda Bdl.-L. Ter. 77,

Julia W. Edw. Anth. 41,

Julia Fab. Col. 184,

JUNONIA HUB.

Jutta Hub. Ch. 314,

Juvenalis Fab. Nis. 431,

Juvenis Hub. Nis. 431,

127

78

138

148

$17 \%$

113

78

114

91

91

91

122

123

93

92

185

132

126

139

86

168

85

78

108,187

138,190

152

177

177

T

Kali Strk. Th. 101!,

186

Keewaydin W. Edw. Col. 60 d. 83 
Kiowah Reak. Pam. 899 ,

Kodiah Kby. Coen. 336,

Kodiak IV. Edw. Coen. \$336,

Kodiak H. Edw. Lye. 147,

KRICOGONIA REAK.

\section{I.}

Labrudorensis scud. Col. 54,

Lrecinir W. Edw. Syn. 253,

Lreta W. Edw. Th. 10s,

L) Album Exp. P(1p. 26\%,

Lamina Fab. Pap. 289,

Lauceolata Bdl. Anth. 37,

Lapponica Kby. Alg. 21s,

Lapponien Stgr. Col. 53,

L-Argenteum Scud. Van. 266 a. 132

Larinia God. Ian. 275,

Laver Fub. Pap. 45,

Larunda Strk. Mel. 2301,

Larvata Ntrk. Lib. $178 \frac{1}{2}$,

Launentina Scud. Col. 54 a.

Lavinin Cr. Pap. 27.),

Lavinia Fab. Pap. 286,

Laviniu Har. Cym. 275,

Leanira Bdl. Mel. 250,

Leilia W. Edw. Ap. 293 c.

LEMONIAS WEST.

Leonardus Har. Pam. 379,

LEPTALIS DALM.

Lethe Fal. Eur. 2.58,

Leto Behr, Arg. 193 b.

L'herminieri God. Pier. 38,

Libya scud. Anc. 4201,

LIBITHEA FAB.

LIB Y'THEID A,

Liciuus W. Edw. Pam. 375,

Liliana H. Edw. Arg. 201,

LIMINITIS FAB.

Lintuerii Fitch, Van. 270 a.

Liparops Bdl.-L. Th. 91,

Lisa Bdl.-I. Ter. 76,

Lividus Hub. Pol. 344,

Loammi Whit. Pam. $391 \frac{1}{2}$,

Logan Wr. Edrr. Hesp. 397,

Lolquini Bdl. Lim. '291,

Lorquini Bdl. Rhod. 51,

Lorquini Beler, Lyc. 1:38,

Lorata G.-R. Th. 8! a.

Lncia Kby. ("np). 136,

Lucia Kby. Lyc. 136,

Inecia seud. Cy. 131,

Laeia ear. Mead, Lye. 136;,

Lucilius Lint. Nis. 437 a.

Lupini Bdl. Lye. 1:34,

Luteolus Reak. Nat. 4t,
Page

171

160

160

98

79

81

126

90

132

144

77

$110^{\circ}$

81

139

78

189

187

81

139

142

139

125

146

104

169

73,183

127

111

77

192

105,187

10.5

169

112

142,190

134

87

85

163

191

172

145,190

80

96

87

9.)

95,186

95

9.5

178

$9 . \overline{5}$

78
Lnteus Goez. Pap. 184,

LYCANA FAB.

LYCANIDA,

Lycam Fab. Pap. 293 ,

Lycaste Fab. Cer. 181,

Lycer W. Edw. Lyc. 147,

Lyciales Hub. P'rot. 3399,

Lycidas Ab.-S. Eud. 389,

Lyclia Fclil. Ter. 74,

Lygdamus Dbl. Lyc. 139,

Lyside God. Kric. 48 ,

Page

187

91,136

8.5

145

107

98

161

161

8.5

96

79

\section{MI}

Macaria W. Edw. Arg. 2221,

Machaon L. Pap. 13,

189

Maculata IV. Edw. Pam. 407,

Mierula Fab. Gon. 4?,

70,182

173

Worula Hub. Aut.50,

79,185

Met. Pap. 13, 182

M-Album Bdl.-L. Th. 82, 86

Manataaqua Scud. Pan. 38:, 170

Mancinus Dbl.-H. Sat. 310, 191

Wancinus H-S. Exy. 347, 163

Mancinus var. Dbl.-H. Ereb. 311, 152

Mandan W. Edw. Car. 421, 17.5

Meriviole Schrk.

Wrmitobu sond. Pan. 371,

Mareellina Cr. Prip. 46,

Hareellina Hlst. P(i). 46,

Marcellus Bdl.-L. Pap. 5 c.

Marcellu. Goes. Pap. 5,

151

168

79

185

Marcia IV. Edw. Mel. 231 a. 120

Hurginulis Send. Pier. 28,

Murginutu. Har. Het. 419,

Maricopa Reak. Lyc. 147 a.

75

175

98

Marina Reak. Lyc. 119,

Mariposa Reak. Lyc. 161,

92

101

Marius Cr. Pup. 282,

Mars Fab. Pap. 92,

141

Marsyas IV. Edw. Van. 262 a. 131

Martialis Seud. Nis. $438, \quad 178$

Massasoit Scud. Pam. 400, 17'

Mata Reak. Mel. 23:' b. 1:1

Meadii IV. Edw. Aro. 191 b. $\quad 110$

Meadii WV. Edw. Col. 61, $8: 3$

Meadii W. Edw. Sat. 326, 156

MECHANITIS FAB. 107

Mediatrix Feld. Syn. 25t, $126 ;$

Vegulippe Hub. An. 179, 106

MEGA NOSTOMA REAK. 80, 18.5

Megathymus somd.

MEGISTANIS WESTIV.

Melane IV. Jdw. Pan. 402,

Melenger Hub. Pap. 149,

Melicerta Brk. Pap. 366,
16.3

147

172

99

167 
Melinus Huh. Th. 88,

Melinus mar. H. Elw. Th. 83,

Meliset Fab. Pap.

Melissa W. Edw. Lyc. 127,

MELITEA FAB.

Melite L. Lep. 23,

Memaleuts Pod. Pap. 333,

Menapia Feld. Neoph. 24,

Menetriesii H. Edw. Parn. 21,

Memippe Hub. An. 179,

Mertila W. Edle. Lye. 141,

Mesopano Sind. Hesp. 421,

Meskei W. Edw. Pam. 378,

Metacomet Har. Pann. 388,

Metea Scud. Pan. 376,

Mexicana Bull. Ter. 71,

Midea Hub. Murn. ror. 38,

Milberti God. Van. 269,

Withertii Pack. Van. 269,

Wincha Kby. Pleb. 147 a.

Wingo W. Edw. Hexp. 422,

Winijas Bdl. Eum. 171,

Vinima W. Edu. Hesp. 417 a.

Mimmehaha Sénd. Agr. 134,

Hinor ex aureo etc. Pet. Pap. 366 ,

Winthe W. Edu. Lyc. 147 a.

Minuta IV. Edw. MIel. 239,

Minyas Hub. Eum. 171,

Misippus L. Lim. 287,

Modesta Bates, Eum. 279,

Modesta Maym. Lye. 105,

Monica Reak. Lyc. 116,

Monima Cr. Eun. 279,

Monoco Scud. Hesp. 391,

Montana Behr, Mel. 234,

Monticola Belnr, Arg. 205.

Montinus Scud. Arg. 217 b.

Montivago Behr, Arg. 208 c.

Montivago Kby. Arg. 208 a.

Montivago WV. Edw. Arg. 208 b.

Momusta ('?. Pap. 29,

Monuste Lin. Pier. 29,

Mopsus Hub. Str. 109,

Morio Ene. Weth. Pap 270,

Morio L. Pap. 270,

Mormo Feld. Ap. 172,

Mormonia Bdl. Arg. 208 b.

Mormonia Bdl. Chry. 172,

Horphea God. Arg. 231,

Norphens Fab. Pap. 231,

Horphins Fab. Pap. 231,

Morrisii Reak. Arg.

Morrisoni W. Edw. Pam. 3712,

Motya var. K by. Lib. 177,

Mylitta W. Edw. Mel. 235,
Page

86

86

154

93

119,189

73,183

160

74,183

183

106

97

175

169

171

169

85,185

77

133

133

99

175

103

175

95

167

99

123

103

142

140

89

91

140

171

121

112

116

114

113

114

76

76

90

189

134

104

114

104

120

120,189

189

118

191

$10 \overline{5}$

122
Mylotes Bates, Pap. 4,

Myrina Cr. Arg. 214,

Myrina Mart. Pap. 221,

Myrimus Hbst. I'up. 214,

Myrissa God. Arg. 214,

Nyrta God.? Nym. 279,

Mystic W. Edw. Pam. 361,

$\mathrm{N}$

Napa W. Edw. Pam. 355,

Napi Lin. Pier. 26,

Nastes Bdl. Col. 64,

Nastes Fitch, Col. 58,

Nestutii Bdl. Pier. 26,

NATHALIS BDL.

Nausica W. Edw. Arg. 199,

Neglecta K by. Cup. 135,

Neglecta W. Edw. Lye. 135,

Negreta var. Reak. Cer. 181 a.

Neleus Fr. Hip. 306,

Nelsoni Bdl. Th. 101,

Nemesis W. Edw. Cha. 176,

Nemoris W. Edw. Hesp. 411,

Nemorum Bdl. Pam. 363,

Nenoquis Kby. Arg. 208 b.

Nenoquis Reak. Arg

Neocypris Hub. Col. 47,

NEONYMPHA HUB.

NEOPHASIA BEHR,

Neplecle Hufn. Pap. 333,

Nephele Kby. Sat. 328,

Nephon Dbl.-H. Th. 111,

Nereus W. Edw. Pam. 414,

Nessus W. Edw. Nis. 448,

Nestos Bdl. Lyc. 149,

Nevada Scud. Pam. 371,

Nevada Scud. Thor. 343 a.

Nevadensis Bdl. Ch. 320,

Nevadensis IV. Edw. Arg. 191 a. 110

Nicippe Cr. Ter. 68, 84

Nig. ab. Ap. 294 b. $\quad 146$

Nig. ab. Lim. 287 b. $\quad 143$

Nig. ab. Lyc. 136 a. $\quad 95$

Nig. Col. ab. 58 b. $\quad 82$

Nigromarginatus Goez. Pap. 184, 187

Nigrosignatus Goez. Pap. 187, 188

Nilus W. Edw. Pam. 416 , 192

Ninonia Bdl. Pier. 24, 74

Ninus IV. Edw. Th. 93, 88

Niphon Hub. Th. 111, 90

NISONIADES HUB. 177

Nitocris WV. Edw. Arg. 194, 111

Nivalis Bdl. Poly. 161, 101

Nivium Bdl. Lye. 132, 94

Nokomis W. Edw. Arg. 192, 110

\section{8}

117

115

40

65

\section{5}

84

82

78

12

107

89

174

66

18

79

48

60

90

74

00

68

3

90

95

154

4

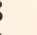

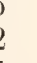

4


Page

Norma Quen. I'r(p).

Nomena var. Ochs. I'rep. \$14,

Nortonii H. Elwo. Hesp. 391,

Notabilis Atrk. Spi]. $4: 30$,

Novanglize Scud. Pier. 28 a.

Nubigena Behr, Mel. 244 a.

Numitor Fab. Anc. 419,

Nycteis Dbl.-H. Mel. 236,

Nycteis II. Edu. Mel. 237,

Nyctis Bdl. Mel. 236,

NYMPHALID A,

Nyse W. Edue. Amb. 416,

\section{$\mathrm{O}$}

Obsoleta H. Edw. Mel. 250 a.

Occideutalis Reak. Pier. 31,

Occidentalis Scud. Col. 58 e.

Oceanus W. Edw. Pyrg. 429,

Ocellata ver. H. Edw. A p. 294 ,

Ocellifere Grote, Call. 105,

Ochracea IV. Edw. Coen. 334, 160, 191

Ocola W. Edw. Pam. 405,

Odiu Hub. His. 295,

Odines Fab. I'tip. 295,

Eneis Hub.

Oeno Bdl. Ch. 315,

Oeno Scud. Ch. 316,

Oeno vur. Kby. (En. 316,

Oenone Seud. Mel. 236,

Oetus Bdl. Sat. 325,

Oetus Scud. Cer. 324,

Oileus. II.-H. Pyr. 423,

Oleracea Bdl. Pier. 26 c.

Oleracea Har. Pier. 26 b.

Olympia W. Edw. Anth. 42,

Olynthus Bell.-L. Eud. 406,

Omaha IV. Edw. Car 42.,

Oneko Scud. Hesp. 413,

Ontario IV. Edw. Th. 94,

Opis IV. Edw. Arg. 213 a.

Ophis II. Edw. Hesp. 404,

Optilete Kn. Lyc. 130 ,

Orbitulus DeP. Lyc. 149,

Orbitulus Scud. Agr. 151,

Orbitulus var Kby. (up. 150,

Orbitulus var. Stgi. Lyc. 150,

Oreus ( 2 . P(t). 423,

Oreus W. Edw. Lyc. $14 t$ c.

Oreas IV. Edw. Van. 26:39,

Oregonia W. Edw. 14 a.

Orestes Lint. Eud. 342,

Origcues Fub. Pup. 382,

Orion Fab. Ag. 295,

Oro Seud. Lye. 139 a.

Orona Scud. Hed. 381,
154

152

171

177

124

175

122

122

122

108

191

125

76

82

177

146

90

173

147

147

152

153

153

153

122

156

156

176

75

75

78

173

175

174

88

115

173

94,186

99

100

100

100

176

97

131

183

162

170

146

96

169
76,184 ()iphise (r. Irap). 279,

Orsa Bdl. Mel. 2:4,

Orscis Gorl. Pier. 29,

Orseis IV. Edw. Mel. 233 c.

Orythiu Ab.-S. Pup. 27.5,

Osceolat Lint. Pam 390,

Oskya IV. Edw. Pam. 408,

Oscimens Bdl. Arg. 215,

Otho Ab.-S. Pam. 384,

Otho Ball.-L. Hexp. 384 a.

Ottoe IV. Edw. Pam. 357,

Ovidius Scud.-B. Nis. 431,

U.xilus Hub. Her. 7 ,

\section{$\mathrm{P}$}

Packardii Saund. Mel. 231 b.

Pacuvius Lint. Nis. 436 ,

Paleno ('r. Pap. 58,

Palieno L. Col. 5:3,

Palamerles Dru. Pap. 19,

Palatke sevel. Lim. 387,

Palla Bdl. Mel. 2to,

Pallida Scud. Pier. 26 a.

Pallida IT. Edw. Mel. 233 a.

Pallideflarus Goez. Pap. 45,

Palmerii W. Eun. Lem. 173,

Palmira Poey, Ter. 74 ,

PAMPHILA FAB.

Page

140

$12 \%$

76

121

139

171

$17: 3$

115)

170

170

16.5

177

69

Promphiloides Reak Coen 333

Panphiloules var. K by. Coen. 333, 160

P'omphilus ver. Kby. Coen. 333, 160

Pamphilus L. Coen. 333, $\quad 160$

I'tul Har Th. 83, 86

Panoquin Scud. Pam. 404, 173

PAPHIA WESTW.

PAPILIO L.

PAPILIONIDE,

$1+7$

PARARGE HUB.

67

67

159

Pardalis Behr, Lyc. 147 a.

PARNASSIUS LATR.

Pessaflore Fab. Pap. 186,

Pawnee Dod. Pam. 370,

P'eckii Nor. Pans. 362,

Peckius Kby. Pam. 362,

Pegala Fab. Nat. 38 e.

I'egulu Hlbst. Pap. \$28 e.

Peleus Sulz, Tim. 285,

Peliclne Bdl. Col. 54,

98

$7: 3,183$

108

167

166

166

1.58

158

141,190

81

Pelidue var. Strk. Col. 54 al.

81

$\begin{array}{lr}\text { P'ellenis God. Nym. 284, } & 141 \\ \text { Pembina W. Edw. Lyc. 148, } & 99\end{array}$

I'embina H. Edu. Lye. 140, 96

Pergamus H. Edw. Pap. 16, 71

Persius Seud. Nis. t37,

Petreius H. Edw. Syr. 425, 
Petreus Enc. Meth. Pap. 285,

Petreus Cr. Pap. 285,

Phodon H-S. M[el. 249,

Phaetaena Hub. Mel. 249,

Phreton Drtu. Mel. 249,

Phuetontea God. Arg. 249,

Phaon W. Edw. Mel. 229,

Pharos Emm. Mel. 231,

Pherecydes Cr. Pap. 296,

Pheres Bdl. Lyc. 144,

Philemon Bdl. Lyc. 128,

Philenor L. Pap. 1,

Phileros Bdl. Lyc. 144 a.

Phileta Fab. Pier. 29 a.

Thilete Bdl. Pier. 29 a.

Phleas var. D'U. Lyc. 158,

Philodice God. Col. 58,

Philodice var. Scud. Col. 54 a.

Philomene Hub. Pap. 53,

Phocion Fab. Neo. 303,

Phocus W. Edw. Sat. 327.

Phyciodes Hub.

Phylace W. Edw. Pam. $408 \frac{1}{2}$,

Phylaus Dru. Pam. 354,

Phylous Emm. Pam. 354,

Piasus Bdl. Lyc. 135 :

Picta W'. Edw. Mel. 227,

PIERIDE,

PIERIS SCHR.

Pirus W. Edw. Nis. 447,

Pilalka K by. Pam. 387,

Pilatka W. Edw. Hesp. 387 ,

Pilumnus Bdl. Pap. 8,

Plautus Scud.-B. Nis. 432,

Plexippus L. Dan. 179,

Plexippus ab. Dan. 179 b.

Plexippus ab. Dan. 179 d.

Plexippus var. Dan. 179 a.

Plexippus var. Dan. 179 c.

Pocahontas'Scud. Pam. 399 b.

Podarec Feld. Lyc. 149,

Poeas Hub. Rust. ar. 84,

Pola Bell. Mel. 240 a.

Polaris Bdl. Arg. 219,

Polixenes Fab. Pap.

Polychlorus Cr. Pap. 267,

Polydamas L. Pap. 3,

Polyommatus Latr.

Polyphemus Bdl. Lyc. 142,

Polyxenes Fab. Pap. 17,

Pompadour Poll. Pap. 270,

Pontiac W. Edw. Pam. 381,

Porsenna Scud. Poly. 169,

Portlandia Fab. Deb. 299,

Portlandia ab. Deb. 299 a.
Page

190

142

125

125

125, 189

125

120

120

147

97

94

67, 181

97

76

76

101

82

81

80

149

157

119

191

164

164

95

119

73

74,184

179

171

170

69

178

105,187

106

106

106

106

172

99

87

124

116

154

132

67,181

91

97

71

134

169

103

148

148
Powesheik Par. Hesp. 420,

Page

Pratensis Behr, Mel. 233,

Pratensis Scud. Phyc. 234,

Pratincola Bdl. Pam. 369,

Procris W. Edw. Anc. 417,

Progne Cr. Van. '266,

PRONOPHILA WESTIV.

Propertius Scud.-B. Nis. 43.), 178

Proserpina Scud. Ap. 294 a. $\quad 146$

Proserpina W. Edw. Lim. 289 a. 144

Proterpia Fab. Ter. 69,

Proterpia var. Bdl. Ter. 70,

Protesilaus Dru. Pap 6,

Proteus L. Eud. 337,

175

121

122

167

174

132

148

78

84

85

68

161

Protodice Bdl.-L. Pier. 30, 76, 184

Pseudargiolus Bdl.-L. Lyc. 135, 95

Psendargiolus K by. Cup. 135, $\quad 9.5$

Psendargiolus var. Mead, Lyc. 136, 95

Pseudodorippus Strk. Lim. 287 c. 143

Pseudoptiletes Bdl.-L. Arg. 123, 93

Psendofea Hor. Lyc. 122, 92

Psyche Bdl.-L. Th. 8:, 86

Pudica var. H. Edw. Th. 83, 86

Puer Hub. Thy. 419, 175

Pulchella Bdl. Mel. 233, 121

Pulchella Scud. Phy. 235, $\quad 122$

Pumila Bdl.-L. Nym. 174, 104

Punctata W. Edw. Mel. 225, 119

Punctella G.-R. Hesp. 391, 171

Purpurascens H. Edw. Arg. 20.) c. 113

Putnami H. Edw. Th. 79, 86

Pylades Scud. Eud. 343 a.

162

PYRAMEIS HUB.

PYRGUS HUB.

135,190

176

PYRRHOPYGE HUB.

163

\section{$Q$}

Quadaquina Scud. Pam. 399 a. $\quad 172$

Quino Behr, Mel. 243,

124

$\mathrm{R}$

Rapæe Lin. Pier. 28,

75,184

Rapahoe Reak. Lyc. 147,

98

Reakirtii W. Edw. Anth. 39 a. $\quad 77$

Regia Bdl. Lyc. 137,

Regince Ret. Pap. 13,

Residae Bdl. Pier. 26 a.

96

70

74

96

Rhop Bdl. Lyc. 138,

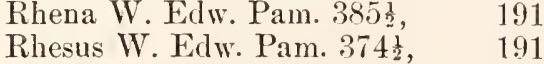

Rhodia W. Edu. Ereb. 308, 151

Rhodope W. Edw. Arg. 205 a. 113

Ricara W. Edw. Pyrg. 425, 176

Ridingsii Reak. Pan. 372, 168

Ridiugsii W. Edw. Sat. 321, 156 
Rossii Curt. Ereb. 310 ,

Rossii Gn. Col. 64 a.

Rubida Scud. Ch. 156,

Rubidus ab. Lim. 288 b.

Rubidus Behr, Lyc. 156,

Rubricata IV. Edw. Neo. 301, 149

Rufescens Bdl. Lyc. 146 a.

Rupestris Behr, Arg. $208 \mathrm{~d}$.

Ruralis Bdl. Syr. 424,

Ruralis Scud. Hesp. 425 ,

Rurea W. Edw. Pam. 388,

Ruricola Bdl. Pam. 368,

Russice Esp. (Pap. Dap. var.) 33,

Rustica W. Edw. Lyc. 149,

Rusticus W. Edw. Van. 261 a.

Rutulus Bdl. Pap. 11,

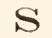

Sabuleti Bdl. Pan. 373,

Srepiolus Bdl. Lyc. 146,

Srepium Bdl. Th. 96,

Saga Kad. Arg. 220 a.

Sagittigera Feld. Lyc. 138,

Samoset Scud. Pam. 411,

Sanguinea Scud. Ery. 349,

Santes Fitch, Col. 58,

Sara Bdl. Anth. 39,

Sassacus Har. Pam. 360,

SATYRIDA,

SATYRUS LATR.

Satyrus IV. Edw. Van. 262,

Sanudersii W. Edw. Syn. 254,

Sanignyi Latr. Hesp. 344,

Sayii W. Edw. Parn. 20,

Scriptura Bdl. Pyrg. 427,

Soudderii Real. Col. 54,

Scudderii W. Edw. Lyc. 129,

Selenis Kby. Mel. 231,

Semidea Say, Ch. 315,

Seminole Scud. Pam. 377 a.

Sennce Lin. Pap. 46,

Shasta W. Edw. Lyc. 132,

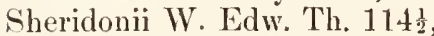

Silenus Dbl. Th. 83,

Silenus W. Edw. Grap. 263,

Silvestris W. Edw. Sat. 323,

Silvius IV. Edw. Van. 264,

Simethis Dru. Pap. 102,

Simethis Fab. Pap. 102,

Similis Strk. Pam. 416,

Simplicius Stoll, Eud. 338,

finon Fab. Pap. 6,

Sirius IV. Edw. Iyc. 155,

Sisymbrii Bdl. Pier. 32,

siva W. Edw. Th, 103,
70,182
Skada W. Edw. Cyc. 421,

Smerdis Hew. Eres. 224,

Smilacis Bdl.-I. Th. 102 ,

Smilax God. Pier. 76,

Smintheus Dbl.-H. Parn. 20, 73, 183

Snowi W. Edw Pam. 380,

Sonora Scud. Och. :tii,

Sonorae Bdl. Mel. 240 b.

Sonorensis Feld. Ap. 172 a.

Sonorensis Feld. Lyc. 137,

Sosybius Fab. Neo. 302,

Sonhegan Whit. Th. 99,

Spadix H. Edw. 'Th. 106,

speciosa H. Edw. Lyc. 152,

Sphyrus Hub. Pap. (foot-note),

SPILOTHYRUS DUP.

Spinetorum Bdl. Th. 104,

Stelenes L. Vic. 286,

Steneles Blan. Vic. :286,

Sterope W. Edw. Mel. 242,

Sthevele Bdl. Sat. 322,

Sthenele Hub. Met. 286,

Stretchii H. Edw. Ch. 321,

Striata IV. Edw. Lye. 125!,

Strigosa Bates, Dau. 180 a.

Strigosa Har. Th. 91,

Sulasa Bdl. Lyc. 110,

Suasa Bdl. Pier. 29 a.

Subhyalina Curt. Hip. 316,

Superba Strk. Mel. 249 a.

Surainsomia Swain. Am. Cy. 50,

Sylla Per. Pay. 283,

Sylvanoides Bdl. Pam. 367,

Syleanoides Scud. Pan. $371 \mathrm{c}$.

Sylvauus Esp. Pam. 366,

Sigleestri: Kby. Hip. 325,

Sylvinus Bdl. Th. 100,

SYNCHLOE BDL.

Syrichtus Fab. Pyr. 42:,

\section{'I'}

Tages $\mathrm{Nis} .42$,

Tamenumd Ii. Kdu. Hesp. 449,

180

Tarpeia Pall. Ch.

1.5 .5

Tarpeius God. Sat.

156

Tarpejus Fab. Pup.

156

Taryuinius Curt. A rg. 218 a. $\quad 116$

Tarquinius Fab. Fen. 169, 10\%, 186

Tartarus Hub. Pap. 423 ,

Tau soud. Pier. 24,

176

Tumun Fub. Pap. 382,

74

Taygete Hub. Ch. :317,

169

153

Tuigycte $H-S .$, Ch. :316,

Taygete var. stgr. 317,

Tehamu Reak. Lyc. 149,

153

154

Tejua Reak. Lye. 115,
99

91 
Telamonides Feld. Pap. 5 a.

Terentius Scud.-B. Nis. 431, TERIAS SWAINS.

Terlooii Behr, Neop. 25,

Tessellata Scud. Hesp. 423 ,

Tetra Behr, Th. 95,

Texana Scud Ery. 350,

Texana W. Edw. Mel. 224,

Textor Hub. Pam. 413,

Thenaos Bell.

Tharos Dru. Mel. 2:21,

Tharossa God. Arg. 231,

THECLA FAB.

Thekla W. Edw. Mel. 252,

Theona Men. Mel. 251,

Theonus Luc. Lyc. 120,

Thersites Lee, P(i). 10,

Thetis DeB. Pal 285,

Thety. Fab. Pap. 285,

Thiodames Scurl. Poly. 265,

Thoos: Bdl.-L. Pap. 7,

Thoas Sh--1Tod. Pap. 7,

Thoe Bd]. Lyc. 159,

Thoosa Seud. Anth. 43,

Thraso Hub. Ach. 449,

TIMETES BDI.

Titus Fab. Th. 109,

Tityrus Fab. Eud. 340,

Toxen God. Eum. 171,

Toxea Gray, Eum. 170,

Transmontana Gos. Hip. 329,

Triclaris Hub. Arg. '215,

Triclaris Mead, Arg. 215,

Tristis Bdl. Nis. 4:34,

Tritona W. Edw. Pron. 298,

Thoglodita Hub. An. 297.

Troglodyta Fab. Paph 297,

Troilus Iru. Pap. 17 ,

Troilus Hbst. Pap. 17,

Troilus L. Pap. 18,

Turnus Lin. Pap. 10,

Tymdurellu: H bst. P'up. :306,

Tyndarus Esp. Ereb. 306,

Tymdarus var. Mead, Ereb. 306, 151

Typhon var. Kby. Coen. 331, 160

\section{$\mathrm{U}$}

Uhleri Reak. Ch. 319,

Llrica W. Edw. Mel. 230 ,

Umbrosa Lint. Van. 259 a

Uncas WV. Edw. Pam. 374,

Urania West. Ery. 348,

Ur.sula Em. Lim. 288,

Crisula Fab. Pap. 288,

Urtice Har. Van. 267 ,

127,189

Utahensis Strk. Pap. 17 e.
189

169

163

190

143

133

126

126

182

141

131

89

101

184

80

90

101

$10: 3$

59

115

178

148

147

147

0

33

V

I Album Fab. Pap. 267,

Page

VANESSA FAB.

Vanillæ ab. Agr. $186^{\circ}$ a.

132

Vanillæ L. Agr. 186,

127,189

108

Vau-Album W-V. Van 267, 188,188

Venosa Scud. Pier. 26,

Verna W. Edw. Pam. 395,

74

Vernalis W. Edw. Pier. 30 a. $\quad 76$

Vesagus Dbl.-H. Ereb. 307, 151

Versicolor Goez. Pap. 25, 184

Vesta W. Edw. Mel. 230, 120

Vestris Bdl. Pam. 393,

Viaer W. Eilw. Lyc. 138,

Vialis WV. Edw. Pam. 410,

Viator W. Edw. Pam. 401,

VICTORINA BLANCH.

Villiersii Bdl-L. Pap. 2,

Violacea Kby. Cup. 136,

Vinlacen Scud Cy. 136,

Violacea W. Edw. Lyc. 136,

Virgilius scud.-B. Nis. 431,

171

96

174

172

142

67

9.5

95

95

178

Virginiensis Bdl. Ery. 174, $\quad 104$

Virginiensis Kby. Pyr. 274, 138

Virginiensis IV. Edw. Lyc. 168, 102

Virginiensis W. Edw. Pier. 27, 75

Virgula Retz, Pap. 371,

Virgulti Behr, Nem. 172 a. $\quad 104$

Virida Col. ab. 58 c. 82

Viridis var. Lim. 288 a. $\quad 144$

Viridis $W^{.}$Eilw. Th. 114, 91

Titellius Ab.-S. Pap. 403, 173

Vitellius Fab. Pam. 397, 171

Voleanica Perry, P(ip. 4h, $\quad 78$

Tuleain Ene. Weth. Pup. 271, 190

\section{W}

Waco W. Edw. Anc. 417 a. 174

Wakulla W. Edre. Hesp. 413, 174

Wulshii W. Edu. Pap. 5, 68

Wamsutta Har. Hesp. 362, 166

Weidemeyerii W. Edw. Lim. 290, 145

Werdandi $H-S$. Col. 53, $\quad 81$

Westwoodii Bdl. Ter. 7\%, 85

Wheeleri W. Edw. Sat. 328 f. $\quad 158$

Whitneyi Behr, Mel. 240 d. $\quad 124$

Winginu Send. Hesp. 359, 165

Wosnesenskii Men. Col. 51, 80

Wosnesenskii Men. Parn. 22, 73

Wyandot W. Ed w. Hesp. 424, 176

Nirnthe Sepr. Peip. 45, T8

Vanthidia Bill. 84

Xanthoides Bdl. Lyc. 164, $\quad 102$

Xerees Bull. Lye. 143, 


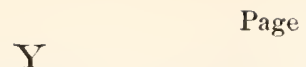

Yuccæ Bdl.-L. Æg. 351, Treka Reak. Pier. 28,

Yreka W. Edw. Hesp. 363,

Yuma W. Edw. Pam. 358,

I

Zabulon Bdl.-L. Pam. 398, Zabulon Scud. Atr. 399,

Zampa IV. Edw. Nis. 443,
163,191

75

166

16.5

17.2

172

179
Zelicaon Luc. Pap. 14,

Zelmira Feld. Lyc. 132,

Zephyrus W. Edw. Vau. 26.5, 131

Zephyius Scud. Poly. 261 a. $\quad 130$

Zerene Bdl. Arg. 208, 113

Zerene Bdl. Arg. 205, 113

Zeroe Bdl. Lyc. 163, 102

Zerynthia Hub. Mar. 283,

Zolicaon Bdl. Pap. 14,

Zonaria But. Pap. 6,
71. 183

141

69 


\section{BIBLIOGRAPITY.}

List of authors and their works cited; elneidating the abbreviations nsed in this Catalogue, with short hiographical or antobiographical notest

In riting the publications of those authors who have treated of the Lepidoptera of various parts of the work, I have not comfined myself to the titles of such of their articles as lelate to the $\mathrm{X}$. Ameriean tama aloue, hut have given all others as well, in the order in which they were published. Nor is any excuse required for so doing, as no one can be the loser by the perusal of anything that has been written hy Hewitson, the Felders, Mosehler, etr.

The works of those authors who have treated solely on the Heteroceres will be given in a continuation of the Billiography which will be appender to the Catalogne of the Heteroceres to be issued as the second series of this work.

All those works which I have myself' examined have an wefixed.

*ABB.-SMITH. INs. GA.

John Abbot and Jomes Edured simith. The latter was borw in Eclinburgh Dec. :2, 1759 ; died in London Mareh 17, 1828.

The Natural History of the rarer Lepidopterous Insects of Georgia, inanding their srstematic chameters, the particulars of their several metmorphoses and the plants on which they feed. Collected from the obscrvations of John Ablot, many years resident in that enutry. Lomilon, 1797.

2 vol. Il!ustrated with 104 coloured plates representing the larva, chrysalis and perfect insect, as well as the foot-plant; engraved from the original drawings of John Abbot. In English and French.

*Bates. Ext. Mon. Mag.

Henry Wr. Butes, in Lorilon. Sturlicel and collected Lepidoptera on the Aniazons, A. Ans, for a number of years.

'The Entomologists' Monthly Magazine. Jomelon: John Van Voorst. Tols. I-XTY, 1864-187\%.

Contains following papers on Lepidoptera :

New Species of Butterflies from Guatemala and Panama, p. 205, vol. I, 1864.

()n the Blue-helted Epiralize of the Fonests of the Amazons, p. 17t-177, vol. II, 1865-1866.

New Speeies of Butterflies from Guatemala and Panama, 1. 49-52; 85$88 ; 13: 3-1: 36 ; 152-157$; vol. III, 1866-1867.

New Speeies of Insects from the Province of Canterbury, New '/ealand. Coll. by R. II. Fereday, P. 52-56.

Notes on the genus Panclora, p. 169, vol. IV', 1867-1868.

(In a collection of Butterflies made by Mr. John Milne in Newfonndland, p. 244-246, vol. XI, 1874-1875.

† For some of these I am indebterl to Oken's Isis. Hagen's Bib. Ent. \& Ferussac's Bull. 
*Bates. Jnis. ENT. I.

Jourual of Entomology, vol. 1, 1862. Contributions to an Insect Fauna. of the Amazon Valley: Iepidoptera, Papilionidse, p. 218-245.

*Bde. Icon. du Reg. Ax. par Gier.

Jean Alphonse Boisduval, Doctor of Medicine, in Paris. Born in Ticheville June 17, 1801.

Icomographie du Règne Animal de G. Cuvier, ou representation d'après nature de l'une des espèces les plus remarquables et sonvent non encore figurees, de chaque genre d'animaux aree un texte descriptif mis an conrant de la science. Onvrage ponvant servir d'atlas a tous les traites de Zoologie par M. F. E. Gnérin-Méneville. Paris. J. B. Bailliere. 1829-1844. 2 rol.

*Bde. Griff. Cuv. An. King.

The Animal Kingdom arranged in conformity with its organization, by the Baron Cuvier, ete. The Class Insecta, with Supplementary Additions to each order by Edward Griffith, Edward Pidgeon and George Gray. Loudon: Whitaker, Treacher and Co., 1832. Tol. XIV., XY.

*Bit. ICONEs.

Leones historique des Lépidoptères d'Enrope, noveanx on pen eommus. Collection avee figures coloriées des Papillons d'Europe nouvellement decouverts. Ouvage formant le complément de tous les auteurs iconographer. Paris. Roret, 1832-1843.

*Bde. Faun. Ext. Mad.

Faune eutomologique do Madagascar, Bourbon et Manrice, I sépidoptères. Aree des notes sur les moenrs par M. Sganzin. Paris, Roret, 1833.

Col. plates $1-16$.

*BDi. Sp. GEN.

Histoire Naturelle des Insectes. Species général des Lépidoptères. Tome premicr Paris, Roret, 1836.

Contains 690 pages text and 24 (4 of them larvæ) fine eoloured plates of Lepidoptera from varions parts of the world.

*Btel. Cuv. Reg. AN. INs.

Le Riogne Animal distribue d'apres son organisation, pour servir de base a l'histoire natmelle des animaux et d'introduction a l'anatomie comparén, par Georges Cuvier. Paris, Fortin, Masson et Cie.

Les Insectes, par Audonin, Blanchard, Dovere et Milne Fdwards.

2 vol. text, 2, plates.

* Bde. Gen. Ind. Meth. (or Gen. et Ind.).

Genera et Index methodicus enropseorum Lepidopterorum. Paris, Roret, 1840.

Bdi. Air. ToY. DE DELeG.

Voyage dans l'Afripue Anstrale notament dans le terriore de Natal dans celui des Cafres Amazonlous et Makatisse et jusqu'au Tropique du Capricorne, exécuté durant les anuées 1838-184t, par M. Adulphe Delegorene (De Donai) avec une Introduction par M. Albert-Montemont. Paris, A. René et Cie. 1847. 2 rol.

The Lepidop. are p. 585-602, vol. II.

*Bde. ANr. Soc. Ent. Fr.

Lépidoptères de la Californie. p. 275-324 of the Anuales de la Sucieté Entomologique de France $2 \mathrm{~d}$ ser. vol. X, 1852.

*Bdi. Lep. Cal.

Lépidoptères de la Californic. Entomologique de Belgique.

p. S-94 in the Anmales de la Société Vol. XII, 1868-1869. 
*BdL.-Lec. Lep. AM. SEPT.

Boisdunal (Dr. Jean Alphonse) and Leconte (Mujor John E.). The latter born in New Jersey Feb. 22, 1784; clied in Philadelphia Nov. 21, 18 (i0.

Histoire générale et ieonographique des Lépidoptères et des Chenilles de l'Amerique septentrionale. Paris, 1833.

Contains 78 coloured plates of larva, chrysalis and perfect insect.

*Beauv. (De) Ins. Afr. ET. Am.

Ambroise Marie Francois Joseph Palisot de Beanwois. Born in Arras.July 27, 1752; died in Paris Jan. 21, 1820.

Insectes recueillis en Afrique et en Amerique dans les royanmes d'Oware, ì Saint-Domingue et dans les etats-mnis prurlant les annéces 1786-1797. Paris, Levrault, Schoell et Cie. 1805-1821.

Completed after De B.'s death by Audinet Serville. Large folio. 90 col. plates.

*Behr. Stett. Ent. Zeit.

Hermann Behr, Doctor of Medicine, in Coethen; now in San Francisco, California.

Zeitung Herausgegeben von dem Entomologische Vereine zn Stettin. Contains :

Correspondence p. 210, 211, rol. VT, 1815.

Naturhistorische Benerknngen über die Ungegend von Irlalaide in Nenholland, p. 167-176, vol. VIII, 1847.

Verzeichniss der Rhopraloceren Californiens, p. 213-216, vol. X X V I, 1866.

Ein Brief des Herm Dr. Behr ans St. Francisen in Californien von. 3. März. 1868, p. 294-303, vol. XXIX, 1868.

*Behr. Proc. Ext. Soc. Pint.

Proceedings of the Ent. Soc. of Philadelphia.

Description of a new species of Chrysophanns, p. 208, vol. VI, 1866.

*Behr. Trrans. Am. ENT. Soc.

The following papers are in the Transations of the American Entomological Society :

Deseription of a new genus of Pieridse, and certain new species of bntterHies from Cilifomia, p. 303, 304, rol. II, 1869.

Synopsis Noctuidarum hucuspue in California repertarum, p. 23-28, vol. III, 1870 .

* Behr. Proc. Cal. Arad. Nat. Sc.

Proceedings of the California Academy of Natural Sciences, San Francisco, published by the Acalemy, vol. I, 1854-1857; vol. II, 18581862 ; vol. III, 1863-1867; vol. IT, 1868-1872.

Contains the following on Lepidoptera:

Deseription of native Silk IV orm, p. 46.

Saturnia Ceanothi Behr', p. 72, vol. I, 1855.

On certain Butterflies of California, p. 167-169.

On Californian Argynuides, 1). 172-177, vol. II, 1862.

On Californian Lepidoptera, No. III, 1. 84-93; No. IV, 1. 123-127.

Notes on Californian Satyrides, p. 16:3-166.

On Californian Lepidoptera, p. 178-179.

Californian Lepidoptera, p. 279 and 296, vol. III, 1863-1867. 
On a Butterfly, Vanessa Antiopa, 11. 56, rol. IV, 1868-1872.

* Berge. SCHMETT.

Fr. Berge, in Stuttgart.

Schmetterlingsheh, oder algemeine und besondere Naturgesehichte der Schmetterhnge, mit brwonderer liürksicht ant die enropäischen Gattungen. Nebst einer volständigen Anweisung sie zu fingen, zn erzichen, zuzubereiten und aufzubewahren. Stuttgart, Hoffman, 1842.

48 plates filled with coarsely executed and coloured fignres of Lepidoptera and their linva and pupere

A later improved edition was issuel in 18.1.

* Bergas. Nom. U. Besch. Ins.

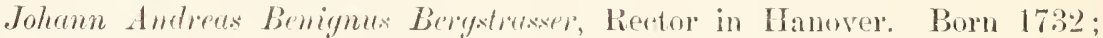
died 1812 .

Nomenclatm und Beschreihnng der Insecten in der Gratschatt HanauMïnzenberge, wie auch der IV etteran und der angrenzenden Nachbarschaft dies nnd jenseits des Mains, nit erlenchteten Kuptertafeln helansgegeben. Hanau, I I, III, IV, 1779-1780.

(First part, 1778, is Coleoptera.)

* Blanchi (Mar, Faun. Chil.

Emile Blonclearl, Naturalist, in Paris. Burn Mareli \&, 1819.

Gay historia ficeial y politiea de Chile Zoologia vol. VII, 1852.

The Lepidoptera are on pages 1-112. In the Atlas (1s,-t) plates 1-7 are Lepidoptera. Blaxch. Hist. NAt. INS.

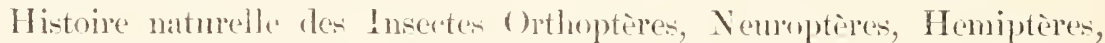
Hymenoptères, Lapidoptères of Diptères; aver nue introdnetion par M. Brulle. Paris, Duménil, 18 to.

* Browas. Congt. Mis. Butot.

Captain Thome. Brome.

The Book of Butterfies, Sphinger and Moths, illustrated br ninety-six crepranes, colonred after nature. Isondon, Whitaker, Treatcher and Co. Vol. I, II, $18: 92$, III, 18:34.

These are vols. $75,76,80$ of Constable's Miscellany.

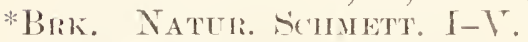

Horiz Bullhase Borlifunsen. Born in Giessen 1760; died in Darmstadt Nov. 30, 1806 . Forstreth t in Darmetadt.

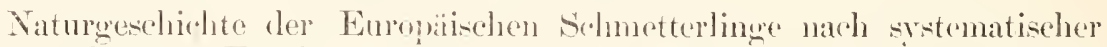
()rinung. Frankfint, Varentraple u. Wenner. I, 1788; II, 1789 ; III, 1790; IV $1792 ; V^{r}, 1794$.

* Busker. Gan. Hext.

Robert Bunlien, in Rochester, New York.

Canalian Fintomologint contains tho following :

Yintes on Collecting Catocalas, 1. 25, 26, vol. VI, 18.4.

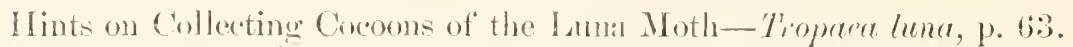

Notes on the Life Kistory of lle American Tigere Moth, p. 149, 150, vol. VII, 1875.

Coprespondence, p. 120.

Notes on Vanemsi Lintnerii, Fitrh, 1. 240, vol. VIJI, 1876.

Sotes on the Food Plant of IIemilenaa Maial, p. 11!.

bifferet of hot weather upon the transformation of the Sphinxes, 1) 120.

Hiterally, Forest Connsellor; we have mo public oflice in Imerica analogous to it. 
Notes on the Egg, Larva and Pupa of Smerintlus Modestal, p. 210, 211, vol. IX, 1877.

Butr. Cat. Satrir. B. M.

Arthur Gurdiner Butler, Sr. Assistant Zoological Dep. Brit. Mus. Born at Chelsea, London, June 24, 1844.

Catalogue of the Satrride in the British Muscum, 1868.

Buth. Cist. Ext.

Cistula Entomologina sive Inseetorum nov. diagnoses. Vol. I, 1870-1876.

* Butra. Laep. Exot.

Lepidoptera Exotica, or Descriptions and Illustrations of Exotic Lepidopteria.

Published in 20 parti, 1869-187t. 4to, 64 colunred plates (chromo-lithographs).

* Buter. Ent. Mon. Mag.

The Entomologist's Montlily Magazine, conducted by .J. W. Douglas, R. M'Ladhlan, H. L.S., E. C. Rye, F. L. S., H. 'T. Stanton, F. R. S., and at various times by others. Londom. Vol. I-XIV, 1S64-1877.

Description of a new species of Morpho (M. Thetis), p. 81.

Description of a new speries of Butterfly belonging to the Lyomida, p. 169,170 .

Deseription of some curions valuations in the genus Morplo, 1). 202-204.

Biston Hirtaria, 1. 211.

Deseription of a new species of Innonia (J. [xia), 1. 227, 228, vol. II, $18650-1866$.

O)servations on two species of Hamma, p. 19.

Renarks on the distinctiveness of certain species of Ervoina.

Description of sonte new species of Dinr. Lep. in the B. M., 1. 76-7s.

Notes on two forms of Mesene hitherto comsidered to he sexes of one species, p. 165.

Deseription of a new species of Dint. Jep. helonging to the Erycinida, p. $17+176$.

Conrections of errors hitherto existing in the nomenclature of soveral species of Nymphidimm, 1. 221-228, vol. I I I, 1866-1867.

Description of a new genus of Dimmal Lepidoptera, 1) 121, 122.

Erelia Eurvale of Esper, a speedes posibly new to the British lists, p. $151,152$.

An Essay towards an arrangement of the genera of the fanily satyridae, 1. 19:3-197, vol. I' ', 1867-1868.

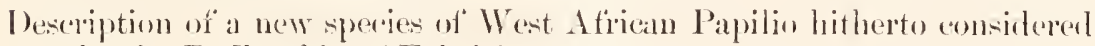
to be the P. Zenobia of Faluricine, p. 60.

The Larva of Ahraxas grosulariata distasteful to froge, 1. 131, 13:2.

Deseription of species of Lepidoptera ronfoumled with others describer by Limneus and Fabricius, p. 270-273, vol. V, $1868-1869$.

Descr!ption of a fine new Charaxes firom Africa, 1). 28, 29.

Duscription of new species of I immal I depidaptera, p. 55-57.

The sexes of Pajpilio Merope p. 148.

Adelitional mote (and corrections) respecting the sexes of Papilio Merope, p. 171 .

On new or recently described species of Diurnal Lepidoptera, 1. 250252, vol. VI, 1869-1870. 
The genera of Hesperida in the Collection of the British Museum, p. $55-58$; p. $92-99$.

Remarks upon the elassification of the Hesperidse, p. 265, 266, vol. VII, 1870-1871.

Note on the identity of Argymuis Atlippe and A. Niobe, p. 166.

The Nomenclature of Rhopalocera as affected by the names given in Perry's Areana, p. 167.

Note on Argymis Adippe and A. Niobe, p. 206, vol. VIII, 1871-1872.

Vanessa Antiopa at Great Yamouth, p. 88.

Vanessa Antiopa at Herne, p. 108.

Note on Crinodes Sommeri and Taesolepis Remiauda, p. 111, 112.

Answer to Mr. Kitsema's note on Crinoles Sommeri, p. 198, 199.

Occurlence of Apatura Ilia in England, p. 217.

Note on Apatura Ilia and A. Iris, p. 270, 271, vol. IX, 1872-1873.

Description of a new species of Bralnmaea in the Collection of the British Museum, p. 56, 57 .

Description of a new genus and species of Satyridian butterflies, 1. 204, 205, vol. X, 1873-1874.

Notes on a collection of Butterflies recently bronght from Cape Coast, West Afriar, with description of a new species from Natal, p. 57, 58.

Deseription of two new species of Heterncerons Lepidopteria in the Collection of the British Museum, p. 77, 78.

Description of six new speries of Diumal Lepidoptera in the Collection of the British Musenm, j. 163, 164, vol. XI, 1874-1875.

Notes on Mr. Scmtder's Historical S'ketel of the generie nance proposed for Butterflies, p. 15-17.

Revision of the Lepidopterons gents Eusemia, with deseriptions of new specics, p. 116-125.

Note on Mr. Schelder's Remarks on the oll genus Callidrvas, 1). 206, vol. XI1, 1875-1876.

Description of three new speries of Papilio from the Collertion of Mr. Herbert Druce, 1). $56,57$.

Observations on Mr. Hewitson's note resperting Mr. Buxton's Collertion of Orange-tipped Butterflies, 1. 89, 60.

List of Buttertlies known to inhabit New /ealand, with deseriptions of a new gemms and a new speeies in the collection of John D. Eny's, Herfo, p. $152-154$.

Description of a new species of Argynnis from Aretic Amerian, p. 206, rol. XIII, 1876-1877.

List of Heteronerous I depidoptera recently collerted by the Rer. 'T. Blackburn in the Hawaiian Islands, p. 47-50.

Description of three lepidopteroms insects from Qneenslant, p. 10s-110.

On Lepidoptera from the Hawaian Lslands, p. 185.

Descriptions of several new species of Heterocerous I epidoptera firom Japan, p. 206, 207, vol. XIV, 1877-1878.

*Butl. Jnl. I in. Soc. Lono.

fournal of the Limnean Soricty. Idomlon, 1857-1877.

A list of the Inimal Isepidoptera recently colleceted hy Mr. Whitily in Hakoradi (North Japain), 1\%. 50-59. 
A Monograph of the genus Lemonias, with deseriptions of new species in the Colleetion of the British Musenm, including other forms sometimes placed in that genus, (2 plates, ) 1. 213-229, vol. IX, 1868.

Notes on the Lepidoptera of the Family Zyganidae, with descriptions of new genera and species, (2 plates, ), p. 3\$2-407.

( )n the sub-families Antichlorins and Chardeine of the Lepidopterons families Zygrenidse and Arctiida, (1 plate,) 1) 408-433, vol. XII, 1876.

Descriptions of two new Isepidopterons Insects firom Malacea, p. 115, 116.

( $n$ new speeies of the grenus Euptychia, with a tabular view of those hitherto recorded, p. 116-128.

The Buttertlics of Malacea, p. 196, 197. vol. XIII, 1877.

*Butr. Proc. Zool. Soc. Lond.

Procedings of the Srientific Meetings of the '/oological Society of I undon. Longmans.

In the above are the following on Lepidoptera:

Description of six new species of Diurnal Lepidoptera in the B. M. Coll., 1. 430,1865 .

Deseription of six new species of Exotic Butterflies in the Coll. of the B. M., 1. $455,1865$.

Description of the charaters of six new species of Rhopalocerons Lepidoptera in the Coll. of B. M., with notes on allied species, p. 481, 1865.

Monograph of the species of Claraxes, a genus of Diurnal Lepidoptera, p. 622,1865 .

Description of six Butterflies new to science, belonging to the genera Heterochroa and Ronaleosoma, p. 667, 1865.

Description of some new Exotic Butterflies in the National Coll., p. 39, 1866.

Monograph of the Diurnal Lepidoptera belonging to the genus Danais, heing a revision of the inserts of that genns, with deseriptions of new speeies in the National Coll., p. 43, 1866.

Notes on the grenus Brahmea of Walker, p. 118, 1866.

Supplement to a Monograph of the genus Danais, founded on speeimens in the coll. of Mr. Osbert Salvin, p. 171, 1866.

A Revision of the genus Hypna, with deseriptions of new species, p. 206, 1866.

A Monograph of the Dimmal Lepidoptera belonging to the genus Euploea, with descriptions of many new speeies founded prineipally on the speeimens in the Coll. of the B. M., p. 268, 1866 .

Corrections and Addenda to certain papers on Lepidoptera published during the year's $1865-66$, with additional notes on some of the species described, j. 451, 1866.

A Monograph of the genus Euptychia, a numerous race of Butterflics belonging to the Family Satyridæ, with descriptions of sixty speeies new to science and notes on their affinities, \&c., p. 458, 1866. 
Note on some -pecies of Butterflies belonging to the grenus Catogramma, p. $578,1866$.

Note on the identity of certain specios of Jyesenidx, P. 34-36, 1867.

Description of a new genus of Dinrual Lepirloptera belonging to the Family Erycinidae, p. 37-39, 1867.

Deweription of some new species of Satrride betonging to the genus Euptychia, p. 104-110, 1867.

Remarks mon the Fabrician species of the Satyride grenns Mycalesis, with descriptions and notes on the named varieties, p. 718-721, 1867 .

Note on the Nymphalis Calerlonia of Hewiton, p. 873, 874, 1867.

Description of new or little known species of Lepideptera, p. 221-224, 1868.

I Monographic Revision of the Lepidoptera hitherto included in the genus Adolias, with description of mew genera and species, p. 599615, (1 coloured plate,) 1868.

Deseription of a new genus of Hetereseroms Lepidoptera fommled upon the Papilio Chamione of Fabricius, p. 43-45, 1869.

List of Iniurnal lepidoptera collerted by Mr. Spaight in Northern Indial, 1. $724-728,1870$.

Note on the Abnormities in the Neuration of the hind wings in Acrea Andromacha, p. 777, 778, 1870.

Derepiption of nome new species of Exotic Lepidoptera, p. 79-83, 1871.

Deseription of some new species and a new gemus of Pierine, with a monographic list of the species of Ixias (with plate), p. 250-254, 1871.

A Monograph of the Lepidoptera hitherto included in the genus Elymuias, p. 518-525, 1871 .

A Revision of the species formerly indurled in the senus Terias (P'icrine) P. 526--5+1, 1871 .

() a small collection of Butterflies from Angola, p. 721--725, 1871.

Description of a new genus of I Lepiscoptera allied to A patura, p. 725, 726, 1871.

A Synonymic list of the speries formerly inchuded in the genus Pieris, with all others described since the sub-division of the group by recent anthors, p. 26--67, 1872.

Revision of the genus Protogonius, p. 772--775, 1873.

List of the Dimmal I epridoptera of the South Sea Islanms, p. 27t--291, 1874.

list of the Buttertlies of Costa Rica, with description of new species, A. G. Butler \& H. Druce, p 330--370, 1874.

Deseription of 33 new or little known spreies of sphingide in the coll. of the B. M., p. 3--16, 1875 .

Description of four new species of Protogonins, 1. 35, 36, 1875.

Description of new species of Sphingicle, p. 238--261, 1875. 
Notice of a Memoir on the Heterocerons Lepidoptera of the family Sphingilæ, p. 269, 1875.

Description of several new species of Indian Heterocerous Lepidoptera, p. $391-393,1875$.

On a coll. of Buttertlies from the New Hebrides and Loyalty Islands, with description of now species, p. 610-619, 1875.

On a small coll. of Buttertlies from Fiji, p. 619, 620, 1875.

Deseription of several new species of Sphingidx, p. 621-62:3, 1875.

Revision of the Lepidopterous genus Teracolns, with deseription of new species, p. 126-165, 1876.

On a small coll. of Butterflies fiom the New Hebrides, p. 251-25.3, 1876.

Deseription of Iepicloptera fiom coll. of Lt. H. Roberts, p. 308-310, 1876.

Deseription of new species of Lepidoptera from New Guinea, with notice of a new genus, p. 765-768, 1876 .

Description of new species of Heteroeerous Lepidoptera in the coll. of the B. M., p. 168-170, 1877.

*Butl. Trans. Ent. Soc. Lonis.

Transations of the Entomologieal Soeiety of London, 1865-1876.

A Monograph of the genus Hestia; with a tabular view of the Danaidx, 1. 467-484, vol. V, 3d Series, 1865-1867.

Description of a new species of Hestina which mimies a Danais, p. 9, 10.

Remarks upon certain Catcrpillars, \&e., which are umpalatable to their enemies, p. $27-29$.

Description of new and little known forms of Dimmal I Lepidoptera, p. $273-276,1869$.

Descriptions of six new species of Callidryas, p. 9-12.

Notes on the species of Charaxes described in the "Reise der Novara," with descriptions of two new species, p. 119-122.

On Butterflies received by Mr. Swanzy from West Africa, p. 123, 124.

Deseriptions of some new Dimmal Lepidoptera, chiefly Hesperiidse, p. $485-520,1870$.

Deseriptions of a new genus and six new species of Pierine, p. 169, 173.

Descriptions of five new speries and a new genus of Dinrmal lepidoptera from Shanghai, p. 401-40:3, 1871.

On certain species of Pericopides in the collection of $\mathrm{Mr}$. Wr. Wr. Sannders, with a list of the described species belonging to that gromp, p. $49-58$.

Notes on rertain species of P'ericopides onitted in a list of species recently read before the Society, p. 255-257, 1872.

Contributions towards a knowledge of the Rhopalocera of Anstralia, p. $1-10$.

A list of the Lepidoptera referahle to the genus Hypa of Walker's I ist, with a description of new genera and species, p. 315-329, 1875.

*Catesby. Nat. Hist. Car.

Mark Catesby, of London. Bom 1679; died 1749. 
The Natural History of Carolina, Florida and the Bahama Islands, containing the figmres of Birds, Beasts, Fishes, Serpents, Insects and Plants, partieularly the Forest-trees, Shrubs and other Plants, not hith(rto deseribed, or very ineorrectly figured ly anthors. Together with their deseriptions in English and French. 'To which are added observations on the air, soil and water, with remarks upon Agriculture, Grain, Pulse, Roots, ete. 'To the whole of which is prefixed a new and correct Map of the Countries treated of. By Mark Catesby, F.R.S. London, W. Innys and R. Manby. Vol. I, 1731; vol. II, 1743. Appendix, 1748. In English and French.

Some of the figures of Lepidoptera are curious exaggerations. (others are quite good.

A second edition was issued in 17.54 , and a third in 1771 .

*Caulfield. Can. ENT.

Fronk. B. Caulfield, in Montreal, Canada.

In Canadian Entonologist are the following relating to Lepidoptera:

Pieris Rapale, p. 98, vol. IV, 1872.

Pieris Ralpale, p. 5!).

Rate Captures, 1). 155, vol. I, 187:3.

Notes on the Idarva of Lencania Psendargyria, Gnenee, J. 132, 133, vol. VI, 187 .

Notes on the Larva of Grapta Fannus, Edwards, p. 49, 50.

List of Dinmal Lepidoptera of the Island of Montral, P. Q., P. 86-90. Correspondence, p. 11?.

Totes ou the Larva of Catocala Ilia, Cram., p. 208, 209.

List of Sphingilac and '/yganide ocenring on the Island of Montreal, P. Q., p. 241, 242, vol. VII, 1875.

Adilenda to Lists of Dinrnal Lepidoptera, Sphingida and Kygænide occurring on the Island of Montreal, P. Q., p. 38, 39.

On Platysamia Columbia, Smith, p. 77-80; 95-98; vol. VIII, 1876.

Notes on Hyberuating Butterflies, p. 40.

List of Bombrcidie oceurring on the Island of Montreal, P. Q., P. 90-92, vol. IX, $1 \dot{8} 77$.

Notes on the Lanva of Samia Columbia, Smith, p. 41, 42, (with col. plate,) vol. X, 1878.

* Chenu. Pap. Diur.

Di. Jean Charles Chem. Born in Metz 1808.

Encvolopédie d'Histoine Naturelle, on traité complet de rette science d'apres les travaux des naturalistes les plus éminents de tous les pays et de toutes les époques Buffon, Daubenton, etr., etc., par le Dr. Chenu, Paris. Vol. of Paprillons, 1851-1858; vol. of Papillons Nocturnes, $\because 1857$.

Clerck. ICONes.

Charles Alexunder Clerck. Died July 22, 1765.

Jeones Insectorum rariorum atum nominibus corum trivialibus locisque C. Limaei Syst. Nat. allegatis. Holmiae, 1759-1764.

Text in Swedish and Latin.

Owing to this work having been privately distributed, and not sold, it has become exceedingly rare. Old Gottlob Wilhelm in his "Unterhaltungen," lns. Il, (1779), p. 16, relieves himself in this wise: "Fifty-five pages large 4to, a simple Register, 10- 
gether with a Dedication and I'refuce, compose the whole work, which at auction was sold for 600 Swedish dollars."

*Cran. Pap. Exót. I-IV.

Pierre Cramer.

l'apillons exotiques des trois parties du mondo l'Asie, l'Afrique et l'A merique rassemblés et décrits par Mr. Pierre Cramer, dessinés sur les originaux, gravés et enluminés sons sa direction. Amsteldam, Batalde; Utrecht, Birthelemy Wild.

Vol. I, 1779, plates 1-96; II, 1779, plates $97-192$; III, 1782, plates 193-288; IV, 1782 , plates 289-400. Text in Hollandish and French.

* Curtis. App. To Narr. Ross' 2n Voy.

John Curtic, in London, Naturalist and Artist.

Description, \&e, of the Insects bronght home by Commander James Clark Ross, 1835.

In the "Appendix to the Narrative of" a second voyage in search of a nortl-west passage, and of a residence in the Arctic Regions luring the years 1829-1833, ete, etc. London, A. W. Webster."

Lepidoptera are on pages $l \times v-l x x v$.

* Dalis. Vetensk. Acad. Handl.

.Johamn Wilhelm Dalman. Born at Hinseberg in Westmanland Nov. 4, 1787; died at Stockholm July 11, 1828. Professor at and Inspector of the Museum of the Academy.

Förök till svstematisk Uppställning af Sveriges Fjärilar.

In Kongl. Vetenskaps Academiens Handlingar, Stockholm, p. 48-101; $199-225,1816$.

*DBlat. Entom.

Edward Doubleday. Born at Epping, Eng., Oct. 9, 1810; died in London Dec. $14,18+9$.

The Entomologist, conducted by Edward Newman. London. I, 1841. Contains the following on $\mathrm{N}$. Am rican Lepidoptera :

Remarks on some North American Lepidoptera; inchuding a communication from T. W. Harris, p. 97-101.

Description of a new North American Polyommatus, p. 209-211.

*Deldy. List (or Cat. Liep.) B. M.

Tist of the Specimens of Lepirlopterons Insects in the Collection of the British Musemm. Lomdon. Part I, 18t4; II, 1847. Appendix, 1848.

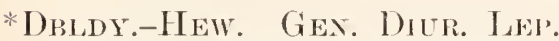

Erlward Inombleday and William (: Hewitson.

The Genera of Dinmal Lepidoptera, comprising their generic characters, a notice of their habits and transformations, and a catalogue of the species of ear.h yenus; illnstrated with 86 plates by W. C. Hewitson. London: Longman. Vol. I, 1846-1850; vol. II, 1850-1852.

With atlas of 79 magnificent coloured plates.

With the above was also associated Prof. J. O. Westwood in the completion of this work.

* Dodie. Can. Eint.

G. M. Dodge, in Glencoe, Nebraska.

In Canadian Entomologist are the following relative to Irepidoptera:

An Error Corrected, p. 198. 
A new Hesperian (H. Illinois), p. 217, 218, vol. IV, 1872.

Hesperia Illinois identieal with Hesp. Aconootns, Send., p. 60, vol. V, 1873.

Hesperia Pawnec, n. sp., p. 44, 45.

Notes on collecting Lepicloptera, p. 11t, 115.

Catocala Whitneyi, n. sp., p. 125, 126, vol. VI, 1875.

Catocala Nebriske, Dodge, p. 2, vol. VII, 1875.

* Don. Brit. Ins. (or Nat. Hist. Ins.).

Edward Donowan, Painter, in London. Died 1837.

The Natural History of British Inseets, explaining then in their several states, with the periods of their transformations, their food, eronomy, ete., together with the history of such minute Insects as require investigation by the microseope. Iondon: Rivington, 1813.

In 16 volumes; each year one vol.

*IOON. Ins. IND.

An Epitome of the Natural History of the Inseets of India, and the Islancls of Indian Seas. London, 1800-1803.

58 coloured plates.

*Don. NAT. REP.

The Naturalist's Repository, or monthly miscellany of exotic natural history, consisting of elegantly coloured plates with appropriate scientifie and general descriptions of the most eurions, scaree and beautiful productions of nature that have been recently discovered in various parts of the world; and more espeeially such novelties as from their extreme rarity remain entirely undeseribed, or which have not been duly noticed by any preeeding naturalist. The whole composed aceording to the latest improvements in the varions departments of the scienee, and forming collectively a truly valuable compendium of the most important discoveries of Quadrupeds, Birds, Fishes, Insects, Shells, marine productions, and every other interesting objeet of natural history, the produce of Foreign Climates. Printed for the author and W. Simpkin and R. Marshall. London.

Vol. I, 1823; II, 1824; III, 1825 ; IV, 1826 ; V, 1827.

Coloured plates.

*Dru. Ill. Ex. Ext.

Dru Drury, Goldsmith, of London. His collection, the largest of his time, containing 11,000 species, was sold at auction during his life, owing to pecuniary embarrassments, the result of his expenditures in pursuit of his beloved science.

Illustrations of Natural History, wherein are exhibited upwards of two hundred and forty figures of exotic inseets, according to their different genera; very few of whieh have hitherto been fignred by any anthor, being engraved and coloured from nature, with the greatest aecuracy and under the author's own inspeetion, on fifty copper plates; with a partienlar deseription of each insect, ete. London: White.

Vol. I, 1770 ; II, 1773; III. 1782.

The plates were engraved by Moses Harris, the best entomologieal artist of his day. The text is in English and French.

*Duncan. Nat. Lib. Ent, III.

James Duncen. 
The Natural History of British Butterflies. Illustraterl by thirty-six plates; with memoir and portrait of Werner. By . James Duncan, MI. IV. S., Edinburgh. 1835.

Being vol. III Entomology of "the Naturalist's Library, endurted hy" Sir William . Iardine, Bart." and vol. X of the whole serien.

*Duncan. Nat. Iaib. Hent, IV.

The Natural History of British Moths, Sphinxes, ate. Edinhurech, 18:36. With thirty-two col. plates, and portrait and memoir of Man!am Merian.

Vol. IV Ent of the Nat. Lib. and vol. XIV of the whole series.

*Iouncas. Nat. Lib. Ent. V.

The Natural History of Foreign Buttertlies, etr. Edinburgh, 1837. With thirty-three col. plates, and portrait and memoir of Lamarek.

Vol. V Ent. of the Nat. Lib., and rol. XVIII of the whole series:

*Duncan. Nat. Lib. Ext. VII.

The Natural History of Exotic Moths, ete. Eslinhurerh, 1841. With thirty-four col. plates, and portrait and menoir of Latreille.

Vol. VII of the Nat. Lib. and vol. XXXIII of the whole serier.

*Dup. TI-XI.

Philogene Auguste Joseph. Duponchel. Born 1774 in Valenciennes; died Jan. 10, 1846, in Paris.

Histoire Naturelle des Lépidoptères. on papillons de la France par M. I. B. Goklart; ouvrage basé sur la méthode de M. I atrulle, avee les tiuures de cliaque espèce dessinées et colorieses d'alpeès nature par M. P. Duménil. Paris, Mequignon-Marvis.

Vol. VI, 1826 ; VII, part 1, 1827, p. 2, 1829; VIII, p. 1, 1830, p. 2, 18.31; 1X, 1834 ; X, 1836; XI, 1838. Cat. Neth. to Hist. Nat., etc., 1841.

This is a continuation of Godard's "Histoire Naturelle iles Lepilopteres," etc., vol. $\mathrm{I}-\mathrm{V}, 1821-18^{2} 4$.

* Dur. ICON.

Iconographie et Histoire Naturelle des Chenilles, pour sorvir de eomplemént à l'Histoire Naturelle des Lópirloptères ou Papillons de France par P. A. J. Duponehel (et Guénée), Parris, 184 !).

* Due. Iep. Fr. Suppl. I-IT.

Histoire Naturelle des Tépidoptìres de: France, Supplément. Parris, Mérquighon-Marvis.

Vol. I, Diurnals, 50 coloured plates, 1832. Vol. II. Crepuscrulaires, 12 col. pil. 1835. Vol. III, Nocturnes, 50 col. pl. 1836. Vol. IV, Nocturnes, 2t col. pl. 1842.

* Enwde. (IV. H.) Proc. Ent. Soc. Phil. I-T'I.

William H. Edwards, of Coalburgh, W. Virginial.

Papers in the Proceedings of the Entomological Socioty of Philadehphia:

Notes upon Grapta Comma, Harris, and Grapta Faumu, Edwards, (Calbum of some authors, p. 18:-1st.

Descriptions of certain species of Diurnal Lepidoptera found within the United States, figured in Doublekly's Genera, but undeseribed, p. 2:21224, vol. I, 1861-1863.

Deseriptions of certain species of Dimmal Lepidoptera found within the limits of the United States and British America. No. 1, 1. 14-22; No. 2, p. 78-82; No. 3, p. 501-507. 
Description of certain Catocala, found within the United States, p. 508512, vol. II, 1863-1864.

Deseription of the female of Argymis Diana, p. 431-434.

Notes on the Argymides of California, p. 434-436, vol. III, 1864.

Descriptions of rertain species of Dimmal Lepidoptera found within the limits of the United States and British America. No. 4, p. 201-204.

Notes upon Papilio Asterias and Satmrnia Promethea, hermaphrodites, p. 390, vol. IV, 1865.

Deseription of a new species of Limenitis, 1) 148, vol. V, 186.5.

On certain North American species of Satyrus, p. 195-200.

Descriptions of rertain species of Dimmal Lepidoptera, etr., etc. No. 5, p. 200-208, vol. VI, 1866-1867.

*Edwds. (IV. H.) Trans. Am. Ent. Soc. I-V.

The following Papers in the Transactions of the American Entonologi(al Soeiety :

Descriptions of certain speries of Diurnal Lepidoptera found in the United States, p. 286-288, vol. I, 1867-1868.

Description of a new Hesperian, 1\% 122.

Notes on a remarkable variety of Papilio 'Turnus, and descriptions of two new species of Dinmal Lepidoptera, p. 207-210.

I) escriptions of certain speries of Diurnal Iepidoptera found in the United States, 1. 311-312.

Descriptions, ete., etc., ete., p. 369-376, vol. II, 1868-1869.

Notes on Graptas C Aureum and Interrogationis, Fab., p. 1-9.

Deseriptions of new species of Diturnal Lepidoptera, ete., ete., p. 10-22.

Descriptions, ete., etc., etc., p. 205-216.

Deseriptions of new Nortl American Diumal Lepidoptera, p. 189-196.

Descriptions of new species of 'Torth American Lepictoptera, p. 266-277, vol. III, 1870-1871.

Descriptions of new speeies of Diumal Lepirloptera, ete., p. 61-70.

Descriptions, etc., etc., etc., p. 343-348, vol. IV, 1872-1873.

Deseriptions of new species of Dimmal Lepidoptera, ete., p. 13-19.

Descriptions, etc., etc., ete., p. 10:3-111.

Description of a new species of Catocala from Arizona, p. 112.

Deseriptions of new species of Diumal Lepidoptera found within the United States and British North America, p. 202-208.

New species of Diumal Lepidoptera, p. 289-292, vol. V, 1874-1876.

*Edwds. (II. H.) Proc. Acad. TAt. Sc. P'hil.

Proceedings of the Academy of Natural Sciences of Philarlelphia. Vols. I-XX III, 1841-1876.

In the above are the following papers:

Descriptions of certain species of Diurnal Lepidoptera fommd within the limits of the United States and British America, p. 160-164, vol. XIII, 1861 ; continued p. 54-58 and 221-226, vol. XIV, 1862.

*Eowds. (W. H.) Butr. N. Aм. I, II.

'The Butterflies of North America, by Wm. H. Erwards, member of the American Entomological Society. Philadelphia: The American Entomological Society, vol. I, 1868-1872; vol. II, 1874-1878. 
*EDWDS. (II. H.) Sirn. N. AM. I.eP.

Synopsis of North American Butterflies. By W. H. Eelwards, member of the American Entomological Soriety. Philadelphia: The Ancriaun Entomological Society, 1872.

Text, 51 pages. Afterwards issued with vol. I of the Butlerflies of $\mathrm{N}$. America. *Enwds. (IV. H.) Cax. ENT.

In the Canadian Entomologist are the following:

Papilio Machaon in British America, 1. 22.

Habits of Melitiea Phaton, p. 59, 60.

Melita: Phaton, p. 80.

Isarval of Melitaea Phicton, p. 102, vol. I, 1869.

Melitrea Phaton, Cram., p. 36.

Rearing Egess of Butterflics, 1. 115.

Rearing Buttertlies from the Fgo, p. 133.

Foorl-plant of Darapsa Versicolor, p. 134.

Rearing Butterflier from the Ega, 1. 162-164.

Colias Philorlice, p. 179, vol. II, $1869-1870$.

Rearing Buttertlies from the Egg, p. 70, vol. III, 1871.

Notes on some Butterflies and their Iarva, p. 238, 239, vol. IV, 1872.

Some remarks on changes in names of certain Butterflies, p. 8-10.

Some remarks on Entomological Nomenclature, p. 21-36.

On the identity of Grapta Dryas with Comma, p. 184.

Notes on the early stages of some of onr Buttertlies, p. 223-225, vol. V, 1873.

Larva of P. Brevicauda, p. 20.

Notes on the Larre of Arormmis Cybele, Aphrodite and Diana, p. 121125.

Grapta Comma and Dryas, 1. 157, vol. VI, 1874.

Some notes on I rycana Psendargiolus, p. 81-83.

Notes on Butterflies, p. 150, 151 .

Argymis Mrrina and its alleged abnormal peculiarities, p. 189-195.

An Alstract of Dr. Ang. Weismann's Paper on "The Seasonal-Dinorphism of Buttertlies." 'To which is Appended a Statement of Some Experiments marle upon Papilio Ajax, p. 228-240, vol. VII, 1875.

Notes on Entomological Nomenclature. Part I, p. 41-52; Part II, p. 81-94; Part II concluded, p. 113-119.

Notes on Preparatory Stages of Dameis Archippus, p. 119, 120.

No. of Broods of Danais Arehippus, p. 148.

Correspondence, p. 160.

Farther notes 11pon Argynuis Myrina, p. 161-163.

The Preparatory Stages of Lycaena Comyntas, 1. 202--205, vol. I'III, 1876.

History of Phyciodes Tharos, a Polrmorphic Butterfly, p. 1--10.

Correspondence, p. 17.

Description of a new species of Pamphila from Coloraclo, p. 29, 30.

Supplementary Notes upon Argynnis Myrina, with mention of the species Bellona, Atlantis and Cybele, 1. 34--36. 
History of Plyeiodes Tharos, a polymorphic Butterfly, continued from p. 10 , p. $51--58$.

Deseription of a new species of Hesperian from Texas, p. 58, 59.

Totes on Limenitis Proserpina and Arthemis, p. 114.

Correspondence, p. 120.

On the Preparatory Stages of Satyrus Nephele, p. 141--143.

Description of the Preparatory Stages of Phycioder Harricii, Sondder, p. $165--168$.

Buttertlics on Martha's Vinevard, 1) 178.

Description of new speries of Buttertlies bolonging to the N. American Fituma, 1. 189--192.

An acennt of some farther experinents upon the effect of cohl in change ing the form of certain Butterflier, p. 20:3--206.

Deseription of the Preparatory Stages of Neonympla Sosylums, p. 229-$2: 31$, vol. [X, 1877.

Totes on Ifyachal Psemlarginlus and its Lanral Mistory, ]. 1--11, rol. X, 1878.

* Edowds. (W. H.) Haydex's Rer. Exp. Montana.

I ist of Species of Butterflies rollected hy Camplell Cirrington and Willian B. Logan, of the Expedition in 1871.

Being pages 466,467 , in the "Preliminary Report of the IT. S. Geon. Survey of Montana and portions of adjacent Territories, being a tifth Annual Report of Progress, by F. V. Harden, Washington, 1872."

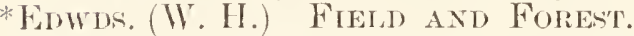

Ficld and Forest, a monthly joumal devoted to the Natmal Sejeners. Charles R. Dorlue, Editor, líahington.

In vol. III of the above are the following:

Lepidopterat of the Big Hos'n Mountains, p. 48, Sept., 1877.

1)erriptions of new speeien of Dimmal Lepidoptera fomd in Nortl Ameri(ä, p. 86j--8.9, Nov., 1877.

Discriptions, etr., cotce, etc., p. 101--10i), Dec., 1877.

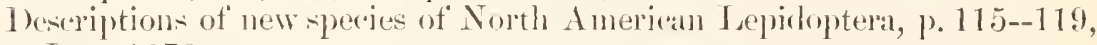
Jill., 1878.

Doscriptions of new species of North Amcrian Lepidopteral (Pyrgus Tanthus, Aryynnis Electa), p. 142--144, March, 1878.

* Howns. (Hy.) Proc. Cal. ACan.

Henry EAlumels, Tragedian. Bom in Fngland; now living in san Francisco, California.

Parditic Coats Lepidoptera.

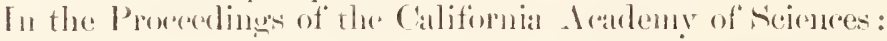

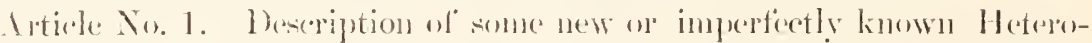
("2la, 1). 109, Duly 7, 1873.

No. 2. On the Thansformation of the I)immal Jepidoptera of (aliformia and the adjacont Districts, p. 161. Oct. 6; 187:?.

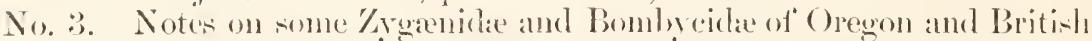
Colmmbia ; with derojptions of new species, p. 183, Nov. 3, 1873.

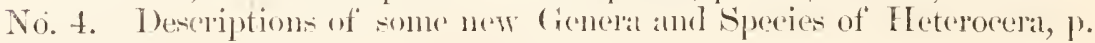
$264, \mathrm{~F}(\mathrm{~h}, 17,187 \mathrm{t}$.

No. 5. (On the Earlice Stages of some species of Dinmal Ixpialopteral, 1. :325, Jnly $6,1874$. 
No. 6. Notes on the Earlice Stages of Ctenucha Multifaria, Boiscluval, p. 344, July 20, 1874.

No. 7. Deseriptions of some New Species of Heterocera, p. 365, Sept. 7, 1874.

No. 8. On the Transformations of some Species of Heteroeera not previonsly described, p. 367, Sept. 7, 1874 .

No. 9. "Description of a Now Species of 'Thrris, from the Collection of' Dr. Hermann Behr, p. 413, Nor. 2, 1874.

No. 10. On a New Species of Papilio from California, p. 423, Dec. 7, 1874. Vol. V.

No. 11. List of the Sphingida of California and adjacent Districts, with Descriptions of New Species, p. 86, Apr. 19, 1875.

No. 12. On some New Species of Noctuidre, p. 132, May 17, 1875.

No. 13. On the Earlier Stages of V'anessa Californica, p. 146, June 7, 1875.

No. 14. Notes on the genus Catocalat, with Descriptions of New Speeies, p. 207, July $19,1875$.

No. 15. Description of a New Species of Catocala firom San Diego, p. 185, Oct. 18, 1875. Tol. VI.

No. 16. Totes on the Thansformations of some Species of Lepidoptera, not hitherto recorded, 1. 19, Apr. 1!), 1876.

No. 17. On the Trunsformations of Colias (Neganostoma Reak.) Eurydice, Bdv. p. 60, Jume 5, 1876.

No. 18. Description of a New Species of Heterocampa, (Larva and Imago), 1. 121, ()et. 16, 1876 .

No. 19. Notes on a Singular Tariety of the Larva of Malesidota Agassizii Packd. p. 128, Noy. 3, 1876.

No. 20. Notes on the Case-Bearing Moths. (Psvchiclae, with notices of Californian Species, 1. 140, Noу. 20, 1876.

No. 21. Description of two New species of the genus Theela, p. 143, Dec. 1,1876 .

No. 22. Notes on some Diurual Lepiloptera, with descriptions of New Varieties, p. 163, Пес. 18, 1876.

No. 23. Deseription of a New Species of Catocala, and a Lint of the Californian Sperimens of the yenus known to ocenr in collections, Jan. $15,187 \overline{7}$.

No. 24. Notes on the genu- Colials, with descriptions of some apparently new forms, Feb. 5, 1877.

No. 25. Description of a New Speries of Plusia from Arizona, Mareh 5, 1877. Vol. VII.

Of these last three papers the advance sheets (author's proofs) have so far only been issued.

*Emmons. Agr. Nat. Hist. N. Y. Y.

Ebenezer Emmons, Doctor of Medicine, in Albany.

The Natural History of New York. Agriculture of New York, comprising an accomnt of the clasification, composition, and distribution of the Soils and Rocks and of the climate and agricultural productions of the State, toguther with descriptions of the more common and injurions insects. Albany, Van Benthuysen, 1854.

Vol. V, p. 198-256, and plates 35-47 relate to the Insects.

The plates are mostly execrably drawn and as badly coloured, and the text abounds in errors of all sorts. 
* Enc. Meth. Ins. Plates.

Tableau Encyclopedique et Methodique des trois Règnes de la Nature. Dix-huitieme partie Inseetes. A Paris, Chez Henri Agasse, Imprimeur-Libraire, rue des Poitevins. L'an V. de la Republiqne Frangaise. 1797.

*Engr. Pap. I'Eur.

Marie Dominique Joseph Engramelle. Monk of the order of St. Augustine. Born March 24, 1727, at Nedonchel in Artois; died in Paris 1780.

Papillons d'Europe, peints d'apres nature par M. Erust, gravés et colories sous sa direction. Les Chenilles, Chrisalisles et Papillons de Jour. Décrits par Engramelle Relig. Augtin. Q. S. G. Paris.

Vol. I, 1779; II, 1780; III, 1782 ; IV , 1785; V, 1786; VI, 1788; VII, $1790 ;$ VIII, 1792.

Esch. Kotzeb. Rerse.

Johann Friederich Eschholtz, Doctor of Medicine and Professor of 'Loology. Born in Dorpat, Russia, Nor. 1, 1793; died in same place May 19, 1831. He made the voyage around the world twice with Krusenstern and Kotzebue.

Beschreibung exotischer Schmetterlinge with 6 plates.

In Kotzebue's Reise $n 1 n$ die Welt. IT'innar, 1830.

* Ess. A ts. Schmett.

Eugene Joham C'hristoph Esper, Profeswor in Erlangen. Died July 27, 1810.

Die Ausländischen orler die aus-erhall, Europa zur \%eit in den übrigen Weltheilen vorgefundenen sihmetterlinge in Abbildungen nardh der natur mit Beschroibungen. I, Erlangen, Walther, 1785--1798.

EVERsM. ENT. Russ. Y.

Edeard Eversmann, Professor of Zoology in Kasan. Died in 1861.

Nymplalides, in vol. I Entomographia imperii russei; Genera Insectorum systemation exponita of analysi iromographica instructal. Noscon, 18.51.

* Fabr. Gex. Ins.

Johemn Christian Fubricins, the pupil of Linnseus, counsellor to the King of Denmark, Professor in Kiel. Born Jan. 7, 1745, in Tondern in Schleswig; died March 3, 1808, at Copenhagen.

Genera Insectorum eorumgue characteres naturales secundum numerum, figuram, situm et proportionem omninm partimm oris adjecta mantisa specierum nuper retectarmn. Chilonii, Bartsch. ?1776.

*Fabr. SYst. ENT.

Srstema Entomologix sistens Insectorum elasses, ordines, genera, species, adjectis svnonynis, locis, descriptionibus, observationibus. Flensburgi et Lipsia, 1775.

In Latin; 1 vol., pages 892

*FABR. SP. INS. II.

Species Insectorum exhibentes cortum differentias specificas, synonyma anctorum, loca natalia, metamorphosin adjectis observationibus, deseriptionibus. Tom. II, IIamburgi et Kilonii, 1781.

Latin. Pages 494. (With Appendix p. 510 )

*Fabr. Mant. INs. II.

Mantisca Insectorum sistens species nuper detectas adjectis syonymis, observationilus, descriptionibus, emendationibus. Tom. II, Hafnie, 1787 .

Latin. Pages 38:. 
*Fabr. ENT. SYst. III.

Entomologia Systematica emendata et ancta, secundum classes, ordines, genera, species, adjectis synonymis, locis, observationibus, deseriptionibus. Tom. III, pars 1 et II. Hafinise, 1793--1794.

Part I, 1793, pages 487; Part II, 1794, pages 349. Latin.

*Fabr. Ent. Sist. Suppl.

Supplementum Entomologiae systematicate. Hatiniae, Proft et Storch, 1798.

Pages 572. (Index Alphabeticus, p. 5\%.) Latin.

FABR. IIL. MIAG.

Systema glossatorum.

In Illiger's Magazin für Insectenkunde, p. 277--296, vol. VI, 1807.

* Fabr. (Otto). Faun. Gronen.

Otto Fubricius, Missionary in Frederikshaab, Greenland, from 1768 to 1774. Born in Rudkjoebing Mareh 6, 1744; died May 20, 1822.

Fanna Groenlandica, systematice sistens animalia groenlandiae oceidentalis hactenus indagata, quoad nomen specificum, triviale, vernaculumque, synonyma anctorm plurium, descriptionem, loeum, victum, generationem, mores, usum, capturamque singuli ; prout detegendi oceasio fit, maximaque parte sceundum proprias observationes. Hafniae et Iipsiale, Rothe, 1780.

lnsects, pages 184-221.

*Feld. Reise Nov. Lep.

Di. Cajetun Felder, Vice-Presilent Zoological-Botanical Society of Vienna, Lord Mayor of Vienua, etc., etc., ete.

Dr. Rudolf Felder, son of the above, dien in 1871, in his 28th year.

Reise der Oesterreichivehen Fregatte Novana un die Erde in den Jahren 1857, 1858, 185!) unter den hefehlen des Commodore B. von Wüllerstorf-Urbair. '/oologischer 'Theil zweiter Band. zweite ahtheilung: Lepidoptera vim Dr. Cajotan und Rudolf Feler. Rhopalocera, Wien. $186+-1867$.

Lepidoptera von Dr. Cajetan Felder, Dr. Rudulf Felder and Alois F. Rogenhofer. Atlas von 140 Tafeln, mit 2,500 Abbildungen Wien. $186+$ - Juli 1875.

Text in German and Latin. 549 pages. Plates of the most sumptnous description possible, and comprise 2,500 coloured figures of all families and genera of Lepidoptera.

* Fetid. Verh. Kool, Bót. Gess.

Verhandlungen der Káriserlichen-Königlichen, Koologisches-Botanischen Gesellschaft in Wien. Heransgegehen von der (tesellschaft. Vol. IXXVI, 1852-1876.

Contains the following:

Verzeichniss der Macrolepidopteren der Novara Expedition p. 473-496, vol. XII, 1862.

Species Lepidopterorum hucnsque descriptae veliconibus Expressae in Seriam Systematicum digestae, (C. et R. Felder,) p. 28.9-378, vol. XIV, 1864.

Diagnosen neuer von E. Baron v. Ransonnet in vorder-Indien gresammelter Lepidopteren (Dr. R. Felder), p. 281-286, vol. X V III, 1868.

Diagnosen neuer von dem K. K. Oberlieutenant H. v. Hedemann, gesammelter Lepidopteren, p. 465-480, vol. XIX, 1869. 
* Felid. Wien. Ext. Mos.

Wiener Entomologische Monatschritt. Verantwortliche Redacteme: Julins Lerlerer und Ludwig Miller. . Vien. vol. I, 1857; II, 1858; III, 1859; IV, $1860 ; \mathrm{V}, 1861 ; \mathrm{VI}, 1862$; VII, 1863;VIII, 1864 .

The following papers of Drs. C. and R. Felfler are contained in the above work:

Lepidopterologische Frigmente von C : u. R. Felder. No. 1, p. 178186 ; No. 2, p. 26:3-27.3; No. 3, p. 321-328; No. 4, 1. 390-405, vol. I [I, 1859 .

No. 5, p. 97-112; No. 6, p. 225-251.

Lepidoptera nova in paeninsula Malayiua collecta diagnosibus instructa a C.\& R. Felder. Series prima, p. 39t-102, vol. IV, 1860.

Lepidoptera nova Columbiae diagmosibus collustrata a C. et R. Felder. Series prima, p. 72-87. Series scomda, p. 97-111.

Lepidopteria nosa a Dre. Carolo Semper in insulis Philippinis rollecta diagnosihus exposuerunt C. ct R. Felder. Series prima, p. 297-306, vol. $Y^{\top}, 1861$.

Observationes de Isepidopteris nonnullis Chinae centralis et .Japoniae, communicatale a C. et R. Felder, 1). 22-32; 33-40.

Specimen faunac lepidopterologiae riparum fluminis negro superioris in Brazilia septentrionali anetoribus C: et R. Felder, p. $65-80 ; 109-$ $126 ; 175-192 ; 229-2.35$.

Lepidoptera nova a Dre. Carolo Semper etc, etc, ete. Series secunda, 1. $282-294$.

Lepidoptera nova Columbine ete. Series tertia, p. 409-427, vol. VI, 1862.

Lepidoptera nova a Ire. Carolo Semper etc, etc, etc. Series tertia, p. 105-127, vol. VII, 1863.

Feld, (Dr. Cajetax). Neu. Lep.

Ein Neues Lepidopteron aus der Familie der Nymphaliden und seine Stellung im matürlichen Systeme, begründet ans der Synopse der übrigen Gattungen. Jena, Frommann, 1861.

Printed separately out of the Act. Acad. Leopold. Carol. V. 28, 1861.

*Fisher. Proc. Acad. Nat. Sc. Phil.

James C. Fisher, Doctor of Merlicine.

Proceedings of the Academy of Natmal Sciences of Philadelphia.

Description of a new speeies of Arevmis, p. 179, 180, t. 2, v. X, 1858 : p. 352 , v. XI, 1859 .

*Fitch. Rep. N. I. State IGr. Soc.

Asa Fitch, M. D., formerly Entomologist of the New York State Agricultural Society.

First Report on the Noxions, Bencticial and other insects of the State of New York, made to the State Agricultural Society, pursuant to an annual appropriation for this purpose from the Legislature of the State. P. 705-880, in vol. XIV of the Transarctions of the New York State Agricultural Society, 1854 .

Second Report, etc., p. 409-559 in Trans. vol. XV, 1855. 
Third Report, etc., p. 315-490 in Trans. vol. XVI, 1856.

Fourth Report, ete., p. 687-753 in Trans. vol. X VII, 1857.

Fifth Report, etc., 1). 781-854 in Trans. vol. X VIII, 1858.

An address on our most pernicious insects p. 587-598 in Trans. vol. XIX, 1859.

Sixth Report, ete, p. 745-868 in Trans. vol. XX, 1860.

Seventh Report, etc., p. 814-859, in Trans. vol. XXI, 1861.

Eighth Report, etc., 1. 657-691 in Trans. vol. XXII, 1862.

Ninth Report, etc., p. 778-823 in Trans. vol. XXIII, 1863.

Tentl, Report, ete, p. 433-461 in Trans. vol. XXIV, 1864.

Eleventh Report, etc., p. 487-543 in Trans. vol. XXVI, 1866.

Twelfth Report, etc., p. 889-932 in Trans. vol. XXVII, 1867.

Thirteentl Report, etc., p. $495--566$ in Trans. vol. XXIX, 1869.

Fourteenth Report, ete., p. 355--381 in Trans. vol. XXX, 187 ().

Reprints of some of the ahove appeared at intervals as follows:

First and Second Reports on the Noxions, Beneficial and other insects of the Stite of New York, etc. Mlbany: Yan Benthuysen, 1856, p. 1336.

Thirel, Fourtl and Fifth Reports, ete., 1859, p. 1-74.

Sixth, Seventh, Eighth and Ninth Reports, etc., 1865, p. 1-259.

*Foure. Ent. Paris.

Antoine Francois Fourcroy, Doctor of Medicine and Professor of Chemistry. Born in Paris 1775; died Dec. 16, 1809, in Paris.

Entomologia Parisiensis, sive catalogus Insectorum, quæ in Agro Parisiensi reperiuntur; secundum methodum Geoffreanam in sectiones, genera \& speeies distributus: cui addita sunt nomina trivialia \& fere trecentre nova species. Paris, 1785.

In two vols.

* Freyer. Neue. Beit. I-VII.

C. F. Freyer, in Augsburg.

Nenere Beiträge zur Schmetterlingskunde mit Abbildungen nach der natur. Augsburg. Vol. I, 1833; II, 1836 ; III, 1839; IV, 1842 ; V, 1845; VI, 1852 ; VII, 1858.

*Gay, Faun. Chil.

See Blanch. Gay, Faun. Cliil.

*Glov. U. S. Agr. Rep.

Prof. Townend Glover, for many years previous to 1878 Entomologist to the Department of Agriculture at Washington.

In the varions Reports of the United States Department of Agriculture are the following relative to Lepidoptera :

Insects injurious and beneficial to vegretation, p. 59-89, (8 plates,) 1854 .

Insects frequenting the cotton plant, p. 6t-105.

Insects found in cotton fields not injurious to erops, p. 105-108.

Insects beneficial to cotton, p. 108-115.

Insects injurious and beneficial to the Orange tree, p. 115-119.

Accidents and diseases of cotton plants, p. 230, 1855.

Investigations on the insects and diseases affecting the cotton plant, p. $128-157,1857$.

Insects frequenting the Orange trees of Florida, p. 256-271.

Insects injurious to the cotton plant, p. 271-272, 1858. 
The Hang Worm, p. 551-554, 1859.

Report of the Entomologist, p. 561-576, 1863.

Report of the Entomologist, p. 540-564, 1864.

Report of the Entomologist, p. 33-45.

Entomological Exhibition in Paris, p. 88-102, 1865.

Report of the Entomologist, p. 27-45, 1866.

Report of the Entomologist, p. 58-76, 1867.

Report of the Entomologist, p. 60-6t, 1869.

Report of the Entomologist, p. 65-91, 1870.

Report of the Entomologist, p. 69-88, 1871.

Report of the Entomologist, 1. 112-138, 1872.

Reprort of the Entomologist, p. 152-169, 1873.

Reprort of the Entomologist, p. 122-146, 1874.

Report of the Entomologist, p. 114-140, 1875.

Report of the Entomologist, p. 17-46, 1876.

*GLOV. IND.

Manuseript Notes from my Journal or Entomological Index to names, \&c., in Agricultural Reports. With list of Vegetable and Animal substances injured or destroyed by Insects, \&e. Written by Townend Glover. Transferred to and printed from stone by F. C. Entwisle. Washington, 1877.

Only fifty copies printed.

*Girel. Sirst. NAT. I.

Johann Friederich Gmelin, born in Tubigen Aug. 8, 1748; died in Gottingen Nov. 1, 1804.

Caroli a Limné Systema Naturae. Ed. XIII, Lipsiate 1788.

*Gs. ANx. Soc. ENT, Fr.

A. Guenee.

Annales de la société Entomologiqne de France ser. IV, rol. IV, 1864. Note sur Quelques especes din genre Colias, p. 198-200. *GODT, I-V.

Jean Baptiste Godart (or Godard). Born at Origny Sainte-Benoit, Picardy, Nov. 2.5, 1775 ; died July 27, 18.25.

Histoire Naturelle des Lépidloptères on papillons de Franec, decrits par M. Godart, peints par M. C. Vauthier. Paris, Crevot, vol. I Diumes, 1821 ; II, Diurnes, 1822 ; III, Crepuseulaires, 1821 ; IV, Nocturnes, $1822 ; \mathrm{V}$, Tocturnes, 1824.

Contimed by Duponchel. See "Dup. VI-XI."

*GodT. ENc. Метн. IX.

Encyclopédie Méthodique. Histoire Naturelle. Entomologie, on Histoire Naturelle des Crustaces, des Arachnides et des Insectes, par. M. Latreille. 'Tome Nenvième, par M. Latreille, de l'Académie des Sciences, et M. Godart, ancien Proviseur du Işcée de Bonn, ete. A Paris, 1819. 
*Godt. Exc. Meth. IX Sur.

Encyelepédie Méthodique. Supplement. 1823.

Being the last pages, $804-828$, of the above vol. IX of the Euc. Meth.

*GoEZE. ENT. BEYT. I-III.

Johann August Ephraim Goeze, Pastor of the St. Blasius Church in Quedlinburg. Born in Aschersleben May 28, 1731; died in Berlin June 27, 1793.

Entomologisehe Beitrïge zu des Ritter Linné Zwölften Ansgabe des Natursystems. Leipzig, bey Weidmann, Erben und Reieh.

- Vol. I, 1777 ; II, 1778 ; III, part 1, 1779 ; p. 2, 1780; p. 3, 1781 ; p. 4, 1783.

* Gosse, CAN, NaT.

Philip Henry Gosse, born in Worcester Apr. 6, 1810.

The Canadian Naturalist, a series of conversations on the Natural History of Lower Canada.

"Every kingdom, every province should have its own monographer." Gilbert White. London: John Van Voorst, 1840.

* Gosse. Newm. Ent.

List of Butterflies taken at Compton in Lower Canada. Pages 137-139 of Newman's Entomologist. 1841. (The Entomologist, conducted by Edward Newman. London, John Van Voorst, 1840-1842.)

*Gosse. I nN, Nat, Hist, Ser, 2.

On the Insects of Iamaica.

Is contained in the following pages of-

The Annals and Magazine of Natural History, including Zoology, Botany and Geology (being a continuation of the 'Magazine of' Botany and Zoology, and of Loudon and Charlesworth's 'Magazine of Natural History,') condueted by Sir W. Jardine (and others). London, R. \& J. E. Taylor, 1848.

2d Series, vol. I, p. 109-115; 197-202; 268-270; 349-352; vol. II, p. $109-114 ; 176-181 ; 268-273$.

Lepidoptera on p. 111-114; 176-181; 268-273. The previous pages are on Coleoptera.

On the last cited page it is stated that the article is "to be continued," but the continuation never appear $d$.

* Gray, Griff, An. King.

Georye Robert Gray, born July 8, 1808 ; Sen. Assistant in the Zoological Department of the British Museum.

Notices of new general and species (of Inserts).

Contained in

The Animal Kingdom arranged in conformity with its organization, by the Baron Cuvier. The Class Insecta, with Supplementary Additions by Edward Griffith, Edward Pidgeon, and notices of new genera by George Gray. Whittaker, Treacher and Co., London, 1832.

Lepidoptera are on p. 577-680, plates 1-137, vol. II Insecta (vol. $\mathrm{X} Y$ ' of whole work.)

*Groxor. 'ZOOPH.

Lorenz Theodore Gronor, born 1730; died 1778. Municipal officer in Leyden.

Zoophylacium Gronovianum, Exhibens Animalia quadrupeda, Amphibia, Pisces, Insecta, Vermes, Mollusca. Testacea, et Zoophyta, Quæ in 
Museo suo adservarit, exanini subjecit, systematice disposuit atque descripsit Laur. Theod. Gronovius, ete. Additis rarissimorum objectorum iconismis. Part I, 1763.

'Loophylacii Gronoviani fasciculus secundus exhibens enumerationem Insectornm, quae in Museo suo arlservat, examini subjecit, systematice disposuit atque descripsit Lamr. 'Theod. Gronovius, ete. Lugduni Batarolum, Haak, par II, 1764.

Insects on p. 141-236. Lepidoptera p. 187-212, part II.

Zooph. Gron., ete. Vermes, Mullusca, etc, etc., part III, 1781.

*Grote. Ans. N. Y. Lyc. Nat. Hist.

Augustus Radeliffe Grote, in Buffalo, New York.

Anmals of the New York Lyceum of Natural History :

Remarks on the Sphingidre of Cuba and description of a new species of Ambulyx from Brazil, p. 195-207, vol. VIII, 1867.

On a new species of Anarta and on an allied genus, with a note on the genus Adita, p. 107-109.

Note on a name in Entomology proposed by the late Coleman 'Townsend Roluinson, p. 128, 129, vol. XT, 1875.

*Gróte. Acad. Nat. Sici. Phil.

Proceedings of the Academy of Natural Sciences of Philadelphia:

New species North American Noctuide, p. 197-214, vol. XXVJ, 1874. Continued p. 418-436, vol. XXVII, 1875.

*Grote. Bufr. Butl. I-III. (Or Bull. Buff: Soc. I-III.)

Bulletin of the Buffalo Society of Natural Sciences, Buffalo, (New York). Vol. I, 187:3-1874; II, 1874-1875; III, 1875-1877.

The following papers on Lepidoptera, by A. R. Grote, are in the above:

Deseription of new North American Moths, p. 1-16.

Catalogne of the Sphingidae of North Ameriea, p. 17--28.

Catalogue of the Kyaenidae of North Ameriar, p. 29-36.

Conchisions drawn from a study of the genera Hypena and Herminia, 1). $37-10$.

Contrilutions to a knowledge of North Ameriean Moths, p. 73-94.

A Study of North American Noctuidae, 1. 95-128.

Descripitions of Toctuidae principally from California, p. 129-155.

On the North Ancrican Creometridace in the Collection of the British Museum, P. 156-160.

Kleiner Beitrag zm Kenntnis einiger Nordamerikanischer Lepidoptera, p. $168-17 t$.

Description of the genera Argrophyes and Condylolomia and of a spe(aies of Deuterollyta, p. 175-177.

Deseription of a Butterfly new to the Lower Lake Region, p. 178-179.

Deseription of three genera of Noctuidae, p. 180-182.

On IIallengren's "Lepidoptera Sumulinaviae Heterocera disposita et descripta." p. $183,181$.

On the Butterflies of Anticosti, p. 185.

On Eight Species of Noctuidae, \%. 190--194.

Determination of Brazilian Sphingidate collected by Mr. Charles Linden, 1. 279--281, vol. I, 1873--1874.

Iist of the Noetuidae of North America, 1. 1--77. 
On the species of Helicopis inhabiting the Valley of the Amazon, p. $106--108$.

Additions to the "List of North American Noctuidae," p. 122--126.

New Noctur, p. 143, 144.

Notes on American Lepidoptera with Descriptions of Twenty-one New Species, p. $145--163$.

Determination of the Species of Moths Figured in the "Natural History of New York," p. 164--168.

On Allied Species of Noctuidae inlabiting Europe and North America, p. 193--200.

Supplement to the List of North American Noctuidae, p. 209--223.

Clieck List of North American Sphinges, p. 224--228.

North American Pyralides, p. 229--232.

On the grenns Agrotis with Additions to the "List of" North American Noctuidae," p. 301--312.

On Allied Species of Noctuidat inhabiting Europe and North America, p. 313, 314, vol. II, 1874--1875.

On Noctuidae from the Pacific Coast of North America, p. 77--87.

On Certain Species of Black-winged Catocala, p. 187--188, vol. III, $1875-187 \pi$.

*Grote. Can. Ent.

Canalian Entomologist contains the following:

Notice of the Species of Drepranodes, p. 114, 115.

On Theela Inorata, G. \& $R$., and Thecla Falacer, Godt., p. 165--168, vol. II, 1870.

Descriptions of Lepidoptera from A labama, p. 101--105; 124--126 ; 181.

Description of a species of Agrotis from Canada, p. 192, 193, vol. III, 1871.

On a New Checkered Hesperia, p. 69, 70.

Descriptions of Lepidoptera from Alabama, p. 101, 102.

Deseriptions of Gelechia Aduncella and Gelechia Lahmadorica, p. 125, 126.

Descriptions of 'Two Species of Anaphora, p. 136--138.

List of the North Amerian Species of Catocala, p. 164--167.

Cirrhophanus Triangulifer, nov. gen. et sp., p. 187.

On Mr. Sendder's Systematic Revision of some of the Ameriean Butterflies, p. 214--216.

Note on Hesperia Communis, p. 2200, vol. IV, 1872.

On Mr. Sendder's Systematic Rerision of some of the American ButterHies, p. 62,$63 ; 143--145$.

Notes on Cosmia Orina, Guenee, p. 205, 206.

Description of New Deltoids, p. 225--228.

Synonymical note on Adelocephala Albolineata, p. 228.

Note on Catocala Walshii, Edwards, p. 233, 234, vol. V, 1873.

Notes on Noctuidse, p. 13--16.

On Mr. Couper's collections of Lepidoptera made on Anticosti Island in 1873, p. $69--72$.

New Canadian Nocture, p. 115--118.

On two species of Agrotis, allied to A. Triangulum, p. 131, 132.

Preliminary Catalogue of the Noctuide of California, p. 154--157. 
Note on the "List" of 1868, p. $170,171$.

Correspondence, p. 178, 179.

Synonymical Note, p. 180.

Correspondence, p. 199.

Preliminary Catalogue of the Noctuidæ of California, p. 214--217, vol. VI, 1874 .

Note on Catocala Nebraskæ, p. 2, 3.

Colias Philodice, p. 18.

Preliminary List of the Noctuidre of California, p. 25--28; 44-49.

Correspondence, p. 57--60.

Preliminary List of the Noctuicle of California, p. 67--72.

On three New Speeies of Noetuidie, p. 8:3--85.

Preliminary List of the Noctuide of California, p. 101--104.

On Genera in the Moths, p. 113--115.

Correspondence, p. 138, 139.

Deseription of a New Californian Agrotis, p. 144.

Deseription of Pachnobia Orilliana, p, 154, 155.

The effect of the Glacial Epoch upon the distribution of Insects in North America, p. 164--167.

On a Canadian Speeies of Agrotis, p. 172, 173.

On Certain Speeies of Moth from Florida, p. 173--176.

On Catoeala Verrilliana, with notes on Catoeala Relicta, p. 185, 186.

On New Species of Agrotis, p. 186--188.

On a new Cinadian Lithophane and Seopelosoma, p. 188, 189.

On Datana Perspiena, G. \&. R., p. 195, 196.

Notes on Certain Species of Arctil, p. 196, 197.

On a New Euchaetes, p. 200.

On North American Species of Phuia, p. 202--205.

On Scopelosoma and allied genera, 1. 205--207.

Agrotis Rubifera, 11. s., P. 207.

Lepidopterological Observations, 1. 221--226, vol. VII, 1875.

On Choephora and allied genera, p. 17, 18.

Deseriptions and Notes on Certain Moths, p. 25--29.

On Genera and the Law of Priority, 1. 56--58.

New Pyralids, p. 98, 99.

On Copidryas Gloveri $(G . \& R$. ), n. 99, 100.

Larve of Thyreus Abbotii, p. 100.

On Homoptera and allied forms, p. 107--109.

New Mothis, p. 111, 112.

On a New Canadian Bombycid Moth, p. 125, 126.

On Jacob Hülmer and his Works on the Butterflies and Moths, p. 131-135.

Notes on Gicometridle, 1). 152--154.

New Pyralides, p. 156--158.

Notes on Nireture, ]. 188--190.

Notes on Certain speeies of Moths, p. 205--208.

On Species of Catocala, p. 229--232, vol. VIII, 1876.

Deseription of a New Botis allied to Flavidalis, p. 10.

New Nocture, p. 21, 22.

Notes on a collection of Canadian Moths made by W'm. S. M. D'Urban and named by F. Walker, 1. 27--29. 
Six New Noetur, p. 67--71.

Notes and deseriptions of New Moths, 1. 84--90.

On Preudohazis Hera, (Harris), p. 96.

On a New Canadian Crambus allied to Conchellus, p. 101, 102.

New Pyralides, p. 103-107.

A new genus and speeies of Geometre, p. 114, 115.

Correspondence, p. 119, 120.

Notiee of Mr. Butler's Revision of the Sphingide, p. 130-133.

A new Plusia allied to Hochenwarthi, p. 135, 136.

New Species of Lepidopteri, p. 156-158.

A new Lepidopterous Insect injurions to vegetation, p. 161--163.

Notes on Catocalæ, p. 168--170.

Notes on Noctuidre, p. 196--200.

Note on Larval Variation, p. 209, 210.

Notes on Lepicloptera, p. 213--215.

Correspondenee, p. 220.

1 new genus of Tortricilie, p. 227.

On the genera Nola and Argrrophyes, p. 235--238, vol. IX, 1877.

Description of a new Drepanoles, p. 17.

I new Hepialus from New York, p. 18.

Note on the Structure of Nephopteryx Zimmennani, p. 19.

New Prralides, p. 23--30.

Description of a $11 \mathrm{ew}$ Grapholitha, p. 54, 5.5.

Correspondence, p. 59, 60.

New Spreeies of Acopa and Hehothis and note on Hamadryas, p. 67--69.

A new Aretian from Florira, p. 78.

On Euproserpinus Phacton, G. \& R., p. 94--97, vol. X, 1878.

*Grote. Noct. Cal.

Descriptions of Noctuide, chiefly from California.

On pages 169-187 of the Bulletin of the United States Geological and Geographical Surver of the Territories, F. V. Hayden, U. S. Geologist-in-charge. Tol. IV, Number 1. Washington: Goremment Printing Office, February 5, 1878.

*Grote. Proc. AM. Phil. Šoc.

Proeedings of the American Philosophical Society, held in Philadelphia for promoting useful knowlerlge, vol. I--X Y, 1838--1877.

List of the North American Platyptericices, Attaci, Hemilencini, Ceratocampadae, Laehneides, Teredines and Hepiali, with notes, p. 256--264, vol. XIV, 1876.

*Grote. Proc. ENt. Soc. Phil. I-- VI.

The following papers on Lepidoptera in the Proceedings of the Entomologieal Society of Philadelphia :

Additions to the Catalogue of U. S. Lepidoptera: No. 1, 1. 218--219; No. 2, p. 345--347, vol. I, 1862.

Additions to the Catalogne of U. S. Lepidoptera : No. 3, p. 30, 32 ; No. 4, p. 64--68; No. 5 , p. $273--276$.

A Revision of the Species of Cymatophorina, found in the United States and British America, with descriptions of New Speeies, p. 54--59.

Descriptions of North American Lepidoptera: No. 1, p. 334--34t; No. $2,433--441$. 
Description of a New Species of North American Gortyna, p. 431, 432.

Description of a New Species of 'Torth American Papilio, p. 441,442 , vol. II, $186: 3--1864$.

Description of a New Genus and Species of North American Noctuina, p. 2--4.

Descriptions of North American Icpidoptera: No. 3, p. 73--92; No. 4, p. 322--327; No. 5, p. 521--535.

Iist of a Collection of Lepidoptera Heterocera taken near Williamsport, Mass., p. 92--96.

Notes on Certain Species of North American Iepidoptera, P. 535--542, rol. III, 1864 .

On the Symonymy of Parathyris Angelica, Grote, r. 207.

Descriptions of North American Lepidoptera: No. 6, p. 315--330, vol. I Y, 1865 .

Notes on Cuban Sphingida, p. :33--84.

Totes on the Bombycidae of Cuba, p. 227--255, vol. V, 1865.

Totes on the Zygænidæe of Cuba: Part 1, p. 173--189; part 2, p. 297 -. 334 , vol. $\mathrm{VI}, 1866--1867$.

*Grote. Trans. Ax. Ext. Soc. I-- $Y$.

The following Papers on Lepidoptera in Transactions of the American Entomological Society :

On the North American Platypteryinse, p. 65--67.

On the Synonymy, ete, of certain speeies of American Lepidoptera, p. $115-122$.

On the Structural Charaeters of Polyommatus Tarquinius, p. 307, 308.

On a new genus of Noctuidie allied to Dyops, with remarks on certain species of Agrotis, p. 308, 309, vol. II, 1868--1869.

List of the Sphingidæ, Ageridx, 'Krgænidxe and Bombycidæ of Cuba, p. 183--188, vol. III, $1870--1871$.

On the North American Speeies of Catocala, p. 1--20.

Deseriptions of North American Noctuidre: No. 1, p. 20--28; No. 2, p. 89--108; No. 3, p. 293--310.

Deseription of Tortrix Lintneriana, p. 424, vol. IV, 1872--1873.

Remarks on North Ameriean Noctuidre with descriptions of new speeies, p. 89--98.

Descriptions of North American Moths, p. 118--118.

Note on Papilio Gundlachianus, p. 118, vol. V, $1874--1876$.

* Grote. Rep. PBdy. ACAd. Sc.

Report Peabody Academy of Seiences, 1873, contains :

Noetuidæe of North America, p. 21--53.

*Grote. Stett. Ent. Zeit.

Entomologische Zeitung herausgegehen von dem Entomologische Tereine zu Stettin, vol. I-- XXXVIII, 1840--1877.

Ueber die Nordamerikanisehen Noctuinen, p. 19:--202; 340--343, rol. XXXVI, 1875.

Continued p. 134--137, vol. XXXVII, 1876. 
*G.--R. Ans. N. Y. Lyc. Nat. Hist.

A. R. Grote and Coleman T. Robinson. The latter, a stock broker in New York, was born in Putnam Co., New York, in 1838, and met his death May 1st, 1872, through injuries caused by being thrown from his carriage. A list of such writings as he was alone responsible for may be found in the Canadian Entomologist, vol. V, p. 109, 111. They are almost solely on the Microlepidoptera.

Annals New York Lyceum Natural History.

Contain the following:

Lepidopterologieal Contributions, p. 351--387.

Notes on the Lepidoptera of America, p. 432--466, vol. VIII, 1867.

*G.--R. Proc. Ent. Soc. Phil.

Proceedings Entomological Society of Philadelphia.

Contain the following:

Description of a new species of Citheronia, and remarks on Anisota Rubicunda, p. 222, 223 .

Lepidopterologieal notes and deseriptions: No. 1, p. 489--496, vol. IV, 1865 .

A Synonymieal Catalogue of North American Sphingidae, with Notes and Deseriptions, p. 149--193, vol. $\mathrm{V}^{\top}, 1865$.

Lepidopterologieal Notes and Descriptions: No. 2, p. 1-30, vol. VI, 1866.

*G.-R. Trans. Am. Ent. Soc.

Transactions of the American Entomological Soeiety.

Contain the following:

Deseriptions of American Lepidoptera: No. 1, p. 1-30 ; No. 2, p. 171192 ; No. 3, p. 323-360 ; vol. I, 1867-1868.

Notes on the North American Lepidoptera in the British Museum and deseribed by Mr. Francis Walker, p. 67-88.

Deseriptions of American Lepidoptera : No. 4, p. 179-206.

On the American Butterflies referred to the genus Charis by Donbleday, p. 310, 311, vol. II, 1868-1869.

Remarks on Dr. Boisdural's "Lepidopteres de la Californie,” p. 173-176.

Deseriptions of Ameriean Lepidoptera: No. 5, p. 176-182, vol. III, $1870-1871$.

A Supplement to the "Descriptions of American Lepidoptera," p. 425, vol. IV, 1872-1873.

*Guer. ICON. Reg. Ax.

Felix Edward Guerin-Meneville. Born in Toulon Oct. 12, 1799.

Iconographie du regne animal de G. Cuvier, ou représentation d'apres nature de l'une des espèces les plus remarquables et souvent non encore figurées, de ehaque genre d'animanx; ponvant servir d'atlas à tous les traites de Zoologie. Paris, J. B. Bailliere, 1829-1844.

Insectes, p. 1-575, 1829-1838; Lep., p. 466-530 ; Lep. Plates, 76-91. *Hagen. Bib. Ent.

Dr. Hermann August Hagen. Born in Konigsberg May 30, 1817 ; now in Cambridge, Massachusetts. 
Bibliotheca Entomologica. Die litteratur ïber das ganze gebiet der entomologie bis zum . Jahre 1862. Von Dr. Hermann August Hagen in Königsberg. Leipzign, 1862.

Vol. I, A-M., 566 pages; vol. II, N-Z, 512 pages.

A work indispensable to every entomologist.

*Hagen. Can. Ext.

In Canadian Entomologist are the following :

The Limnan Signification of the Generic 'Term Papilio, p. 163-166, vol. II, 1874.

On Genera, p. 194-198, vol. VIII, 1876.

On Samia Gloveri and Columbia, p. 1:3, vol. I X, 1877.

* Hagen. BiffF. Bull.

In Bulletin of the Buffalo Soc. Nat. Se. is the following:

On Attaleus (Samia) Columbia and its Parasites, p. 201-208, vol. II, 1875. * Harris. Agass. Lake Superior.

Thaddens William Harris, M. D., in Cambridge, Massachusetts. Died in 18.36. His Collection is in the Boston Museum of Natural History.

Descriptions of some species of Lepidoptera from the Northern Shores of Lake Superior.

P. 386-394, \& t. 7, in, Lake Superior ; its phrsical charaeter, regetation, and animals, compared with those of other and similar regions. By Louis Agassiz. With a Narrative of the tour by .J. Elliot Cahot, and contributions ly other scientific gentlemen. Boston: Gould, Kendall and Lincoli, 1850 .

*Harr. Am. JNL. Sc.

American Journal of Science and Art has :

Descriptive Catalogue of the North American Insects belonging to the Linnean genus Sphinx in the cabinet of the author, XXXVI, p. 282320,1839 .

Harr. Bost. Culit.

Boston Cultivator.

Canker Worms (Anisopteryx Vernata), XI, p. 376, 1849.

HARr. D†G. HORT.

Downing's Horticulturist.

The rosy Hispa and the Drop-Worm (Hispa rosea, Oiketicus Coniferarum, ) VIII, p. 461--464, 1853.

*Harris. Hitch. Rep. Geol. Min., etc., Mass.

List of the Insects of Missachusetts.

Being pages 566-595 of the Reprort on the Geologr, Mincralogy, Botany and

Zoology of Massachusetts, by Prof. Edward Hitcheock. Amherst, is33.

Harr. Hov. Mag.

Hover's Magazine of Horticulture:

Some account of the insect that attacks the grape vine (Procris Americana) X, p. 201--205, $18+4$.

'The currant-tree borer (Lgeria Tipuliformis), X V II, p. 241--24t, 1851.

The Measure-Worm (Geometra Niveosericearia), XXI, 418--423, 1855. 
*HARRIS. INS.

A Report on the Insects of Massachusetts which are injurious to vegetation, published agrecably to an order of the Lecislature, 'by the Commissioners of the Zoological and Botanical Survey of the State. Cambridge, 1841 .

A Second Edition was issued by the author in 1842, and another in 1852.

*Harris. INS., Flint's Ed.

A later revised, improved and illustrated edition of the above, with the title as follows:

A Treatise on some of the Insects Injurious to Vegetation. By Thaddens William Harris, M. D. A new Edition, enlarged and improved, with additions from the anthor's manuscripts and original notes. Illustrated by engravings drawn from nature under the supervision of Professor Agassiz. Edited by Charles I. Flint, Secretary of the Massachusetts State Board of Agrieulture. Boston, 1862.

640 pages of text, eight finely coloured steel plates and numerous excellent wood cuts representing insects of various orders, and is a book that no American Entomologist can well be without.

Harr. Mass. Rep.

Massachusetts Agrieultural Repository and Journal contains:

Upon "the Natural History of the Salt Marsh Caterpillar (Aretia Pseuderminea), vol. VIT, p. 322--331, 1823.

Harr. Mass. Plough.

Massachusetts Ploughman.

Canker Worms (Anisopteryx Vernata), X, No. 8, 1850; No. 33, 1851.

*Harris. New ENg. Farier.

New England Farmer.

In the above are the following papers on Lepidoptera:

Description of any remedy against the Catterpillar which destroys grass in Salt-Meadows, I, p. 238, 1823.

Natural History of the Salt-Marsh Caterpillar (Aretia psenderminea), I, p. 385-386, 1823.

Caterpillars (Clisiocampa americana), IV, p. 354, 1826.

On (A egeria exitiosa) the peach tree insect, V, p. 33, 1826.

Description of Aegeria eucurbitae and Aretia textor, VII, p. 33, 34, 1828.

American turnip butterfly (Pontia Oleracea), VII, p. 402, 1829.

Egeria pyri, Ichnemmon hordei, IX, p. 1, 2, 1830.

On the Wheat Insects (Calandra granaria, Tinea granella, Oecophora cerealella), XIX, p. 300, 1841.

On the Squash vine destroyer (Aegeria cucurbitae), XX, p. 260, 1842.

On the Apple Worm, Plum Grub, (Carpocapsa pomonella, Conotrachelus nenuphar) XXII, p. 13, 1843.

On Clisiocampa sylvatica, a new depredator of the orchard; the Wheat worm, etc., XXII, 1). 412, 1844.

Injurious inseets (Conotr. nenuphar, Carpocapsa pomonella, Aphides, 
Clisio. americana, Anisopt. vernata, Macr. subspinosus,) II, ser. 2, p. 252,1850 .

Canker-Worms, (A. Vernata,) IV, ser. 4, p. 155, 156, 1852.

Canker-Worms, (A. Vernata,) VI, ser. 8, p. 363, 1854.

Harr, Pr. Far.

Prairie Farmer.

Canker Worms (Anisopteryx Vernata), VIII, p. 172, 173, 1848.

*Herbst, NAt. Schmett, I-XI.

Joham Friederich Wilhelm Herbst. Preacher in Berlin, and Carl Gustav Jablonsky. Herbst was born in Petershagen Nov. 1, 1743; died in Berlin Nov. 5, 1807. Jablonsky was born in 1756; died May 25, 1787.

Natursystem aller bekannten in und ausländischen Inseckten als eine Fortsezzung der von Büffonschen naturgeschichte, nach dem System des Ritters Carl ron Limne bearbeitet Carl Gustav Jablonsky.

Vol. I, 1783; II, 1784; III, 1788.

Jablonsky dying before the completion of the last mentioned vol. (III), it and the remaining eight were continued and finished by Herbst.

Vol. IV, 1790; V, 1792; VI, 1793; VII, 1794; VIII, 1796; IX, 1798; X, 1800; XI, 1804 .

The figures of Exotic Lepidoptera in the eight volumes edited solely by Herbst are nearly all fac-similes of Cramer's and represent nearly all the diurnals of that author excepting the Hesperidæ. The above does not apply to the figures in the first volumes by Jablonsky. In the eleven volumes, besides an antique frontispiece and a plate of Collecting Instruments, etc., there are 327 plates of coloured figures. Th re are many misprints among names and references, and the errors of previous authors are repeated.

*Hew. Anv, \& Mag. Nat. Hist.

William Chapman Hewitson, born in 1806; died at his residence, Oatlands, Walton-on-Thames, Surrey, England, May 28, 1878; was interred in the little country churchyard about half a mile from his home. His collection, probably the finest and largest extant of Diumal Lepidoptera, was bequeathed to the British Museum on the condition that it was to remain intact for 21 years.

The Annals \& Magazine of Natural History (including Zoology, Botany and Geology).

First series, vol. I-XX, 1838-1847 ; Second series, vol. I-XX, 1848-1857; Third series, vol. I-XX, 1858-1867; Fourth series, vol. I-XX, 1868-1877.

Deseriptions of some new species of Butterflies, p. 257-264, vol. XX, 1 st series, 1847.

On a new specics of Agrias, p. 224, 225, vol. III, 2d series, 1849.

On a new genus and species of Satyridæ, p. 215-217, vol. IV, 2d series, $18+9$.

On some new species of Butterflies, p. 434-440, vol. VI, 2 d series, 1850.

On Butterflies taken on the March to Coomassie, p. 380-383, vol. XIII, th series, 1874 .

On a new speeies of Butterflies from the Andaman Islands, p. 356-358.

On new genus of Butterflies from Madagascur, 1. 359, 360, vol. XIV, 4 th series, 1874.

On a new species of Hesperidæe, p. 347-355; 449-457, vol. XVIII, th series, 1876. 
On a new species of Hesperidac, 1'. 76-85, vol. XIX, th series, 1877.

On a new species of Hespericlae, p. 319-328, vol. XX, 4th series, 1877. * Hew. Ent. Mon. Mag.

The Entomoloyist's Monthly Magazine.

Deseription of a new species of Leptalis, (Lepirlopt. Rhopaloceres,) p). $68,69$.

Description of a new species of Epitola, (Lyecnad.) 1. 86.

Curious oceurrence of the Wrood Leopard, p. 96.

Descriptions of new species of Lepidoptera Rhopalocera from old Calabar and Ecuador, 1). 97-99.

Descriptions of two new species of Lepidopt. Rhopalocera, p. 177, 178.

Descriptions of new species of Erycinidae from Chontales Nicarauga, p. 226-228, vol. VI, 1869-1870.

Deseriptions of five new speries of Dimmal Lepidoptera from Chontales Nicarauga and of one from Minas Geraes, 1. 3-6, vol. VII, 1870-1871.

Description of seven new Fxotic Rhopalocera, p. 83-86.

Description of new species of Papilio from Lagos, p. 146, 147.

Vanessa Antiopa in November, p. 161.

Descriptions of two new Butterflies from the west wast of Africa, p. 23:2, 233 , vol. IX, 1872-1873.

Description of three new species of Rhopalocera from Angoli, p. 57, 58.

Description of nine new species of Iyeaenidae fiom the west coast of A fivea, p. 122-125.

Deseription of six new species of Epitola from the west const of Africa, p. 149-151.

Description of four new African Butterflies, p. 20.5, 206.

Description of a new species of Charaxes from the west coast of Ifrica, 1. 247,248 .

Description of two new West African Butterflies from the collection of H. (i. Smith, p. 274, rol. X, 1873-1874.

Note on Rhopalocera firom Africa, p. 16.

Descriptions of new I yeacinilac from West Africa, p. 36.

Desuription of new species of Buttertlies, p. 56.

Note on Bolivian Rhopalocera, p. (;5.5.

Deseriptions of new speries of Lycaenidae from South America, p. 104 107.

Note on the Capture of Papilio Antimachus, p. 113.

Description of five new species of Acraea from West Africa, p. 130-132.

Descriptions of six new species of Butterflies from Sonth America, West Africa and Borneo, p. 182-184:

Deseriptions of Rhoplocera from Madagascar, 1. 226, 227, vol. XI, $1874-1875$.

Descriptions of three new Butterflics, p. 9, 10.

Description of three new species of Lyeaenidae, p. :38, 39.

Description of a new species of Myrina from West Africa, p. 106.

Notes on Butterflies from Bolivia with descriptions of two new species, p. 153.

Deseriptions of four new South American Hesperidae, 250, 251, rol. XII, 1875-1876. 
Note on Mr. Buxton's Collections, p. 57.

Notes on Mr. Atkinson's Collection of East Indian Lepidoptera with descriptions of new species of Rhopalocera, p. 149-152.

Descriptions of two new Buttertlies from the Philippine Islands, p. 178179.

Notes on Rhopalocera from Angola with deseription of a new species of Deudorix from Zanzibar, 1. 205.

Note on Mr. Buxton's Eastern Butterflies with a description of a new species of Poritia, p. 223.

Deseription of a new Harma from West Africa, p. 277, 278, vol. XII, 1876-1877.

Deseription of a new Butterfly from Lake Nyassa, p. 5, 6.

Deseriptions of four new species of Acraea from Lake Nyassa, p. 51, 52.

Deseriptions of three new species of Butterflies from Delagoa Bay, p. $81-83$.

Deseription of new specics of Rhopalocera, p. 107, 108.

Notes on a collection of Butterflies from Zamzilar with descriptions of two new species of Acraea, 1. 15.3-155.

Deseription of a new Leptalis from Ecuador, p. 180.

Deseription of the male of Charaxes (Philognoma) Azota, p. 181.

Descriptions of four new species of Pronophila, 1. 227, 228, vol. XIV, $1877-1878$.

Hew. Descrip. Hesp.

Description of New Species of Hesperidae. Van Voorst, 1867-1869.

*Hew. Illa. Ex, Butt.

Illustrations of new speeies of Exotie Butterflies, selected chiefly from the Collections of William Wilson Saunders and William C. Hewitson. London: Yan Voorst.

Vol. I, 1851-1857 ; II, 1857-1861 ; III, 1862-1866; IV, 1867-1871.

One of the grandest works ever published on Lepidoptera.

*Hew. Ill. Diur. LeP.

Illustrations of Diurnal Lepidoptera. London: Van Vourst, 18671877. Supplement in 1869 .

*Hew. JNL. LiN. SOC. I GOND.

The Journal of the Limnean Society. London, 1857-1877.

List of Diurnal Lepidoptera collected by Mr. Wallace in the Eastem Archipelago, p. 143-149, vol. VIII, 1865.

* Hew. Proc. Tool. Soc. Lond.

Proceedings of the Zoological Society of London, 1830-1877.

Description of a new species of Buttertly of the genus Agrias, p. 45-47.

Description of a new species of Satyridie, p. 115-117, vol. XVI, 1848.

Description of some Butterflies from the collestion of $\mathrm{Mr}$. Wallace, p. $46 t-466$, vol. XXVI, 1858.

Description of Butterflies from the collection of Mr. Wallace, p. 422-425, vol. XXVII, 1859.

Description of some Butterflies from the eollection of Mr. Wallace, p. 50-53, vol. XXIX, 1861. 
Description of Butterflies from the collections of Messis. A. R. Wallace and W. C. Hewitson, 1). 87-91, 1862.

A list of Dinrual Lepidoptera taken in Madagasear by Mr. Caldwell, 1. $64,65,1863$.

*Hew. Trans. Ent. Soc. Jond.

The Transactions of the Entomological Society of London.

Deseriptions of some new Butterflies, and remarlis on the sexes of some Papilios, p. 97-100, rol. I, 2d series, 1850-1851.

Descriptions of five new speries of Butterflies of the family Papilionidae, p. $22-24$.

Description of some new species of Butterflies from Sonth America, p. 245-248, rol. II, $2 \mathrm{~d}$ series, 1852-1853.

On Pronophila, a genus of Diurnal Lepidoptera, with figures of new species and references to all those which have been previously figured and deseribed, p. 1-17.

Description of two new species of Dimrnal Lepidoptera, p. 517, 518, vol. I, 3d series, $1862-1864$.

Description of a new species of Diumal Lepidoptera, 1. 245-249.

A monograph of the genus Y phthima with descriptions of two new genera of Diumal Lepidoptera, p. 281-293.

Description of new Hesperidae, p. 479-501, rol. II, 3d series, 1864 1866.

Description of some new species of Diurnal Lepidoptera, p. 561-566, vol. V, 3d series, $1865-1867$.

Remarks on Mr. A. R. Wallace's Pieridae of the Indian and Anstralian regions, p. 97-100, 1868 .

Deseription of two new species of Papilio from Eeualor, p. 31, 32.

Description of six new species of Dimmal Lepidoptera from Nicaranga, p. $33-35$.

Description of new species Diurnal Lepidoptera, p. 71-75, 1869.

Description of twenty-two new species of Equatorial Lepidoptera, p. 153163,1870 .

New species of Dimnal Lepidoptera from Sonth and Central America, 1. 165-167, 1871.

Deseriptions of some new species of Lycanidae from his own collection, p. $343-355,1874$.

* Hew. ZOOL. LoND.

The Zoologist, (a popular Miscellany of Natural History,) London.

Vol. I-XXII1, 1843-1865, 1st series; vol. I-XF, 1866-1876, 2d series; vol. I, 1877, 3d series.

Remarks on Butterflies of Switzerland, p. 991-994, vol. III, 1845, 1st series.

Colias Edusa on the 24th of October, 1). 8342, vol. XXI, 1863.

*H-S. BerL. Ent. Zeit.

Gottlieb August Wilhelm Herrich-Schaeffer, Doctor of Medicine. Born in Regensburg 1799 ; died at Ratisbon Apr. 14, 1874. 
Berliner Entomologische Zeitschrift.

Vorabbeiten zu Einer Synonymik Sïmmtlicher Lepidopteren, p. 126-13:3, vol. III, 1859.

*H-S. Cokr.-Bintt, Zool. Min. Ges.

Correspondenz Blatt des Zoologisch Mineralogischen Vereins in Regensburg.

Systematisches Verzeichniss der Europäischen Schmetterlinge mit Einschluss der von den Sammeln gewöhnlich dazugerechneten Sibirien und Kleinasiaten, p. 17-47.

Die Lepidopteren Famna der Regensburg Lmgegend, p. $57--88$; 133-149 , vol. IX, 1855.

Kritischer Anzeiger, p. 33--72, vol. XI, 1857.

Kritischer Anzeiger der werke von Guence, Walker, Lederer, Spever dann der Phytophagen von Kaltenlach, p. 11:--154.

Dritter Nachtrag zur Lepidopteren Fauna von Regensburg, p. 177-193, vol. XII, 1858.

Kritischer Anzeiger der Lepidopteren Werke von Guenee, Walker, Lederer, Speyer dann der Phytophagen von Kaltenbach, 1) 143--152; 175--182, vol. XIII, 1859.

Kritischer Anzeiger, 1. 67--82; 154--168.

Ueber die Klassification der 'Tortricinen, 168--182, vol. XIV, 1860.

Revision der Lepidopteren mit besonderer Berïcksichtigung der Answerепrop:ïer, 9,$10 ; 29,30 ; 60-62 ; 143-151$.

Entomologische literatur des .Jahres 1861, p. 10--13; 25--27; 44--48; $57--59$; rol. XVI, 1862.

Zur Spannergattung Eupithecia, p. 21--24.

Die geographische Terbreitung der Schmetterlinge Europas, p. 54--56; 10:3--107, vol. XVII, 1863.

Criticism on Morris' Synopsis, p. 132--137.

Zwei neue Miero-lepidopteren, p. 115--117, vol. XIX, 1865.

Eine für Dentschland nene Geometrine, p. 90, vol, XX, 1866.

*H--S. Ind. Syst, Reg. Corr.--BlatT.

Lepidopterorum Index systematicus.

In Correspondenz Blatt des Zool.-min. vereines, in Regensburg.

See the following.

*H--S. Prodr. Lep. Reg. Corr.--Blatt.

Prodromus Systematis Lepidopterorun. Versuch einer systematisehen anordnung der Schmetterlinge.

In the Corre-pondenz--Blatt des Zool.-min. vereines, in Regensburg:

P. 89--112; 123--136; 148--152; 173--181, vol. XVIII, 1864.

Continued under the title of Lepidopterorum index Srstematiens.

P. $63-76$; 84-92 ; 100-108, vol. XIX, 1865.

P. $100-106 ; 124-128 ; 138-144 ; 161-172$, vol. XXI, 1867.

P. 119-138; 172-176, vol. XXII, 1868. 
P. 56--64; 67--77; 130--141；163--172；185--216, vol. XXIII, 1869.

P. 15t-160, vol. XXIV, 1870.

P. 103--104, vol. XXV, 1871.

*H--S. Schmett. Cuba, Corr.--Blatti Zool. Min. Ges.

Schmetterlinge aus Cuba. In the Correspondenz--Blatt des Zool.--Min. Vereines in Regensburg.

P. 118-120; 141-143; 156, $157 ; 174-180$, vol. XVI, 1862.

P. 138--143; 147--150, vol. X VII, 1863.

P. 159--172, vol. XVIII, 1864.

P. 52--60, vol. XIX, 1865.

P. 103--109; 113--120; 130--136, vol. XX, 1866.

P. 113--118; 147--156; 179--186, vol. XXII, 1868.

P. 153--160, vol. XXIII, 1869.

P. 97--108; 180--190, vol. XXIV, 1870.

P. 15--30, vol. XXV, 1871.

*H--S. Sami. Ausseur. Schmett. (or Exot. Lep.).

Sammlung nener oder wenig bekannter aussereuropäischer Schmetterlinge. Regensburg, 1850--1858.

1 vol. 4to. 120 fine coloured plates.

*H--S. SchmetT. Eur. (or Eur. SchmeTt.) I--TI.

Systematische Bearbeitung der Schmetterlinge von Europa, zugleich als Text, Revision und Supplement zu Jakob Hübner's Sammlung europäischer Schmetterlinge von Dr. G. A. W. Herrich--Schäffer. Regensburg.

Vol. I, 1843--1856, Diurnæ; II, 1845, Sphingidæ, Bombyeidæe, Noctuidæ; III, 1847, Phalaenidæe; IV, 1849, Microlep. ; V, 1853--1855, Microlep.; VI, 1813--1856.

Vols. V and VI I have not been able to examine.

Published as supplement and revision to Hubner's Sammlung Europaischer Schmetterlinge.

*H--S. Stett. Ent. Zeit.

Entomologische Zeitung herausgegeben von dem Entomologischen Vereine zu Stettin.

Bezüglich der Gastropacha Arbusculae, p. 55--57, 1861.

Neue Schmetterlinge aus dem " Museum Godeffroy" in Hamburg, p. 65-$80,1869$.

*H-S. ZOOL. LoNd.

The Zoologist, London.

Notes on new or little known Macrolepidoptera from England, p. 82918295, vol. XX, 1862.

*Horsf.--Mloore. Cat. Lep. Mus. E. I. C.

Dr. Thomas Horsfield, London. Spent 1813-1816 in Banka, Sumatra and Java. Died in London.

Frederick_Moore, in_London. 
Catalogue of the Lepidopterous Insects in the Musem of the Hon. EastIndia Company. Printed by order of the Court of Directors. Irondon, Allen.

Vol. I, 1857 ; II, 1858--1859.

* Hueb. Beitr.

Jacob Huebner, a designer in a cotton-print factory. Born at Augsburg June 20,1761 ; died Sept. $13,1826$.

Beitrïge zur geschichte de Schmetterlinge, Angsburg.

Two vols. Vol. I, 1786-1789; II, 1790. With 16 good coloured plates in each.

*Hueb. Eur. ScmintT.

Sammlung Europäischer Schmetterlinge. Augsburg, 1805--1832.

In 5 vols. 4to. Vol. I, Papiliones; II, Sphinges, Bombyces; III, Noctuæ; IV, Geometræ; V, Pyralides, Tortrices, Tineæ, Alucite.

Contains 700 excellent colourerl plates.

*Hueb. Eur. Schmett.

Geschichte enropäischer Schmetterlinge gresammelt ron .Jacob Hübner in Augsburg, 1806--1834.

In 3 vols. 4to. Vol. I, Papiliones, Sphinges, Bombyees; II, Noctuæ; III, Geometre, Pyralides, Tortrices, Tineæ, Alueitæ.

406 excellently executed coloured figures, all Larvæ, Pupæ and food-plants.

In my present Catalogue the above work has been cited along with the preceding (Eur.

Schmett.) and further indicated by the word "Lar." (Larva) following No. of vol. or fig.

*Hueb. Ex. Schuett.

Sammlung Exotischer Schnetterlinge erriehtet ron Jacoh Hälner. Augshurg, 1806--1824.

In 3 rols. 4 to.

Contains 439 coloured plates; these plates are beautifully drawn and eoloured true to nature * Hueb. Ixd. Ex. Lep.

Index exoticorum Lepidopterorum in foliis 244 a .T. Hnebnero hactenus effigratorum. Angustae Vindelicorum, 1821.

*Hueb. Ver\%. Bek. Schuett.

Verzeichniss bekannter Schmetterlinge. Verfasst von Jacob Hülnner. Angsburg, 1816.

In German. 431 pages, exclusive of Index.

*Hueb. Zutr. Exot. Schmet. (\& Huer.--Ger., Eur. Schmett.).

Zuträge zur Sammlung exotischer Schmetterlinge, bestehend in Bekundigung sinzelner Fliegmuster neuer oder rarer nicht europäischer Gattungen. Augsburg, 1818--1823; $1825--1832$.

Continued_by Carl Geyer, 1832--18:37.

170 fine coloured plates.

HufN. BerL. Mag.

Hufnagel.

In the Berlinisches Magazine:

Tabellen ron den Tagrögeln der Gegend Berlin, p. 51--90.

Abendvögeln, p. 174--195.

Nachtvögeln, p. 391--437, vol. II, 1766.

Nachtvögelı, p. 202--215; 279--309; 393--426, vol. III, 1767.

Fortsetzung der 'Tabellen von den Nachtvögeln, p. 504--527; 599--626, vol. IV, 1768 . 
* Humpei., West. Britr. Butrt.

H. N. Humphreys.

British Butterflies and their transformations, arranged and ${ }^{2}$ illustrated in a series of plates by H. N. Humphreys, Esq., with deseriptions by J. O. Westrood, Esq. London, W'ill. Smith, 1841. (2d Ed., 1848.) Une vol. 4to. 42 colonred plates.

*ILl. MaG. INs.

Johann Carl Withelm Illiyer. Born in Brannschweig 175.5; died in Berlin 1815. Director of the Zoological Museum of Berlin.

Magazin für Insektenkunde. Braunschweig.

Vol. I, 1801-1802; II, 1803; III, 1804; IV, 1805; V, 1806; V'I, 1807.

*Kirby. Faun. Bor. Alr.

William Kirby, Preacher, born in Witnesham Hall 1759; dier in Barham, near Ipswich, July 4, 1850.

Fama boreali--Ameriema, or the Zoology of the Northern Parts of British Ameriea, containing descriptions of the objects of natural history collected on the late northern land expeditions, under command of "Captain Sir John Franklin, by John Richardson. Part IV. The Insects by $\mathbb{W}^{r}$. Kirby, I condon, Longman, 1837.

Lep., p. $286-308$, plates III, IT.

* Kirby. Max. Eur. Butt.

W. F. Kirby, Naturalist in the Mnseum of the Royal Dublin Society. Dublin, Ireland.

A Mannal of European Butterflies. On the plan of Stainton's "Manual of British Butterflies and Moths." London, 1862.

Containing descriptions of all the known Species and Larve; with times of appearance, Tables of Genera, Appendices of Geographical Distribution, Synonymy, and Bibliograpliy, and a copious Index.

*Kiriby. Cat.

A Sinonymic Catalogue of Diurnal Lepidoptera. London, 1871.

Pages 690 . Contains names and synonyms of all the Rhopalocerous Lep. described to that time.

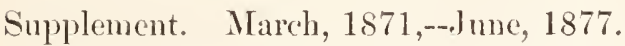

Contains all species described after issne of Catalogue of 1871 , and additional citations of numerons species.

*Kirtland, Sill. JNi. Sc., 2D Ed.

Jared P. Kirtland, Doctor of Medicine. Borm at Wallingford, Connecticut, Nov. 10, 1793; died near Cleveland, Ohis, Dec. 11, 1877.

Americm Journal of Science and Art, Ed. 2.

Method of preserving Lepidoptera, p. 286, 287.

A new Liluythea and Mareroglosisa, 1. 336-338, vol. XIII, 1852.

Localities and hal hits of some insects, p. 44t, vol. XVII, 1854.

* Kietland. Proc. Acad, Nat. Sc. Phil.

Proceedings of the Academy of Natural Sciences of Philadelphia.

On the Larva of Thyreus Abbotii, p. 148, vol. IX, 1857.

* Kirtland. Proc. Cleve. Acad. Sc.

Proceedings of the Cleveland Academy of Natural Seience. 1845--1859. Pnblished by al gentleman of Cleveland, Ohio, 1874. 
Diurnal Lepidoptera of Northern and Middle Ohio, p. 17--25.

Vanessa Furcillata. Extract from a Letter to Prof. Kirtland, read before the Academy and dated Cambridge, March 15, 1854, p. 94--96.

Description of a new species of Libythea and of Macroglossa, p. 171--173.

Letters from Dr. Harris, p. 189--194.

* KNoch. Bertr. Ins. I--III.

August Wilhelm Knoch, Professor in Braunschweig. Born in Braunschweig June 3, 1742; died June 2, 1818.

Beitrïge zur Insectengeschichte. Leipzig, Schwickert.

Part I, 1781; II, 1782 ; III, 1783.

* Leach. Zool. Mis.

William Elford Leach, Curator at the British Museum. Died of cholera at Genoa Aug. 25, 1836.

The Zoological Miscellany, being descriptions of new or interesting animals, illnstrated with eoloured figures, drawn from nature by R. P. Nodder. "Plus nos noms sont générae plus nos idées sont incompletes." Lundon, MeMillan.

3 vols. Vol. I, II, 1815; III, 1817.

*Lamarck. Hist. Anim. sans Vert.

Jean Baptiste Pierre Antoine de Monet, Chevalier de Lamarck. Born in Picardy Aug. 1, 17t4; died in Paris Dec. 19, 1829. Prof. of Zoology in the Jardin des Plantes. He was blind for a number of years previous to his death.

Histoire Naturelle des Animaux sans vertèbres. Paris, Verdière, 1815-1822.

7 vols. The Insects in vol. III, 1816, vol. IV, 1817.

*Latr. Hist. Nat. Crust. ext Ins.

Pierre Andre Latreille. Born in Brives, province of Limosin, Nov. 29, 1762. Died in Paris Feb. 6, 1833. His tomb.is Pere la Chaise.

Histoire naturelle, générale et partienlière. Des Crustacés et des Insectes. Ourrage faisant suite aux ocuvres de Leclere de Buffion et partie du Cour's complet d'Histoire naturelle rédigé par C. S. Sonnini, par P. A. Latreille. Paris, Dufart.

Tol. I--IV, 1802; V, VI, 1803; VII--XII, 1804; XIII, XIV, 1805.

Lep. in vol. XIV.

*Latr. Gen. Crust. et Ins.

Genera Crustaceorum et Insectorum secundum ordinem naturalem in fimilias disposita, iconibus exemplisque phurimis explieata. Parisiis et Argentorat., Amand Kinenig.

Vol. I, 1806; II, III, 1807 ; IV, 1809.

*Latr. Enc. Meth. IX.

Encyclopédie Méthodique IX, 1823.

See "Godt., Enc. Meth. IX Sup."

*Led. Verh. Zool. Bot. Ver.

Julius Lederer, Merchant in Vienna. Died in 1870.

Verhandlung des Zoologisch--Botanischen Vereins in Wien. 1851-1876.

Die Europäischen Lepidopteren:

1. Abtheilung Die Rhopaloceren, p. 14--54.

2. Abtheilung Die Heteroceren, p. 65--126. 
Ueber Gynancycla canclla, und eine ihr in form und zeichnmug ähnliche neue Art Spermatophthora Hornigii, p. 132, 133, vol. II, 1852.

Die Europäischen Lepidopteren. Die Spanner, p. 165-270.'

Lepidopterologisches aus Silerien, p. 351-394, vol III, 1853.

Grapholitha Hornigiana, 11. sp., p. 77-80.

Weiterer Beitrag zur Schmetterlings-Fanna des Altai-Geberiges in Siberien, p. 97-121.

Beitrag zu einer Schmetterlings-Fauna von Cypern, Beirut n. einem Theile Kleinasiens, p. 177-254.

Psyche Eeksteinii, n. sj)., 1. 755, 756, vol. V, 1855.

* Led. Berl. En't. 'ZeIT.

Berliner Entomologische Keitschrift.

Lepidopterologische Mittheilungen; Psyche atra; Ochsenheimersche gattung Notodonta; Europäischen Cymatophoriden; Boletolia fuliginaria, p. 353-360, vol. II, 1858.

Celonoptera Mirificaria ein nene Europäischer Spanner, 1). 59, 60, vol. VI, 1862 .

LED. NoCT. Eur.

Die Noctuinen Europas, mit zuziehung einiger bisher meist dazugezählten Arten des asiatischen Russlands, Kleinasiens, Syriens ı. Labradors. Wien., Gerold, 1857.

*Led, WIEN, ENT. MoN.

Wiener Entomologische Monatschrift. Verantwortliche Reclacteure: Julius Lederer und Ludwig Miller. Wien. Tol. I-VIII, 1857-1864.

Ueber die Lycaeniden-gattungen der enropäischen Fanna, p. 25-32.

Die Körperlichen Auszeichnungen der europ. Hesperien, p. 75-80.

Vier nene europäische Schmetterlinge, p. 80-83.

Nachtrag zur Schmetterlings-Fauna von Beirut, p. 90-95; 97-102, rol. I, 1857.

Erebia Arete F. wieder anfigefunden, p. 36, 37.

Noch einige svrische Schmetterlinge, p. 135-152.

Für die Wiener-Fauna nene Schmetterlinge, p. 288-360, vol. II, 1858.

Classification der europäischen 'Tortricinen, p. 118-126 ; 141-155; 241$255 ; 273-288 ; 328-346 ; 366-389$.

Ein par Worte ïber Dr. Herrich-Schïffer's Kritik meiner "Noctuinen Europas" in Regensburger Korrespondenzblatte 1858, p. 186-191; 193--199, vol. III, 1859.

Ueber Guenée's Uranides 11. Phalénites, p. 121--128; 150--157; 182-187.

Abwehr eines Angriffes mit geschlossenem Visir, p. 157--160.

Zukunfts-Styl., p. 187--192.

Albert Kindermann (Sohn) Necrolog., 251--255.

Lepidoptera, p. 284, 285.

Die Raupen von Agrotis lucipeta S. V. nnd Eccrita ludiera Hbn., p. 310--313.

Cremor Tartari für Herrn Dr. O. Standinger, p. $318--328$.

Traurige Folgen der Curpfuscheri, p. 402--403, vol. IV, 1860. 
Ueber anerkennenswerthe Unpartheilichkeit moderner Kritik, p. 112 -136.

Ueber Albert Kindermann's letste lepidopterologische Ansbeute, p. 144-155.

Nemeophila Metelkana, 1. sp., 1. 162, 16:, vol. Y', 1861.

Nur logisch! p. 94--96.

Replik., j. 157, 158, vol. VI, 1862.

V'erzeichniss der von H. Joh. und Frum Ludnilla Haberhaner 1861 und 1862 in Bulgarien und Rumelien gesimmelten Lepidopteren, p. 17--27; $40--47$.

Ein 'Wittel' von Bombyx Pini, p. 28.

Beitrag zur Kemntmiss der Pyralidinen, p. 24:3--280; 3931--378; 379--502.

Bücher-Anzeigen, p. 320, vol. VII, 1863.

Zur Jepidopteren-Famna von Imeritien und Grusien, p. 165--172, rol. VIII, 1864.

ILE. Coloured Sipec. Ill. ext:

Jumes Lee, of Hammersmith.

Colomed Sipecinens to illustrate the natural history of hutterflies. London, 1806.

* Isefbr. Ans. Sor. Ent. Fr.

Alexunder Lefebre, born in Paris 1797.

Ammales de la Soeietie Entomologique de France, vol. I', 1836.

llas the following papers on Lepidoptera:

Description de quelques I sépidoptères nowturnes hyperhoréenes, p. 38.$4(1)$.

Description d'une nouvelle espèce de Coliale, p. 38:3-387.

* Inewte. Pap. Grt. Brits.

John Willium Lewin.

The Papilios of Great Britain systematically anranged, accurately engraved, and painted from nature, with the natural history of each species, from a close application to the subject and observations made in different connties of this kingdon; as well as from breeding numbers from the expe or eaterpillar, during the last thirty rears; the figures engraved from the snliects thenselves by the antlior, Wr. Lewin, and painted moler his immediate direction. London, Johnson, 1795.

In English and French. 46 colonred plates of Lepidoptera.

*IINN. FAUN. Suec.

Carl ron Linne, born May 24, 1707; died Jan. 10, 1778.

Fanna Suecieo sintens Animalia sUECLE Regni ; puadrupedial, ares. amphibia, pisces, insecta, relues, distributa per classes, of ordines, genera \& species, cum Differentiis specierum, symonymis Antorun, Nominibus Ineolarmm, Locis Habitationmm, Desipiptionibus Insertorum. Storkhohmice, Isumentii Salvii, 1746.

Inother and enlarged edition was published in 1761.

Editio altera anctior. Stockloolnie, Ialnentii Salvii, 1761.

*Liñ. SYAtr. NAT. X.

Systema Naturae Per Regna tria naturar Seeundum classes, ordines, 
genera, species, Cum characteribus, differentiis, synonymis, locis. Erl. Deeima Reformata. Holmiae, Lamentii Salvii, $175 \dot{8}$.

This is the first edition of the Systema Naturae which contains descriptions of species with the addition of the synonym.

The next edition was published in 1760 :

Arl editionem Decimam Reformatam Hohmiensem. Halae Magdeburgicae. Iohamnes Ioachimus Jangins. MDCCI AS.

*Linn. JoH. Avren. \CAD.

Amoenitates Academicae, Sen Dissertationes varise Physica, Medicie, Antehac seorsim ellite nunc collectse et auctie cum tabulus reneis. Lugluni Batavolum Haak.

Tol. I-VI, 1749-1763.

Insects in vol. VI, p. 384-415.

*Lins. Mus. Lud. Ulur.

Mnsenm S: æ R: a M:tis Ludovicia Uhicix Reginx Svecorum, gothorum, Vandalormmque \&e. \&r. \&e. In quo Animalia Rariora, Exotica, Imprimis Inserta de Comehilia descopibuntur of determinantur. Holmiæ 1764 .

l'art I, 462 pagen, contains descriptions in hatin of Insects of all ordel's from various parts of the world. Part II, p. 468-720, is on Conchology.

*Linn. Sist. Nat. I, 2.

Systema Nitura, Tom. I, Pars. II. Elitio Duodecima Reformata. Holmix 1767.

P. 533-1327, Latin descriptions of Insects of all orders.

*Lins. Mant.

Nantissa Plantarum Altera Crenerum editionis VI\& Specierum alitionis II. Holmiae, Lamrentii Salvii, 1771.

Insects on p. 529-543. Lepid. 534-540.

*Lint. 23n, 24th and 26th Rep. N. Y. Sitate Cab. Nat. Hist.

J. A. Lintner, of the New York State Museum of Natural History, Albany, New York.

Entomological Contributions:

Appendix D \& E, p. 137-222 of the $2: 3$ Anunal Report of the New York State Cabinct of Natural History, for the year 1869. Two lith. plates.

Also printed separately, p. 1-90. Albany, Weed, Pal'sons and Company, 1872.

Entomologieal Contributions No. II :

P. 110-170 of the 24th Report X. Y. State Mus. for 1870.

Separately printed, 1. 1-66. Albany: The Argus Company, Printers, 187:.

Entomological Contributions No. III :

P. 117-119 of the 26th Report N. Y. State Mıs. for 1872.

Separately printed. Albany: The Argus Company, Printers, May, 1\&74.

Two photographic plates of 10 species of Cucullia.

Entomologrial Contributions No. IV:

Printed in advance of the Report. Albany, Weed, Pasons and Company, June, 1878. P. 1-144. 
*Lint. Proc. Ent. Soc. Phil.

In Proceedings of the Entomological Soeiety of Philadelphia are:

Metamorphoses of Ceratomia quadricornis, Harris, p. 286-293, vol. I, 1862.

Notes on some of the Diurnal Lepidoptera of the State of New York, with deseriptions of their Larre and Chrysalides, p. 50-64.

Notes on some Sphingida with deseriptions of their larve and pupæ, p. $645-672$, vol. III, 1864.

*Lint. Trans. Anr. Ent. Soc.

Transactions of the American Entomological Society contains:

Deseription of a new species of Grapta, and notes on G. interrogationis, p. 313-319, vol. II, 1869.

On Graptre Interrogationis and Fabrieii of Edwards, p. 197-204, vol. III, 1870.

*Lint. Can. Ent.

In the Canadian Entomologist are the following:

Hypena Scabra (Fabr.) and H. Erectalis, Guen., p. 81, vol. V, 1873.

On Lycaena Neglecta, Edw., p. 122, 123.

On Orthosia Ralla, Gr. \& Rob., p. 128, 129, vol. VII, 1875.

On Catocala Pretiosa, n. s., p. 121, 122, vol. VIII, 1876.

On a new species of Cossus, p. 129, 130, vol. IX, 1877.

*Lint, Buff. Bull.

In Bulletin of the Buffalo Soe. of Nat. Se. is the

Description of a new species of Calocampa, p. 188, 189, vol. II, 1874. Loche (De). Mem. Acad. Tur.

Conte Francois Mouxy De Loche, born in Aix les Bains. Major-General in Sardinia.

Papillons du Piémont nouvellement connus. (Pap. Polychaon, Phoebus, Themistoeles, Peas, Seyta, Gardetta, Merope, Bertholis, Xenophon).

Vol. XI, p. 139-150 of Mémoires de l'Acad. de 'Turin, 1801.

*Lurde. Pap. Eur.

Hippolyte Lucas.

Histoire naturelle des Lépidoptères d'Europe, ouvrage orne de près de 400 Figures peintes d'après nature par A. Noel. Paris, Pauquet, 1834.

79 coloured plates.

A second edition in 1845 .

*Lueas. Lep. Ехот.

Histoire naturelle des Lépidoptères exotiqnes. Paris, 1835.

Contains 80 coloured plates of Lep. from various parts of the world.

*Lucas. Rev. Zool.

Deseription de nouvelles espèces de Lépidoptères appurtenant aux colleetions entomologiques du Musée de Paris.

In Revue et Magazin Zoologie. Paris. Sér 2, IV, p. 128-141; 189$198 ; 290-300 ; 324-343 ; 422-432,1852 . \quad$ V, p. 310-322, 1853. 
*Lucas. Sagra Hist. Nat. Cuba.

Historie Physique et politique et naturelle de l'Isle de Cuba, Animanx articules. Paris, Bertrand, 1857.

The Lepidoptera by Lucas in above volume comprise pages $475-750$, and illustrated in the atlas with four coloured plates (14-17).

Martyr. Psyche.

Thomas Martyn. Born in Chelsea 1735; died in Patenhall, Bedford, June 3, 1825 .

Psyche: figures of nondescript Lepidopterous Insects or rare Moths and Butterflies from different parts of the World. London, 1797.

Hagen says, Bib. Ent. 523, accorling to Westwood but 10 copies were published.

*Matrard. Am. Nat. VII.

C. J. Maymard.

American Naturalist has the following:

A new species of Butterfly from Florida, p. 177, 178, 1873.

* Mead. Can. Ent.

Theodore L. Mead, in New York.

In the Canadian Entomologist are the following :

Musical Larrae, p. 47, vol. I, 1868.

Extension of habitat of Pieris Rapae, Limn., p. 36.

Larva of Sesia diffinis, p. 157, 158, vol. II, 1869.

Generic Nomenclature, p. 18.

Notes on Collecting, p. 78-80, vol. V, 1873.

Interesting Captures, p. 39, 40.

Notes upon some Butterfly Eggs and Larvae, p. 161-163, vol.VII, 1875.

Notes on some of the genera of Mr. Scudder's "Systematic Revision," p. 232-238, vol. VIII, 1876.

* Mead. IVheeler's ReP. V.

Report upon the Collections of Diumal Lepidoptera made in portions of Colorado, Utah, New Mexico, and Arizona, during the years 1871, 1872,1873 , and 1874, with notes upon all species known to inhabit Colorado, by Theodore L. Mead; and a list of all species collected by W. H. Edwards.

Being chap. VIII and p. 739-794 of vol. V of the

Report upon Geographical and Geological Explorations and Surveys west of the one-hundredth meridian in charge of First-Lieut. Geo. M. Wheeler, Corps of Engineers, U. S. Army, under the direction of Brig.-Gen. A. A. Humphreys, Chicf of Engineers, U. S. Army. Washington: Govermment Printing Office, 1875.

* Meigen. Handbuch.

Johann Wilhelm Meigen, born 1763; died July 11, 1845.

Handbuch für Schmetterlingsliebhaber besonders für Anfünger im Sammeln. Aachen, La Ruelle, 1827.

*Meigen. Eur. Schmett.

Systematische Beschreibung der europäischen Schmetterlinge. Aachen und Leipzig, vol. I-III, 1829-1832.

* Men. Nouv. Meir. Soc. Mosc.

E. Menetries, Director of Entomology in the St. Petersburg Museum. Died in 1861. 
Notice sur quelques Lépidoptères des Antilles avec la description de plnsieur's espèces nouvelles.

Being pages $115-133$ of

Nonveanx Mémoires de la Société Impériale des Naturalistes de Moscon. Dédiés a S. M. l'Empereur Nicolas I. Tome III. Formant le Tome IX de la collertion avec 32 planches. Moscon, de l'Imprimerie d'Auguste Semen, Imprimeur de l'A cadémie Impériale Médico-Chirurgicale, 1834.

* Men. Cat. Mus. Petr. Lep.

Enumeratio corporum animalium Musei imperialis Academiae Scientiarum Petropolitanae. Classis Insectorum. Ordo Lepidopterorum. Petropoli.

Part I, 18.5, 6 coloured plates. Part II, 1857, 8 plates.

*Meriax. Eur. Ixs.

Maria Sibylla Meriun. Born April 12, 1647, in Frankfurt-on-Main; died Jan. 13, 1717, in Amsterdam. Lived in Surinam from 1699 to 1702, where she collected the material for her great work. The drawings of the various insects were made and the plates coloured by herself.

De Europische Insecten, Naauwkenrig onderzogt, na 't leven geschildert, en in print gebragt door Maria Sibylla Merian: Met een Korte Beschrying, war in door haar gehandelt word van der Rupsen begin, Troeitzel en wonderbare I'erandering, en ook rertoont word De Oorspronk, Spys en Gestalt-verwisseling, de Tyd, Platats en Eigenschappen den Rupzen, Uiltjes, Vligen en andere diergelyke bloedeloose Beesjes. Hier is nog bygeroegt Een naawkeurige Beschrrving van de Planten, in dit Werk voorkomende; en de Uitlegging van agtien nienwe Platen, door dezelve Maria Sibylla Merian geteekent, en die men na haar dood gevonden heeft. In't Frans beschreeven door .J. Marrat, Merlicinae Doctor, En door een voornaam Lief hebber in 't Uederduits vertaalt. Tot Amsterdam, by J. F. Bernard, 1730.

Large folio. 84 p. text, in Hollandish, 184 coloured copper-plates; always four plates on one sheet.

Also in French:

Histoire des Insectes de l'Europe, dessincée d'après nature \& expliquée par Marie Sibille Merian: Oul'on traite de la Generation \& des différentes Metamorphoses des Chenilles, Vers, Papillons, Mouches \& autres Insertes; \& des Plantes, des Flenrs of res Fruits dont ils se nourrissent, Traduite du Hollandois en Frangois Par Jean Marret, Docteur en Medicine; Augmentée par le mene d'une Description exacte des Plantes, dont il ent parlé dans cette Histoire; \& des Explications de dix-huit nonvelles Planches, dessinées par le meme Dame, \& qui n'ont point encore paru. Onvage qui contient XCIII Planches. A Amsterdam, Clez Jean Frederic Bernard, 1730.

To the plates of this work is the additional title:

Histoire Generale des Insectes de l'Europe par Mad. De Merian.

*Meriax. Ixs. Sur.

Maria Sybilla Meriaen Orer de Voortteeling en Wonderbaerlyke Veranderingen der Surinaemsche Insecten, waer in de Surinaemsche Rupsen en Wormen, met alle der'zelver Veranderingen, naer het leeven afgebeeldt, en beschreeven worden; zijnde elk geplaest op dezelfde Gewassen, Bloemen, en V'ruchten, daer ze op gevonden zijn ; Beneffens: de Beschryving dier Gewassen. Waer in ook de wonderbare Padden, 
Hagedissen, Slangen, Spinnen, en andere Zeltzame Gediertens worden vertoont, en beschreeven. Alles in Amerika door den zelve M. S. Meiraen naer het leeven, en leevens grootte Geschildert, en me in 't Koper overgebracht. Benevens cen Aenhangsel van de Veranderingen van Visschen in Kikvorschen, en van Kikrorschen in Visschen. t'Amsterdam. By Johannes Ooslerwyk, Bockrerkoper op den Dam in de Bockzael: Alwaer dit werk, als ook de Europeesche Insecten in quarto van dezelve Juffrouw Meriaen naer 'tleven geschildert en afgezet te bekomen zyn. 1719.

Large folio. 72 pages text in Hollandish, 72 coloured copper-plates, and an illuminated frontispiece.

Another edition in Latin and French with following title:

Marice Sibillixe Merian Dissertatio de Generatione et Metamorphosibus Insectorum Surinamensimm: In qua, prater Vermes of Erucas Surinamenses, earumque admirandam metamorphosin, Plantæ, flores of fructus, quibus vescuntur, of in quibus firernt inventse, exhibentur. His adjunguntur Bufones, Lacerti, Serpentes, Arance, aliogne admiranda istius regionis animalicula, omnia manu ejusdem Matronse in America ad vivum accuraté depicta \& nme ari incisa. Aceedit Appendix Transformationnm Piscium in Ranas, of Ranarum in Pisces. Hagre Comitum, Apud Petrum Gosse 1726.

The same title also repeated in French.

Large folio. 68 pages text. 72 coloured copper-plates.

The above two editions I have exanined myself. The first edition of 1705 I have never seen. It has 60 pages text and 60 copper-plates, mostly colonred by Mad. Merian herself, and bears the title-

Metamorphosis Insectorum Suranamensimm. In qua Erucae ac Vemes Suranamensis, crm omnilns suis Transformationibus, ad rivm delineantur et describuntur, singulis eorum in Plantas, Flores et Fructus collocalis, in quibus reperta sunt; tunc etian Generatio Ranarum, Bufonum rariorm, Lacertarm, Serpentum, Araneorum, el Formicarum exhibetur; omnia in America ad rivmm naturali magnitudine pieta atque descripta per Mariam Sibyllam Merian. Amstelodami, Sumtilms anctoris venduntur et apud Gereordmu Yalk, 1705.

(Hagen's Bibl. I, p. 535.)

Meyer-Duer. Schuett. Schiweiz.

L. R. Neyer-Duer in Burgdorf, Switzerland.

Verzeichniss der Schmetterlinge der Sohweiz. I Tagfaltor; mit Berïcksichtigung ihrer Klinatischen Abweichungen nach horizontaler und vertikaler verbreitung bearbeitet, 1852.

Mill. Brit. ENt.

Simeon Werner Millard.

Outlines of British Entomology, in prose and verse. Bristol, 1821.

* Millar Icon. Chen. et Lep.

Pierre Williere, in Lyons.

Icomographie et Description de Chenilles et Iépirloptères inérlits.

In Annales de la Société Limnéenne de Lyon, 1858-1870.

Has most splendid coloured figures of many most extraordinory aburrations, variations, etc. It was also issnerl in separate form under same title.

* Morris. Agr. Ref.

Rev. Dr. John G. Morris, of Baltimore, Lutheran Minister.

The Ailanthus Silkworm. 
In the Report of the U. S. Department of Agriculture, p. 374, 1861. *Morris. Cat. Lep. N. Am.

Catalogue of the described Lepinloptera of North America. Prepared for the Smithsonian Institution, by John G. Morris. Washington: Smithsonian Institution, May, 1860.

*Morisis. Sys.

Synopsis of the described Lepidoptera of North America. Part I : Diurnal and Crepuscular Lepidoptera. Compiled for the Smithsonian Institution. Washington, 1862.

Contains descriptions of most of the, then, known Diurnce, Splingidee and Bombycida. 358 pages.

*Morrison. Buff. Bull.

H. K. Morrison, formerly a shoemaker in Boston; now a dealer in Insects in North Carolina.

In the Bulletin of the Buffalo Society of Natural Seiences are the following of his articles:

Notes on North American Lepidoptera, p. 186-189.

Description of two new Noctuide from the Atlantie Distriet, p. 274, 275, vol. I, 1873-1874.

Deseriptions of new Noctnidae, p. 109-117.

On the Speeies of Calocampa, p. 190-192, vol. II, 1874-1875.

* Morrison. Cax. Ent.

Canatlian Entomologist:

Specifie Nomenelature, p. 70, 71.

Notes on an Interesting Specimen of Pamphila Zabulon, Boisd. \& Lec., 1. 164.

The Law of Priority in Nomenclature, p. 166-168.

Remarks on recent names given to some Lepidopterons Insects, p. 204205, vol. V, 1873.

On Anisopteryx Vernata and Pometeria, p. 29-32.

On two new Species of Noctuidie, p. 105, 106.

A new Species of Ceramica, p. 249-251.

On the Species referred to Orthodes by Guenee, p. 251-254.

Correspondence, p. 259, 260, vol. VI, 1874.

Correspontence, p. 15-17.

Description of a new North American Species of Mamestra, and of a genus allied to Homohadena, p. 90, 91.

On two new Species of Homoptera, p. 148, 149.

Deseription of a new Hadena from the White Mountains, p. 198.

Notes on an interesting variety of Oncoenemis Chandleri, p. 213, 214.

Deseriptions and Notes on the Noctnidre, p. 214-216, vol. VII, 1875.

* Mlorrison. Proc. Acad. Nat. Sc. Phil.

Procedings of the Acadeiny of Natural Science, Philadelphia :

Notes on the Noctuidae, with deseriptions of eertain new species, p. 55$71 ; 428-436$, vol. XXVII, 1875.

* Morrison. Psscue.

Psyche. Organ of the Cambridge Entomologieal Clnb. Cambridge, Massachusetts. 
Interesting Capture, p. 4.

List of Lepidoptera collected at Cliftondale and $\mathrm{W}^{r}$ yoming, Mass., May 30,1874, p. 16.

An Appendage of the male Lencarctia Acraea, 1. 21, 22.

Summer Butterflies at the White Momtains, 1. 25, 26; $: 4,35$, vol. I, 1874.

Notes on White Mountain Noctuidle, p. 41-43.

Varieties of Cleora Pulchraria Minot, p. 68-70.

On the Insect Fauna of the White Mountains, p. 85, vol. I, 1875.

*Moesch. Stett. Ext. Zeít.

Heinrich Benno Moeschler, in Kronforstchen bei Bautzen, Saxony.

Stettiner Entomologische Zeitung.

Contains the following articles:

Beitrag zur Schmetterlingsfanna von Labrador, p. 172-174, vol. IX, 1848 .

Ein Neuer Spanner, Pericallia (Ennomos) Freitagaria, p. 143-145.

Bemerkungen zu einigen Südrussischen Falterarten, 1. 218-2:32; p. 261264, vol. XV, 1854.

Heliothis Nubigera, Friv., p. 211, vol. XVI, 1855.

Butalis Heinemanni, p. 372, 373, vol. XXX, 1869.

Beiträge zur Schmetterlingsfauma von Labrador, p. 113-125; 251-254; $265-272$; 364-375, vol. XXXI, 1870.

Neue Exotische Schmetterlinge, 1. 336-362, vol. XXXIII, 1872.

Beschreibung des Mannes von Lomalosticha Nigrostriata, p. 148, 149. Exotisches, p. 303-313, vol. XXIT, 1874.

Exotisches (a Revision of Synonymic List of N. A. Buttertlies north of Mexico. By S. H. Scudder), p. 202-211; 282-289, vol. XXXVI, 1875.

P. 32-41; 293-315, vol. XXX VII, 1876.

Bericht ïber Boisduval's Spéc. Général, p. 360-362, vol. XXXYII, 1876.

Deutsch Exotisches, 1. 121, 122.

Nordamerikanisches, p. 414-426.

Anarta Tenebricosa, n. sp., p. 498-500, vol. XXX Y 1 I1, 1877.

* Moesch. Terh. Kool.-Botian. Ges.

Verhandlungen Zoologisch-botanischen Gescllschatt.

Beiträge zur Schmetterlings-Famna von Surinam, 1. 293-35.52, (2 plates), vol. XXVI, 1876.

* Moesch. Wien. Monat.

Wiener Entomologische Monatschrift. Verantwortliche Redartenre: Julius Lederer und Luhwig Miller. Wien. vol. I, 1857; II, 1858; III, 1859 ; IV $1860 ; \mathrm{V}, 1861$; VI, 1862; VII, 186.3; VIII, 1864 . Contains the following papers on Lepidoptera:

Acentropus latipennis, Möschler, p. 55.

Vicr nene sïdrussicche Schmettcrlinge, p. 27:-276.

Beiträge zur Lepidopteren-Fauna von Labrador, p. 329-381, vol. IV, 1860 . 
Beitrïge zur Lepidopteren-Fauna von Lahrador, p. 129-139.

Neue südrussische Schmetterlinge, p. 139-143.

Dianthoeeia Christophi, n. sp., 1). 235, 236, vol. VI, 1862.

Bemerkungen zu einigen Sareptan Schmetterlingen, p. 63, 64.

Bemerkungen zu einigen Arten der Gattung Atychia Latr. p. 77-79.

Die zur Fauna von Europa gezählten Arten der Gattung Chionobas, p. $169-193$; 201-217, vol. YII, 1863.

Beiträge zur Schmetterlingsfauna von Labrador, p. 193-200, vol. I'IJI, 1864.

Muell. Voll. Naturs.

Philip Ludwig Statius Mueller, Professor in Erlangen. Born in Esens, Eastfriesland, April 25, 1725 ; died in Erlangen Jan. 5, 1776.

Vollständiges Natursstem des C. v. Linné mit einer Erklärung. Nürnberg $1773-1776$.

* Ochs. $1,1,2 ; \mathrm{II}, \mathrm{II}, \mathrm{IV}$.

Ferdimand Ochsenheimer, Comedian in the Royal Theatre. Born in Mainz 1767 ; died in Vienna Nov. 2, 1822.

Die Schmetterlinge son Europa. Leipzig, hey Gerharl Fleischer dem Jüngern. Tol. I, 1, 1807; I, 2, 1808; II, 1808; IIJ, 1810; IV, 1816.

The work was continued by Friederich Treitsche as

Die Schmetterlinge von Enropa. (Fortsetzung des Ochsenheimer'schen Werks.) Leipzig, bey Gerhard Fleisher. Vol. $\mathrm{Y}, 1,1825,2,1825$, 3,1826 ; VI, 1, 1827, 2, 1828; VII, 1829; VIII, 1830; IX, 1, 18:32, 2, 18:3: ; X, 1, 18:34, 2, 18:35, 3, 1835 .

*Pack. Bost. Jour. Nat. Hist.

A. s'. Puckurd, Jr., Doctor of Medicine, in Salem, Massachusetts.

Boston .Journal of Natural History, vol. I-VII, 1834-1863.

On Synthetie Types in Inserts, 1. 590--60:3, vol. VII, 1863.

*PAik. GEOM.

Monograph of the Geometrid Moths.

Being vol. I of the Report of the United States Geological Surver of the Territories, F. V. Hayden, T. S. Geologist-in-charge. Washingtol1, 1876.

*PACK. GuIDE.

Guide to the Study of Inseets and a treatise on those Injurious and Bencficial to Crops, etc. By A. S. Packard, Jr., M. D. Salem: Naturalist's Book Ageney, 1869.

*Pack. Mem. Bost. Soc. Nat. Hist.

Memoins of the Boston Soeiety of Natural History, vol. I--I1, 1866-1878.

Gynandromorphism in Lepidoptera, p. 409--412, vo]. II, 1870--1878.

* Pack. Proc. Bost. Soc. Nat. Hist.

Proceerlings Boston Sreciety of Nitural History, vol. I-XIX, 1841-1877.

$\checkmark$ 'iew of the Lepidopterous Famma of Labrador, 1) 32--6:3.

Increasing distribution of Canker worm, p. 88, rol. XI, 1868.

Catalogue of the Phalaenidie of California, p. 381-411, vol. X1II, 1871. 
Catalogne of the Phalænidæ of California, No. 2, p. 13-40, vol. XVI, 1874 .

*Pack. Proc. Ent. Soc. Phil.

Srnopsis of the Bombycidie of the United States.

P. 97-130; 331-394, in the Proceedings of the Entonological Society of Philadelphia, vol. [I, 1864.

*PACk. Proc. Ess. INst.

Proceedings of the Essex Institute, rol. I-VI, 1848-1870.

Notes on the family Zygrenicle, p. 7-47. vol. IV, 186t-1865.

*Pack. Rer. PBdr. Acad. Sc.

Report of the Peabody Academy of Science. Pamphlet, 1864-1877.

Record of American Entomology :

Rhopaloceres, p. 112-119, Ann. Report, 1871.

Rhopaloceres, p. 110-116, Ann. Report, 1872.

Heteroceres, p. 74-88, Ann. Report, 1873.

Descriptions of N. A. Phalcenidæ, p. 52-81.

Notes on Moths of the families Phalienidæe and Pvralidae, p. 82-92, Ann. Report, 1872.

*Pali. ReIs. I.

Peter Simon Pullax, born in Berlin Sept. 22, 17+1; died in Berlin Sept. 8, 1811.

Reise durch verscheidene Provinzen des Russichen Reichs in den Jahren 1768-1774. St. Petersburg, 1770-1801.

Large 4 to, 5 vol.

*Paxz. SYst. Nom.

Georg Holffgang Franz Ponzer, Doctor of Medicine. Born at Etzelwangen in the Ptalz 1755; died June 28, 1829.

Systematische Nomenclatur über weiland Herrn Dr. Jacob Christian Schïffer's natïrlich ansgemahlte Abbildungen regenshurgischer Insekten. Erlangen, bey .Johamn Jacol, Palm, 1804.

See Shaef., Icon. Ins.

* Parker. Cin. Ext.

H. H. Purler, Professor at Amherst, Massachusetts.

Canalian Entomologist contains the following:

Description of Hesperia Conspicua, (Edw.) p. 51, 52.

The Nisoniales Butterflies, p. 112, 113, vol. III, 1871.

* Parker. Am. ENT.

The American Entomologist and Botanist, an illustrated Magazine of popular and practical Entomology and Botany, edited by Charles $V$. Riley and Dr. Geore Vasey. St. Louis, Mo.: R. P. Sturlley \& Co., vol. I. $1868-1869$; II, 1870 .

I new Hesperian, p. 271, 272, vol. II, 1870.

*Peale. Lep. Au.

Titian Ramsay Peale, Naturalist and Artist. Born in the Philosophical Hall, Philadelphia, Oct., 1779. Member of the first Scientific Corps for exploration of Territories by the U. S. Government, and accompanied Major S. H. Long's Expedition to the Rocky Mountains in 
1819-'20, and the U. S. Exploring and Surveying Expedition to the South Sea in 1838-'t2.

Lepidoptera Americuna: or, original figures of the Moths and ButterHies of North America, in their various stages of existence, and the plants on which they feed. Drawn on stone, and coloured from nature: with their characters, synonyms, and remarks on their habits and manners. By 'Titian R. Peale, Curator of the Philadelphia Museum. Vol. I. Philadelphia: William P. Gibbons, 1833.

*Pearson. Can. Ent.

C. W. Pearson, in Montreal, Canada.

Canadian Entomologist contains :

Platysamia Colmmbia, S. I. Smith, p. 119, vol. VI, 1874.

Rare Captures, p. 80 .

Grapta Satyrus (Edwards), p. 216, 217, vol. VII, 1875.

List of Bombycidae, ete. (Caulfield and Pearson) 1. 90-92, vol. IX, 1877. Perry. ArCá̃a.

Arcana or Musemm of Nature. London, Stratford, 1810-1811. 2 vols. Perty. Del. Animal.

Maximitian Perty, Professor in the University of Bern.

Delectus animalium articulatorum, quae in itinere per Brasiliam annis 1817, 1820 jussu et auspiciis Maximiliani Josephi Bavariae regis angustissimi peracto, collegerunt Dr. J. B. de Spix et Dr. C. F. Ph. de Martins; digessit, descripsit et pingenda curavit Dr. M. Perty. Monachii, $1830-1834$.

* Petiv. Mus.

James Petiver, Apothecary in London. Died in that city April 20, 1715.

Musei Petiveriani Centuria Prima ( $-\mathbf{X}$ ) Rariora naturae continens: vi\%. Animalia, Fossilia, Plantas, ex Variis Mundi Plagis adrecta, Ordine digesta, et nominibus propriis Signata. A Jacobo Petiver. Londoni: Pauli, 1695-1703.

*Petiv. Gazoph.

Gazophylacii Naturae \& Artis Decas prima (-5). In qua Animalia, Quadrupeda, Ares, Pisces, Reptilia, Inseeta Vegetabilia; Item Fossilia, Corpor’a Marina of Stirpes Minerales è Terra eruta, Lapides figura insignes \&c. Descriptionibns brevibus \& Iconibus illustrantur. Hisce Annexa erit Supellex Antiquaria, Numismata, Gemmae exeisae, \& Sculpturae, Opera Figulina, Incernae, Urmae, Instrumenta varia, Inscriptiones Busta, reliquaque ad rem priscam spectantia: Item Machinae, Effigies Clarorum vivorum, omniarue Arte prodncta. Patronis suis \& Moecenatibus D. D. D. Jacobus Petiver. Londoni, 1702-1705.

* Peteris. Pap. Brite Icon.

Papilionum Brittaniae Icones, nomina, \&e., containing the Figures, Numes, Places, Seasons, \&e, of above eighty Finglish Butter-flies, being all that have hitherto been observed in Great Britain. London, 1717 .

Pod. Ixs. Mus. Graec.

Nicolaus Poda von Neuhaus. Born in Vienna Oct. 4, 172:3; died April 29, 1798. A Jesuit; Prof. Phys. in Gratz. 
Insecta Musei Graecensis, quae in ordines, genera et species, juxta Systema Naturae Linnaei digessit. Graecii, Widmanstad, 1761.

* Poer. C'ente Lep. Cuba.

Prof. Felippe Poey, of Havana, Cuba.

Centurie de Lépidoptères de l'Ile de Cuba. Contenant la description et les figures coloriées de Cent Espèces de Papillons noveaux ou peu connts représentés d'après nature, souvent avec la Chenille, la Chrysalide, et plusieurs détails Microscopiques. Paris, 1832.

Latin and French.

* Poey. Mem. Nat. Hist. Is. Cuba I.

Memorias Sobre la Historia Natural de la Isla de Cuba. Habanna, Acopanadas de sumarios Latinos y extractos en Frances. Habana. Vol. I, 1851 ; II, 1856-1858.

* Poey. Cat. Met. etc. Mem. Soc. Econ. Hab. 2 Ser.

Catálogo metodico y descriptivo de las Mariposis de la Isla de Cuba.

In the Memorias de la Sociedad Economica. Tom. II, III, 2d Series, 1846.

Poll. Bemerk. Churpf. Oek. Ges.

Johann Adam Pollich, born Jan. 1, 1740, at Lautern iu the Pfalz; died Feb. 24,1780 .

Beschreibung einiger Insekten die in des Ritters v. Linne Natursvstem nicht befindlich sind.

Pages 252-287 in Chuptïilz. OEken. Gesellich. 1779.

* Prunner (De). Lep. Pedemontana.

Leonuido De Prumer.

Lepidoptera Pedemontana. 'Turin, 1798.

* Putrair. Proc. Datexport Acad. śc.

J. Duncan Putnam, in Davenport, Iowa.

The following Lepidopterological papers are in the Procerlings of the Davenport Academy of Natural Sciences, Vol. I, 1867-\$876:

No. 1. List of Lepidoptera collected in the vicinity of Davenport, Jowa, p. $17+177$.

No. 2. List of Lepidoptera collected in Colorado during the summer of 1872 , p. 182-187.

No. 3. Report on the Insects collected by Captain .Jones' Expedition to Northwestern Wyoming in 1873, p. 187-191.

No. 4. Report on the Insects collected in the vicinity of Spring Lake Villa, Utah Co., Utah, during the summer of 1875, p. 193-198.

*Quens. ACT. Hol.

Conrud Quensel, born Dec. 10, 1767. at Leyda in Schonen ; died at Carlberg Aug. 2, 1806. Prof. of Natural History in Stockholm.

Beskrifningar öfver 8 nya svenska Dagtjürillar.

P. 268-281 in Kongl. Vetenskaps Academiens nya Handlingar, vol. XII. Stocklolm, 1791.

* Rar. Hist. INs.

John Ray or Wray), Preacher. Born in Blacknotley, Essex, Nov. 29, 1628; died Jan. $7, ? 1704$.

Historia Insectorum. Autore Joanne Raio, Collegii S. 'Trinitatis apud Cantabrigienses, \& Societatis Regiae olim Socio. Opus Posthumum .Jussu Regiae Societatis Londinensis Editum. Cui subjungitur Appen- 
dix de Scarabeis Britannicis, Autore M. Lister, S. R. S. ex MSS.

Musaei Ashmolaeani. Londoni. A. \& J. Churchill, 1710.

*RAnB. AnN. SOC. OBs.

J. Pierre Rumbur, Doctor of Medicine in Fontainblean.

Notice sur plusienrs espèces de Lépidoptères nouveaux du midide la France.

Pages 25.5-268, Anmales des Soc. d'Observation, II, 1829.

*RAuB. FaUn. ENT. AND.

Famne entomologique de l'Andalousie. Paris, Art. Bertrand, 1838-1839. RAMB. CAT. Ler. Axd.

Catalogue Systématique des Lépidoptères de l'Andalonsite. Paris, Baillière, $1828^{\circ}$.

*Rath. Agr. Rep.

S. S. Ratheon, Elitor, in Lancaster, Penna.

In United States Agricultural Reports:

Entomology and its relations to Agriculture, p. 585-620, 1861.

Entomology, p. 372-390, 1862 .

* Reak. Proc. Ext. Soc. Phil. II-VI.

Tryon. Reakint, boin in Philadelphia, Penna.

'The following papers in the Proceedings of the Entomological Society of Philadelphia:

No. 1. Notes on Central American Lepidoptera, with descriptions of new species, No. I, p. 135-142, vol. II, 1868.

No. 2. Notes on Central American Lepidoptera, with descriptions of new species, No. II, p. 345-360, rol. II, 1863.

No. 3. Contributions towards a Monograph of the genus Crocota, p. 371373, vol. II, 1864.

No. 4. Teseription of three new speeies of Limacodes, p. 250-252, vol. III, 1864.

No. 5. Sotes upon Exotic Lepidoptera, diefly from the Philippine Islands, with deseriptions of some now species, p. 443-50t, vol. III, 1864 .

No. 6. Observations on some American Pierinae, p. 216-222, vol. IT', 186.5 .

No. 7. Description of some new species of Danainae, p. 217-223, vol. $\mathrm{T}, 1865$.

No. 8. Deriptions of some new speries of Eresia, 1) 224-227, rol. Y, 1865.

No. 9. Coloradian Butterflies, p. 122-151, vol. VI, 1s66.

* Reak. Proc. ICad. Nat. Śc. Phis.

The following papers in the Proseedings of the Academy of Natural Sciences of Philadelphia :

Descriptions of some new species Diurnal Lepidoptera, 1. 238--249; $331--3+2$, vol. X TIII, 1866.

Continued p. 87--91, vol. XX, 1868.

ReTzITS. GEN. ET SP. INS.

Andreas Johamn Retzius, Prof. of Natural History. Born in Christianstadt Oct. 3, 1742; died in Stockholm Oct. 6, 1821.

(aroli t)e Geer genere et species insectorm of generalissimi anctoris 
scriptis extraxit, digessit, latine quand. partem reddidit, et terminologiam insectorum Limneanam addidit. Lipsiae, Cruse, 178:?.

*Ridings. Proc. Ent. Soc. Phil.

James Ridings, cabinet maker in Philadelphia, Pa. Born in England.

In the Proceedings of the Entomologieal Society of Philatelphia, rol. I, 1861--1863:

Description of a supposerl new speeies of Ageridae from Tirginia, and observations upon Papilio Daunus, Boisd., p. 277, 278.

*Rilet. Ext, Rep. State uf Missouri.

Charles V. Riley, formerly State Entomologist of Missouri; now, Entomologist to the U. S. Department of Agriculture at Washington.

First Annual Report on the Noxions, Beneficial and other Inserts of the State of Missouri, made to the State Board of Agrioulture, et". "Jefferson City, Missouri, 1869.

Second, 1870 ; Third, 1871 ; Fonrth, 1872; Fifth, 187:; Sixth, 1874; Seventh, 1875; Eighth, 1876 ; Ninth, 1877.

*Riley. Ay. ENT.

American Entomologist, an Illustrated Magazine of Popular and Practi(al Entomology. Edited by Benj. D. II alsh and Charles V. Riley. Vol. I, St. Lonis, 1868-1869. Tol. I1, by Charles 'T. Riley and Dr. George Vasey, 1870.

*Rilet. Proc. Bost. Soc. Nat. Hist.

Proceedings of the Boston Society of Natural History, vol. I-XJX, $1841-1877$.

Description of a new Agrotis (A. Morrisoniana), p. 286-288, vol. X Y II. 1875 .

*Riley. Can. Ento

In the Camadian Entonologist are the following relative to I sepidoptera:

How to distinguish between Limenitis Disippus, Godt., and 1. Ursula, Fab., in their preparatory states, p. 52, 53.

Notes, p. 117-119.

Inquilinous Moth I arva in Oalk Galls, p. 195, 196, vol. III, 1871.

The Acom Moth, Holocera glandulella, n. sp., p. 18, 19.

"Polvhistor")" p. 38, 39.

Yamessa Antiopa or Papilio Antiopa:" p. 218, vol. IV', 187.2.

Notes on Hyperehiria Io, (Fabr.) p. 10!, vol. V, 1873.

(On the Insects more partieularly associated with Sarracenia Variolaris (Spotted Trmmet-Ieaf'), 1). 207-214, vol. VI, 18 it.

Pieris V'ernalis and P. Protodice, p. 39, vol. X, 1878.

* Riler. Trans. St. Louis Acad.

The Transations of the Acalemy of Science of St. Imuis, vol. I-III, $1856-1878$.

On a new gents in the Lepidopterous fanily Tineirle, with remarlis on the fortilization of the Yucai, p. 55-64.

Supplementary Notes on Pronulba Ynecasella, p. 17:3--177.

Hackberry Butterflies: Description of the Early Stages of Apatura I vcaon, Fabr., and Apatura Herse, Fabr., with remarks on their syonymr, p. 193--208. 
On the ovaposition of the Yucea Moth, p. 208--210.

Deseriptions and Natural History of two Insects which brave the dangers of Sarracenia vulgaris, p. $235--210$.

Descriptions of two new Moths, p. 240--242.

Remarks on Canker Worms and description of a new genus of Phalrenidxe, p. $273--280$.

Notes on the Yucca-borer, Megathymus I ucce, p. 323--34t.

Further remarks on Pronuba Yuccasella, p. $568--573$.

On the difference between Anisopteryx pometaria, Harr., and Anisopteryx ascularia, W. T., with remarks on the genus Paleacrita, p. 573--577, vol. III, 1878.

*Riler. Proc. Am. Ass. Adv. Sc.

Proceedings Anrerican Association for the Adrancement of Science:

On the Insects more particularly associated with Sarracenia Variolaris, p. $18--25$.

On the summer dormaney of the larva of Phyciodes nyeteis, Dbldy., with lemarks on the natural history of the species, p. 108-112, vol. XXIII, 1874.

Biological Notes on the Army Worm, p. 279--283, vol. X X V, 1876. *Rilet. My. Nat.

The American Naturalist, an Illustrated Magazine of Natural History. Salem, Mass.: Peabody Acad. Sc., vol. I--XI, 1867--1877.

Controlling Sex in Butterflies, (a review of an article by Mrs. Mary Treat, 1. 129, \&e.) p. 513--521.

On the Ovipositor of the Yucea Moth, p. 619--623, vol. VII, 1873.

* Ross. Faun. Etr.

Peter Rossi, Professor in Pisa.

Fauna Etrusca, sistens insecta, quate in provineiis Florentina et Pisana praesertim collegit. Liburni, Thonae Masi, vol. I, II, 1790.

* La sagr Hist. Cub. Axim. Art.

Ramon de la Sagra, Director of the Botanical Gardens of Havaua. Born in Coruna 1798.

Histoire Physique, Politique et Naturelle de l'Ile de Cuba par M. Ramon de la Sagra. Animaux Artieulés a pieds irticulés p. M. F. E. Guérin-Méneville. Paris, Arthus Bertrand, 1857.

*Saunders. Can. Ent.

W. Sumders, Apothecary in London, Ontario, Canada.

The Canadian Entomologist contains the following articles on Lepidoptera :

Entomological Notes: Paper No. I, p. 3--(;.

Entomological Notes during a trip to Sagnenary, p. 11--13.

Description of the Larva of Callimorpha Lecontei, p. 20.

Entomologral Notes: Paper No. III, p. 5:)--57; No. I V, p. 65--67; No. Y.p. 73--77; No. VI, p. (13--101.

Notes on the Larva of Pramcis Huntera, Sunith, p. 105, 106, vol. I, 1868.

On a supposed new Aretian, p. 4, 5.

Notes on Alaria Florida, Guén., p. 6, 7.

Notes on Halena Xylinoides, p. 3:3, 34. 
On the Larva of Theela Inorata, G. \& R., p. 61--64.

On the Larve of some Lepidoptera, p. $74--76$.

Hints on describing Caterpillars, p. 94.

Entomological Gleanings: Paper No. 1, p. 111--113; No. 2, p. 126-129 ; No. 3, p. 146--149.

Notes on the Larva of Ophiusa Bistriaris, Hïbner, p. 130.

On Neonympha Eurythris, Fab., p. 139--142.

On the Larva of Diphthera Deridens, Guénée, p. 145, 146, vol. II, 1870.

Hints to Fruit Growers: Paper No. 1, p. 12, 13 ; No. 2, p. 25--27; No. 3, p. $66--70$; No. 4, p. 149--155.

Entomological Gleanings: Paper No. 4, the eggs of the Vaporer Moth, Orgyia leucostigma, p. 14, 15.

On the Larva of the Peach Borer (Egeria Exitiosa), p. 22, 23.

Notes on Lepidopterous Larve, p. $35-37$; 225-227.

Notes on the Egg and young Larva of Alaria Florida, p. 76.

Notes on the Larva of Priocycla Armataria, Herr.-Sch., p. 130, 131.

On the Swarming of Danais Arehippus, p. $156,157$.

Notes on the Larva of Halesidota Maculata, Harris, p. 186.

Notes on the Larva of Agrotis Depressus, Grote, p. 193.

On the Larva of Hyperetis Alienaria, Herr.-Sch., p. 209, 210, vol. III, 1871.

Smerintluas Modestus, p. 36.

Notes on the Jarva of Acronycta Occidentalis, Grote, p. 49-52.

Notes on Argynnis Cybele, p. 121-123.

Hints to Fruit Growers: Paper No. 5, p. 133--136.

Notes on the Eggs and young Larva of Melitæa Harrisii, p. 161--163.

Melitrea Harrisii, p. 237, vol. IV, 1872.

On some of our Common Insects: Paper No. 1, (Danais Plexippus), p. 4-8.

On the Larva of Plusia Balluca, p. 10, 11.

The Isabella Tiger Moth, Pyrrharctia (Spilosoma) Isabella, p. 75-77.

The Grape Vine Phume, Pterophorus periscelidactylus, p. 99, 100.

Notes on the Larva of Cosmia Orina, Guen., p. 206.

The Clouded Sulphur Butterfly, Colias Philodice, Godt., p. 221--223, vol. $\mathrm{V}, 1873$.

'The Tiger Swallow 'Tail, Papilio Turnus, Linn., p. 2--5.

The Americau Copper Underwing, Amphipyra Pyramidoides, Gnen., p. $27,28$.

Notes on the Larva of Boarmia Larvaria, Gnenee, p. 32, 33.

The Disippus Butterfly, Limenitis disippus, Godt., p. 46--49.

The Currant Geometer or Measuring Worm, Ellopia (abraxis) ribearia, Fitch, p. 138, 139 .

On the Larva of Catocala Ultronia, Hübn., p. 147--149, vol. VI, 1874.

The Green Grape-rine Worm, Amphipyra pyramidoides, p. 14, 15.

The Beautiful Wood Nymph, Eudryas grata, p. 41--44.

The Beantiful Deiopeia, Deiopeia bella, p. 85, 86 .

Drasteria erichtea, Cram., p. 115--117.

Insect Captures, p. 139, 140.

Meetings of the Entomological Club of the American Association for the Advancement of Science, p. 177--185, vol. VII, 1875. 
Notes on Catocalas, p. 72--75, vol. VIII, 1876.

The Luna Moth, Actias Luna, Linn., p. 32, 33.

On Deilephila Chamænerii and Lineata, p. 63--67.

Clisiocampa Sylvatica, the forest tent Caterpillar, p. 158, 159.

Cisthene Subjecta, p. 160.

Food-plant of S. Cecropia, p. 160, vol. IX, 1877.

Observations on the Eggs of Clisiocampa Sylvatica and Amerieana, p. $21--23$.

On the Food-plants of Papilio Cresphontes (Thoas), p. 48-50, vol. X, 1878.

*Saunders. Packard's Guide.

Deseribes Papilio Brevicauda in a foot-note on p. 245--246 in Guide to the Study of Insects, by A. S. Packard, Jr., 1869.

*Saunders. Ċan. Nat. \& Geol.

The Canadian Naturalist \& Geologist, and Proceedings of the Natural History Society of Montreal, vol. I--VIII, 1857--1863.

List of Diurnal Lepidoptera collected in the immediate vicinity of London, C. W., p. 130--132, vol. VII, 1862.

*SAY. An. Entr.

Thomas Say, born in Philadelphia, Pa., July 27, 1787; died Oet. 10, 1834. One of the founders of the Academy of Natural Sciences of Philadelphia.

American Entomology, or Descriptions of the Insects of North America. Illustrated by Colonred Figures from Original Drawings executed from nature. S. A. Mitchell. Vol. I, plates 1--18, 1824; II, plates 19--36, 1825; III, plates 37-54, 1828.

There was a previous edition published in 1817 which is scarcely known, being very rare. A later edition was issued by Dr. Le-Conte under the title of

The Complete Writings of Thomas Say on the Entomology of North Ameriea. With a Memoir of the Author by George Ord. New York, Bailliere Bros, vol. I, II, 1859.

*SChaEF. ICON. (or ICON INS.).

Jacob Christian Schaeffer, Doctor of Theology in Regensburg. Born in Querfurt May 30, 1718 ; died in Regensburg Jan. 5, 1790.

Icones Insectorum Ratisbonensium methodo systematica illustratre et Indice Systematico auctie a D. Georg. Wolfgango Frantisco Panzero. Editio nova Erlangae, J. J. Pálmii, 1804, 3 vol.

I have not been able to see the first edition cited by Hagen (Bib. Ent. I, p. 114) under the title

Icones Insectorum cirea Ratisbonam indigenorum coloribus naturam referentibus expressa.

Vols. I-III, 1766-1779.

*SChN. SYST. Beschi.

David Heinrich Schneider, Lawyer in Stralsund.

Systematische Beschreibung der Europäischen Schmetterlinge. Halle, Henmerde, 1787.

*Schneider. Neu. Mag.

Neueste Magazin für die Liebhaber der Entomologie. Stralsund, Struck. Part I, 1791 ; II, III, IV. 1792; V, 1794. 
*SCOP. Ent. CARN.

Johann Anton Scopoli, born at Cavalese in Tyrol June 13, 1723; died in Pavia May 8, 1788. Professor of Chemistry and Botany in Pavia. Was blind the last year of his life.

Eutomologia Carniolica exhibens insecta Carnioliae indigena et distributa in ordines, genera, species, varietates, methodo Linncana. Vindobonae, Trattner, 1763.

*Scud. Ent. Notes, etc.

Samnel H. Scudder, in Cambridge. Massachusetts.

Entomological Notes in Proceedings of the Boston Society of Natural History :

A chronological index to the Entomological Writings of Thaddeus William Harris, p. 213-222, vol. VII, 1859-1861.

Notice of some North American species of Pieris, p. 178-185, vol.VIII, 1861-1862.

On the genus Colias in North America, p. 103-111, vol. IX, 1862-1863.

Supplement to a list of Butterflies of New England, p. 375-384.

Notes on Crysophanus Dione, \&c., p. 401.

Deseription of a new Butterfly from Florida, p. 435, 436, vol. XI, 1868.

Report on a collection of Diurnal Lepidoptera made in Alaska by the Scientific Corps of the Russo-American Telegraph Expedition, p. 404408, vol. XII, 1868-1869.

Ocelli in Butterflies, p. 165, 166, vol. XVI, 1873.

Report on Butterflies from Dakota and Montana, p. 86-91.

Remarks on the old genus Callidryas, p. 206-209.

Description of some Labradorian Butterflies, p. 294-314, vol. XVII, 1875.

On the Butterflies of Cape Breton Island, p. 188-190, vol. X VIII, 1875.

*Scud. Proc. Essex Ixst.

Proceedings of the Essex Institute, vol. I-IV, 1848-1869:

A List of the Butterflies of New England, p. 161-179, vol. III, 18601863.

*Scud. Bost. Jour. Nat. Hist.

Boston Journal of Natural History, vol. I-YTI, 1834-1863.

Remarks on some characteristies of the insect fauna of the White Mountains, p. 612-631, vol. VII, 1863.

*Ścud. Mem. Bost. Soc. Nat. Hist.

Memoirs read before the Boston Society of Natural History, vol. I-II, 1869-1878.

Speeies of the Lepidopterous genus Pamphila, p. 341-353.

The Structure and Transformations of Eumæus Atala, p. 413-419, vol. II, 1878.

*Scud. Trans. Chicago Acad. Sc.

Transactions of the Chicago Academy of Sciences, vol. I, 1869.

A preliminary list of the Butterflies of Iowa, p. 326-337, vol. I, 1869. 
*Scud. Am. NAt.

The American Naturalist, vol. I-XI, 1867-1877.

The insects of Ancient America, p. 625-631, vol. I, 1867-1868.

The Curious History of a Butterfly, p. 513-518.

Fossil Insects from the Rocky Mountains, p. 665-668, vol. VI, 1872.

The Preservation of Caterpillars by Inflation, p. 321-326, vol. VIII, 1874 .

A cosmopolitan Butterfly-Its Birth-place, p. 392-396; Its History, p. $602-611$, vol. $\mathrm{X}, 1876$.

*Scud. Can. Ent. I-X.

The Canadian Entomologist. Edited by the Rer. C. J. S. Bethune, M. A., etc. Vol. I, 1869 ; II, 1870, in Toronto, Canada. Vol. III, 1871 ; IV, 1872 ; V, 1873, in London, Canada. The following five volumes were edited by $\mathrm{W}$. Saunders, and also published in London, Canada: Vol. VI, 1874; VII, 1875; VIII, 1876 ; IX, 1877 ; X, 1878.

In the above are the following articles relating to Lepidoptera:

Rearing Butterflies from the Egg, p. 156, vol. II, 1870.

On the Embryonic Larva of Butterflies, reprinted from "the Entomologist's Monthly Magazine," volume viii, p. 45-49.

Abbott's Notes on Georgian Butterflies, p. 73-77.

A variety of Pieris Rapæ unknown in Europe, p. 79.

Abbott's Notes on Georgian Butterflies, continued from page 77, p. 8487 , vol. IV, 1872 .

Canons of Systematic Nomenelature for the higher groups, p. 55-59, vol. $\mathrm{V}, 1873$.

The Food-plants of European Butterflies, p. 21-25.

The Preservation of Caterpillars by Inflation, p. 107-111.

The Food-plants of European Butterflies, Second Notice, p. 126, 127.

The Linnean signification of the generic term Papilio, p. 143-145, rol. VI, 1874.

The North American Blue Butterflies of the genus Nomiades, p. 21-24.

The Relationship of the early spring Blues, p. 61-65.

On the Seasons of the species of Cyaniris in New England, p. 65, 66, vol. VIII, 1876.

* Scuj. Proc. Am. Ac. Bost.

Proceedings of the American Academy of Arts and Sciences, Boston. Vol. I-X II, 1846-1877.

Historical Sketch of the generic names proposed for Butterflies, p. 91293, vol. X, 1874-1875.

Antigeny or Sexual Dimorphism in Butterfies, p. 150-153, vol. XII, 1876-1877.

*Scud. Repts. Peabody ACad.

Reports of the Peaborly Academy of Science. Pamphlet, 1869-1877.

A Systematic Revision of some of the North American Butterflies, with Brief Notes of those known to oceur in Essex Co., Mass., p. 21-92, 4th Annual Report, 1871. 
Record American Entomology, Rhopaloceres, p. 68-73, Report 1874. *Scud. Syst. Rev. Am. Butt.

A Systematic Revision of the American Butterflies, with brief notes on those known to oceur in Essex County, Mass.

Being p. 24-82 of the Report of the Peabody Academy of Science for 1871 .

It was also printed separately in pamphlet form, p. 1-62. Salem, Mass., 1872.

*Scud. BufF. Bull.

Bulletin of the Buffalo Society of Natural Sciences.

Has the following articles:

The two Principal Groups of Urbicolae (Hesperidae auct.) p. 195, 196.

Note on the species of Glaucopsyche from Eastern North America, p. 197,198 , vol. I, 1873-1874.

Synonymic List of the Butterflies of North Ameriea, north of Mexico, p. 233-269, vol. II, $187 \mathrm{t}-1875$.

Synonymic List of the Butterflies of North Ameriea, north of Mexico: Part II, Rurales, p. 98-129, vol. III, 1875-1876.

*Scud. Hist. Sketch Gen. Names, etc.

Historical Sketch of the Generic Names proposed for Butterflies (from the Proc. of the An. Acad. Arts and Sc. Bost.). Salem, 1875.

*Scud. Psyche.

Psyche: Organ of the Cambridge Entomological Club.

English Names of Butterflies, p. 2, 3; 10, $11 ; 31 ; 40 ; 43,44 ; 56$.

Collecting in the White Momtains, p. 7.

Arrest of Development, p. 12.

Early spring Butterflies at the White Mountains, p. 13. 14; 18, 19.

Butterflies attracted by Lamp-light, p. 28.

A North Greenland Butterfly, p. 57-59.

On Eumenia Atala, p. 120, vol. I, 1875.

Chrysalis with Attached Larval Head, p. 131, 132.

Pieris Rapæ in mid-ocean, p. 152.

Mimicry, p. 160.

Prothoracic Tubercles in Butterfly Caterpiliars, p. 168.

Guadaloupe Orthoptera and Butterflies, p. 168, vol. I, 1876.

*Scud. Proc. Ent. Soc. Phil.

Proceedings Entomological Society of Philadelphia.

Revision of the hitherto known species of Chionobas in North America, p. 1-28, vol. V, 1865 .

*Scud. Trans. Ay. Ent. Soc.

Transactions of the American Entomological Society.

On the Classification of Butterflies, with special reference to the position of the Equites or Swallow-tails, p. 69-80, vol. VI, 1878.

*Scud. Hayder's Bull. U. S. Geo. Sur.

Notice of the Butterflics collected by Dr. Edward Palmer in the arid regions of Southern Utah and Northern Arizona during the summer of 1877 . 
Being pages 253-258 in the Bulletin of the United States Geologieal and Geographical Survey of the Territories, F. V. Hayden, United States Geologist-in-Charge, vol. IV, NTo. 1, 1878.

*Seba. Thes. IV.

Albert Seba, Apothecary in Amsterdam. Born May 2, 1665, in Etzeln; died in Amsterdam May 3, 1736.

Description exacte des principales enriosites naturelles du magnifique Cabinet d'Albert Seba. Tome quatrieme et dernier.

Locupletissimi Rerum Naturalium Thesaru aceurata deseriptio et iconibus artificiasissimis expressio per universam physices historiam. Opus, cui, in hoe rerum genere, nullum par exstitit, ex toto terrarum orbe collegit, digessit, descripsit, et depingenchum curavit Albertus Seba, etc., etc. Tomus IV. Amstelaedani, apud H. C. Arksteum et H. Merkum, et Petrum Schouten, 1765.

Large folio; pages 226; plates 108; text Latin and French. This fourth vol. is the only one devoter to Insects. The three previous volumes treat and illustrate Birds, Mammals, Plants, etc., etc., etc.

Sepp. Surin. Vhlind. III.

Christian Sepp, copper-plate engraver. Born in Goslar; died in Amsterdam.

Surinaamsche V'linders, naar het, leven geteekned. Amsterdam.

Vol. I, 1848 ; II, III, 1855.

*ShaW-Nodd. Nat. Miss.

George Shan, born in Bierton Dec. 10, 1751; died in London July 22, 1813. Librarian in the British Museum.

The Naturalist's Miscellany : or Coloured Figures of Natural Objects; drawn and deseribed immediately from nature.

Vivarium Nature, sive Rerum Naturalium variæ et vividæ icones ad ipsan naturam depicte et deseripte.

George Shaw. Copper-plates by Frederiek Nodder. 24 vol., 1790-1813. *SHAw. ZOOL.

General Zoology of Systematic Natural History. With plates from the first anthorities and most select specimens engraved by Mr. Heath \& Mrs. Griffith.

Vol. I-XIV, 1800-1826.

Vol. VI, 1806, contains the Insects.

*Sloane. Jamaica (or Hist. Jamaica).

Sir Hans Slotme. Born in Killileagh, Ireland, April 16, 1660; died at Chelsea, Eng., Jan. 11, 1752. Sojourned some time in the West Indies.

A Voyage to the Islands Madera, Barbados, Nieves, S. Christophers and Jamaiea, with the Natural History of the Herbs and Trees, Four-footed Beasts, Fishes, Birds, Insects, Reptiles, etc., of the last of those Islands; to which is prefixed An Introduction, wherein is an account of the Inhabitants, Air, Water, Diseases, Trade, \&e., of that Place, with some Iiclations concerning the Neighboring Continent, and Islands of Ameriec. Illustrated with The Figures of the Things described, which have not been heretofore engraved; In large Copper-Plates as big as the Life. By Hans Sloane, M. D.; (in vol. II. By Sir Hans Sloane, Bart.). In Two Volumes. Many shall run to and fro, and knowlledge shall be increased. Dau. xii. 4. London, vol. I, 1707; II, 1725 . 
*SPEyEr. IsIS.

Dr. Adolph Speyer.

Isis von Oken, vol. I-XLI, 1817-1843. Leipzig, bey Brodhaus.

Lepidopterologische Beitrïge :

I. P. 277-314, vol. XXXI, 1838.

II. P. 89-126, vol. XXXII, 1839 .

III. P. 161-207; 243-264, vol. XXX VI, 1843.

IV. P. 816-864, vol. XXX VIII, $1845 ; 19-48 ; 84-116$, vol. XXXIX, $18 \pm 6$.

*Speyer. SteTt. Ent. Zeit.

Entomologische Zeitung herausgegeben von dem Entonologischen Vereine zu Stettin, vol. I-XXXVIII, 1840-1877.

Zur naturgeschichte der Talaeporia liehenella Zell (Psyche triquetrella Tr.), p. 18-21, vol. VIII, 1847.

Kritische Bemerkungen zu Herrick-Schaffer's Systematischer Bearbeitung der Schmetterlinge von Europa, \&e. 1. Bd. Tagschm. Regensberg 1845 , p. $67-76 ; 136-144$, vol. IX, 1848.

Zur naturgesehichte zweier pterophoriden (Lep.), p. 2t--27, vol. X, 1849.

Aufruf zur Bitte um Unterstutzung zur Uebersicht der geosraphischen Verbreitung der Schmetterlinge in deutschland, 1) 126, 127, rol. X, 1849 ; p. 406, 407, vol. XI, 1850 ; p. 205--207, vol. XX, 1859.

Ueber die V'erbreitung d. Schmetterlinge in deutschland Fin Beitrag zur Zoolog. Geographie, (mit Angust Speyer, ) p. 225--296, vol. XI, 1850 ; p. $273--288$; 313--328; 337--367, rol. XIII, 1852.

Eine Exeursion auf den Patscher Kofel bei Innisburck, p. 329--340, vol. XII, 1851 .

Literatur Anzeige v. H-Schaffer's Werk, Syst. Beschreibung der Schmetterlinge r. Emropa, 1856 vollendet. 6 Bide. (4333 Arten Excl. Nachtrage) p. 383--385, vol. XVII, 1856.

Verzeichniss der in Fürstenthume Waldeck im geflügclten zustande äberwinterden Schmetterlinge, p. 74--8:3, vol. XIX, 18.58.

Ueber Noetua (Cneullia) Iactucas IT. Terz und die mit ihr verwerhselten Arten, p. 83--93, vol. XIX, 1858.

Ueber die Naturgeschichte und die Artrechte r. Noctua Cerasina Tr. (N. Castanea Esp.) p. 105-110, vol. XIX, 1858.

Lepidopterologische Beobachtungen auf Einer Wanderung über das Stilfser Ioch. (August) p. 12--34, vol. IX, 1859.

Aufforderung wegen Untersutzung zur Forderung des Nerkes: "Geograph :- Yerbreitung d. Schmetterlinge Deutsehland und der Schweiz.," p. 205--207, vol. XX, 1859.

Besprechung von: "Die schmetterlinge deutschland und der Schweiz, systematisch bearbeitet $\vee . H . ~ V$. Heineman 1859. Besplochen nnd mit gelegentlichen Systematischen Bemerkungen begleitet v. Ir. A. Speyer, p. 57--87, vol. XXI, 1860.

Einige Lepidopterologische Beobachtungen und Bemerkungen, p. 369-375, vol. XXI, 1860. 
Kritische Bemerkungen zu dem Catalog der lepidopt. Europas und der angrenzenden Länder von Standinger und Wocke, Dresden 1861, p. 161--171, vol. XXIII, 1862.

Psyche tenella, nov. sp., p. 212--215, vol. XXIII, 1862.

Zur Yertheidigung (Lederer), p. 480, 481, vol. XXIII, 1862.

Weitere Bemerkingen zu dem Catalog. der lepidopteren Europas, U. S. W. von Standinger und Wocke, p. 84--96, vol. XXIV, 1863.

Zu Seite 336 и. 339 des Jahrg. 1862 der Weiner Entom. Monatschrift (gegen Lederer) p. 126, 127, vol. XXIV, 1863.

Lepidopterologisehe Beobachtungen (acid. rustic., Lycaena polona, acid. corsival.) p. 126, 127, vol. XXIV, 1863.

Beitrïge zur Schnetterlingskunde, Recension von Weinburg's Krit. Bearbeitung der Wichtigsten Entomologisehen Werke des 17 und 18 Jahrh. Erfurt 1864, p. 48--54, vol. XXVI, 1865.

Lepidopterologische Mitheilungen :

1. Erebia nerine, Reichlini, Morula, p. 241--248.

2. Erebia Triopes Gorge's var., p. 248, 249.

3. Psyehe (0)eopsyche) Tenella sp., p. 249--252.

4. Ueber Einige in Freyer's neuern Beitrïgen zur Schmetterlingekunde publicirte Arten, p. 253--268, vol. XXVI, 1865.

Lepidopterologische Mittheilungen:

1. Melit. Parthenie Borkh., p. 65--71.

2. Nemoria Viridata L. u. Porrinata Z., p. 71, 72.

3. Zonosoma (Calsera) Subpunctaria, Zell., p. 73.

4. Cilix ruffa L. (Spinula W. V.) p. 73.

5. Caradrina Sericea n. sp., p. 73--76, vol. XXYIII, 1867.

Bemerkungen über Einige Englische Schmetterlinge, p. 125-128, vol. XXVIII, 1867.

Lepidopterologische Mittheilungen :

1. Gnophos Opthahnicata, Led. 11. Einige Verwandte Arten, p. 349--357.

2. Gnophos Serotinaria, H., p. 416--418, vol. XXVIII, 1867.

Ennychia Minutallis, n. sp., p. 111, 112, vol. XXIX, 1868.

Notizen (Lepidopt.) p. 81--83, vol. XXX, 1869.

Zwitter Bildungen bei Sphinx Nerii und Einige Worte über den Hermaphraditismus der insecten überhanpt (Bienen p. 254) p. 235--255, vol. XXX, 1869. (Cf. p. 77, vol. XXXI, Nachtrag.)

Enpitheeia Actacata n. sp., p. 395--400, vol. XXX, 1869.

Bemerkmngen ïber den Bau und die Systematisehe Stellung der gattung Acentropus Cnrt., p. 400--406, vol. XXX, 1869.

Ueber Setima aurita-ramosa und die Bildung Montaner Varietïten, p. 63--76, vol. XXXI, 1870.

Nachtrag zu den Benerkungen ïber den Hermaphroditismus der insecten (Cif. p. 245, vol. XXX) p. 77, vol. XXXI, 1870.

Zur Genealogie der Schmetterlinge (mit zasats zu dem über Parap. Stratiotata aus dem Treitschkesehen auszuge mitgetheilthen V. D. Red., p. 223,224 , ) p. 202--223, vol. XXXI, 1870. 
Europäisch amerikanische Verwandtsehaften (C'nc. intermedia 11. sp. und C. lueifuga W. V.) p. 400--406, vol. XXX I, 1870.

Lepidopterologisehe Notizen, p. 169--175, vol. XXXIII, 1872.

Lepidopterologische Notizen, p. 357--365, vol. XXXIV, 1873.

Ein interessanter Zwitter von Zygaena Trifolii E. p. 98--103, rol. XXXV, 1874.

Europäisch amerikanisch Verwandtschaften, p. 97--127; $131-175$; 345-351, vol. XXXVI, 1875.

Anzeige von Grote's Check List, p. 198--204, vol. XXX V II, 1876.

Ueber Zygänen, p. 40--51, vol. XXXVIII, 1877.

*Staint. Man. Brit. Butt.

Henry Tibbats Stainton, at Mountsfield, Lewisham near London. Born in London Aug. 13, 1822.

A Mannal of British Butterflies and Moths. London, Van Voorst. In two vol. I, 1857 ; II, 1859.

*Steph. Ill. Brit. Ext. Haust. I-IV.

James Francis Stepliens, born in London Sept. 16, 1792; died Dec. 22, $185 \%$.

Illustrations of British Entomology, or a Synopsis of Indigenous Insects :

Containing their Generic and Specific Distinetions; with an account of their Metamorphoses, times of Appearance, Localities, Food and Economy, as far as practicable, embellished with coloured figures of the rarer and more interesting species. Hanstellata. London, Baldwin and Cradock. Vol. I, 1828; II, 1829 ; III, 1829; IV, 1834 . Supplement, $18+6$.

*Steph. Cat. Brit. Ins.

A Systematical Catalogue of British Insects; being an attempt to arrange all the hitherto discovered indigenous insects in accordance with their natural affinities; containing also the references to every English writer on Entomology, and to the principal foreign authors; with all the published British genera to the present time. I condon, Baldwin, 1829 .

*Stgr. Śtet't. ENT. Zeit.

Dr. Otto Staudinger, in Blasewitz bei Dresden, Saxony. Born May 2, 1830.

Entomologische 'Leitung heransgegeben von dem Entonologischen Vcreine zu Stettin, vol. I-XXXVIII, 1840-1877.

Beitrag zur Lepidopteren Fauna v. ober Kärnthen, 1. 374-379, rol. XVI, 1855. Fortsetsung, p. 37-46, vol. X VII, 1856.

Beitrag zur Feststelhng der bisher bekannten Serien Arten Europa's und des angrenzenden Asiens, p. 145-176; 193-224; 257-288; 323338, vol. XVII, 1856.

Reise nach Island zu Entomologischen Zwecken Untemomen 1856, p. 209-289, vol. XVIII, 1857.

Beitrag zur kentniss der Nordischen anarta Arten, p. 289-298, vol. XYIII, 1857.

Beitrag zur Lepidopteren Fauna Grönlands, p. 299-308, vol. X YIII, 1857 . 
Diagnosen nebst kurzen beischreibungen nener Andalusischen Lepidopteren, p. 211-259, vol. XX, 1859.

Zur Rechtfertigung, p. 259-270, vol. XX, 1859.

Erklärung, p. 421, vol. XXI, 1860.

Ueber Einige neue und bisher Verwoehselte Lepidopteren, p. 287-293, vol. XXII, 1861.

Reise nach Finnmarken, p. 325-341, vol. XXII, 1861.

Macrolepidopteren v. Standinger, p. 342-404, vol. XXII, 1861.

Microlepidopteren von Dr. Wocke, p. 30-78; 233-257, rol. XXIII, 1862.

Ueber Einige nene Greichlische Lepidopteren, p. 257-271, vol. XXIII, 1862.

Die Arten der Lepidopteren Gattung, "Ino, Leach." nebst Einige Vorbemerknngen ueber Local Varieten, p. 341--359, vol. XXIII, 1862.

Eine nene Europäische Lepidopteren, p. 264--271, vol. XXIV, 1863.

Bemerkungen ïber dic Arten gattmo Colias, p. 44--50, vol. XXVII, 1866.

Drei nèue Sesien nnd Berichtignno neber Einige älten Arten, p. 50--55, vol. XXIII, 1866.

Zur gattung Heliorles, p. 56, 57, vol. XXVII, 1866.

Einige nene Lepidopteren, p. 310, 311, vol. XX VII, 1866.

Gelechia Petaitella und Phyllobrostis Hartmanii, p. 210--212, vol. XXVIII, 1867.

Bermerkung über Guophos Meyeriria, p. 35, vol. XXIX, 1868.

Bermerkung über Einige /weifelhafte oder verkannte Iepidoptera, p. 84--9:, vol. XXX, 1869.

Antheraea Gueinzii Eine neue Saturnide von P'ort Natal, 1) 120--12:3, vol. XXXII, 1872 .

Einige nene Lepidopteren des Europäischen Faunengeliets, 1. 87--98, vol. XXXT, 1874.

Ueber Cupido Fylgia, p. 235, vol. XXXVII, 1876.

Nene Lepidopteren des Europäirchen Fannengebiets an meiner Sammlung, p. 175--208, vol. XXXYIII, 1877.

* Stgr. WiEN. HeNt. Monat.

Wiener Entonologische Monatschrifte, vol. I-- Y III, 1857--1864.

Pieris Kruperi, Eine none Europäische 'Taytalter, p. 19, 20, vol. 11', 1860 .

*Stgr. Verh. '/onl. Bote. Ges.

Terhandlungen der Kariserlich Koniglichen Zoologrische Botanischen Gesellschatt in Wien. vol. I--XXYI, 1852--1877.

Drie nome Osterriehische I tepidopteren, p. 73:-736, rol. XXII, 1872.

Teue Lepidopteren des sudamericanisehen Fammengebiets, p. 89--124, vol. XXV, 1875 . 
*StgR. CAT.

Catalon der Lepidopteren des Europeischen Hannengebiets. I, Marrolepirloptera loarbeitet rou Dr. O. Standinger. II, Microlepidoptera bearbeitet von Dr. M. Wocke. Dreslen, Jin., 1871.

Pages 426. In German and French.

* Stoli. Sup. Ciram.

Casper Stoll, dierl in 1795.

Aanhangsel ran het Werk, de Uitlandsche Kapellen, vook komende in de drie Waereld-reelen Asia, Africa en Ameria, door den Heere Picter Cramer, rervattendo natuwkeurige af beeldingen van Surinaamsche Rupsen en Poppen; als mede ran reele zolzame en nienwe ontclekte Uitlandsche Dag en Niugt-Kapellen. By cen verzameld en beschreeren door Caspar Stoll Lid van het Natuurönderzockend Genoodschap te Halle onder dezelfs opzigt allen naw het leven getekend, in het koper gebragt en net Natuurlyke Koleuren afgetekend. A. Amstelam, chez Nic. Th. Graviss, 1791.

Published as Supplement to Cramer's Papillons Exotiques. [n Hollandish and French. *STRECK. LEP. RHOP.--HET.

Ferdinand Heimich Herman itrecker, Sculptor, in Reading. Born in Philadelphia March 24, 1836.

Lepidoptera Rhopaloreres and Heteroceres, Indigenons and Exotic. ITith colonred illustrations. Reading, Pa.: Printed for the Author. Vol. I, Parts 1--15, 1872--1878.

Part 1. Samia Gloveri, n. sp., (4 fiess.) p. 1--7.

Notes relative to some varieties of Lepiloptera, 1. 8, Jan., 1872.

2. Descriptions and (8) tigures of four species (one new) of Diurnal Lep., p. 9-- 15 .

Notes on some species, p. 15, April, 1873.

3. Descriptions and (11) figures of ten (two new) species of Catocalae, P. $17--23$.

Notes on some species, p. 23, 24, May, 187:3.

4. Descriptions and (15) figures of seven (one new) species of Diumal Lep., p. 25--32, June, 1873.

5. Descriptions and (12) figures of eleren (one new) species of Catocalae, 1). $33--40$.

Identity of Anarta Lutenla, G.--R., with A. Cordigera, Thnb., p. 40. Personal, p. 41--44, July, 1873.

6. Descriptions and (13) figures of five specie of Diurnal Lep., p. 45-50, Aug., 1873.

7. Monograph of the known species of Smerinthus in N. America, (with 15 figures), 1. 51--60, Sept., 1873.

8. Deseriptions and (24) figures of ten species and varieties of Diurnal Lej., p. $61--68$.

Entomologral Notes: Eudryas; Anticosti Lepidoptera; Limenitis Proserpina; Pieris Beckerii ; Catocala Meskei, P. 68-70, 1874.

9. Deseriptions and $(12)$ figures of eleven species and one variety of Catocalae, p. 71--77. 
A few words on the Catocala Nomenclature, p. 77, 78.

Entomological Notes: Polar Lepidoptera; Northern Lepidoptera; Nemeophila Plantaginis and its N. Am. Varieties and Synonyms; Parnassius Smintheus, p. 78--80, March, 1874.

10. The N. American species of the genus Lycaena (with 47 figures), p. $81--93$.

Notes on some specics, p. 93.

Notices of some new and rare speeies: Macroglossa Fumosa, n. sp., Sph. Conifercerum, Ab.-S., Sph. Eremitoides, n. sp., Eurlcemonia Jehovah, n. sp., Cat. Magdalena, n. sp., Cr.t. Aspasia, n. sp., Dryobota Califormica, Behr MS., Taeniseampa Pavia, Behr MS.. Cosmia Sambuci, Behr MS., Cucullia Solidaginis, Behr MS., C. Matricurice, Behr MS., Plusia Echinocystides, Behr MS., Plusic Gamma, L., p. 93, 94, May, 1874.

11. Descriptions and (16) figures of twelve species and one variety (ten new) of Catocalae, p. 96--99.

Notices of some new species of WVestern Catocala, p. 99--100.

Note on Colias Chrysotheme, p. 100, Aug., 1874.

12. Descriptions and (10) figures of five (two new) species of Bombyeidie, p. 101--105.

Notes on valrious species and varieties: Lycaena. Regia, Bdl., a synonym of L. Sonorensis, Feld.; Lyc. Rhaea, Bdl., asynonym of L. Catalina, Reak.; Catocola Levettei, Grote, a synonym of C. Judith, Streck.; C. Anna, Grote, a synonym of C. Amestris, Streck.; C. Adoptina, Grote, a synonym of C. Delilah, Streck.; Gorgopis Quadriguttatus, Grote, a synonym of Hep. Argenteo-maculatus, Harr.; Aretia Anna, Grote, a var. of A. Persephone, Grote; Catocala simulatilis, Grote, the of of $C$. Obscura, Streck.; a variety of Crtocala Cucumbens, p. 105, 106.

Meacre descriptions of some $(5)$ new species, to be followed in a sulsequent jart by what is infinitely better-good representations, p. 106, 107.

On Nomenclature, p. 107, 108, Feb., 1875.

13. Descriptions and (18) figures of seventeen (six new) species of Sphingidie, p. 109--118.

On the Generic Phantasies of S. H. Seudiler, p. 118--120.

Notes, new species. etc.: New sp. Melinaca Dora, Ageronia Anomala, Catocala Herodias, C. Circe, Bunaea Eblis, Heliothis Regia, Fastidiosa, Siren, Inclara, Nubila, Rubiginosa, Imperspicua, Ultima, Spectunda, Anigma Mirificum, p. 120--122.

Ten minutes' notice of "A Check List of $\mathrm{N}$. Am. Noctuidae by A. R. Grote," p. 124, Jan., 1876.

14. Descriptions and (9) figures of eight (two Sph. new) Sphingidæe and Bombrcidre, 1. 125--128.

New species, varieties, etc.: Pap. var. Utahensis, Pap. Rutulus var., Thecla Lali, Th. Fotis, Satymes Ashtaroth, Aedephron Grandis, Cucullir Antipodu, Catocala var. Zillah, p. 128, 129.

New Lep. from the vicinity of New Bramnfels and San Antonio, Texas: Melitaea Imitata, M. Larunda, Libythea Larvata, Charis Guadeloupe, Pamphila Similis, Spilothyrus Notabilis, Aretia Oithona, Datana Robusta, Heliothis Lanul, H. Gloriosa, Catocala Ulahune, p. 130, 132.

On some Isepidlopteri from the regions west of Hudson's Bay, between the latter and Lake Athabasca, p. 132--134, Sept., 1877. 
15. Deseriptions and (19) figures of sixteen species and varieties of Lep., two dimmals (one new); two (new) Sphingida; eleven Bombycidæ (two species and five varieties new), p. 135--139.

On the N. Am. Sphingille in Mr. A. G. Butler's Revision of that family, p. 139--143, Nov., 1877.

*Streci. Proc. ACad. Nat. Sc. Phil.

Description of a new species of Agiale and notes on some other species of North American Lepidoptera, p. 148--153, in the

Procedings of the Aeademy of Natural Sciences of Philadelphia for 1876. *STIECK. RuFF.

Classified List of Insects collected by Lieut. Thos. M. Moodruff at the heal waters of the Red River, Texas, pages 1427--1431 of Annual Report upon Explorations and Surveys in the Department of the Missouri by E. H. Ruffner, First-Lient. Engr. U. S. A., being Appendix RR of the Anmual Report of the Chief of Engineers for 1877. Washington, Government Printing Office, 1877.

*Sulzer. AbG. Gesch.

Johann Heinrich Sulzer, born in 1735; died in Winterthur Aug. 10, 1813.

Abgekïrzte Gesehichte der Insecten nach dem Limnaeischen System.

Winterthur, bey H. Steiner u. Comp., 1776.

*SWAINS. ZOOL. ILL.

Williams Swainson, born in England; died in New Zealand in 1856.

'Zoological Illustrations, or original Figures and Deseriptions of new, rare or interesting Animals, selected chiefly from the Classes of Ornithology, Entonology and Conchology, and arranged on the prineiples of Cuvier and other modern Zoologists. London, Baldwin \& Co., \&e.

Vol. I, 66 plates, 1820-1821 ; II, 53 plates, 1821-1822 ; III, 63 plates, 1822-182:3; 2 d series, vol. I, 45 plates, 1829 ; II, 46 plates, 1831 1832.

'The figures beautifully drawn and coloured.

*Thxв. Diss. Ent. Suec. I-VII.

Curl Peter Thunberg. Born Nov. 11, 1743, in Jonkoping; died Aug. 8, 1828 , at his country-seat Tunaberg. 'The successor of Linnaeus as Professor of Natural History in the University of Upsala. From 1772 to 1775 he was a Physician in the service of the Dutch East India Company. In 1775 he lived in Batavia and Japan.

Dissertatio Entomologico sistens Insecta Suecica. Upsaliae. Part I, Joh. Borgström, Dec. 11, 1784; II, P. E. Becklin, Dec. 10, 1791 ; III, J. Akerman, May 9, 1792 ; IV, C. F. Seebalt, May 23, 1792 ; V, Haij, May 10, 1794; VI, Kinmanson, Dec. 3, 1794; VII, G. M. Wenner, Dec. 22, 1794 ; VIII, Kullberg, Dee. 15, 1794; IX, Westman, Nay 20, 1795.

*'Treits. $\mathrm{I}^{\top}-\mathrm{X}$.

Friedrich Treitschke, born in Leipzig 1776; died in Vienua 1842.

Die Schmetterlinge ron Enropa (Fortsetzung des Ochsenheimer'schen Werks) Leipzig.

Vol. V, part 1, 2, 1825, p. 3, 1826 ; VI, p. 1, 1827, p. 2, 1828 ; VII, 1829 ; VIJI, 1830 ; IX, p. 1, 1832, p. 2, 1833 ; X, p. I, 1834, p. 2, 3,1835 .

This is a continuation of Ochsenheimer's work, "Die Schmetterlinge von Europa," vols. I-IV, 1807-1816. 
*Trim. Rirop. Afr. Austr. I.

Roland Trimen.

Rhopalocera Africa Australis. A catalogue of sonth African Butterflies, comprising descriptions of all the known species, with notices of their Larve, Pupre, Localities, Habits, Seasons of Appearance, and geoyraphical distribution. Part I, Papilionidre, Pierida, Danaidæ, Acræidee, and Nymphalidæ. Cape Town: W. F. Mathew, 1862.

*D'Urban. Cax. Nat.

Hilliam Stewart I' Urbun, Newport, Rhode Island.

Canadian Naturalist and Geologist, Montreal. Vol. I, 1857 ; II, 1857 ; III, 1858; IV, $1859 ; \mathrm{V}, 1860$.

Has the following:

Notes on Insects now injuring the crops in the vicinity of Montreal, p. $161-170$.

On the order Lepidoptera, with the deseription of two species of Canada Butterflics, p. 215-226.

Description of four species of Canada Butterflies, p. 310-318; 345-355, rol. II, 1857 .

Deseription of two species of Canada Butterflies, p. 346-351.

Description of a Canadian Butterfly, and some remarks on the genus Papilio, p. 410-419, vol. III, $185 \dot{8}$.

Observations on the Natural History of the valley of the River Ronge, and the surrounding townhips in the counties of Argentenil and Ottawa, p. 81-99, vol. V, 1860.

* Uhler. Pat. Office Report-Agriculture.

Philip R. Uhler, Librarian of the Peabody Institute, Baltimore.

Inscets Injurious to Vegetation, p. 312-322, vol. for 1860.

* Waleer. List Lep. B. M.

Francis Walker, born July 31, 1809, at Arno's Grove, Southgate, England ; died Oct. 5, 1874, at his residence Elm Hall, Wanstead, England.

List of the Specimens of Lepidopterous Insects in the Collection of the British Musenm. Printed by order of the Trustees. L London.

Lepidoptera Heterocera, Parts i, ii, 1854; p. iii, iv, v, vi, 1855; p. vii, 1856 ; p viii (Sphingidre), 1856 ; p. ix, $x$ (Noctuide), 1856 ; p. xi, xii, xiii (Noctuidre), 1857 ; p. xiv, xv (Noctuide), 1858 ; p. xvi (D)ltoides), 1858 ; p. xvii, xviii, xix (Prralides). 1859 ; p. xx, xxi (Geometrites), 1860; p. xxii, xxiii (Geom.), 1861 ; p. xxiv, xxv, xxvi (Geom.), 1862; 1) xxvii (Crambites \& Tortricites), 1863; p. xxviii (Tortr. \& Tineites), 1863; p. xxix, xxx (Tineites), 1864; p. xxxi (Supplement 1), 1864; p. xxxii, xxiii, xxxir (Suppl. 1, 2, 3) 1865 ; p. xxxr (Suppl. 4), 1866.

Wallexg. Sikand. Dagf.

H. D. J. Wallengren.

Lepidoptera rhopaloeera Scandinaviae disposita ac deseripta.

Skandinaviens Dagf jürilar. Malmö, Cronholm, 1853.

* Westw. Trans. Lins. Soc.

John Obadiah Westicood, born in Sheffield, England, Dec. 22, 1805. Professor of Zoology in the University of Oxford.

A Monograph of the Lepidopterous genus Castnia and some allied groups. By.J. O. Westwood, M. A., F. L. S., de. 
Pages 155-207 (6 plates; 4 col.) of the Transactions of the I Limnean Society of London, Second Series,-Zoology, vol. I, 1875.

* Whitrey. Proc. Bost. Soc. Nat. Hist.

Chas. P. Whitney, Storekeeper in Milford, New Hampshire.

Proceedings of the Boston Society of Natural History, vol. I-XIX, $1844-1877$.

Description of Thecla Souhegan, p. 162, 163, vol. XII, 1868-1869.

Description of the male of Linenitis Proserpina, p. 85, vol. XII, 1869 1871.

* Irhtiney. Can. ENT.

In Canadian Entomologist, vol. VIII, 1876, is the following:

Notes on Lepidoptera, p. 75-77.

* WIEN. TERZ.

Systematisches Terzeichniss der Schmetterlinge der Wiener gegend heransgegeben von einigen Lehrern am $\mathrm{K}: \mathrm{K}$ : Theresimmm. Wien.1776

By Ignaz Schiffermuiller and Michael Denis.

Prof. Schiffermueller was born in Helmonstedt, upper Austria, Nov. 2, 1727; died in Linz 1809. Denis, a Jesuit scholar and witer, was born in Schaerding, Bavaria, Sept. 27, 1729; died in Vienna Sept. 29, 1800.

* Wiluelim. UNt. Nat. II.

Gottlob Tobias Wilhelm, died Dec. 10, 1811.

Unterhaltungen aus der Naturgesehichte der Insecten. 'Zweyter Theil. Angsburg, 1797.

* WOOD. IND. ENT.

Willium Wood.

Index Entomologicns, or a complete Illustrated Catalogne of the Lepidopterous Insects of Great Britain, containing 1944 figures of Moths and Butterflies accurately engraved and carcfully coloured after nature. London, 1845.

*ZETT. INS. LAPP.

Joham Withelm Zetterstedt, Professor in Lund. Born May 20, 178.j.

Insecta Lapponica descripta. Isipsiae, Voss, 1840.

*'Zeller. SitetT. Ent. Zeit.

Philip Christoph Zeller, Prof: in Messeritz. Born A pril 9, 1s08, in Steinheim, Wurtemberg.

Entomologische Zeitung herausgegehen ron dem Entomolugischen Vereine zu Stettin, vol. I-XXXYIII, 1840-1877.

Correspondenz (Wegeen Grünspan und Tabakssaft), p. 110, vol. I, 1810.

Ueber die Sehmetterlingsarten in Ratzeburg's Forstinsecten, 2 'Thei] 1840 , p. 185, 192, vol. I, 1840 ; p. 9-13, vol. II, 1841.

Nachricht über die Sufelder bei Reinerz in Entomologischer Beziehung, p. 171-176; 178-182, vol. II, $18 \notin 1$.

Beschreilung vou Gelechia Lapuxla, L., p. 259-263, vol. III, 1842.

Asopia lienigialis nnd Crambus lienigiellus, zwei nene Falter Arten. p. 139-143, vol. I V, 1843.

/wei Hormaphroditische Falter (Hipp. Janira, Geom. lichenaria), p. 229$232, \mathrm{~m}] . \mathrm{IT}, 1843$. 
Phalæna Tinea xylostella, Linn., p. 281-283, vol. IV, 1843.

Einige Bemerkungen über Zygänen, p. 38-48, vol. V, 1844.

Berichtigung der Synonymie in genus Psecadia, p. 379-381, vol. V, $18+1$

Ueber Linne's eitate aus Schaffer's icomnes, p. 219, 220, vol. VI, 1845.

Polyommatus Polonus, Eine neue Tagfalterirt (Beseh.) p. 351-354, vol. VI, 1845.

Ueber Anthophila rosina (Noetua), p. 354-357, vol. VI, 1845.

Beschreibung der Triehosoma Loweii, n. sp., nebst Bemerkungen über Carreno's insecte dont le ordre est ineertain, p. 5-11, vol. VII, 1846.

Ueber die Synonymie der Emydia Arten Coseinia und Candida (Geom.), p. 150-152, vol. VII, 1846 .

Correspondenz Mittheilnng, Eine Breifes von Mann. (Lep.) p. 163, 164, vol. VII, 1846.

Euplocamus Boleti und tessulatellus, p. 178-182, vol. VII, 1846.

Lepidopterologische Mittheilungen :

1. Sammelnotizen, p. 323-328, vol. VII, 1846. Mit Ammerk v. Dohm, p. 176-188, vol. VIII, 1847 .

2. P. 331-339, vol. VIII, 1847.

Beitrage zur Naturgeschiehte der Sericoris Artemisiana, Z., p. 282-284, vol. VIII, 1847.

3. Ueber Melitæa Cinxia, p. 23-26, vol. IX, 1848 ; p. 221-223 ; 273277, vol. XIII, 1852.

Ueber die Artrechte des Polyommatus Amyntas und P. Polysperehon, p. $177-182$, vol. $\mathrm{X}, 1849$.

Verzeichniss der von Herrn Jos. Minn, Beolachteten Toscanischen Micolepidopteren, p. 200-223; 231-256; 275-287; 312-317, vol. X, 1849 ; р. 59-64; 134-136; 139-162; $195-212$, vol. XI, 1850.

Zwei nene Tagfalter (Triphysa dohrnii, Lycen. Hoffimanseggii), p. 308311 ; 311-313, vol. XI, 1850.

Recension von: versueh Einer Systematischen Aufstellung der in Sehweden Vorkommenden Nachtfalter-Försök till Srstematisk Uppställning af de i Sverige förekommande Natij̈irilar at C. H. Bohem. p. $12-17$, vol. XII, 1851.

Recension von: versuch Einer Monographie der Lycänen mit Abbildungen nach der Natur von Bernard Gerhard. p. 17-20, vol. XII, 1851.

Lepidopterologische Bemerkungen: Thais Polyxena, Simyra dentinosa, Gnophos, p. 145-151, vol. XII, 1851.

Lepidopterologisehe Mitheilungen: (Lebensw. Besehreibung), p. 17i187, vol. XIII, 1852.

Die Raupen von Polyommatus Corydon, p. 425-428, vol. XIII, 1852.

Verzeiehmiss der in den Mittlem odergegenden im geflügelten zustande ïberwinterden Lepidopteren, p. 49-55; $82-86 ; 112$, rol. XIV, 1853. 
Recension, ete. ; von Caroli Clerck icones insectorum rariorum cum nominibus eorum trivialibus E. C. Limnei Syst. Nat. allegatis. Holmiae, 1759. Kritich Bestimmt, p. 199-214; 239-244; 271-294, vol. XIV. 1853.

Lepidopterologische Synonymie, p. 408-416, vol. XIV, 1853.

Ueber Zygaena Ephialtes, p. 92-94, vol. XV, 1854.

Literarisches :

I. Gladbach beschreibung v. Europäischen Schmetterlingen, p. 168-173.

II. Beitrage zur Schmetterlingre fauna des Nordlichen China v. Bremer und Grey, p. 174, 175, vol. XIV', 1853.

III. Lepidopterologisches aus Siberien, p. 168-176, vol. XV, 1854.

Ueber Exploration Scientifique de l'Algeria pendant lés amnees 18401842 publie par ordre du Government (Lucas) Zoologie, III, Paris, 1849. Eine Art Auszug, p. 280-296 ; 299-310, vol. XV, 1854.

Gladbachiana, p. 59-6.3; 94-96, vol. XVI, 1855.

Recension : Die Geographische Verbreitung der Europäischen Schmetterlinge in andern Weltheilen von G. Koch, Leipzig, 1854, p. 68-70, vol. XVI, 1855.

Die Lepidopteren in Scopoli's Eutomologia Carnioliea, p. 233-237, rol. XVI, 1855.

Zwolf amerikanische Nachtfalter dazu Tafel II, p. 136-155, vol. XXIV, 1863.

Nachricht über Einige Falter d. Meseritzer gegend, p. 26-48, vol. XXVI, 1865.

Einige worte der Sepp'sche Werk nebst proben aus der Fortsetzung desselben, p. 4--21, vol. XXVII, 1866.

Beschreibung Einiger Amerikanischer Wickler und Crambiden dazu Tafel I, p. 137--157, vol. XXVII, 1866.

Ueber Senta Maritima Tauscher, p. 353--356, vol. XX V II, 1866.

Ueber die Europäischen Setina Arten, p. 33--49, vol. XXVIII, 1867.

Naturgeschichte der Fidonia Fasciola, p. 178--183, vol. XX VIII, 1867.

Ueber die Entschuppung der Schmetterlings flugel, 1. 184--187, vol. XXVIII, 1867.

Recension von: "Die Schmetteringe deutschlands und der Schweiz, Systematisch bearbeitet von H. V. Heinemann, II Abthl. Bd. 1, Heft 2, die Zunzler," p. 188--195, vol. XXVIII, 1867.

Recension von: "Skandinaviens Fjädermott (Alucita, Linn.) beskrifna af H. D. J. Wallengren, Till K. Vet. Akad. inlemudad d. 8 Oct., 1869," p. 321--339, vol. XXVIII, 1867.

Einige von Herrn Pickard Cambridge besonders in Aegypten und Palästina gessammelte Microlepidopteren, p. 365--387, vol. XXVIII, 1867.

Einige Ostindische Microlepidopteren dazu Tafel II, p. 387-415, vol. XXVIII, 1867.

Lepidopterologische Ergebnisse Einer Reise in Oberkarnthen von Prof. P. C. Zeller in Messeritz, p. 121-149, vol. XXIX, 1868. 


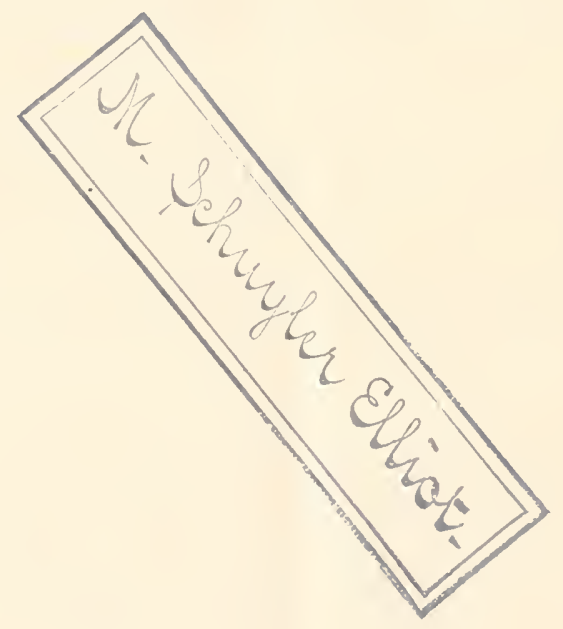









